\title{
NATURAL GAS RESOURCES IN DEEP SEDIMENTARY BASINS
}

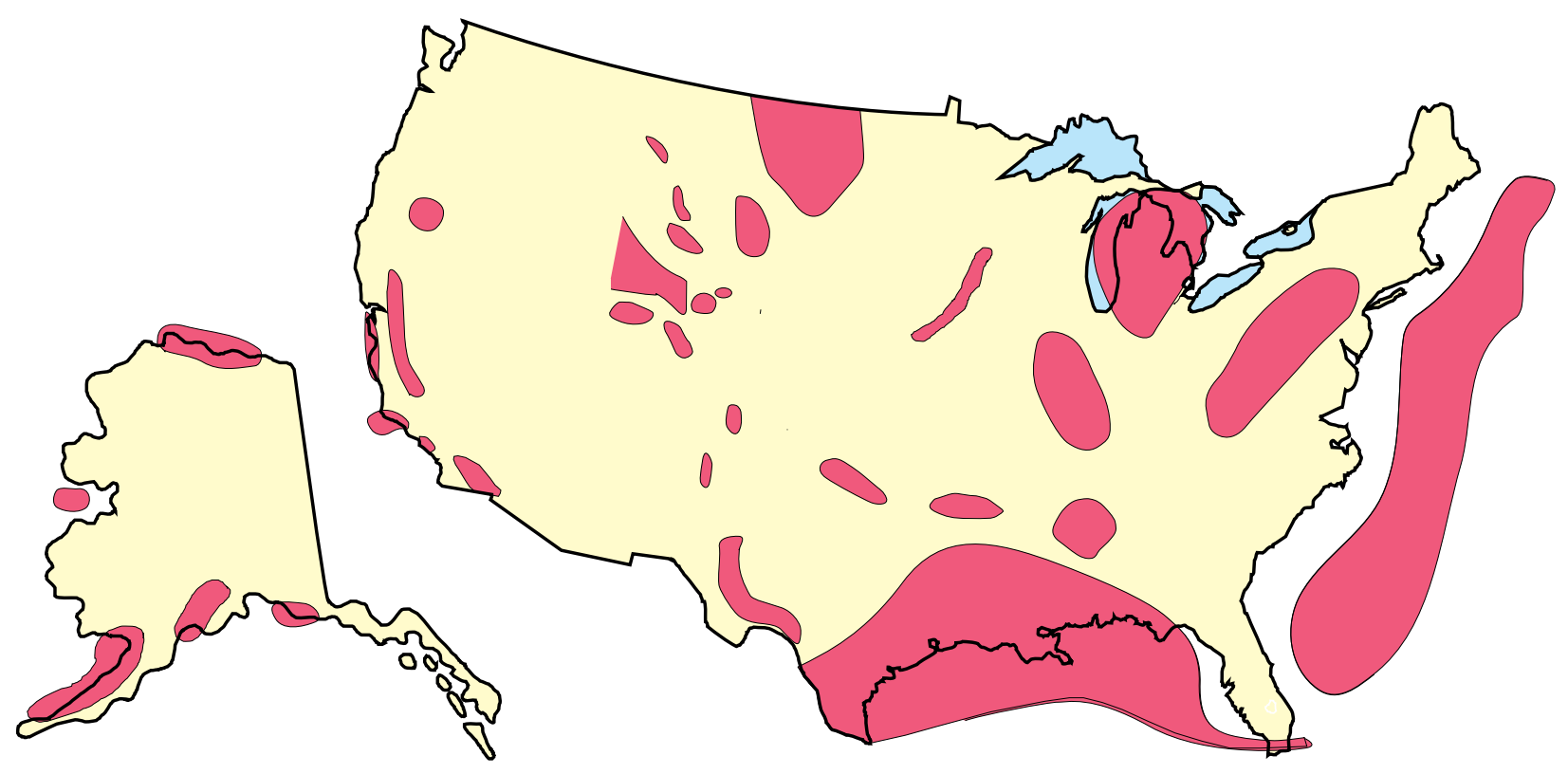

\section{FINAL REPORT}

PROJECT CHIEF: Thaddeus S. Dyman

U.S. GEOLOGICAL SURVEY PROJECT STAFF

Troy Cook, Robert A. Crovelli, Allison A. Henry, Timothy C. Hester, Ronald C. Johnson, Michael D. Lewan, Vito F. Nuccio, James W. Schmoker, Dennis B. Riggin, 


\begin{abstract}
From a geological perspective, deep natural gas resources are generally defined as resources occurring in reservoirs at or below 15,000 feet, whereas ultra-deep gas occurs below 25,000 feet. From an operational point of view, "deep" is often thought of in a relative sense based on the geologic and engineering knowledge of gas (and oil) resources in a particular area. Deep gas can be found in either conventionally-trapped or unconventional basin-center accumulations that are essentially large single fields having spatial dimensions often exceeding those of conventional fields.

Exploration for deep conventional and unconventional basin-center natural gas resources deserves special attention because these resources are widespread and occur in diverse geologic environments. In 1995, the U.S. Geological Survey estimated that 939 TCF of technically recoverable natural gas remained to be discovered or was part of reserve appreciation from known fields in the onshore areas and State waters of the United. Of this USGS resource, nearly 114 trillion cubic feet (Tcf) of technically-recoverable gas remains to be discovered from deep sedimentary basins. Worldwide estimates of deep gas are also high. The U.S. Geological Survey World Petroleum Assessment 2000 Project recently estimated a world mean undiscovered conventional gas resource outside the U.S. of 844 Tcf below $4.5 \mathrm{~km}$ (about 15,000 feet).

Less is known about the origins of deep gas than about the origins of gas at shallower depths because fewer wells have been drilled into the deeper portions of many basins. Some of the many factors contributing to the origin of deep gas include the thermal stability of methane, the role of water and non-hydrocarbon gases in natural gas generation, porosity loss with increasing thermal maturity, the kinetics of deep gas generation, thermal cracking of oil to gas, and source rock potential based on thermal maturity and kerogen type. Recent experimental simulations using laboratory pyrolysis methods have provided much information on the origins of deep gas.
\end{abstract}

Technologic problems are one of the greatest challenges to deep drilling. Problems associated with overcoming hostile drilling environments (e.g. high temperatures and pressures, and acid gases such as $\mathrm{CO} 2$ and $\mathrm{H} 2 \mathrm{~S}$ ) for successful well completion, present the greatest obstacles to drilling, evaluating, and developing deep gas fields. Even though the overall success ratio for deep wells is about 50 percent, a lack of geological and geophysical information such as 
reservoir quality, trap development, and gas composition continues to be a major barrier to deep gas exploration.

Results of recent finding-cost studies by depth interval for the onshore U.S. indicate that, on average, deep wells cost nearly 10 times more to drill than shallow wells, but well costs and gas recoveries vary widely among different gas plays in different basins.

Based on an analysis of natural gas assessments, many topical areas hold significant promise for future exploration and development. One such area involves re-evaluating and assessing hypothetical unconventional basin-center gas plays. Poorly-understood basin-center gas plays could contain significant deep undiscovered technically-recoverable gas resources. 


\section{Volume Contents}

A. Introduction

By Thaddeus S. Dyman and Vello A. Kuuskraa

B. Summary of Deep Oil and Gas Wells in the United States Through 1998

By Thaddeus S. Dyman and Troy A. Cook

C. Geology and Natural Gas Potential of Deep Sedimentary Basins in the Former Soviet Union

By Thaddeus S. Dyman, Vadim A. Litinsky, and Gregory F. Ulmishek

D. Comparison of Kinetic-model Predictions of Deep Gas Generation By Allison A. Henry and Michael D. Lewan

E. Gas:Oil Ratios for Source Rocks Containing Type-I, -II, -IIS, and -III Kerogens as Determined by Hydrous Pyrolysis

By Michael D. Lewan and Allison A. Henry

F. Probabilistic Method for Subdividing Petroleum Resources into Depth Slices By Robert A. Crovelli

G. Relative Uncertainty of Conventional Natural Gas Plays in the Gulf Coast Region By Thaddeus S. Dyman, James W. Schmoker, and Christopher J. Schenk

H. A Possible Deep-Basin High-Rank Gas Machine Via Water-Organic-Matter Redox Reactions

By Leigh C. Price

I. Potential for Deep Basin-Centered Gas Accumulation in Hanna Basin, Wyoming By Michael S. Wilson, Thaddeus S. Dyman, and Vito F. Nuccio

J. Is There a Basin-Centered Gas Accumulation in Cotton Valley Group Sandstones, Gulf Coast Basin, U.S.A.?

By Charles E. Bartberger, Thaddeus S. Dyman, and Steven M. Condon

K. Deep Natural Gas Resources

By T.S. Dyman, R.E. Wyman, V.A. Kuuskraa, M.D. Lewan, and T.A. Cook 


\title{
Chapter A
}

\section{Introduction}

\author{
By Thaddeus S. Dyman and Vello A. Kuuskraa
}

Prepared in cooperation with the U.S. Department of Energy-National Energy Technology Laboratory, the Gas Technology Institute, and

Advanced Resources International

U.S. Department of the Interior

U.S. Geological Survey 


\section{Introduction}

ByThaddeus S. Dyman and Vello A. Kuuskraa ${ }^{1}$

In 1995, the U.S. Geological Survey estimated a mean resource of 114 trillion cubic feet of undiscovered technically recoverable natural gas in plays deeper than 15,000 feet $(4,572$ $\mathrm{m}$ ) in onshore regions of the United States (Dyman and others, 1996). This estimated resource represents nearly 20 percent of the total undiscovered conventional and continuous-type (unconventional) natural gas resources of the onshore United States based on the U.S. Geological Survey 1995 National Petroleum Assessment (U.S. Geological Survey National Oil and Gas Assessment Team, 1995). Because these deep resources are widespread and occur in diverse geologic environments, they deserve special attention.

Efficiently finding and developing these deep undiscovered natural gas resources depend on improving our knowledge of the geology and reservoir characteristics of deep sedimentary basins, continued advances in exploration, drilling, and completion technologies, and improved economics. During the 1990's, deep natural gas exploration and development were strongly influenced both by advances in technology and by lower unit costs. This progress in technology and costs helped spur the development of frontier plays such as the deep Norphlet Play in the eastern Gulf Coast basin, the low-permeability deep Cretaceous plays of the Green River basin, and the deep Madison Play on Madden anticline in the Wind River basin. The importance of continued technology progress was amplified by Reeves and others (1998) when they identified current barriers to deep gas development. They suggested the need to reduce well costs through improving drilling practices, reducing dry-hole rates with more focused exploration technologies, optimizing completion practices, and developing new technologies to better process sour gas.

In 1997, the U.S. Geological Survey published Bulletin 2146, comprising 12 chapters dealing with geologic, geochemical, and assessment issues related to deep gas resources (Dyman and others, 1997). A primary goal of that bulletin was to provide geology-based information that might aid in future improvements to technology for deep gas exploration and development. Chapters of this report represent a continuation of that work funded by the U.S. Geological Survey, Denver, Colo. The current work is funded by the U.S. Department of Energy, National Energy Technology Laboratory, Morgantown, W. Va. (contract

\footnotetext{
${ }^{1}$ Advanced Resources International, 1110 N. Glebe Rd., Suite 600, Arlington,
} VA 22201.
No. DE-AT26-98FT40032), and Gas Technology Institute (formerly Gas Research Institute (GRI)), Chicago, Ill. (contract No. 5094-210-3366 through a Cooperative Research and Development Agreement with Advanced Resources International, Arlington, Va.). Two GRI-sponsored deep gas workshops were held in 1998 (Oil and Gas Journal, 1998). These workshops provided an opportunity for industry participants to discuss the improved economic outlook for deep drilling, present case studies of deep exploration and development in key deep gas regions, outline how new technologies are being used to better define deep drilling opportunities, and introduce new deep gas resource assessments.

Chapters in the present report summarize major conclusions of this ongoing work. Chapters $\mathrm{B}$ and $\mathrm{C}$ address the areal extent of drilling and the distribution of deep basins. Chapter B provides an update of deep drilling in the U.S. during the 1990's, and Chapter $\mathrm{C}$ summarizes the distribution of deep sedimentary basins and the potential for deep gas in the Former Soviet Union.

Chapters D and E are geochemical papers addressing source-rock issues and deep gas generation. Chapter $\mathrm{D}$ presents gas generation kinetic models based on laboratory pyrolysis methods and examines them for hypothetical basin scenarios based on end-member heating rates of $1^{\circ}$ and $10^{\circ} \mathrm{C} / \mathrm{m}$.y. Chapter E presents gas:oil ratios (GOR) from hydrous-pyrolysis experiments conducted on immature source rocks and summarizes how they are affected by kerogen type. The quantity of expelled oil and the gas generated during hydrous pyrolysis allows for the calculation of GOR's for a particular source rock at hydrous-pyrolysis temperatures representing different stages of oil generation.

Chapters $\mathrm{F}$ and $\mathrm{G}$ discuss assessment issues related to deep gas. In Chapter F, a probabilistic method is developed for subdividing gas resources into depth slices. This is important for deep natural gas assessments because gas plays often range across many depth intervals, and estimating the amount of gas in each interval aids in both geologic and economic analysis of the play and province. In Chapter $\mathrm{G}$, the relative uncertainty of estimates of deep gas in plays in the Gulf Coast region is analyzed. More than 60 plays in the Western Gulf and Louisiana-Mississippi Salt Basins provinces are compared and analyzed for their conditional uncertainty.

Chapter $\mathrm{H}$ evaluates the mechanism of hydrogenation of deep, high-rank spent kerogen by water, with subsequent generation of methane-rich $\mathrm{HC}$ gas. 
Acknowledgments.-We acknowledge the helpful and critical manuscript reviews by Katharine Varnes, Paul Lillis, James Schmoker, Timothy Klett, Vito Nuccio, Curtis Huffman, Robert Crovelli, and Mitchell Henry of the U.S. Geological Survey, Denver, Colo.; and John Curtis of the Potential Gas Agency, Colorado School of Mines, Golden, Colo. We also wish to acknowledge the technical guidance of Tom Fate, Richard Parker, and Charles Brandenberg, Gas Technology Institute, Chicago, Ill., and William Gwilliam and Charles Komar, U.S. Department of Energy, National Energy Technology Laboratory, Morgantown, W.Va. Lorna Carter reviewed manuscripts for editorial standards and formatted them for this report. Ken Takahashi designed the jewel case cover. Many of the figures were prepared by Ken Vogel, a graphics consultant in Aurora, Colo. The editors note with regret the untimely death, in August 2000, of organic geochemist Leigh C. Price, author of Chapter $\mathrm{H}$ of this volume.

\section{References Cited}

Dyman, T.S., Rice, D.D., and Westcott, P.A., eds., 1997, Geologic controls of deep natural gas resources in the United States: U.S. Geological Survey Bulletin 2146, $239 \mathrm{p}$.

Dyman, T.S., Schmoker, J.W., and Root, D.H., 1996, Assessment of deep conventional and continuous-type (unconventional) natural gas plays in the U.S.: U.S. Geological Survey Open-File Report 96-529, $30 \mathrm{p}$.

Oil and Gas Journal, 1998, Advances, needs highlighted for deep U.S. gas drilling: Oil and Gas Journal, November 30, 1998, p. 82-84.

Reeves, S.R., Kuuskraa, J.A., and Kuuskraa, V.A., 1998, Deep gas poses opportunities, challenges to U.S. operators: Oil and Gas Journal, May 4, 1998, p. 133-140.

U.S. Geological Survey National Oil and Gas Resource Assessment Team, 1995, 1995 National assessment of United States oil and gas resources: U.S. Geological Survey Circular 1118, 20 p. 


\section{Chapter B}

\section{Summary of Deep Oil and Gas Wells in the United States Through 1998}

By Thaddeus S. Dyman and Troy A. Cook

Prepared in cooperation with the U.S. Department of Energy-National Energy Technology Laboratory, the Gas Technology Institute, and

Advanced Resources International

U.S. Department of the Interior

U.S. Geological Survey 


\section{Contents}

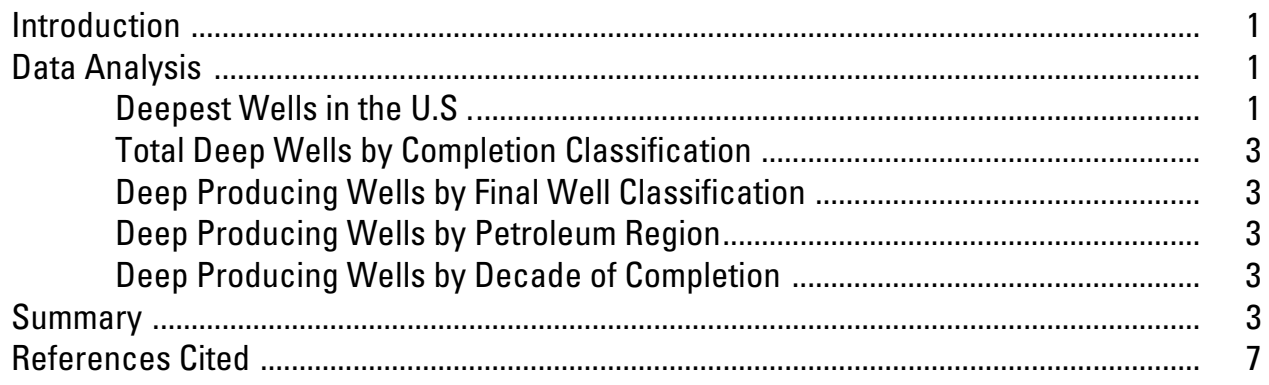

\section{Tables}

1. Summary data for wells drilled deeper than 25,000 feet by province/basin in the U.S.

2. Total deep wells by depth interval for U.S. based on final completion classification

3. Total deep producing wells by depth interval in U.S. based on final completion classification 5

4. Numbers of deep producing wells by depth interval in U.S. by region ........................ 6

5. Total deep producing wells by depth interval in U.S. by decade of completion ........... 7 


\title{
Summary of Deep Oil and Gas Wells in the United States Through 1998
}

\author{
By Thaddeus S. Dyman and Troy A. Cook
}

\section{Introduction}

In 1990, the U.S. Geological Survey summarized the geologic and production characteristics of deep wells and reservoirs in the United States (wells drilled more than 15,000 feet-4,572 $\mathrm{m}$ or deeper) based on data compilations from published computer files (Dyman and others, 1990; 1993). In those reports, tables were compiled on deep wells from Petroleum Information (PI) Corporation's Well History Control System (WHCS) available through 1988 (Petroleum Information Corp., 1988). WHCS contains location, identification, and geologic and engineering data on more than 2 million wells drilled in the U.S. The WHCS file (now referred to as PI-Dwights WHCS files; IHS Energy Group, 1998) is currently available to the U.S. Geological Survey under contract with IHS Energy Group, Denver, Colo. In the reports by Dyman and others, well summaries included the distribution of (1) the 10 deepest wells drilled in the U.S., (2) deep wells in the U.S. based on depth interval and final well classification, (3) deep producing wells based on final completion classification, (4) deep producing wells by region, and (5) deep producing wells by depth interval and decade of completion. The purpose of these reports was to summarize deep drilling in the U.S. in order to develop a better understanding of the distribution of deep wells and reservoirs, to define geologic and engineering factors associated with deep drilling, and to more precisely assess deep natural gas resources.

During the 1990's, deep drilling has continued in the U.S. at a robust pace, and technologic advancements have played an important role in the development of new deep gas plays. Deep drilling frontiers that seemed economically prohibitive in past decades have been reached thanks to technologic advances in the 1990's. The purpose of this report is to update the data summaries of Dyman and others $(1990 ; 1993)$ based on well information through 1998 (PI-Dwights WHCS data from IHS Energy Group through 1998) and to compare deep drilling activity during the 1990's with deep drilling activity of previous decades.

\section{Data Analysis}

The December 1998 version of PI-Dwights WHCS includes a subset of wells drilled deeper than 15,000 feet $(4,572$ m) that contains 20,715 wells, of which 11,522 are classed as producing gas and (or) oil. This figure is up from 16,650 total wells in 1988, an increase of 4,065 wells or a 24 percent increase in the 1990's decade. Of the 11,522 producing wells, 5,119 have a formation reported at total depth that is the same as the first producing formation reported. Wells may contain more than one producing formation, but only the first producing formation listed in the file was recognized for this study. These 5,119 wells, although a minimum number, form a subset of wells actually producing gas or oil below 15,000 feet $(4,572 \mathrm{~m})$. The remaining 6,403 producing wells of the original 11,522 producing wells produce from a formation other than the formation at total depth (above or below 15,000 feet-4,572 m) or have no producing formation reported. Some of these 6,403 wells may be producing oil or gas below 15,000 feet $(4,572 \mathrm{~m})$, but they were not considered for this report. The following discussion is based solely on observations from PI-Dwights WHCS and does not take into account oil and gas wells that are not in these data files. The inclusion of non-WHCS wells could affect the results reached in this report.

\section{Deepest Wells in the U.S.}

Dyman and others (1990; 1993, table 1) identified the 10 deepest wells in the U.S. through 1985 regardless of completion classification. In order to more fully represent the distribution of these and other ultra deep wells, we have selected and summarized wells drilled to depths exceeding 25,000 feet (7,620 m) throughout the U.S. (table 1). The deepest well drilled in the U.S. still remains the Lone Star No. 1 Bertha Rogers, which was completed in 1974 in the Ordovician Arbuckle Formation as a wildcat well to a depth of 31,441 feet $(9,583 \mathrm{~m})$ in Beckham County, Okla., in the Anadarko basin. Fifty-one other wells have been drilled below 25,000 feet $(7,620 \mathrm{~m})$ in eight regions of the U.S. Despite the record-setting Bertha Rogers and other deep wells in the Anadarko basin, the Permian basin currently holds the record for the number of ultra deep wells based on data from PI-Dwights WHCS (table 1) with 21 wells, of which 10 were completed as gas wells. The Anadarko basin ranks second with 19 ultra deep wells of which 12 were completed as gas wells. For the U.S. as a whole, 27 of these 52 ultra deep wells were completed as gas or oil wells (producing at any depth), and based on a set of 48 ultra deep dry holes (after subtracting four abandoned, suspended, or injection wells from the original 52 ultra deep wells), a historic success ratio of more than 50 percent has been achieved. Exxon holds the record as operator for the largest number of ultra deep wells in the U.S. with 12; ten of these wells were drilled in the Permian basin.

Twenty-six of the 52 ultra deep wells reported a producing formation. Of these, six wells were reported as producing from the Ordovician Ellenburger Formation of the Permian basin, six 
$\sim$ Table 1. Summary data for wells drilled deeper than 25,000 feet by province/basin in the U.S.

\begin{tabular}{|c|c|c|c|c|c|c|c|c|}
\hline Basin/province & $\begin{array}{l}\text { No. wells by } \\
\text { completion } \\
\text { (gas-oil-dry) }\end{array}$ & $\begin{array}{l}\text { Dominant rock } \\
\text { units at TD } \\
\text { (no. wells) }\end{array}$ & $\begin{array}{l}\text { Important } \\
\text { prod. unit } \\
\text { (no. wells) }\end{array}$ & $\begin{array}{l}\text { Representative } \\
\text { fields } \\
\text { (no. wells) }\end{array}$ & $\begin{array}{l}\text { Wildcat } \\
\text { wells }\end{array}$ & $\begin{array}{l}\text { Deepest } \\
\text { wells ( } \mathrm{ft} \text { ) }\end{array}$ & $\begin{array}{l}\text { Operators } \\
\text { (no. wells) }\end{array}$ & $\begin{array}{l}\text { Completion } \\
\text { (no. wells) }\end{array}$ \\
\hline \multirow[t]{5}{*}{ Anadarko } & \multirow[t]{5}{*}{$12-0-7$} & Hunton (4) & Hunton (5) & Mayfield (7) & \multirow[t]{5}{*}{3 (dry) } & 31,441 & GHK (3) & 1970’s (7) \\
\hline & & Arbuckle (3) & Morrow (2) & Mills Ranch (3) & & \multirow[t]{4}{*}{30,050} & Chevron (3) & 1980’s (8) \\
\hline & & Sylvan (6) & Springer (1) & Elk City (2) & & & Exxon (2) & 1990’s (4) \\
\hline & & & Arbuckle (1) & & & & Mesa (2) & \\
\hline & & & Atoka (1) & & & & Union (2) & \\
\hline Arkansas/N. Louisiana & $0-0-1$ & Cotton Valley (1) & - & - & 1 (dry) & 25,015 & SOHIO (1) & 1980’s (1) \\
\hline Chautauqua Platform & $0-0-1$ & - & - & Adair (1-Inj.) & - & 30,835 & Econ Con. (1) & 1970’s (1) \\
\hline \multirow[t]{4}{*}{ Permian } & \multirow[t]{4}{*}{$10-4-7$} & Ellenburger (15) & Ellenburger (6) & \multirow[t]{4}{*}{ McComb (5) } & \multirow[t]{4}{*}{4 (dry) } & \multirow[t]{4}{*}{29,670} & \multirow[t]{4}{*}{ Exxon (10) } & Pre 1970's (2) \\
\hline & & Granite (2) & Permian (5) & & & & & 1970's (3) \\
\hline & & & Leonardian (2) & & & & & 1980’s (12) \\
\hline & & & Woltcampian (3) & & & & & 1990’s (4) \\
\hline \multirow[t]{2}{*}{ Florida-Atlantic Off. } & \multirow[t]{2}{*}{$0-0-4$} & \multirow[t]{2}{*}{ Pliocene (4) } & \multirow[t]{2}{*}{ - } & \multirow{2}{*}{$\begin{array}{l}\text { Garden Banks } \\
\text { Block (3) }\end{array}$} & \multirow[t]{2}{*}{1 (dry) } & \multirow[t]{2}{*}{28,600} & Shell (2) & 1990’s (4) \\
\hline & & & & & & & $\begin{array}{l}\text { Amerada (1) } \\
\text { Conoco (1) }\end{array}$ & \\
\hline \multirow[t]{3}{*}{ Gulf Coast } & \multirow[t]{3}{*}{$1-0-3$} & Cotton Valley (1) & \multirow[t]{3}{*}{ Cotton Valley (1) } & \multirow[t]{3}{*}{ Bogalusa (1) } & \multirow[t]{3}{*}{3 (dry) } & \multirow[t]{3}{*}{25,703} & Placid (2) & 1970’s (3) \\
\hline & & Smackover (1) & & & & & Martin (1) & 1980’s (1) \\
\hline & & Tuscaloosa (1) & & & & & LLE (1) & \\
\hline Green River Basin & $0-0-1$ & Mississippian (1) & - & - & 1 (dry) & 25,764 & Williams (1) & 1980’s (1) \\
\hline S. OK Foldbelt & $0-0-1$ & Arbuckle (1) & - & - & 1 (dry) & 25,726 & Getty (1) & 1980’s (1) \\
\hline
\end{tabular}

a Data taken from PI-Dwights WHCS file updated through December, 1998 (IHS Energy Group, 1998). 
wells were reported as producing from Permian reservoirs of the Permian basin (three in the Wolfcampian, two in the Leonardian, and one in the Guadalupian), and five wells were reported as producing from the Hunton Group of the Anadarko basin.

\section{Total Deep Wells by Completion Classification}

Table 2 summarizes the final well classification by depth interval for all 20,715 wells in the PI-Dwights WHCS database drilled 15,000 feet $(4,572 \mathrm{~m})$ or deeper. Depths in table 2 are total well depths, and production may be at any depth, above or below 15,000 feet $(4,572 \mathrm{~m})$. Gas wells account for nearly 75 percent of producing wells with total depths below 15,000 feet $(4,572 \mathrm{~m})$. More gas wells $(8,600)$ occur than dry holes $(8,414)$, although Dyman and others $(1990 ; 1993)$ reported more dry holes $(7,090)$ than gas wells $(6,347)$ based on 1988 WHCS data. Gas wells $(8,600)$ are three times more abundant than oil wells $(2,829)$. Of the 20,715 deep wells drilled, 1,676 wells have total depths exceeding 20,000 feet $(6,096 \mathrm{~m})$. This figure represents an increase of 234 wells since 1988 when 1,442 wells exceeded 20,000 feet $(6,096 \mathrm{~m})$. Of these 1,676 wells, 974 are producing wells, of which 847 (87 percent of producing wells) are producing gas at any depth. This is up slightly from 86 percent based on 1988 data (Dyman and others, 1990; 1993). The ratio of gas producing wells to total producing wells increases with increasing total depth of well.

\section{Deep Producing Wells by Final Well Classification}

Table 3 summarizes the final well classification by depth interval for 5,119 wells in the PI-Dwights WHCS file that produce oil or gas from the formation encountered at total depth. These 5,119 wells represent a 42 percent increase based on 1988 data, when 2,981 wells were reported by Dyman and others (1990; 1993) as producing from the formation at total depth. Based on data through 1998, gas wells continue to outnumber oil wells for every depth interval. The percent of gas wells to total producing wells ranges from 73 percent in the 15,000 to 16,000 foot interval $(4,572$ to $4,877 \mathrm{~m}$ interval) to 100 percent in both the 25,000 to 26,000 foot interval $(7,620$ to $7,925 \mathrm{~m}$ interval) and the 26,000 to 27,000 foot interval $(7,925$ to $8,230 \mathrm{~m}$ interval). For all depths together, gas wells make up nearly 78 percent of the deep wells producing from formations encountered at total depth. This is the same percent reported by Dyman and others $(1990 ; 1993)$ for deep well data through 1988.

\section{Deep Producing Wells by Petroleum Region}

Table 4 summarizes deep producing wells from PI-Dwights WHCS by depth interval and geographic region. Of the six regions with deep productive wells, the onshore Gulf Coast region includes the greatest number of deep producing wells $(2,496)$. This represents an increase of 601 wells from 1988 data when 1,895 deep producing wells were reported for the Gulf Coast. The Rocky Mountain region includes 298 deep producing wells, up from 265 in 1988. The U.S. Federal Offshore region includes 1,097 deep producing wells. For most depth intervals below 15,000 feet $(4,572 \mathrm{~m})$, gas producing wells form the majority of deep producers. For all depths together, the Rocky Mountain and California-Alaska regions have the smallest percentage ( 34 and 8 percent respectively) of deep gas wells to total producing wells. Deep oil production in some Rocky Mountain basins such as the Powder River and Uinta basins is an important factor in the regional resource base. The deepest oil producing wells in California are in Ventura field in the Ventura basin and Yowlumne field in the San Joaquin basin. Production ranges in depth from 15,000 to 22,000 feet $(4,572$ to $6,706 \mathrm{~m})$. The deepest producing wells in the Rocky Mountain region are gas producers in the Wind River basin at Madden field in north-central Wyoming.

The deepest gas producing wells in the Gulf Coast onshore region are in Smackover, Norphlet, and Tuscaloosa reservoirs at fields such as Chunchula in southern Alabama (about 18,000 feet), False River in southern Louisiana (about 19,000-21,000 feet-5,791-6,401 m), and Thomasville in southern Mississippi (about 20,000-21,000 feet-6,096-6,401 m). The deepest gas well currently reported by PI-Dwights WHCS in the Gulf Coast onshore region is from a Cotton Valley Formation well at Bogalusa field in southern Louisiana at a depth of 25,415 feet (7,746 $\mathrm{m})$. The deepest offshore gas wells are located in Mobile Blocks 8 and 9 and produce gas from Smackover, Norphlet, and Pleistocene(?) reservoirs at depths ranging from about 15,000 to 22,000 feet. Only eastern U.S. basins including the Appalachian and Michigan basins are not represented in table 4 .

\section{Deep Producing Wells by Decade of Completion}

Table 5 contains well summaries from PI-Dwights WHCS data files illustrating deep producing wells for year of completion, in 10-year increments by depth. The 1960's decade was the first to show significant deep production (125 deep producing wells were completed). Only eight deep producing wells were completed prior to 1960 . Deep producing well completions subsequently peaked in the deep drilling boom of the early 1980 's (1,650 deep producing completions). For all years together, nearly 90 percent of the wells that are classed as producers below 20,000 feet $(6,096 \mathrm{~m})$ are gas producers. For each decade through the 1980's, the ratio of deep gas producing wells to total producing wells increased with depth to a peak of 83 percent in the 1980's. During the 1990's, an increase in the number of completed oil producing wells resulted in a decrease in the ratio to 75 percent.

The decade of the 1980's had the greatest number of ultra deep completions ( $>25,000$ feet-7,620 m deep) for all regions with 24 , but all of these wells were completed during 19801985 before the industry downturn of the late 1980's.

\section{Summary}

Deep wells are widely distributed throughout many basins in the U.S. Twenty thousand seven hundred fifteen wells have 
- Table 2. Total deep wells by depth interval for U.S. based on final completion classification ${ }^{\text {a }}$.

\begin{tabular}{|c|c|c|c|c|c|c|c|c|c|c|c|c|}
\hline \multicolumn{13}{|c|}{ Final well classification } \\
\hline Depth $^{b}$ & $\operatorname{Misc}^{\mathrm{C}}$ & Dry & ------- & 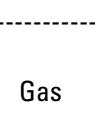 & $\begin{array}{c}\text { oducin } \\
\text { Oil } \\
\text { mul }\end{array}$ & $\begin{array}{l}\text { Gas } \\
\text { mul }\end{array}$ & Oil- & $\begin{array}{l}\text { Total } \\
\text { wells }\end{array}$ & $\begin{array}{l}\text { Prod. } \\
\text { total }^{d}\end{array}$ & $\begin{array}{l}\text { Prod. } \\
\text { gas }\end{array}$ & $\begin{array}{l}\text { Total prod. wells/ } \\
\text { total wells (\%) }\end{array}$ & $\begin{array}{l}\text { Total gas wells/ } \\
\text { total prod. wells } \\
\quad(\%)\end{array}$ \\
\hline $15-16$ & 270 & 3,072 & 1,249 & 2,905 & 140 & 171 & 49 & 7,856 & 4,514 & 3,076 & 57 & 68 \\
\hline $16-17$ & 203 & 2,199 & 621 & 1,952 & 69 & 119 & 21 & 5,184 & 2,782 & 2,071 & 54 & 74 \\
\hline $17-18$ & 125 & 1,279 & 354 & 1,302 & 26 & 61 & 5 & 3,152 & 1,748 & 1,363 & 55 & 78 \\
\hline $18-19$ & 72 & 832 & 176 & 768 & 5 & 21 & 4 & 1,878 & 974 & 789 & 52 & 81 \\
\hline $19-20$ & 43 & 396 & 72 & 426 & 2 & 29 & 1 & 969 & 530 & 455 & 55 & 86 \\
\hline $20-21$ & 24 & 268 & 63 & 279 & 2 & 17 & 2 & 655 & 363 & 296 & 55 & 82 \\
\hline $21-22$ & 22 & 159 & 29 & 229 & 0 & 17 & 1 & 457 & 276 & 246 & 60 & 89 \\
\hline $22-23$ & 20 & 111 & 15 & 213 & 0 & 6 & 0 & 365 & 234 & 219 & 64 & 94 \\
\hline $23-24$ & 4 & 39 & 2 & 46 & 0 & 0 & 0 & 91 & 52 & 46 & 57 & 88 \\
\hline $24-25$ & 1 & 36 & 0 & 17 & 0 & 0 & 0 & 54 & 18 & 17 & 33 & 94 \\
\hline $25-26$ & 1 & 15 & 1 & 14 & 0 & 0 & 0 & 31 & 16 & 14 & 52 & 88 \\
\hline $26-27$ & 1 & 3 & 2 & 3 & 0 & 0 & 0 & 9 & 6 & 3 & 67 & 50 \\
\hline $27-28$ & 0 & 0 & 0 & 2 & 0 & 0 & 0 & 2 & 2 & 2 & 100 & 100 \\
\hline $28-29$ & 1 & 2 & 1 & 0 & 0 & 0 & 0 & 4 & 2 & 0 & 50 & 0 \\
\hline $29-30$ & 0 & 3 & 0 & 2 & 0 & 0 & 0 & 5 & 2 & 2 & 40 & 100 \\
\hline $30-31$ & 1 & 0 & 0 & 1 & 0 & 0 & 0 & 2 & 2 & 1 & 100 & 50 \\
\hline $31-32$ & 0 & 0 & 0 & 1 & 0 & 0 & 0 & 1 & 1 & 1 & 100 & 100 \\
\hline Totals & 788 & 8,414 & 2,585 & 8,160 & 244 & 441 & 83 & 20,715 & 11,522 & 8,600 & 56 & 75 \\
\hline
\end{tabular}

${ }^{a}$ Data taken from PI-Dwights WHCS file updated through December 1998 (IHS Energy Group, 1998).

${ }^{b}$ Depth interval in thousands of feet.

${ }^{\mathrm{c}}$ Miscellaneous wells include those with unknown final completion classification, sulfur wells, suspended wells, dry development wells, injection wells, and drilled and abandoned wells.

${ }^{\mathrm{d}}$ Producing wells may be producing at any depth. 
Table 3. Total deep producing wells by depth interval in U.S. based on final completion classification .

[Oil, oil producing wells; Gas, gas producing wells; mul, wells producing from multiple horizons, either gas or oil; Oil-gas, oil and gas producing wells. Total gas, gas and multiple gas column wells]

\begin{tabular}{|c|c|c|c|c|c|c|c|c|c|}
\hline \multicolumn{10}{|c|}{ Final well classification } \\
\hline $\begin{array}{c}\text { Depth } \\
(\mathrm{X} 1,000 \mathrm{ft})\end{array}$ & Oil & Gas & $\begin{array}{l}\text { Oil } \\
\text { mul }\end{array}$ & $\begin{array}{l}\text { Gas } \\
\text { mul }\end{array}$ & $\begin{array}{l}\text { Misc } \\
\text { wells }^{b}\end{array}$ & $\begin{array}{l}\text { Oil- } \\
\text { gas }\end{array}$ & $\begin{array}{c}\text { Total } \\
\text { gas }\end{array}$ & $\begin{array}{l}\text { Total } \\
\text { wells }\end{array}$ & $\begin{array}{c}\% \\
\text { gas }^{\mathrm{c}}\end{array}$ \\
\hline $15-16$ & 522 & 1,501 & 28 & 47 & 4 & 17 & 1,548 & 2,119 & 73 \\
\hline $16-17$ & 244 & 924 & 11 & 40 & 4 & 7 & 964 & 1,230 & 78 \\
\hline $17-18$ & 130 & 563 & 7 & 11 & 8 & 2 & 574 & 721 & 80 \\
\hline $18-19$ & 66 & 338 & 0 & 9 & 2 & 3 & 347 & 418 & 83 \\
\hline $19-20$ & 27 & 199 & 1 & 11 & 1 & 0 & 210 & 239 & 88 \\
\hline $20-21$ & 18 & 115 & 0 & 1 & 8 & 0 & 116 & 142 & 82 \\
\hline $21-22$ & 7 & 86 & 0 & 1 & 2 & 0 & 87 & 96 & 91 \\
\hline $22-23$ & 2 & 119 & 0 & 0 & 3 & 0 & 119 & 124 & 96 \\
\hline $23-24$ & 0 & 14 & 0 & 0 & 3 & 0 & 14 & 17 & 82 \\
\hline $24-25$ & 0 & 4 & 0 & 0 & 1 & 0 & 4 & 5 & 80 \\
\hline $25-26$ & 0 & 7 & 0 & 0 & 0 & 0 & 7 & 7 & 100 \\
\hline $26-27$ & 0 & 1 & 0 & 0 & 0 & 0 & 1 & 1 & 100 \\
\hline $27-28$ & 0 & 0 & 0 & 0 & 0 & 0 & 0 & 0 & \\
\hline $28-29$ & 0 & 0 & 0 & 0 & 0 & 0 & 0 & 0 & \\
\hline Total & 1,016 & 3,871 & 47 & 120 & 36 & 29 & 3,991 & 5,119 & \\
\hline
\end{tabular}

${ }^{a}$ Data taken from PI-Dwights WHCS file updated through December 1998 (IHS Energy Group, 1998). Only includes wells having producing formation same as formation at total depth.

${ }^{\mathrm{b}}$ Includes miscellaneous wells, injection wells, and wells with no designation.

c $\%$ gas equals percent total producing wells completed as gas wells (gas and gas mul columns combined). 
o) Table 4. Numbers of deep producing wells by depth interval in U.S. by region ${ }^{\mathrm{a}}$.

[Depth intervals in thousands of feet where $15=$ interval of 15,000 to $16,000 \mathrm{ft}$. Total number of producing wells for each depth interval is on left and number of gas producing wells is on right]

\begin{tabular}{|c|c|c|c|c|c|c|c|c|c|c|c|c|c|}
\hline $\begin{array}{l}\text { Depth interval......... } \\
\text { Region }\end{array}$ & 15 & 16 & 17 & 18 & 19 & 20 & 21 & 22 & 23 & 24 & 25 & 26 & Total \\
\hline Rocky Mountains & $143-39$ & $79-20$ & $41-13$ & $21-16$ & $8-7$ & $6-6$ & & & & & & & 298-101 \\
\hline Midcontinent & $239-214$ & $138-134$ & $125-122$ & 79-77 & $28-26$ & $14-14$ & 6-6 & 4-4 & $1-1$ & 3-3 & $1-1$ & $1-1$ & $639-603$ \\
\hline Permian basin & $109-100$ & $56-43$ & $73-63$ & $35-32$ & $47-38$ & $41-32$ & $48-46$ & $103-100$ & $8-5$ & $2-1$ & $5-5$ & $0-0$ & $527-465$ \\
\hline Gulf Coast (onshore) & $1,095-829$ & $638-522$ & $311-247$ & 216-172 & $122-105$ & $69-57$ & $29-27$ & $10-8$ & $5-5$ & & $1-1$ & & $2,496-1,973$ \\
\hline California-Alaska & $31-3$ & $17-1$ & 8-0 & $3-0$ & $1-1$ & $0-0$ & $2-0$ & $0-0$ & & & & & $62-5$ \\
\hline Federal Offshore & $502-316$ & $302-204$ & $163-118$ & $64-41$ & $33-22$ & $12-6$ & $11-7$ & 7-7 & $3-3$ & & & & $1,097-724$ \\
\hline Total & $2,119-1,501$ & $1,230-924$ & $721-563$ & $418-338$ & 239-199 & $142-115$ & $96-86$ & $124-119$ & $17-14$ & $5-4$ & $7-7$ & $1-1$ & $5,119-3,871^{\mathrm{b}}$ \\
\hline
\end{tabular}

a Data taken from PI-Dwights WHCS file updated through December 1998 (IHS Energy Group, 1998). Only includes wells with producing formation same as formation at total

ڤ depth (total $=5,119$ wells).

P $\quad \mathrm{b}$ Total number of gas producing wells does not include 120 wells from multiple producing formations. 
Table 5. Total deep producing wells by depth interval in U.S. by decade of completion ${ }^{\mathrm{a}}$.

[Data for 1980's decade incomplete because PI-WHCS available only through 1988. Data for 1990's decade only through December 1998 (IHS Energy Group, 1998). First number represents total producing wells for that depth interval and decade; second number (following dash) represents wells producing gas for that depth interval]

\begin{tabular}{|c|c|c|c|c|c|c|c|}
\hline $\begin{array}{c}\text { Depth } \\
\text { interval } \\
\text { (X1,000 ft) }\end{array}$ & 1930 & 1940 & 1950 & 1960 & 1970 & $1980-88$ & 1989-98 \\
\hline $15-16$ & & $1-0$ & $5-5$ & $61-21$ & $394-260$ & $678-534$ & $708-506$ \\
\hline $16-17$ & & & $1-1$ & $14-9$ & $319-224$ & $365-281$ & $376-307$ \\
\hline $17-18$ & & & $1-1$ & $9-3$ & $152-106$ & $233-200$ & $201-156$ \\
\hline $18-19$ & & & & $1-1$ & $108-90$ & $157-137$ & 99-76 \\
\hline $19-20$ & & & & $1-0$ & $67-59$ & 99-96 & $53-38$ \\
\hline $20-21$ & & & & $13-5$ & $45-38$ & $44-42$ & $24-16$ \\
\hline $21-22$ & & & & $9-8$ & $25-23$ & $44-44$ & $13-7$ \\
\hline $22-23$ & & & & $17-17$ & $76-74$ & $17-16$ & $9-9$ \\
\hline $23-24$ & & & & & 6-6 & 6-6 & $3-3$ \\
\hline $24-25$ & & & & & $3-2$ & $1-1$ & $1-1$ \\
\hline $25-26$ & & & & & $1-1$ & $6-6$ & \\
\hline $26-27$ & & & & & $2-1$ & & \\
\hline $27-28$ & & & & & & & \\
\hline Total & & $1-0$ & $7-7$ & $125-64$ & $1,198-884$ & $1,650-1,363$ & $1,487-1,113$ \\
\hline Grand Total & & & & & & & $4,468-3,431$ \\
\hline
\end{tabular}

${ }^{\text {a }}$ For columns through 1988, data taken from PI-WHCS file updated through February 1988 (Petroleum Information Corp., 1988). This data set does not include 292 deep producing wells with unlisted well completion year. For column 1989-98, data taken from PI-Dwights WHCS file updated from January 1989 through December 1998. Only includes wells having producing formation same as formation at total depth. Data for 651 wells completed from March through December 1988 not included.

been drilled deeper than 15,000 feet $(4,572 \mathrm{~m})$ in the U.S. since the first deep well was drilled in 1920, according to data in PIDwights WHCS data files through December 1998. Of these 20,715 wells, 11,522 wells are classed as producing wells that could be producing oil and (or) gas at any depth (above or below 15,000 feet $-4,572 \mathrm{~m}$ ). Nearly as many gas wells exist as dry holes; gas wells $(8,600)$ are more than three times more abundant than oil wells $(2,829)$. In the PI-Dwights WHCS files, 1,676 wells have a total depth greater than 20,000 feet $(6,096 \mathrm{~m})$.

Of the 11,522 producing wells in PI-Dwights, 5,119 wells have a formation at total depth equal to the producing formation. These wells represent a minimum number that are producing oil and gas below 15,000 feet $(4,572 \mathrm{~m})$. For all depths together, gas wells make up nearly 78 percent of the deep wells producing from formations encountered at total depth. Deep producing wells are distributed in six regions of the U.S.: Rocky Mountains, Midcontinent, Permian basin, Gulf Coast onshore, California-Alaska, and the Federal Offshore. Of these six regions, the onshore Gulf Coast region includes the greatest number of deep producing wells with 2,496 wells, followed by the Federal Offshore region with 1,097 wells.

\section{References Cited}

Dyman, T.S., Nielsen, D.T., Obuch, R.C., Baird, J.K., and Wise, R.A., 1990, Summary of deep oil and gas wells and reservoirs in the U.S. from the Well History Control System and Petroleum Data System: U.S. Geological Survey Open File Report 90-305, 35 p.

Dyman, T.S., Rice, D.D., Nielsen, D.T., Obuch, R.C., and Baird, J.K., 1993, Geologic and production characteristics of deep oil and gas wells and reservoirs in the conterminous U.S., in Johnson, K.S., and Campbell, J.A., eds., Petroleum-reservoir geology in the southern Midcontinent, 1991 Symposium: Oklahoma Geological Survey Circular 95, p. 208-215.

IHS Energy Group, 1998, PI-Dwights WHCS (through October 1998): Available from IHS Energy Group, Denver, CO 80112.

Petroleum Information Corporation, 1988, Well History Control System (through February 1988): Available from Petroleum Information Corporation, Denver, CO 80122. 


\section{Chapter C}

\section{Geology and Natural Gas Potential of Deep Sedimentary Basins in the Former Soviet Union}

By Thaddeus S. Dyman, Vadim A. Litinsky, and Gregory F. Ulmishek

Prepared in cooperation with the U.S. Department of Energy-National Energy Technology Laboratory, the Gas Technology Institute, and

Advanced Resources International

U.S. Department of the Interior

U.S. Geological Survey 


\section{Contents}

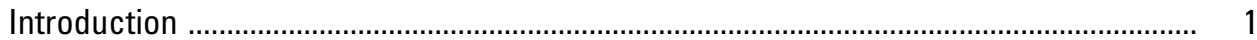

Dnieper-Donets Basin ....................................................................................................... 1

Tectonic and Sedimentary History . .................................................................... $\quad 6$

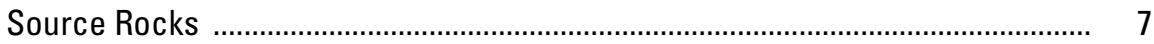

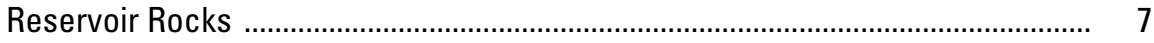

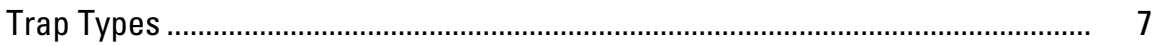

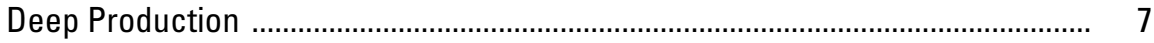

Vilyuy Basin .......................................................................................................... 8

Tectonic and Sedimentary History . ...................................................................... $\quad 9$

Source Rocks ............................................................................................ 10

Reservoir Rocks ............................................................................................. 10

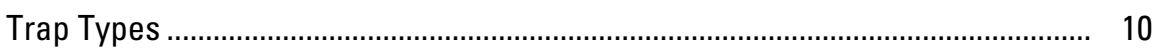

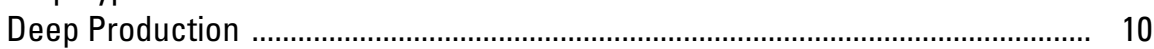

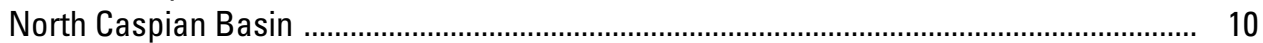

Tectonic and Sedimentary History . .................................................................... 10

Source Rocks .................................................................................................... 13

Reservoir Rocks ....................................................................................... 13

Trap Types .................................................................................................. 13

Deep Production ............................................................................................... 13

Middle Caspian Basin ............................................................................................ 14

Tectonic and Sedimentary History . ..................................................................... 14

Source Rocks ........................................................................................... 14

Reservoir Rocks .............................................................................................. 14

Trap Types ......................................................................................................... 16

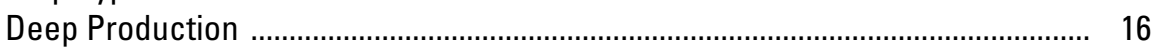

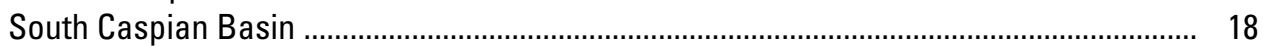

Tectonic and Sedimentary History ................................................................. 18

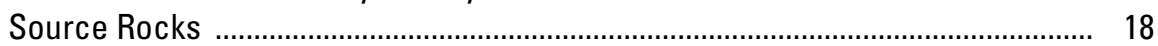

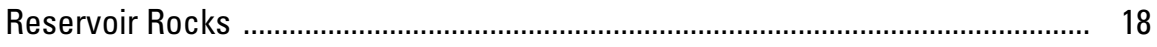

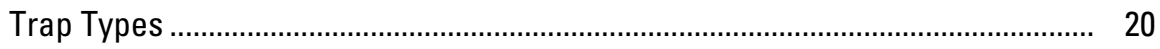

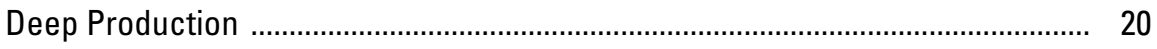

Amu-Darya Basin .................................................................................................. 21

Tectonic and Sedimentary History ..................................................................... 21

Source Rocks ................................................................................................... 21

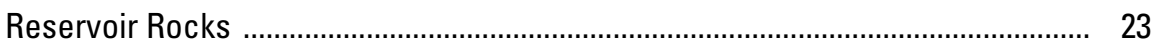

Trap Types ................................................................................................ 24

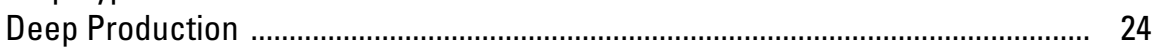

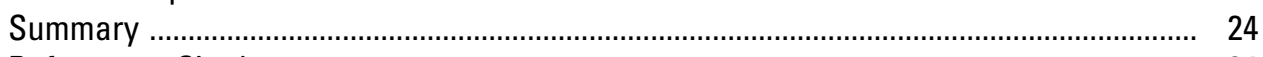

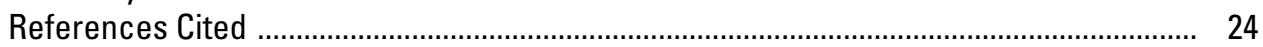




\section{Figures}

1. Map of sedimentary basins of the Former Soviet Union .......................................... 2

2. Map of Dnieper-Donets basin showing political boundaries, gas fields, and major geologic and geographic features

3. Generalized stratigraphic column of Dnieper-Donets basin .....

4. Map of Vilyuy basin showing political boundaries, gas fields, and major geologic and geographic features

5. Generalized stratigraphic column of Vilyuy basin

6. Map of North Caspian basin showing political boundaries, gas fields, and major geologic and geographic features

7. Generalized stratigraphic column of North Caspian basin

8. Map of Middle Caspian basin showing political boundaries, gas fields, and major geologic and geographic features

9. Generalized stratigraphic column of Middle Caspian basin ..................................... 16

10. Map of South Caspian basin showing political boundaries, gas fields, and major geologic and geographic features

11. Generalized stratigraphic column of South Caspian basin

12. Map of Amu-Darya basin showing political boundaries, gas fields, and major geologic and geographic features

13. Generalized stratigraphic column of Amu-Darya basin

\section{Tables}

1. Geologic data for deep gas basins and areas of the Former Soviet Union

2. Geologic data for 21 representative deep fields and reservoirs in Dnieper-

Donets, North Caspian, Middle Caspian, South Caspian, and

Amu-Darya basins 


\title{
Geology and Natural Gas Potential of Deep Sedimentary Basins in the Former Soviet Union
}

\author{
By Thaddeus S. Dyman, Vadim A. Litinsky, ${ }^{1}$ and Gregory F. Ulmishek
}

\section{Introduction}

Deep sedimentary basins in the Former Soviet Union (FSU) (having sedimentary rocks in excess of 15,000 feet$4,572 \mathrm{~m}$ thick) comprise a total area greater than 1.5 million $\mathrm{mi}^{2}$ $\left(3.9\right.$ million $\mathrm{km}^{2}$ ). Some of these basins are among the deepest in the world with depths to basement exceeding 65,000 feet (about $20 \mathrm{~km}$ ) (table 1). Deep basins occur in both offshore and onshore areas of the FSU and extend from the Arctic Shelf in the north, to the Sea of Okhotsk and the Kamchatka Peninsula in the east, the Central Asian republics in the south, and Ukraine in the west. These basins formed in a wide variety of plate-tectonic regimes and include rift basins, foreland basins, collisional passive margins, and pull-apart (small oceanic) basins.

In this report, we summarize the distribution of deep sedimentary basins, their geologic framework, and their potential for deep natural gas resources (fig. 1; table 1) in order to determine the future of deep undiscovered natural gas resources in the FSU. Some of the basins presented here contain oil and gas fields discovered at great depths. Other basins have not been deeply drilled, but the potential for future discoveries remains high. For many basins, little or no data are available-particularly those basins in the Arctic offshore and Russian Far East (Oil and Gas Journal, 1998).

Six of these basins-Dnieper-Donets, Vilyuy, North Caspian, Middle Caspian, South Caspian, and Amu Darya-were chosen for discussion in this report (fig. 1), and their geologic and production characteristics are presented in the following sections. We selected these basins from a complete list in table 1 based on an analysis of the geologic characteristics and production potential leading to future development of deep oil and gas resources. For each basin, we discuss location, tectonic and sedimentary history, principal source and reservoir rocks, trapping mechanisms, and potential for deep production. Basin maps are from the Map of Petroleum Potential of the U.S.S.R. (Gabrielyants, 1990) and from Gramberg and Pogrebitsky (1984) but have been simplified to include only the most important geologic features that pertain to the potential distribution of deep oil and gas resources. Each basin map includes basin boundary, major structural boundaries, and

\footnotetext{
${ }^{1}$ Consultant, Aurora, Colo.
}

faults. Existing gas fields are identified on our maps regardless of depth, and the portions of each basin below 15,000 feet (about $4.5 \mathrm{~km}$ ) are shaded. Our primary emphasis in this report is on natural gas, but deep oil resources are also included in our summary because many deep plays in the FSU have both oil and gas potential.

Table 1 lists all known basins of the FSU that contain sedimentary rocks deeper than $4.5 \mathrm{~km}$; it includes basin name, location, and size of the deep portions of the basin in square kilometers; maximum depth; chief reservoirs; plate-tectonic classification of basin; and notes on deep gas production potential for each basin.

This report was funded in part by the Gas Research Institute, Chicago, Ill. (contract No. 50942103366) and the Energy Resources Program of the U.S. Geological Survey, Denver, Colo. We acknowledge Vello Kuuskraa of Advanced Resources International, Arlington, Va., and Tim Klett, USGS, Denver, Colo., for their careful and thoughtful reviews of this manuscript.

\section{Dnieper-Donets Basin}

The Dnieper-Donets basin is an elongated depression located in the eastern part of Ukraine (figs. 1,2). The northeastern basin boundary is marked by the Voronezh regional high above which the Precambrian basement of the Russian craton is covered by a thin veneer of Paleozoic sedimentary rocks. The Ukrainian shield borders the basin to the southwest. The basin is separated from the Pripyat basin of Byelarus by the Loev-Bragin uplift. The southeastern basin boundary includes anticlines of the Donbas foldbelt which gradually plunge into the basin and lose their tectonic expression (Law and others, 1998; Ulmishek and others, 1994).

The basin includes an area of about $8,880 \mathrm{mi}^{2}(23,000$ $\mathrm{km}^{2}$ ) that contains sedimentary rocks more than 15,000 feet (about $4.5 \mathrm{~km}$ ) thick. The basin is a Late Devonian rift that separated the Ukrainian shield from the main body of the Precambrian Russian craton. The basement is encountered at a depth of $13,000-16,000$ feet (about 4-5 km) in the northwestern part of the basin but dips along its strike southeastward such that it lies below 49,000 feet (about $15 \mathrm{~km}$ ) near the Donbas foldbelt (fig. 2). The Donbas foldbelt is a structurally inverted and deformed continuation of the rift (Kabyshev, 1987). 


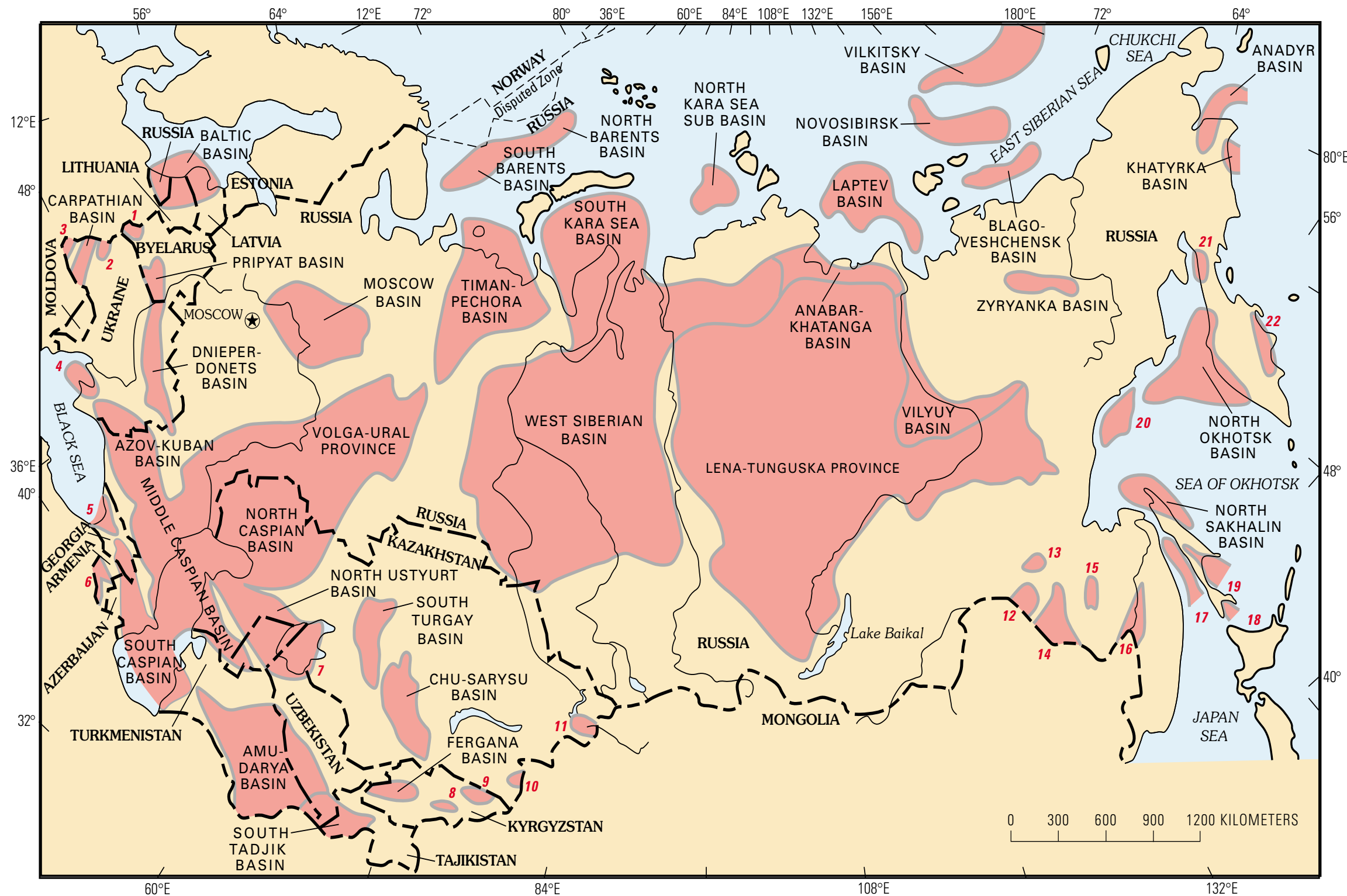

Figure 1. Sedimentary basins of the Former Soviet Union. Numbered basins as follows: 1, Brest; 2, Lvov; 3, Transcarpathian; 4, North Black Sea-Crimean; 5 , Rioni; 6, Araks; 7, East Aral 8, Naryn; 9, Issyk-Kul; 10, Ili; 11, Zaysan; 12, Ushumun; 13, Upper Zeya; 14, Zeya-Bureya; 15, Upper Bureya; 16, Middle Amur; 17, West Sakhalin; 18, Aniva; 19, South Sakhalin; 20, West Okhotsk; 21, Kinkil; 22, East Kamchatka. 
Table 1. Geologic data for deep gas basins and areas of the Former Soviet Union.

[Basin size, areal extent of portion of basin below $4.5 \mathrm{~km}$. Basins sorted by size; na, data not available]

\begin{tabular}{|c|c|c|c|c|c|c|}
\hline Basin & Location & $\begin{array}{l}\text { Size } \\
\text { (sq. km) }\end{array}$ & Chief deep reservoir & $\begin{array}{l}\text { Max. } \\
\text { depth }\end{array}$ & Deep gas possibilities & Basin classification \\
\hline North Caspian & Northern part of Caspian Sea & 518,000 & Permian-Carb-Devonian (carb) & $20 \mathrm{~km}+$ & Good, overpressures & Rift basin \\
\hline Middle Caspian & Eastern part of North Caucasus & 430,000 & Cretaceous-Triassic (carb-clastic) & $12 \mathrm{~km}$ & Good, overpressures & Foreland basin \\
\hline West Sib.- S. Kara Sea & Western Siberia & 405,000 & Paleozoic-Mesozoic (carb) & $12 \mathrm{~km}$ & Unknown & Jurassic-Tertiary sag-Triassic rift basin \\
\hline Lena-Tunguska & Siberian craton & 385,000 & Middle-Late Proterozoic (carb-clastic) & $7 \mathrm{~km}+$ & Unknown & Rift basin \\
\hline South Caspian & Turkmenistan-Iran-Azerbaijan & 207,000 & Pliocene (clastic) & $25 \mathrm{~km}$ & Excellent & Intermontane depression of Alpine System \\
\hline Amu-Darya & Uzbekistan-Afghanistan & 150,000 & Jurassic (carb-clastic) & $10 \mathrm{~km}+$ & Good-major gas producer of FSU & Mesozoic-Tertiary sag over Mes.-Perm. rift \\
\hline Vilyuy & Eastern margin Siberian craton & 115,000 & Permian (clastic) & $12 \mathrm{~km}+$ & Basin-centered gas possibilities & Rift-foreland basin complex \\
\hline Timan-Pechora & Northeastern European Russia & 68,000 & Devonian, Silurian & $12 \mathrm{~km}$ & Good, H2S problems & Foreland basin \\
\hline Volga-Ural & Eastern European Russia & 55,000 & Devonian, Carboniferous, Permian & $10 \mathrm{~km}+$ & Good, but in limited areas & Foreland basin \\
\hline North Ustyurt & Kazakhstan & 43,000 & Paleozoic Carb?-clastic & $11 \mathrm{~km}+$ & Unknown & Mesozoic-Tertiary sag-complex \\
\hline Azov-Kuban & Western part of North Caucasus & 25,000 & Cretaceous-Jurassic (clastic) & $12 \mathrm{~km}+$ & Fair, overpressures & Foreland basin \\
\hline Dnieper-Donets & Eastern Ukraine & 23,000 & Permian-Carb (carb-clastic) & $15 \mathrm{~km}$ & Good, overpress., basin-centered (?) & Rift basin \\
\hline North Sakhalin & Northern part of Sakhalin Island & 20,000 & Miocene-Pliocene (clastic) & $11 \mathrm{~km}$ & Unknown & Rift/delta \\
\hline South Tadjik & Tajikistan-Uzbekistan & 17,000 & Jurassic (carb) & $14 \mathrm{~km}$ & Unknown- $\mathrm{H}_{2} \mathrm{~S}$ problems & Collisional passive margin \\
\hline Fergana & Uzbekistan-Tadjikistan-Kyrgystan & 5,000 & Paleogene (carb-clastic) & $10 \mathrm{~km}$ & Good, overpressures & Intermontane depression of Alpine System \\
\hline Carpathian & Ukraine & 4,000 & Paleogene-Mesozoic (clastic) & $8 \mathrm{~km}+$ & Good & Thrusted fold belt-flysch basin \\
\hline North Okhotsk & Sea of Okhotsk & na & Cretaceous-Tertiary (clastic) & $10 \mathrm{~km}+$ & Unknown & Rift basins-horst/graben complexes \\
\hline South Barents & Arctic Shelf & na & Triassic-Jurassic(?) (carb-clastic) & $20 \mathrm{~km}$ & Unknown & Paleozoic rift basin \\
\hline North Barents & Arctic Shelf & na & Triassic-Jurassic(?) (carb-clastic) & $15 \mathrm{~km}$ & Unknown & Paleozoic rift basin \\
\hline North Kara Sea & Arctic Shelf & na & Triassic-Jurassic(?) (carb-clastic) & $10 \mathrm{~km}$ & Unknown & Paleozoic rift basin \\
\hline Laptev Sea & Arctic Shelf & na & na & $12 \mathrm{~km}+$ & Unknown & Complex rift basin \\
\hline Blagoveshchensk & Arctic Shelf & na & na & $6 \mathrm{~km}$ & Unknown & Unknown \\
\hline Novosibirsk & Arctic Shelf & na & Cretaceous-Tertiary (?) & na & Unknown & Unknown \\
\hline Vilkitsky & Arctic Shelf & na & Cretaceous-Tertiary (?) & na & Unknown & Unknown \\
\hline Anabar-Khatanga & E. part Siberian craton & na & Triassic-Permian (clastic?) & $8 \mathrm{~km}+$ & Unknown & Deformed rift basin \\
\hline
\end{tabular}


Table 1-Continued. Geologic data for deep gas basins and areas of the Former Soviet Union.

[Basin size, areal extent of portion of basin below $4.5 \mathrm{~km}$. Basins sorted by size; na, data not available]

\begin{tabular}{|c|c|c|}
\hline Basin & Deep gas production? & Potential source and reservoir rocks \\
\hline North Caspian & Yes & Devonian-Permian black shales \\
\hline Middle Caspian & Yes & Jurassic, Triassic, Tertiary \\
\hline West Sib.- S. Kara Sea & No, but $80 \%$ of gas overall in Russia & L.-M. Jurassic Tyumen Fm., U. Jurassic Bazhenov Fm. \\
\hline Lena-Tunguska & No & Proterozoic \\
\hline South Caspian & Yes, much deep drilling & Miocene Maykop Series, Diatom Fm. \\
\hline Amu-Darya & Yes, but not developed & Jurassic black shales, coal-bearing rocks \\
\hline Vilyuy & No & Permian, Middle Cambrian \\
\hline Timan-Pechora & No & Devonian Domanik Fm. \\
\hline Volga-Ural & Yes, minor amount & Devonian Domanik Fm., Permian shales \\
\hline North Ustyurt & No & Paleozoic \\
\hline Azov-Kuban & Yes & Miocene Maykop Series, Jurassic \\
\hline Dnieper-Donets & Yes, most explored deep basin in FSU & Devonian and Visean black shales \\
\hline North Sakhalin & No & Miocene siliceous shales \\
\hline South Tadjik & No & Jurassic basinal shales, coal-bearing rocks (?) \\
\hline Fergana & No-some deep oil production & Eocene Suzak Fm. (?), Jurassic coal-bearing rocks \\
\hline Carpathian & No-4 oil fields only, some deep drilling & Oligocene Menilite Fm., Jurassic black shales \\
\hline North Okhotsk & No production in basins/subbasins & Miocene-Oligocene siliceous shales, L. Tertiary coals \\
\hline South Barents & No, but shallow prod. (Shtokman gas field) & Jurassic-Triassic (?) \\
\hline North Barents & No & Jurassic-Triassic (?) \\
\hline North Kara Sea & No & Jurassic-Triassic (?) \\
\hline Laptev Sea & No & Cretaceous-Tertiary coal-bearing rocks (?) \\
\hline Blagoveshchensk & No & Unknown \\
\hline Novosibirsk & No & Unknown \\
\hline Vilkitsky & No & Unknown \\
\hline Anabar-Khatanga & No & Permian coal-bearing rocks (?), Cambrian Kuonam Fm. \\
\hline
\end{tabular}




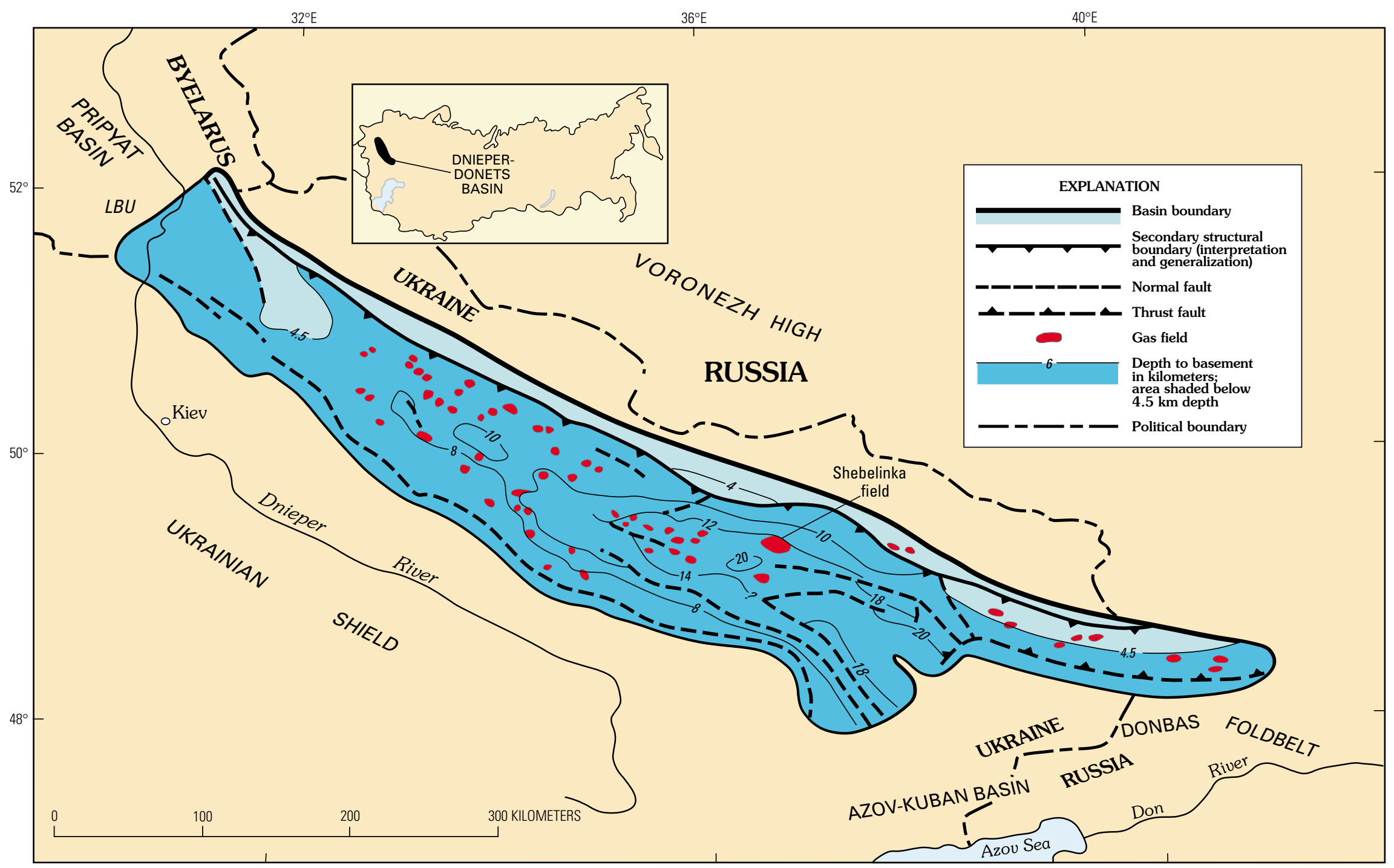

Figure 2. Dnieper-Donets basin showing political boundaries, gas fields, and major geologic and geographic features discussed in text. Dark shade, portion of basin with sedimentary rocks below $4.5 \mathrm{~km}$. LBU, Loev-Bragin uplift. 


\section{Tectonic and Sedimentary History}

Middle Devonian clastic rocks were deposited on Proterozoic and Archean basement and compose a pre-rift platform sequence (fig. 3). Initial rifting occurred in the Late Devonian (Frasnian) and increased in intensity from the northwest to the southeast due to clockwise rotation of the Ukrainian shield relative to the Russian craton (Ulmishek and others, 1994). Oceanic crust underlies both the southeastern part of the DnieperDonets basin and the Donbas foldbelt. The rift was filled with carbonate and evaporite rocks of Frasnian and Famennian age.
Concurrently, clastic rocks derived from the Ukrainian shield were deposited along the southeastern margin of the basin, and active volcanism occurred in the northwest. Total thickness of the synrift sequence is estimated at 5-6 km (Kabyshev, 1987). The synrift sequence is unconformably overlain by Carboniferous rocks.

The overlying Carboniferous to Lower Permian sequence was deposited in a post-rift sag that deepened southeastward along the rift strike. Thickness of the post-rift sequence increases in this direction to 26,000 feet (about $8 \mathrm{~km}$ ) or more (fig. 2). The Carboniferous is primarily composed of fluvial and

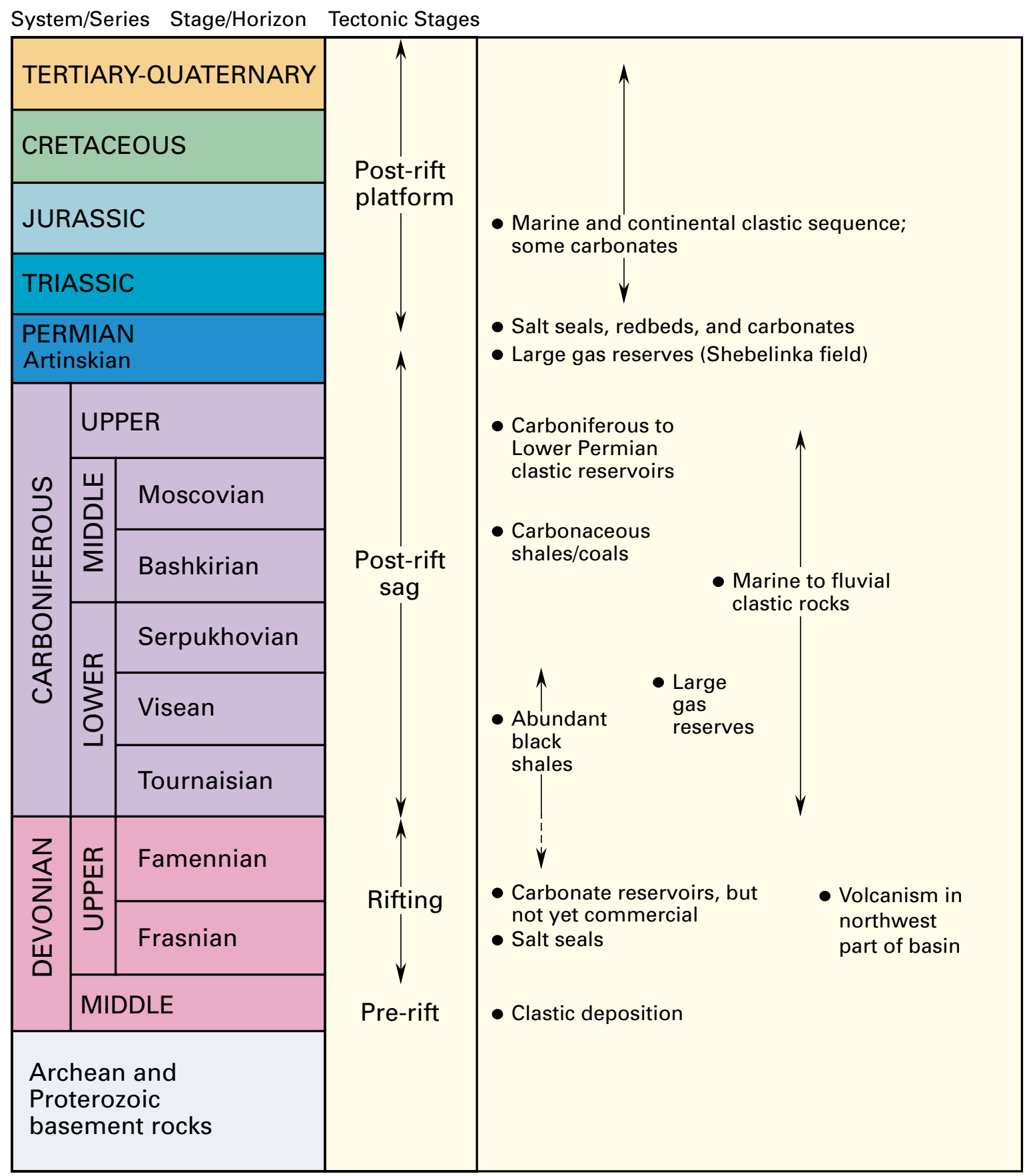

Figure 3. Major geologic events, primary source and reservoir rocks, and basin history of Dnieper-Donets basin. Dashed line below black shales indicates that they may extend into the Devonian. 
marine clastic rocks, but some Visean and Bashkirian carbonates are present on the margins in the basin (fig. 3). The Middle to Upper Carboniferous section is composed of rocks deposited in coastal settings and includes abundant coal beds. During the Early Permian, redbeds, carbonates, and salt were deposited in the basin. The Upper Permian salt seal controls the major gas reserves of the basin (fig. 3). During the late Early Permian (Artinskian), a collision with micro-continents along the southern border of the Russian craton resulted in compressional stress and termination of the post-rift sag stage of basin development. The deepest part of the Paleozoic rift/sag basin was then structurally inverted, thrusted, and folded resulting in the Donbas foldbelt. The entire basin was subsequently uplifted and eroded (Law and others, 1998). Truncation of older rocks was greatest in the southeastern part of the basin.

Sedimentation resumed during the Triassic and continued into the Tertiary; resulting deposits were mostly marine clastics (fig. 3). Pre-Tertiary uplift and erosion occurred in approximately the same areas affected by pre-Triassic erosion. Plastic flow of Devonian salt began in the Early Carboniferous, and formation of salt domes and plugs continued into Tertiary time (Kurilyuk and others, 1991).

\section{Source Rocks}

Knowledge of source rocks in the Dnieper-Donets basin is scant, especially in the southeastern part, because of a lack of deep drillhole data. At least two major source rocks are presumed to exist: Devonian (Famennian) and Lower Carboniferous (Visean) black shales (fig. 3). Devonian shales have not been cored in wells but their presence is indicated by geochemical analyses of oils (U.S. Geological Survey, unpub. data, 1998). Visean shales have total organic carbon (TOC) content ranging from 3 to 13 percent and are primarily gas generating Type-III source rocks (Law and others, 1998). They are highly mature in the northwestern part of the basin and overmature elsewhere.

A third potential source rock, coals and carbonaceous shales of the Middle Carboniferous, is also a possible source of gas, but source-rock data are not available from this interval (fig. 3) (Law and others, 1998). The average present-day temperature at a depth of 16,000 feet (about $5 \mathrm{~km}$ ) is about $150^{\circ} \mathrm{C}$. Throughout most of the basin area, potential source rocks occur deeper than $5 \mathrm{~km}$ (Ammosov and others, 1977).

\section{Reservoir Rocks}

Most reservoirs in the Dnieper-Donets basin are found in Carboniferous to Lower Permian sandstones. Additionally, Lower Permian fractured carbonates are also productive in a few large gas fields including the giant Shebelinka field (figs. 2, 3). The largest reserves are concentrated in multiple productive intervals within the Lower Permian and Visean sections (Ulmishek and others, 1994). According to Khanin (1979), reservoir quality is good to depths of 9,800-11,500 feet (about 3$3.5 \mathrm{~km}$ ) (porosity 20-22 percent; permeability in hundreds of millidarcies range), but it decreases at greater depths such that porosity seldom exceeds $12-14$ percent at 15,000 feet $(4,572 \mathrm{~m})$ except where overpressures occur. More recent data on reservoir quality were not available for this report.

At great depths, permeability is controlled primarily by fracturing. Porosity of some deep sandstone reservoirs (deeper than 16,400 feet - about $5 \mathrm{~km}$ ) may be 14-17 percent or greater, and permeability may reach 300 millidarcies (Maksimov and others, 1984). Devonian carbonate reservoirs are not yet commercial, and data on reservoir properties are not available (Ulmishek and others, 1994).

\section{Trap Types}

The most common traps in the Dnieper-Donets basin are faulted anticlines associated with salt domes. Structural traps are also found in the shallower northeastern part of the basin and along the basin margins where Devonian salt is thin or absent. These traps are related to basement structures associated with Devonian rift development. A few gas accumulations have been discovered in stratigraphic traps in updip pinchout zones in sandstone beds. Very little exploration for stratigraphic traps has been conducted, but the potential for new discoveries is high (Ulmishek and others, 1994). Trapping mechanisms for potential basin-centered gas accumulations include abnormal pressures and lithologic controls on fracture development.

\section{Deep Production}

The Dnieper-Donets basin is the most explored deep basin in the FSU. By 1980, 137 prospects had been drilled to depths greater than 15,000 feet (4,572 m) (Krylov, 1980), and during the 1980's about 50 percent of all exploratory wells drilled in the basin reached these depths (Aksionov, 1985). Only a few small deep pools are currently producing from Devonian and Mesozoic reservoirs. The principal reserves are gas, commonly with significant volumes of natural gas liquids (NGL) (table 2). Oil fields are present only in the shallower northwestern part of the basin.

Exploration and production wells in the deep DnieperDonets basin have encountered significant problems. Outdated seismic data have yielded insufficient resolution, and many wells have missed their targets. Deep drilling has also been complicated by significant overpressuring. About 30-40 percent of tested wells flowed gas and (or) oil (Krylov, 1980), but flow rates were commonly low due to poor reservoir quality. The FSU lacked appropriate technologies for stimulation of overpressured reservoirs at great depths. Low flow rates and small accumulation size of many discoveries have hindered further development.

Based on the presence of overpressures and gas shows in deep reservoirs, Law and others (1998) identified a large (more than $13,513 \mathrm{mi}^{2}-35,000 \mathrm{~km}^{2}$ ) unconventional basin-centered gas accumulation in the Dnieper-Donets basin. They suggested that the accumulation could include as much as 23,000 feet (about 7,000 m) of Carboniferous rocks. Wells have tested gas, and proper reservoir stimulation practices could be used to develop a deep commercial accumulation. 


\section{Vilyuy Basin}

The Vilyuy basin is a Late Permian to Mesozoic sag superimposed on the eastern margin of the Siberian craton (figs. 1, 4). The basin also includes a narrow foredeep along frontal thrusts of the Verkhoyansk foldbelt north and south of the sag. The eastern basin boundary adjoins the foldbelt, and the western boundary is associated with a pinchout zone of Mesozoic rocks.
The base of the Permian dips eastward from a depth of a few hundred meters to more than $5 \mathrm{~km}$, and maximum depth to basement reaches $12 \mathrm{~km}$ or more (fig. 4). Throughout approximately $44,401 \mathrm{mi}^{2}\left(115,000 \mathrm{~km}^{2}\right)$ of the total basin area, the basement is deeper than 15,000 feet (4,572 m) (Simakov, 1986). Tectonically, the basin is a southwest-to-northeast-trending Devonian rift with a superimposed foreland basin that is transverse to the rift trend (Kontorovich, 1994).

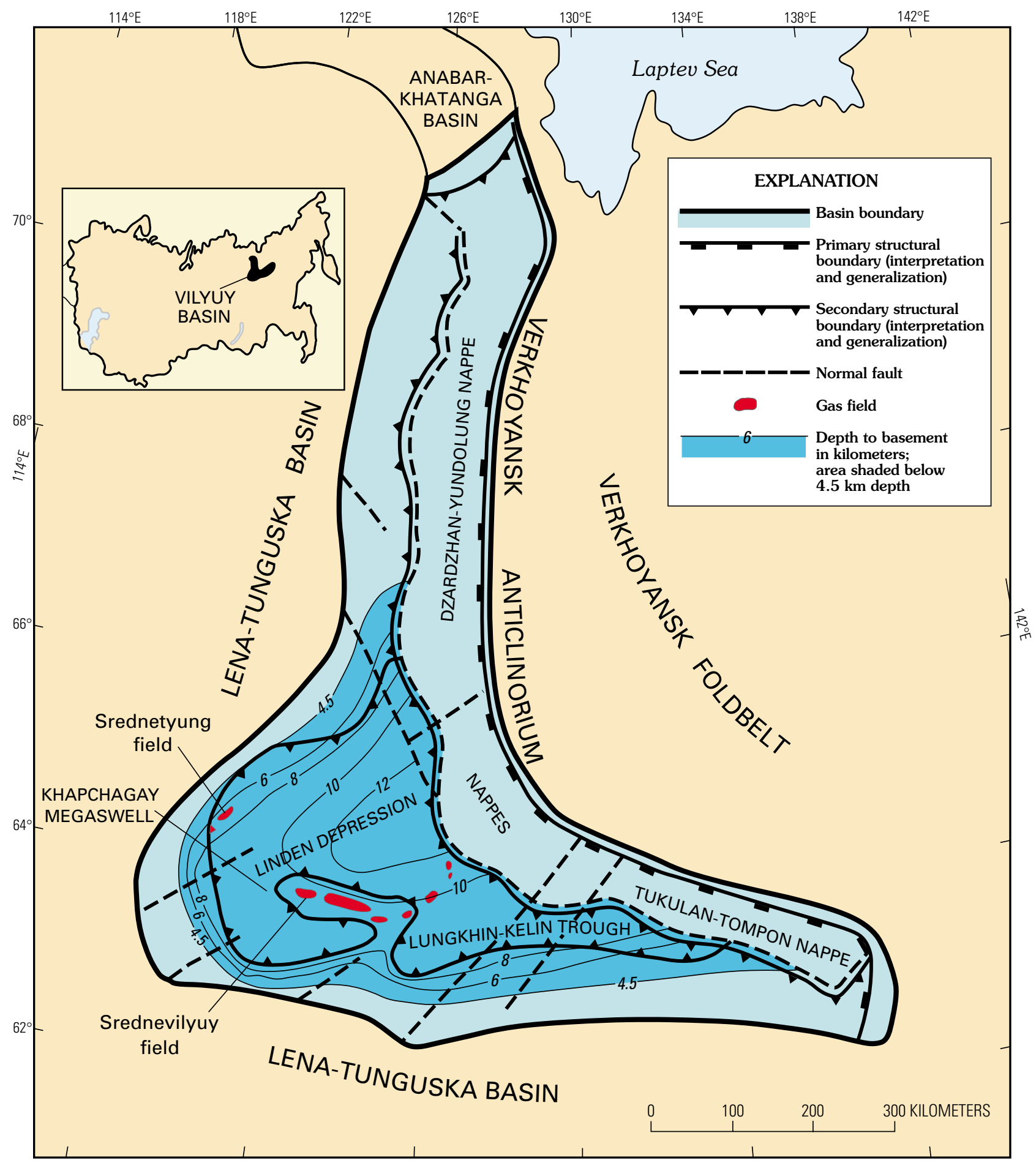

Figure 4. Vilyuy basin showing political boundaries, gas fields, and major geologic and geographic features discussed in text. Dark shade, portion of basin with sedimentary rocks below $4.5 \mathrm{~km}$. 


\section{Tectonic and Sedimentary History}

The Vilyuy basin is underlain by a Proterozoic to lower Paleozoic basement sequence that has been drilled only on the basin margins (fig. 5). A northeast-striking Middle to Late Proterozoic rift sequence is hypothesized to exist below uppermost Proterozoic carbonate and clastic rocks. Rifting also occurred along this same zone of weakness in the Devonian. The latter rift was filled with a thick sequence of volcanic rocks and salt. From late Paleozoic through Jurassic, the Vilyuy basin was a passive continental margin dominated by clastic sedimentation under humid climatic conditions (Kontorovich, 1994). The entire upper Paleozoic through Jurassic sequence in the basin thickens eastward from 1,000 feet (about $300 \mathrm{~m}$ ) to more than 16,000 feet (about $5 \mathrm{~km}$ ) and grades from continental to marine rocks. The continental sequence commonly contains coal beds.

During Late Jurassic and Cretaceous time, the Siberian craton collided with a series of micro-continents that resulted in thrusting, deformation of the basin margin, and development of the Verkhoyansk foldbelt (Dmitriyevsky and others, 1995). A narrow foredeep formed to the west in front of the foldbelt and filled with Cretaceous continental sediments as much as 6,500

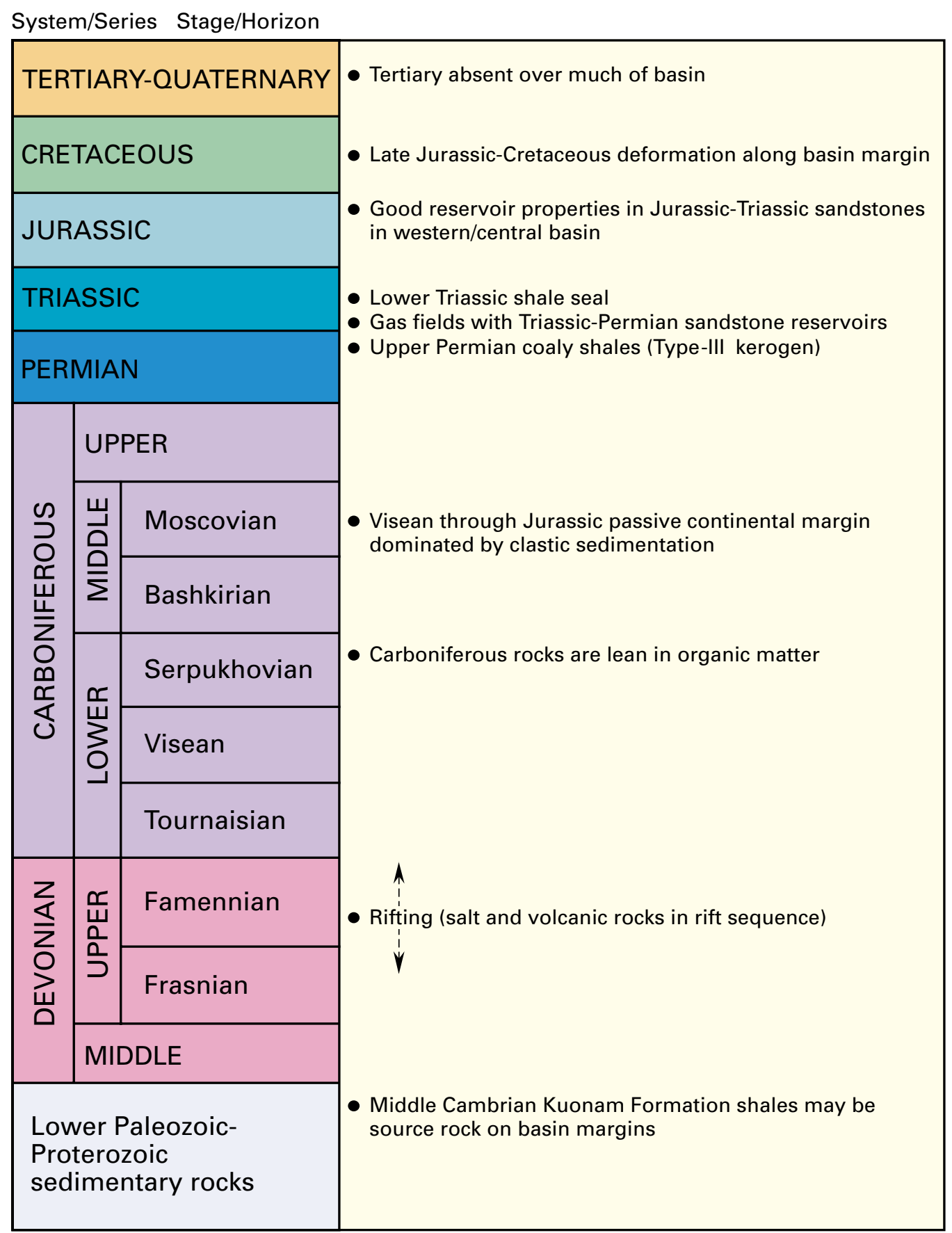

Figure 5. Major geologic events, primary source and reservoir rocks, and basin history of Vilyuy basin. Dashed line above and below rifting stage indicates that rifting may extend throughout the Upper Devonian. 
feet (about $2 \mathrm{~km}$ ) thick. Tertiary sediments are absent in the basin, except in local depressions, where they may be a few hundred meters thick (Kontorovich, 1994).

Based on interpretation of gravity data, a broad thrust system (as much as 49-62 miles-80-100 km wide) is presumed to exist adjacent to the Verkhoyansk foldbelt. This system is composed of intensively folded Paleozoic rocks that were thrust onto the east half of the foredeep. Gravity data suggest that the foredeep is much deeper under the thrust system than under the exposed part of the basin (Litinsky, 1977a; 1977b; Kontorovich, 1994).

\section{Source Rocks}

Source rocks for deep gas in the Vilyuy basin are believed to be Upper Permian shales enriched by coaly organic matter (Type-III kerogen) from interbedded coals (fig. 5). The underlying Lower Permian and Carboniferous rocks are low in organic matter, and younger Triassic rocks are thermally immature with respect to hydrocarbon generation. A very rich (TOC content as much as 20 percent, Type-II kerogen) source rock unit of Middle Cambrian age (Kuonam Formation; fig. 5) is present on the basin margin and apparently dips to great depths in the central part of the basin. However, hydrocarbons directly attributed to the Kuonam Formation have not yet been discovered (Kontorovich, 1994).

\section{Reservoir Rocks}

Triassic and Jurassic sandstones in the western and central parts of the basin occur at depths of less than $3 \mathrm{~km}$ and have high porosity and permeability. These sandstones are laterally discontinuous, and well-developed seals are only locally present. Large gas reserves occur in Triassic reservoirs, but they are almost entirely concentrated in the Srednetyung field at an average depth of 8,858 feet $(2,700 \mathrm{~m})$ and in the Srednevilyuy field at an average depth of 7,874 feet (2,400 m) (Kontorovich, 1994) (fig. 4). Upper Permian reservoir rocks are fair to poor in quality, but they contain significant reserves simply because of the presence of the regional Lower Triassic shale seal at depths of 8,858-11,482 feet (2,700-3,500 m). In general, sandstones of the Upper Permian to Jurassic section decrease in thickness eastward and are replaced by shales. Few adequate reservoir rocks are found in outcrops in the foldbelt and adjacent foredeep. Sandstones exhibit a significant loss of porosity with depth (Kontorovich, 1994).

\section{Trap Types}

Structural traps are dominant in most fields, although many pools are enhanced by stratigraphic pinchouts. The principal fields are found in large, local structures located on linear arches formed by partial inversion of the Devonian rift. Structures are primarily low relief anticlines.

\section{Deep Production}

Ten gas fields have been discovered in the basin. The principal reserves are found in Upper Permian and Triassic clastic reservoirs. All of the discovered gas pools occur at depths of less than 13,100 feet (about $4 \mathrm{~km}$ ), and no wells have been drilled deeper than 15,000 feet $(4,572 \mathrm{~m})$. The potential for significant deep discoveries in conventionally trapped reservoirs may be limited by a loss of porosity with increasing depth. Lower and Upper Permian rocks at depths of 15,000-16,500 feet (about 4.5-5 km) and deeper in most of the central part of the basin are regionally overpressured, and the presence of a basin-centered gas accumulation in low-permeability reservoirs of this age is possible based on indirect data of Safronov and others (1997). Both autochthonous and allochthonous rocks of the Verkhoyansk overthrust belt also are highly prospective as basin-centered gas accumulations (Kontorovich, 1994).

\section{North Caspian Basin}

The North Caspian basin occupies the northern part of the Caspian Sea and a low-lying plain to the north (figs. 1, 6). The basin is about $200,000 \mathrm{mi}^{2}\left(518,000 \mathrm{~km}^{2}\right)$ in area, all of which includes sedimentary rocks deeper than 15,000 feet $(4,572 \mathrm{~m})$. The northern and western basin boundaries with the Volga-Ural basin are steep flexures along which the basement abruptly deepens to 33,000-40,000 feet (about 10-12 km). In the central part of the basin, Precambrian basement is deeper than 65,000 feet (about $20 \mathrm{~km}$ ). The eastern boundary lies along the Ural foldbelt, and the southern continuation of the foldbelt is buried under a thin veneer of Mesozoic rocks. In the south, the basin is bounded by the Karpinsky foldbelt west of the Caspian Sea and by the South Emba uplift east of the Caspian Sea. The basin is a rift underlain by oceanic crust (Malushin, 1985).

\section{Tectonic and Sedimentary History}

The North Caspian basin was formed by rifting of the Archean to lower Proterozoic basement of the Russian craton. The rifting separated a continental crustal block presently expressed as a series of arches along the southern and eastern basin boundaries from the main body of the craton. The age of rifting is not known, although different models suggest a Late Proterozoic, Early Ordovician, or Middle Devonian rift event (Malushin, 1985).

The oldest rocks penetrated by drilling are Middle Devonian carbonates and clastic rocks in the northeastern part of the basin. Seismic data indicate that in the basin center, about $6 \mathrm{~km}$ of lower Paleozoic rocks are present between Precambrian basement and the base of the Middle Devonian sequence. The upper Paleozoic through Tertiary basin fill is separated by Kungurian (uppermost Lower Permian) salt into subsalt and suprasalt sequences (fig. 7). The salt is deformed into domes and plugs; its original depositional thickness in the basin center is estimated to be 13,000 feet (about $4 \mathrm{~km}$ ) (Komissarova, 1986). 


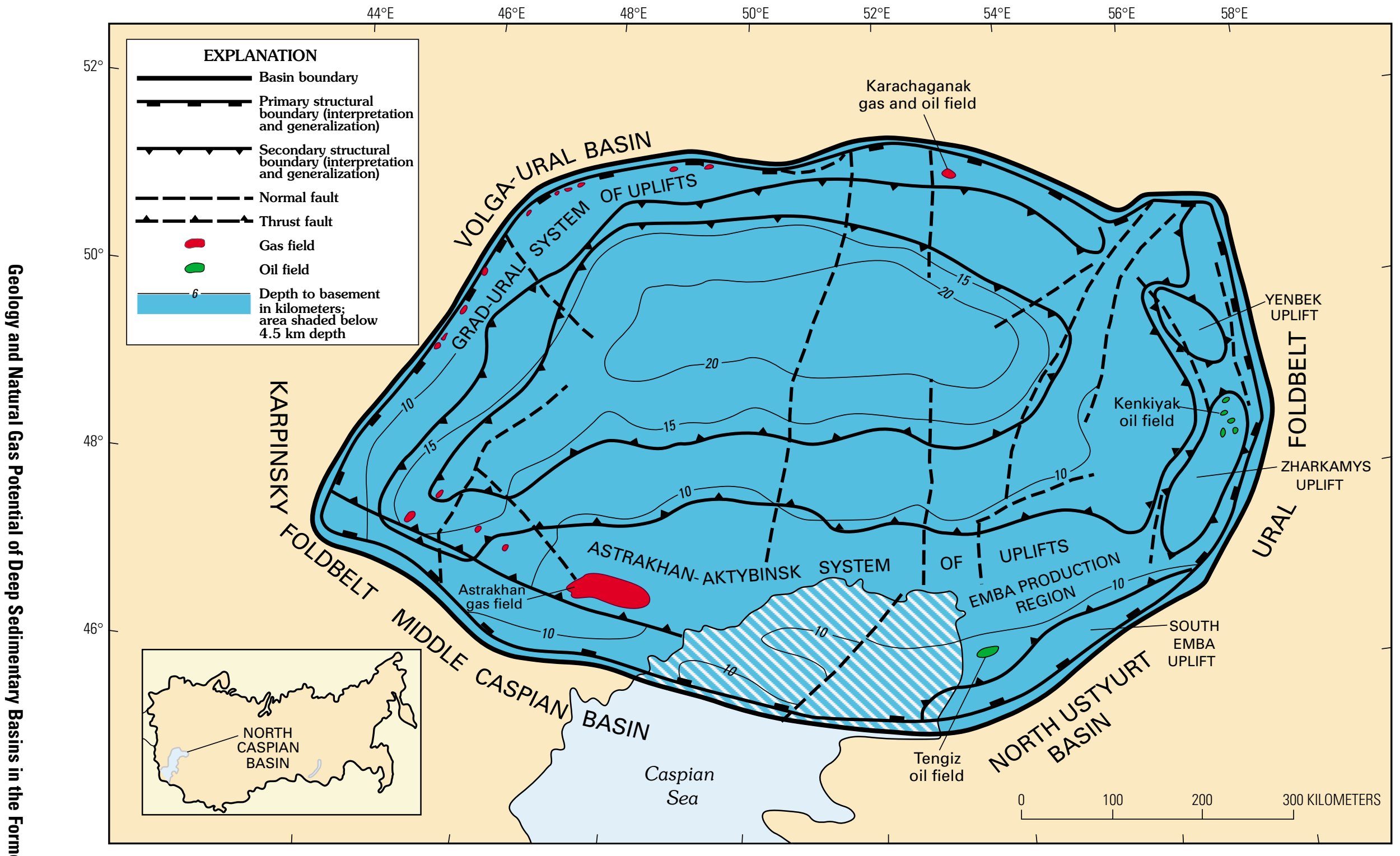

Figure 6. North Caspian basin showing political boundaries, gas fields, and major geologic and geographic features discussed in text. 


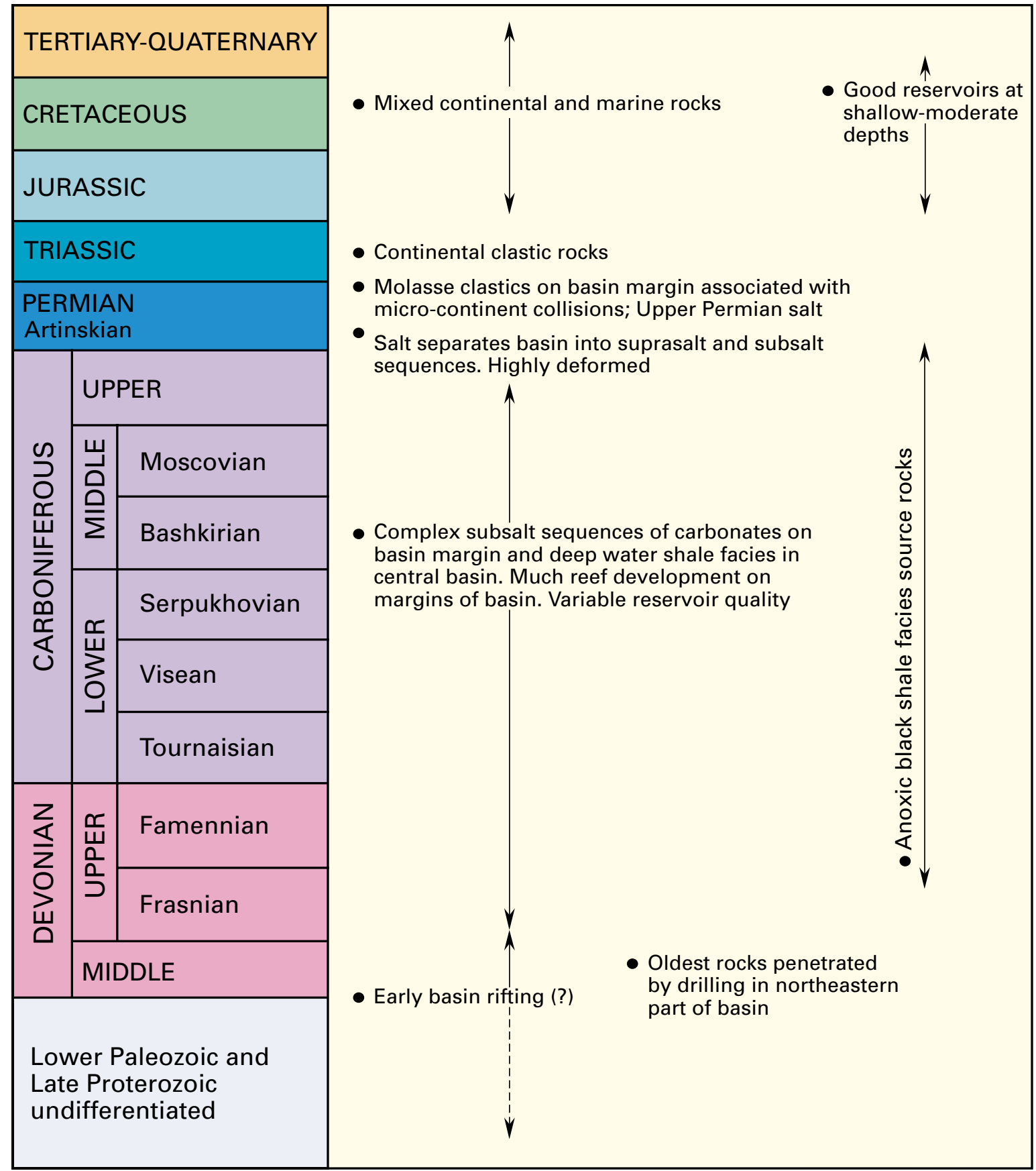

Figure 7. Major geologic events, primary source and reservoir rocks, and basin history of North Caspian basin. Dashed line below early basin rifting event indicates that the event may extend into the lower Paleozoic.

Stratigraphy of the subsalt sequence is complex and varies throughout the basin. In general, the sequence is principally composed of carbonate rocks on the basin margins and a poorly known deep-water basinal facies in the basin center. The top of the subsalt sequence occurs at a depth of about 33,000 feet (about $10 \mathrm{~km}$ ) in the deepest parts of the basin. Shallow-water carbonate rocks along the basin margins contain the principal basin reserves primarily in the widespread Late Devonian through Early Permian reef reservoirs.
During much of the late Paleozoic, the North Caspian basin was a deep-water embayment of the Tethys Sea. Carbonate facies including reefs were formed on surrounding shelves, and deepwater black shales and turbidites were deposited under anoxic conditions in the basin center. Thrusting and orogeny in the Ural Mountains region to the east resulted in deposition of a thick Upper Carboniferous to Lower Permian clastic wedge in adjoining basin areas. The basin margins were uplifted and eroded in pre-Permian time in response to this orogenic compression. 
During the late Early Permian (Artinskian, fig. 7), the basin collided with a system of micro-continents from the south, resulting in development of the Karpinsky foldbelt and uplift of the South Emba high (fig. 6). The basin was subsequently separated from the Tethys Sea (except for a narrow strait in the southwest corner) and was quickly filled with salt (Zonenshain and others, 1990).

The post-Early Permian depositional sequence is primarily composed of continental to shallow marine clastic rocks. At the base of the sequence lie Upper Permian and Triassic continental clastic rocks derived from the Ural uplift. Continental sedimentation was briefly interrupted by marine transgressions in middle Late Permian and Middle Triassic time. The overlying Jurassic to Tertiary stratigraphic sequence is composed of continental and marine clastic rocks (Beznosov, 1987).

\section{Source Rocks}

Because of their extreme depths, source rocks in the central part of the basin are poorly known. They are most likely Upper Devonian to Lower Permian black shale intervals interbedded with deep-water sandstone and siltstone turbidites. These rocks are basinal anoxic facies equivalent to the shallow-water carbonates and reefs of surrounding basin margins. This deep-water facies has been penetrated by only a few wells because drilling has targeted carbonate reservoirs in shallow-water facies.

The North Caspian basin has a low geothermal gradient, and the top of the oil window occurs as deep as 20,000 feet (about $6 \mathrm{~km}$ ). Source rocks are unlikely to exist in the suprasalt sequence, and oil and gas in suprasalt fields probably migrated from subsalt source rocks through migration pathways between salt domes from which the salt was completely withdrawn (Svetlakova, 1987).

\section{Reservoir Rocks}

Reservoir rocks in the subsalt sequence are almost exclusively shallow shelf and reef carbonates. Reservoir quality is highly variable and depends on facies, fracturing, and diagenetic alteration of the carbonate rocks. Pre-Permian erosion resulted in significant leaching of carbonates and formed the best reservoir quality in the supergiant fields. Only a few pools have been found in clastic rocks of the eastern and southeastern basin margins. These sandstone reservoirs have low permeabilities, and reservoir quality depends on fracturing. Pools in subsalt clastic reservoirs have not been commercially developed.

In the suprasalt sequence, productive sandstones of Jurassic and Cretaceous age occur at shallow to moderate depths and possess good reservoir properties. Loss of porosity with depth is substantial, and at 15,000-16,500 feet (about 4.5-5 $\mathrm{km}$ ), porosity of sandstones generally does not exceed 3 percent. Reservoir properties of sandstones in Upper Permian and Triassic continental rocks are much poorer, and these sandstones tend to lose porosity with depth rapidly (Proshlyakov and others, 1987).

\section{Trap Types}

Trapping mechanisms in the North Caspian basin are diverse. The giant Tengiz and Karachaganak fields (fig. 6), and some others are trapped by pinnacle reefs. Barrier reefs contain gas condensate fields on the northern and western margins of the basin, but the fields are much smaller. The unique Astrakhan field (fig. 6) occupies the crest of a regional arch. Several fields along the eastern and southeastern margins of the basin are trapped by anticlines that were probably formed by compressional stress related to the Ural foldbelt and South Emba high. Anticlines of the eastern basin margin are probably associated with thrusts. Fields producing from the suprasalt sequence are in various salt-controlled structural traps.

\section{Deep Production}

Principal oil and gas reserves in the basin occur in subsalt upper Paleozoic rocks. Production from this sequence dates to the 1970's when several oil and gas fields were discovered (Maksimov, 1987). These fields include three supergiants: Astrakhan (gas), Karachaganak (gas condensate and oil), and Tengiz (oil). Significantly smaller reserves (mostly oil) are found in suprasalt Upper Permian and Mesozoic rocks. Most fields producing from suprasalt reservoirs are located in the Emba production region in the southeastern part of the basin (fig. 6).

Several deep accumulations exceeding 15,000 feet $(4,572$ m) are in Lower Permian and Carboniferous reefs along the northern and western basin margins (fig. 7). Porosity of reef carbonates commonly ranges from 10 to 12 percent and permeability ranges from tens to hundreds of millidarcies. These fields contain gas with abundant condensate. Most of these fields are not currently in production because of relatively small reserves and significant overpressures, and data are not currently available for them.

The youngest reservoir at the giant Karachaganak gas field occurs at 12,000 feet (about $3.7 \mathrm{~km}$ ). A single massive sour gas and condensate pool with a thick $(1,000$ feet-about $300 \mathrm{~m})$ oil leg is developed in an Upper Devonian to Middle Carboniferous carbonate atoll overlain by a Lower Permian pinnacle reef. The height of the pool hydrocarbon column is about 5,000 feet (about $1.5 \mathrm{~km}$ ), indicating that production extends to a depth of more than 17,000 feet $(5.2 \mathrm{~km})$. A well drilled in this field in the mid-1990's reached an oil pool in Middle Devonian rocks at a depth of about 18,000 feet $(5.5 \mathrm{~km})$. No information on this discovery is currently available.

The top of the primary reservoir in the supergiant Tengiz oil field lies at a depth of about 13,000 feet (about $4.0 \mathrm{~km}$ ). The reservoir is developed in an Upper Devonian to Bashkirian atoll. Wells drilled to about 18,000 feet $(5.5 \mathrm{~km})$ did not reach the oil-water contact. The field is currently under development by a consortium of international and Russian companies. The oil pool is strongly overpressured, and dissolved gas contains as much as 25 percent hydrogen sulfide (Maksimov, 1987). 


\section{Middle Caspian Basin}

The Middle Caspian basin lies in the east half of the North Caucasus region, the central part of the Caspian Sea, and the South Mangyshlak subbasin to the east (figs. 1, 8). The southern basin boundary follows the Great Caucasus foldbelt on the west and the Karabogaz regional basement high on the east. The northern boundary extends along the Karpinsky ridge (a Mesozoic uplift over a deformed and inverted Paleozoic rift) and the Mangyshlak foldbelt (a deformed and inverted Triassic rift). On the west, the basin is bounded by the Stavropol arch, which separates it from the Azov-Kuban basin (fig. 8). The western onshore part of the Middle Caspian basin is in Russia except for a small part in the southeast which is in Azerbaijan. The South Mangyshlak subbasin is in Kazakhstan. The basin is tectonically heterogeneous; its western part is a typical foreland basin, whereas the South Mangyshlak subbasin is on a crustal block between two uplifts, which was subjected to deep subsidence in the Mesozoic (Ulmishek, 1990). A large part of the basin $166,000 \mathrm{mi}^{2}$ (about 430,000 $\mathrm{km}^{2}$ ) is deeper than 15,000 feet (4,572 m) (fig. 8). West of the Caspian Sea, the Terek-Sulak foredeep reaches a maximum depth to basement of 40,000 feet (about $12 \mathrm{~km}$ ). In the east, the deepest area includes the central part of the South Mangyshlak subbasin (fig. 8) (Ulmishek and Harrison, 1981).

\section{Tectonic and Sedimentary History}

Tectonic development of the Middle Caspian basin is generally similar to that of the Azov-Kuban basin to the northwest (figs. 1, 9). Hercynian (late Paleozoic) basement was rifted in latest Permian and Triassic time. Rifts were subsequently filled with a thick sequence of clastic and carbonate sediments. Volcanism occurred during the Late Triassic followed by a Late Triassic-Early Jurassic compressional event resulting in partial inversion of the rift grabens and erosion. One of the rifts was strongly deformed by thrusting and folding and is expressed in the present-day structure as the Mangyshlak foldbelt (Letavin, 1978). From Jurassic through Eocene time, much of the western part of the basin became a passive margin. Coastal coal-bearing Jurassic rocks thicken southwestward toward the Caucasus and pinch out northwestward on the Stavropol arch and its eastern slope (fig. 8). Rocks of Upper Jurassic and Neocomian age are predominantly carbonates and salt in the western Terek-Sulak foredeep (fig. 9). These rocks onlap and pinch out on the Stavropol arch. The remaining passive margin section is composed of Aptian to Albian clastic rocks, Upper Cretaceous carbonates, and thin Paleocene to Eocene marls and calcareous shales (Ulmishek and Harrison, 1981).

The overlying Oligocene to lower Miocene Maykop Series is about $1.6 \mathrm{~km}$ thick. Thick olistostromes indicate incipient deformation and uplift in the Caucasus at this time. The overlying upper Tertiary section is mainly composed of coarseningupward orogenic clastic rocks increasingly dominated through time by Caucasus provenance. The section is very thick (as much as 16,500-20,000 feet-about 5-6 km) in the narrow foredeep and thins rapidly northward on the foreland slope (Ulmishek and Harrison, 1981).
The South Mangyshlak subbasin developed as a gentle cratonic depression during the Jurassic through the Cenozoic. Lithologies and thicknesses of stratigraphic units in the Mesozoic to lower Tertiary are similar to those in the rest of the basin, but the orogenic section is absent, and only a thin sequence is present above the moderately thick (as much as 2,000-2,300 feet-about 600-700 m) Maykop Series.

\section{Source Rocks}

Geochemical data for source rocks of the Middle Caspian basin are limited, but geologic and geochemical data suggest that several source rock intervals are present in different parts of the basin. The oldest source rocks occur in the Lower to Middle Triassic interval (fig. 9). They are documented by indigenous oil and gas accumulations within that same section. The source rocks commonly have TOC contents ranging from 1 to 4 percent and contain Type-II kerogen (Mirzoev and Dzhapuridze, 1979; Shablinskaya and others, 1990). These source rocks are responsible for some of the oils on the Prikum arch and probably most of the oils in the South Mangyshlak subbasin (Shablinskaya and others, 1990).

A second source rock interval occurs in the Middle Jurassic section (fig. 9). TOC contents range from 1 to 3 percent, and the organic matter is of mixed marine and terrestrial origin. These rocks have contributed most of the oils and gases now present on the Prikum arch and possibly some gas in the South Mangyshlak subbasin. A third source rock interval occurs in the lower part of the Maykop Series (fig. 9) and is composed of anoxic black shales with TOC contents reaching from 7 to 8 percent. Maykop Series source rocks are mature in the foredeep and slope but immature to marginally mature in more northern areas and in the South Mangyshlak subbasin where burial depth was shallower. These source rocks generated most of the oil and gas found in the thrust belt of the northern Caucasus including large oil fields in the Groznyi area (fig. 8) (Sokolov and others, 1990).

\section{Reservoir Rocks}

Nearly the entire sedimentary interval of the basin, from the Triassic to the middle Miocene, is productive. Triassic rocks contain oil and some gas pools in the South Mangyshlak subbasin and on the Prikum arch, primarily in carbonate reservoir rocks (fig. 8). Lower to Middle Jurassic sandstones contain much of the rich oil and gas reserves in the South Mangyshlak subbasin (Ulmishek and Harrison, 1981). Most pools are at depths of 3,600-7,500 feet (about 1.1-2.3 km). Sandstone reservoirs are heterogeneous but are generally characterized by high porosity and moderate to high permeability (Ulmishek and Harrison, 1981).

Reservoir quality of Jurassic sandstones of the Prikum area is fair to poor for oil but good for gas. Sandstones occur at greater depths here, commonly between 10,000 and 13,000 feet (about 3.0 and $4.0 \mathrm{~km}$ ). Porosity ranges from 12 to 18 percent and permeability is usually not higher than a few tens of millidarcies. Aptian and Albian sandstones contain the majority of 


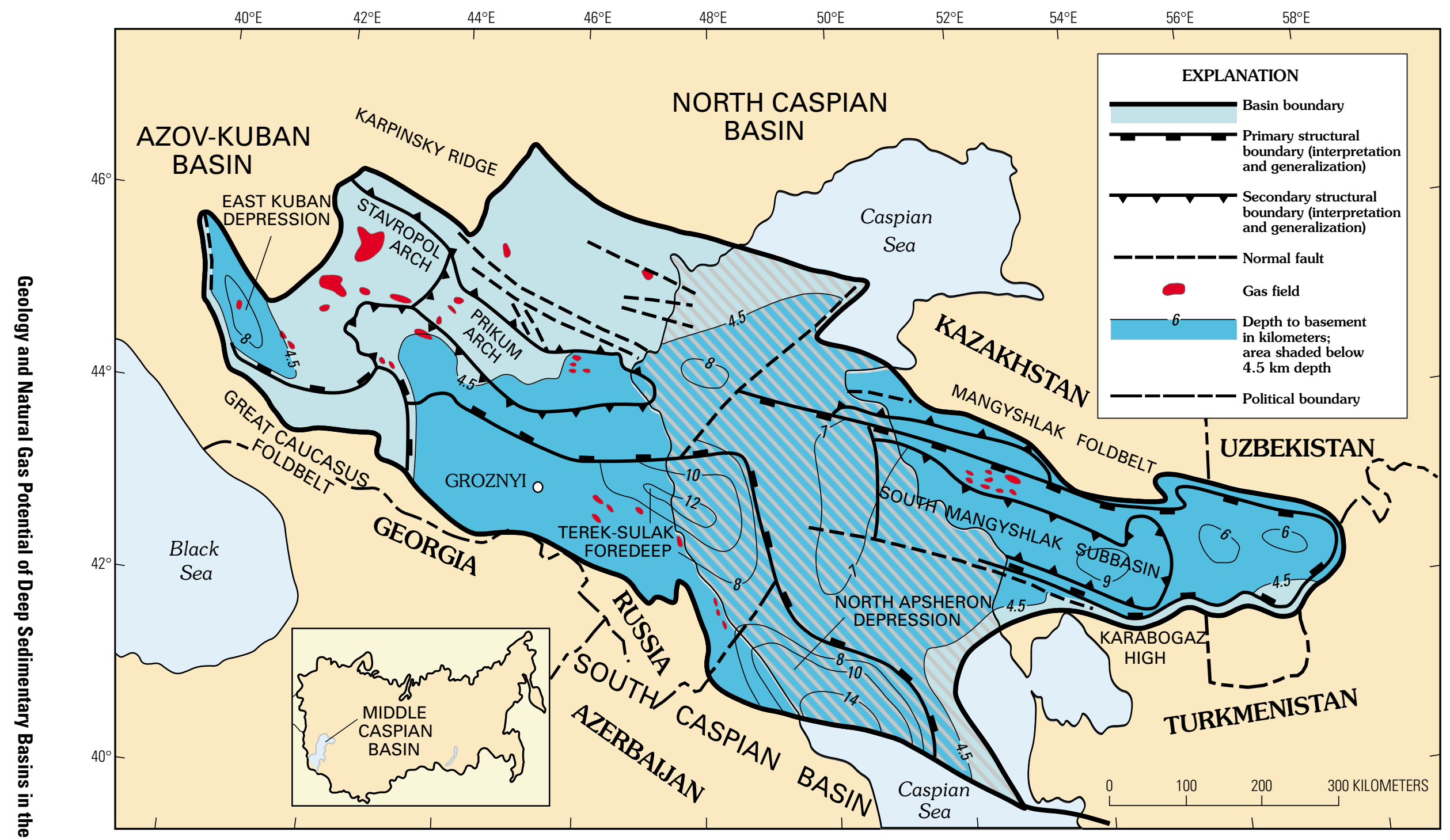

Figure 8. Middle Caspian basin showing political boundaries, gas fields, and major geologic and geographic features discussed in text. Dark shade, portion of basin with sedimentary rocks below $4.5 \mathrm{~km}$. 


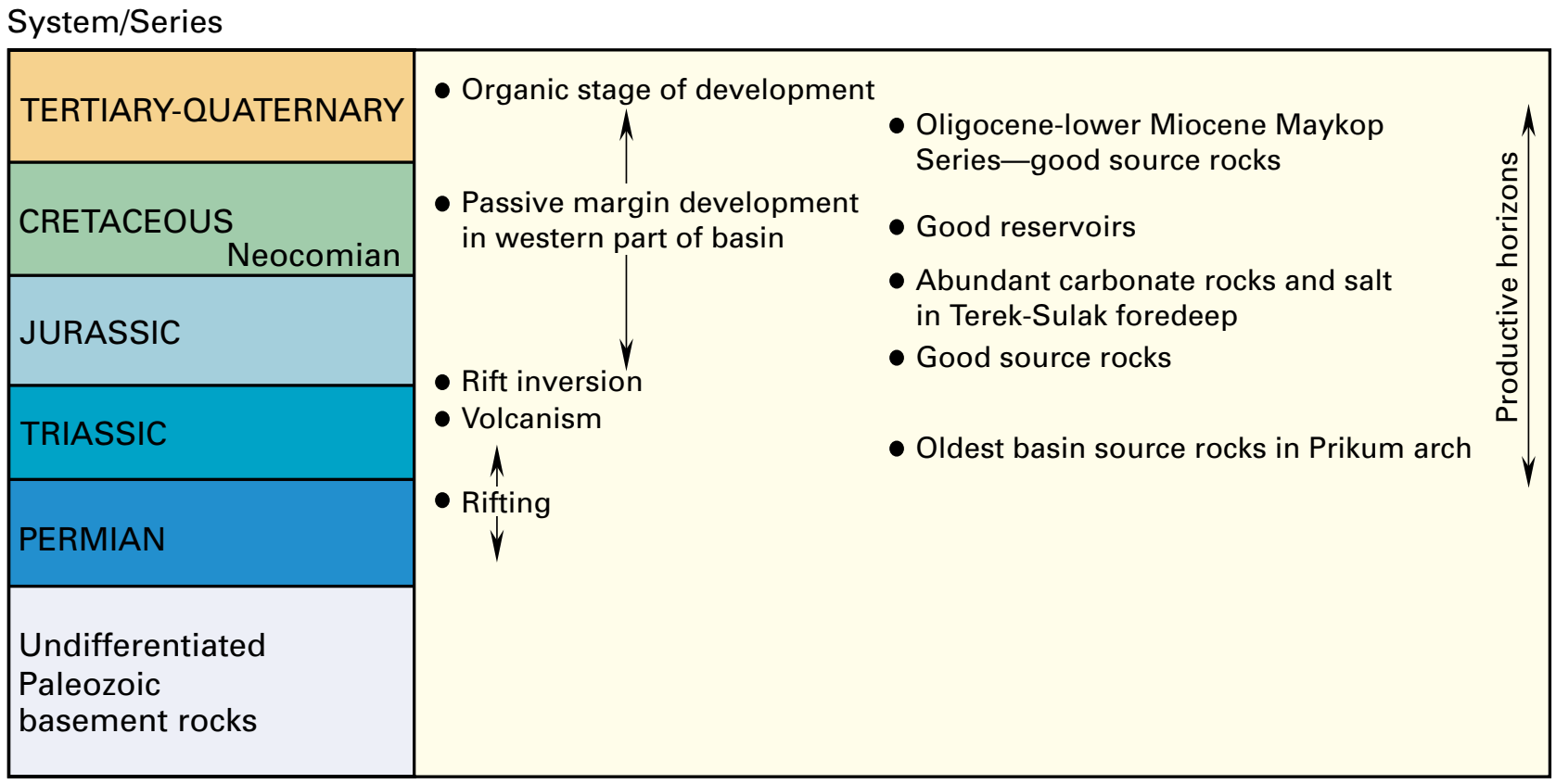

Figure 9. Major geologic events, primary source and reservoir rocks, and basin history of Middle Caspian basin.

reserves on the Prikum arch where most pools are at depths of 8,200-9,800 feet (about 2.5-3.0 km). Porosity varies from 15 to 22 percent and permeability varies from 100 to 200 millidarcies (Maksimov, 1987).

Upper Cretaceous carbonates contain more than 50 percent of reserves in fields of the thrust belt along the northern boundary of the Great Caucasus (mainly in the Groznyi area) where reservoir properties are controlled by fracturing - nonfractured limestones are effectively impermeable. Middle Miocene sandstones also form reservoirs in this thrust belt. They commonly occur at shallow depths and possess excellent reservoir properties. Large gas reserves on the Stavropol arch are mainly in the Khadum Horizon at the base of the Maykop Series. Depth of the pools is 4,000 feet (about $1.2 \mathrm{~km}$ ) or less. Porosity ranges from 30 to 40 percent and permeability often exceeds 1 darcy (Maksimov, 1987).

\section{Trap Types}

Most of the oil reserves in the basin occur within structural traps in front of the Great Caucasus foldbelt. These are long and narrow faulted anticlines whose closures commonly exceed 3,300 feet $(1,005 \mathrm{~m})$. Most of the anticlines are located along the leading edges of thrust sheets, but plastic flow of Maykop Series shales complicates the structural model. Oil and gas fields of the Prikum arch and Stavropol arch are in isometric, low-relief anticlines over basement highs or Triassic reefs. Closure of the anticlines progressively decreases in younger horizons, which indicates early structural growth. Structural traps of the South Mangyshlak subbasin are asymmetric anticlines underlain by thrusted Triassic rocks. Most of this structural growth in this region took place during the Miocene (Popkov, 1991).
In addition to structural traps, many pools are controlled by fracturing, in particular, pools in Triassic carbonates of the South Mangyshlak subbasin and in fractured lower Maykop Series shales of the Prikum arch. Very few stratigraphic traps have been found in the Middle Caspian basin.

\section{Deep Production}

The basin is primarily oil prone, but large gas reserves are present on the Stavropol arch. The largest oil and gas reserves are found in Middle Jurassic sandstones of the South Mangyshlak subbasin, in Upper Cretaceous carbonates and Miocene sandstones of the Terek-Sulak foredeep, in Lower Cretaceous sandstones of the Prikum arch, and in Oligocene sandstones of the Stavropol arch (Ulmishek and Harrison, 1981).

According to Maksimov (1987) and Petroconsultants (1997), oil and gas pools below depths of 15,000 feet (4,572 m) have been discovered in 30 fields of the Middle Caspian basin. Most of the pools are classed as oil pools, but some of them are classed as oil and gas, and gas and condensate pools (table 2). Deep pools are found in two zones: (1) Triassic carbonate rocks mostly in the Prikum arch and (2) Upper Cretaceous carbonates in the Groznyi producing area in the western part of the TerekSulak foredeep (table 2). In the Groznyi area, a few pools are located in Lower Cretaceous sandstones. The primary reservoir rocks in the Triassic interval are carbonates of the Lower Triassic Neftekumsk Formation. Most of the pools occur in reef facies, in zones where reservoir properties are controlled by leaching and fracturing of the carbonates. A few pools have been developed and these currently produce oil.

In the Groznyi area, Cretaceous oil and gas pools have accumulated in high-amplitude thrust anticlines (Sobornov, 1995). Reservoir properties of both Upper Cretaceous 
Table 2. Geologic data for 21 representative deep fields and reservoirs in Dnieper-Donets, North Caspian, Middle Caspian, South Caspian, and Amu-Darya basins.

[Not all deep fields and reservoirs identified. Data not available for Vilyuy basin. --, missing data]

\begin{tabular}{|c|c|c|c|c|c|c|c|c|}
\hline Country & Basin & Field name ${ }^{1}$ & Type $^{2}$ & Disc. $y r^{3}$ & $\mathrm{Age}^{4}$ & Lithology 5 & Ave. depth 6 & Trap $^{7}$ \\
\hline Ukraine & Dnieper-Donets & Krasnozavodskoye & g-c & 1987 & Lower Carboniferous & clastic & 5,447 & Structural \\
\hline Ukraine & Dnieper-Donets & Berezovskoye & g-c & 1978 & Middle Carboniferous & clastic & 4,567 & Structural \\
\hline Ukraine & Dnieper-Donets & Gadyachskoye & g-c & 1972 & Lower Carboniferous & clastic & 4,830 & Stratigraphic \\
\hline Ukraine & Dnieper-Donets & Bogatoy & g-c & 1976 & Lower Carboniferous & clastic-carb. & 4,450 & -- \\
\hline Kazhakstan & N. Caspian & Karachaganak & g-c-o & 1979 & Middle Devonian & clastic & 5,630 & Structural \\
\hline Russia & N. Caspian & Upryamovo & o-g & 1989 & Lower Permian & carbonate & 5,935 & Structural \\
\hline Russia & Middle Caspian & Arak-Dalatarek & o & 1981 & Lower Cretaceous & -- & 4,950 & -- \\
\hline Russia & Middle Caspian & Gudermes-Vostochny & o & 1985 & Upper Cretaceous & carbonate & 4,560 & Stratigraphic \\
\hline Chechnya & Middle Caspian & Andreyevo & o-g & 1978 & Upper Cretaceous & -- & 5,612 & -- \\
\hline Russia & Middle Caspian & Norolak-Arkabash & g-c & 1983 & Upper Cretaceous & carbonate & 5,341 & Structural \\
\hline Russia & Middle Caspian & Yubileynoe & o & 1971 & Lower Triassic & carbonate & 4,470 & -- \\
\hline Azerbaijan & S. Caspian & Garasu-Deniz & o-g & 1974 & -- & -- & 4,710 & Structural \\
\hline Azerbaijan & S. Caspian & Zyrya & o-g-c & 1955 & Pliocene & clastic & 4,560 & Structural \\
\hline Azerbaijan & S. Caspian & Bulla-Deniz & g-c-o & 1973 & Pliocene & clastic & 4,890 & Structural \\
\hline Turkmenistan & S. Caspian & Barsa-Gel'mes & $\mathrm{o}-\mathrm{g}-\mathrm{c}$ & 1962 & Pliocene & clastic & 4,900 & Stratigraphic \\
\hline Azerbaijan & S. Caspian & Yuzhnoe & $\mathrm{g}-\mathrm{c}$ & 1962 & Pliocene & clastic-carb. & 4,700 & -- \\
\hline Afghanistan & Amu-Darya & Shakhmolla & $\mathrm{g}$ & 1988 & Middle Jurassic & clastic & 4,880 & Structural \\
\hline Turkmenistan & Amu-Darya & Karadzhanlak-Zapadny & $\mathrm{g}$ & 1986 & Lower Jurassic & carbonate & 4,747 & Structural \\
\hline Turkmenistan & Amu-Darya & Miana & $\mathrm{g}$ & 1985 & Lower Jurassic & carbonate & 4,500 & Structural \\
\hline
\end{tabular}

${ }^{1}$ In some cases, additional reservoirs may exist for fields listed.

${ }^{2}$ Type production for field; o, oil; g, gas; c, condensate.

${ }^{3}$ Disc. yr., discovery year of field.

${ }^{4}$ Geologic age of producing formation.

${ }^{5}$ Primary lithology of field/reservoir listed; carb, carbonate reservoir rocks.

${ }^{6}$ Depth to top of reservoir in meters.

${ }^{7}$ Dominant trap type of field. 
limestones and Lower Cretaceous sandstones are dependent on fracturing. Away from the fracture zones along anticlinal crests, the rocks tend to be impermeable. Deep drilling in the area is extremely difficult because of overpressures approaching geostatic pressure in some fields and plasticity of thick Maykop Series shales. Data are not available to support or discount the presence of a deep basin-centered gas accumulation in the Middle Caspian basin.

\section{South Caspian Basin}

The South Caspian basin occupies the southern, deep-water portion of the Caspian Sea, the surrounding shelf, and the onshore region (figs. 1, 10). The northern basin boundary extends along the Great Caucasus foldbelt and offshore, along the Apsheron-Pribalkhan zone of uplifts. The basin is bounded on the south and east by the Lesser Caucasus, Elburz, and KopetDag foldbelts (fig. 10). The basin is a typical intermontane depression surrounded by foldbelts of the Alpine system (Khanin, 1979). The basin area is about $80,000 \mathrm{mi}^{2}\left(207,000 \mathrm{~km}^{2}\right)$, and nearly all of this area includes sediments in excess of 15,000 feet $(4,572 \mathrm{~m})$ thick. In the central basin area, the basement may be as deep as 80,000 feet (about $25 \mathrm{~km}$ ). The basin occupies a part of Azerbaijan in the west, Turkmenistan in the east, and Iran in the south (fig. 10).

\section{Tectonic and Sedimentary History}

Earliest basin history is poorly understood because the oldest rocks occur only at great depths. Much of the offshore part of the basin is underlain by oceanic crust. Plate-tectonic reconstructions indicate that the basin was formed in Late Jurassic or Early Cretaceous time in conjunction with back-arc rifting of the northern margin of the Tethys Sea (Zonenshain and others, 1990). The Cretaceous to early Tertiary interval is known only from outcrops along the basin margins where rocks are primarily composed of shallow-shelf carbonates and sandstones (fig. 11). These rocks were deposited in marine deep-water (flysch) depositional environments in the area of the present-day Alpine foldbelts. The oldest rocks penetrated by wells in the basin are deepwater, organic-rich marine shales of the Oligocene-lower Miocene Maykop Series (Bagir-Zade and others, 1987). These rocks are overlain by deep-water organic-rich shales and limestones of the Miocene Diatom Formation. Total thickness of this combined interval may reach several thousand meters. Both intervals contain the principal source rocks of the basin (fig. 11).

In latest Miocene time, the South Caspian basin was separated from the Tethys Sea by orogenic uplifts and became a large inland lake. The lake received clastic sediments from several large fluvial systems, the largest of which was the paleo-Volga River and its associated delta which developed in the western part of the Apsheron-Pribalkhan zone of uplifts. Several rivers brought sediments to the lake from the south, west, and east. The Pliocene Productive Series, which is as much as 16,000 feet (about $5 \mathrm{~km}$ ) thick in the central basin area, was deposited under high subsidence rates (Amanniyazov, 1992). During the late
Pliocene, the Caspian and Black Sea basins were connected during a marine transgression. Rapid subsidence and sedimentation continued into Quaternary time.

Rapid basin subsidence during Pliocene and Quaternary time may have prevented normal development of compaction in Maykop Series shales. Recent compression, which mainly affected marginal areas of the basin, resulted in plastic flow of the shales and formation of linear anticlines with shale cores. Many anticlines contain active mud volcanoes with roots in the Maykop Series and older(?) strata. The recent compressional event may be related to initiation of subduction of the South Caspian oceanic crust under the continental crust of the Middle Caspian basin (Granth and Baganz, 1996).

\section{Source Rocks}

Source rocks occur at great depths but are known largely from outcrops on the basin margins and from fragments of breccias associated with mud volcanoes. Two source rock units are present: deep-water black shales of the Oligocene-lower Miocene Maykop Series and deep-water, anoxic shales of the middle Miocene Diatom Formation (fig. 11). The Diatom Formation directly overlies the Maykop Series, and both units together are generally viewed as a single source rock. However, as revealed by recent geochemical data obtained by western companies, oils generated from each of the stratigraphic units contain a specific set of biomarkers. Both source rocks contain 2 or more percent TOC and mixed Types-I and -II kerogen (Pigott and others, 1996; Abrams and Narimanov, 1997).

The basin, especially its offshore part, is characterized by a very low geothermal gradient. In drilled structures, present-day temperatures (generally maximum temperatures) at a depth of 20,000 feet (about $6 \mathrm{~km}$ ) do not exceed $120^{\circ} \mathrm{C}$ (Bagir-Zade and others, 1987). The average geothermal gradient is about $16^{\circ} \mathrm{C} /$ km (Buryakovsky and Dzhevanshir, 1990). The geothermal gradient and burial history indicate that the top of the oil window occurs at depths of 18,000-21,000 feet (about 5.5-6.5 km) and that the base occurs at 26,000-30,000 feet (8-9 km). The top of the source rock interval in much of the basin area is in the upper part of the oil window. However, as the source rock section may be several kilometers thick, the lower part is probably in the gas window. This thermal regime and source rock richness result in gas generation as suggested by the large volumes of gas emitted from mud volcanoes annually (Yakubov, 1980).

\section{Reservoir Rocks}

Reservoir rocks of the Pliocene Productive Series are sandstones and siltstones. Reservoir properties of the sandstones vary depending on paleogeographic conditions of sedimentation. The best reservoir rocks are quartz-rich sandstones on the Apsheron-Pribalkhan Peninsula near Baku in the western Apsheron-Pribalkhan zone of uplifts offshore, and in adjacent areas. In this region, clastic sediments entered the basin from the paleo-Volga river, which drained a large part of the Russian craton. Sandstones were deposited in deltaic and alluvial environments. At depths of 6,600-9,800 feet (about 2-3 km), 


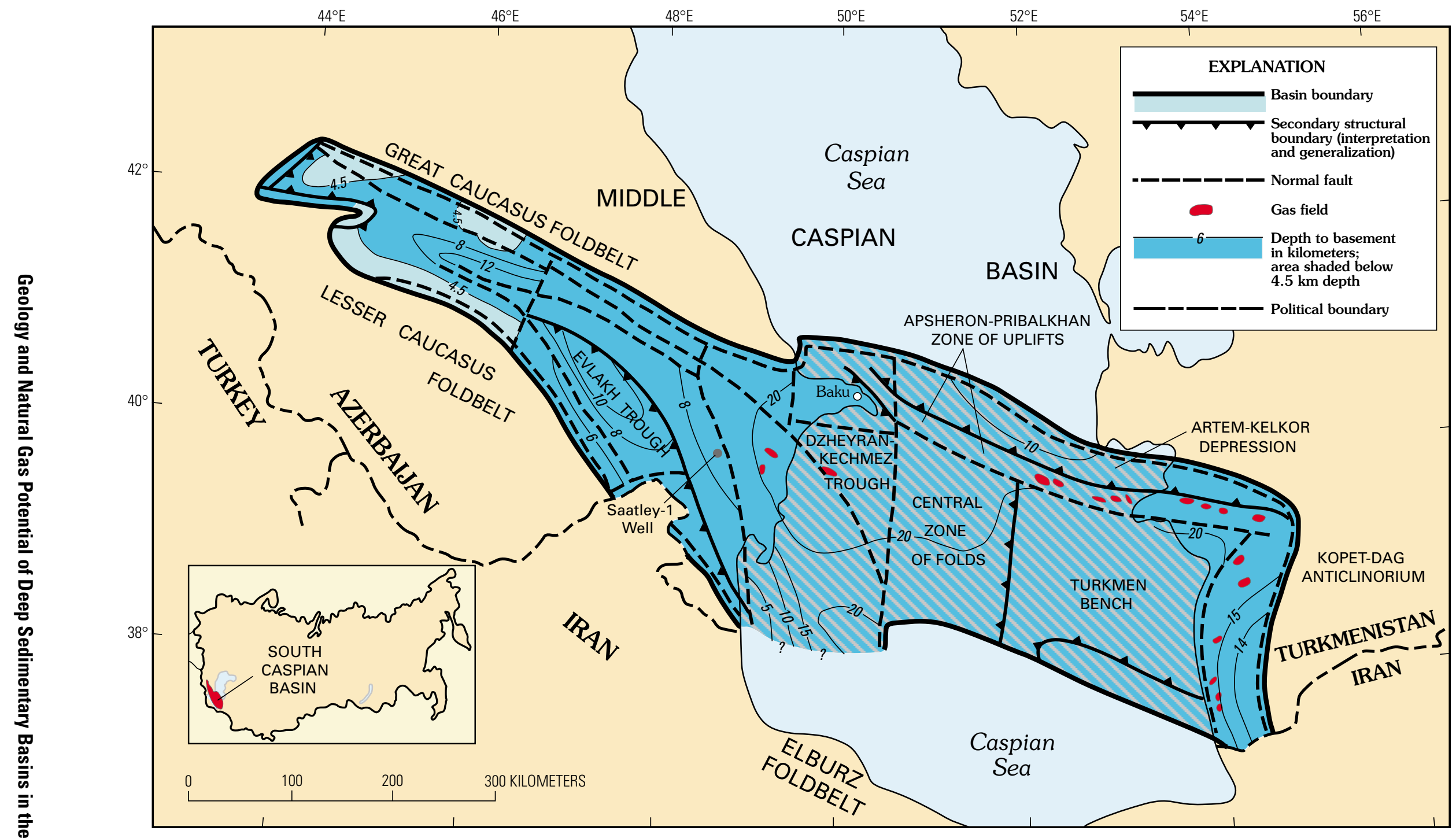

Figure 10. South Caspian basin showing political boundaries, gas fields, and major geologic and geographic features discussed in text. Dark shade, portion of basin with sedimentary rocks below $4.5 \mathrm{~km}$. 


\begin{tabular}{|c|c|}
\hline TERTIARY-QUATERNARY & 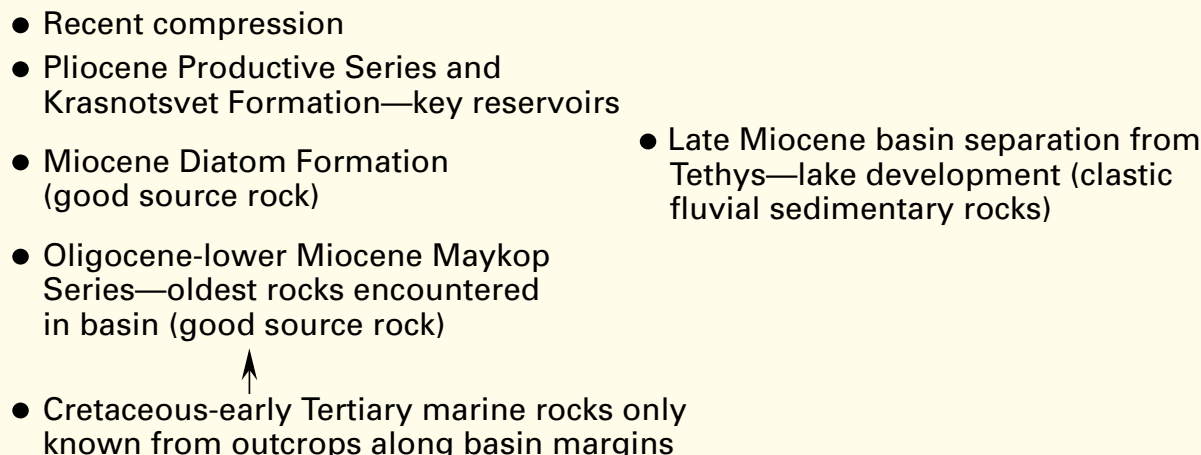 \\
\hline CRETACEOUS & \\
\hline JURASSIC & $\begin{array}{l}\text { - Back-arc rifting of northern } \\
\text { Tethys-early basin formation on } \\
\text { oceanic crust }\end{array}$ \\
\hline
\end{tabular}

Figure 11. Major geologic events, primary source and reservoir rocks, and basin history of South Caspian basin.

porosity varies from 15 to 30 percent, and permeability varies from several tens to 1,000 millidarcies. Little porosity and permeability loss is observed to depths of 20,000 feet (about $6 \mathrm{~km}$ ) (Kheirov and others, 1990). Preservation of good reservoir properties is related to the low geothermal gradient and widespread overpressuring (Proshlyakov and others, 1987). To the east and south, grain size decreases and clay content increases, resulting in poorer reservoir quality.

In the southwestern part of the basin, clastic rocks of the Productive Series were deposited by the paleo-Kura River system, which drained a Caucasus source area of lithic-rich clastic and volcanic rocks. The resulting reservoirs are poor when compared to those of the Apsheron area. At depths of 8,200-9,800 feet $(2.5-3.0 \mathrm{~km})$, porosity commonly does not exceed 20 percent and decreases to $12-14$ percent at 16,400 feet $(5.0 \mathrm{~km})$. The Krasnotsvet Formation in onshore areas of the eastern part of the basin is composed mainly of alluvial sandstones. Even at shallow depths sandstone porosity seldom exceeds 20 percent and permeability is a few tens of millidarcies. Reduction of porosity with depth is significant, and at 14,800-16,400 feet (about $4.5-5 \mathrm{~km}$ ), porosity varies from 8 to 14 percent. Better quality deltaic sandstones of the paleo-Amu-Darya River may be present offshore, but these areas have not yet been drilled.

\section{Trap Types}

Oil and gas fields in the South Caspian basin are controlled primarily by structural traps (table 2), although pool outlines are often associated with lateral stratigraphic changes. The dominant traps are compressional anticlinal folds grouped into long linear zones in onshore and shallow-shelf areas along the periphery of the basin. Fold amplitudes along the Apsheron-
Pribalkhan zone of uplifts vary from 3,300-9,800 feet (about 1$3 \mathrm{~km}$ ) in the lower part of the Productive Series to 1,000-5,000 feet (about $0.3-1.5 \mathrm{~km}$ ) along the western and eastern basin margins (Amanniyazov, 1992). Folding took place in PlioceneQuaternary time, and amplitudes of structures decrease upward in the section. Folds are strongly faulted and subdivided into distinct structural blocks. Vertical displacements along the faults vary widely from several meters to more than 6,600 feet (about $2 \mathrm{~km}$ ). Seismic data suggest that the cores of folds are composed of plastic shales of the Maykop Series. Many folds have active and buried mud volcanoes along their crests. Fold amplitudes on the eastern basin margin are usually smaller than on the western margin, but are still measured on a scale of hundreds of meters. In the central, deep-water part of the Caspian Sea, large, gentle structures have been mapped by seismic surveys. These structures have not been drilled, and their origin is as yet unknown (Bagir-Zade and others, 1987).

\section{Deep Production}

Nearly all the oil and gas reserves of the South Caspian basin are in clastic reservoirs of the Pliocene Productive Series in the west and its stratigraphic equivalent, the Krasnotsvet (Red Color) Formation in the east (fig. 11). Most of the oil reserves are concentrated in structures of the Apsheron-Pribalkhan zone of uplifts along the northern basin boundary (fig. 10) (Dikenshtein and others, 1983).

In the South Caspian basin, deep drilling began in the mid1950's. By 1975, more than 500 wells had been drilled to depths exceeding 15,000 feet $(4,572 \mathrm{~m})$, but only 300 of them reached their targets. The deepest well, Saatley-1 located in Azerbaijan, was projected to reach 36,000 feet (about $11 \mathrm{~km}$ ) as 
part of the Soviet superdeep drilling program. The well reached a depth of more than $9 \mathrm{~km}$ in the early 1990's before the drilling program was canceled.

Twenty-two oil and gas pools have been discovered at depths greater than $4.5 \mathrm{~km}$ in the South Caspian basin (Krylov, 1980). Major deep drilling problems include overpressuring and the plasticity of shales. Petroconsultants database (1996) identifies nine fields with reservoirs at great depths, seven of which have been developed and produce oil. Several more fields are indicated by Maksimov (1987). Development of deep fields is economically feasible because sandstones of the Productive Series have high porosity and permeability. Both deep oil and deep gas potential of the South Caspian basin are believed to be very high (Bagir-Zade and others, 1987).

\section{Amu-Darya Basin}

The Amu-Darya basin occupies the eastern part of the Turanian plate, which consists of Mesozoic basins and uplifts on Hercynian-late Paleozoic basement east of the Caspian Sea (fig. 1). The south side of the basin is bounded by ranges of the Alpine fold system (fig. 12), including the Kopet-Dag foldbelt on the southwest and the Bandi-Turkestan and Gissar Ranges on the southeast and east. The north end of the basin abuts the Kyzylkum regional basement uplift.

Tectonically, the basin is a deep Mesozoic and Tertiary sag overlying a Permian to Triassic rift system and includes a foredeep in front of the Kopet-Dag foldbelt. The larger western part of the basin is in Turkmenistan, its northeastern part is in Uzbekistan, and a small southeastern part is in Afghanistan. The basin is more than 33,000 feet (about $10 \mathrm{~km}$ ) deep in the Murgab depression; it is 15,000 feet $(4,572 \mathrm{~m})$ deep throughout an area of more than $58,000 \mathrm{mi}^{2}\left(150,000 \mathrm{~km}^{2}\right)$ (fig. 12) (Simakov, 1986).

\section{Tectonic and Sedimentary History}

Basement rocks of the Amu-Darya basin are deformed and metamorphosed clastic wedges primarily of Carboniferous age. The Karakum and Karabogaz arches in the northwestern part of the basin are Hercynian micro-continents with Precambrian and early Paleozoic metamorphic rocks intruded by granites (fig. 12). This basement sequence was rifted in Late Permian and Triassic time (fig. 13), but the rift structure is poorly known because of thick overlying rocks and the absence of outcrops (Gabrielyants and others, 1991).

The overlying Jurassic through Paleogene sequence was deposited on a passive margin separated from the Tethyan subduction zone by marginal seas (fig. 13). The lower Middle Jurassic sequence, as much as $1 \mathrm{~km}$ thick, lies unconformably on Triassic rocks and onlaps basement highs. This interval is mainly composed of continental coal-bearing clastic rocks (fig. 13) and locally of volcanic rocks. Marine beds appear in the mid-Jurassic (upper Bajocian) and become increasingly common upward in the section in the southern part of the basin.
During the Late Jurassic a transgressive carbonate sequence was deposited on the northeastern and possibly southern margins of the Murgab depression where a deep-water marine basin was being formed. This basin was filled by a thick (reaching 4,000 feet-about $1.2 \mathrm{~km}$ ) latest Jurassic (Tithonian) evaporite unit (Gaurdak Formation; Maksimov and others, 1986). Lower Cretaceous marine carbonate and clastic rocks lie unconformably on Jurassic rocks. The section includes a continental interval with a widespread sandstone bed (Shatlyk Formation) that is the main gas producer in the basin. The Upper Cretaceous section is about $1.2 \mathrm{~km}$ thick and consists mainly of clastic rocks that laterally grade into carbonates in the Kopet-Dag foredeep. Marine carbonate and clastic rocks are abundant in the lower Tertiary (Paleogene) sequence that forms the top of the passive margin sequence (Dikenshtein and others, 1983).

Thrusting and orogeny in the Kopet-Dag foldbelt started in late Oligocene (late Paleogene) and has continued to the present time. This uplifted terrane gradually became the main source of clastic detritus that included marine sediments in the Miocene and continental sediments in the Pliocene. The collision of Eurasia with India resulted in deformation of the eastern part of the Mesozoic-Paleogene sedimentary basin and formation of the Gissar Range. This deformed area is designated as the AfghanTajik basin (fig. 12).

\section{Source Rocks}

The main source rocks of the Amu-Darya basin occur in the subsalt Jurassic section. Suprasalt rocks have minor source potential but are the primary reservoirs. Migration of hydrocarbons through the thick, substantially undeformed salt formation presents a significant problem. One proposed model suggests updip lateral migration of gas southward along Jurassic rocks to the salt pinch-out zone, then vertical migration upward into Lower Cretaceous sandstones, and updip lateral migration northward to traps in the sandstones. This model is possible due to the opposite tilt of Jurassic and Lower Cretaceous beds (Akramkhodzhaev and Egambergiev, 1985).

Organic-rich black shale of the Upper Jurassic Khodzhaipak Formation is a well-known source rock on Bukhara and Chardzhou structural terraces (steps) of the northeastern basin margin (fig. 12). The Khodzhaipak Formation has high TOC contents and contains Type-II kerogen. In the Murgab depression, the Upper Jurassic carbonate section laterally grades into deep-water calcareous shales, but few wells have penetrated these subsalt rocks and geochemical information is not available. Based on regional data about depositional environments, these rocks should have a significant source rock potential. The Khodzhaipak Formation occurs at shallower depths and is presently in the oil window (Akramkhodzhaev and Egambergiev, 1985).

The most likely source for deep gas in the Amu-Darya basin is the thick lower Middle Jurassic coal-bearing clastic sequence. Middle Jurassic source rocks reached maturity in the Early Cretaceous. By the time structural traps developed during the late Tertiary, these rocks had subsided deep into the gas window. 


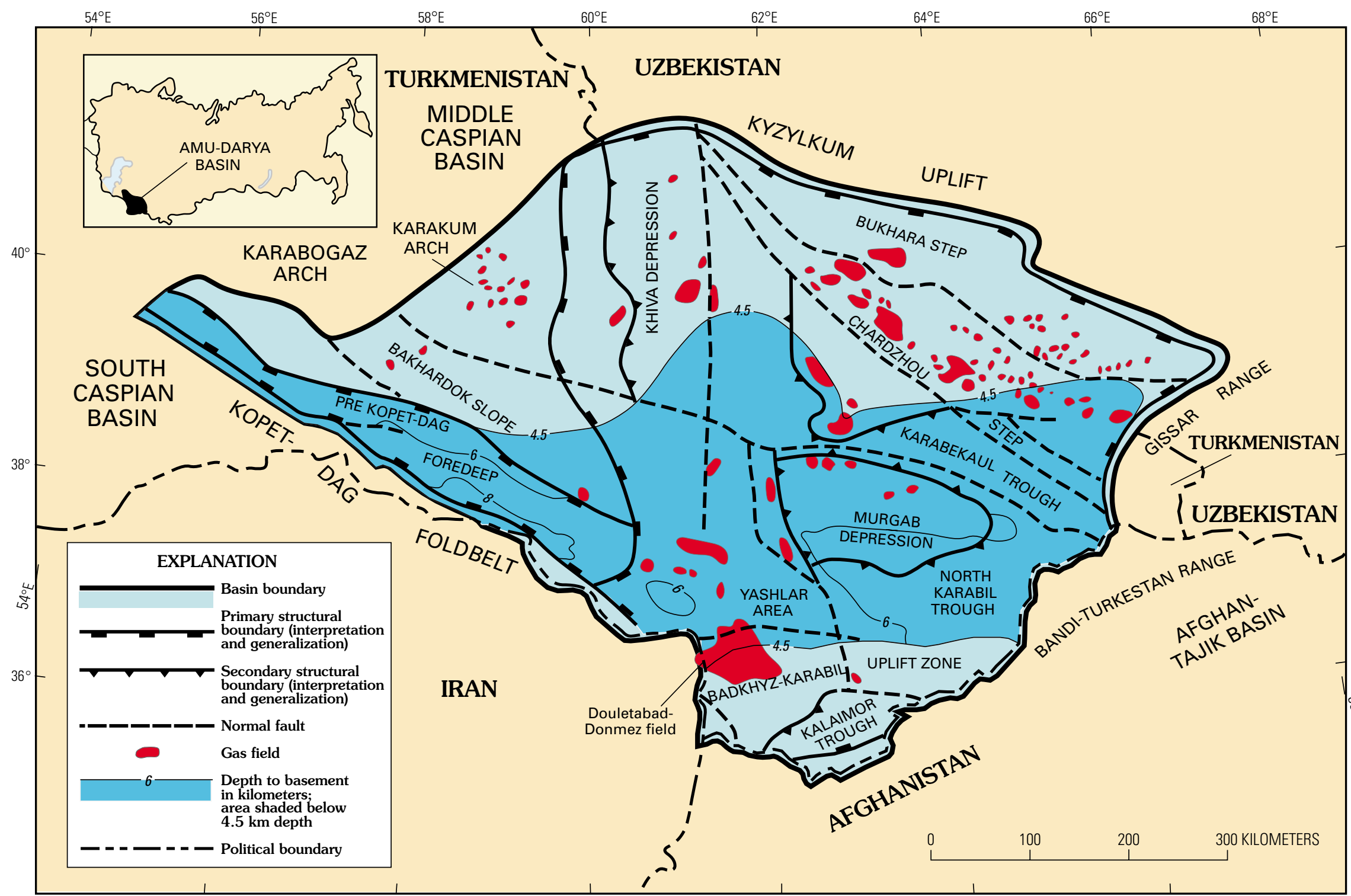

Figure 12. Amu-Darya basin showing political boundaries, gas fields, and major geologic and geographic features discussed in text. Dark shade, portion of basin with sedimentary rocks below $4.5 \mathrm{~km}$. 


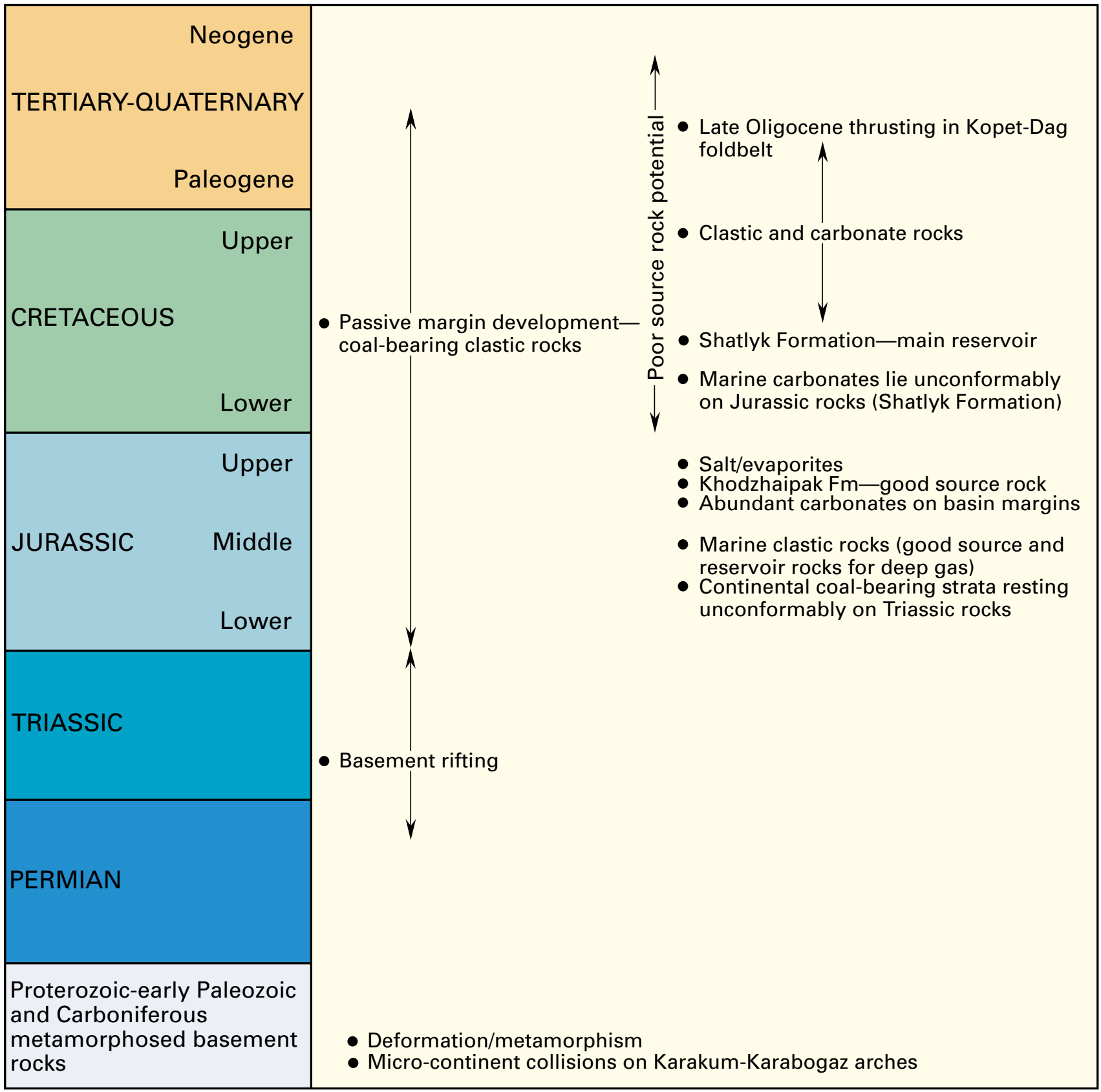

Figure 13. Major geologic events, primary source and reservoir rocks, and basin history of Amu-Darya basin.

\section{Reservoir Rocks}

Gas-producing Cretaceous reservoir rocks occur at depths not exceeding 9,800 feet (about $3 \mathrm{~km}$ ). About 50 percent of the gas reserves of the basin are found in quartzose sandstones of the Lower Cretaceous Shatlyk Formation. The sandstones are generally characterized by porosity varying from 17 to 23 percent and permeabilities ranging from 1 to several hundred millidarcies. For discovered fields at about 13,000 feet (about 4 $\mathrm{km}$ ) depth, porosity of Shatlyk sandstones is $18-20$ percent.
Reservoir quality of other Cretaceous horizons is variable (Maksimov and others, 1986).

Principal Jurassic reservoirs are Upper Jurassic carbonates, primarily reefs, on the Bukhara and Chardzhou structural steps (fig. 12). Reservoir properties of these carbonates are variable and depend primarily on diagenetic factors. Porosity usually averages $10-15$ percent but in some fields reaches 20 percent. No significant loss of porosity with depth has been identified to depths reaching 11,500 feet (about $3.5 \mathrm{~km}$ ). Lower-Middle Jurassic sandstones are gas productive in several fields that are 
mainly located on the northern margin of the basin at depths averaging 7,200-8,200 feet (about 2-2.5 km). Reservoir quality of these rocks is poor. Even at shallow depths, porosity ranges from 7 to 15 percent and permeability is low (Maksimov and others, 1986).

\section{Trap Types}

Two principal trap types control the majority of fields in the basin. The first type includes structural traps that control gas accumulations in Cretaceous reservoirs. These traps are gentle platform-type uplifts that are related to local basement highs on the Karakum arch in the northwestern part of the basin (fig. 12). In the rest of the basin, relationships have not been identified between traps and basement tectonics, but traps probably formed in late Tertiary (Neogene) time influenced by regional compression. Most traps in the Upper Jurassic carbonate section are reefs (pinnacles and atolls). Several fields are known to have combination traps formed by marginal barrier reefs associated with anticlines. The reef zone may have extended from the Chardzhou step in the northeast around the southern margin of the Murgab depression where the Upper Jurassic occurs at depths of about 16,500 feet (about $5 \mathrm{~km}$ ). Anticlines are also productive north and northeast of the reef zone (Dikenshtein and others, 1983).

The largest gas field in the basin, the Douletabad-Donmez field, is located at the south end of the basin in a pinch-out zone of Jurassic salt along a southward-dipping monocline (fig. 12). Primary reservoirs are highly permeable (as much as 700 millidarcies) gas-saturated sandstones of the Shatlyk Formation in a hydrodynamic trap. Average depth to production is about 3.1 km (Maksimov and others, 1986).

\section{Deep Production}

The Amu-Darya basin is the second most important gas producing basin in the FSU (after the West Siberian basin). Oil and gas resources are concentrated in two stratigraphic intervals: Lower Cretaceous clastic and Upper Jurassic carbonate rocks. Most of the gas in the Amu-Darya basin is sweet gas currently produced from Lower Cretaceous reservoirs in several giant fields and one supergiant field (Douletabad-Donmez field) at depths averaging 10,000 feet (about $3 \mathrm{~km}$ ). Upper Jurassic carbonate rocks are productive mainly in the northeastern part of the basin (Bukhara and Chardzhou structural steps northeast of the Murgab depression; fig. 12). They contain both sour gas and condensate fields and oil fields. Recently, large gas reservoirs were discovered at depths of about 16,000 feet (about $5 \mathrm{~km}$ ) in the Yashlar field area on the southern margin of the Murgab depression (fig. 12).

According to Petroconsultants (1996), three deep fields have been discovered in the basin (see table 2). Potential deep prospects are likely in Lower to Middle Jurassic clastic and Upper Jurassic carbonate rocks. Clastic reservoirs have poor reservoir quality at shallower depths and are considered high risk. Carbonate reservoirs have good porosity and permeability but contain hydrogen sulfide. In shallow fields of the Bukhara and Chardzhou steps, the amount of hydrogen sulfide in Upper Jurassic reservoirs varies from near zero to 6 percent. This value will most likely increase with increasing depth and temperature. In some older wells in the Yashlar field, hydrogen sulfide content reached 25 percent (Maksimov and others, 1986).

Deep drilling is also complicated by very high overpressures in the Amu-Darya basin. Reservoir pressures in brinebearing carbonate beds within the salt formation are nearly equal to geostatic pressure.

\section{Summary}

Sedimentary basins in the Former Soviet Union (FSU) are among the deepest in the world with depths to basement exceeding 65,000 feet $(20 \mathrm{~km})$ in the North Caspian, South Caspian, and South Barents basins. Deep basins occur in both offshore and onshore areas of the FSU and extend from the Arctic Shelf in the north, to the Sea of Okhotsk and the Kamchatka Peninsula in the east, to the Central Asian republics in the south, and to Poland and Romania in the west. These basins formed in a wide variety of plate-tectonic regimes and include rift basins (such as Dnieper-Donets basin), foreland basins (such as VolgaUral and Timan-Pechora basins), and collisional passive margins (such as Afghan-Tajik basin).

Six basins (Dnieper-Donets, Vilyuy, North Caspian, Middle Caspian, South Caspian and Amu-Darya basins) have the greatest potential for deep gas resources based on data available to us and are summarized in this report.

Source and reservoir rocks range in age from Proterozoic to Tertiary. Major source rocks include Devonian to Permian anoxic shales of the North Caspian and Timan-Pechora basins, black shales of the Cambrian Kuonan Formation in the Vilyuy basin, and siliceous shales of the Maykop Series of the South Caspian basin. Both carbonate and clastic reservoirs are abundant. Reservoirs are predominantly clastic in the Vilyuy, West Siberian, Dnieper-Donets, and South Caspian basins, whereas the North Caspian basin contains predominantly carbonate reservoirs.

\section{References Cited}

Abrams, M.A., and Narimanov, A.A., 1997, Geochemical evaluation of hydrocarbons and their potential sources in the western South Caspian depression, Republic of Azerbaijan: Marine and Petroleum Geology, v. 14, no. 4, p. 451-468.

Aksionov, A.A., ed., 1985, Petroleum potential at great depths (Perspektivy neftegazonosnosti bolshikh glubin): Moscow, Nauka, 96 p.

Akramkhodzhaev, A.M., and Egambergiev, M.E., 1985, Rocks of the Upper Jurassic Khodzhaipak Formation-Possible Central Asian analogs of bazhenites: Geologia Nefti i Gaza, no. 2, p. 19-24.

Amanniyazov, K.N., ed., 1992, Morphostructures, neotectonics and history of development of the South Caspian petroleum basin (Morfostructury, neotektonika i istoriya razvitiya YuzhnoKaspiyskogo neftegazonosnogo basseyna): Ylym, Ashgabad, Turkmenistan, $156 \mathrm{p}$.

Ammosov, I.I., Gorshkov, V.I., Grechishnikov, N.P., and Kalmykov, G.S., 1977, Paleogeothermal criteria of distribution of oil fields 
(Paleogeotermicheskie kriterii razmeshcheniya neftyanykh zalazhey): Moscow, Nedra, 158 p.

Bagir-Zade, F.M., Kerimov, K.M., and Salayev, S.G., 1987, Deep geologic framework and petroleum productivity of the South Caspian megadepression (Glubinnoye stroeniye I neftegazonosnost YuzhnoKaspiyskoy megavpadiny): Baku, Azerbaijan, Azerbaijanskoye Gosudarstvennoye Izdatelstvo, $304 \mathrm{p}$.

Beznosov, N.V., ed., 1987, Stratigraphy of petroleum provinces of the USSR (Spravochnik po stratigrafii neftegazonosnykh provintsiy SSSR): Moscow, Nedra, $336 \mathrm{p}$.

Buryakovsky, L.A., and Dzhevanshir, R.D., 1990, Reservoir rocks of the South Caspian petroleum basin and prediction of their quality at great depths, in Proshlyakov, B.K., ed., Reservoir rocks at great depths (Porody-kollektory na bolshikh glubinakh): Moscow, Nauka, p. 147-155.

Dikenshtein, G.Kh., Maksimov, S.P., and Semenovich, V.V., eds., 1983, Petroleum provinces of the USSR (Neftegazonosnye provintsii SSSR): Moscow, Nedra, $271 \mathrm{p}$.

Dmitrievsky, A.N., Lobkovsky, L.I., Balanyuk, I.E., Ilyukhin, L.N., and Dongaryan, L.S., 1995, Geodynamic criteria of differential prognosis of hydrocarbons (on example of Vilyuy-Cis-Verkhoyan sedimentary basin) (Geodinamicheskiye kriterii razdelnogo prognoza uglevodorodov na primere Vilyuysko-Priverkhoyanskogo osadochnogo basseyna): Geologiya, Metody Razvedki i Otsenki Mestorozhdeniy Toplivno-Energeticheskogo Syrya, Obzor, AOZT Geoinformmark, $53 \mathrm{p}$.

Gabrielyants, G.A., ed., 1990, Map of petroleum regions of the USSR: Ministry of Geology of U.S.S.R., scale 1:2,500,000.

Gabrielyants, G.A., Dikenshtein, G.Kh., Kapustin, I.N., Kiryukhin, N.G., and Razmyshlyaev, A.A., 1991, Regional geology of hydrocarbon-bearing regions of the USSR (Regionalnaya geologiya neftegazonosnykh territoriy SSSR): Moscow, Nedra, $284 \mathrm{p}$.

Gramberg, I.S., and Pogrebitsky, Yu. E., eds., 1984, Geological structure and economic minerals of the USSR, Volume 9 , Seas of the Soviet Arctic (Geologicheskoe stroenie i zakonomernosti razmeshcheniya poleznykh iskopaemykh): Leningrad, Nedra, 280 p.

Granath, J.W., and Baganz, 0.W., 1996, A review of Neogene subsidence mechanism for the South Caspian basin: AAPG/ASPG Research Symposium-0il and Gas Petroleum Systems in Rapidly Subsiding Basins, October 6-9, 1996, Baku, Azerbaijan, Abstracts, unpaginated.

Kabyshev, B.P., 1987, Paleotectonic studies and petroleum productivity of aulacogens (Paleotektonicheskiye issledovaniya I neftegazonosnost v avlakogennykh oblastyakh): Leningrad, Nedra, 192 p.

Khanin, V.A., 1979, Siliciclastic reservoir rocks for oil and gas at great depths (Terrigennye porody-kollektory nefti i gaza na bolshikh glubinakh): Moscow, Nedra, $140 \mathrm{p}$.

Kheirov, M.B., Daidbekova, E.A., and Dzhavadov, Ya.D., 1990, Reservoir rocks and seals of Mesozoic-Cenozoic rocks of Azerbaijan, in Proshlyakov, B.K., ed., Reservoir rocks at great depths (Porodykollektory na bolshikh glubinakh): Moscow, Nauka, p. 155-164.

Komissarova, I.N., 1986, Main characteristics of ancient and modern salt accumulation in the North Caspian depression, in New data on geology of salt-bearing basins of the Soviet Union (Novye dannye po geologii solenosnykh basseynov Sovetskogo Soyuza): Moscow, Nauka, p. 171-180.

Kontorovich, A.E., ed., 1994, Petroleum basins and regions of Siberia, Volume 4, Lena-Viliuy basin (Neftegazonosnye basseyny i regiony Sibiri, vyp. 4, Leno-Viliuyskiy basseyn): Novosibirsk, Russia, OIGGM, $108 \mathrm{p}$.
Krylov, N.A., ed., 1980, Oil and gas productivity at great depths (Neftegazonosnost bolshikh glubin): Moscow, Nauka, $119 \mathrm{p}$.

Kurilyuk, L.V., Vakarchuk, G.I., Slobodyan, V.P., and Khmel, F.F., 1991, Paleozoic salt formations of the Dnieper-Donets depression: Sovetskaya Geologia, no. 4, p. 15-21.

Law, B.E., Ulmishek, G.F., Clayton, J.L., Kabyshev, B.P., Pashova, N.T., and Krivosheya, V.A., 1998, Basin-centered gas evaluated in Dnieper-Donets basin, Donbas Foldbelt, Ukraine: Oil and Gas Journal, v. 96, no. 47, p. $74-78$.

Letavin, A.I., 1978, Tafrogennyi kompleks molodoy platformy yuga SSSR (Taphrogenic complex of the young platform of southern USSR): Moscow, Nauka, $148 \mathrm{p}$.

Litinsky, V.A., 1977a, The junction of the northern part of the Cis-Verkhoyansk basin and the Verkhoyansk meganticlinorium by geophysical data, in Geologia i neftegazonosnost mezozoiskikh progibov severa Sibirskoy platformy (Geology and petroleum potential of the northern part of the Siberian craton): Leningrad, NIIGA, p. 63-81.

1977b, Structures of the basement of the Cis-Verkhoyansk Lowland and adjacent territories and seas based on geophysical data, in Tektonika Arktiki, Skladchatyi fundament shelífovykh sedimentatsionnykh basseynov (Tectonics of the Arctic; The folded basement of shelf sedimentary basins): Leningrad, NIIGA, p. 98-121.

Maksimov, S.P., ed., 1987, Oil and gas fields of the USSR (Heftyanye i gazovye mestorozhdeniya SSSR), Volumes 1 and 2: Moscow, Nedra, 360 and $304 \mathrm{p}$.

Maksimov, S.P., Dikenshteyn, G.Kh., and Lodzhevskaya, M.I., 1984, Formation and distribution of oil and gas pools at great depths (Formirovaniye i razmeshcheniye zalezhey nefti I gaza na bolshikh glubinakh): Moscow, Nedra, 288 p.

Maksimov, S.P., Kleschev, K.A., and Shein, V.S., eds., 1986, Geology and geodynamics of petroleum-bearing regions of the southern USSR (Geologiya i geodynamika neftegazonosnykh territoriy yuga SSSR): Moscow, Nedra, $232 \mathrm{p}$.

Malushin, I.I., 1985, Genesis of the North Caspian depression: Sovetskaya Geologia, no. 10, p. 72-77.

Mirzoev, D.A., and Dzhaparidze, L.I., 1979, Determination of catagenesis of dispersed organic matter and stages of oil and gas generation in sedimentary sequences of the platform cover of eastern North Caucasus, in Vassoevich, N.B., and Timofeev, P.P., eds., Neftematerinskie svity i printsypy ikh diagnostiki (Oil-source formations and principles of their identification): Moscow, Nauka, p. 200-209.

Oil and Gas Journal, 1998, Russians to seek exploration in difficult Far East basins: Oil and Gas Journal, June 1, 1998, p. 79-80.

Petroconsultants Corp., 1996, Petroleum exploration and production database through 1996: Geneva, Switzerland, Petroconsultants, Inc.

Pigott, N., Smith, M.S., and Simmons, M.D., 1996, Petroleum systems of the South Caspian, AAPG-ASPG Research Symposium Oil and Gas Petroleum Systems in Rapidly Subsiding Basins, October 6-9, 1996: Baku, Azerbaijan, Abstracts, unpaginated.

Popkov, V.I., 1991, Role of horizontal compression in formation of platform anticlines of Mangyshlak and Ustyurt: Geologia Nefti I Gaza, no. 7, p. 2-6.

Proshlyakov, B.K., Galyanova, T.I., and Pimenov, Yu.G., 1987, Reservoir properties of sedimentary rocks at great depths (Kollektorskiye svoystva osadochnykh porod na bolshikh glubinakh): Moscow, Nedra, $201 \mathrm{p}$.

Shablinskaya, N.V., Budanov, G.F., and Lazarev, V.S., 1990, Promezhutochnye kompleksy platformennykh oblastey SSSR I ikh neftegazonosnost (Intermediate complexes of the platform regions of the USSR and their petroleum potential): Leningrad, Nedra, $180 \mathrm{p}$. 
Simakov, S.N., ed., 1986, Prediction and assessment of oil and gas resources at great depths (Prognoz i otsenka neftegazonosnosti nedr na bolshikh glubinakh): Leningrad, Nedra, 248 p.

Sobornov, K.O., 1995, Geologic framework of the petroleum productive thrust belt of eastern Caucasus: Geologia Nefti I Gaza, no. 10, p. 1621.

Sokolov, B.A., Korchagina, Yu. I., Mirzoev, D.A., Sergeeva, V.N., Sebernov, K.O., and Fadeeva, N.P., 1990, Neftegazoobrazovanie I neftegazonakoplenie v Vostochnom Predkavkazye (Oil and gas generation and accumulation in eastern North Caucasus): Moscow, Nauka, 204 p.

Svetlakova, E.A., 1987, Model of formation regularities of distribution of hydrocarbon pools in the North Caspian basin, in Krylov, N.A., and Nekhrikova, N.A., eds., Petroleum potential of the North Caspian basin and adjacent areas (Neftegazonosnost Prikaspiyskoy vpadiny i sopredelnykh rayonov): Moscow, Nauka, p. 151-154.

Ulmishek, G.F., 1990, Uzen field, in Beaumont, E.A., and Foster, N.H., compilers, Structural traps III, Treatise of petroleum geology, Atlas of oil and gas fields: American Association of Petroleum Geologists, p. 281-298.

Ulmishek, G.F., Bogino, V.A., Keller, M.B., and Poznyakevich, Z.L., 1994, Structure, stratigraphy, and petroleum geology of the Pripyat and Dnieper-Donets basin, Byelarus and Ukraine, in Landon, S.M., ed., Interior rift basins: American Association of Petroleum Geologists Memoir 59, p. 125-156.

Ulmishek, G.F., and Harrison, W., 1981, Petroleum geology and resource assessment of the Middle Caspian basin, USSR, with special emphasis on the Uzen field: Argonne National Laboratory Report ANL/ES-116, $146 \mathrm{p}$.

Yakubov, A.A., 1980, Mud volcanism of the Soviet Union and its relation to the petroleum productivity (Gryazevoy vulkanizm Sovetskogo Soyuza i ego svyaz s neftegazonosnostyu): Baku, Azerbaijan, Elm, $166 \mathrm{p}$.

Zonenshain, L.P., Kuzmin, M.I., and Natapov, L.M., 1990, Tectonics of lithospheric plates of the USSR territory (Tektonika litocfernykh plit territorii SSSR): Moscow, Nedra, v. 1, 328 p. 


\section{Chapter D}

\section{Comparison of Kinetic-Model Predictions of Deep Gas Generation}

By Allison A. Henry and Michael D. Lewan

Prepared in cooperation with the U.S. Department of Energy-National Energy Technology Laboratory, the Gas Technology Institute, and

Advanced Resources International

U.S. Department of the Interior

U.S. Geological Survey 


\section{Contents}

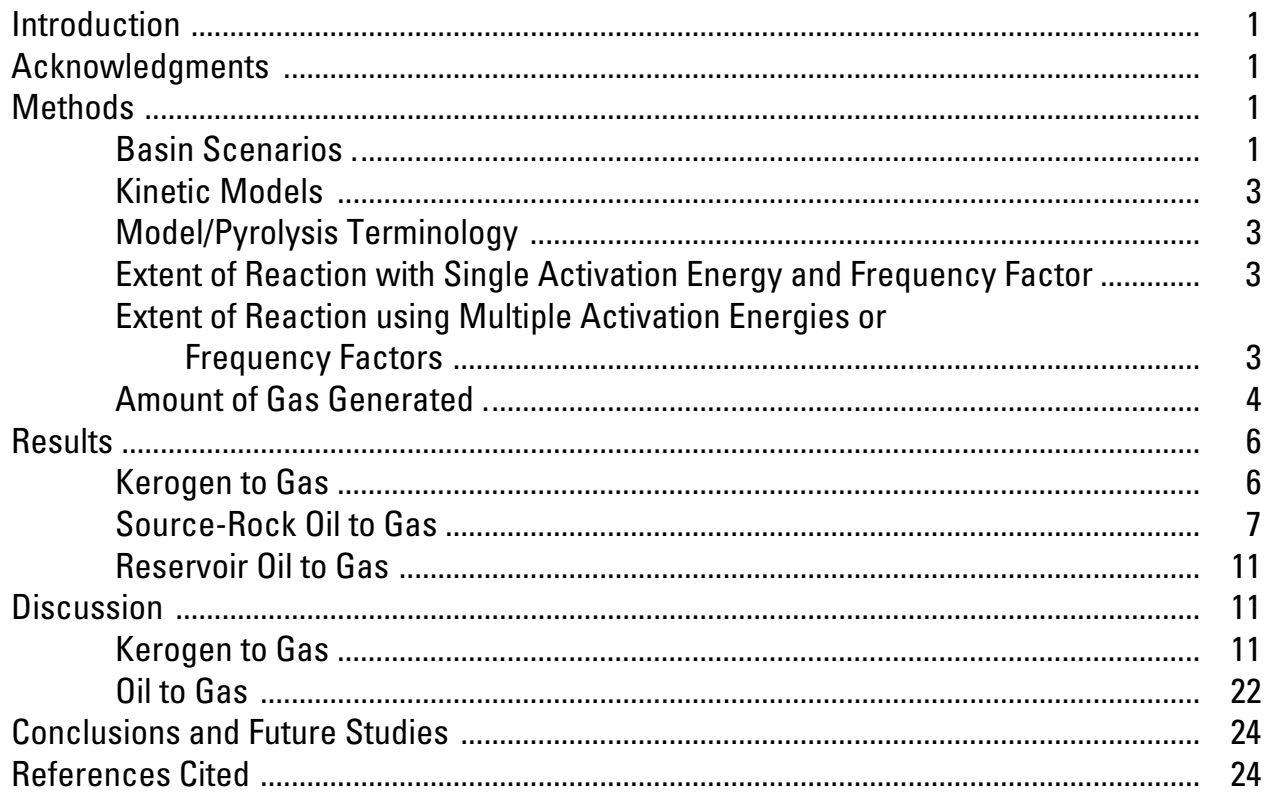

\section{Figures}

1-7. Graphs showing:

1. Amount of $C_{1}-C_{5}$ gas generated from Type-I kerogen with increasing burial depth, according to open-pyrolysis and composite-pyrolysis models at geologic heating rates of $1^{\circ} \mathrm{C} / \mathrm{m}$.y. and $10^{\circ} \mathrm{C} / \mathrm{m}$.y.

2. Amount of $C_{1}-C_{5}$ gas generated from Type-II kerogen with increasing burial depth, according to open-pyrolysis and composite-pyrolysis models at geologic heating rates of $1{ }^{\circ} \mathrm{C} / \mathrm{m}$.y. and $10^{\circ} \mathrm{C} / \mathrm{m}$.y.

3. Amount of $\mathrm{C}_{1}-\mathrm{C}_{5}$ gas generated from Type-IIS kerogen with increasing burial depth, according to open-pyrolysis and composite-pyrolysis models at geologic heating rates of $1^{\circ} \mathrm{C} / \mathrm{m} . \mathrm{y}$. and $10^{\circ} \mathrm{C} / \mathrm{m} . \mathrm{y}$.

4. Amount of $\mathrm{C}_{1}-\mathrm{C}_{5}$ gas generated from Type-III kerogen with increasing burial depth, according to open-pyrolysis and composite-pyrolysis models at geologic heating rates of $1^{\circ} \mathrm{C} / \mathrm{m} . \mathrm{y}$. and $10^{\circ} \mathrm{C} / \mathrm{m} . \mathrm{y}$.

5. Amount of $\mathrm{C}_{1}-\mathrm{C}_{5}$ gas generated from Type-III' kerogen with increasing burial depth, according to open-pyrolysis and composite-pyrolysis models at geologic heating rates of $1{ }^{\circ} \mathrm{C} / \mathrm{m}$.y. and $10^{\circ} \mathrm{C} / \mathrm{m}$.y. 
6. Amount of $C_{1}-C_{5}$ gas generated from the cracking of oil in 16 different source rocks with increasing burial depth, according to anhydrouspyrolysis model at geologic heating rates of $1{ }^{\circ} \mathrm{C} / \mathrm{m}$.y. and $10^{\circ} \mathrm{C} / \mathrm{m} . \mathrm{y}$.

7. Amount of gas generated from the cracking of reservoir oil with increasing burial depth, according to anhydrous-pyrolysis and hydrous-pyrolysis models at geologic heating rates of $1^{\circ} \mathrm{C} / \mathrm{m}$.y. and $10^{\circ} \mathrm{C} / \mathrm{m}$.y.

\section{Tables}

1. Summary of six gas-generation kinetic models considered in this study

2. Fractional gas yields assigned to discrete activation energies and singlefrequency factors used by Behar and others (1997) to model gas generation from kerogen

3. Fractional $\mathrm{C}_{1}-\mathrm{C}_{4}$ gas yields assigned to discrete activation energies by Horsfield and others (1992) to model gas generation from the cracking of oil

4. Gaussian distributions and their calculated discrete distributions of activation energies (a) with fractional $C_{1}-C_{5}$ gas yields from kerogens as predicted by the composite-pyrolysis model (Pepper and Corvi, 1995); (b) with fractional $C_{1}-C_{5}$ gas yields from oil retained in mature source rocks as predicted by the anhydrous-pyrolysis model (Pepper and Dodd, 1995); and (c) with fractional methane $\left(C_{1}\right)$, ethane $\left(C_{2}\right)$, propane $\left(C_{3}\right)$, and butane $\left(C_{4}\right)$ yields from Type-II kerogen in the New Albany Shale (Devonian-Mississippian) as predicted by the hydrous-pyrolysis model (Knauss and others, 1997)

5. Maximum $\mathrm{C}_{1}-\mathrm{C}_{5}$ gas yields for different starting materials used in six kinetic models

6. Summary of gas generation curves for kerogens and oils (figs. 1-6) with respect to yield, depth, time, and temperature for fraction of reaction values of $0.05,0.25,0.50,0.75$, and 0.99 at $1^{\circ}$ and $10^{\circ} \mathrm{C} / \mathrm{m}$.y. heating rates for each kinetic model

7. Amounts of gas generated from kerogen above and below deep gas depth of $15,000 \mathrm{feet} / 4,572 \mathrm{~m}$

8. Amounts of gas generated from cracking of oil above and below deep gas depth of 15,000 feet $/ 4,572 \mathrm{~m}$ 


\title{
Comparison of Kinetic-Model Predictions of Deep Gas Generation
}

\author{
By Allison A. Henry ${ }^{1}$ and Michael D. Lewan²
}

\section{Introduction}

The origin of and processes resulting in natural gas generation remain a controversial issue in petroleum geochemistry (Price, 1997). Various investigations have used different pyrolysis methods and organic sources to develop models to predict timing and quantities of natural gas generation in sedimentary basins (table 1). The results and implications of these different models on predicting natural gas generation have not previously been compared in the literature. The objective of this study is to compare six different published gas-generation kinetic models (table 1) with respect to their predictions of timing and quantities of deep gas generation. As discussed by Dyman and others (1997), the potential for deep gas at depths greater than 15,000 feet/4,572 $\mathrm{m}$ remains an uncertain domestic exploration frontier. Two geologic settings for the occurrence of deep gas emerge from this definition. The first geologic setting envisages gas being initially generated and accumulating in traps at shallow depths $(<15,000$ feet $/ 4,572 \mathrm{~m})$. As sedimentation and basin subsidence continue with geologic time, these shallow traps remain coherent and are eventually buried to depths greater than 15,000 feet/4,572 $\mathrm{m}$. Deep gas accumulations resulting from this setting are dependent on the competence of trap closures and seals with burial to depths greater than 15,000 feet $/ 4,572 \mathrm{~m}$. The second geologic setting envisages gas generation and accumulation in traps at deeper depths ( $>15,000 \mathrm{feet} / 4,572 \mathrm{~m})$. Deep-gas accumulations resulting from this setting are dependent on a source of gas at burial depths greater than 15,000 feet/4,572 m. It is this dependence on sources of deep gas generation that this study examines.

Various kinetic models for the generation of natural gas in sedimentary basins have been published over the last several years. These gas-generation kinetic models are primarily based on different types of laboratory pyrolysis methods, which include open-system anhydrous pyrolysis (for example, RockEval; Behar and others, 1997), closed-system anhydrous pyrolysis (for example, microscale sealed (MSSV) pyrolysis; Horsfield and others, 1992), and closed-system hydrous pyrolysis (flexible gold-bag autoclaves; Knauss and others, 1997). In addition to employing different pyrolysis methods, different starting materials are considered as the source of natural gas. Some kinetic models consider crude oil in deeply buried reservoirs (Tsuzuki

\footnotetext{
${ }^{1}$ Current Address: The Scripps Research Institute, 10550 North Torrey Pines Road, La Jolla, CA 92037. (<ahenry@scripps.edu>)

$2^{2}<$ mlewan@usgs.gov>
}

and others, 1997), and others consider unexpelled oil retained in mature source rocks (Pepper and Corvi, 1995).

These kinetic models are examined in two hypothetical basin scenarios that represent end-member heating rates of $1^{\circ}$ and $10^{\circ} \mathrm{C} / \mathrm{m}$.y. This study makes no attempt to judge the validity of the six kinetic models used but only intends to present and compare their results and the implications they have on deep gas generation. Kinetic models for the thermal stability of crude oil that are based on model hydrocarbons were not included in this study. Although studies of such models provide useful information on the influence of pressure, oil matrices, and cracking mechanisms (Domine, 1991; Behar and Vandenbroucke, 1996; Burnham and others, 1997), either they are based on the loss of the model compound rather than generated gas, or the generated gases have peculiar gas compositions significantly different from natural gases.

\section{Acknowledgments}

This study was funded in part by the U.S. Department of Energy (National Energy Technology Laboratory, Morgantown, W.Va., contract No. DE-AT26-98FT40032), Gas Research Institute (Chicago, Ill.) as a Cooperative Research and Development Agreement with Advanced Resources International (Arlington, Va.), and the U.S. Geological Survey, Denver, Colo. The authors also appreciate the helpful reviews of this report made by John Curtis (Colorado School of Mines), Thaddeus Dyman (USGS), and Katharine Varnes (USGS).

\section{Methods}

\section{Basin Scenarios}

Gretener and Curtis (1982) have estimated common heating rates for sedimentary basins to be between $1^{\circ}$ and $10^{\circ} \mathrm{C} / \mathrm{m}$.y. In keeping with these limits, the kinetic models used in this study are compared in two end-member basin scenarios. One basin scenario uses a thermal gradient of $30^{\circ} \mathrm{C} / \mathrm{km}$ and burial rate of $33.3 \mathrm{~m} / \mathrm{m}$.y., which results in a heating rate of $1^{\circ} \mathrm{C} / \mathrm{m} . \mathrm{y}$. The other scenario uses a thermal gradient of $45^{\circ} \mathrm{C} / \mathrm{km}$ and burial rate of $222.2 \mathrm{~m} / \mathrm{m} . \mathrm{y}$., which results in a heating rate of $10^{\circ} \mathrm{C} / \mathrm{m}$.y. The heating rates were assumed to be linear in both basin scenarios. 
Table 1. Summary of six gas-generation kinetic models considered in this study.

\begin{tabular}{|c|c|c|c|c|}
\hline Model name & $\operatorname{Ref}^{*}$ & Starting material & Kinetic approach & Kinetic parameters \\
\hline Open pyrolysis & 1 & $\begin{array}{l}\text { Kerogen } \\
\text { (Type-I, -II, -IIS, -III) }\end{array}$ & $\begin{array}{l}\text { Optimization of non-isothermal } \\
\text { experiments at different heating rates. }\end{array}$ & $\begin{array}{l}\text { Discrete distribution of activation } \\
\text { energies with single frequency factor. }\end{array}$ \\
\hline Composite pyrolysis & 2 & $\begin{array}{l}\text { Kerogen } \\
\text { (Type-I, -II, -IIS, -III) }\end{array}$ & $\begin{array}{l}\text { Optimization of open and } \\
\text { anhydrous pyrolysis and natural data. }\end{array}$ & $\begin{array}{l}\text { Gaussian distribution of activation } \\
\text { energies with single frequency factor. }\end{array}$ \\
\hline \multirow[t]{2}{*}{ Hydrous pyrolysis } & 3 & $\begin{array}{l}\text { Kerogen } \\
\text { (Type-II) }\end{array}$ & $\begin{array}{l}\text { Optimization of isothermal pyrolysis } \\
\text { experiments. }\end{array}$ & $\begin{array}{l}\text { Gaussian distribution of activation } \\
\text { energies with single frequency factor. }\end{array}$ \\
\hline & 4 & $\begin{array}{l}\text { Crude oil } \\
\text { (light and heavy saturates) }\end{array}$ & $\begin{array}{l}\text { Optimization of isothermal pyrolysis } \\
\text { experiments. }\end{array}$ & $\begin{array}{l}\text { Single activation energies and frequency } \\
\text { factors for light and heavy saturates. }\end{array}$ \\
\hline Anhydrous pyrolysis & 6 & $\begin{array}{l}\text { Immature source rock } \\
\text { (organofacies } \mathrm{A}, \mathrm{B}, \mathrm{C}, \mathrm{D} / \mathrm{E}, \mathrm{F} \text { ) }\end{array}$ & $\begin{array}{l}\text { Optimization of isothermal pyrolysis } \\
\text { experiments at one temperature. }\end{array}$ & $\begin{array}{l}\text { Gaussian distribution of activation } \\
\text { energies with single frequency factor. }\end{array}$ \\
\hline
\end{tabular}

* References: 1, Behar and others (1997); 2, Pepper and Corvi (1995); 3, Knauss and others (1997); 4, Tsuzuki and ot hers (1997); 5, Horsfield and others (1992); 6, Pepper and Dodd (1995). 


\section{Kinetic Models}

Attributes of the six kinetic models considered in this study are given in table 1. Three of the models consider gas generation from kerogen (Behar and others, 1997; Pepper and Corvi, 1995; and Knauss and others, 1997). Behar and others (1997) used kerogen samples including a Type-I kerogen from the Eocene Green River Formation, Type-II kerogen from a Toarcian shale of the Paris basin, Type-IIS kerogen from the Miocene Monterey Formation, and two Type-III kerogens from a Miocene coal in the Mahakam delta and a Dogger coal from the North Sea. Pepper and Corvi (1995) organized their kerogen samples into organofacies A, B, C, D/E, and F. According to their definitions of organofacies, organofacies A kerogen is similar to Type-IIS kerogen, organofacies B kerogen is similar to Type-II kerogen, organofacies C kerogen is similar to Type-I kerogen, organofacies D/E is similar to Type-III kerogen, and organofacies F is similar to Type-III/IV kerogens. Knauss and others (1997) used New Albany Shale (Devonian-Mississippian), which contains Type-II kerogen.

The other three models consider gas generation from the cracking of oil (Horsfield and others, 1992; Pepper and Dodd, 1995; and Tsuzuki and others, 1997). Horsfield and others (1992) used a medium-gravity crude oil from a Middle Jurassic reservoir in the Central Graben of the Norwegian North Sea (NOCS 33/9-14). Pepper and Dodd (1995) focused on the insource cracking of oil as opposed to the cracking of reservoir oils; the authors used 16 samples of source rocks classified as members of their five organofacies. Tsuzuki and others (1997) used a Sarukawa crude oil with an API gravity of $33.6^{\circ}$.

\section{Model/Pyrolysis Terminology}

The four types of models in this study are based on different pyrolysis methods. The open-pyrolysis model uses RockEval pyrolysis to determine kinetic parameters (Behar and others, 1997). The composite-pyrolysis model refers to Pepper and Corvi's (1995) mixed data set from many different references, natural data sets, and open- and closed-system pyrolysis methods. The anhydrous-pyrolysis model refers to closed-system pyrolysis of kerogen or oil without liquid water and is used by Pepper and Dodd (1995) and Horsfield and others (1992). The hydrous-pyrolysis model refers to pyrolysis of kerogen or oil in the presence of liquid water and is used by Knauss and others (1997) and Tsuzuki and others (1997).

\section{Extent of Reaction with Single Activation Energy and Frequency Factor}

As demonstrated by Wood (1988), the extent of a reaction (that is, $k=$ rate constant) that follows the Arrhenius equation,

$$
k=A \exp \left(-\frac{E}{R T}\right)
$$

can be reasonably estimated over a linear heating rate by the approximate analytical integral solution derived by Gorbachev (1975):

$$
\begin{gathered}
\text { TTIARR }=\left\{\left(A\left(\mathrm{tn}+1-\mathrm{tn}_{\mathrm{n}}\right)\right) /\left(T \mathrm{n}+1-T_{\mathrm{n}}\right)\right\} \\
\left\{\left[\left(R T^{2}{ }_{\mathrm{n}+1} /(E+2 R T \mathrm{n}+1)\right) * \exp \left(-E / R T_{\mathrm{n}+1}\right)\right]\right. \\
\left.-\left[\left(R T^{2} \mathrm{n} /(E+2 R T \mathrm{n})\right) * \exp \left(-E / R T_{\mathrm{n}}\right)\right]\right\}
\end{gathered}
$$

where TTIARR is the extent of reaction function or time-temperature index, $A$ is the frequency factor in m.y. ${ }^{-1}, E$ is the activation energy in cal $/ \mathrm{mol}, R$ is the ideal gas constant in cal $/ \mathrm{mol}-\mathrm{K}$, tn is the beginning of the time interval in m.y., $\mathrm{tn}+1$ is the end of the time interval in m.y., $\mathrm{Tn}$ is the temperature in $\mathrm{K}$ at the start of the time interval, and $T \mathrm{n}+1$ is the temperature in $\mathrm{K}$ at the end of the time interval. TTIARR can be equated to the integrated first order rate equation,

$$
\ln (1 /[1-X])=k t
$$

by

$$
\text { TTIARR }=\ln (1 /[1-X])
$$

where $X$ represents the extent of reaction as a decimal fraction, which is referred to as fraction of reaction. TTIARR values can be calculated for various intervals in the burial history of a potential source rock using equation 1 . The TTIARR calculated for each burial interval is additive, and the sum values can be converted to fraction of reaction by solving equation 3 for $X$ :

$$
X=1-(1 / \exp [\text { TTIARR }])
$$

Tsuzuki and others (1997) derived single $E$ and $A$ values for the generation of $\mathrm{C}_{1}-\mathrm{C}_{5}$ hydrocarbon gas from the cracking of light $\left(\mathrm{C}_{6}-\mathrm{C}_{14}\right.$ saturates $)$ and heavy $\left(\mathrm{C}_{15+}\right.$ saturates $)$ components of crude oil. The activation energy and frequency factor for the cracking of the light component are respectively $86 \mathrm{kcal} /$ mol and $6.4868 \times 10^{35}$ m.y. $^{-1}$ The activation energy and frequency factor for the cracking of the heavy component are respectively $76 \mathrm{kcal} / \mathrm{mol}, 3.4187 \times 10^{33}$ m.y. ${ }^{-1}$ These kinetic parameters and the two end-member heating rates were used in equation 1 to determine the extent of gas generation from the cracking of oil in the two basin scenarios.

\section{Extent of Reaction using Multiple Activation Energies or Frequency Factors}

In order to reflect a first-order reaction with more than one frequency factor or activation energy, $X$ of equation 4 must also represent the fractional extent of reaction for each activation energy and frequency factor. Multiple activation energies or frequency factors are derived by curve-fitting methods that assume first-order parallel reactions. The multiple kinetic parameters are described as discrete or Gaussian distributions, wherein each of the multiple parameters is assigned a fractional part of the overall reaction (Ungerer and others, 1986; Braum and Burnham, 1987). 
The discrete distribution is used by Behar and others (1997) and Horsfield and others (1992). Both groups optimized their experimental kinetic data in such a way as to give a variety of activation energies with associated fractions of reaction and a single frequency factor. Behar and others (1997) presented discrete activation-energy distributions for the generation of methane $\left(\mathrm{C}_{1}\right)$ and $\mathrm{C}_{2}-\mathrm{C}_{5}$ hydrocarbon gas from five kerogens (table 2). Horsfield and others (1992) also used a discrete activationenergy distribution between 50 and $73 \mathrm{kcal} / \mathrm{mol}$ with a frequency factor of $3.47 \times 10^{29} \mathrm{~m} .{ }^{-1}$ for oil cracking to $\mathrm{C}_{1}-\mathrm{C}_{4}$ hydrocarbon gas (table 3). Equation 1 is used for each discrete activation energy for the fractional part of the reaction it is assigned and then summed with results from the other discrete activation energies to give a cumulative generation curve for the extent of reaction.

The Gaussian distribution of activation energies is employed by Pepper and Dodd (1995), Pepper and Corvi (1995), and Knauss and others (1997). The distribution is presented by a mean activation energy, Emean, and a standard deviation, $\sigma E$, as shown in table 4. A Gaussian distribution is expressed by the equation

$$
Y=\frac{1}{\sigma \sqrt{2 \Pi}} e^{-\frac{1}{2}(\mathrm{X}-\mu)^{2} / \sigma^{2}}
$$

where $\sigma$ is the standard deviation at the 68 percent confidence level $(\sigma E), \mu$ is the mean activation energy (Emean), and $Y$ is the height of the curve above a given $X$ (discrete activation energy). The function reaches a maximum value of

$$
\frac{1}{\sigma \sqrt{2 \Pi}}
$$

when $X=\mu$. Using equation 5 and the parameters given by the cited authors, the Gaussian distribution was divided into discrete $1.0-\mathrm{kcal} / \mathrm{mol}$ activation energies. As the area under the normal curve is one and each rectangle of discrete activation energy is one unit wide, the area of the rectangle becomes the fractional part of the reaction for a given discrete activation energy. When summed, the values at each discrete energy will equal 1. Equation 1 is used for each discrete activation energy to determine the fractional part of the reaction it is assigned and then summed with results from the other discrete activation energies to give a cumulative generation curve for the extent of reaction. Pepper and Corvi (1995) and Knauss and others (1997) used a different single frequency factor with each distribution, but Pepper and Dodd (1995) used the same single frequency factor for all of their activation energy distributions (table 4).

\section{Amount of Gas Generated}

All the kinetic models considered in this study employ firstorder reaction rates, which give the extent of reaction, $X$, as a decimal fraction of the completed reaction at unity (that is, $X$ equals amount of gas generated at a particular thermal stress divided by the maximum amount of gas that can be generated from a particular source material). The obvious question that remains is, how much gas per mass of starting material does unity equal? Behar and others (1997) explicitly stated the maximum amounts $(X=1)$ of $\mathrm{C}_{1}$ and $\mathrm{C}_{2}-\mathrm{C}_{5}$ generated from kerogen, as given in table 5. These values were combined to give maximum yields for $\mathrm{C}_{1}-\mathrm{C}_{5}$ in milligrams per gram of total organic carbon (mg/g C). Pepper and Corvi (1995) gave maximum $\mathrm{C}_{1^{-}}$ $\mathrm{C}_{5}$ gas generation for each of their five organofacies: $\mathrm{A}=105$ $\mathrm{mg} / \mathrm{g} \mathrm{C} ; \mathrm{B}=101 \mathrm{mg} / \mathrm{g} \mathrm{C} ; \mathrm{C}=78 \mathrm{mg} / \mathrm{g} \mathrm{C} ; \mathrm{D} / \mathrm{E}=77 \mathrm{mg} / \mathrm{g} \mathrm{C}$; and $\mathrm{F}=70 \mathrm{mg} / \mathrm{g} \mathrm{C}$.

The maximum gas concentrations reported as mmolal for the hydrous-pyrolysis experiments by Knauss and others (1997) are converted to $\mathrm{mg} / \mathrm{g} \mathrm{C}$ by the equation

$$
\operatorname{Gas}(\mathrm{mg} / \mathrm{gC})=\frac{M W \times \text { Gmmolal } \times \frac{w}{S}}{1000 \times \mathrm{TOC}}
$$

where $M W$ is the formula weight of the gas component (that is, $\mathrm{C}_{1}=16.04 \mathrm{~g} / \mathrm{mol}, \mathrm{C}_{2}=30.07 \mathrm{~g} / \mathrm{mol}, \mathrm{C}_{3}=44.10 \mathrm{~g} / \mathrm{mol}$, and $\mathrm{C}_{4}=$ $58.12 \mathrm{~g} / \mathrm{mol}), G_{\text {mmolal }}$ is the maximum gas yield in mmolal (Knauss and others, 1997; table 2, p. 482-483), $w / s$ is the water:shale ratio at time zero for the experiments $(4.06 \mathrm{~g} / \mathrm{g})$, and TOC is the total organic carbon of the rock expressed as a fraction (0.114). Equation 6 gives maximum gas yields of $26.5 \mathrm{mg} /$ $\mathrm{g} \mathrm{C}$ for methane $\left(\mathrm{C}_{1}\right), 24.9 \mathrm{mg} / \mathrm{g} \mathrm{C}$ for ethane $\left(\mathrm{C}_{2}\right), 22.0 \mathrm{mg} / \mathrm{g} \mathrm{C}$ for propane $\left(\mathrm{C}_{3}\right)$ and $19.4 \mathrm{mg} / \mathrm{g} \mathrm{C}$ for butane $\left(\mathrm{C}_{4}\right)$. The total of these values $\left(92.8 \mathrm{mg} / \mathrm{g} \mathrm{C}\right.$ ) gives the maximum $\mathrm{C}_{1}-\mathrm{C}_{4}$ gas generated from the New Albany Shale (table 5).

According to Pepper and Dodd (1995), the maximum amount of $\mathrm{C}_{1}-\mathrm{C}_{5}$ gas generated from the cracking of oil in a source rock is equivalent to the amount of oil remaining in the kerogen after expulsion. Therefore, the maximum amount of gas for all 16 kerogen samples is $100 \mathrm{mg} / \mathrm{g} \mathrm{C}$, which they considered the threshold for oil retained by sorption in the kerogen (A.S. Pepper, pers. commun., 1998).

Horsfield and others (1992) experimentally determined that the maximum amount of $\mathrm{C}_{1}-\mathrm{C}_{4}$ gas generated from the cracking of reservoired oil by closed-system anhydrous pyrolysis is $460 \mathrm{mg} / \mathrm{g}$ oil. Tsuzuki and others (1997) considered gas generation from the cracking of reservoired Sarukawa oil by closed-system hydrous pyrolysis. The generation of $\mathrm{C}_{1}-\mathrm{C}_{5}$ gas is described by two reactions. One reaction $(k 11)$ involves the conversion of $\mathrm{C}_{15+}$ heavy saturates $\left(\mathrm{C}_{15+}\right.$ Sat $)$ to $\mathrm{C}_{15+}$ heavy condensed aromatics $\left(\mathrm{C}_{15+}\right.$ Aro $), \mathrm{C}_{1}-\mathrm{C}_{5}$ gas $\left(\mathrm{C}_{1}-\mathrm{C}_{5}\right)$, and $\mathrm{C}_{6}-$ $\mathrm{C}_{14}$ light saturates $\left(\mathrm{C}_{6}-\mathrm{C}_{14} \mathrm{Sat}\right)$ :

$$
\mathrm{C}_{15+} \text { Sat } \stackrel{k \mathbf{1 1}}{\longrightarrow} 0.36\left(\mathrm{C}_{15+} \text { Aro }\right)+0.27\left(\mathrm{C}_{1}-\mathrm{C}_{5}\right)
$$

The other reaction $(k 2)$ involves the conversion of the generated $\mathrm{C}_{6}-\mathrm{C}_{14}$ light saturates $\left(\mathrm{C}_{6}-\mathrm{C}_{14} \mathrm{Sat}\right)$ generated in reaction 7 to $\mathrm{C}_{1}-\mathrm{C}_{5}$ gas $\left(\mathrm{C}_{1}-\mathrm{C}_{5}\right)$ and insoluble coke $\left(\mathrm{C}_{\infty}\right)$ :

$$
\mathrm{C}_{6}-\mathrm{C}_{14} \text { Sat } \stackrel{k 2}{\longrightarrow} 0.60\left(\mathrm{C}_{1}-\mathrm{C}_{5}\right)+0.40\left(\mathrm{C}_{\infty}\right) \text {. }
$$

Jamil and others (1991) reported that $\mathrm{C}_{15+}$ heavy saturates $\left(\mathrm{C}_{15+}\right.$ Sat) compose 64.9 wt. percent of Sarukawa oils. Therefore, $1 \mathrm{~g}$ of oil will initially generate $175 \mathrm{mg}$ of $\mathrm{C}_{1}-\mathrm{C}_{5}$ gas through the cracking of $\mathrm{C}_{15+}$ heavy saturates $\left(\mathrm{C}_{15+} \mathrm{Sat}\right.$; equation 7) and an additional $144 \mathrm{mg}$ of $\mathrm{C}_{1}-\mathrm{C}_{5}$ gas through the cracking of $\mathrm{C}_{6}-\mathrm{C}_{14}$ light saturates $\left(\mathrm{C}_{6}-\mathrm{C}_{14} \mathrm{Sat}\right.$; equation 8$)$. These two values are combined to give $319 \mathrm{mg} / \mathrm{g}$ oil as the maximum amount of gas generated from the cracking of oil. 
Table 2. Fractional gas yields assigned to discrete activation energies and single-frequency factors used by Behar and others (1997) to model gas generation from kerogen.

\begin{tabular}{|c|c|c|c|c|c|c|c|c|c|c|c|}
\hline & \multicolumn{11}{|c|}{ Fractional Part of Total Gas Yield } \\
\hline & & \multicolumn{2}{|c|}{ Type-I kerogen } & \multicolumn{2}{|c|}{ Type-Il kerogen } & \multicolumn{2}{|c|}{ Type-IIS kerogen } & \multicolumn{2}{|c|}{ Type-III' kerogen } & \multicolumn{2}{|c|}{ Type-III kerogen } \\
\hline & & $\mathrm{C}_{1}$ & $\mathrm{C}_{2}-\mathrm{C}_{5}$ & $\mathrm{C}_{1}$ & $\mathrm{C}_{2}-\mathrm{C}_{5}$ & $\mathrm{C}_{1}$ & $\mathrm{C}_{2}-\mathrm{C}_{5}$ & $\mathrm{C}_{1}$ & $\mathrm{C}_{2}-\mathrm{C}_{5}$ & $\mathrm{C}_{1}$ & $\mathrm{C}_{2}-\mathrm{C}_{5}$ \\
\hline & $\begin{array}{c}\text { Activation } \\
\text { energy }(\mathrm{kcal} / \mathrm{mol})\end{array}$ & $\begin{array}{r}\text { Fractional } \\
\text { gas yield }\end{array}$ & $\begin{array}{l}\text { Fractional } \\
\text { gas yield }\end{array}$ & $\begin{array}{l}\text { Fractional } \\
\text { gas yield }\end{array}$ & $\begin{array}{c}\text { Fractional } \\
\text { gas yield }\end{array}$ & $\begin{array}{c}\text { Fractional } \\
\text { gas yield }\end{array}$ & $\begin{array}{c}\text { Fractional } \\
\text { gas yield }\end{array}$ & $\begin{array}{c}\text { Fractional } \\
\text { gas yield }\end{array}$ & $\begin{array}{c}\text { Fractional } \\
\text { gas yield }\end{array}$ & $\begin{array}{r}\text { Fractional } \\
\text { gas yield }\end{array}$ & $\begin{array}{r}\text { Fractional } \\
\text { gas yield }\end{array}$ \\
\hline & 74.0 & 0.00 & 0.00 & 0.00 & 0.00 & 0.00 & 0.00 & 0.00 & 0.00 & 0.032 & 0.00 \\
\hline & 70.0 & 0.00 & 0.00 & 0.00 & 0.00 & 0.00 & 0.00 & 0.13 & 0.00 & 0.133 & 0.06 \\
\hline & 68.0 & 0.00 & 0.00 & 0.00 & 0.002 & 0.00 & 0.00 & 0.16 & 0.02 & 0.136 & 0.05 \\
\hline & 66.0 & 0.02 & 0.00 & 0.02 & 0.006 & 0.004 & 0.00 & 0.16 & 0.04 & 0.159 & 0.10 \\
\hline & 64.0 & 0.08 & 0.00 & 0.07 & 0.014 & 0.019 & 0.00 & 0.16 & 0.07 & 0.155 & 0.18 \\
\hline & 62.0 & 0.08 & 0.00 & 0.11 & 0.024 & 0.034 & 0.00 & 0.14 & 0.17 & 0.129 & 0.25 \\
\hline & 60.0 & 0.10 & 0.00 & 0.13 & 0.040 & 0.174 & 0.01 & 0.11 & 0.28 & 0.094 & 0.24 \\
\hline & 56.0 & 0.19 & 0.00 & 0.15 & 0.225 & 0.186 & 0.05 & 0.03 & 0.13 & 0.003 & 0.02 \\
\hline $\bar{z}$ & 54.0 & 0.38 & 0.95 & 0.15 & 0.247 & 0.144 & 0.19 & 0.01 & 0.05 & 0.00 & 0.00 \\
\hline$\overline{\bar{n}}$ & 52.0 & 0.02 & 0.05 & 0.11 & 0.241 & 0.080 & 0.27 & 0.00 & 0.02 & 0.00 & 0.00 \\
\hline 0 & 50.0 & 0.00 & 0.00 & 0.05 & 0.092 & 0.080 & 0.16 & 0.00 & 0.01 & 0.00 & 0.00 \\
\hline $\overrightarrow{\text { 즈 }}$ & 48.0 & 0.00 & 0.00 & 0.02 & 0.016 & 0.068 & 0.21 & 0.00 & 0.00 & 0.00 & 0.00 \\
\hline$\stackrel{\mathbb{\Phi}}{=}$ & 46.0 & 0.00 & 0.00 & 0.00 & 0.002 & 0.042 & 0.06 & 0.00 & 0.00 & 0.00 & 0.00 \\
\hline$\stackrel{?}{1}$ & 44.0 & 0.00 & 0.00 & 0.00 & 0.00 & 0.011 & 0.01 & 0.00 & 0.00 & 0.00 & 0.00 \\
\hline דृ & $\begin{array}{c}\text { Frequency } \\
\text { factor }(1 / \mathrm{m} . y .)\end{array}$ & $2.33 \mathrm{E}+27$ & $2.33 \mathrm{E}+27$ & $5.05 \mathrm{E}+27$ & $5.05 \mathrm{E}+27$ & $7.88 \mathrm{E}+26$ & $7.88 \mathrm{E}+26$ & $9.46 \mathrm{E}+28$ & $9.46 \mathrm{E}+28$ & $9.78 \mathrm{E}+28$ & $9.78 \mathrm{E}+28$ \\
\hline 言 & Total gas yields & $16.4 \mathrm{mg} / \mathrm{g} \mathrm{C}$ & $72.1 \mathrm{mg} / \mathrm{g} \mathrm{C}$ & $18.8 \mathrm{mg} / \mathrm{g} \mathrm{C}$ & $50.2 \mathrm{mg} / \mathrm{g} \mathrm{C}$ & $26.4 \mathrm{mg} / \mathrm{g} \mathrm{C}$ & $43.9 \mathrm{mg} / \mathrm{g} \mathrm{C}$ & $30.6 \mathrm{mg} / \mathrm{g} \mathrm{C}$ & $23.6 \mathrm{mg} / \mathrm{g} \mathrm{C}$ & $30.9 \mathrm{mg} / \mathrm{g} \mathrm{C}$ & $26.2 \mathrm{mg} / \mathrm{g} \mathrm{C}$ \\
\hline
\end{tabular}


Table 3. Fractional $\mathrm{C}_{1}-\mathrm{C}_{4}$ gas yields assigned to discrete activation energies by Horsfield and others (1992) to model gas generation from the cracking of oil.

\begin{tabular}{cc}
\hline $\begin{array}{c}\text { Activation } \\
\text { energy (kcal/mol) }\end{array}$ & $\begin{array}{c}\text { Fractional } \\
\text { gas yields }\end{array}$ \\
\hline 73 & 0.0174 \\
72 & 0.0087 \\
70 & 0.0587 \\
69 & 0.1109 \\
68 & 0.1478 \\
67 & 0.2870 \\
66 & 0.3435 \\
63 & 0.0043 \\
58 & 0.0065 \\
55 & 0.0022 \\
54 & 0.0022 \\
53 & 0.0043 \\
51 & 0.0022 \\
50 & 0.0022 \\
Frequency & $3.47 \mathrm{E}+29$ \\
factor $(1 / \mathrm{m} . \mathrm{y})$. & \\
Total gas yield & $460 \mathrm{mg} / \mathrm{g}$ oil \\
\hline
\end{tabular}

\section{Results}

\section{Kerogen to Gas}

Figure 1 shows the gas-generation curves for Type-I kerogens in basins with $1^{\circ}$ and $10^{\circ} \mathrm{C} / \mathrm{m}$.y. heating rates as predicted by the open- and composite-pyrolysis models. At the top of the deep gas depth $(15,000$ feet/4,572 m), 91 and 64 percent of gas generation from Type-I kerogen are completed at $1{ }^{\circ} \mathrm{C} / \mathrm{m} . \mathrm{y}$. according to the open- and composite-pyrolysis models, respectively. Therefore, 7.9 and $27.9 \mathrm{mg} / \mathrm{g} \mathrm{C}$ of deep gas are generated according to the open- and composite-pyrolysis models, respectively (fig. $1 A$ and table 6). Both models predict that the deep gas generation is finished (that is, $X=0.99$ ) at depths of 22,310 and 18,373 feet $(6,800$ and $5,600 \mathrm{~m})$ (table 6$)$. At the top of the deep gas depth $(15,000$ feet/4,572 $\mathrm{m})$, the open- and compositepyrolysis models respectively predict that 99 and 100 percent of gas generation from Type-I kerogen are completed at $10^{\circ} \mathrm{C} / \mathrm{m} . \mathrm{y}$. According to these models, essentially no deep gas is generated from Type-I kerogen at this heating rate.

Figure 2 shows the gas-generation curves for Type-II kerogens in basins with $1^{\circ}$ and $10^{\circ} \mathrm{C} / \mathrm{m}$.y. heating rates as predicted by the open- and composite-pyrolysis models. At the top of the deep gas depth $(15,000$ feet/4,572 $\mathrm{m}), 75,67$, and 35 percent of gas generation from Type-II kerogen are completed at $1{ }^{\circ} \mathrm{C} / \mathrm{m}$.y. according to the hydrous-, open-, and composite-pyrolysis models, respectively. These percentages indicate that 23.0, 22.9, and $65.0 \mathrm{mg} / \mathrm{g} \mathrm{C}$ of deep gas are generated according to the hydrous-, open-, and composite-pyrolysis models, respectively (fig. $2 A$ and table 6). Deep gas generation is finished (that is, $X=0.99$ ) according to these three models at depths of 19,029 , 22,310 , and 23,622 feet $(5,800,6,800$, and 7,200 m) (table 6). At the top of the deep gas depth $(15,000 \mathrm{feet} / 4,572 \mathrm{~m})$, the openand composite-pyrolysis models predict $92,97,95$, and 100 percent of gas generation from Type-II kerogen completed at $10^{\circ} \mathrm{C} /$ m.y., respectively. Therefore, according to these models, essentially no significant amounts of deep gas are generated from Type-II kerogen at this heating rate.

Figure 3 shows the gas-generation curves for Type-IIS kerogens in basins with $1^{\circ}$ and $10^{\circ} \mathrm{C} / \mathrm{m}$.y. heating rates as predicted by the open- and composite-pyrolysis models. At the top of the deep gas depth $(15,000$ feet/4,572 m), 74 and 93 percent of gas generation from Type-IIS kerogen are completed at $1^{\circ} \mathrm{C} / \mathrm{m}$.y. according to the open- and composite-pyrolysis models, respectively.

Therefore, 17.9 and $7.0 \mathrm{mg} / \mathrm{g} \mathrm{C}$ of deep gas are generated according to the open- and composite-pyrolysis models, respectively (fig. $3 A$ and table 6). These models predict that the deep gas generation is finished (that is, $X=0.99$ ) at depths of 20,997 and 16,404 feet $(6,400$ and 5,000 m) (table 6). At the top of the deep gas depth $(15,000$ feet/4,572 m), the open- and composite-pyrolysis models predict 99 and 100 percent of gas generation from Type-IIS kerogen completed at $10^{\circ} \mathrm{C} / \mathrm{m}$.y., respectively. Therefore, essentially no deep gas is generated from Type-IIS kerogen at this heating rate.

Figure 4 shows the gas-generation curves for Type-III kerogens in basins with $1^{\circ}$ and $10^{\circ} \mathrm{C} / \mathrm{m}$.y. heating rates as predicted by the open- and composite-pyrolysis models. At the top of the deep gas depth $(15,000$ feet/4,572 m), 26 and 3 percent of gas generation from Type-III kerogen are completed at $1^{\circ} \mathrm{C} / \mathrm{m} . \mathrm{y}$. according to the open- and composite-pyrolysis models, respectively. Therefore, 39.7 and $73.8 \mathrm{mg} / \mathrm{g} \mathrm{C}$ of deep gas are generated according to the open- and composite-pyrolysis models, respectively (fig. $4 A$ and table 6). These models predict that the deep gas generation is finished (that is, $X=0.99$ ) at depths of 20,997 and 22,966 feet $(6,400$ and 7,000 m) (table 6). At the top of the deep gas depth $(15,000 \mathrm{feet} / 4,572 \mathrm{~m})$, the open- and compositepyrolysis models predict 85 and 92 percent of gas generation from Type-III kerogen completed at $10^{\circ} \mathrm{C} / \mathrm{m}$.y., respectively. According to these models, 7.9 and $6.0 \mathrm{mg} / \mathrm{g} \mathrm{C}$ of deep gas are generated from Type-III kerogen at this heating rate.

Figure 5 shows the gas-generation curves for more paraffinic Type-III kerogens (Type-III') in basins with $1^{\circ}$ and $10^{\circ} \mathrm{C} /$ m.y. heating rates as predicted by the open- and compositepyrolysis models. At the top of the deep gas depth $(15,000$ feet/ 4,572 $\mathrm{m}$ ), 11 and 3 percent of gas generation from Type-III' kerogen are completed at $1^{\circ} \mathrm{C} / \mathrm{m}$.y. according to the open- and composite-pyrolysis models, respectively. Therefore, 50.6 and 67.7 $\mathrm{mg} / \mathrm{g} \mathrm{C}$ of deep gas are generated according to the open- and composite-pyrolysis models, respectively (fig. $5 A$ and table 6). These models predict that the deep gas generation is finished (that is, $X=0.99)$ at depths of 25,591 and 22,966 feet $(7,800$ and $7,000 \mathrm{~m})$ (table 6). At the top of the deep gas depth $(15,000 \mathrm{feet} /$ $4,572 \mathrm{~m}$ ), the open- and composite-pyrolysis models predict 74 and 91 percent of gas generation from Type-III kerogen completed at $10^{\circ} \mathrm{C} / \mathrm{m}$.y., respectively. According to these models, 14.9 and $6.0 \mathrm{mg} / \mathrm{g} \mathrm{C}$ of deep gas are generated from Type-III' kerogen at this heating rate. 
Table 4a. Gaussian distributions and their calculated discrete distributions of activation energies with fractional $\mathrm{C}_{1}-\mathrm{C}_{5}$ gas yield from kerogens as predicted by the composite-pyrolysis model (Pepper and Corvi, 1995).

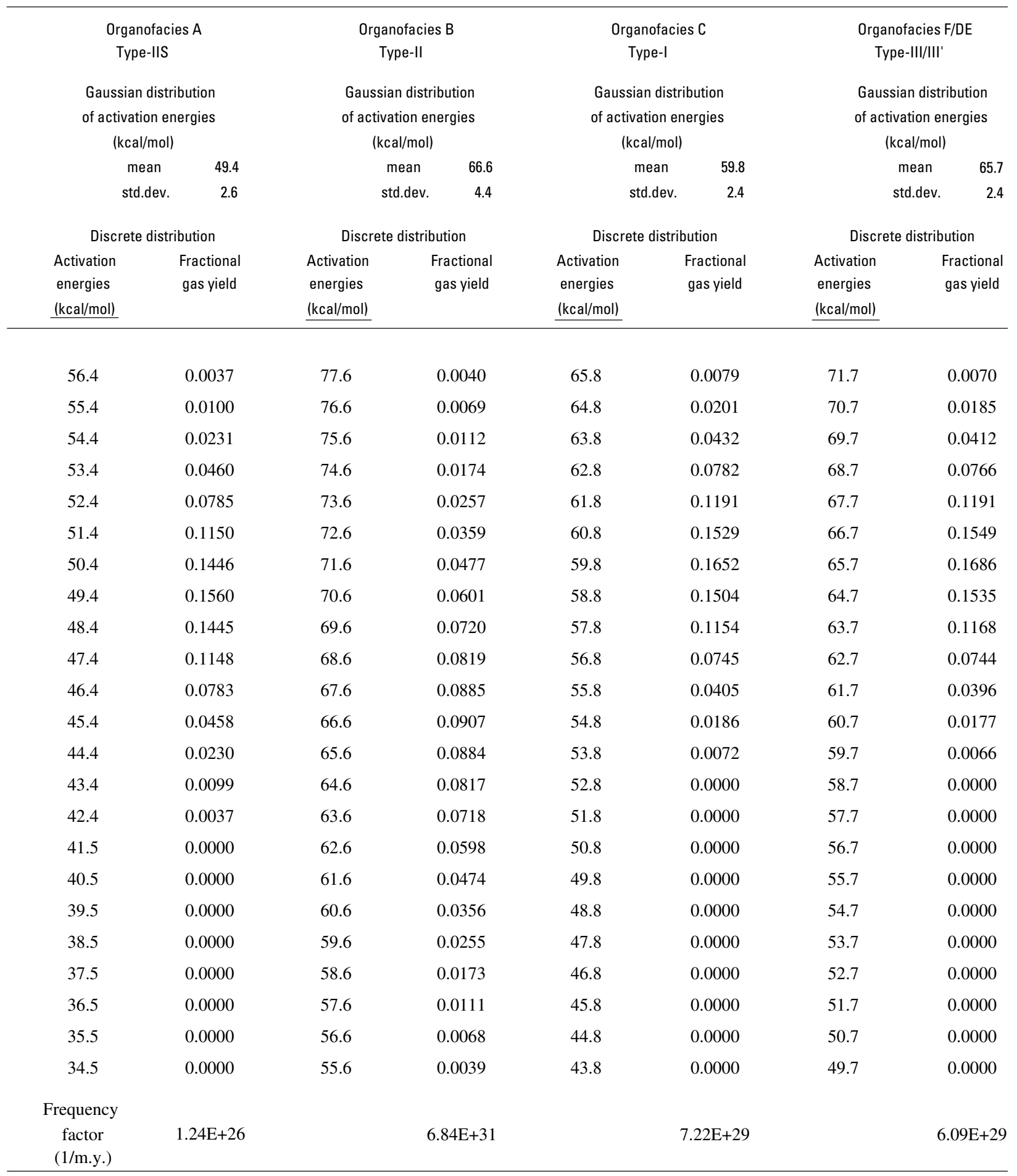

\section{Source-Rock Oil to Gas}

The anhydrous-pyrolysis model by Pepper and Dodd (1995) considers the kinetics of gas generation exclusively from the cracking of unexpelled oil retained in a source rock after the main stages of oil generation and expulsion are completed. Figure 6 shows their model's predicted gas-generation curves for oil retained in 16 source rocks in basins with $1^{\circ}$ and $10^{\circ} \mathrm{C} / \mathrm{m}$.y. heating rates. These gas-generation curves are similar for all 16 source rocks irrespective of kerogen type or rock mineralogy. 
Return to

Table 4b. Gaussian distributions and their calculated discrete distributions of activation energies with fractional $\mathrm{C}_{1}-\mathrm{C}_{5} \mathrm{gas}$ yields from oil retained in mature source rocks as predicted by the anhydrous-pyrolysis model (Pepper and Dodd, 1995). Frequency factor (1/m.y.) for all source rocks is $3.15 \times 10^{27}$.

[BL, Brown Limestone; SM, St. Medard; Ha, Haltenbanken; LC9, LC995; Ta, Tarakan; CO, COST; AWD, PAL, not given]

\begin{tabular}{|c|c|c|c|c|c|c|c|c|c|c|}
\hline Source rock & BL & SM & Source rock & AWD & $\mathrm{Ha}$ & Source rock & PAL & LC9 & Ta & CO \\
\hline \multicolumn{3}{|c|}{ Gaussian distribution } & \multicolumn{3}{|c|}{ Gaussian distribution } & \multicolumn{5}{|c|}{ Gaussian distribution } \\
\hline \multicolumn{3}{|c|}{ Activation energies $(\mathrm{kcal} / \mathrm{mol})$} & \multicolumn{3}{|c|}{ Activation energies $(\mathrm{kcal} / \mathrm{mol})$} & \multicolumn{5}{|c|}{ Activation energies $(\mathrm{kcal} / \mathrm{mol})$} \\
\hline Mean & 58.7 & 57.7 & Mean & 58.4 & 56.4 & Mean & 58.1 & 57.1 & 58.1 & 57.1 \\
\hline Std. dev. & 1.7 & 2.9 & Std. dev. & 2.4 & 3.6 & Std. dev. & 2.2 & 3.6 & 2.6 & 2.4 \\
\hline \multicolumn{3}{|c|}{ Discrete distribution } & \multicolumn{3}{|c|}{ Discrete distribution } & \multicolumn{5}{|c|}{ Discrete distribution } \\
\hline $\begin{array}{l}\text { Activation } \\
\text { energy } \\
\text { (kcal/mol) }\end{array}$ & \multicolumn{2}{|c|}{$\begin{array}{c}\text { Fractional } \\
\text { gas yield }\end{array}$} & $\begin{array}{l}\text { Activation } \\
\text { energy } \\
\text { (kcal/mol) }\end{array}$ & \multicolumn{2}{|c|}{$\begin{array}{l}\text { Fractional } \\
\text { gas yield }\end{array}$} & $\begin{array}{l}\text { Activation } \\
\text { energy } \\
\text { (kcal/mol) }\end{array}$ & \multicolumn{4}{|c|}{$\begin{array}{l}\text { Fractional } \\
\text { gas yield }\end{array}$} \\
\hline 65.7 & 0.0000 & 0.0030 & 68.4 & 0.0000 & 0.0000 & 68.1 & 0.0000 & 0.0000 & 0.0000 & 0.0000 \\
\hline 64.7 & 0.0000 & 0.0073 & 67.4 & 0.0000 & 0.0000 & 67.1 & 0.0000 & 0.0022 & 0.0000 & 0.0000 \\
\hline 63.7 & 0.0026 & 0.0161 & 66.4 & 0.0000 & 0.0000 & 66.1 & 0.0000 & 0.0046 & 0.0000 & 0.0000 \\
\hline 62.7 & 0.0132 & 0.0313 & 65.4 & 0.0022 & 0.0048 & 65.1 & 0.0000 & 0.0089 & 0.0043 & 0.0000 \\
\hline 61.7 & 0.0466 & 0.0537 & 64.4 & 0.0069 & 0.0093 & 64.1 & 0.0037 & 0.0161 & 0.0110 & 0.0024 \\
\hline 60.7 & 0.1147 & 0.0818 & 63.4 & 0.0182 & 0.0166 & 63.1 & 0.0122 & 0.0268 & 0.0245 & 0.0073 \\
\hline 59.7 & 0.1977 & 0.1102 & 62.4 & 0.0401 & 0.0275 & 62.1 & 0.0323 & 0.0413 & 0.0471 & 0.0191 \\
\hline 58.7 & 0.2384 & 0.1316 & 61.4 & 0.0745 & 0.0422 & 61.1 & 0.0691 & 0.0588 & 0.0784 & 0.0418 \\
\hline 57.7 & 0.2011 & 0.1391 & 60.4 & 0.1162 & 0.0598 & 60.1 & 0.1193 & 0.0775 & 0.1129 & 0.0768 \\
\hline 56.7 & 0.1187 & 0.1302 & 59.4 & 0.1520 & 0.0785 & 59.1 & 0.1657 & 0.0945 & 0.1407 & 0.1185 \\
\hline 55.7 & 0.0490 & 0.1079 & 58.4 & 0.1669 & 0.0953 & 58.1 & 0.1855 & 0.1066 & 0.1517 & 0.1535 \\
\hline 54.7 & 0.0142 & 0.0792 & 57.4 & 0.1538 & 0.1071 & 57.1 & 0.1672 & 0.1113 & 0.1416 & 0.1669 \\
\hline 53.7 & 0.0029 & 0.0515 & 56.4 & 0.1190 & 0.1113 & 56.1 & 0.1215 & 0.1074 & 0.1143 & 0.1523 \\
\hline 52.7 & 0.0000 & 0.0296 & 55.4 & 0.0773 & 0.1070 & 55.1 & 0.0711 & 0.0960 & 0.0799 & 0.1167 \\
\hline 51.7 & 0.0000 & 0.0151 & 54.4 & 0.0422 & 0.0952 & 54.1 & 0.0335 & 0.0793 & 0.0483 & 0.0750 \\
\hline 50.7 & 0.0000 & 0.0068 & 53.4 & 0.0193 & 0.0783 & 53.1 & 0.0127 & 0.0606 & 0.0253 & 0.0405 \\
\hline 49.7 & 0.0000 & 0.0027 & 52.4 & 0.0074 & 0.0596 & 52.1 & 0.0039 & 0.0429 & 0.0114 & 0.0184 \\
\hline 48.7 & 0.0000 & 0.0000 & 51.4 & 0.0024 & 0.0420 & 51.1 & 0.0000 & 0.0281 & 0.0045 & 0.0070 \\
\hline 47.7 & 0.0000 & 0.0000 & 50.4 & 0.0000 & 0.0274 & 50.1 & 0.0000 & 0.0170 & 0.0000 & 0.0022 \\
\hline 46.7 & 0.0000 & 0.0000 & 49.4 & 0.0000 & 0.0165 & 49.1 & 0.0000 & 0.0095 & 0.0000 & 0.0000 \\
\hline 45.7 & 0.0000 & 0.0000 & 48.4 & 0.0000 & 0.0092 & 48.1 & 0.0000 & 0.0049 & 0.0000 & 0.0000 \\
\hline 44.7 & 0.0000 & 0.0000 & 47.4 & 0.0000 & 0.0047 & 47.1 & 0.0000 & 0.0024 & 0.0000 & 0.0000 \\
\hline
\end{tabular}


Table $4 \mathbf{b}$-Continued. Gaussian distributions and their calculated discrete distributions of activation energies with fractional $C_{1}-C_{5}$ gas yields from oil retained in mature source rocks as predicted by the anhydrous-pyrolysis model (Pepper and Dodd, 1995). Frequency factor (1/m.y.) for all source rocks is $3.15 \times 10^{27}$.

[LC1, LC1005; Tu, Tuna; GA, Garlin; P5, Pematang 52.7; KCF, not given; Maui, Maui; WE, Westfield; P4, Pematang 45.2]

\begin{tabular}{|c|c|c|c|c|c|c|c|c|c|c|}
\hline Source rock & LC1 & Tu & & GA & KCF & P5 & Maui & WE & & P4 \\
\hline \multicolumn{3}{|c|}{ Gaussian distribution } & \multicolumn{6}{|c|}{ Gaussian distribution } & \multicolumn{2}{|c|}{ Gaussian distribution } \\
\hline \multicolumn{3}{|c|}{ Activation energies $(\mathrm{kcal} / \mathrm{mol})$} & \multicolumn{6}{|c|}{ Activation energies $(\mathrm{kcal} / \mathrm{mol})$} & \multicolumn{2}{|c|}{ Activation energies $(\mathrm{kcal} / \mathrm{mol})$} \\
\hline Mean & 57.3 & 58.3 & Mean & 56.6 & 58.6 & 58.6 & 57.6 & 57.6 & Mean & 58.8 \\
\hline Std. dev. & 2.9 & 2.4 & Std. dev. & 4.8 & 2.6 & 1.9 & 3.6 & 4.3 & Std. dev. & 1.2 \\
\hline \multicolumn{3}{|c|}{ Discrete distribution } & \multicolumn{6}{|c|}{ Discrete distribution } & \multicolumn{2}{|c|}{ Discrete distribution } \\
\hline $\begin{array}{c}\text { Activation } \\
\text { energy } \\
\text { (kcal/mol) }\end{array}$ & \multicolumn{2}{|c|}{$\begin{array}{l}\text { Fractional } \\
\text { gas yield }\end{array}$} & $\begin{array}{c}\text { Activation } \\
\text { energy } \\
\text { (kcal/mol) }\end{array}$ & & & $\begin{array}{c}\text { Fractional } \\
\text { gas yield }\end{array}$ & & & $\begin{array}{c}\text { Activation } \\
\text { energy } \\
\text { (kcal/mol) }\end{array}$ & $\begin{array}{r}\text { Fractiona } \\
\text { gas yield }\end{array}$ \\
\hline 68.3 & 0.0000 & 0.0000 & 68.6 & 0.0037 & 0.0000 & 0.0000 & 0.0000 & 0.0035 & 68.8 & 0.0000 \\
\hline 67.3 & 0.0000 & 0.0000 & 67.6 & 0.0060 & 0.0000 & 0.0000 & 0.0023 & 0.0062 & 67.8 & 0.0000 \\
\hline 66.3 & 0.0000 & 0.0000 & 66.6 & 0.0095 & 0.0000 & 0.0000 & 0.0048 & 0.0104 & 66.8 & 0.0000 \\
\hline 65.3 & 0.0028 & 0.0023 & 65.6 & 0.0144 & 0.0042 & 0.0000 & 0.0092 & 0.0165 & 65.8 & 0.0000 \\
\hline 64.3 & 0.0069 & 0.0073 & 64.6 & 0.0209 & 0.0108 & 0.0014 & 0.0165 & 0.0247 & 64.8 & 0.0000 \\
\hline 63.3 & 0.0152 & 0.0190 & 63.6 & 0.0290 & 0.0241 & 0.0064 & 0.0274 & 0.0351 & 63.8 & 0.0000 \\
\hline 62.3 & 0.0298 & 0.0416 & 62.6 & 0.0384 & 0.0465 & 0.0223 & 0.0421 & 0.0472 & 62.8 & 0.0012 \\
\hline 61.3 & 0.0517 & 0.0766 & 61.6 & 0.0488 & 0.0776 & 0.0588 & 0.059 & 0.0602 & 61.8 & 0.0142 \\
\hline 60.3 & 0.0795 & 0.1183 & 60.6 & 0.0593 & 0.1122 & 0.1179 & 0.0784 & 0.0727 & 60.8 & 0.0818 \\
\hline 59.3 & 0.1082 & 0.1534 & 59.6 & 0.0689 & 0.1402 & 0.1798 & 0.0952 & 0.0832 & 59.8 & 0.2345 \\
\hline 58.3 & 0.1303 & 0.1669 & 58.6 & 0.0768 & 0.1517 & 0.2086 & 0.107 & 0.0903 & 58.8 & 0.3338 \\
\hline 57.3 & 0.1391 & 0.1525 & 57.6 & 0.0818 & 0.1420 & 0.1841 & 0.1113 & 0.0927 & 57.8 & 0.2360 \\
\hline 56.3 & 0.1314 & 0.1169 & 56.6 & 0.0835 & 0.1150 & 0.1236 & 0.1070 & 0.0903 & 56.8 & 0.0828 \\
\hline 55.3 & 0.1100 & 0.0752 & 55.6 & 0.0815 & 0.0806 & 0.0631 & 0.0952 & 0.0832 & 55.8 & 0.0144 \\
\hline 54.3 & 0.0815 & 0.0406 & 54.6 & 0.0762 & 0.0489 & 0.0245 & 0.0784 & 0.0727 & 54.8 & 0.0012 \\
\hline 53.3 & 0.0535 & 0.0184 & 53.6 & 0.0681 & 0.0257 & 0.0072 & 0.0597 & 0.0602 & 53.8 & 0.0000 \\
\hline 52.3 & 0.0311 & 0.0070 & 52.6 & 0.0583 & 0.0117 & 0.0016 & 0.0421 & 0.0472 & 52.8 & 0.0000 \\
\hline 51.3 & 0.0160 & 0.0022 & 51.6 & 0.0478 & 0.0046 & 0.0000 & 0.0274 & 0.0351 & 51.8 & 0.0000 \\
\hline 50.3 & 0.0073 & 0.0000 & 50.6 & 0.0375 & 0.0000 & 0.0000 & 0.0165 & 0.0247 & 50.8 & 0.0000 \\
\hline 49.3 & 0.0029 & 0.0000 & 49.6 & 0.0282 & 0.0000 & 0.0000 & 0.0092 & 0.0165 & 49.8 & 0.0000 \\
\hline 48.3 & 0.0000 & 0.0000 & 48.6 & 0.0203 & 0.0000 & 0.0000 & 0.0048 & 0.0104 & 48.8 & 0.0000 \\
\hline 47.3 & 0.0000 & 0.0000 & 47.6 & 0.0139 & 0.0000 & 0.0000 & 0.0023 & 0.0062 & 47.8 & 0.0000 \\
\hline 46.3 & 0.0000 & 0.0000 & 46.6 & 0.0092 & 0.0000 & 0.0000 & 0.0000 & 0.0035 & 46.8 & 0.0000 \\
\hline 45.3 & 0.0000 & 0.0000 & 45.6 & 0.0058 & 0.0000 & 0.0000 & 0.0000 & 0.0000 & 45.8 & 0.0000 \\
\hline 44.3 & 0.0000 & 0.0000 & 44.6 & 0.0035 & 0.0000 & 0.0000 & 0.0000 & 0.0000 & 44.8 & 0.0000 \\
\hline
\end{tabular}


Table 4c. Gaussian distributions and their calculated discrete distributions of activation energies with fractional methane $\left(C_{1}\right)$, ethane $\left(C_{2}\right)$, propane $\left(C_{3}\right)$, and butane $\left(C_{4}\right)$ yields from Type-II kerogen in the New Albany Shale (Devonian-Mississippian) as predicted by the hydrous-pyrolysis model (Knauss and others, 1997).

\begin{tabular}{|c|c|c|c|c|c|c|c|}
\hline \multirow{2}{*}{\multicolumn{2}{|c|}{$\begin{array}{c}\text { Methane }\left(\mathrm{C}_{1}\right) \\
\text { Gaussian distribution }\end{array}$}} & \multirow{2}{*}{\multicolumn{2}{|c|}{$\begin{array}{c}\text { Ethane }\left(\mathrm{C}_{2}\right) \\
\text { Gaussian distribution }\end{array}$}} & \multirow{2}{*}{\multicolumn{2}{|c|}{$\begin{array}{c}\text { Propane }\left(\mathrm{C}_{3}\right) \\
\text { Gaussian distribution }\end{array}$}} & \multirow{2}{*}{\multicolumn{2}{|c|}{$\begin{array}{c}\text { Butane }\left(\mathrm{C}_{4}\right) \\
\text { Gaussian distribution }\end{array}$}} \\
\hline & & & & & & & \\
\hline $\mathrm{E}(\mathrm{kcal} / \mathrm{mol})$ & 45.2 & $\mathrm{E}(\mathrm{kcal} / \mathrm{mol})$ & 56.2 & $\mathrm{E}(\mathrm{kcal} / \mathrm{mol})$ & 52.9 & $\mathrm{E}(\mathrm{kcal} / \mathrm{mol})$ & 55.0 \\
\hline Std. dev. $(\% \mathrm{E})$ & 1.92 & Std. dev. $(\% E)$ & 5.0 & Std. dev. $(\% \mathrm{E})$ & 6.0 & Std. dev. $(\% \mathrm{E})$ & 5.0 \\
\hline \multicolumn{2}{|c|}{ Discrete distribution } & \multicolumn{2}{|c|}{ Discrete distribution } & \multicolumn{2}{|c|}{ Discrete distribution } & \multicolumn{2}{|c|}{ Discrete distribution } \\
\hline $\begin{array}{c}\text { Activation } \\
\text { energies } \\
\text { (kcal/mol) }\end{array}$ & $\begin{array}{l}\text { Fractional } \\
\text { gas yield }\end{array}$ & $\begin{array}{c}\text { Activation } \\
\text { energies } \\
\text { (kcal/mol) }\end{array}$ & $\begin{array}{l}\text { Fractional } \\
\text { gas yield }\end{array}$ & $\begin{array}{c}\text { Activation } \\
\text { energies } \\
\text { (kcal/mol) }\end{array}$ & $\begin{array}{l}\text { Fractional } \\
\text { gas yield }\end{array}$ & $\begin{array}{c}\text { Activation } \\
\text { energies } \\
\text { (kcal/mol) }\end{array}$ & $\begin{array}{c}\text { Fractional } \\
\text { gas yield }\end{array}$ \\
\hline 65.4 & 0.0000 & 65.2 & 0.0008 & 64.9 & 0.0000 & 65.0 & 0.0000 \\
\hline 64.4 & 0.0000 & 64.2 & 0.0025 & 63.9 & 0.0000 & 64.0 & 0.0007 \\
\hline 63.4 & 0.0000 & 63.2 & 0.0064 & 62.9 & 0.0009 & 63.0 & 0.0021 \\
\hline 62.4 & 0.0000 & 62.2 & 0.0145 & 61.9 & 0.0023 & 62.0 & 0.0057 \\
\hline 61.4 & 0.0000 & 61.2 & 0.0292 & 60.9 & 0.0052 & 61.0 & 0.0134 \\
\hline 60.4 & 0.0000 & 60.2 & 0.0515 & 59.9 & 0.0110 & 60.0 & 0.0278 \\
\hline 59.4 & 0.0000 & 59.2 & 0.0803 & 58.9 & 0.0211 & 59.0 & 0.0504 \\
\hline 58.4 & 0.0000 & 58.2 & 0.1102 & 57.9 & 0.0363 & 58.0 & 0.0800 \\
\hline 57.4 & 0.0000 & 57.2 & 0.1333 & 56.9 & 0.0568 & 57.0 & 0.1114 \\
\hline 56.4 & 0.0000 & 56.2 & 0.1420 & 55.9 & 0.0804 & 56.0 & 0.1358 \\
\hline 55.4 & 0.0000 & 55.2 & 0.1333 & 54.9 & 0.1031 & 55.0 & 0.1451 \\
\hline 54.4 & 0.0000 & 54.2 & 0.1102 & 53.9 & 0.1196 & 54.0 & 0.1358 \\
\hline 53.4 & 0.0000 & 53.2 & 0.0803 & 52.9 & 0.1257 & 53.0 & 0.1114 \\
\hline 52.4 & 0.0000 & 52.2 & 0.0515 & 51.9 & 0.1196 & 52.0 & 0.0800 \\
\hline 51.4 & 0.0000 & 51.2 & 0.0292 & 50.9 & 0.1031 & 51.0 & 0.0504 \\
\hline 50.4 & 0.0000 & 50.2 & 0.0145 & 49.9 & 0.0804 & 50.0 & 0.0278 \\
\hline 49.4 & 0.0000 & 49.2 & 0.0064 & 48.9 & 0.0568 & 49.0 & 0.0134 \\
\hline 48.4 & 0.0012 & 48.2 & 0.0025 & 47.9 & 0.0363 & 48.0 & 0.0057 \\
\hline 47.4 & 0.0329 & 47.2 & 0.0008 & 46.9 & 0.0211 & 47.0 & 0.0021 \\
\hline 46.4 & 0.2370 & 46.2 & 0.0000 & 45.9 & 0.0110 & 46.0 & 0.0007 \\
\hline 45.4 & 0.4577 & 45.2 & 0.0000 & 44.9 & 0.0052 & 45.0 & 0.0000 \\
\hline 44.4 & 0.2370 & 44.2 & 0.0000 & 43.9 & 0.0023 & 44.0 & 0.0000 \\
\hline 43.4 & 0.0329 & 43.2 & 0.0000 & 42.9 & 0.0009 & 43.0 & 0.0000 \\
\hline 42.4 & 0.0012 & 42.2 & 0.0000 & 41.9 & 0.0000 & 42.0 & 0.0000 \\
\hline $\begin{array}{l}\text { Frequency } \\
\text { factor (1/m.y.) }\end{array}$ & $7.88 \mathrm{E}+23$ & & $1.23 \mathrm{E}+28$ & & $5.68 \mathrm{E}+26$ & & $3.15 \mathrm{E}+27$ \\
\hline
\end{tabular}

As a result, the gas-generation curve of the St. Medard (SM) source rock serves as a representative average for this anhydrous-pyrolysis model (table 6). At the top of the deep gas depth $(15,000 \mathrm{feet} / 4,572 \mathrm{~m}), 35$ percent of gas generation from oil retained in a source rock is completed at $1^{\circ} \mathrm{C} / \mathrm{m}$.y. Therefore 65 $\mathrm{mg} / \mathrm{g} \mathrm{C}$ of deep gas is generated (fig. $6 \mathrm{~A}$ and table 6 ). This model predicts that the deep gas generation is finished (that is, $X=0.99)$ at a depth of 21,654 feet $(6,600 \mathrm{~m})$ (table 6). At the top of the deep-gas depth $(15,000 \mathrm{feet} / 4,572 \mathrm{~m})$, this model predicts 100 percent of gas generation from oil retained in a mature 
Table 5. Maximum $C_{1}-C_{5}$ gas yields for different starting materials used in six kinetic models.

\begin{tabular}{|c|c|c|}
\hline Starting material & $\begin{array}{c}\text { Model } \\
\text { reference* }\end{array}$ & $\begin{array}{l}\text { Maximum } \\
\text { gas yield } \\
(\mathrm{mg} / \mathrm{g} \mathrm{C})\end{array}$ \\
\hline \multirow[t]{2}{*}{ Type-I kerogen } & 1 & 88.5 \\
\hline & 2 & 78.0 \\
\hline \multirow[t]{3}{*}{ Type-II kerogen } & 1 & 70.0 \\
\hline & 2 & 100.6 \\
\hline & 3 & $* * 92.8$ \\
\hline \multirow[t]{2}{*}{ Type-IIS kerogen } & 1 & 70.3 \\
\hline & 2 & 104.9 \\
\hline \multirow[t]{2}{*}{ Type-III kerogen } & 1 & 57.1 \\
\hline & 2 & 76.6 \\
\hline \multirow[t]{2}{*}{ Type-III' kerogen } & 1 & 54.2 \\
\hline & 2 & 69.5 \\
\hline Source-rock oil & 4 & 100.0 \\
\hline \multirow[t]{4}{*}{ Reservoir oil } & 5 & 541.2 \\
\hline & (mg/g oil) & $(460.0)$ \\
\hline & 6 & 376.2 \\
\hline & (mg/g oil) & $(319.8)$ \\
\hline \multicolumn{3}{|c|}{$\begin{array}{l}\text { * References: 1, Behar and others (1997); 2, Pepper and Corvi (1995); } \\
\text { 3, Knauss and others (1997); 4, Pepper and Dodd (1995); 5, Horsfield } \\
\text { and others (1992); 6, Tsuzuki and others (1997). }\end{array}$} \\
\hline
\end{tabular}

source rock completed at $10^{\circ} \mathrm{C} / \mathrm{m}$.y. Therefore, according to this model, essentially no deep gas is generated from oil retained in a source rock at this heating rate.

\section{Reservoir Oil to Gas}

Generation of gas from the cracking of oil in reservoirs is considered by the anhydrous- and hydrous-pyrolysis models by Horsfield and others (1992) and Tsuzuki and others (1997), respectively. Figure 7 shows the gas generation curves for reservoir-oil cracking in basins with $1^{\circ}$ and $10^{\circ} \mathrm{C} / \mathrm{m}$.y. heating rates as predicted by the anhydrous- and hydrous-pyrolysis models. At the top of the deep gas depth (15,000 feet/4,572 m), 2 and 0 percent of gas generation from reservoir-oil cracking are completed at $1{ }^{\circ} \mathrm{C} / \mathrm{m} . \mathrm{y}$., according to the anhydrous- and hydrouspyrolysis models, respectively. Therefore, 449.5 and $320.2 \mathrm{mg} /$ $\mathrm{g}$ oil of deep gas are generated according to the closed anhydrous- and hydrous-pyrolysis models, respectively (fig. $7 A$ and table 6). These models predict that the deep gas generation is finished (that is, $X=0.99$ ) at depths of 24,934 and 24,278 feet $(7,600$ and 7,400 m) (table 6). At the top of the deep gas depth
$(15,000 \mathrm{feet} / 4,572 \mathrm{~m})$, the anhydrous- and hydrous-pyrolysis models predict 80 and 53 percent of gas generation from reservoir-oil cracking completed at $10^{\circ} \mathrm{C} / \mathrm{m}$.y., respectively. According to these models at $10^{\circ} \mathrm{C} / \mathrm{m} . \mathrm{y}$., 459.6 and $320.2 \mathrm{mg} / \mathrm{g}$ oil of deep gas are generated from reservoir oil cracking when reservoirs reach depths of 13,780 and 17,060 feet (4,200 and 5,200 $\mathrm{m})$, respectively.

\section{Discussion}

\section{Kerogen to Gas}

Gas generation from kerogen at deep depths is more likely at slow basin heating rates irrespective of kerogen type or kinetic model (table 7). At the slow heating rate of $1^{\circ} \mathrm{C} / \mathrm{m} . \mathrm{y} ., 5-$ $75 \mathrm{mg} / \mathrm{g}$ C of deep gas can be generated irrespective of kerogen type or kinetic model. In contrast, at the fast heating rate of $10^{\circ} \mathrm{C} / \mathrm{m}$.y., only $0-15 \mathrm{mg} / \mathrm{g} \mathrm{C}$ of deep gas are generated irrespective of kerogen type or kinetic model (table 7). The implication here is that only a finite amount of gas can be generated from kerogen within a specific thermal-stress interval. Slow heating rates result in lower temperatures at greater depths, which allows this thermal-stress interval to be extended to greater depths within a basin. Therefore, according to these models, deep basins with cooler subsurface temperatures are more likely to generate deep gas from kerogen than deep basins with hotter subsurface temperatures.

For the slow heating rate, the composite-pyrolysis model predicts the greatest amount of deep gas, with values ranging from 5 to $75 \mathrm{mg} / \mathrm{g} \mathrm{C}$ (table 7). The open-pyrolysis model gives a lower value for deep gas generation, from 8 to $51 \mathrm{mg} / \mathrm{g} \mathrm{C}$ (table 7). However, at the rapid heating rate, the open-pyrolysis model predicts greater amounts $(1-15 \mathrm{mg} / \mathrm{g} \mathrm{C})$ of deep gas generation than that predicted by the composite-pyrolysis model ( 0 $7 \mathrm{mg} / \mathrm{g} \mathrm{C}$ ). The hydrous-pyrolysis model for only Type-II kerogen yields no deep gas at the high heating rate and $23 \mathrm{mg} / \mathrm{g} \mathrm{C}$ of deep gas at the slow heating rate. Obviously, more hydrouspyrolysis kinetic studies on the other kerogen types are needed.

It would be valuable to compare all the different kerogen types for the three pyrolysis models, but a complete comparison of kerogen types is only possible between the open- and composite-pyrolysis models. At both heating rates, the open-pyrolysis model predicts an increase in the amount of deep gas generated from Type-I to Type-II to Type-III kerogen. With the exception of Type-IIS kerogen, this trend is also predicted by the composite-pyrolysis model (that is, Type-I < Type-II < Type-III kerogen). The composite-pyrolysis method predicts that TypeIIS kerogen generates the least amount of deep gas at both heating rates. The implication of this prediction is that deep basins with high-sulfur oils and carbonate source rocks are not good prospects for deep gas. However, in the open-pyrolysis model, Type-IIS kerogen generates about the same amount of deep gas as Type-II kerogen at both heating rates.

For the slow heating rate, the composite-pyrolysis model predicts more deep gas generation than the open-pyrolysis model for all kerogen types except for Type-IIS kerogen. As an 

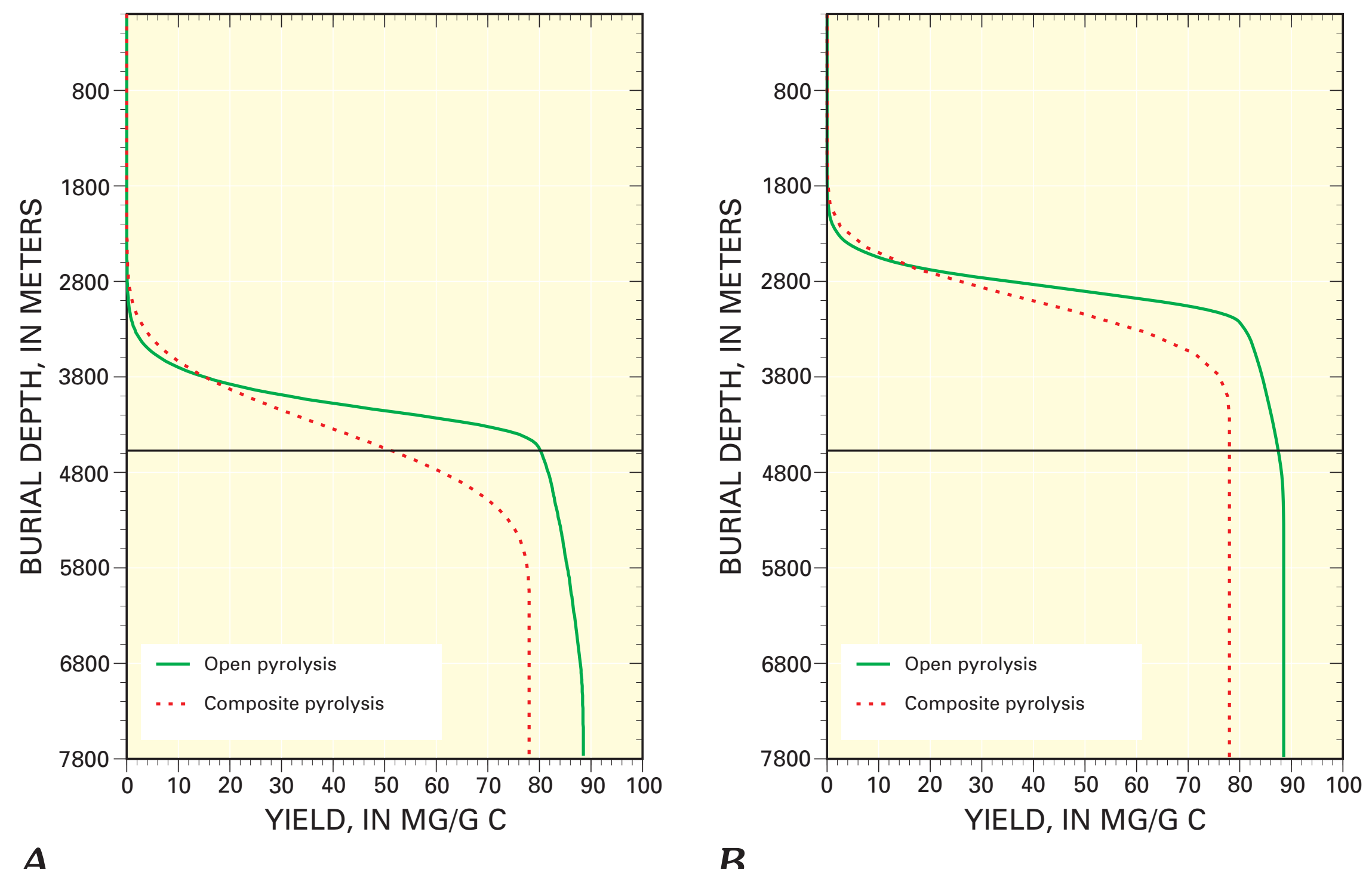

A

B

Figure 1. Amount of $C_{1}-C_{5}$ gas generated from Type-l kerogen with increasing burial depth, according to open-pyrolysis (solid line; Behar and others, 1997) and composite-pyrolysis (dotted line; Pepper and Corvi, 1995) models at geologic heating rates of $A, 1^{\circ} \mathrm{C} / \mathrm{m} . y$. , and $B, 10^{\circ} \mathrm{C} / \mathrm{m}$.y. Deep gas depths occur below solid horizontal line drawn at $15,000 \mathrm{feet} / 4,572 \mathrm{~m}$. 

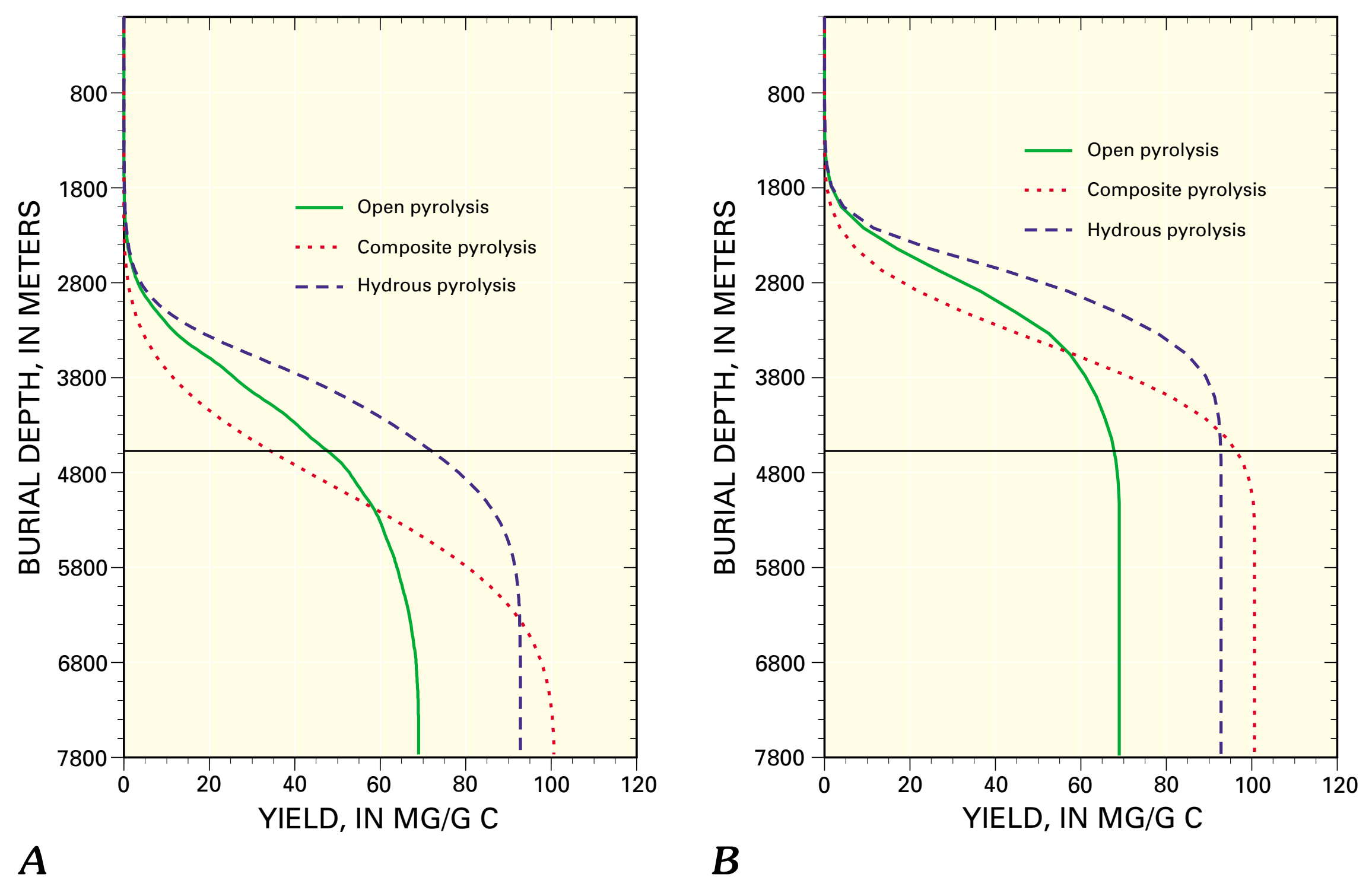

Figure 2. Amount of gas generated from Type-II kerogen with increasing burial depth, according to open-pyrolysis (solid line; $\mathrm{C}_{1}-\mathrm{C}_{5} ;$ Behar and others, 1997), composite-pyrolysis (dotted line; $C_{1}-C_{5} ;$ Pepper and Corvi, 1995), and hydrous-pyrolysis (dashed line; $C_{1}-C_{4} ;$ Knauss and others, 1997) models at geologic heating rates of $A, 1^{\circ} \mathrm{C} / \mathrm{m} . y .$, and $B, 10^{\circ} \mathrm{C} / \mathrm{m} . y$. Deep gas depths occur below solid horizontal line drawn at 15,000 feet $/ 4,572 \mathrm{~m}$. 


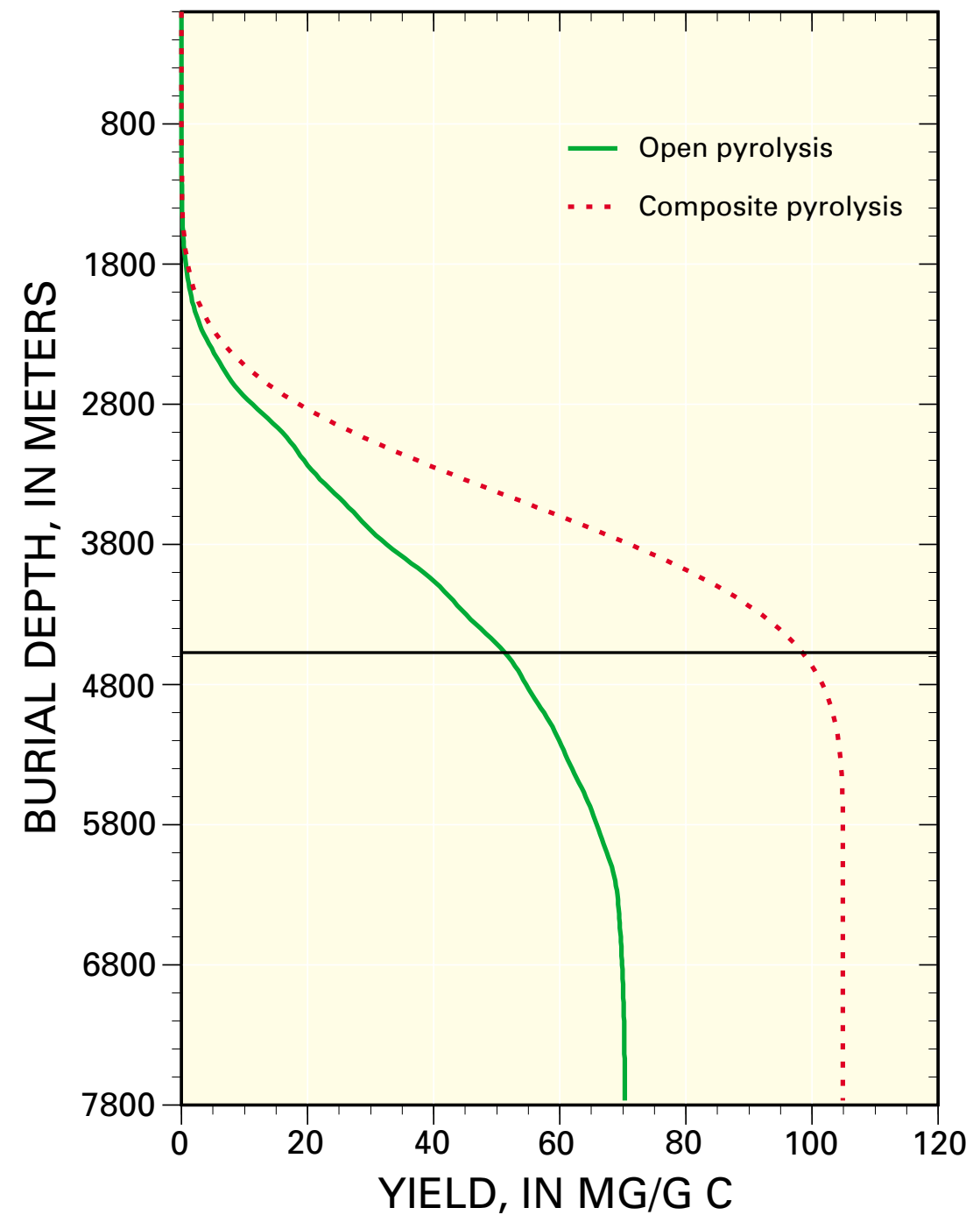

A

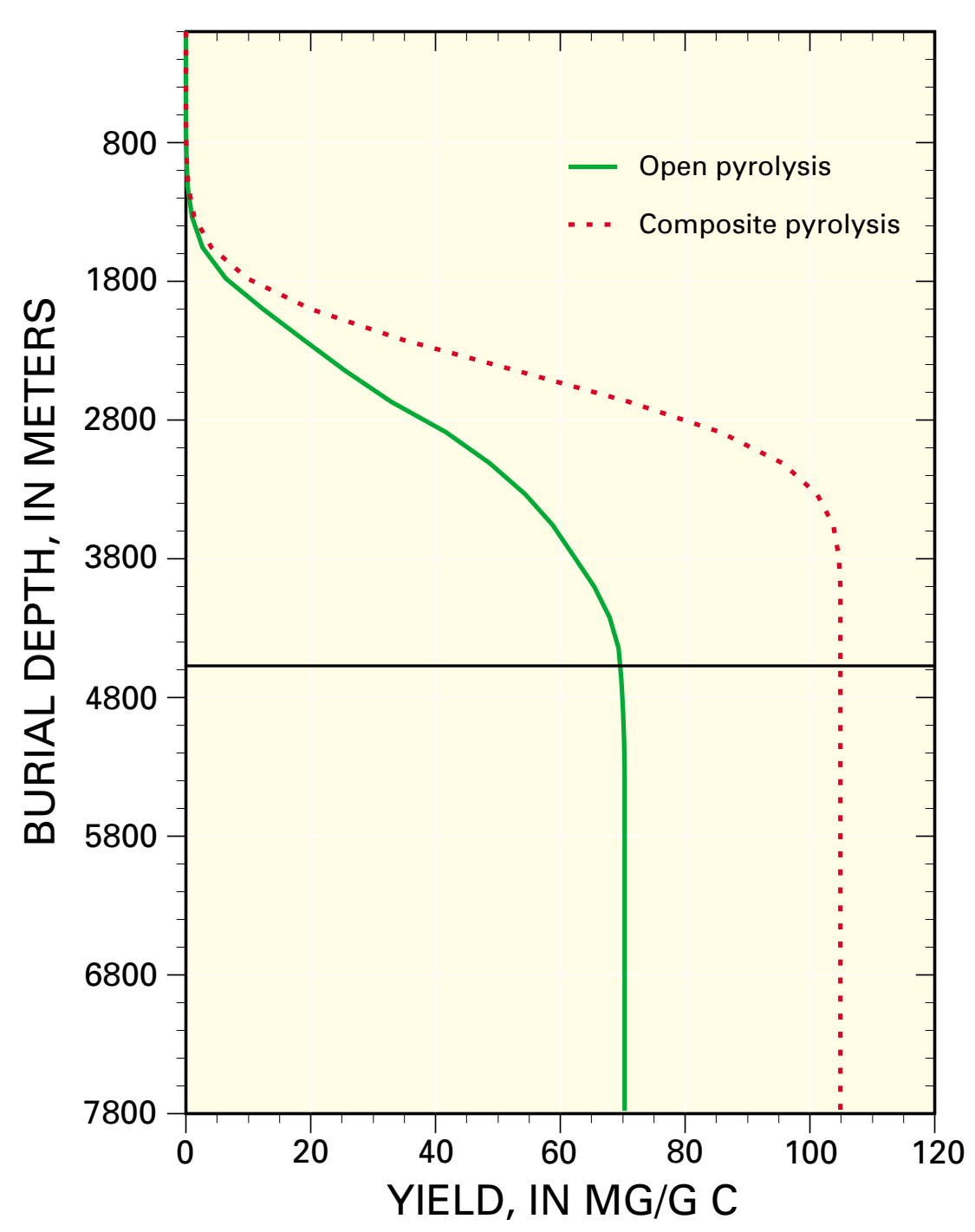

B

Figure 3. Amount of $C_{1}-C_{5}$ gas generated from Type-IIS kerogen with increasing burial depth, according to open-pyrolysis (solid line; Behar and others, 1997) and composite-pyrolysis (dotted line; Pepper and Corvi, 1995) models at geologic heating rates of $A, 1^{\circ} \mathrm{C} / \mathrm{m} . y$. , and $B, 10^{\circ} \mathrm{C} / \mathrm{m}$.y. Deep gas depths occur below horizontal line drawn at 15,000 feet/4,572 $\mathrm{m}$. 

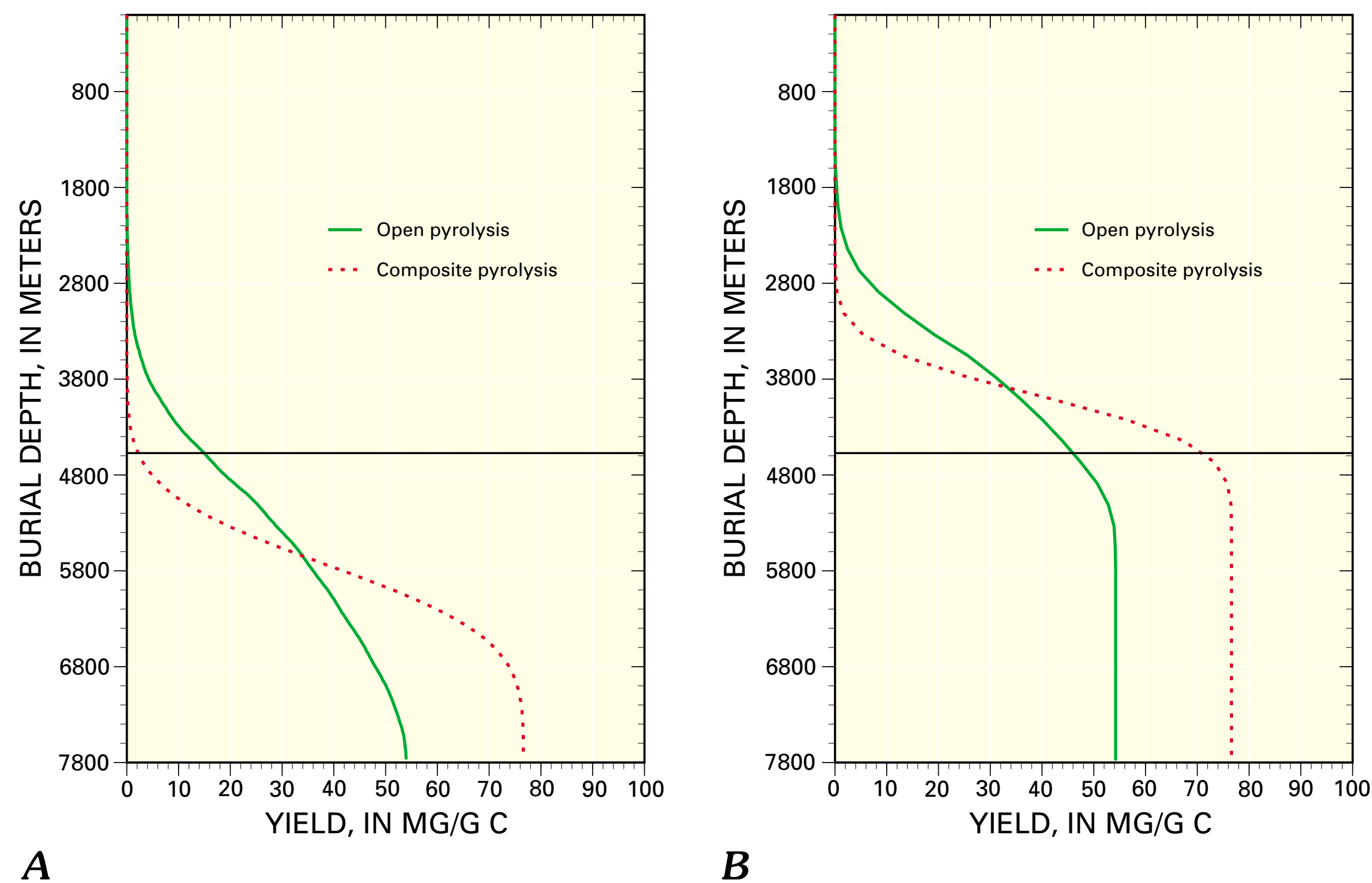

Figure 4. Amount of $C_{1}-C_{5}$ gas generated from Type-III kerogen with increasing burial depth, according to open-pyrolysis (solid line; Behar and others, 1997) and composite-pyrolysis (dotted line; Pepper and Corvi, 1995) models at geologic heating rates of $A, 1^{\circ} \mathrm{C} / \mathrm{m}$.y., and $B, 10^{\circ} \mathrm{C} / \mathrm{m}$.y. Deep gas depths occur below horizontal line drawn at $15,000 \mathrm{feet} / 4,572 \mathrm{~m}$. 

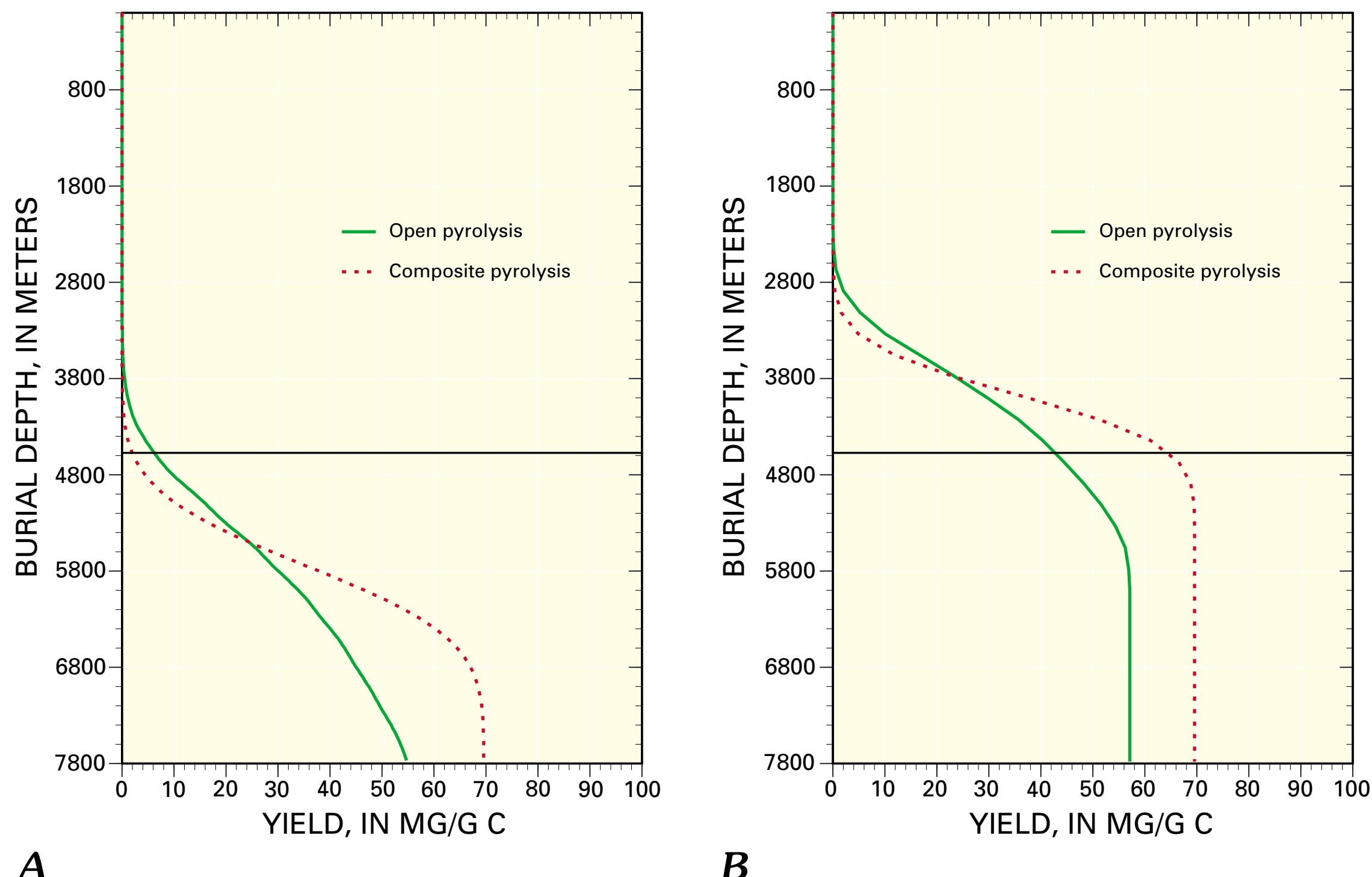

Figure 5. Amount of $C_{1}-C_{5}$ gas generated from Type-III' (paraffinic) kerogen with increasing burial depth, according to open-pyrolysis (solid line; Behar and others, 1997) and composite-pyrolysis (dotted line; Pepper and Corvi, 1995) models at geologic heating rates of $A, 1^{\circ} \mathrm{C} / \mathrm{m} . y$. , and $B, 10^{\circ} \mathrm{C} / \mathrm{m} . y$. Deep gas depths occur below horizontal line drawn at 15,000 feet $/ 4,572 \mathrm{~m}$. 

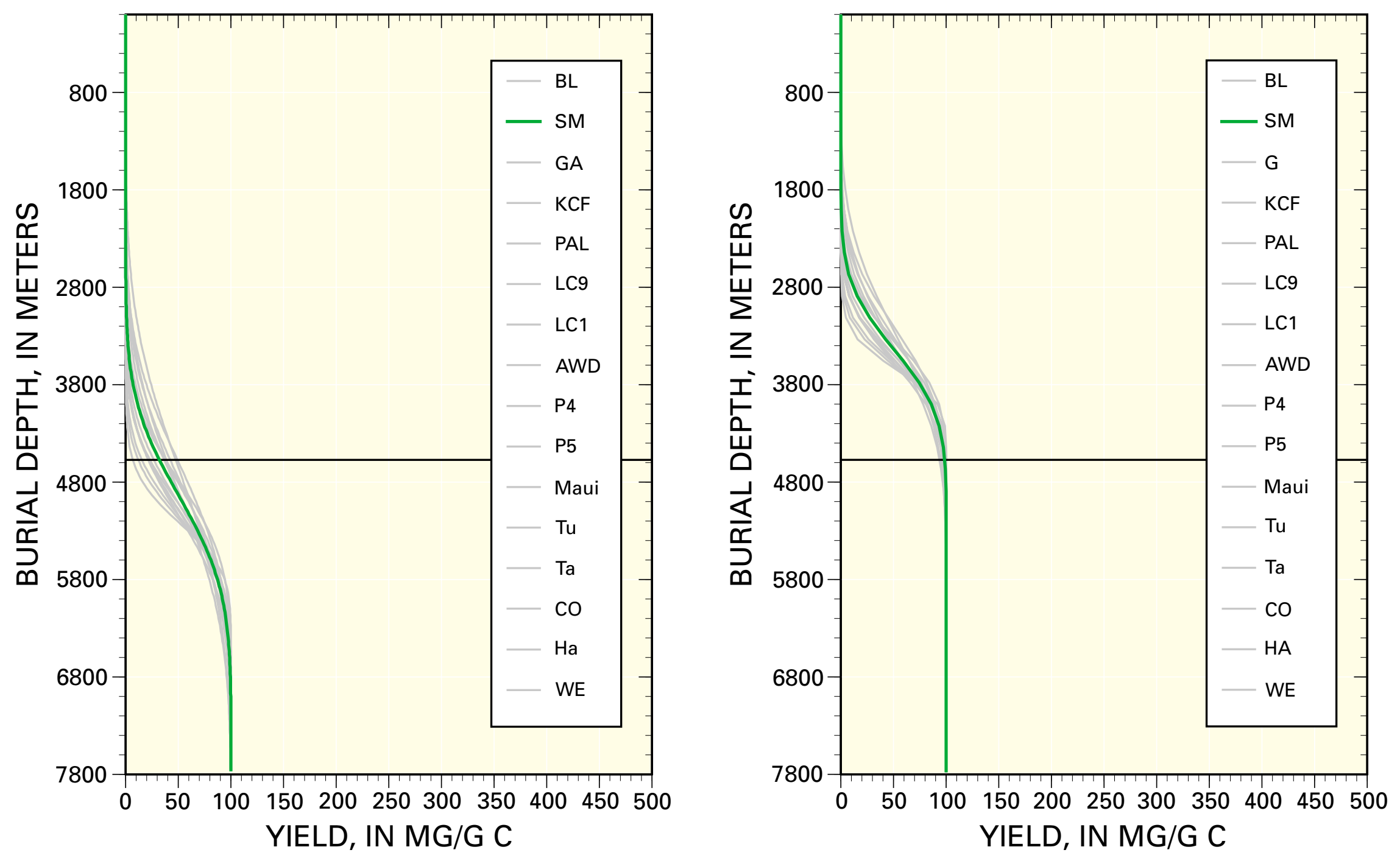

A

B

Figure 6. Amount of $\mathrm{C}_{1}-\mathrm{C}_{5}$ gas generated from the cracking of oil in 16 different source rocks with increasing burial depth, according to anhydrous-pyrolysis model (solid lines; Pepper and Corvi, 1995) at geologic heating rates of $A, 1^{\circ} \mathrm{C} / \mathrm{m}$.y., and $B, 10^{\circ} \mathrm{C} / \mathrm{m}$.y. Deep gas depths occur below horizontal line drawn at 15,000 feet/4,572 m. BL, Brown Limestone; SM, St. Medard; GA, Garlin; KCF, not given; PAL, not given; LC9, LC995; LC1, LC1005; AWD, not given; P4, Pematang 45.2; P5, Pematang 52.7; Maui, Maui; Tu, Tuna; Ta, Tarakan; C0, COST; Ha ، Haltenbanken; and WE, Westfield. Bold-solid St. Medard (SM) curve was selected to be the single representative gas generation curve for all 16 samples. 

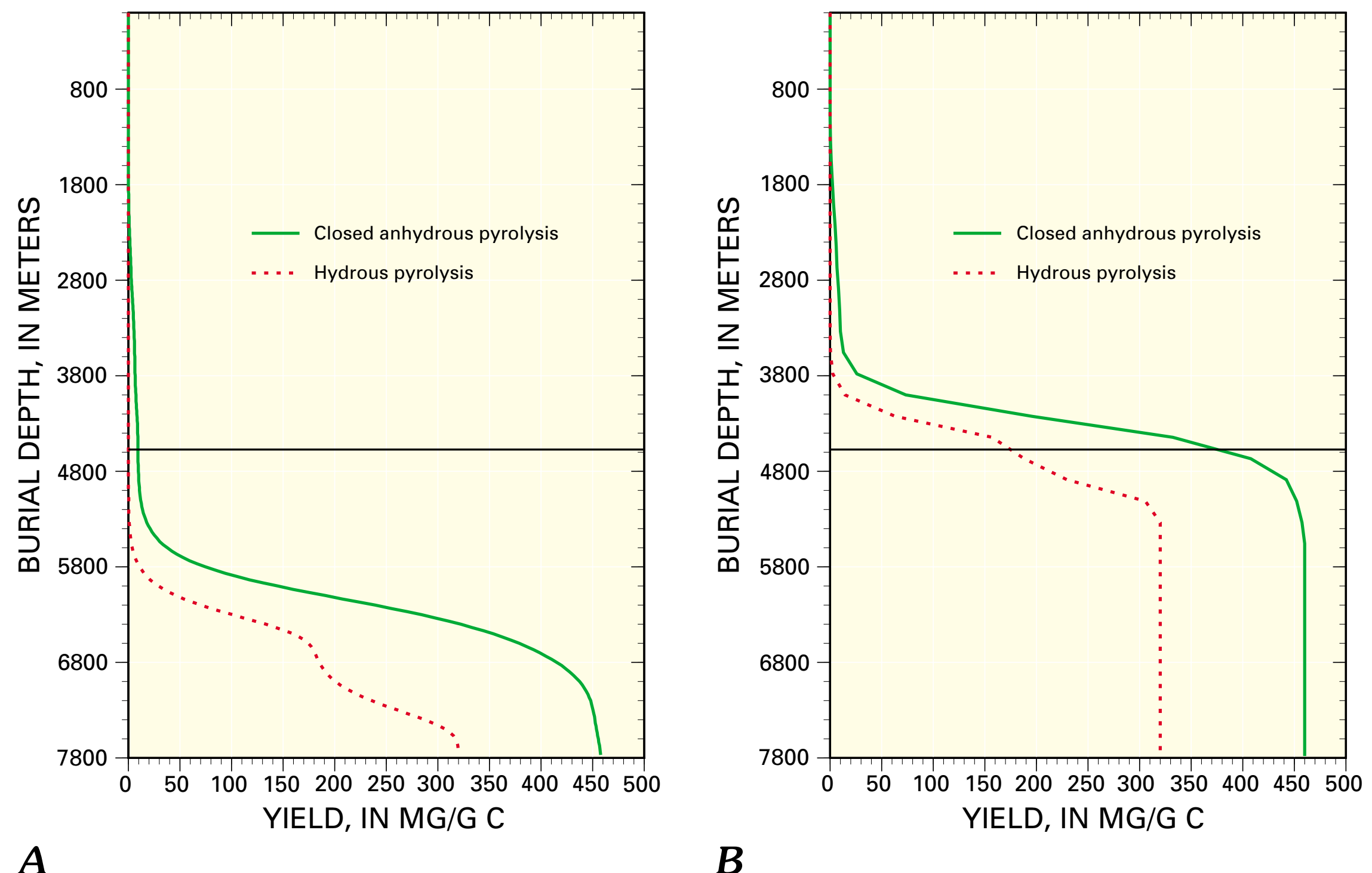

Figure 7. Amount of gas generated from the cracking of reservoir oil with increasing burial depth, according to anhydrous-pyrolysis model (solid line; $\mathrm{C}_{1}-\mathrm{C}_{4} ; \mathrm{H}_{\mathrm{B}}$ rsfield and others, 1992 ) and hydrous-pyrolysis (dotted line; $\mathrm{C}_{1}-\mathrm{C}_{4} ;$ Tsuzuki and others, 1997 ) models at geologic heating rates of $A, 1^{\circ} \mathrm{C} / \mathrm{m} . y$. , and $B, 10^{\circ} \mathrm{C} / \mathrm{m} . y$. Deep gas depths occur below horizontal line drawn at 15,000 feet/4,572 m. 
Table 6. Summary of gas generation curves for kerogens and oils (figs. 1-6) with respect to yield, depth, time, and temperature for fraction of reaction values of $0.05,0.25,0.50,0.75$, and 0.99 at $1^{\circ}$ and $10^{\circ} \mathrm{C} / \mathrm{m}$.y. heating rates for each kinetic model.

[Last column of each heating rate gives the fraction of reaction, yield, time, and temperature at the start of deep gas (15,000 feet-4,572 m)]

\begin{tabular}{|c|c|c|c|c|c|c|c|c|c|c|c|c|}
\hline \multirow{2}{*}{$\begin{array}{l}\text { Type-I kerogen } \\
\quad \text { Open-pyrolysis model }\end{array}$} & \multicolumn{6}{|c|}{$1^{\circ} \mathrm{C} / \mathrm{m} \cdot \mathrm{y}}$. & \multicolumn{5}{|c|}{$10^{\circ} \mathrm{C} / \mathrm{m} . \mathrm{y}$. } & \\
\hline & & & & & & & & & & & & \\
\hline Fraction of reaction $(\mathrm{X})$ & 0.050 & 0.250 & 0.500 & 0.750 & 0.990 & 0.909 & 0.050 & 0.250 & 0.500 & 0.750 & 0.990 & 0.989 \\
\hline Gas yield (mg/g C) & 4 & 22 & 44 & 66 & 87 & 80 & 4 & 22 & 44 & 66 & 87 & 87 \\
\hline$\left(\mathrm{ft}^{3} / \mathrm{kg} \mathrm{C}\right)$ & 0.168 & 0.840 & 1.680 & 2.520 & 3.326 & 3.054 & 0.168 & 0.840 & 1.680 & 2.520 & 3.326 & 3.321 \\
\hline Depth (m) & 3600 & 4000 & 4200 & 4200 & 6800 & 4572 & 2400 & 2600 & 2800 & 3000 & 4572 & 4572 \\
\hline Time (m.y.) & 108 & 120 & 126 & 126 & 204 & 137 & 11 & 12 & 13 & 14 & 21 & 21 \\
\hline Temperature $\left({ }^{\circ} \mathrm{C}\right)$ & 128 & 140 & 146 & 146 & 224 & 157 & 128 & 137 & 146 & 155 & 226 & 226 \\
\hline \multicolumn{13}{|l|}{ Composite-pyrolysis model $^{2}$} \\
\hline Fraction of reaction $(\mathrm{X})$ & 0.050 & 0.250 & 0.500 & 0.750 & 0.990 & 0.641 & 0.050 & 0.250 & 0.500 & 0.750 & 0.990 & 1.000 \\
\hline Gas yield $(\mathrm{mg} / \mathrm{g} \mathrm{C})$ & 4 & 20 & 39 & 59 & 77 & 78 & 4 & 20 & 39 & 59 & 77 & 78 \\
\hline$\left(\mathrm{ft}^{3} / \mathrm{kg} \mathrm{C}\right)$ & 0.149 & 0.744 & 1.489 & 2.233 & 2.948 & 2.978 & 0.149 & 0.744 & 1.489 & 2.233 & 2.948 & 2.978 \\
\hline Depth $(\mathrm{m})$ & 3400 & 4000 & 4400 & 4800 & 5600 & 4572 & 2400 & 2600 & 3000 & 3400 & 4000 & 4572 \\
\hline Time (m.y.) & 102 & 120 & 132 & 144 & 168 & 137 & 11 & 12 & 14 & 15 & 18 & 21 \\
\hline Temperature $\left({ }^{\circ} \mathrm{C}\right)$ & 122 & 140 & 152 & 164 & 188 & 157 & 128 & 137 & 155 & 173 & 200 & 226 \\
\hline \multicolumn{13}{|l|}{ Type-II kerogen } \\
\hline \multicolumn{13}{|l|}{ Open-pyrolysis model $^{1}$} \\
\hline Fraction of reaction $(\mathrm{X})$ & 0.050 & 0.250 & 0.500 & 0.750 & 0.990 & 0.671 & 0.050 & 0.250 & 0.500 & 0.750 & 0.990 & 0.971 \\
\hline Gas yield (mg/g C) & 4 & 18 & 35 & 53 & 69 & 47 & 4 & 18 & 35 & 53 & 69 & 68 \\
\hline$\left(\mathrm{ft}^{3} / \mathrm{kg} \mathrm{C}\right)$ & 0.134 & 0.668 & 1.336 & 2.004 & 2.645 & 1.794 & 0.134 & 0.668 & 1.336 & 2.004 & 2.645 & 2.596 \\
\hline Depth (m) & 2800 & 3600 & 4200 & 4800 & 6800 & 4572 & 1800 & 2400 & 2800 & 3200 & 4800 & 4572 \\
\hline Time (m.y.) & 84 & 108 & 126 & 144 & 204 & 137 & 8 & 11 & 13 & 14 & 22 & 21 \\
\hline Temperature $\left({ }^{\circ} \mathrm{C}\right)$ & 104 & 128 & 146 & 164 & 224 & 157 & 101 & 128 & 146 & 164 & 236 & 226 \\
\hline \multicolumn{13}{|l|}{ Composite-pyrolysis model $^{2}$} \\
\hline Fraction of reaction $(\mathrm{X})$ & 0.050 & 0.250 & 0.500 & 0.750 & 0.990 & 0.350 & 0.050 & 0.250 & 0.500 & 0.750 & 0.990 & 0.950 \\
\hline Gas yield (mg/g C) & 5 & 25 & 50 & 75 & 99 & 35 & 5 & 25 & 50 & 75 & 99 & 95 \\
\hline$\left(\mathrm{ft}^{3} / \mathrm{kg} \mathrm{C}\right)$ & 0.191 & 0.954 & 1.909 & 2.863 & 3.779 & 1.336 & 0.191 & 0.954 & 1.909 & 2.863 & 3.779 & 3.627 \\
\hline Depth (m) & 3400 & 4400 & 5000 & 5600 & 7200 & 4572 & 2400 & 3000 & 3400 & 3800 & 5000 & 4572 \\
\hline Time (m.y.) & 102 & 132 & 150 & 168 & 216 & 137 & 11 & 14 & 15 & 17 & 23 & 21 \\
\hline Temperature $\left({ }^{\circ} \mathrm{C}\right)$ & 122 & 152 & 170 & 188 & 236 & 157 & 128 & 155 & 173 & 191 & 245 & 226 \\
\hline \multicolumn{13}{|l|}{ Hydrous-pyrolysis model $^{3}$} \\
\hline Fraction of reaction $(\mathrm{X})$ & 0.050 & 0.250 & 0.500 & 0.750 & 0.990 & 0.753 & 0.050 & 0.250 & 0.500 & 0.750 & 0.990 & 1.000 \\
\hline Gas yield (mg/g C) & 5 & 23 & 47 & 70 & 92 & 70 & 5 & 23 & 47 & 70 & 92 & 93 \\
\hline$\left(\mathrm{ft}^{3} / \mathrm{kg} \mathrm{C}\right)$ & 0.180 & 0.899 & 1.797 & 2.696 & 3.559 & 2.706 & 0.180 & 0.899 & 1.797 & 2.696 & 3.559 & 3.595 \\
\hline Depth (m) & 2800 & 3400 & 3800 & 4572 & 5800 & 4572 & 2000 & 2400 & 2800 & 3200 & 4000 & 4572 \\
\hline Time (m.y.) & 84 & 102 & 114 & 137 & 174 & 137 & 9 & 11 & 13 & 14 & 18 & 21 \\
\hline Temperature $\left({ }^{\circ} \mathrm{C}\right)$ & 104 & 122 & 134 & 157 & 194 & 157 & 110 & 128 & 146 & 164 & 200 & 226 \\
\hline
\end{tabular}


Return to

Volume Contents

ก

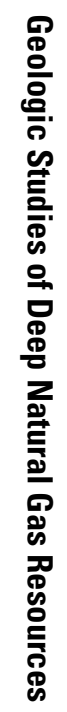

Table 6-Continued. Summary of gas generation curves for kerogens and oils (figs. 1-6) with respect to yield, depth, time, and temperature for fraction of reaction values of $0.05,0.25$, $0.50,0.75$, and 0.99 at $1^{\circ}$ and $10^{\circ} \mathrm{C} / \mathrm{m}$.y. heating rates for each kinetic model.

[Last column of each heating rate gives the fraction of reaction, yield, time, and temperature at the start of deep gas (15,000 feet—4,572 m)]

\begin{tabular}{|c|c|c|c|c|c|c|c|c|c|c|c|c|}
\hline \multirow{2}{*}{\multicolumn{13}{|c|}{$\begin{array}{l}\text { Type-IIS kerogen } \\
\quad \text { Open-pyrolysis model }{ }^{1}\end{array}$}} \\
\hline & & & & & & & & & & & & \\
\hline Fraction of reaction $(\mathrm{X})$ & 0.050 & 0.250 & 0.500 & 0.750 & 0.990 & 0.743 & 0.050 & 0.250 & 0.500 & 0.750 & 0.990 & 0.986 \\
\hline \multirow{2}{*}{$\begin{array}{r}\text { Gas yield }(\mathrm{mg} / \mathrm{g} \mathrm{C}) \\
\left(\mathrm{ft}^{3} / \mathrm{kg} \mathrm{C}\right)\end{array}$} & 4 & 18 & 35 & 53 & 69 & 52 & 4 & 18 & 35 & 53 & 69 & 69 \\
\hline & 0.134 & 0.668 & 1.336 & 2.004 & 2.645 & 1.985 & 0.134 & 0.668 & 1.336 & 2.004 & 2.645 & 2.634 \\
\hline Depth (m) & 2400 & 3000 & 4000 & 4572 & 6400 & 4572 & 1600 & 2200 & 2800 & 3200 & 4572 & 4572 \\
\hline Time (m.y.) & 72 & 90 & 120 & 137 & 192 & 137 & 7 & 10 & 13 & 14 & 21 & 21 \\
\hline Temperature $\left({ }^{\circ} \mathrm{C}\right)$ & 92 & 110 & 140 & 157 & 212 & 157 & 92 & 119 & 146 & 164 & 226 & 226 \\
\hline \multicolumn{13}{|l|}{ Composite-pyrolysis model $^{2}$} \\
\hline \multirow{3}{*}{$\begin{array}{c}\text { Fraction of reaction }(\mathrm{X}) \\
\text { Gas yield }(\mathrm{mg} / \mathrm{g} \mathrm{C}) \\
\left(\mathrm{ft}^{3} / \mathrm{kg} \mathrm{C}\right)\end{array}$} & 0.050 & 0.250 & 0.500 & 0.750 & 0.990 & 0.933 & 0.050 & 0.250 & 0.500 & 0.750 & 0.990 & 1.000 \\
\hline & 5 & 26 & 53 & 79 & 104 & 98 & 5 & 26 & 53 & 79 & 104 & 105 \\
\hline & 0.200 & 1.002 & 2.004 & 3.006 & 3.968 & 3.741 & 0.200 & 1.002 & 2.004 & 3.006 & 3.968 & 4.008 \\
\hline Depth (m) & 2400 & 3000 & 3400 & 4000 & 5000 & 4572 & 1600 & 2000 & 2400 & 2800 & 3600 & 4572 \\
\hline Time (m.y.) & 72 & 90 & 102 & 120 & 150 & 137 & 7 & 9 & 11 & 13 & 16 & 21 \\
\hline Temperature $\left({ }^{\circ} \mathrm{C}\right)$ & 92 & 110 & 122 & 140 & 170 & 157 & 92 & 110 & 128 & 146 & 182 & 226 \\
\hline \multicolumn{13}{|l|}{ Type-III kerogen } \\
\hline \multicolumn{13}{|l|}{ Open-pyrolysis model ${ }^{1}$} \\
\hline Fraction of reaction $(\mathrm{X})$ & 0.050 & 0.250 & 0.500 & 0.750 & 0.990 & 0.259 & 0.050 & 0.250 & 0.500 & 0.750 & 0.990 & 0.852 \\
\hline \multirow{2}{*}{$\begin{array}{r}\text { Gas yield }(\mathrm{mg} / \mathrm{g} \mathrm{C}) \\
\left(\mathrm{ft}^{3} / \mathrm{kg} \mathrm{C}\right)\end{array}$} & 3 & 14 & 27 & 41 & 53 & 14 & 3 & 14 & 27 & 41 & 53 & 46 \\
\hline & 0.000103 & 0.000515 & 0.001031 & 0.001546 & 0.002041 & 0.000534 & 0.000103 & 0.000515 & 0.001031 & 0.001546 & 0.002041 & 0.001756 \\
\hline Depth (m) & 3600 & 4400 & 5200 & 6200 & 7400 & 4572 & 2400 & 3200 & 3600 & 4200 & 5200 & 4572 \\
\hline Time (m.y.) & 108 & 132 & 156 & 186 & 222 & 137 & 11 & 14 & 16 & 19 & 23 & 21 \\
\hline Temperature $\left({ }^{\circ} \mathrm{C}\right)$ & 128 & 152 & 176 & 206 & 242 & 157 & 128 & 164 & 182 & 209 & 254 & 226 \\
\hline \multicolumn{13}{|l|}{ Composite-pyrolysis model $^{2}$} \\
\hline Fraction of reaction $(\mathrm{X})$ & 0.050 & 0.250 & 0.500 & 0.750 & 0.990 & 0.026 & 0.050 & 0.250 & 0.500 & 0.750 & 0.990 & 0.921 \\
\hline \multirow{2}{*}{$\begin{array}{r}\text { Gas yield }(\mathrm{mg} / \mathrm{g} \mathrm{C}) \\
\left(\mathrm{ft}^{3} / \mathrm{kg} \mathrm{C}\right)\end{array}$} & 4 & 19 & 38 & 57 & 75 & 2 & 4 & 19 & 38 & 57 & 75 & 70 \\
\hline & 0.145 & 0.725 & 1.451 & 2.176 & 2.872 & 0.076 & 0.145 & 0.725 & 1.451 & 2.176 & 2.872 & 2.672 \\
\hline Depth (m) & 4800 & 5400 & 5800 & 6000 & 7000 & 4572 & 3200 & 3600 & 4000 & 4200 & 4800 & 4572 \\
\hline Time (m.y.) & 144 & 162 & 174 & 180 & 210 & 137 & 14 & 16 & 18 & 19 & 22 & 21 \\
\hline Temperature $\left({ }^{\circ} \mathrm{C}\right)$ & 164 & 182 & 194 & 200 & 230 & 157 & 164 & 182 & 200 & 209 & 236 & 226 \\
\hline \multicolumn{13}{|l|}{ Type-III' kerogen } \\
\hline \multicolumn{13}{|l|}{ Open-pyrolysis model $^{1}$} \\
\hline Fraction of reaction $(\mathrm{X})$ & 0.050 & 0.250 & 0.500 & 0.750 & 0.990 & 0.105 & 0.050 & 0.250 & 0.500 & 0.750 & 0.990 & 0.737 \\
\hline Gas yield (mg/g C) & 3 & 14 & 29 & 43 & 56 & 6 & 3 & 14 & 29 & 43 & 56 & 42 \\
\hline$\left(\mathrm{ft}^{3} / \mathrm{kg} \mathrm{C}\right)$ & 0.109 & 0.544 & 1.088 & 1.632 & 2.154 & 0.229 & 0.109 & 0.544 & 1.088 & 1.632 & 2.154 & 1.603 \\
\hline Depth (m) & 4200 & 5000 & 5800 & 6600 & 7800 & 4572 & 3000 & 3400 & 4000 & 4572 & 5600 & 4572 \\
\hline Time (m.y.) & 126 & 150 & 174 & 198 & 234 & 137 & 14 & 15 & 18 & 21 & 25 & 21 \\
\hline Temperature $\left({ }^{\circ} \mathrm{C}\right)$ & 146 & 170 & 194 & 218 & 254 & 157 & 155 & 173 & 200 & 226 & 272 & 226 \\
\hline
\end{tabular}


Table 6-Continued. Summary of gas generation curves for kerogens and oils (figs. 1-6) with respect to yield, depth, time, and temperature for fraction of reaction values of 0.05 , 0.25 , $0.50,0.75$, and 0.99 at $1^{\circ}$ and $10^{\circ} \mathrm{C} / \mathrm{m}$.y. heating rates for each kinetic model.

[Last column of each heating rate gives the fraction of reaction, yield, time, and temperature at the start of deep gas $(15,000$ feet—4,572 m)]

\begin{tabular}{|c|c|c|c|c|c|c|c|c|c|c|c|c|}
\hline \multirow{2}{*}{$\begin{array}{l}\text { Type-III' kerogen } \\
\quad \text { Composite-pyrolysis model }^{2}\end{array}$} & \multicolumn{6}{|c|}{$1^{\circ} \mathrm{C} / \mathrm{m} . \mathrm{y}}$. & \multicolumn{6}{|c|}{$10^{\circ} \mathrm{C} / \mathrm{m} . \mathrm{y}}$. \\
\hline & & & & & & & & & & & & \\
\hline Fraction of reaction $(\mathrm{X})$ & 0.050 & 0.250 & 0.500 & 0.750 & 0.990 & 0.029 & 0.050 & 0.250 & 0.500 & 0.750 & 0.990 & 0.914 \\
\hline Gas yield $(\mathrm{mg} / \mathrm{g} \mathrm{C})$ & 4 & 18 & 35 & 53 & 69 & 2 & 4 & 18 & 35 & 53 & 69 & 64 \\
\hline$\left(\mathrm{ft}^{3} / \mathrm{kg} \mathrm{C}\right)$ & 0.134 & 0.668 & 1.336 & 2.004 & 2.645 & 0.076 & 0.134 & 0.668 & 1.336 & 2.004 & 2.645 & 2.443 \\
\hline Depth (m) & 4600 & 5400 & 5800 & 6000 & 7000 & 4572 & 3200 & 3600 & 4000 & 4200 & 4800 & 4572 \\
\hline Time (m.y.) & 138 & 162 & 174 & 180 & 210 & 137 & 14 & 16 & 18 & 19 & 22 & 21 \\
\hline Temperature $\left({ }^{\circ} \mathrm{C}\right)$ & 158 & 182 & 194 & 200 & 230 & 157 & 164 & 182 & 200 & 209 & 236 & 226 \\
\hline \multicolumn{13}{|l|}{ Oil in source rock } \\
\hline \multicolumn{13}{|l|}{ Anhydrous-pyrolysis model ${ }^{4}$} \\
\hline Fraction of reaction $(\mathrm{X})$ & 0.050 & 0.250 & 0.500 & 0.750 & 0.990 & 0.353 & 0.050 & 0.250 & 0.500 & 0.750 & 0.990 & 1.000 \\
\hline Gas yield (mg/g C) & 5 & 25 & 50 & 75 & 99 & 35 & 5 & 25 & 50 & 75 & 99 & 100 \\
\hline$\left(\mathrm{ft}^{3} / \mathrm{kg} \mathrm{C}\right)$ & 0.191 & 0.954 & 1.909 & 2.863 & 3.779 & 1.347 & 0.191 & 0.954 & 1.909 & 2.863 & 3.779 & 3.817 \\
\hline Depth (m) & 3600 & 4400 & 5000 & 5400 & 6600 & 4572 & 2400 & 3000 & 3400 & 3800 & 4200 & 4572 \\
\hline Time (m.y.) & 108 & 132 & 150 & 162 & 198 & 137 & 11 & 14 & 15 & 17 & 19 & 21 \\
\hline Temperature $\left({ }^{\circ} \mathrm{C}\right)$ & 128 & 152 & 170 & 182 & 218 & 157 & 128 & 155 & 173 & 191 & 209 & 226 \\
\hline \multicolumn{13}{|l|}{ Oil in reservoirs } \\
\hline \multicolumn{13}{|l|}{ Anhydrous-pyrolysis model ${ }^{5}$} \\
\hline Fraction of reaction $(\mathrm{X})$ & 0.050 & 0.250 & 0.500 & 0.750 & 0.990 & at $15,000 \mathrm{ft}$ & 0.050 & 0.250 & 0.500 & 0.750 & 0.990 & at $15,000 \mathrm{ft}$ \\
\hline Gas yield (mg/g oil) & 23 & 115 & 230 & 345 & 455 & 0.022 & 23 & 115 & 230 & 345 & 455 & 0.804 \\
\hline$\left(\mathrm{ft}^{3} / \mathrm{kg}\right.$ oil $)$ & 0.889 & 4.445 & 8.890 & 13.336 & 17.603 & 0.001 & 0.889 & 4.445 & 8.890 & 13.336 & 17.603 & 0.031 \\
\hline Depth (m) & 5400 & 6000 & 6200 & 6400 & 7600 & 4572 & 3800 & 4000 & 4200 & 4400 & 5000 & 4572 \\
\hline Time (m.y.) & 162 & 180 & 186 & 192 & 228 & 137 & 17 & 18 & 19 & 20 & 23 & 21 \\
\hline Temperature $\left({ }^{\circ} \mathrm{C}\right)$ & 182 & 200 & 206 & 212 & 248 & 157 & 191 & 200 & 209 & 218 & 245 & 226 \\
\hline \multicolumn{13}{|l|}{ Anhydrous-pyrolysis model ${ }^{6}$} \\
\hline Fraction of reaction $(\mathrm{X})$ & 0.050 & 0.250 & 0.500 & 0.750 & 0.990 & 0.000 & 0.050 & 0.250 & 0.500 & 0.750 & 0.990 & 0.531 \\
\hline Gas yield (mg/g oil) & 16 & 80 & 160 & 240 & 317 & 0.000 & 16 & 80 & 160 & 240 & 317 & 170.000 \\
\hline$\left(\mathrm{ft}^{3} / \mathrm{kg}\right.$ oil $)$ & 0.000611 & 0.003054 & 0.006108 & 0.009162 & 0.012094 & 0.000 & 0.000611 & 0.003054 & 0.006108 & 0.009162 & 0.012094 & 0.006490 \\
\hline Depth (m) & 5800 & 6200 & 6400 & 7200 & 7400 & 4572 & 4000 & 4200 & 4400 & 5000 & 5200 & 4572 \\
\hline Time (m.y.) & 174 & 186 & 192 & 216 & 222 & 137 & 18 & 19 & 20 & 23 & 23 & 21 \\
\hline Temperature $\left({ }^{\circ} \mathrm{C}\right)$ & 194 & 206 & 212 & 236 & 242 & 157 & 200 & 209 & 218 & 245 & 254 & 226 \\
\hline
\end{tabular}

References: 1, Behar and others (1997); 2, Pepper and Corvi (1995); 3, Knauss and others (1997); 4, Pepper and Dodd (1995); 5, Horsfield and others (1992); 6, Tsuzuki and others (1997). 
Table 7. Amounts of gas generated from kerogen above and below deep gas depth of 15,000 feet/4,572 $\mathrm{m}$.

[All values refer to $\mathrm{C}_{1}-\mathrm{C}_{5}$ gas, except where otherwise noted]

\begin{tabular}{|c|c|c|c|c|c|}
\hline \multirow[t]{2}{*}{ Kinetic model ${ }^{*}$} & \multirow{2}{*}{$\begin{array}{c}\text { Kerogen } \\
\text { type }\end{array}$} & \multicolumn{2}{|c|}{$\begin{array}{l}1^{\circ} \mathrm{C} / \mathrm{m} . \mathrm{y} . \\
\text { Gas generated }\end{array}$} & \multicolumn{2}{|c|}{$\begin{array}{l}10^{\circ} \mathrm{C} / \mathrm{m} . \mathrm{y} . \\
\text { Gas generated }\end{array}$} \\
\hline & & $\begin{array}{c}\text { Above } 4,572 \mathrm{~m} \\
(\mathrm{mg} / \mathrm{g} \mathrm{C})\end{array}$ & $\begin{array}{c}\text { Below 4,572 m } \\
(\mathrm{mg} / \mathrm{g} \mathrm{C})\end{array}$ & $\begin{array}{c}\text { Above } 4,572 \mathrm{~m} \\
(\mathrm{mg} / \mathrm{g} \mathrm{C})\end{array}$ & $\begin{array}{c}\text { Below 4,572 m } \\
(\mathrm{mg} / \mathrm{g} \mathrm{C})\end{array}$ \\
\hline \multirow[t]{5}{*}{ Open pyrolysis $^{1}$} & Type-I & 80 & 8 & 87 & 1 \\
\hline & Type-II & 50 & 20 & 68 & 2 \\
\hline & Type-IIS & 50 & 20 & 69 & 1 \\
\hline & Type-III & 6 & 51 & 42 & 15 \\
\hline & Type-III' & 14 & 40 & 46 & 8 \\
\hline \multirow[t]{5}{*}{ Composite pyrolysis $^{2}$} & Type-I & 50 & 28 & 78 & 0 \\
\hline & Type-II & 35 & 65 & 95 & 5 \\
\hline & Type-IIS & 100 & 5 & 105 & 0 \\
\hline & Type-III & 2 & 75 & 70 & 7 \\
\hline & Type-III' & 2 & 68 & 64 & 6 \\
\hline Hydrous pyrolysis ${ }^{3}$ & Type-II & $70 * *$ & $23 * *$ & $93 * *$ & $0 * *$ \\
\hline
\end{tabular}

*References: 1, Behar and others (1997); 2, Pepper and Corvi (1995); 3, Knauss and others (1997).

**All total gas is defined as $\mathrm{C}_{1}-\mathrm{C}_{5}$ except in these cases, where it is defined as $\mathrm{C}_{1}-\mathrm{C}_{4}$.

example, three times as much deep gas generation is predicted by Type-II kerogen in the composite-pyrolysis model than in the open-pyrolysis model. The hydrous-pyrolysis model for deep gas generation from Type-II kerogen predicts an intermediate value $(23 \mathrm{mg} / \mathrm{g} \mathrm{C})$ at the low heating rate and the lowest value $(0 \mathrm{mg} / \mathrm{g} \mathrm{C})$ at the high heating rate relative to the predictions by the composite- and open-pyrolysis models. Type-II kerogen is the most common source of oil, and the results presented here (table 7) suggest that the predicted potential for deep gas from this kerogen type is highly dependent on the pyrolysis model employed.

Type-I kerogen, which is typically associated with lacustrine sequences and source rocks, consistently has low yields of deep gas generation in both open- and composite-pyrolysis models and at both heating rates (table 7). These predictions suggest that basins with deeply buried lacustrine source rock sequences are not favorable for deep gas generation from kerogen. Conversely, Type-III kerogen produces more deep gas than the other kerogen types in both the open- and composite-pyrolysis models and for both heating rates. These predictions imply that basins with deeply buried coals are the most favorable for deep gas generation from kerogen.

\section{Oil to Gas}

Deep gas from the cracking of oil retained in a source rock does not depend on kerogen type or lithology according to the anhydrous-pyrolysis model by Pepper and Dodd (1995). Similar to deep gas generation from kerogen, deep gas from retained oil in source rocks is most favorable at low heating rates (table 8). At $1^{\circ} \mathrm{C} / \mathrm{m} . y$., this model predicts amounts of deep gas generation that are comparable to those predicted by the compositepyrolysis model for deep gas generation from Type-II and -III kerogens (table 8). At the high heating rate, no deep gas generation from the cracking of retained oil in source rocks is predicted (table 8 ). Therefore, at $10^{\circ} \mathrm{C} / \mathrm{m}$.y., deep gas generation from kerogen is more favorable than from the retained oil in a source rock.

Anhydrous- and hydrous-pyrolysis models predict that amounts of deep gas generated from the cracking of reservoir oil are 4-7 times greater at $1{ }^{\circ} \mathrm{C} / \mathrm{m}$.y. and 6-20 times greater at $10^{\circ} \mathrm{C} / \mathrm{m}$.y. than the best deep gas yields obtained from kerogen (table 7). This difference is readily explained by the fact that oil has a higher thermal stability than kerogen. It has also been shown that the thermal stability of oil increases in the presence of liquid water (Hesp and Rigby, 1973), which would be ubiquitous in most subsurface reservoirs. This increase in stability with water is supported in part by the lower deep gas yields predicted by the hydrous-pyrolysis model than predicted by anhydrous-pyrolysis model at the high heating rate (table 6).

Although the deep gas yields predicted for the cracking of reservoir oil are considerably higher than those for kerogen, the amount of kerogen in deeply buried source rocks of a sedimentary basin may be several orders of magnitude greater than the amounts of deeply buried reservoir oil. 
Table 8. Amounts of gas generated from cracking of oil above and below deep gas depth of 15,000 feet/4,572 m.

[All values refer to $\mathrm{C}_{1}-\mathrm{C}_{5}$ gas, except where otherwise noted]

\begin{tabular}{|c|c|c|c|c|c|}
\hline \multirow{3}{*}{ Kinetic model* } & \multirow{3}{*}{ Oil type } & \multicolumn{2}{|c|}{$1^{\circ} \mathrm{C} / \mathrm{m} . \mathrm{y}}$. & \multicolumn{2}{|c|}{$10^{\circ} \mathrm{C} / \mathrm{m} . \mathrm{y}$} \\
\hline & & \multicolumn{2}{|c|}{ Gas generated } & \multicolumn{2}{|c|}{ Gas generated } \\
\hline & & $\begin{array}{l}\text { Above 4,572 m } \\
\quad(\mathrm{mg} / \mathrm{g} \mathrm{C})\end{array}$ & $\begin{array}{l}\text { Below 4,572 m } \\
\quad(\mathrm{mg} / \mathrm{g} \mathrm{C})\end{array}$ & $\begin{array}{c}\text { Above } 4,572 \mathrm{~m} \\
(\mathrm{mg} / \mathrm{g} \mathrm{C})\end{array}$ & $\begin{array}{c}\text { Below 4,572 m } \\
(\mathrm{mg} / \mathrm{g} \mathrm{C})\end{array}$ \\
\hline \multicolumn{6}{|l|}{ Source-rock oil } \\
\hline Anhydrous pyrolysis ${ }^{4}$ & Oil in source rock $* *$ & 29 & 71 & 100 & 0 \\
\hline & & \multicolumn{2}{|c|}{ Gas generated } & \multicolumn{2}{|c|}{ Gas generated } \\
\hline Reservoir oil & & $\begin{array}{l}\text { Above } 4,572 \mathrm{~m} \\
\quad(\mathrm{mg} / \mathrm{g} \text { oil })\end{array}$ & $\begin{array}{c}\text { Below 4,572 m } \\
\text { (mg/g oil) }\end{array}$ & $\begin{array}{c}\text { Above } 4,572 \mathrm{~m} \\
(\mathrm{mg} / \mathrm{g} \text { oil })\end{array}$ & $\begin{array}{c}\text { Below } 4,572 \mathrm{~m} \\
(\mathrm{mg} / \mathrm{g} \text { oil })\end{array}$ \\
\hline Anhydrous pyrolysis ${ }^{5}$ & North Sea (36 API) & $2 * *$ & $458 * *$ & $370 * *$ & $90 * *$ \\
\hline Hydrous pyrolysis ${ }^{6}$ & Sarukawa $\left(33.6^{\circ} \mathrm{API}\right)$ & 0 & 320 & 170 & 150 \\
\hline
\end{tabular}

*References: 4, Pepper and Dodd (1995); 5, Horsfield and others (1992); 6, Tsuzuki and others (1997).

**All total gas is defined as $\mathrm{C}_{1}-\mathrm{C}_{5}$ except in these cases, where it is defined as $\mathrm{C}_{1}-\mathrm{C}_{4}$. 


\section{Conclusions and Future Studies}

1. Basins with slow heating rates, where source rocks subside slowly through low thermal gradients, are more likely to yield deep gas from kerogen than basins with fast heating rates and rapid subsidence of source rock. Because this is one of the most important implications of this study, it would be interesting to compare amounts of deep gas and heating rates from different sedimentary basins. This would involve creating an inventory of heating rates for domestic basins as well as the amount of deep gas recovered to the present time. A future study of this type can be used to evaluate the validity of the different models used in this study and target basins with high potential for deep gas.

2. According to the open- and composite-pyrolysis models, Type-III kerogen will yield the most deep gas of the three kerogen types irrespective of heating rate. This implies that basins with deeply buried coals are most likely to contain deep gas. A future study comparing deep gas yields from basins with differing amounts of deeply buried coal would be a useful way of testing this model-based prediction and targeting basins with high potential for deep gas.

3. According to the open- and composite-pyrolysis models, Type-I kerogen has the least potential or no potential for deep gas generation. This implies that basins with deeply buried lacustrine source rocks are not likely to contain deep gas. A future study comparing deep gas yields from basins with differing amounts of deeply buried lacustrine source rocks would be a useful way of testing this model-based prediction and exclude basins with low potential for deep gas.

4. Cracking of reservoir oil is predicted by the anhydrousand hydrous-pyrolysis models to generate the most deep gas irrespective of heating rate. Therefore, basins that currently have deeply buried overmature source rocks have the potential of previously having reservoir oil that has since cracked to generate deep gas. The main control for deep gas accumulations in this geologic setting is the original oil trap remaining competent with burial depth. The Gulf Coast offshore and the Anadarko basin may serve as examples of this geologic setting. Future studies of these types of basins can further elucidate the factors controlling deep gas accumulations and target other areas with high potential for deep gas.

5. No significant differences occur between the predicted amount of deep gas generated from kerogen by the different pyrolysis kinetic models. However, the hydrous-pyrolysis model considers only Type-II kerogen, and more hydrous-pyrolysis experiments with kinetic models for gas generation from Type-I, Type-IIS, and Type-III kerogens are needed to test this preliminary conclusion.

6. A significant difference occurs between the predicted amounts of deep gas generated from the cracking of reservoir oil by the anhydrous- and hydrous-pyrolysis kinetic models. The kinetic model derived from hydrous pyrolysis indicates that reservoir oil is more thermally stable and that oil cracking to gas requires higher thermal stress levels than those predicted by the anhydrous-pyrolysis model. More experimental work on the cracking of oil in the presence of water is needed. In addition, these future experiments need to consider the effects of commonly occurring reservoir minerals and their surfaces. Experiments published to 2000 on the cracking of reservoir oil have neglected the potential effects of minerals on gas generation.

\section{References Cited}

Behar, F., and Vandenbroucke, M., 1996, Experimental determination of the rate constants of the $n-C_{25}$ thermal cracking at 120,400 , and 800 bar-Implications for high-pressure/high-temperature prospects: Energy \& Fuels, v. 10, p. 932-940.

Behar, F., Vandenbroucke, M., Tang, Y., Marquis, F. and Espitalié, J., 1997, Thermal cracking of kerogen in open and closed systemsDetermination of kinetic parameters and stoichiometric coefficients for oil and gas generation: Organic Geochemistry, v. 26, p. 321-339.

Braum, R.L., and Burnham, A.K., 1987, Analysis of chemical reactions using a distribution of activation energies and simpler models: Energy \& Fuels, v. 1, p. 153-161.

Burnham, A.K., Gregg, H.R., Ward, R.L., Knauss, K.G., Copenhaver, S.A., Reynolds, J.G., and Sanborn, R., 1997, Decomposition kinetics and mechanism of $n$-hexadecane-1,2- ${ }^{13} C_{2}$ and dodec-1-ene-1,2- ${ }^{13} C_{2}$ doped in petroleum and $n$-hexadecane: Geochimica et Cosmochimica Acta, v. 61, pp. 3725-3737.

Domine, F., 1991, High pressure pyrolysis of $n$-hexane, 2,4-dimethylpentane and 1-phenylbutane-Is pressure an important geochemical parameter?: Organic Geochemistry, v. 17, p. 619-634.

Dyman, T.S., Rice, D.D., and Westcott, P.A., 1997, Introduction, in Dyman, T.S., Rice, D.D., and Westcott, P.A., eds., Geologic controls of deep natural gas resources in the United States: U.S. Geological Survey Bulletin 2146, p. 3-5.

Gorbachev, V.M., 1975, A solution to the exponential integral in the nonisothermal kinetics for linear heating: Journal of Thermal Analysis, v. 6, p. $349-350$.

Gretener, P.E., and Curtis, C.D., 1982, Role of temperature and time on organic metamorphism: American Association of Petroleum Geologists Bulletin, v. 66, p. 1124-1129.

Hesp, W., and Rigby, D., 1973, The geochemical alteration of hydrocarbons in the presence of water: Erdol Kohle-Ergas-Petrochem. Brennstoff-Chemie 26, p. 70-76.

Horsfield, B., Schenk, H.J., Mills, N., and Welte, D.H., 1992, An investigation of the in-reservoir conversion of oil to gas-Compositional and kinetic findings from closed-system programmed-temperature pyrolysis: Advances in Organic Geochemistry, v. 19, p. 191-204.

Jamil, A.S.A., Anwar, M.L., and Kiang, E.S.P., 1991, Geochemistry of selected crude oils from Sabah and Sarawak: Geological Society of Malaysia Bulletin, v. 28, p. 123-149.

Knauss, K.G., Copenhaver, S.A., Braun, R.L., and Burnham, A.K., 1997, Hydrous pyrolysis of New Albany and Phosphoria Shales-Production kinetics of carboxylic acids and light hydrocarbons and interactions between the inorganic and organic chemical systems: Organic Geochemistry, v. 27, p. 477-496.

Pepper, A.S., and Corvi, P.J., 1995, Simple kinetic models of petroleum formation-Part I, Oil and gas generation from kerogen: Marine and Petroleum Geology, v. 12, p. 291-319.

Pepper, A.S., and Dodd, T.A., 1995, Simple kinetic models of petroleum formation-Part II, Oil-gas cracking: Marine and Petroleum Geology, v. 12, p. 321-340.

Price, L.C., 1997, Origins, characteristics, evidence for and economic viabilities of conventional and unconventional gas resource bases, 
in Dyman, T.S., Rice, D.D., and Westcott, P.A., eds., Geologic controls of deep natural gas resources in the United States: U.S. Geological Survey Bulletin 2146, p. 181-207.

Tsuzuki, N., Yokoyama, Y., Takayama, K., Yokoi, K., Suzuki, M., and Takeda, N., 1997, Kinetic modeling of oil cracking: 1997 Eastern Section American Association of Petroleum Geologists and The Society of Organic Petrology Joint Meeting, Lexington, Kentucky, Abstracts and Program, v. 14, p. 94-96.
Ungerer, P., Espitalié, J., Marquis, F., and Durand, B., 1986, Use of kinetic models of organic matter evolution for the reconstruction of paleotemperatures, in Burruss, J., ed., Thermal modeling in sedimentary basins: Paris, Editions Technip., p. 531-546.

Wood, D.A., 1988, Relationships between thermal maturation indices calculated using Arrhenius equation and Lopatin method-Implications for petroleum exploration: American Association of Petroleum Geologists Bulletin, v. 72, p. 115-134. 


\title{
Chapter E
}

\section{Gas:Oil Ratios for Source Rocks Containing Type-I, -II, -IIS, and -III Kerogens as Determined by Hydrous Pyrolysis}

\author{
By Michael D. Lewan and Allison A. Henry
}

Prepared in cooperation with the U.S. Department of Energy-National Energy Technology Laboratory, the Gas Technology Institute, and

Advanced Resources International

U.S. Department of the Interior

U.S. Geological Survey 


\section{Contents}

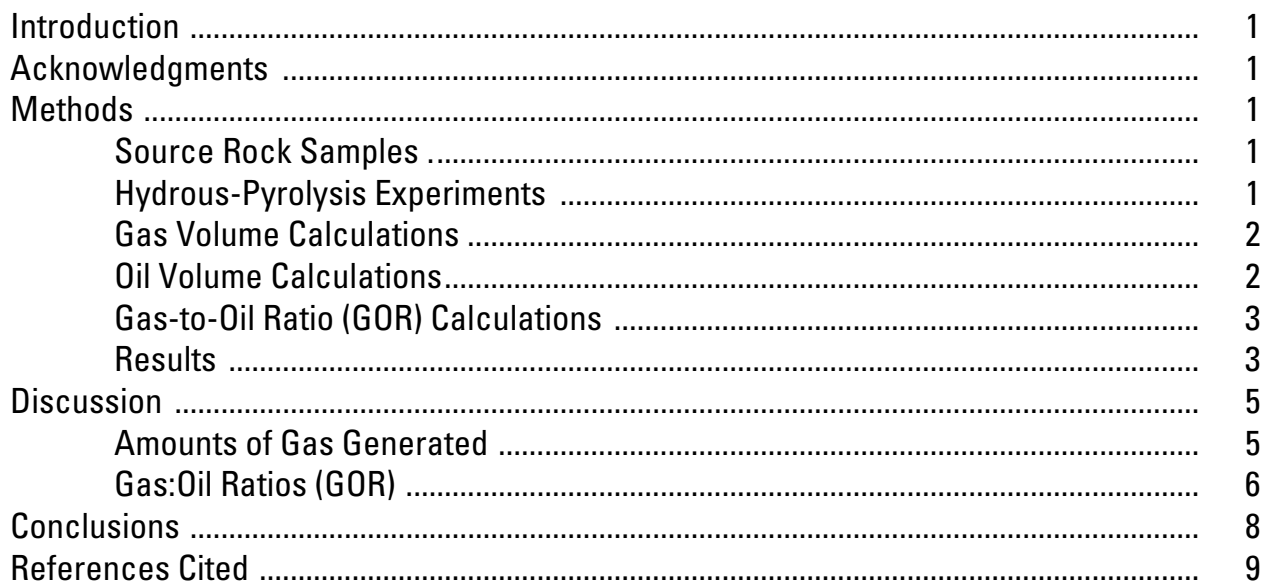

\section{Figures}

\section{1-4. Graphs showing:}

1. Amount of gas generated from source rocks with different kerogen types subjected to hydrous-pyrolysis temperatures between $270^{\circ}$ and $365^{\circ} \mathrm{C}$ for 72 hours

2. Gas:oil ratios (GOR) for source rocks with different kerogen types subjected to hydrous-pyrolysis temperatures between $270^{\circ}$ and $365^{\circ} \mathrm{C}$ for 72 hours

3. Comparison of gas:oil ratios (GOR) for source rocks with different kerogen types subjected to hydrous- and anhydrous-pyrolysis temperatures between $270^{\circ}$ and $365^{\circ} \mathrm{C}$ for 72 hours

4. Comparison of gas:oil ratios (GOR) for aliquots of a sample of Woodford Shale (Type-II) subjected to hydrous and anhydrous pyrolysis at $300^{\circ}$, $330^{\circ}$, and $350^{\circ} \mathrm{C}$ for 72 hours 政

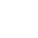
西

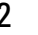
3 3 5 5 6 8 


\title{
Gas:0il Ratios for Source Rocks Containing Type-I, -II, -IIS, and -III Kerogens as Determined by Hydrous Pyrolysis
}

\author{
By Michael D. Lewan ${ }^{1}$ and Allison A. Henry ${ }^{2}$
}

\section{Introduction}

Predicting the gas:oil ratio (GOR) of a petroleum play or prospect is important in evaluating the economics of an exploration venture and in assessing petroleum resources. Estimates of the GOR of prospects in well-drilled areas can typically be determined with analogs from neighboring production in the same play. In poorly drilled areas, GOR of prospects may be estimated by using analogs from more distant well-drilled plays that have similar geologic settings or by use of models based on oil and gas generation from potential source rocks (Mackenzie and Quigley, 1988; Kuo and Michael, 1994, among others). GOR have also been determined by hydrous pyrolysis of potential source rocks in an exploration play or petroleum system (Noble and others, 1991; Lillis and others, 1999, among others). Unlike open- or closed-system anhydrous pyrolysis, hydrous pyrolysis generates an expelled oil that is physically and chemically similar to natural crude oil (Lewan, 1993a; 1997). As a result, the quantity of this expelled oil and the gas generated allows one to calculate GOR of a particular source rock at hydrous-pyrolysis temperatures representing different stages of oil generation.

The objectives of this report are to present gas:oil ratios (GOR) from hydrous-pyrolysis experiments conducted on immature source rocks and report how they are affected by kerogen type and thermal maturity during petroleum generation. The source rocks used in this study contain the major kerogen types, including Type-I, -II, -IIS, and -III. Thermally immature samples were used to provide a complete understanding of changes in GOR from incipient petroleum generation through peak petroleum generation.

\section{Acknowledgments}

This study was funded in part by the U.S. Department of Energy (National Energy Technology Laboratory), Morgantown, W.Va., contract No. DE-AT26-98FT40032), Gas Research

\footnotetext{
$1<$ mlewan@usgs.gov>

${ }^{2}$ Current address: The Scripps Research Institute, 10550 North Torrey Pines Road, La Jolla, CA 92037 <ahenry@scripps.edu>
}

Institute. Chicago, Ill., as a Cooperative Research and Development Agreement with Advanced Resources International, Arlington, Va., and the U.S. Geological Survey, Denver, Colo. The authors appreciate the helpful reviews of this report made by Paul Lillis, Thaddeus Dyman, and Katharine Varnes. The authors also acknowledge the collaborative experimental work of Tim Ruble (CSIRO, Australia), J. Guthrie (Mobil, Dallas), Eli Tannenbaum (Kimron, Israel), Hasim Ramini (NRA, Jordan), and Robert Dias (The Pennsylvania State University), which provided the basic gas data used in this report.

\section{Methods}

\section{Source Rock Samples}

Experimental data were available on five immature source rocks, described in table 1. The major kerogen types in these source rocks include Type-I, -II, -IIS, and -III. Collaborators who collected and pyrolyzed aliquots of these samples are also referenced in table 1 . With respect to vitrinite reflectance (\%Ro), all these samples have initial random mean \%Ro values equal to or less than 0.5 or atomic $\mathrm{H} / \mathrm{C}$ and $\mathrm{O} / \mathrm{C}$ ratios indicative of precatagenesis (that is, diagenesis) according to Tissot and Welte (1984, fig. II.5.1, p. 161).

\section{Hydrous-Pyrolysis Experiments}

Complete details of hydrous-pyrolysis experiments are given by Lewan (1993a). Briefly, the experiments consist of isothermally heating several hundred grams of gravel-sized immature source rock in the presence of liquid water in 1-L stainlesssteel reactors at subcritical-water temperatures $\left(<374^{\circ} \mathrm{C}\right)$ for several days (2-10 days). After the experiment is completed and allowed to cool to room temperatures $\left(20^{\circ}-25^{\circ} \mathrm{C}\right)$, the gas pressure and temperature are recorded and a gas sample is collected in $30-\mathrm{cm}^{3}$ stainless-steel cylinders. Gas compositions are determined by mass spectometry according to an enhanced version of the ASTM D2650-88 method. The remaining gas is vented and the reactor is opened to quantitatively collect the expelled oil, which floats on the water surface above the submerged source 
Table 1. Description of immature source rocks subjected to hydrous pyrolysis.

[Fm., Formation; Sh., Shale; Ls., Limestone; Gp., Group]

\begin{tabular}{|c|c|c|c|c|c|}
\hline Kerogen type....... & Type-I & Type-II & Type-IIS & Type-IIS & Type-III \\
\hline Rock unit.......... & Green River Fm. & New Albany Sh. & Ghareb Ls. & Ghareb Ls. & Wilcox Gp. \\
\hline Sub-rock unit...... & mahogany shale & Clegg Creek Mbr. & "oil shale" & "oil shale" & Calvert Bluff Fm. \\
\hline Geologic age....... & Eocene & Mississippian & Cretaceous & Cretaceous & Paleocene \\
\hline Sample No. ....... & $930923-8$ & $931026-3$ & $930616-9$ & $930608-6$ & WX-3 \\
\hline Location............ & Utah & Indiana & Israel & Jordan & Texas \\
\hline Basin................ & Uinta & Illinois & Dead Sea & Dead Sea & Gulf Coast \\
\hline TOC (wt. \%)...... & 15.23 & 14.34 & 14.14 & 16.63 & 61.53 \\
\hline Lithology........... & marlstone & claystone & limestone & limestone & lignite \\
\hline Collaborators*..... & Ruble $^{1}$ & Guthrie $^{2}$ & Tannenbaum ${ }^{3}$ & Ramini $^{3}$ & Dias $^{4} ;$ IFP $^{5}$ \\
\hline
\end{tabular}

*Collaborator references are: 1, Ruble and others (1994); 2, Lewan and others (1995); 3, Lewan and others (1997); and 4, Dias and others (1997); 5, Behar and Lorant (work in progress).

rock. All the experiments considered in this study were conducted for 72 hours at temperatures ranging from $160^{\circ}$ to $365^{\circ} \mathrm{C}$ (table 2). These experimental conditions simulate thermal maturities associated with oil generation. Atomic $\mathrm{H} / \mathrm{C}$ and $\mathrm{O} / \mathrm{C}$ ratios of kerogens at temperatures equal to or less than $355^{\circ} \mathrm{C}$ for 72 hours indicate that the samples have only been subjected to catagenesis according to Tissot and Welte (1984, fig. II.5.1, p. 161). Low-rank coals $(<0.5 \%$ Ro $)$ subjected to hydrous pyrolysis at $355^{\circ} \mathrm{C}$ for 72 hours obtain random mean vitrinite reflectance values of $1.55 \%$ Ro (Lewan, 1993b).

\section{Gas Volume Calculations}

The first step in calculating a gas volume is to determine the number of moles of hydrocarbon gas generated, which consists of methane, ethane, propane, $n$-butane, $i$-butane, $n$-pentane, and $i$-pentane. The number of moles of total gas at the end of each experiment, $n_{\text {tot }}$, was calculated by the ideal gas law:

$$
n_{\text {tot }}=(P V) /(R T)
$$

where $P$ is the measured cool-down pressure, $T$ is the measured cool-down temperature, $V$ is the head-space gas volume, and $R$ is the ideal gas constant. The number of moles of each of the component hydrocarbon gases is calculated using gas analyses, which are reported in mole percent of the total gas. The number of moles of each hydrocarbon gas is summed to give the number of moles of hydrocarbon gas generated in the experiment, $n_{\mathrm{HC}}$. Assuming that these gases behaved ideally at room temperatures, the volume of hydrocarbon gas at $14.7 \mathrm{psi}$ and $288.71 \mathrm{~K}, V_{\mathrm{HCgas}}$, was determined by rearranging the ideal gas equation:

$$
V_{\mathrm{HC}}=\left(n_{\mathrm{HC}} R T\right) / P
$$

where $P$ is 14.7 psia, $T$ is $288.71 \mathrm{~K}, n_{\mathrm{HC}}=n_{\text {methane }}+n_{\text {ethane }}+$ $n_{\text {propane }}+n_{n \text {-butane }}+n_{i \text {-butane }}+n_{n \text {-pentane }}+n_{i \text {-pentane }}$, and $R$ is $1,206.00\left(\mathrm{~cm}^{3} \bullet \mathrm{psi}\right) /(\mathrm{mol} \bullet \mathrm{K})$. Equation 2 gives the volume in cubic centimeters. This quantity is multiplied by $3.5315 \times 10^{-5}$ to give the volume of hydrocarbon gas in standard cubic feet (scf):

$$
V_{\mathrm{HC}}\left(\mathrm{ft}^{3}\right)=V_{\mathrm{HC}}\left(\mathrm{cm}^{3}\right) \times 3.5315 \times 10^{-5}
$$

In this report, gas volumes are given in units of $\mathrm{mcf} / \mathrm{kg}$ TOC (for example, table 3 and fig. 1). For clarification, mcf is millistandard cubic feet $\left(\mathrm{scf} \times 10^{-3}\right)$ and $\mathrm{kg}$ TOC is the mass of total organic carbon (TOC) in the original unheated sample.

\section{Oil Volume Calculations}

The volume of oil generated in each experiment was calculated by dividing the total mass of oil in grams, $m_{\mathrm{oil}}$, by its density in grams per cubic centimeter, $d_{\mathrm{oil}}$ :

$$
V_{\text {oil }}\left(\mathrm{cm}^{3}\right)=\left(m_{\text {oil }}\right) /\left(d_{\text {oil }}\right)
$$

The resulting number of cubic centimeters of oil is divided by 158,983 to convert the volume of oil to barrels: 


$$
V_{\text {oil }}(\mathrm{bbl})=V_{\text {oil }}\left(\mathrm{cm}^{3}\right) / 158,983
$$

Densities of all the expelled oils $\left(d_{\mathrm{oil}}\right)$ generated by hydrous pyrolysis were not determined, but typically their API gravities range between $25^{\circ}$ and $42^{\circ}$, which equates to densities of 0.904 and $0.816 \mathrm{~g} / \mathrm{cm}^{3}$, respectively. For this study, a density of 0.876 $\mathrm{g} / \mathrm{cm}^{3}$ (30.0 API gravity) was used to calculate volumes for all the oils generated by hydrous pyrolysis.

\section{Gas-to-0il Ratio (GOR) Calculations}

GOR in scf/bbl was calculated by dividing the volume of hydrocarbon gas by the volume of oil generated in the experiment.

$$
\operatorname{GOR}\left(\mathrm{ft}^{3} / \mathrm{bbl}\right)=V_{\mathrm{HC}}\left(\mathrm{ft}^{3}\right) / V_{\text {oil }}(\mathrm{bbl})
$$

A sensitivity test was conducted to evaluate the effect a range of API gravities between $25^{\circ}$ and $42^{\circ}$ had on calculated GOR. The average difference in GOR calculated with densities of 0.816 and $0.904 \mathrm{~g} / \mathrm{cm}^{3}$ for all the experiments considered in this study is $84 \pm 57 \mathrm{scf} / \mathrm{bbl}$. This difference in GOR indicates that the use of a constant oil density of $0.876 \mathrm{~g} / \mathrm{cm}^{3}\left(30.0^{\circ}\right.$ API gravity) has no significant effect on the calculated GOR presented in this study. As indicated in table 3, GOR is only calculated for experiments in which an expelled oil is generated. Therefore, no GOR are calculated at temperatures below $270^{\circ} \mathrm{C}$.

\section{Results}

The amount of hydrocarbon gas generated from the source rocks containing the different kerogen types is given in table 3 . Figure 1 shows an exponential increase in hydrocarbon gas generated with increasing experimental temperature for all the source rocks. The two source rocks containing Type-IIS kerogen generate the most hydrocarbon gas, which at $350^{\circ} \mathrm{C}$ is more than twice that generated by the Type-III kerogen in the lignite (table 3). Source rocks containing Type-I and -II kerogens generate similar amounts of hydrocarbon gases, which at $350^{\circ} \mathrm{C}$ are slightly less than that generated by the Type-IIS kerogens but nearly twice that generated by the Type-III kerogen in the lignite (table 3).

The GOR for the source rocks containing the different kerogen types are given in table 3 . Figure 2 shows a curvilinear decrease in GOR with increasing experimental temperature for all the source rocks, with the exception of the slight increase at

Table 2. Hydrous-pyrolysis experimental numbers and conditions considered in this study.

\begin{tabular}{|c|c|c|c|c|c|}
\hline \multirow{3}{*}{$\begin{array}{c}\text { Temperature } \\
\left({ }^{\circ} \mathrm{C}\right)\end{array}$} & \multicolumn{5}{|c|}{ Experiment (HP-) Number Designation } \\
\hline & Type-I & Type-II & Type-IIS & Type-IIS & Type-III \\
\hline & $930923-8$ & $931026-3$ & $930616-9$ & $930608-6$ & WX-3 \\
\hline 160.0 & 2186 & $\mathrm{NE}$ & $\mathrm{NE}$ & $\mathrm{NE}$ & NE \\
\hline 180.0 & 2187 & $\mathrm{NE}$ & $\mathrm{NE}$ & NE & NE \\
\hline 200.0 & 2188 & $\mathrm{NE}$ & 2318 & 2351 & 2399 \\
\hline 220.0 & 2189 & $\mathrm{NE}$ & $\mathrm{NE}$ & $\mathrm{NE}$ & $\mathrm{NE}$ \\
\hline 240.0 & 2190 & $\mathrm{NE}$ & 2319 & 2352 & 2400 \\
\hline 270.0 & 2109 & 2066 & $\mathrm{NE}$ & NE & $\mathrm{NE}$ \\
\hline 280.0 & $\mathrm{NE}$ & $\mathrm{NE}$ & 2320 & 2353 & 2667 \\
\hline 285.0 & 2110 & 2073 & $\mathrm{NE}$ & $\mathrm{NE}$ & $\mathrm{NE}$ \\
\hline 300.0 & 2111 & 2067 & 2326 & 2344 & 2635 \\
\hline 307.5 & 2114 & $\mathrm{NE}$ & $\mathrm{NE}$ & $\mathrm{NE}$ & $\mathrm{NE}$ \\
\hline 310.1 & $\mathrm{NE}$ & 2074 & 2337 & 2354 & 2396 \\
\hline 315.0 & 2115 & $\mathrm{NE}$ & $\mathrm{NE}$ & $\mathrm{NE}$ & $\mathrm{NE}$ \\
\hline 320.3 & $\mathrm{NE}$ & 2068 & 2336 & 2361 & $\mathrm{NE}$ \\
\hline 322.5 & 2116 & $\mathrm{NE}$ & $\mathrm{NE}$ & $\mathrm{NE}$ & $\mathrm{NE}$ \\
\hline 330.0 & 2117 & 2075 & 2335 & 2362 & 2637 \\
\hline 337.5 & 2118 & $\mathrm{NE}$ & $\mathrm{NE}$ & $\mathrm{NE}$ & $\mathrm{NE}$ \\
\hline 340.2 & $\mathrm{NE}$ & 2076 & 2334 & 2363 & $\mathrm{NE}$ \\
\hline 345.0 & 2119 & $\mathrm{NE}$ & 2321 & 2368 & $\mathrm{NE}$ \\
\hline 350.0 & 2107 & 2070 & 2317 & 2348 & 2398 \\
\hline 355.1 & 2108 & 2078 & 2316 & 2347 & $\mathrm{NE}$ \\
\hline 360.3 & 2113 & 2071 & 2327 & 2345 & $\mathrm{NE}$ \\
\hline 365.0 & 2112 & 2085 & 2314 & 2346 & $\mathrm{NE}$ \\
\hline
\end{tabular}

[All experiments were conducted for 72 hours. NE, no experiment was conducted at this temperature for 72 hours] 
Return to

Volume Contents

- Table 3. Volume of hydrocarbon gas $\left(C_{1}-C_{5}\right)$ generated and calculated $G O R$ for source rocks subjected to hydrous-pyrolysis experiments for 72 hours.

\begin{tabular}{|c|c|c|c|c|c|c|c|c|c|c|}
\hline \multirow{2}{*}{$\begin{array}{l}\text { Experimental } \\
\text { temperature } \\
\quad\left({ }^{\circ} \mathrm{C}\right)\end{array}$} & \multicolumn{2}{|c|}{${ }_{\text {Type-I }}-$} & \multicolumn{2}{|c|}{$\square_{-}$Type-II } & \multicolumn{2}{|c|}{ Type-IISi } & \multicolumn{2}{|c|}{$\square_{\text {Type-IISj }}$} & \multicolumn{2}{|c|}{ Type-III } \\
\hline & $\begin{array}{l}\text { Volume } \\
\text { (mct/kg TOC) }\end{array}$ & $\begin{array}{c}\text { GOR } \\
\left(\left[\mathrm{ft}^{3} / \mathrm{bbl}\right)\right.\end{array}$ & $\begin{array}{c}\text { Volume } \\
\text { (mct/kg TOC) }\end{array}$ & $\begin{array}{c}\text { GOR } \\
\left(\mathrm{ftt}^{3} / \mathrm{bbl}\right)\end{array}$ & $\begin{array}{l}\text { Volume } \\
\text { (mcf/kg TOC) }\end{array}$ & $\begin{array}{c}\text { GOR } \\
\left(\mathrm{ft}^{3} / \mathrm{bbl}\right)\end{array}$ & $\begin{array}{l}\text { Volume } \\
\text { (mct/kg TOC) }\end{array}$ & $\begin{array}{c}\text { GOR } \\
\left(\mathrm{ft}^{3} / \mathrm{bbl}\right)\end{array}$ & $\begin{array}{l}\text { Volume } \\
\text { (mcf/kg TOC) }\end{array}$ & $\begin{array}{c}\mathrm{GOR} \\
\mathrm{fft}^{3} / \mathrm{bbl}\end{array}$ \\
\hline 160.0 & 2.4 & NO & - & - & - & - & - & - & - & - \\
\hline 180.0 & 3.5 & NO & - & - & - & - & - & - & - & - \\
\hline 200.0 & 5.1 & NO & - & - & 13.3 & NO & 5.0 & NO & 3.3 & NO \\
\hline 220.0 & 6.4 & NO & - & - & - & - & - & - & - & - \\
\hline 240.0 & 13.8 & NO & - & - & 55.8 & NO & 21.1 & NO & 22.0 & NO \\
\hline 270.0 & 45.0 & NO & 112.9 & 2,381 & - & - & - & - & - & - \\
\hline 280.0 & - & - & - & - & 205.1 & 1,262 & 112.5 & 1,513 & 86.4 & 2,831 \\
\hline 285.0 & 81.5 & 1,240 & 129.9 & 1,037 & - & - & - & - & - & - \\
\hline 300.0 & 161.7 & 801 & 232.6 & 1,522 & 410.8 & 923 & 297.5 & 832 & 162.9 & 2,621 \\
\hline 307.5 & 234.6 & 924 & - & - & - & - & - & - & - & - \\
\hline 310.1 & - & - & 339.6 & 1,243 & 517.1 & 754 & 422.3 & 639 & 230.2 & 2,393 \\
\hline 315.0 & 307.7 & 922 & - & - & - & - & - & - & 252.6 & 1,799 \\
\hline 320.3 & - & - & 495.5 & 1,122 & 795.4 & 606 & 667.0 & 503 & - & - \\
\hline 322.5 & 454.4 & 714 & - & - & - & - & - & - & - & - \\
\hline 330.0 & 584.8 & 648 & 726.3 & 978 & $1,033.50$ & 559 & $1,004.0$ & 481 & 373.4 & 1,325 \\
\hline 337.5 & 704.6 & 687 & - & - & - & - & - & - & - & - \\
\hline 340.2 & - & - & 967.0 & 992 & $1,438.60$ & 509 & $1,473.5$ & 382 & - & - \\
\hline 345.0 & $1,047.3$ & 458 & - & - & $1,581.90$ & 505 & $1,549.8$ & 389 & - & - \\
\hline 350.0 & $1,340.8$ & 401 & $1,374.8$ & 935 & $1,861.90$ & 527 & $1,865.1$ & 408 & 755.8 & 883 \\
\hline 355.1 & $1,533.20$ & 463 & $1,582.90$ & 768 & $2,117.70$ & 606 & $2,123.8$ & 439 & - & - \\
\hline 360.3 & $1,710.90$ & 434 & $1,850.80$ & 944 & $2,409.10$ & 716 & $2,349.6$ & 522 & - & - \\
\hline 365.0 & $1,898.30$ & 492 & $2,030.90$ & 1,006 & $2,688.80$ & 757 & $2,942.8$ & 630 & - & - \\
\hline
\end{tabular}




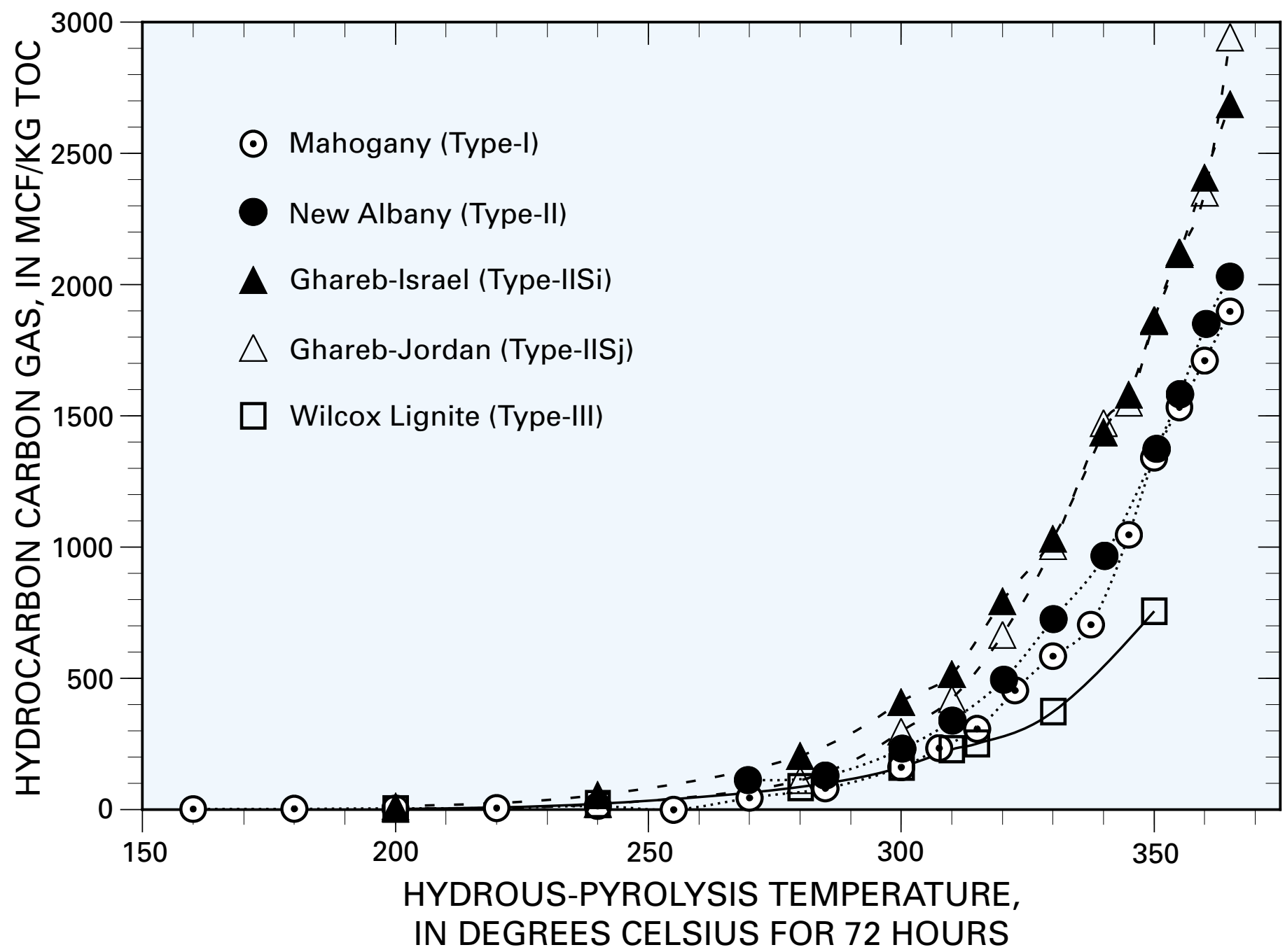

Figure 1. Amount of gas generated from source rocks with different kerogen types subjected to hydrous-pyrolysis temperatures between $270^{\circ}$ and $365^{\circ} \mathrm{C}$ for 72 hours; mcf, milli-standard cubic feet.

temperatures greater than $340^{\circ} \mathrm{C}$ for the Type-IIS kerogens. At $350^{\circ} \mathrm{C}$ for 72 hours, the GOR for the Type-IIS and -I kerogens are similar and range between 401 and $527 \mathrm{scf} / \mathrm{bbl}$ (table 3). Type-II and -III kerogens at these same experimental conditions have significantly higher GOR of 935 and $883 \mathrm{scf} / \mathrm{bbl}$, respectively. These two kerogen types also have consistently higher GOR at the lower experimental temperatures with the exception of the Type-II kerogen at $285^{\circ} \mathrm{C}$ for 72 hours. Overall, GOR during oil generation are between 500 and 1,500 scf/bbl irrespective of kerogen type.

\section{Discussion}

\section{Amounts of Gas Generated}

Type-III kerogen is typically described as a gas-prone source (Hunt, 1996, and references therein). Although Type-III kerogen has the highest GOR during catagenesis (fig. 2), it generates the lowest amounts of hydrocarbon gas compared with the oil-prone kerogens (Type-I, -II, and -IIS). Previously reported hydrous-pyrolysis results have also shown that Type-I and -II kerogens generate significantly more gas than Type-III kerogen (Lewan, 1993c; Hunt, 1996, p. 601, table 16-3). These results are also in general agreement with open-system pyrolysis results as modeled by Behar and others (1997) and the composite-pyrolysis model by Pepper and Corvi (1995). An implication of these results is that oil-prone kerogens can be the source of more hydrocarbon gas during catagenesis than so-called gasprone Type-III kerogen.

The only notable contradiction between hydrous pyrolysis and the open-system pyrolysis modeled by Behar and others (1997) is that the Type-IIS kerogen does not generate the highest amount of hydrocarbon gas in the open-system pyrolysis as observed in hydrous pyrolysis (fig. 1). However, the compositepyrolysis model by Pepper and Corvi (1995) predicts that TypeIIS kerogen generates the most hydrocarbon gas, which is in agreement with the hydrous-pyrolysis results. Hydrouspyrolysis experiments conducted by Seewald and others (1998) also showed that Type-IIS kerogen in a sample of Monterey Shale generated four times as much hydrocarbon gas as Type-III kerogen in shales of the Smackover and Eutaw Formations. 


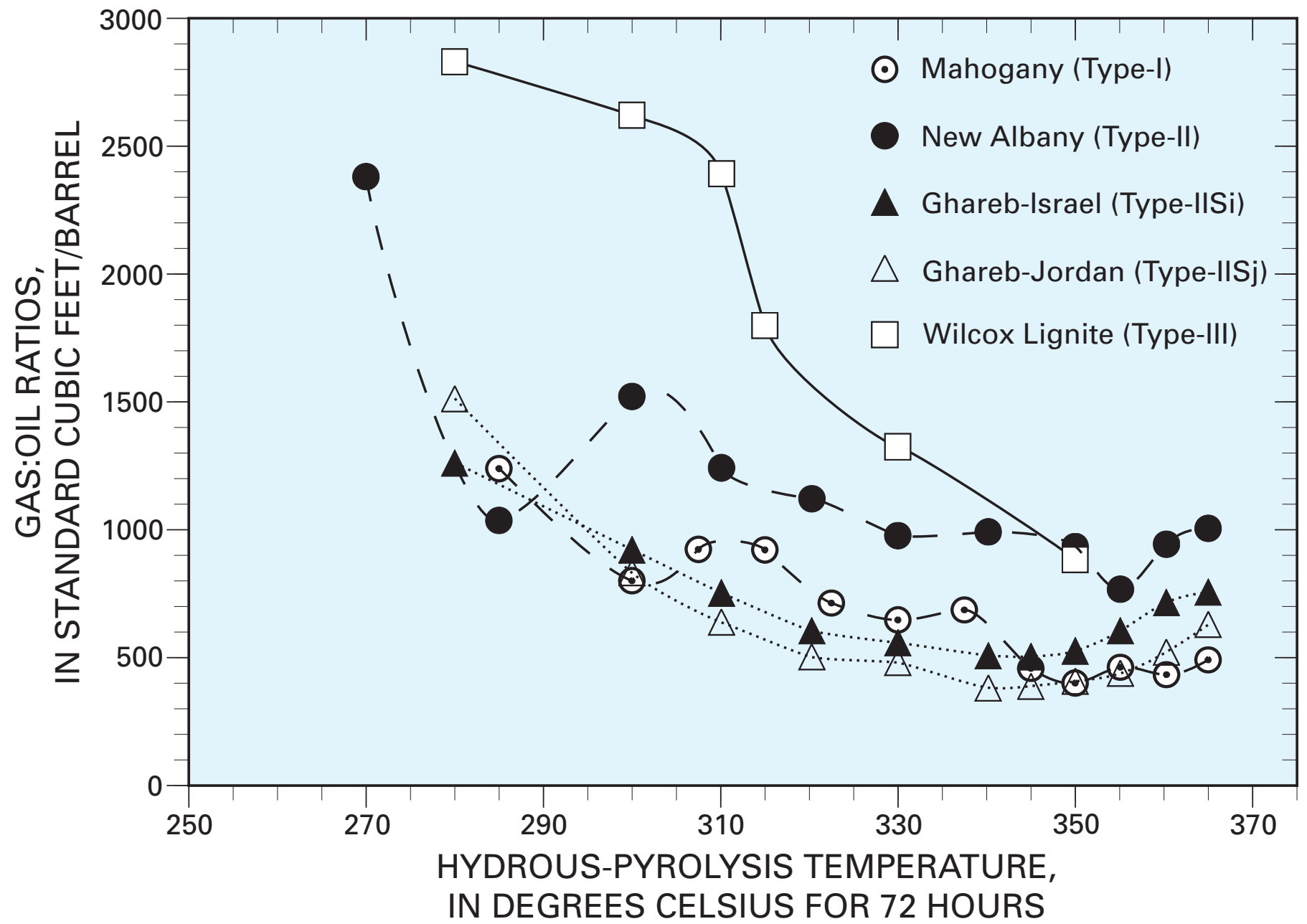

Figure 2. Gas:oil ratios (GOR) for source rocks with different kerogen types subjected to hydrous-pyrolysis temperatures between $270^{\circ}$ and $365^{\circ} \mathrm{C}$ for 72 hours.

These experimental observations suggest that petroleum systems that produce high-sulfur oils from Type-IIS kerogen should also have appreciable quantities of hydrocarbon gas associated with them.

The exponential increase in hydrocarbon generation with increasing temperature (fig. 1) raises the questions whether this increase in gas generation continues through metagenesis and what is the maximum amount of gas that can be generated from a source rock. Note that the results from the hydrous-pyrolysis experiments represent a closed system in which gas may be generated from the decomposition of kerogen or bitumen retained in a rock, as well as from the expelled oil on the water surface within the closed reactor. Note too that with all these possible sources for gas, there are no obvious breaks in the slope of gas generation that would suggest changes in the source of gas with increasing temperature. Additional experiments are needed to determine the extent of this exponential increase in hydrocarbon gas and the maximum amount of hydrocarbon gas that can be generated from different source materials (kerogen, bitumen, and oil).

Clay-mineral catalysis has been suggested to play an important role in petroleum generation (Johns and Shimoyama, 1972; Goldstein, 1983). However, experimental pyrolysis results indicate that the presence of clay minerals has no significant effect on generation of methane and ethane from kerogen (Tannenbaum and Kaplan, 1985). Although results from our study are not unequivocal in indicating that clay-mineral catalysis is not important in gas generation, they do suggest that clay minerals in a source rock are not essential to hydrocarbon gas generation. Specifically, the two source rocks containing TypeIIS kerogen in this study are limestones and generate the most hydrocarbon gas despite their low clay-mineral content. In addition, the claystone with Type-II kerogen does not generate significantly greater amounts of hydrocarbon gas than the marlstone with Type-I kerogen despite the higher clay-mineral content of the former (table 3 ).

\section{Gas:Oil Ratios (GOR)}

Figure 3 shows that hydrous-pyrolysis GOR during oil generation range from 400 to $3,000 \mathrm{scf} / \mathrm{bbl}$. These GOR are within the range of values $(<5,000 \mathrm{scf} / \mathrm{bbl})$ prescribed by Larter and Mills (1991) for petroleum expelled from source rocks based on pyrolysis-gas chromatography. England and Mackenzie (1989) referred to these expelled GOR as 


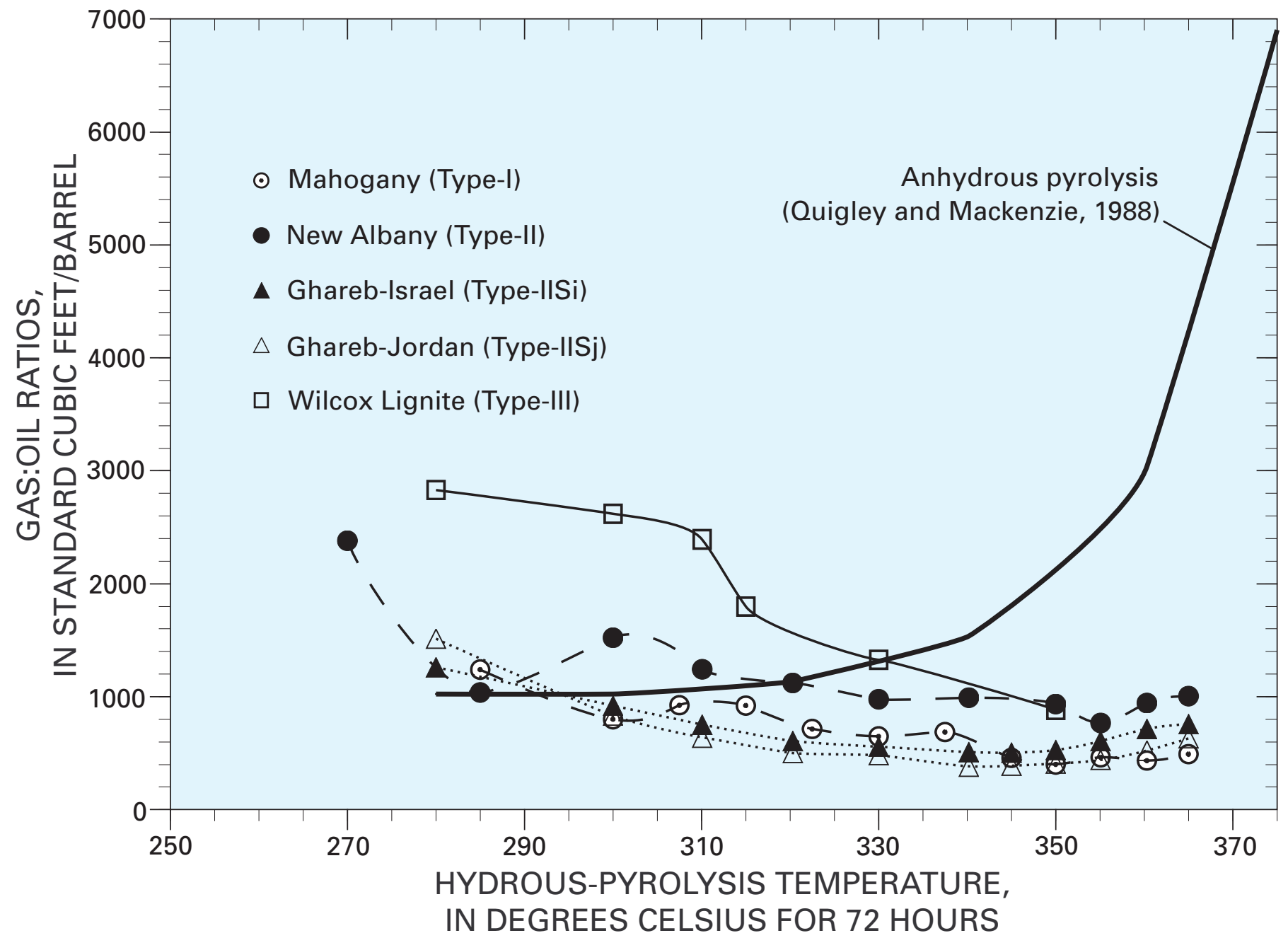

Figure 3. Comparison of gas:oil ratios (GOR) for source rocks with different kerogen types subjected to hydrous- and anhydrous-pyrolysis temperatures between $270^{\circ}$ and $365^{\circ} \mathrm{C}$ for 72 hours.

"feedstock" GOR, which they suggested range between 1,000 and 2,500 scf/bbl. Although these GOR ranges are in agreement with those derived from hydrous pyrolysis (table 3, fig. 2), there is a major difference in the way these GOR change with maturation during oil generation. Figure 2 shows that GOR derived from hydrous pyrolysis decrease during oil generation. The more gas-prone Type-III kerogen in the Wilcox Formation lignite decreases from $2,831 \mathrm{scf} / \mathrm{bbl}$ at $280^{\circ} \mathrm{C}$ for 72 hours to 883 scf/bbl at $350^{\circ} \mathrm{C}$ for 72 hours. The oil-prone Type-I, -II, and -IIS kerogens decrease from $2,381 \mathrm{scf} / \mathrm{bbl}$ at $270^{\circ} \mathrm{C}$ for 72 hours to $401-935 \mathrm{scf} / \mathrm{bbl}$ at $350^{\circ} \mathrm{C}$ for 72 hours. As shown in figure 3, these decreasing hydrous-pyrolysis GOR are contrary to the increasing GOR derived from closed-system anhydrous pyrolysis as reported by Quigley and Mackenzie (1988). These authors stated that their trend is representative of most source rocks irrespective of differences in lithology.

These conflicting results can be explained by differences in the products generated by closed-system anhydrous and hydrous pyrolysis. In hydrous pyrolysis, only the expelled oil and generated gas are used in the calculation of the GOR. In anhydrous pyrolysis, no expelled oil is generated, so GOR are calculated with the generated gas and solvent-soluble or thermally labile bitumen in the rock. In addition, Lewan (1997) showed that cross-linking reactions resulting in the formation of pyrobitumen (insoluble char or inert carbon) are more prevalent in closed-system anhydrous pyrolysis than in hydrous pyrolysis. Therefore, the anhydrous-pyrolysis GOR increase with temperature as soluble or labile bitumen decreases and generated gas increases to a greater extent than in hydrous pyrolysis. The contrary GOR trends determined by these two different pyrolysis methods are shown in figure 4 , which is based on closed-system anhydrous and hydrous pyrolysis experiments conducted on aliquots of the same sample of Woodford Shale (Lewan, 1997). An important implication of this difference is that GOR derived from hydrous pyrolysis indicate that source rocks in the early stages of oil generation can generate accumulations with GOR between 1,500 and 3,000 scf/bbl. Conversely, GOR derived from closed-system anhydrous pyrolysis indicate that source rocks in the early stages of oil generation can only generate accumulations with GOR less than $1,000 \mathrm{scf} / \mathrm{bbl}$.

Although the hydrous-pyrolysis GOR decrease during most of oil generation, this GOR trend is expected to reverse and increase after oil generation. This increase would not be the result of additional oil generation but of additional gas generation from the thermal decomposition of the remaining 


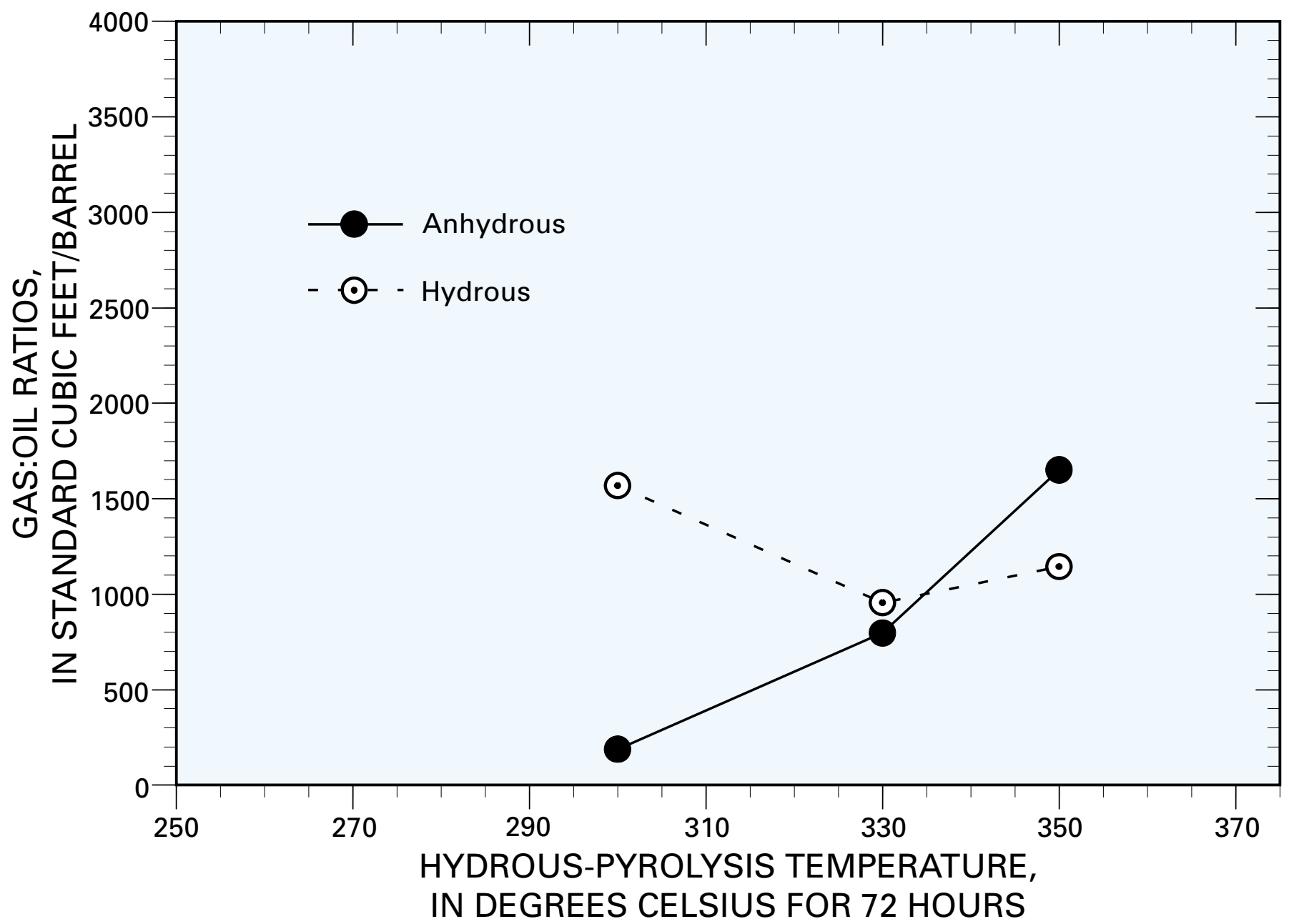

Figure 4. Comparison of gas:oil ratios (GOR) for aliquots of a sample of Woodford Shale (Type-II) subjected to hydrous and anhydrous pyrolysis at $300^{\circ}, 330^{\circ}$, and $350^{\circ} \mathrm{C}$ for 72 hours. Original data reported by Lewan (1997, tables 2 and 6).

kerogen and bitumen within the source rock and the expelled oil on the water surface. Source rocks with Type-IIS kerogen show a distinct GOR increase at the higher temperatures $\left(>340^{\circ} \mathrm{C}\right)$ that suggests the start of this anticipated increase (fig. 2). An important remaining question is whether the gas generated after oil generation is from the kerogen and bitumen remaining in the source rock or from the expelled oil. Additional hydrous-pyrolysis experiments on oil and mature source rock are needed to resolve this question.

\section{Conclusions}

GOR for a given source rock can be derived from hydrous-pyrolysis experiments. During oil generation, source rocks with oil-prone kerogen (Type-I, -II, and -IIS) generate hydrous-pyrolysis GOR between 382 and 2,381 scf/bbl. Source rocks with Type-III kerogen generate higher GOR (883-2,831 $\mathrm{scf} / \mathrm{bbl}$ ) than source rocks with more oil-prone kerogen (Type-I, -II, and -IIS) during catagenesis (oil generation). However, the more oil-prone kerogens can generate twice as much hydrocarbon gas per gram of organic carbon as the more gasprone Type-III kerogen.

During oil generation, GOR determined by closed-system anhydrous pyrolysis increase with increasing temperature, and GOR determined by hydrous pyrolysis initially decrease with increasing temperature. As a result, hydrous-pyrolysis GOR indicate that petroleum accumulations with GOR between 1,500 and 3,000 scf/bbl can be generated during the early stages of oil generation. Conversely, anhydrous-pyrolysis GOR indicate that petroleum accumulations with GOR greater than $2,000 \mathrm{scf} / \mathrm{bbl}$ can only be generated near the end of oil generation.

In conjunction with the recommendations made by Henry and Lewan (this volume), more hydrous-pyrolysis experimental work is needed to quantitatively understand the controls on gas generation from source rocks and expelled oil. These experiments should be designed to determine if the exponential increase in hydrocarbon-gas generation and an increase in GOR occur past oil generation and into metagenesis. Experiments should also be designed to evaluate whether this late-stage hydrocarbon gas is generated from organic components retained in the source rock or from expelled oil. 


\section{References Cited}

Behar, F., Vandenbroucke, M., Tang, Y., Marquis, F., and Espitalie, J., 1997, Thermal cracking of kerogen in open and closed systemsDetermination of kinetic parameters and stoichiometric coefficients for oil and gas generation: Organic Geochemistry, v. 26, p. 321-339.

Dias, R.F., Freeman, K.H., Lewan, M.D., and Franks, S.G., 1997, Kerogen maturation and the $\delta^{13} \mathrm{C}$ of organic acids in oil-associated waters: American Association of Petroleum Geologists Annual Meeting, Dallas, Tex., April 6-9, 1997, Program and Abstracts, v. 6, p. A27-A28.

England, W.A., and Mackenzie, A.S., 1989, Some aspects of the organic geochemistry of petroleum fluids: Geologische Rundschau, v. 78, p. 291-303.

Goldstein, T.P., 1983, Geocatalytic reactions in formation and maturation of petroleum: American Association of Petroleum Geologists Bulletin, v. 67, p. 152-159.

Hunt, J.M., 1996, Petroleum geochemistry and geology: New York, Freeman, $743 p$.

Johns, W.D., and Shimoyama, A., 1972, Clay minerals and petroleumforming reactions during burial and diagenesis: American Association of Petroleum Geologists Bulletin, v. 56, p. 2160-2167.

Kuo, L.-C., and Michael, G.E., 1994, A multicomponent oil-cracking kinetics model for modeling preservation and composition of reservoired oils: Organic Geochemistry, v. 21, p. 911-925.

Larter, S., and Mills, N., 1991, Phase-controlled molecular fractionations in migrating petroleum charges, in England, W.A., and Fleet, A.J., eds., Petroleum migration: Geological Society Special Publication 59 , p. 137-147.

Lewan, M.D., 1993a, Laboratory simulation of petroleum formationHydrous pyrolysis, in Engel, M., and Macko, S., eds., Organic geochemistry: New York, Plenum, p. 419-442.

-1993b, Identifying and understanding suppressed vitrinite reflectance through hydrous pyrolysis experiments: Society for Organic Petrology, Abstracts and Program, v. 10, p. 1-3.

1993c, Hydrocarbon gas generation from different kerogen types subjected to hydrous pyrolysis: American Chemical Society Book of Abstracts, Geochemistry Division Abstract No. 32.

1997, Experiments on the role of water in petroleum formation: Geochimica et Cosmochimica Acta, v. 61, p. 3692-3723.
Lewan, M.D., Comer, J.B., Hamilton-Smith, T., Hausenmuller, N.R., Guthrie, J.M., Hatch, J.R., Gautier, D.L., and Frankie, W.T., 1995, Feasibility study on material-balance assessment of petroleum from the New Albany Shale in the Illinois Basin: U.S. Geological Survey Bulletin 2137, $31 \mathrm{p}$.

Lewan, M.D., Tannenbaum, E., and Ramini, H., 1997, Petroleum formation in Senonian carbonate source rocks of the Dead Sea basin: American Association of Petroleum Geologists Annual Meeting, Dallas, Tex., April 6-9, 1997, Program and Abstracts, v. 6, p. A69.

Lillis, P.G., Lewan, M.D., Warden, A., Monk, S.M., and King, J.D., 1999, Identification and characterization of oil types and their source rocks, in The oil and gas resource potential of the 1002 Area, Arctic National Wildlife Refuge, Alaska: U.S. Geological Survey Open-File Report 98-34, Chapter 0A, p. 0A-1-0A-60.

Mackenzie, A.S., and Quigley, T.M., 1988, Principles of geochemical prospect appraisal: American Association of Petroleum Geologists Bulletin, v. 72, p. 399-415.

Noble, R.A., Wu, C.H., and Atkinson, C.D., 1991, Petroleum generation and migration from Talang Akar coals and shales offshore N.W. Java, Indonesia: Organic Geochemistry, v. 17, p. 363-374.

Pepper, A.S., and Corvi, P.J., 1995, Simple kinetic models of petroleum formation-Part I, Oil and gas generation from kerogen: Marine and Petroleum Geology, v. 12, p. 291-319.

Quigley, T.M., and Mackenzie, A.S., 1988, The temperatures of oil and gas formation in the subsurface: Nature, v. 33, p. 549-552.

Ruble, T.E., Lewan, M.D., and Philp, R.P., 1994, Recognition of distinctive Green River source facies by hydrous pyrolysis - Important implications for basin models, in Grimalt, J.O., and Dorronsoro, C., eds., Organic geochemistry, developments and applications to energy, climate, environment, and human history: A.I.G.O.A. Publishers, p. 188-191.

Seewald, J.S., Benitez-Nelson, B.C., and Whelan, J. K., 1998, Laboratory and theoretical constraints on the generation and composition of natural gas: Geochimica et Cosmochimica Acta, v. 62, p. 1599-1617.

Tannenbaum, E., and Kaplan, I.R., 1985, Role of minerals in the thermal alteration of organic matter-I, Generation of gases and condensate under dry conditions: Geochimica et Cosmochimica Acta, v. 49, p. 2589-2604.

Tissot, B.P., and Welte, D.H., 1984, Petroleum formation and occurrence: Berlin, Springer-Verlag, $699 \mathrm{p}$. 


\title{
Chapter F
}

\section{Probabilistic Method for Subdividing Petroleum Resources into Depth Slices}

\author{
By Robert A. Crovelli
}

Prepared in cooperation with the U.S. Department of Energy-National Energy Technology Laboratory, the Gas Technology Institute, and

Advanced Resources International

U.S. Department of the Interior

U.S. Geological Survey 


\section{Contents}

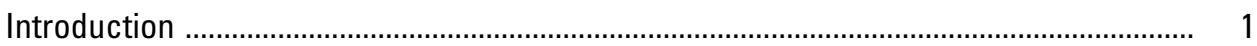

Acknowledgments ................................................................................................... 1

Probabilistic Method .............................................................................................. 1

Spreadsheet .................................................................................................................... 2

Reference Cited …......................................................................................................... 3

\section{Figure}

1. Diagram showing triangular probability distribution of drilling depth ........................... 2 


\title{
Probabilistic Method for Subdividing Petroleum Resources into Depth Slices
}

\author{
By Robert A. Crovelli
}

\section{Introduction}

The U.S. Geological Survey periodically assesses petroleum resources of the United States and the world. Understanding the distribution of these resources by depth interval is an important part of this activity. The purpose of this report is to explain the development of a spreadsheet software system called Deep Energy Estimated Percentages (DEEP). DEEP uses the median-based triangular probability distribution as a probability model for drilling depth to estimate the percentages of estimated petroleum resources below various depths or depth cutoffs and, also, between depth cutoffs, that is, subdividing resources into depth slices. The drilling depth represents the true vertical depth to potential undiscovered resources in an assessment unit or play. An assessment unit is a mappable volume of rock in a total petroleum system. First, the probabilistic method is derived, and second, the spreadsheet DEEP is described.

\section{Acknowledgments}

This report was funded by the U.S. Department of Energy-National Energy Technology Laboratory (NETL) (NETL contract No. DE-AT26-98FT40032), and the U.S. Geological Survey Central Energy Team, Denver, Colo. The author wishes to acknowledge the helpful reviews of T.S. Dyman and J.W. Schmoker.

\section{Probabilistic Method}

The median-based triangular probability distribution is used as a probability model for the random variable $Z$ : drilling depth (meters). The defining parameters of the median-based triangular probability distribution are the minimum (a), maximum $(b)$, and median $(m)$. A necessary condition for a medianbased triangular probability distribution to exist is the following:

$$
0.707 a+0.293 b \leq m \leq 0.293 a+0.707 b
$$

From the defining parameters, the standard characterizing parameters of the triangular probability distribution are obtained: minimum $(a)$, maximum $(b)$, and mode $(c)$. There are three cases for calculating $c$, which are dependent upon the midpoint $=(a+b) / 2$ :
Case I: $m=$ midpoint (symmetric)

$$
c=m
$$

Case II: $m<$ midpoint (right skewed)

$$
c=b-\frac{2(b-m)^{2}}{b-a}
$$

Case III: $m>$ midpoint (left skewed)

$$
c=a+{\frac{2(m-a)^{2}}{b-a}}^{2}
$$

The probability that the drilling depth is below, or equivalently greater than, a particular depth or depth cutoff $(z)$ is denoted by $p(z)$, where

$$
p(z)=P(Z>z)
$$

Figure 1 displays the triangular probability distribution of drilling depth (meters) where $a$ : minimum, $b$ : maximum, $c$ : mode, $z$ : depth cutoff, and $p(z)$ : probability of drilling depth below depth cutoff $z$. The probability function $p(z)$ is the complementary cumulative distribution function for the triangular probability distribution. The triangular cumulative distribution function can be found in Law and Kelton (1991, p. 341). It can be shown that

$$
p(z)=\left\{\begin{array}{l}
1 \text { if } z<a \\
1-\frac{(z-a)^{2}}{(b-a)(c-a)} \text { if } a \leq z \leq c \\
\frac{(b-z)^{2}}{(b-a)(b-c)} \text { if } c<z \leq b \\
0 \text { if } z>b
\end{array}\right.
$$

The drilling depth distribution will be used to estimate the percentages of undiscovered petroleum resources below various depths or depth cutoffs, that is, the problem is to subdivide resources into depth slices. Thus, the primary interest is in the proportion of petroleum resources below a depth cutoff. The simplifying assumption will be made that the proportion or probability of petroleum resources below a depth cutoff can be adequately approximated by the probability of drilling depth 


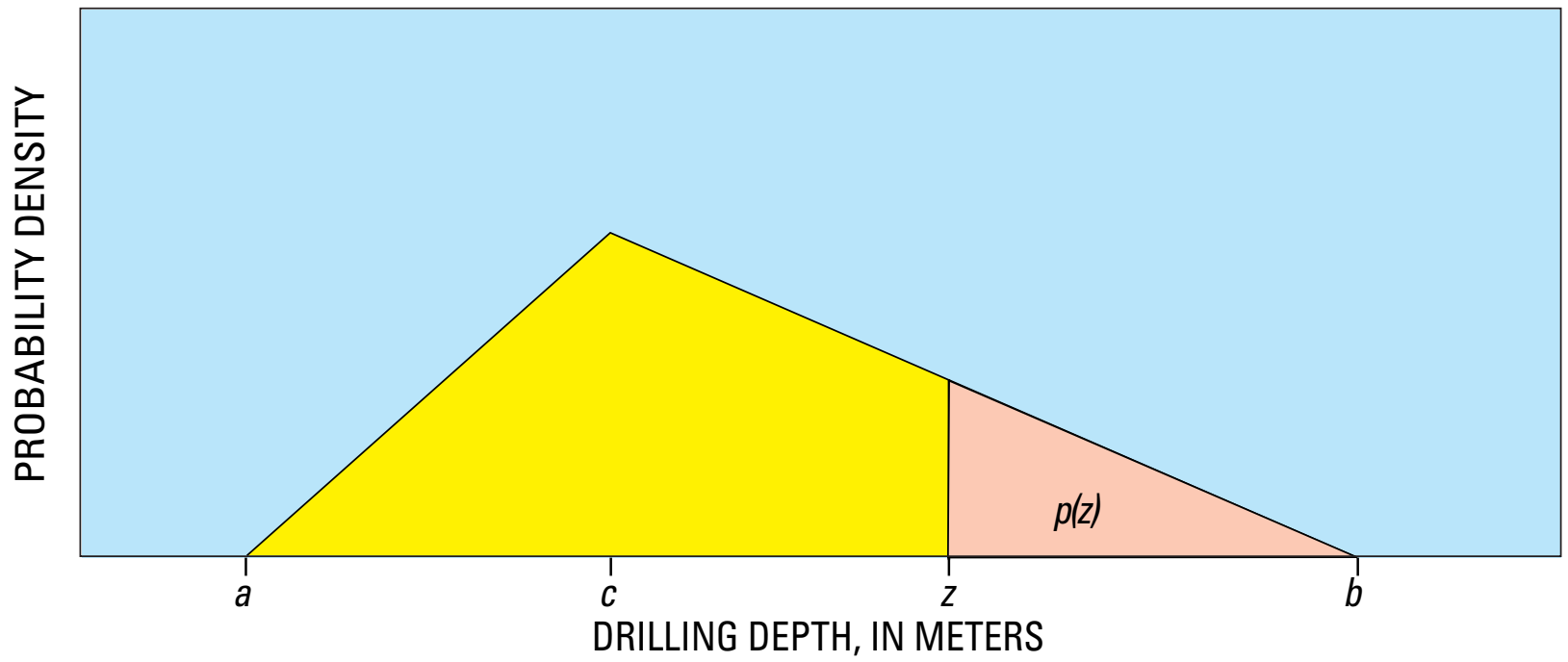

Figure 1. Triangular probability distribution of drilling depth (meters) where $a$ : minimum, $b$ : maximum, $c$ : mode, $z$. depth cutoff, and $p(z)$ : probability of drilling depth below or greater than depth cutoff $z$.

below that depth cutoff. Therefore, $p(z)$ will be used to estimate the proportion of petroleum resources below depth cutoff $z$. An estimate of the proportion of petroleum resources between two depth cutoffs $z_{1}$ and $z_{2}$, where $z_{2}$ is greater than or equal to $z_{1}$, is given by

$$
P\left(z_{1}<\mathrm{Z}<z_{2}\right)=P\left(Z>z_{1}\right)-P\left(Z>z_{2}\right)=p\left(z_{1}\right)-p\left(z_{2}\right)
$$

\section{Spreadsheet}

The preceding probabilistic method is incorporated into a spreadsheet software system called Deep Energy Estimated Percentages (DEEP). DEEP consists of a series of six panels or parts of a spreadsheet that can be expanded depending upon the number of depth cutoff values of interest. Panel 1 comprises the input of the defining parameters of the median-based triangular probability distribution for the drilling depth: minimum, median, and maximum. From the defining parameters, the midpoint and mode are computed. Panels 2 through 6 are similar in their composition. Each of these five panels allows for three depth cutoff values to be entered. From each depth cutoff value, the corresponding percent resource below cutoff and percent resource between (present and previous) cutoffs are computed. For example, in Panel 4 of Test 2 ( $a=3,000 \mathrm{~m}, b=5,000 \mathrm{~m}$, $m=4,000 \mathrm{~m}$, and $c=4,000 \mathrm{~m}$ ), the percent below cutoff value of $3,800 \mathrm{~m}$ is equal to 68 percent, and the percent below cutoff value of $4,000 \mathrm{~m}$ is equal to 50 percent. The percent between cutoffs of $3,800 \mathrm{~m}$ and $4,000 \mathrm{~m}$ is equal to 18 percent. Therefore, an estimate of the percentage of petroleum resources between depths of $3,800 \mathrm{~m}$ and $4,000 \mathrm{~m}$ is equal to 18 percent.

Panel 1 of Spreadsheet DEEP. Parameters of the median-based triangular probability distribution for drilling depth: minimum, median, and maximum are input, whereas midpoint and mode are computed.

\begin{tabular}{lccccccr}
\hline & Assessment Unit & \multicolumn{5}{c}{ Drilling Depth (m) - Median-Based Triangular Distribution } \\
Name & No. & Fields & Minimum & Median & Maximum & Midpoint & Mode \\
\hline Test 1 & 12345671 & Gas & 3000 & 4000 & 5000 & 4000 & 4000 \\
Test 2 & 12345672 & Gas & 3000 & 4000 & 5000 & 4000 & 4000 \\
Test 3 & 12345673 & Gas & 3000 & 4300 & 5000 & 4000 & 4690 \\
\hline
\end{tabular}

Panel 2 of Spreadsheet DEEP. Three depth cutoff values are allowed to be input; corresponding percent resource below cutoff and percent resource between (present and previous) cutoffs are computed.

\begin{tabular}{cccccccccc}
\hline No. & Flds & $\begin{array}{c}\text { Depth } \\
\text { cutoff }(\mathrm{m})\end{array}$ & $\begin{array}{c}\text { Percent } \\
\text { below } \\
\text { cutoff }\end{array}$ & $\begin{array}{c}\text { Depth } \\
\text { cutoff }(\mathrm{m})\end{array}$ & $\begin{array}{c}\text { Percent } \\
\text { below } \\
\text { cutoff }\end{array}$ & $\begin{array}{c}\text { Percent } \\
\text { between } \\
\text { cutoffs }\end{array}$ & $\begin{array}{c}\text { Depth } \\
\text { cutoff (m) }\end{array}$ & $\begin{array}{c}\text { Percent } \\
\text { below } \\
\text { cutoff }\end{array}$ & $\begin{array}{c}\text { Percent } \\
\text { between } \\
\text { cutoffs }\end{array}$ \\
\hline 12345671 & Gas & 4572 & 9.1592 & 4572 & 9.1592 & 0 & 4572 & 9.1592 & 0 \\
12345672 & Gas & 2600 & 100 & 2800 & 100 & 0 & 3000 & 100 & 0 \\
12345673 & Gas & 2600 & 100 & 2800 & 100 & 0 & 3000 & 100 & 0 \\
\hline
\end{tabular}


Panel 3 of Spreadsheet DEEP. Three depth cutoff values are allowed to be input; corresponding percent resource below cutoff and percent resource between (present and previous) cutoffs are computed.

\begin{tabular}{|c|c|c|c|c|c|c|c|c|c|c|}
\hline No. & Flds & $\begin{array}{c}\text { Depth } \\
\text { cutoff }(\mathrm{m})\end{array}$ & $\begin{array}{l}\text { Percent } \\
\text { below } \\
\text { cutoff }\end{array}$ & $\begin{array}{l}\text { Percent } \\
\text { between } \\
\text { cutoffs }\end{array}$ & $\begin{array}{c}\text { Depth } \\
\text { cutoff }(\mathrm{m})\end{array}$ & $\begin{array}{c}\text { Percent } \\
\text { below } \\
\text { cutoff }\end{array}$ & $\begin{array}{l}\text { Percent } \\
\text { between } \\
\text { cutoffs }\end{array}$ & $\begin{array}{c}\text { Depth } \\
\text { cutoff }(\mathrm{m})\end{array}$ & $\begin{array}{c}\text { Percent } \\
\text { below } \\
\text { cutoff }\end{array}$ & $\begin{array}{c}\text { Percent } \\
\text { between } \\
\text { cutoffs }\end{array}$ \\
\hline 12345671 & Gas & 4572 & 9.1592 & 0 & 4572 & 9.1592 & 0 & 4572 & 9.1592 & 0 \\
\hline 12345672 & Gas & 3200 & 98 & 2 & 3400 & 92 & 6 & 3600 & 82 & 10 \\
\hline 12345673 & Gas & 3200 & 98.817 & 1.18343 & 3400 & 95.266 & 3.5503 & 3600 & 89.349 & 5.91716 \\
\hline
\end{tabular}

Panel 4 of Spreadsheet DEEP. Three depth cutoff values are allowed to be input; corresponding percent resource below cutoff and percent resource between (present and previous) cutoffs are computed.

\begin{tabular}{|c|c|c|c|c|c|c|c|c|c|c|}
\hline No. & Flds & $\begin{array}{c}\text { Depth } \\
\text { cutoff }(\mathrm{m})\end{array}$ & $\begin{array}{c}\text { Percent } \\
\text { below } \\
\text { cutoff }\end{array}$ & $\begin{array}{c}\text { Percent } \\
\text { between } \\
\text { cutoffs }\end{array}$ & $\begin{array}{c}\text { Depth } \\
\text { cutoff }(\mathrm{m})\end{array}$ & $\begin{array}{c}\text { Percent } \\
\text { below } \\
\text { cutoff }\end{array}$ & $\begin{array}{c}\text { Percent } \\
\text { between } \\
\text { cutoffs }\end{array}$ & $\begin{array}{c}\text { Depth } \\
\text { cutoff }(\mathrm{m})\end{array}$ & $\begin{array}{c}\text { Percent } \\
\text { below } \\
\text { cutoff }\end{array}$ & $\begin{array}{c}\text { Percent } \\
\text { between } \\
\text { cutoffs }\end{array}$ \\
\hline 12345671 & Gas & 4572 & 9.1592 & 0 & 4572 & 9.1592 & 0 & 4572 & 9.1592 & 0 \\
\hline 12345672 & Gas & 3800 & 68 & 14 & 4000 & 50 & 18 & 4200 & 32 & 18 \\
\hline 12345673 & Gas & 3800 & 81.065 & 8.28402 & 4000 & 70.414 & 10.6509 & 4200 & 57.396 & 13.0178 \\
\hline
\end{tabular}

Panel 5 of Spreadsheet DEEP. Three depth cutoff values are allowed to be input; corresponding percent resource below cutoff and percent resource between (present and previous) cutoffs are computed.

\begin{tabular}{|c|c|c|c|c|c|c|c|c|c|c|}
\hline No. & Flds & $\begin{array}{c}\text { Depth } \\
\text { cutoff (m) }\end{array}$ & $\begin{array}{l}\text { Percent } \\
\text { below } \\
\text { cutoff }\end{array}$ & $\begin{array}{l}\text { Percent } \\
\text { between } \\
\text { cutoffs }\end{array}$ & $\begin{array}{c}\text { Depth } \\
\text { cutoff (m) }\end{array}$ & $\begin{array}{c}\text { Percent } \\
\text { below } \\
\text { cutoff }\end{array}$ & $\begin{array}{c}\text { Percent } \\
\text { between } \\
\text { cutoffs }\end{array}$ & $\begin{array}{c}\text { Depth } \\
\text { cutoff }(\mathrm{m})\end{array}$ & $\begin{array}{l}\text { Percent } \\
\text { below } \\
\text { cutoff }\end{array}$ & $\begin{array}{c}\text { Percent } \\
\text { between } \\
\text { cutoffs }\end{array}$ \\
\hline 12345671 & Gas & 4572 & 9.1592 & 0 & 4572 & 9.1592 & 0 & 4572 & 9.1592 & 0 \\
\hline 12345672 & Gas & 4400 & 18 & 14 & 4600 & 8 & 10 & 4800 & 2 & 6 \\
\hline 12345673 & Gas & 4400 & 42.012 & 15.3846 & 4600 & 24.26 & 17.7515 & 4800 & 6.4516 & 17.8087 \\
\hline
\end{tabular}

Panel 6 of Spreadsheet DEEP. Three depth cutoff values are allowed to be input; corresponding percent resource below cutoff and percent resource between (present and previous) cutoffs are computed.

\begin{tabular}{|c|c|c|c|c|c|c|c|c|c|c|}
\hline No. & Flds & $\begin{array}{c}\text { Depth } \\
\text { cutoff (m) }\end{array}$ & $\begin{array}{c}\text { Percent } \\
\text { below } \\
\text { cutoff }\end{array}$ & $\begin{array}{c}\text { Percent } \\
\text { between } \\
\text { cutoffs }\end{array}$ & $\begin{array}{c}\text { Depth } \\
\text { cutoff }(\mathrm{m})\end{array}$ & $\begin{array}{l}\text { Percent } \\
\text { below } \\
\text { cutoff }\end{array}$ & $\begin{array}{c}\text { Percent } \\
\text { between } \\
\text { cutoffs }\end{array}$ & $\begin{array}{c}\text { Depth } \\
\text { cutoff }(\mathrm{m})\end{array}$ & $\begin{array}{l}\text { Percent } \\
\text { below } \\
\text { cutoff }\end{array}$ & $\begin{array}{c}\text { Percent } \\
\text { between } \\
\text { cutoffs }\end{array}$ \\
\hline 12345671 & Gas & 4572 & 9.1592 & 0 & 4572 & 9.1592 & 0 & 4572 & 9.1592 & 0 \\
\hline 12345672 & Gas & 5000 & 0 & 2 & 5200 & 0 & 0 & 5400 & 0 & 0 \\
\hline 12345673 & Gas & 5000 & 0 & 6.45161 & 5200 & 0 & 0 & 5400 & 0 & 0 \\
\hline
\end{tabular}

\section{Reference Cited}

Law, A.M., and Kelton, W.D., 1991, Simulation modeling and analysis

(Second Edition): New York, McGraw-Hill, Inc., 759 p. 


\section{Chapter G}

\section{Relative Uncertainty of Conventional Natural Gas Plays in the Gulf Coast Region}

By Thaddeus S. Dyman, James W. Schmoker, and Christopher J. Schenk

Prepared in cooperation with the U.S. Department of Energy-National Energy Technology Laboratory, the Gas Technology Institute, and

Advanced Resources International

U.S. Department of the Interior

U.S. Geological Survey 


\section{Contents}

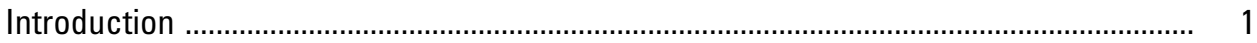

Methodology ............................................................................................................... 2

Gulf Coast Region Gas Plays ........................................................................................... 3

Possible Criteria for Reevaluation of Gulf Coast Gas Plays ............................................ 3

Causes of Uncertainty: Examples of Uncertain Plays ................................................ 6

Discussion ..................................................................................................................... 7

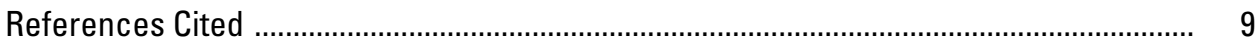

\section{Figures}

1. Diagram showing estimated cumulative probability distributions for undiscovered conventional nonassociated gas resources for two hypothetical plays having the same mean and illustrating the difference in range of $F_{95}$ and $F_{5}$ fractiles.

2. Plot of play uncertainty coefficient versus mean undiscovered nonassociated gas resource for 61 conventional gas plays in the Gulf Coast Region

\section{Tables}

1. Geologic characteristics and estimated undiscovered nonassociated gas resources for 61 gas-bearing plays in the Gulf Coast Region from the U.S. Geological Survey 1995 National Petroleum Assessment

2. Summary data for the 20 nonassociated conventional gas plays in the Gulf Coast Region with the highest and lowest uncertainty coefficients from the plays in table 1

3. Geologic characteristics and estimated undiscovered nonassociated gas resources for 14 gas-bearing plays in the Gulf Coast Region that form a priority list for reevaluation 


\title{
Relative Uncertainty of Conventional Natural Gas Plays in the Gulf Coast Region
}

\author{
By Thaddeus S. Dyman, James W. Schmoker, and Christopher J. Schenk
}

\section{Introduction}

In 1995, the U.S. Geological Survey assessed undiscovered conventional and continuous-type (unconventional) oil and gas resources for 560 plays in 71 U.S. provinces in onshore regions and State offshore waters. This assessment was based on a geologic analysis of plays using probabilistic methodologies. Assessments such as this are inherently dependent on varying degrees of uncertainty associated with a geologic understanding of petroleum provinces and plays and the perceptions and levels of experience of province geologists. Uncertainty in natural gas assessments is the focus of this report.

Uncertainty in petroleum resource estimates can be subdivided into five broad areas:

1. Compiling geologic and production data at the province level. Uncertainty may arise from a lack of data concerning the geologic history and production characteristics of the province.

2. Identifying and describing petroleum plays. Uncertainty may also be due to limited data on the nature of petroleum plays in each province. The experience and perceptions of the province geologist play an important part in uncertainty associated with the petroleum geology at both province and play levels. Some province geologists tend to identify fewer, large plays, whereas others tend to identify a larger number of smaller plays.

3. Risking plays. Hypothetical plays (those plays lacking known production) must be risked for the presence of undiscovered accumulations. Uncertainty is expressed by using a risking structure that incorporates three play attributes: charge, reservoir, and trap, where the probability of occurrence of each of the attributes is expressed as a decimal fraction from zero to one. The product of the three values is the play probability. Uncertainty arises due to the geologist's viewpoint, lying on the continuum from conservative to liberal in risking hypothetical plays.

4. Estimating the sizes, numbers, and types of undiscovered accumulations. Numerous techniques are employed to make these estimates including historic field-size analysis, reservoir-simulation modeling, discovery-process modeling, use of analogs, and spatial analysis (U.S. Geological Survey National Oil and Gas Resource Assessment Team, 1995). Each of these techniques introduces uncertainty in the resource estimation process.

5. Aggregating estimates. To estimate undiscovered resources for provinces, regions, and the Nation, probability distributions representing estimates for plays must be progressively aggregated with geologic dependencies incorporated at each level of aggregation. Aggregating play estimates requires knowledge of geologic dependencies between plays for the three attributes of charge, reservoir, and trap. Uncertainty is introduced when province geologists determine the correlation of each attribute for each set of plays in a province. A high correlation (0.9), a medium correlation (0.5), and a low correlation (0.1) were used in the U.S. Geological Survey 1995 National Oil and Gas Resource Assessment (U.S. Geological Survey National Oil and Gas Resource Assessment Team, 1995).

Analysis of these five areas of uncertainty provides insight into how resource assessments are conducted and helps answer important questions, such as the following: Are the play estimates of some province geologists more uncertain than the estimates of others? Can we define quantitative measures that capture uncertainty? Can we rank plays in an assessment based on their relative uncertainty? Can we identify the relative degree of uncertainty in plays with specific geologic and production characteristics?

The purpose of this report is to analyze uncertainty in estimates for undiscovered natural gas resources for the 61 conventional nonassociated gas-bearing plays of the Gulf Coast Region in the U.S. Geological Survey 1995 National Petroleum Assessment. The results of our analysis will help us to better understand the assessment process and to prioritize those Gulf Coast Region gas plays that may need to be reevaluated or reassessed based on new data and perceptions since the completion of the 1995 assessment.

The Gulf Coast Region was important to the U.S. Geological Survey in 1995 because it contains a significant undiscovered conventional gas resource. The region contains a mean estimated resource of $97.6 \mathrm{Tcf}$ (trillion cubic feet) of recoverable conventional gas, which represents nearly 38 percent of the gas resource for U.S. onshore regions and State offshore waters. Only one continuous-type (unconventional) gas play, the Cotton Valley Blanket Sandstones Play of the Louisiana-Mississippi Salt Basins Province (No. 4923) was assessed contributing a mean estimated resource of $6 \mathrm{Tcf}$ of gas (U.S. Geological Survey National Oil and Gas Resource Assessment Team, 1995; Gautier and others, 1996).

Many nonassociated gas plays in the Gulf Coast Region are also deep. Dyman and others (1996) identified 44 of 61 total Gulf Coast Region plays as deep (all or portion of play equal to or exceeding 15,000 feet/4,572 $\mathrm{m}$ in depth). These deep plays account for a mean resource of 27.4 Tcf of undiscovered conventional technically recoverable nonassociated gas. This estimate is about 10 percent of the entire estimated undiscovered nonassociated gas resource for the U.S. (258.6 Tcf of gas) (U.S. Geological Survey National Oil and Gas Resource Assessment Team, 1995). A better understanding of 
the geologic characteristics and resource potential of these Gulf Coast Region deep gas plays may lead to a better understanding of deep natural gas resources in general.

This report was funded by the U.S. Department of EnergyNational Energy Technology Laboratory (NETL), Morgantown, W.Va. (contract No. DE-AT26-98FT40032), the Gas Research Institute (GRI), Chicago, Ill., through a Cooperative Research and Development Contract with Advanced Resources International, Arlington, Va. (contract No. 50942103366), and the U.S. Geological Survey. We wish to acknowledge the helpful reviews of Vito Nuccio of the U.S. Geological Survey, Denver, Colo., and Vello Kuuskraa, Advanced Resources International, Arlington, Va.

\section{Methodology}

We introduce a dimensionless uncertainty coefficient (UC) to compare the relative uncertainty of undiscovered resource volumes of plays. The uncertainty coefficient is defined as

$$
\mathrm{UC}=\left(\mathrm{F}_{5}-\mathrm{F}_{95}\right) / \mathrm{MEAN}
$$

where $\mathrm{F}_{5}$ and $\mathrm{F}_{95}$ are fractiles of a probability distribution representing the estimate of undiscovered nonassociated gas for each gas-bearing play, and MEAN represents the mean estimate. $\mathrm{F}_{95}$ represents a 19-in-20 chance and $\mathrm{F}_{5}$ represents a 1-in-20 chance of the occurrence of at least the resource amount identified. Use of the uncertainty coefficient is based on the assumption that the fractile range of the undiscovered resource for each play probability distribution $\left(\mathrm{F}_{5}-\mathrm{F}_{95}\right)$ incorporates all areas of uncertainty that may be introduced into the assessment process. A large range in probability represents a relatively high level of uncertainty, whereas a small range represents a relatively low level of uncertainty. Two cumulative probability distributions are identified in figure 1. They represent a large and a small range of probabilities $\left(\mathrm{F}_{5}-\mathrm{F}_{95}\right)$, curves $\mathrm{A}$ and $\mathrm{B}$ respectively, for estimates of undiscovered technically recoverable conventional resources for two example plays. In order to eliminate the effects of magnitude of the resource for each example play, the range is divided by the mean of the probability distribution to define a dimensionless uncertainty coefficient. A similar coefficient is defined by $\left(\mathrm{F}_{5}-\mathrm{F}_{95}\right) / \mathrm{F}_{50}$, but was not used in this report because for many plays in the USGS 1995 assessment, $\mathrm{F}_{50}=0$. Thus, a ranking of uncertainty coefficients for plays represents a relative ranking of play uncertainty based on use of undiscovered gas resource volumes which can be used for establishing priorities for play reevaluation and for assessment planning activities. The play ranking and uncertainty are based on an interpretation of factual data by geologists and engineers using their best interpretive skills and experience.

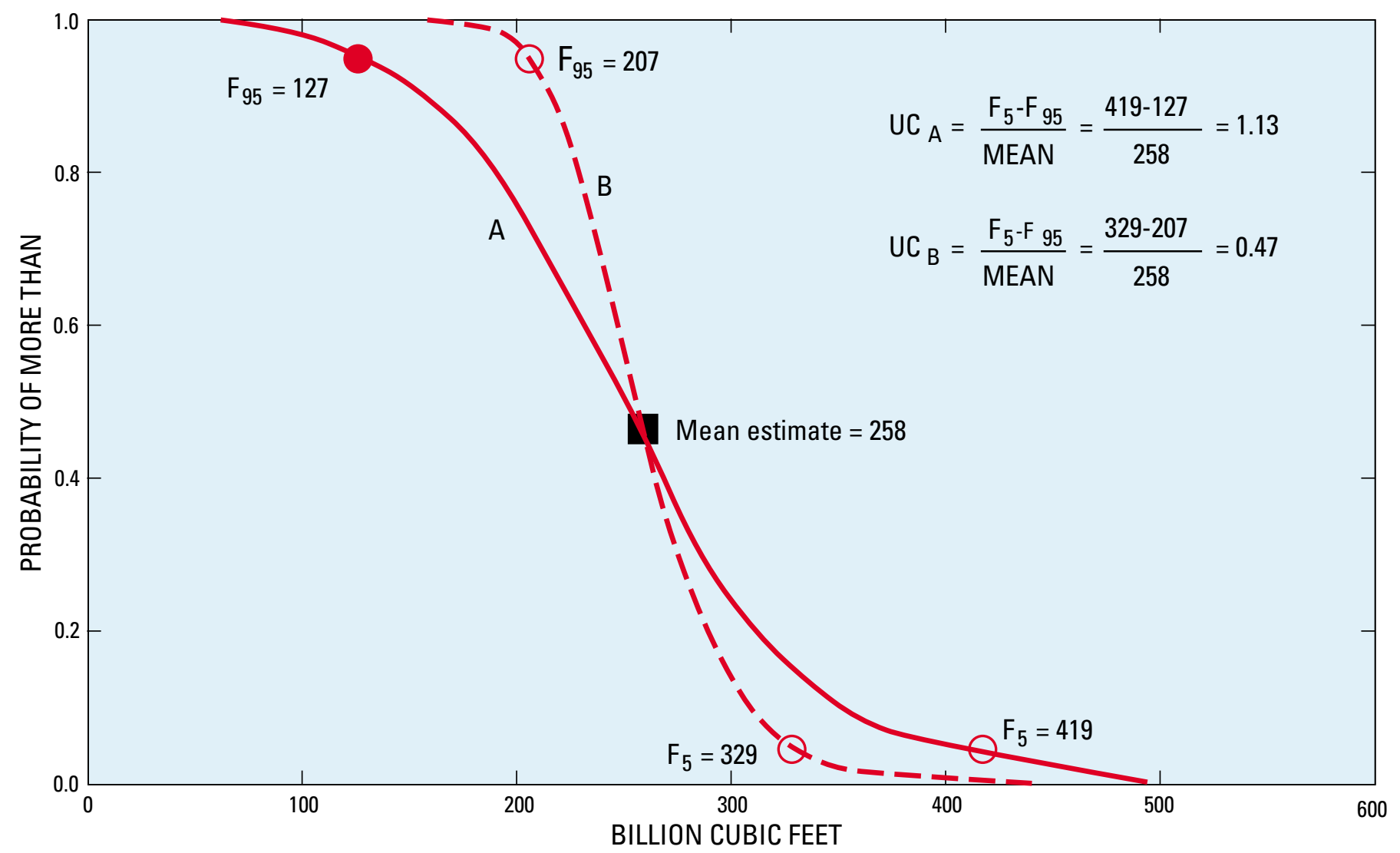

Figure 1. Estimated cumulative probability distributions for undiscovered conventional nonassociated gas resources for two hypothetical plays ( $A$ and $B$ ) having the same mean and illustrating the difference in range of $F_{95}$ and $F_{5}$ fractiles. Uncertainty coefficients (UC) are calculated for each. 


\section{Gulf Coast Region Gas Plays}

Uncertainty is introduced into the assessment process through the five factors discussed in the Introduction, and it can be compared among plays through the use of uncertainty coefficients. Estimates of undiscovered resource volumes of plays with the highest uncertainty coefficients are relatively more uncertain because we know less about these plays than we do about plays with low uncertainty coefficients. Our lack of knowledge may be due to a lack or quality of data and (or) the experience level and perceptions of province geologists responsible for the play assessments. Differences in perception by different province geologists are not an issue for the Gulf Coast Region because all 61 plays were assessed by the same person. (See Schenk and Viger, 1996a, 1996b.)

Natural gas estimates for the 61 gas-bearing conventional plays in the Gulf Coast Region are included in three assessment provinces: Western Gulf (province 47), Louisiana-Mississippi Salt Basins (province 49), and East Texas Basin (province 48). Because many of the plays in provinces 48 and 49 continued across political boundaries with no geologic significance, these provinces were combined for the 1995 National Petroleum Assessment, and plays in both provinces are designated by province 49. Table 1 contains identification, geologic, and resource information for each nonassociated gas-bearing play sorted from high to low uncertainty coefficient. For comparison, table 2 contains summary information for the 20 gas plays with the highest uncertainty coefficient (most uncertain) and the 20 plays with the lowest uncertainty coefficient (most certain) of the 61 Gulf Coast plays presented in table 1 .

The 20 plays with the highest uncertainty coefficients (UC mean=2.81; tables 1 and 2) were analyzed for their geologic characteristics and resource potential. These plays are evenly distributed between the two provinces (47 and combined 49). By contrast, the 20 plays with the lowest uncertainty coefficients (UC mean=1.85; tables 1 and 2) are concentrated in the Western Gulf Province suggesting that our data and knowledge are greater there than for the combined Louisiana-Mississippi Salt Basins and East Texas Basin.

Three hypothetical conventional gas plays were assessed for the Gulf Coast Region. These plays (two Norphlet Formation plays in the Louisiana-Mississippi Salt Basins and East Texas Basin Province (plays 4904 and 4907), and the Jackson Downdip Gas Play in the Western Gulf Province (play 4729)) have high uncertainty coefficients when compared to other Gulf Coast Region gas plays (table 1). As expected, estimates of the undiscovered resource volumes of hypothetical plays are more uncertain because these plays lack known production, and analogs must be used to establish a hypothetical production history.

No relationship was recognized between the dominant reservoir lithology of plays and level of uncertainty. Both the 20 plays with the highest uncertainty coefficients and the 20 plays with the lowest uncertainty coefficients in the Gulf Coast Region are primarily clastic plays. Carbonate plays occur in about equal frequency in both groups.

A relationship exists between the dominant trap type of a play and play uncertainty coefficient. The 20 plays with the highest uncertainty coefficients contain undiscovered accumulations with primarily structurally controlled traps (17 plays; table 2), whereas for the 20 plays with the lowest uncertainty coefficients, only 11 plays are structurally controlled. This contrast is more apparent when all 261 conventional gasbearing plays in the U.S. are compared (Gautier and others, 1996). For all nonassociated gas-bearing plays in the U.S. as a whole, of the 25 plays with the highest uncertainty coefficients, 12 are structurally controlled, only 2 are stratigraphically controlled, and 11 are mixed structurally and stratigraphically controlled. For the 25 nonassociated gas-bearing plays with the lowest uncertainty coefficients in the U.S., only 3 are structurally controlled, 8 are stratigraphically controlled, and an additional 14 are mixed structurally and stratigraphically controlled plays. A lower uncertainty coefficient may be associated with stratigraphically controlled plays because (1) these plays may be perceived as simpler to understand by province geologists than structurally controlled plays (perceptions), and (or) (2) the difference in uncertainty is simply a reflection of differences in the field-size distribution data used for stratigraphically trapped versus structurally trapped accumulations (data).

The play uncertainty coefficient is also related to volume of undiscovered nonassociated gas in each play (play size). The estimate of the mean undiscovered play size (total mean undiscovered gas resources) for the 20 plays with the lowest uncertainty coefficients is more than twice the mean play size of the 20 plays with the highest uncertainty coefficient $(1,356$ $\mathrm{Bcf}$ versus $641 \mathrm{Bcf})$. When the middle and bottom third of ranked plays are combined ( $N=41$; table 1$)$, the average play size is $1,294 \mathrm{Bcf}$, indicating that on the average, large plays are more certain than small plays based on the use of the uncertainty coefficient.

\section{Possible Criteria for Reevaluation of Gulf Coast Gas Plays}

A procedure is identified for prioritizing Gulf Coast Region plays for reevaluation from the 1995 U.S. Geological Survey National Petroleum Assessment. The procedure is based on the assumption that plays with the highest uncertainty coefficients and the largest undiscovered nonassociated gas resource estimates (play size) should be reviewed first. The procedure involves selecting plays based on a combination of uncertainty coefficient and mean estimate of undiscovered conventional nonassociated gas. Figure 2 is a plot of uncertainty coefficient versus mean undiscovered nonassociated gas for the 61 gasbearing plays of the Gulf Coast Region. A minimum uncertainty coefficient of 2.00 and a minimum undiscovered resource of $1 \mathrm{Tcf}$ were arbitrarily chosen for the initial selection process, although other values could also be chosen. An uncertainty coefficient cutoff of 2.00 effectively eliminates the 20 plays with the lowest uncertainty coefficients.

Table 3 contains summary information for the 14 plays meeting these criteria. Together, these plays contain 38 percent of the mean estimated conventional gas resource (37.4 out of 97.6 Tcf) for the entire Gulf Coast Region (U.S. Geological Survey National Oil and Gas Resource Assessment Team, 
Table 1. Geologic characteristics and estimated undiscovered nonassociated gas resources for 61 gas-bearing plays in the Gulf Coast Region from the U.S. Geological Survey 1995 National Petroleum Assessment.

[Size, estimated mean size of individual undiscovered accumulations for each play in Bcf (billions of cubic feet); Lith, lithology of dominant reservoir rocks in play; Trap, dominant trap type in playstructure, structural traps; stratigraphic, stratigraphic traps; mixed, mixed structure and stratigraphic traps; Depth, median depth of play in feet; Status, status of play with respect to known productionconfirmed, play has at least one known accumulation with production of at least 6 Bcf of nonassociated gas; hypothetical, no known production of 6 Bcf; NA mean, mean estimate of nonassociated gas in play in Bcf; F95 res., 95th fractile of the probability distribution for undiscovered conventional resources in play or a 19 -in-20 chance of the occurrence of at least the resource amount identified in $\mathrm{Bcf} ; \mathrm{F}_{5}$ res., 5th fractile of probability distribution for undiscovered conventional resources in play or a 1-in-20 chance of the occurrence of at least the resource amount identified in Bcf; UC, dimensionless uncertainty coefficient defined by $\mathrm{F}_{5}-\mathrm{F}_{95} /$ Mean. Data taken directly from Schenk and Viger (1996a; 1996b)]

\begin{tabular}{|c|c|c|c|c|c|c|c|c|c|c|c|}
\hline No. & Play name & Size & Lith. & Trap & Depth & Status & NA mean & $\mathrm{F}_{95}$ res. & $F_{5}$ res. & $\mathrm{F}_{50}$ res. & UC \\
\hline 4907 & Norphlet SE Margin Jackson Dome Flank Deep Gas & 42.78 & clastic & structure & 22000 & hypothetical & 111.1 & 0 & 411.7 & 7.4 & 3.71 \\
\hline 4904 & Norphlet Wiggins - Hancock Arch Gas & 35.62 & clastic & structure & 17000 & hypothetical & 287 & 0 & 961.8 & 164.6 & 3.35 \\
\hline 4910 & Smackover Alabama/Florida Peripheral Fault Zone Oil and Gas & 57.48 & carbonate & structure & 15000 & confirmed & 639.7 & 33.7 & 2107.8 & 405.1 & 3.24 \\
\hline 4729 & Jackson Downdip Gas & 66.05 & clastic & structure & 14000 & hypothetical & 3053.7 & 0 & 9730.4 & 49.7 & 3.19 \\
\hline 4744 & Upper Miocene Fluvial Sandstone Gas and Oil & 12.24 & clastic & structure & 8000 & confirmed & 99.8 & 8.3 & 315.7 & 46.9 & 3.08 \\
\hline 4721 & Upper Wilcox Updip Fluvial Gas & 9.17 & clastic & structure & 5000 & confirmed & 103.9 & 9.1 & 312.9 & 52.6 & 2.92 \\
\hline 4725 & Middle Eocene Sandstones Updip Fluvial Oil and Gas & 24.04 & clastic & structure & 8000 & confirmed & 303 & 20.7 & 888.3 & 189.7 & 2.86 \\
\hline 4938 & Tuscaloosa Stratigraphic Oil and Gas & 14.79 & clastic & stratigraphic & 12000 & confirmed & 90 & 9.3 & 260.7 & 53.3 & 2.79 \\
\hline 4916 & Smackover East Texas - Southern Arkansas Fault Zone Oil and Gas & 22.96 & carbonate & structure & 10000 & confirmed & 424.4 & 33.7 & 1205.6 & 266.2 & 2.76 \\
\hline 4915 & Smackover North Louisiana Gray Sandstone Gas & 26.29 & clastic & structure & 10000 & confirmed & 245.1 & 20.7 & 691.7 & 151.3 & 2.74 \\
\hline 4931 & James Limestone Gas & 48.42 & carbonate & structure & 11000 & confirmed & 1017 & 52.4 & 2832.7 & 480.5 & 2.73 \\
\hline 4739 & Lower Miocene Fluvial Sandstone Oil and Gas & 12.24 & clastic & structure & 8000 & confirmed & 224.5 & 22.9 & 627.2 & 134.3 & 2.69 \\
\hline 4745 & Upper Miocene Deltaic Sandstone Gas and Oil & 21.97 & clastic & structure & 14000 & confirmed & 253.5 & 24.2 & 681.4 & 172 & 2.59 \\
\hline 4941 & Eutaw Southern Salt Basins Gas & 46.73 & clastic & structure & 7000 & confirmed & 459 & 44.3 & 1226.4 & 314.7 & 2.58 \\
\hline 4924 & Cotton Valley Sabine Uplift Gas & 55 & clastic & structure & 10000 & confirmed & 1080.5 & 104.6 & 2863.6 & 727 & 2.55 \\
\hline 4946 & Wilcox N. Louisiana Salt Basin Gas & 11.9 & clastic & mixed & 3000 & confirmed & 60.1 & 8.1 & 161.5 & 41.1 & 2.55 \\
\hline 4720 & Lower Wilcox Downdip Overpressured Gas & 46.16 & clastic & structure & 16000 & confirmed & 3024 & 280 & 7959.8 & 1931.9 & 2.54 \\
\hline 4730 & Vicksburg Updip Gas & 9 & clastic & structure & 7000 & confirmed & 88.5 & 11 & 235 & 56.7 & 2.53 \\
\hline 4738 & Anahuac Sandstone Gas and Oil & 30.79 & clastic & structure & 15000 & confirmed & 473.2 & 43.8 & 1224.8 & 338.7 & 2.50 \\
\hline 4710 & Woodbine South Angelina Flexure Oil and Gas & 33.47 & clastic & stratigraphic & 14000 & confirmed & 783.5 & 81.8 & 2036.1 & 543.1 & 2.49 \\
\hline 4947 & Mobile Bay Miocene Gas & 10.3 & clastic & stratigraphic & 2000 & confirmed & 180.2 & 21.9 & 448.3 & 129.7 & 2.37 \\
\hline 4922 & Cotton Valley Salt Basins Gas & 13.16 & clastic & mixed & 14000 & confirmed & 407.9 & 39.4 & 986.7 & 238.1 & 2.32 \\
\hline 4929 & Sligo/Pettet Salt Basins Gas & 15.3 & mixed & mixed & 11000 & confirmed & 270.4 & 29.2 & 654.6 & 183.6 & 2.31 \\
\hline 4920 & Gilmer Limestone Gas & 42.01 & carbonate & structure & 14000 & confirmed & 1119 & 92.7 & 2675.8 & 852.9 & 2.31 \\
\hline 4926 & Hosston/Travis Peak Salt Basins Gas & 35.62 & clastic & structure & 9000 & confirmed & 1280.7 & 118.1 & 3068.4 & 892.9 & 2.30 \\
\hline 4937 & Tuscaloosa/Woodbine Structural Oil and Gas & 16.68 & clastic & mixed & 9000 & confirmed & 40.6 & 7.5 & 99.9 & 32.6 & 2.28 \\
\hline 4703 & Smackover South Texas Gas & 30.79 & carbonate & structure & 16000 & confirmed & 1029 & 120 & 2448.2 & 815.3 & 2.26 \\
\hline 4913 & Smackover Jackson Dome Deep Gas & 52.07 & clastic & structure & 21000 & confirmed & 259.8 & 32.7 & 613.2 & 219.7 & 2.23 \\
\hline 4935 & Paluxy Downdip Gas & 16.68 & clastic & structure & 10000 & confirmed & 257.7 & 32.6 & 605 & 211.1 & 2.22 \\
\hline 4705 & Lower Cretaceous Carbonate Shelf/Shelf-Edge Gas and Oil & 62.99 & carbonate & mixed & 14000 & confirmed & 2307.5 & 227.3 & 5276.4 & 1886 & 2.19 \\
\hline 4901 & Piercement Salt Dome Flanks Oil and Gas & 35.62 & mixed & structure & 10000 & confirmed & 651.6 & 75.4 & 1493.8 & 546.7 & 2.18 \\
\hline 4724 & Middle Eocene Sandstones Downdip Gas & 35.62 & clastic & structure & 12000 & confirmed & 1125.3 & 123 & 2559.7 & 902.5 & 2.17 \\
\hline 4709 & Tuscaloosa Deep Sandstone Gas & 162.18 & clastic & mixed & 17000 & confirmed & 6315.3 & 637.2 & 14310.3 & 4782.3 & 2.17 \\
\hline 4927 & Travis Peak Sabine Uplift Gas & 24.04 & clastic & mixed & 8000 & confirmed & 511.6 & 53.1 & 1142.3 & 411.4 & 2.13 \\
\hline 4905 & Norphlet Salt Basin Oil and Gas & 42.78 & clastic & structure & 17000 & confirmed & 240.1 & 30.1 & 540.2 & 213.3 & 2.12 \\
\hline 4912 & Smackover Salt Basins Gas and Oil & 30.79 & carbonate & structure & 12000 & confirmed & 960 & 106.1 & 2145.2 & 713.3 & 2.12 \\
\hline 4727 & Yegua Downdip Gas & 65.98 & clastic & structure & 14000 & confirmed & 5164.2 & 483.9 & 11359.7 & 3713.8 & 2.11 \\
\hline 4736 & Frio SE Texas/S. Louisiana Downdip Gas & 25.07 & clastic & mixed & 14000 & confirmed & 1462.7 & 159.6 & 3215.9 & 1069.7 & 2.09 \\
\hline 4722 & Upper Wilcox Shelf-Edge Gas and Oil & 48.01 & clastic & structure & 9000 & confirmed & 3795.9 & 313.7 & 8104.4 & 2524.8 & 2.05 \\
\hline 4909 & Smackover Wiggins - Baldwin Flanks Gas & 30.79 & carbonate & mixed & 16000 & confirmed & 530.5 & 71 & 1155.3 & 478.1 & 2.04 \\
\hline 4918 & Haynesville Salt Basins Gas and Oil & 40.65 & clastic & structure & 14000 & confirmed & 994.5 & 126.7 & 2157 & 800 & 2.04 \\
\hline 4726 & Yegua Updip Fluvial-Deltaic Oil and Gas & 24.04 & clastic & structure & 7000 & confirmed & 539.6 & 56.8 & 1153.4 & 456.4 & 2.03 \\
\hline 4723 & Upper Wilcox Downdip Overpressured Gas & 56.71 & clastic & structure & 16000 & confirmed & 5709.8 & 649.1 & 12061.8 & 4141.9 & 2.00 \\
\hline
\end{tabular}


Table 1-Continued. Geologic characteristics and estimated undiscovered nonassociated gas resources for 61 gas-bearing plays in the Gulf Coast Region from the U.S. Geological Survey 1995 National Petroleum Assessment.

[Size, estimated mean size of individual undiscovered accumulations for each play in Bcf (billions of cubic feet); Lith, lithology of dominant reservoir rocks in play; Trap, dominant trap type in playstructure, structural traps; stratigraphic, stratigraphic traps; mixed, mixed structure and stratigraphic traps; Depth, median depth of play in feet; Status, status of play with respect to known productionconfirmed, play has at least one known accumulation with production of at least 6 Bcf of nonassociated gas; hypothetical, no known production of 6 Bcf; NA mean, mean estimate of nonassociated gas in play in Bcf; $\mathrm{F}_{95}$ res. 95th fractile of the probability distribution for undiscovered conventional resources in play or a 19-in-20 chance of the occurrence of at least the resource amount identified in Bcf; $F_{5}$ res., 5th fractile of probability distribution for undiscovered conventional resources in play or a 1-in-20 chance of the occurrence of at least the resource amount identified in Bcf; UC, dimensionless uncertainty coefficient defined by $\mathrm{F}_{5}-\mathrm{F}_{95} /$ Mean. Data taken directly from Schenk and Viger (1996a; 1996b)]

\begin{tabular}{|c|c|c|c|c|c|c|c|c|c|c|c|}
\hline No. & Play name & Size & Lith. & Trap & Depth & Status & NA mean & $\mathrm{F}_{95}$ res. & $F_{5}$ res. & $\mathrm{F}_{50}$ res. & UC \\
\hline 4742 & Middle Miocene Fluvial Sandstone Gas and Oil & 25.07 & clastic & structure & 10000 & confirmed & 744.4 & 86.5 & 1563 & 593.1 & 1.98 \\
\hline 4734 & Frio Updip Fluvial Gas and Oil & 10.3 & clastic & mixed & 7000 & confirmed & 219.3 & 33.8 & 414.6 & 194.8 & 1.98 \\
\hline 4704 & Cotton Valley Western Gulf Gas and Oil & 18.74 & clastic & mixed & 12000 & confirmed & 326.6 & 39.3 & 681.9 & 270.9 & 1.97 \\
\hline 4718 & Lower Wilcox Lobo Gas & 49.16 & clastic & structure & 9000 & confirmed & 3187.1 & 404.8 & 6576.1 & 2687.1 & 1.94 \\
\hline 4719 & Lower Wilcox Fluvial Oil and Gas & 19.1 & clastic & mixed & 8000 & confirmed & 563.7 & 76 & 1154.2 & 449.1 & 1.91 \\
\hline 4743 & Middle Miocene Deltaic Sandstone Gas and Oil & 19.89 & clastic & structure & 14000 & confirmed & 345.4 & 49.2 & 705.3 & 285.9 & 1.90 \\
\hline 4732 & Frio South Texas Downdip Gas & 27.52 & clastic & mixed & 12000 & confirmed & 820.9 & 101 & 1650.6 & 618 & 1.89 \\
\hline 4731 & Vicksburg Downdip Gas & 30.79 & clastic & mixed & 14000 & confirmed & 1559.4 & 144.6 & 2967.6 & 948.7 & 1.81 \\
\hline 4930 & Pettet Southern Sabine Uplift Gas and Oil & 9.62 & carbonate & structure & 7000 & confirmed & 151.2 & 23 & 295.9 & 125.5 & 1.80 \\
\hline 4735 & Frio SE Texas/S. Louisiana Mid-Dip Gas and Oil & 24.04 & clastic & structure & 12000 & confirmed & 794.3 & 83 & 1515.6 & 624.6 & 1.80 \\
\hline 4717 & Upper Cretaceous Sandstones Downdip Gas & 12.05 & clastic & mixed & 8000 & confirmed & 242.4 & 38.4 & 475.4 & 234.6 & 1.80 \\
\hline 4933 & Glen Rose/Rodessa Salt Basins Gas & 23.74 & clastic & mixed & 10000 & confirmed & 1068.1 & 136.9 & 2049.6 & 861.4 & 1.79 \\
\hline 4701 & Houston Salt Dome Flank Oil and Gas & 55 & clastic & structure & 9000 & confirmed & 833.5 & 134.1 & 1606.8 & 802.1 & 1.77 \\
\hline 4903 & Norphlet Mobile Bay Deep Gas & 207.05 & clastic & structure & 20000 & confirmed & 5259.6 & 753.7 & 9881.4 & 4889.2 & 1.74 \\
\hline 4737 & Hackberry Sandstone Gas and Oil & 23.41 & clastic & mixed & 10000 & confirmed & 395.8 & 59.6 & 744.8 & 353 & 1.73 \\
\hline 4733 & Frio South Texas Mid-Dip Oil and Gas & 14.52 & clastic & structure & 12000 & confirmed & 517.4 & 54.8 & 944.1 & 345.9 & 1.72 \\
\hline 4741 & Lower Miocene Slope and Fan Sandstone Gas & 73.3 & clastic & mixed & 14000 & confirmed & 2940.4 & 484.9 & 5489.4 & 2895.3 & 1.70 \\
\hline 4740 & Lower Miocene Deltaic Sandstone Gas and Oil & 27.26 & clastic & structure & 10000 & confirmed & 899.4 & 119.9 & 1648.1 & 716.5 & 1.70 \\
\hline
\end{tabular}


Table 2. Summary data for the 20 nonassociated conventional gas-bearing plays in the Gulf Coast Region with the highest (1) and lowest (2) uncertainty coefficients from the plays in table 1.

(1) 20 plays with highest uncertainty coefficients

Mean UC $=2.82$

Province composition: Western Gulf $=10$ plays; East Texas Basin and Louisiana-Miss. Salt Basins $=10$ plays

Hypothetical plays $=3$; confirmed plays $=17$

Average median depth $=11,300 \mathrm{ft}$

Dominant lithology: carbonate plays $=3$; clastic plays $=17$

Trap type: structure $=17$ plays; stratigraphic $=2$ plays; mixed trap type $=1$ play

Total mean undiscovered nonassociated gas $=12,822 \mathrm{Bcf}$

Mean undiscovered nonassociated gas/play ( $N=20$ plays $)=641 \mathrm{Bcf}$

Mean undiscovered nonassociated accumulation size $=31.2 \mathrm{Bcf}$

(2) 20 plays with lowest uncertainty coefficients

Mean UC $=1.85$

Province composition: Western Gulf $=17$ plays; East Texas Basin and Louisiana-Miss. Salt Basins $=3$ plays

Hypothetical plays $=0$; confirmed plays $=20$

Average median depth $=11,050 \mathrm{ft}$

Dominant lithology: carbonate plays $=2$; clastic plays $=17$

Trap type: structure $=11$ plays; mixed $=9$ plays

Total mean undiscovered nonassociated gas $(N=20$ plays $)=27,118 \mathrm{Bcf}$

Mean undiscovered nonassociated gas/play $(N=20$ plays $)=1,356 \mathrm{Bcf}$

Mean undiscovered nonassociated accumulation size $=37.3 \mathrm{Bcf}$

1995). These plays are primarily clastic plays, are structurally trapped, and are associated with a wide range of stratigraphic reservoir units. Only 4 of these 14 plays are part of the 20 plays with the highest uncertainty, suggesting that the volume of undiscovered nonassociated gas resource rather than the uncertainty coefficient may be the most important factor to consider when reevaluating plays.

Ten of the fourteen plays reside in the Western Gulf Province and have a total estimated mean conventional nonassociated gas resource of nearly $33 \mathrm{Tcf}$, about 33 percent of the resource for the Gulf Coast Region. The mean undiscovered field size for nonassociated gas in these 14 gas-bearing plays is nearly $56 \mathrm{Bcf}$, which is far more than the mean undiscovered field size for nonassociated gas for all 61 Gulf Coast Region gas-bearing plays together (mean=36.3 Bcf).

These high-priority nonassociated gas plays are also deep. The 10 Western Gulf Province gas-bearing plays have an average median depth of 14,200 feet and an average maximum depth of 20,400 feet (Schenk and Viger, 1996). Only one of the plays, the Upper Wilcox Shelf-Edge Gas and Oil Play (play 4722), has a median depth of less than 10,000 feet (table 3).

\section{Causes of Uncertainty: Examples of Uncertain Plays}

Three of the sixty-one Gulf Coast Region nonassociated gas-bearing plays are discussed here as examples to illustrate more clearly the actual causes of uncertainty for each. Detailed play descriptions in Gautier and others (1996) provide information about the geology, production history, and risking process associated with assessing plays in the U.S. Geological Survey
1995 National Petroleum Assessment. Data for the following discussion were taken from Schenk and Viger (1996a, 1996b).

Norphlet Southeast Margin Jackson Dome-Flank Deep Gas (play 4907), East Texas Basin and Louisiana-Mississippi Salt Basins Play (table 1). This hypothetical play occurs in both the East Texas Basin and Louisiana-Mississippi Salt Basins and contains only minor undiscovered nonassociated gas resources (mean undiscovered gas equals 111.1 Bcf), but it has the highest uncertainty coefficient of all nonassociated gas-bearing plays in the Gulf Coast Region ( $\mathrm{UC}=3.71$ ). The volume of undiscovered gas ranges from $0.0 \mathrm{Bcf}$ (F95) to 412 (F5). This play is also one of the deepest plays in the Gulf Coast Region (median depth=22,000 feet). The play was defined on the basis of deep eolian gas reservoirs in the Upper Jurassic Norphlet Formation. Trapping mechanisms are faults associated with deep salt structures. The play was risked for the presence and quality of eolian sandstones (probability equals 0.5 ; Schenk and Viger, 1996b), particularly in the deeper portions of the play. Adequate reservoir quality is associated with the thermal and diagenetic history of Jackson Dome. Also, the play boundary was poorly understood but drawn where the Norphlet reaches 25,000 feet along the southeast margin of Jackson Dome. The Smackover Jackson Dome Deep Gas Play (play 4913; table 1) was used as a production analog for this play.

Norphlet Wiggins-Hancock Arch Gas (play 4904; table 1). This hypothetical play $(\mathrm{UC}=3.35)$ ranges in volume of undiscovered nonassociated gas from 0.0 (F5) to $0.9 \mathrm{Tcf}$ (F95). It was defined on the basis of deep eolian and fluvial gas and condensate reservoirs in the Upper Jurassic Norphlet Formation. Trapping mechanisms are basement faults along the flanks of the Wiggins Arch. The play was risked for the presence and quality of eolian and fluvial sandstone reservoirs forming an apron around the flanks of the arch. The Smackover 


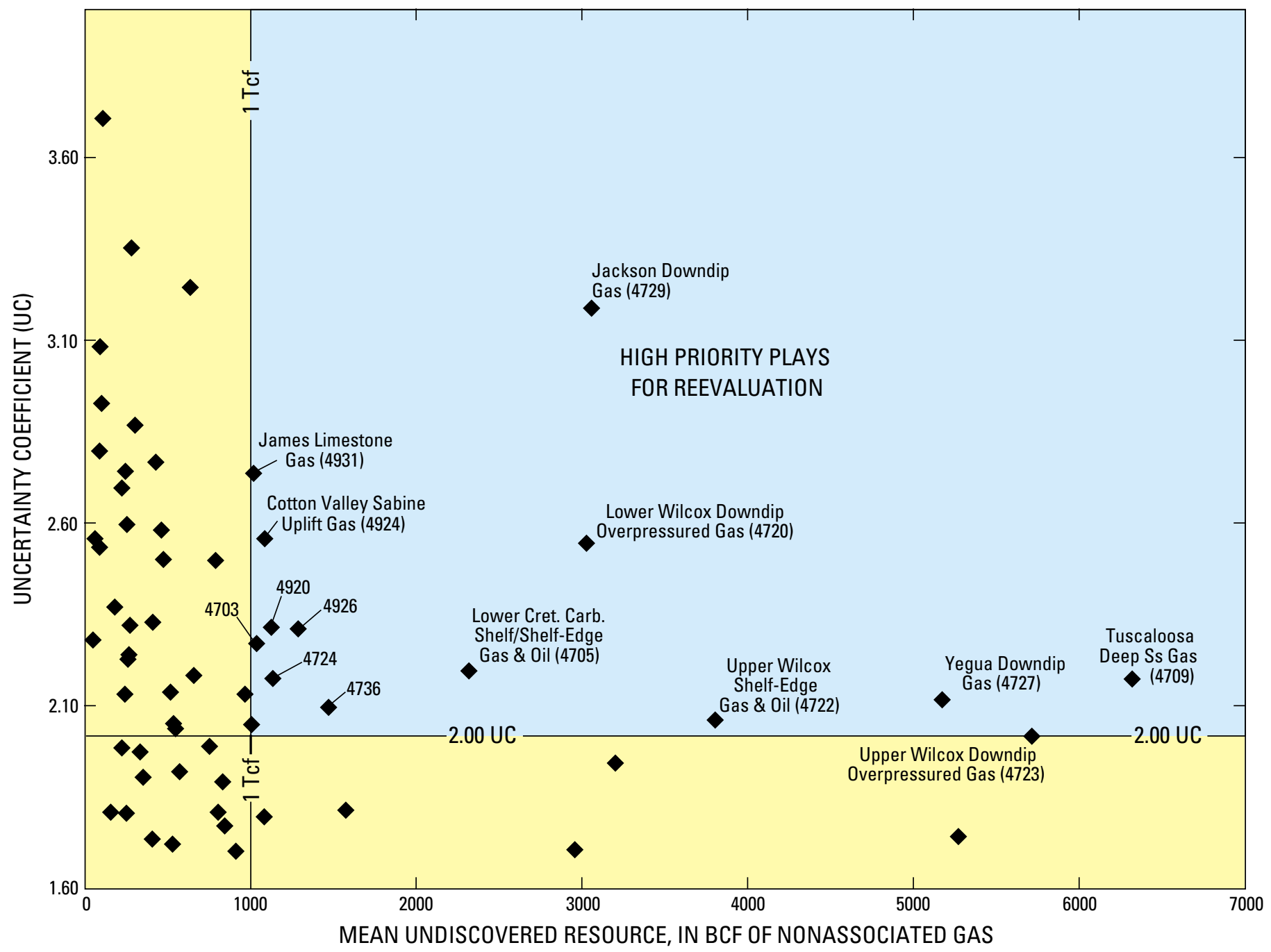

Figure 2. Plot of play uncertainty coefficient (UC, dimensionless) versus mean undiscovered nonassociated gas resource for 61 conventional gas plays in the Gulf Coast Region. Area of possible high-priority plays for reevaluation (in blue) is based on minimum reevaluation criteria of UC=2.00 and mean estimated undiscovered nonassociated gas resource $=1$ Tcf. Unnamed plays in high-priority area are: 4703, Smackover South Texas Gas; 4920, Gilmer Limestone Gas; 4926, Hosston/Travis Peak Salt Basins Gas; 4724, Middle Eocene Sandstones Downdip Gas; 4736, Frio Southeast Texas/South Louisiana Downdip Gas.

Wiggins-Baldwin Flanks Gas Play (4909) was used as a production analog for this play.

\section{Tuscaloosa Deep Sandstone Gas Play (play 4709; table} 1). This confirmed play has an intermediate uncertainty coefficient $(\mathrm{UC}=2.17)$. The volume of undiscovered nonassociated gas ranges from $0.6 \mathrm{Tcf}\left(\mathrm{F}_{95}\right)$ to $14.3 \mathrm{Tcf}\left(\mathrm{F}_{5}\right)$. The play definition was based on the presence of Upper Cretaceous Tuscaloosa Group deltaic sandstone reservoirs in both structural and stratigraphic traps downdip from the Lower Cretaceous shelf margin of southern Louisiana. The updip play boundary was defined by the shelf edge, but the downdip boundary was arbitrarily chosen at 25,000 feet. Although 18 discovered reservoirs were defined for this play in 1995, less was known about the more lightly drilled deeper parts of the play, and uncertainty was based in part on the lack of data on ranges of undiscovered field sizes deeper than about 17,000 feet.

\section{Discussion}

New and useful information from the U.S. Geological Survey 1995 National Petroleum Assessment is revealed when data on uncertainty are analyzed.

Play size. Sixteen of the twenty plays with the highest uncertainty coefficients are small with respect to undiscovered play size ( $<1$ Tcf of mean undiscovered gas) (table 1). In the Gulf Coast Region, large uncertainty coefficients are characteristic of small plays. One important constraint in the U.S. Geological Survey 1995 National Petroleum Assessment was that plays could only be defined to the State-Federal water boundary. If play outlines had included Federal Offshore waters in 1995, many geographically small plays such as Norphlet Mobile Bay Deep Gas (4903), Frio South Texas Downdip Gas (4732), Lower 
Return to

Volume Contents

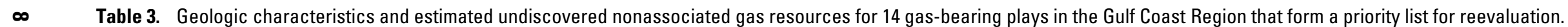
[See table 1 for explanation of data]

\begin{tabular}{|c|c|c|c|c|c|c|c|c|c|c|}
\hline \multirow[t]{2}{*}{ Play name } & \multirow[t]{2}{*}{ UC } & \multicolumn{4}{|c|}{ Estimates of undisc. NA conv. gas } & \multirow[t]{2}{*}{ Lithology } & \multirow[t]{2}{*}{ Trap } & \multirow{2}{*}{$\begin{array}{c}\text { Median } \\
\text { depth }\end{array}$} & \multirow[t]{2}{*}{ Play status } & \multirow{2}{*}{$\begin{array}{l}\text { Undiscovered } \\
\text { accum. size }\end{array}$} \\
\hline & & Mean res. & $\mathrm{F}_{95}$ res. & $F_{5}$ res. & $\mathrm{F}_{50}$ res. & & & & & \\
\hline Jackson Downdip Gas & 3.19 & 3053.7 & 0 & 9730.4 & 49.7 & clastic & structure & 14000 & hypothetical & 66 \\
\hline James Limestone Gas & 2.73 & 1017 & 52.4 & 2832.7 & 480.5 & carbonate & structure & 11000 & confirmed & 48.3 \\
\hline Cotton Valley Sabine Uplift Gas & 2.55 & 1080.5 & 104.6 & 2863.6 & 727 & clastic & structure & 10000 & confirmed & 54.8 \\
\hline Lower Wilcox Downdip Overpressured Gas & 2.54 & 3024 & 280 & 7959.8 & 1931.9 & clastic & structure & 16000 & confirmed & 46.1 \\
\hline Gilmer Limestone Gas & 2.31 & 1119 & 92.7 & 2675.8 & 852.9 & carbonate & structure & 14000 & confirmed & 42 \\
\hline Hosston/Travis Peak Salt Basins Gas & 2.30 & 1280.7 & 118.1 & 3068.4 & 892.9 & clastic & structure & 12000 & confirmed & 35.5 \\
\hline Smackover South Texas Gas & 2.26 & 1029 & 120 & 2448.2 & 815.3 & carbonate & structure & 16000 & confirmed & 30.7 \\
\hline L. Cretaceous Carbonate Shelf/Shelf-Edge Gas and Oil & 2.19 & 2307.5 & 227.3 & 5276.4 & 1886 & carbonate & mixed & 14000 & confirmed & 62.9 \\
\hline Middle Eocene Sandstones Downdip Gas & 2.17 & 1125.3 & 123 & 2559.7 & 902.5 & clastic & structure & 12000 & confirmed & 35.5 \\
\hline Tuscaloosa Deep Sandstone Gas & 2.17 & 6315.3 & 637.2 & 14310.3 & 4782.3 & clastic & mixed & 17000 & confirmed & 162.1 \\
\hline Yegua Downdip Gas & 2.11 & 5164.2 & 483.9 & 11359.7 & 3713.8 & clastic & structure & 14000 & confirmed & 65.9 \\
\hline Frio SE Texas/S. Louisiana Downdip Gas & 2.09 & 1462.7 & 159.6 & 3215.9 & 1069.7 & clastic & mixed & 14000 & confirmed & 25 \\
\hline Upper Wilcox Shelf-Edge Gas and Oil & 2.05 & 3795.9 & 313.7 & 8104.4 & 2524.8 & clastic & structure & 9000 & confirmed & 47.9 \\
\hline Upper Wilcox Downdip Overpressured Gas & 2.00 & 5709.8 & 649.1 & 12061.8 & 4141.9 & clastic & structure & 16000 & confirmed & 56.6 \\
\hline & & 2677.5 & & & & & & & & 55.7 \\
\hline
\end{tabular}


Cretaceous Carbonate Shelf/Shelf-Edge Gas and Oil (4705), and possibly others would have increased in size and also in undiscovered resource. Potentially larger plays would undoubtedly have attained a higher uncertainty coefficient due to a lack of data for the more lightly drilled Federal Offshore areas. The same point can be made for lumping and splitting plays within the onshore and State waters of the region. A different province geologist might have defined fewer plays by combining the geologic and production characteristics of some of the 61 plays already defined. These fewer, larger plays would have different uncertainty characteristics.

The size of the undiscovered resource is clearly a more important play parameter for play reevaluation than the level of uncertainty as demonstrated by the data in figure 2 . Only 4 of the 14 plays suggested for review in figure 2 reside within the list of 20 plays with the highest uncertainty coefficient. Alternatively, for the Gulf Coast Region as a whole, plays with large uncertainty coefficients tend to be small plays with respect to undiscovered nonassociated gas resource and are considered relatively less important for reevaluation.

Use of analogs for uncertain plays with little or no production. In 1995, the lack of play analogs directly impacted the assessment of hypothetical plays. If the U.S. Geological Survey had access to better exploration/production analogs to identify the sizes and numbers of undiscovered accumulations, uncertainty coefficients could have been reduced, and the magnitude of the play resource might have changed. For future assessments, a procedure to identify and document analogs would benefit the assessment process.

Exploration intensity. Data from this study support the view that uncertainty is directly related to the level of petroleum exploration in a play. The Western Gulf Province contains many large, well-explored and well-understood plays. Even though these plays have low uncertainty coefficients for conventional nonassociated gas (tables 1 and 2), they deserve reevaluation because of their large size and greater impact on the future gas resources of the Nation.

Conventional and Continuous-type plays. In 1995 the U.S. Geological Survey assessed only one continuous-type (unconventional) gas play in the Gulf Coast Region, the Cotton Valley Blanket Sandstones Play (play 4923) of the LouisianaMississippi Salt Basins Province and three Austin Chalk continuous oil plays (Austin Chalk Pearsall (play 4747), Austin Chalk Giddings (play 4748), and Austin Chalk Outlying (play 4749)) of the Western Gulf Province, which were estimated to contain some associated gas.

Continuous-type plays contain accumulations that are geographically widespread and generally lack well-defined oil- or gas-water contacts (Schmoker and others, 1995; Schmoker, 1996; U.S. Geological Survey National Oil and Gas Resource Assessment Team, 1995). Continuous-type plays were assessed using geologic criteria but a different quantitative method. Hence, the Cotton Valley Blanket Sandstones Play was not compared to conventional plays in this report based on uncertainty. An unresolved issue from the 1995 assessment is the potential continuous nature of some plays previously assessed as conventional. For example, the Cotton Valley Sabine Uplift Gas play (4924) in the Louisiana-Mississippi Salt Basins and East Texas Basin Province is being reevaluated because of its geologic and production characteristics. The Cotton Valley Sabine Uplift Gas Play was identified as one of the 20 nonassociated gas-bearing plays with high uncertainty coefficients in this study (table 1). A reassessment of plays using new data, changing perceptions, and different methods may likely result in substantially different resource estimates.

\section{References Cited}

Dyman, T.S., Schmoker, J.W., and Root, D.H., 1996, Assessment of deep conventional and continuous-type (unconventional) natural gas plays in the United States: U.S. Geological Survey Open-File Report 96-529, $30 \mathrm{p}$.

Gautier, D.L., Dolton, G.L., Takahashi, K.I., and Varnes, K.L., eds., 1996, 1995 National assessment of United States oil and gas resourcesResults, methodology, and supporting data: U.S. Geological Survey Digital Data Series 30, Release 2.

Schenk, C.J., and Viger, R.J., 1996a, Western Gulf Province (047), in Gautier, D.L., Dolton, G.L., Takahashi, K.I., and Varnes, K.L., eds., 1995 National assessment of United States oil and gas resourcesResults, methodology, and supporting data: U.S. Geological Survey Digital Data Series 30, Release 2.

1996b, East Texas Basin Province (048) and Louisiana-Mississippi Salt Basins Province (049), in Gautier, D.L., Dolton, G.L., Takahashi, K.I., and Varnes, K.L., eds., 1995 National assessment of United States oil and gas resources-Results, methodology, and supporting data: U.S. Geological Survey Digital Data Series 30, Release 2.

Schmoker, J.W., 1996, Method for assessing continuous-type (unconventional) hydrocarbon accumulations, in Gautier, D.L., Dolton, G.L., Takahashi, K.I., and Varnes, K.L., eds., 1995 National assessment of United States oil and gas resources-Results, methodology, and supporting data: U.S. Geological Survey Digital Data Series 30, Release 2.

Schmoker, J.W., Crovelli, R.A., and Balay, R.H., 1995, Potential additions to technically recoverable resources for each continuous-type (unconventional) play of the U.S. Geological Survey 1995 National petroleum assessment of oil and gas resources-Graphical and tabular presentations: U.S. Geological Survey Open-File Report 95$75 \mathrm{E}, 57 \mathrm{p}$.

U.S. Geological Survey National Oil and Gas Resource Assessment Team, 1995, 1995 National assessment of United States oil and gas resources: U.S. Geological Survey Circular 1118, 20 p. 


\title{
Chapter H
}

\section{A Possible Deep-Basin High-Rank Gas Machine Via Water-Organic-Matter Redox Reactions}

\author{
By Leigh C. Price
}

Prepared in cooperation with the U.S. Department of Energy-National Energy Technology Laboratory, the Gas Technology Institute, and Advanced Resources International

U.S. Department of the Interior

U.S. Geological Survey 


\section{Contents}

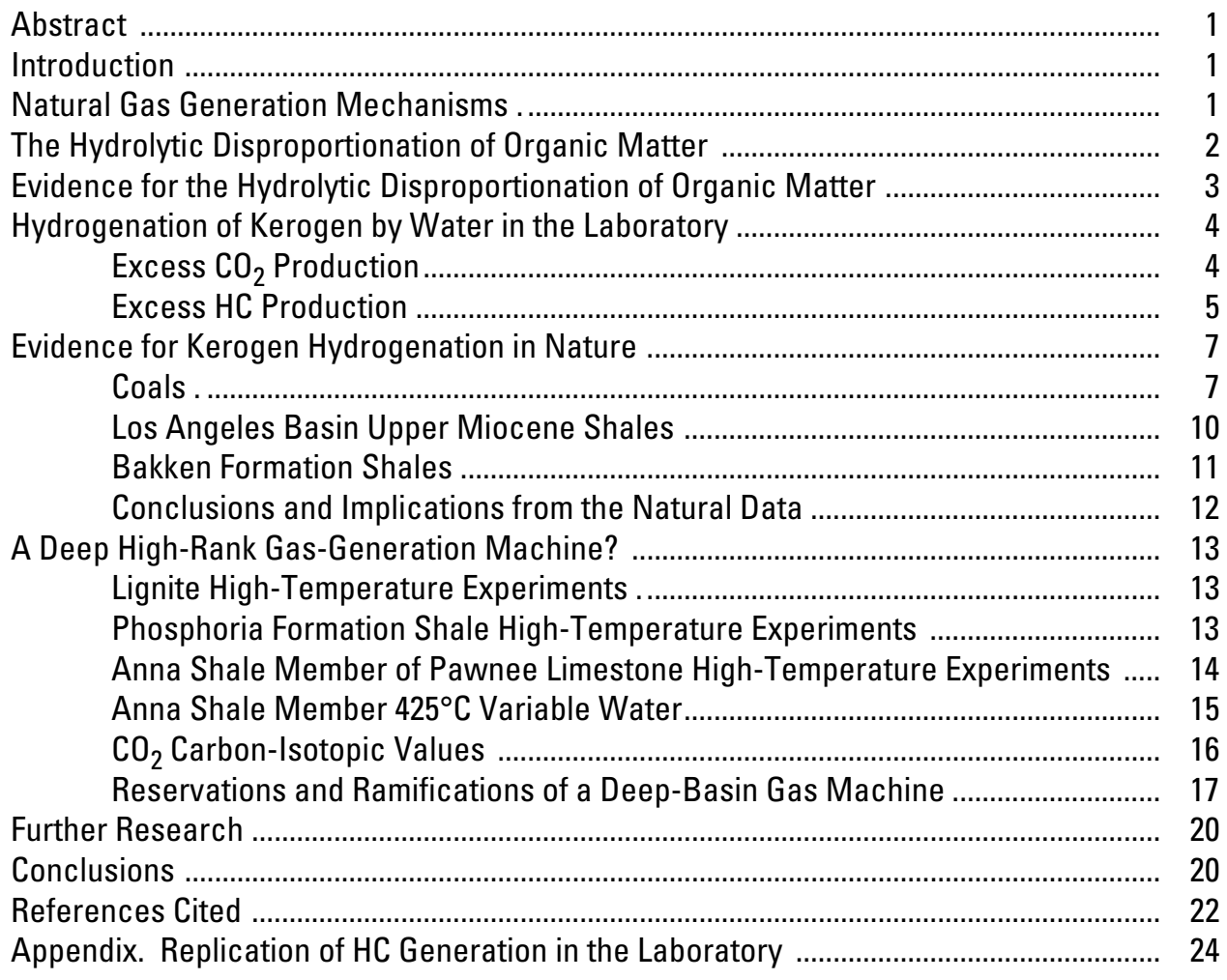

\section{Figures}

\section{1-12. Plots of:}

1. Generated $\mathrm{CO}_{2}$ versus experimental temperature for aqueous-pyrolysis experiments with three different source rocks

2. Generated $\mathrm{CO}_{2}$ versus experimental temperature for aqueous-pyrolysis experiments with two source rocks and a coal

3. HC-generation products versus experimental temperature for aqueous-pyrolysis experiments with a coal and a source rock

4. ROCK-EVAL data for a worldwide suite of coals versus vitrinite reflectance 1 1 2 3 4 4 5 7 7 10 11 12 13 13 13 14 15 16 17 20 20 22

5. ROCK-EVAL hydrogen indices versus vitrinite reflectance for a worldwide suite of coals .......................................................................

6. ROCK-EVAL data versus burial temperature for rocks from the Los Angeles Basin 
7. ROCK-EVAL hydrogen index versus burial depth for Bakken Formation shales, Williston Basin

8. HC-generation products for high-temperature $\left(>350^{\circ} \mathrm{C}\right)$ aqueous-pyrolysis experiments on the Phosphoria Formation shale

9. $\mathrm{HC}$-generation products for high-temperature $\left(>350^{\circ} \mathrm{C}\right)$ aqueous-pyrolysis experiments on the Anna Shale Member of Pawnee Limestone

10. Generated $\mathrm{CO}_{2}$ and $\mathrm{HC}$-generation products for constant temperature $\left(425^{\circ} \mathrm{C}\right)$ aqueous-pyrolysis experiments with the Anna Shale Member of Pawnee Limestone versus experimental rock/water ratio

11. Carbon-isotopic values of $\mathrm{CO}_{2}$ generated in variable-temperature aqueous-pyrolysis experiments for three rocks versus experimental temperature

12. Carbon-isotopic values of generated $\mathrm{CO}_{2}$ for aqueous-pyrolysis experiments on six rocks versus starting $\mathrm{CaCO}_{3}$ content of the rocks 


\title{
A Possible Deep-Basin High-Rank Gas Machine Via Water-Organic-Matter Redox Reactions
}

\author{
By Leigh C. Price
}

\begin{abstract}
Petroleum geochemistry is often portrayed as being well understood and capable of providing accurate predictions reflecting the reality of Nature. Nonetheless, important controlling parameters of organic metamorphism, including oil and gas generation, still go unrecognized. One such parameter is water, which plays especially pivotal roles in HC-generation reactions. Another is the origin of hydrocarbon gases and gas deposits, including deep-basin, high-rank, methane-rich gas deposits. The traditional view for the origin of $\mathrm{HC}$ gases-in-situ thermal cracking of oil deposits - has flaws which have been pointed out by different investigators. Consequently, alternate mechanisms for the origin of natural gas have independently been proposed. One such mechanism which is evaluated in this report is the hydrogenation of deep, high-rank spent kerogen by water, with subsequent generation of methane-rich $\mathrm{HC}$ gas.

Different investigators have presented data, from both the laboratory and Nature, which demonstrate that water, organic matter, and mineral phases take part in aqueous-based redox reactions in attempting to achieve or maintain a metastable equilibrium among themselves. This process has been termed "the hydrolytic disproportionation of organic matter." Data sets presented and discussed herein support a previous proposal that water and high-rank, deeply buried, post-mature kerogen possibly undergo hydrolytic-disproportionation reactions with one another, resulting in the generation of a high-rank methane-rich gas. The most important implication of this reaction occurring in Nature is the possible creation of very large, basin-centered, deep-basin, methane-rich gas reserves in continuous reservoirs.
\end{abstract}

\section{Introduction}

Organic metamorphism in Nature, including hydrocarbon (HC) generation, is traditionally portrayed (Tissot and Welte, 1984; Hunt, 1996) as being well understood and utilitarian in a predictive sense. HC-generation reactions are classically thought to occur by first-order reactions. Thus, geologic time and temperature are held as the only important controlling parameters of organic metamorphism, parameters which can be substituted for one another in first-order Arrhenius equations, which are thought to faithfully describe organic metamorphism in Nature. By these models, generation of $\mathrm{HC}$ gases is thought to occur mainly at elevated burial temperatures from a thermal destruction of oil, and perhaps $\mathrm{C}_{15}+$ hydrocarbons (HCS) residing in shales. Such thermal destruction is held to commence at a vitrinite reflectance $\left(\mathrm{R}_{\mathrm{o}}\right)$ value of 0.9 percent $\left(150^{\circ}-200^{\circ} \mathrm{C}\right.$, depending on the geologic time of burial, and the model being used). Complete $\mathrm{C}_{15}+\mathrm{HC}$ thermal destruction is depicted as occurring by $\mathrm{R}_{\mathrm{o}}=1.35$ percent, with the $\mathrm{C}_{2}-\mathrm{C}_{4} \mathrm{HC}$ gases completely being converted to methane by $\mathrm{R}_{\mathrm{O}}=2.0$ percent, and methane being thermally destroyed by $R_{0}=4.0$ percent.

A minority opinion exists among different investigators that the traditional models of $\mathrm{HC}$ generation are far too simplistic, and have trivialized the complexity and ignored other important controlling parameters of organic metamorphism. Much of this alternate viewpoint is discussed in Price (1997a) and will not be detailed here with two exceptions: the mechanics of natural gas generation and the role of water, via redox reactions, in organic metamorphism. These topics are pivotal to this report because of their control on a possible unrecognized source of high-rank natural gas, generated at great depths ( $>15,000-20,000 \mathrm{ft} ; 4,572-6,096 \mathrm{~m})$ in petroleum basins. As such, I first review these two topics and then discuss evidence, from both the laboratory and the natural system, which appears to strongly support the possible operation in Nature of processes which could result in generation of a late-stage, high-rank, methane-rich $\mathrm{HC}$ gas.

\section{Natural Gas Generation Mechanisms}

To repeat, thermogenic natural gas, especially methanerich "dry gas," has traditionally been thought to originate largely, or solely, from thermal destruction of oil at relatively low maturation ranks. Although this viewpoint is staunchly held by many petroleum geoscientists, there are major problems with the hypothesis: First, $\mathrm{C}_{15}+\mathrm{HCS}$ exhibit remarkable thermal stability in fine-grained sedimentary rocks, persisting to maturation ranks of at least $R_{0}=7-8$ percent (Price, 1993, and references therein). Moreover, biogenically derived saturated HCS, with sediment-like characteristics, including sedimentlike biomarkers, persist to high temperature in metamorphic and other crystalline rocks in moderate to low concentrations (Price and others, 1998) and even in mantle-derived rocks in low concentrations (Sugisaki and Mimura, 1994; Mimura and others, 1999). Numerous other investigators, including Kontorovich and Trofimuk (1976), Sagjò (1980), Guthrie and others (1986), Shock (1990), Mango (1990, 1991), Helgeson (1991), and McNeil and BeMent (1996) have either rejected the traditional view of the thermal instability of $\mathrm{C}_{15}+\mathrm{HCS}$ or have provided telling evidence that this generally accepted hypothesis is unrealistic.

A second problem with the hypothesis of $\mathrm{C}_{15}+\mathrm{HC}$ thermal instability is that the carbon-isotopic values of methane in drygas deposits are far too light (negative) to have originated from the thermal destruction of $\mathrm{C}_{15}+\mathrm{HCS}$ (Price, 1995). Other 
problems with the hypothesis of a pronounced thermal instability of $\mathrm{C}_{15}+\mathrm{HCS}$, and an exclusive, or even predominant, origin of $\mathrm{HC}$ gas from $\mathrm{C}_{15}+\mathrm{HC}$ thermal destruction are presented in Price (1983, 1993, 1995, and 1997a and b) and will not be reviewed here. Whereas some thermal cracking of oil may take place in certain deeply buried oil reservoirs, it is now clear to some investigators that the thermal instability of oil has been greatly overstated. As such, alternate mechanisms for gas generation, and for the origins of methane-rich dry gas, have been proposed by different researchers.

For example, Price (1989a) pointed out that data from both the natural system and laboratory $\mathrm{HC}$-generation experiments in closed water-wet systems demonstrate that $\mathrm{C}_{1}-\mathrm{C}_{4} \mathrm{HCS}$ are cogenerated in large quantities with $\mathrm{C}_{15}+\mathrm{HCS}$. Moreover, these same data demonstrate that the $\mathrm{C}_{1}-\mathrm{C}_{4} \mathrm{HC}$ gases are even generated in measurable amounts before mainstage $\mathrm{C}_{15}+\mathrm{HC}$ generation commences. Price (1989a, b) also pointed out that, based on data from these laboratory experiments, the $\mathrm{C}_{1}-\mathrm{C}_{4}$ $\mathrm{HC}$ gas absolute and relative (to the sum of all generated products) concentrations continuously increase, with increasing experimental temperature, throughout mainstage $\mathrm{C}_{15}+\mathrm{HC}$ generation.

Price and Schoell (1995) sampled oils and gases produced from the source rocks for the HCS (the Upper Devonian-Lower Mississippian Bakken Formation shales) in the North Dakota portion of the Williston Basin. Oils from this self-contained source-reservoir HC system, which had not migrated far from their generation sites (not more than $10 \mathrm{ft}, 3 \mathrm{~m}$ ), had gas-oil ratios averaging 1,100 standard cubic feet (SCF) of gas per barrel of oil. This observation conclusively demonstrated that large amounts of natural gas are cogenerated with oil in source rocks, thus corroborating the results of various laboratory experiments. In fact, I have calculated that 18.5 weight percent of the $\mathrm{HC}$ generation potential of Bakken shale kerogen went toward $\mathrm{C}_{1}-$ $\mathrm{C}_{4} \mathrm{HC}$ gases (unpub. data, 2000). Thus, cogeneration of $\mathrm{C}_{1}-\mathrm{C}_{4}$ $\mathrm{HC}$ gases with oil probably represents the most significant source of wet $\left(\mathrm{C}_{1}-\mathrm{C}_{4}\right) \mathrm{HC}$ gases in the natural system.

The origin of significant deposits of methane-rich ("dry") gas, with $>98$ percent $C_{1}$ and $\delta^{13} \mathrm{C}$ ratios of -39 to -50 , is problematic. As Price (1995) pointed out, if such gases originated from the thermal destruction of $\mathrm{C}_{15}+$ or $\mathrm{C}_{2}+\mathrm{HCS}$, the methanes should have isotopic values of -38 to -5 . Although dry gases exist in Nature with such values, they are usually associated with plutonic or volcanic intrusions or have been sourced from coals (resulting in the more positive $\delta^{13} \mathrm{C}$ ratios). This observation suggests that $\mathrm{C}_{2}+\mathrm{HC}$ thermal destruction is not a common occurrence in Nature. Moreover, Mango (1997) established that ethane is extremely thermally stable in Nature, with a half-life of billions of years at elevated temperatures. As an aside, dry gases with $\delta^{13} \mathrm{C}$ values of -45 to -50 reflect significant admixture of biogenic and thermogenic methanes (Price, 1995).

In light of the preceding considerations, different investigators have proposed alternate origins for these dry gases with light-isotopic values. For example, Mango and others (1994) were able to produce impressive exact examples of these gases in the laboratory using transition metals as catalytic agents during the thermal decomposition of longer-chained HCS. They thus proposed $\mathrm{HC}$ cracking, via transition-metal catalysis, to explain the origin of deposits of isotopically light dry gas. In contrast, McNeil and BeMent (1996) strongly criticized the hypothesis advanced by Mango and others (1994), and proposed instead demethylation reactions in deep post-mature kerogens, which had gone completely through mainstage $\mathrm{C}_{15}+\mathrm{HC}$ generation, to explain these methane-rich gas deposits.

Price (1995) and Price and Schoell (1995) proposed a migration and fractionation of $\mathrm{C}_{1}-\mathrm{C}_{4}$ wet $\mathrm{HC}$ gases generated by source rocks, to isotopically light methane-rich gases. Their mechanism centers on the fact that at significant burial depths, and therefore elevated fluid pressures, the $\mathrm{C}_{2}-\mathrm{C}_{4} \mathrm{HC}$ gases condense into a liquid phase (Salisbury, 1968; Mark Beeunas, Chevron USA, oral communs., June 8, 9, 1999). Thus, Price (1995) and Price and Schoell (1995) proposed that in Nature, the $\mathrm{C}_{2}-\mathrm{C}_{4} \mathrm{HC}$ gases in gas caps over deeply buried oil deposits condense into the oil phase, leaving a methane-rich gas cap riding over the oil deposit from buoyancy differences. As fluids continue to migrate into the trap, eventually the gas cap fills the trap to spill point, displacing the oil phase containing condensed $\mathrm{C}_{2}-\mathrm{C}_{4} \mathrm{HC}$ gases updip to another trap or to commence long-lateral secondary migration (Gussow's (1954) principle of differential entrapment). This process eventually would leave all deep-basin traps filled with dry gas, wherein the methanes would have isotopic signatures characteristic of cogeneration with oil, for example, $\delta^{13} \mathrm{C}$ values of -39 to -50 . Price (1995) termed this process "migration-fractionation."

It is possible that all three of these mechanisms contribute to the formation of dry-gas deposits, or that other yet-unidentified processes are responsible. However, in my opinion, the thermal destruction of $\mathrm{C}_{2}+\mathrm{HCS}$, including $\mathrm{C}_{15}+\mathrm{HCS}$, plays only a minor role, if any, in the creation of dry-gas deposits. As an aside, some investigators have been reticent to accept the possibility of dry-gas formation via transition-metal catalysis, because it has not yet been demonstrated that the laboratory conditions that have resulted in such impressive experimental results are applicable to Nature.

Another possible origin for deep-basin HC gases (proposed by Seewald, 1994) is generation of high-rank methane-rich gas via oxidation-reduction (redox) reactions between water, spent kerogen, and mineral phases. Seewald's (1994) proposal centers on the hydrolytic disproportionation of kerogen. An assessment of the feasibility of this generation path for high-rank natural gases from existing data from both the laboratory and the natural system is the purpose of this report. However, at the outset, we must define, characterize, and provide evidence for the hydrolytic disproportionation of organic matter (OM).

\section{The Hydrolytic Disproportionation of Organic Matter}

In traditional oil and gas generation models, water and most forms of organic matter (OM), especially kerogen and naturally occurring HCS, traditionally are viewed as being completely unreactive. However, Shock (1988) and Helgeson and Shock (1988) proposed the existence of a metastable equilibrium between rocks, water, and reservoired oil in petroleum 
basins, based on thermodynamic considerations. The different phases are linked by the reaction,

$$
2 \mathrm{CO}_{2}(\mathrm{aq})+2 \mathrm{H}_{2} \mathrm{O} \longleftrightarrow \mathrm{CH}_{3} \mathrm{COOH}_{(\mathrm{aq})}+2 \mathrm{O}_{2}(\mathrm{~g})
$$

Helgeson and others (1993) termed the process, "the hydrolytic disproportionation of OM." The overall reaction is thought to be irreversible; however, both reversible and irreversible intermediate reactions occur during the process. The end products are $\mathrm{CO}_{2}$ and $\mathrm{CH}_{4}$. A strong theoretical foundation also exists for the formation of intermediate-step compounds, including lowmolecular weight $\mathrm{HCS}$ and various species of oxygen-bearing (oxidized) HCS. Where the process has proceeded extensively, high concentrations of low-molecular weight $\left(\mathrm{C}_{1}-\mathrm{C}_{6}\right.$ to $\left.\mathrm{C}_{1}-\mathrm{C}_{10}\right)$ HCS would result. The term "hydrolytic disproportionation of OM" results from the premise that water disproportionates into charged ions which then react with OM, which also disproportionates, to form an oxidized carbon species and a lower-molecular weight $\mathrm{HC}$, compared to the molecular weight of the starting OM. Helgeson and others (1993) noted that when all phases (water, OM, and minerals) of a geologic system are in equilibrium with one another, hydrolytic disproportionation of OM would not occur. However, when these phases are out of equilibrium with one another, such reactions would proceed.

\section{Evidence for the Hydrolytic Disproportionation of Organic Matter}

The hypothesis of the hydrolytic disproportionation of $\mathrm{OM}$ has strong supporting evidence from both the natural system and the laboratory. French (1964) carried out experimental siderite synthesis and stability studies, and inadvertently produced measurable amounts of oxidized HCS (alcohols, organic acids, ketones, among others), and most probably HCS themselves, starting only with water and $\mathrm{FeCO}_{3}$. Palmer and Drummond (1986) and Bell and others (1994) also inadvertently produced HCS from water and acetic acid, while experimentally examining aqueous acetic-acid thermal stability. Hoering $(1968,1984)$ deuterated both shale kerogen and HCS with deuterated water, demonstrating that kerogen and HCS exchange hydrogen with water, a pivotal observation.

Seewald (1994) conducted experiments in gold bags containing water, ethane, ethene, and the naturally occurring mineral buffer of pyrite-pyrrhotite-magnetite, which set the oxygen (hydrogen) fugacity of the system. When experimental conditions were modified by injecting ethane, ethene, or water into the system, or by changing the experimental temperature, the ethane:ethene ratio in the system would gradually change towards the equilibrium ratio expected from thermodynamic calculations, given the experimental conditions. The concentrations of $\mathrm{CH}_{4}, \mathrm{CO}_{2}, \mathrm{H}_{2} \mathrm{~S}$, and $\mathrm{H}_{2}$ would also change accordingly, demonstrating that carbon-carbon bonds were being broken. Seewald (1994) concluded that ethane, ethene, water, the mineral buffer, and the other dissolved species were all in reversible equilibrium by exchanging hydrogen and (or) oxygen with one another, and thus provided convincing evidence of the existence of the hydrolytic disproportionation of OM under laboratory conditions. Of pivotal interest to our discussion, considering his experimental results, Seewald (1994) proposed that water might hydrogenate spent, deeply buried, high-rank, post-mature kerogens, which could then generate significant amounts of deepbasin high-rank methane-rich HC gas. We will return to Seewald's (1994) proposal after reviewing evidence that the hydrolytic disproportionation of OM is widespread throughout the natural system.

Price and others (1998) extracted low to moderate concentrations (0.5-200 ppm) of highly modified bitumens, compared to the bitumens found in sedimentary rocks, from crystalline metamorphic and ore-deposit rocks, with maximum "burial" temperatures of $500^{\circ} \mathrm{C}$. These bitumens had high relative concentrations of oxidized HCS (ketones, esters, and aldehydes), and especially of 1,2-benzene dicarboxylic acid esters, and the aromatic-HC and resin fractions of the bitumens had been fundamentally chemically transformed to compositions never before reported in the literature. Pivotally, the results of Price and others (1999) confirmed predictions previously made by Helgeson (1991) and Helgeson and others (1993) regarding the consequences of the hydrolytic disproportionation of OM: (1) high concentrations of oxygen-bearing (oxidized) HCS, (2) the presence of dicarboxylic acids, (3) high concentrations of light HCS, and (4) highly extended HC thermal stabilities. Price and others (1998) concluded that the hydrolytic disproportionation of OM was a previously unrecognized geologic agent of the first magnitude.

Price and others (1998) also concluded that the principal control of the hydrolytic disproportionation of OM is an openfluid system, wherein water or OM flow past one another, resulting in the different phases of a given system being out of equilibrium with each other. In closed-fluid systems, the different phases would reach a metastable equilibrium with one another, and the process would halt. Price and others (1998) also provided a large body of evidence demonstrating the widespread existence of the process in, as well as results of the process from, many different geologic regimes, including petroleum basins. One of these lines of evidence specifically concerns us here: the hydrogen-enrichment of kerogen by water, via the hydrolytic disproportionation of kerogen, during HC generation, including gas generation, reactions. Price and others (1998) found strong evidence for this reaction between kerogen and water in the closed-system, water-wet, aqueous-pyrolysis experiments of Price (1989a, b), Wenger and Price (1991), and Price and Wenger (1992). The results of these experiments also have strong implications for the possible previously unrecognized high-rank, deep-basin, late generation of $\mathrm{HC}$ gases under discussion.

Key data in this report are derived from both ROCK-EVAL analysis and aqueous-pyrolysis experiments. Thus, perceived weaknesses of ROCK-EVAL, the experimental procedures of aqueous pyrolysis, and the validity of $\mathrm{HC}$ generation experiments carried out in the laboratory as a representation of $\mathrm{HC}$ generation in Nature are all discussed at length in an appendix. Suffice it to say that, as discussed in the appendix, the aqueouspyrolysis experiments of Wenger and Price (1991) and Price and Wenger (1992) have a proven record of closely replicating 
numerous aspects of HC generation in Nature, including important aspects which previously were unrecognized. As also discussed in the appendix, cross plots of ROCK-EVAL hydrogen indices to kerogen hydrogen to carbon ratios for our different sample bases demonstrate very good correlations.

\section{Hydrogenation of Kerogen by Water in the Laboratory}

\section{Excess $\mathrm{CO}_{2}$ Production}

In the aqueous-pyrolysis experiments carried out with six different rocks at variable temperatures (Price, 1989a, b; Wenger and Price, 1991; Price and Wenger, 1992), much more $\mathrm{CO}_{2}$ was generated than possibly could be accounted for, considering the original oxygen content of the kerogens. Moreover, the same effect occurs in hydrous-pyrolysis experiments (Lundegard and Senftle, 1987; Barth and others, 1989; Lewan, 1992). This effect appears to be present in all HC-generation experiments carried out in closed, water-wet systems. Examples of this excess $\mathrm{CO}_{2}$ from the HC-generation experiments of Wenger and Price (1991) are shown in figures 1 and 2.

In figure 1 , the amounts of $\mathrm{CO}_{2}$ generated from three different OM types (Type-I, Eocene Green River Formation shale; Type-II-S, Lower Permian Phosphoria Formation shale; and Type-II/III, Middle Pennsylvanian Anna Shale Member of Pawnee Limestone) are shown. In all three cases, 100 percent equals the maximum amount of $\mathrm{CO}_{2}$ possible, given the original oxygen content of the kerogen. Kerogen oxygen contents were determined by ROCK-EVAL oxygen indices. However, kerogen elemental analyses performed on these same samples yield the same results (L.C. Price and L.M. Wenger, unpub. data, 1991). For all experiments, carbonate-carbon determinations on the reacted shales were carried out by Huffman Laboratories, Golden, Colo., by acid dissolution of the carbonate minerals and measurement of the liberated $\mathrm{CO}_{2}$. These analyses were accurate to 0.5 percent of the reported value. Thus, we were able to subtract any $\mathrm{CO}_{2}$ contributions from reactions of carbonate minerals during the experiments from the total $\mathrm{CO}_{2}$ values,

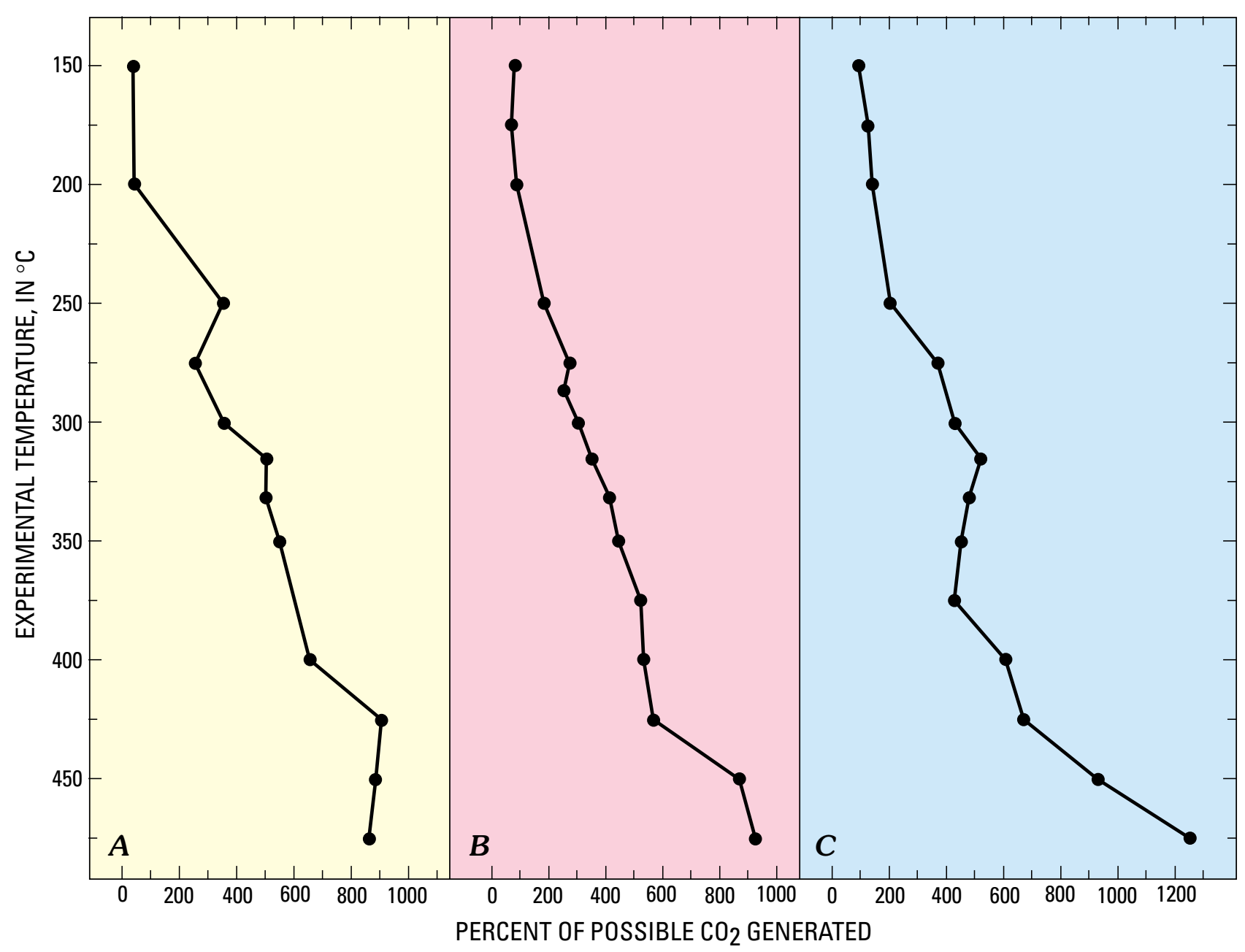

Figure 1. Percent of $\mathrm{CO}_{2}$ generated over what is possible, based on the original oxygen content of the kerogens, for three rocks (Eocene Green River Formation shale, Type-I OM (fig. 1A); Lower Permian Phosphoria Formation shale, Type-II-S OM (fig. 1B); and Middle Pennsylvanian Anna Shale Member of Pawnee Limestone, Type-II/III OM (fig. 1C)) on which 30-day, variable-temperature aqueous-pyrolysis HC-generation experiments were performed. 
to obtain the figure 1 values. In the figure 1 rocks, mainstage pyrolytic $\mathrm{HC}$ generation commences at $250^{\circ} \mathrm{C}\left(275^{\circ} \mathrm{C}\right.$ for the Green River shale) and is complete by $320^{\circ}-333^{\circ} \mathrm{C}$. Experimental temperatures of $350^{\circ} \mathrm{C}$ and higher represent mainstage $\mathrm{C}_{8}+\mathrm{HC}$ thermal destruction. From figure 1 , excess $\mathrm{CO}_{2}$ is generated from all three rocks before mainstage $\mathrm{HC}$ generation commences and also during both the mainstage HC-generation and the HC-destruction phases.

In figure 2, the same type of data is shown for the other three rocks on which variable temperature experiments were also performed: the Upper Devonian-Lower Mississippian Bakken Formation shale (fig. 2A, Type-II/I OM), the Eocene Rattlesnake Butte lignite (fig. $2 B$, Type-IV OM), and a composite of mid-Miocene Monterey Formation time-equivalent Los Angeles Basin shales (fig. 2C, Type-II OM). In all three cases, excess $\mathrm{CO}_{2}$ is generated before, during, and after mainstage $\mathrm{C}_{15^{+}}+\mathrm{HC}$ generation, which occurs from between $250^{\circ} \mathrm{C}$ and $275^{\circ} \mathrm{C}$, to $333^{\circ} \mathrm{C}$.

\section{Excess HC Production}

Not only is excess $\mathrm{CO}_{2}$ generated in these experiments, but also excess HCS are generated, based on the starting values of the ROCK-EVAL $S_{2}$ peaks of all six rocks. At the temperatures exceeding $150^{\circ}, 175^{\circ}$, and $200^{\circ} \mathrm{C}$ in figure $3 A$, the $S_{2}$ peak increases from a starting value of $96.6 \mathrm{mg} / \mathrm{g}$, to values of 97.6 to $104.9 \mathrm{mg} / \mathrm{g}$. The hydrogen index also increases from 451 to between 478 and 507. In other words, over the lower temperature $\left(150^{\circ}-200^{\circ} \mathrm{C}\right)$ experiments, the $\mathrm{HC}$-generation potential of the rock is being increased.

In figure $3 A$, the $\mathrm{HC}$-generation products $\left(\mathrm{C}_{1}-\mathrm{C}_{4} \mathrm{HC}\right.$ gases, $\mathrm{C}_{5}+$ saturated and aromatic HCS $\left(\mathrm{C}_{5}+\mathrm{HCS}\right)$, and resins plus asphaltenes, NSO+ASP) are plotted, along with the value of the $\mathrm{S}_{2}$ peak measured for the Soxhlet-extracted shale for each experimental run, all in $\mathrm{mg} / \mathrm{g}$ rock, for the aqueous-pyrolysis 30 day, variable-temperature experiments carried out with the Phosphoria shale. As is apparent from figure $3 A$, in the $150^{\circ}$, $175^{\circ}$, and $200^{\circ} \mathrm{C}$ experimental runs, the sums of the generated products, plus the $S_{2}$ value for the extracted shale of the particular experiment, all exceed the starting (and theoretically the maximum) value, which is $118.5 \mathrm{mg} / \mathrm{g}$, of the extractable bitumen plus the HC-generation potential of the Phosphoria shale (dashed line, fig. 3A). In other words, at first glance, it appears that something is being made from nothing. Moreover, above $200^{\circ} \mathrm{C}$, the sum of the $\mathrm{S}_{2}$ peak and the generated products exceeds the theoretical limit of $118.5 \mathrm{mg} / \mathrm{g}$ by even greater amounts, reaching maximum values of between 162 and 169

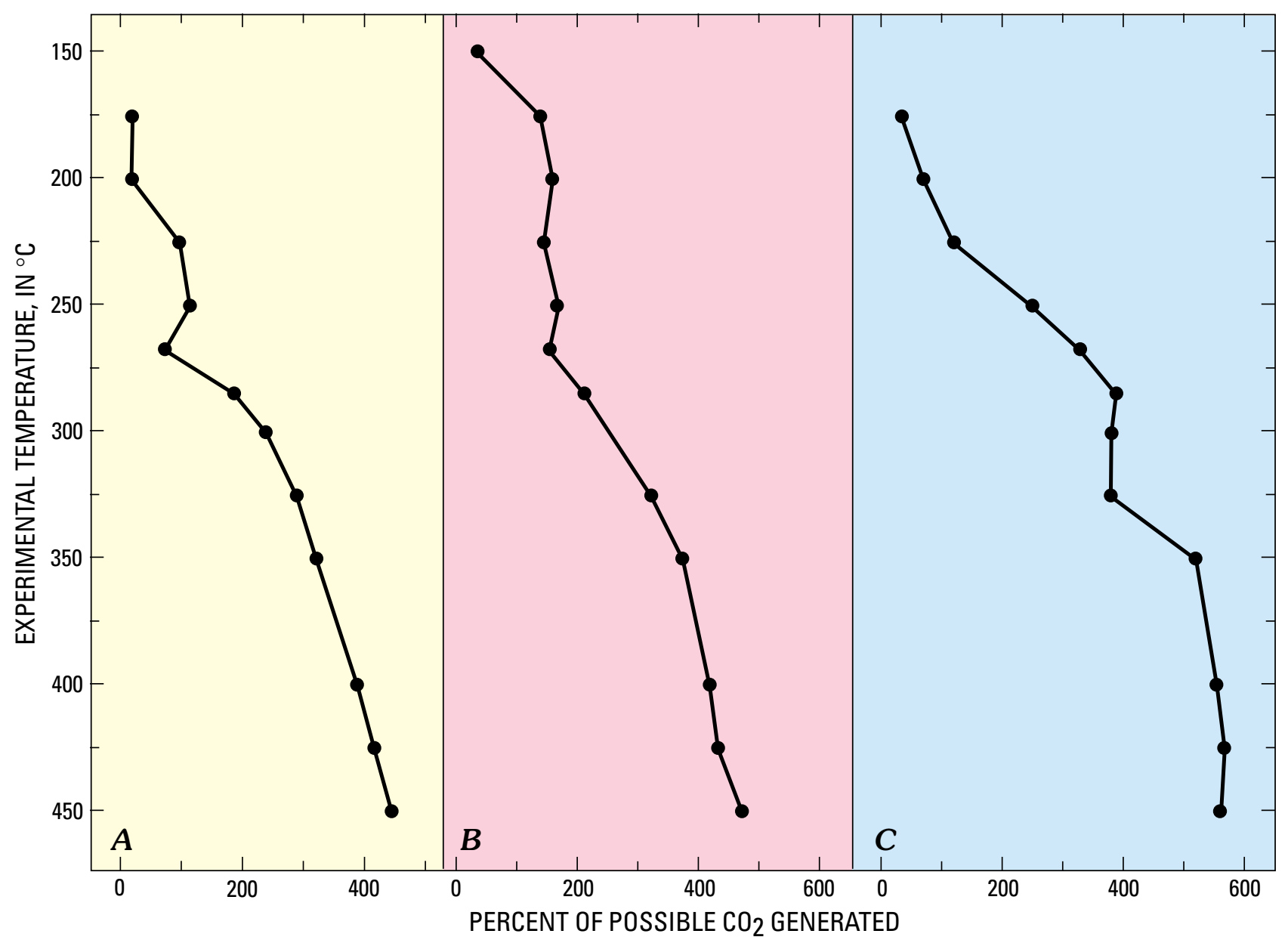

Figure 2. Percent of $\mathrm{CO}_{2}$ generated over what is possible, based on the original oxygen content of the kerogens, for three rocks (Upper Devonian-Lower Mississippian Bakken Formation shale, Type-II/I OM (fig. 2A); Eocene Rattlesnake Butte lignite (fig. 2B); and composite of mid-Miocene Monterey Formation time-equivalent shales, Los Angeles Basin, Type-II OM (fig. 2C)) on which 30-day variable-temperature aqueous-pyrolysis HC-generation experiments were performed. 
$\mathrm{mg} / \mathrm{g}$ at $275^{\circ}-333^{\circ} \mathrm{C}$. I attribute the creation of excess generation potential in figure $3 A$ to water undergoing redox reactions with kerogen, with the oxygen from the water being given off as excess $\mathrm{CO}_{2}$, and the hydrogen from the water hydrogenating the kerogen, thus increasing its generation potential.

Mainstage $\mathrm{C}_{15}+\mathrm{HC}$ generation commences at $250^{\circ} \mathrm{C}$ in the Phosphoria shale experiments (fig. $3 A$ ). However, significant generation of resins and asphaltenes commences at lower temperatures, somewhere between $200^{\circ}$ and $250^{\circ} \mathrm{C}$. Between $333^{\circ}$ and $350^{\circ} \mathrm{C}$, mainstage $\mathrm{C}_{15}+\mathrm{HC}$ thermal destruction commences and largely proceeds to completion. However, from $350^{\circ}$ to $450^{\circ} \mathrm{C}$, the amount of generated $\mathrm{HC}$ gases increases from 33.5 $\mathrm{mg} / \mathrm{g}$ rock to $76.5 \mathrm{mg} / \mathrm{g}$ rock, a difference of $43.0 \mathrm{mg} / \mathrm{g}$ rock (fig. $3 A$ ), whereas the sum of the $\mathrm{C}_{5}+$ products and the $\mathrm{S}_{2}$ peak decreases from $29.0 \mathrm{mg} / \mathrm{g}$ rock at $350^{\circ} \mathrm{C}$ to $8.5 \mathrm{mg} / \mathrm{g}$ rock at $450^{\circ} \mathrm{C}$, a difference of only $20.5 \mathrm{mg} / \mathrm{g}$ rock. This leaves an increase in generated products of $22.5 \mathrm{mg} / \mathrm{g}$, and again it appears that something is being made from nothing. We are most concerned with the data from the $350^{\circ}$ to $450^{\circ} \mathrm{C}$ experiments, data we discuss in the section, "A Deep High-Rank GasGeneration Machine?."

In figure $3 A$, in proceeding from $333^{\circ} \mathrm{C}$ to $350^{\circ} \mathrm{C}$ during the wholesale destruction of $\mathrm{C}_{15}+\mathrm{HCS}$, significant charring occurred and carbon was added back into the Phosphoria shale sample. Thus the total organic carbon (TOC) content of the shale increased from 12.70 percent at $333^{\circ} \mathrm{C}$ to 15.54 percent at $350^{\circ} \mathrm{C}$. However, charred carbon was also deposited on the stainless-steel walls of the reaction vessels, from where it could not be quantitatively recovered. The TOC values for the Phosphoria shale from experiments above $333^{\circ} \mathrm{C}$ are thus all minimal values.

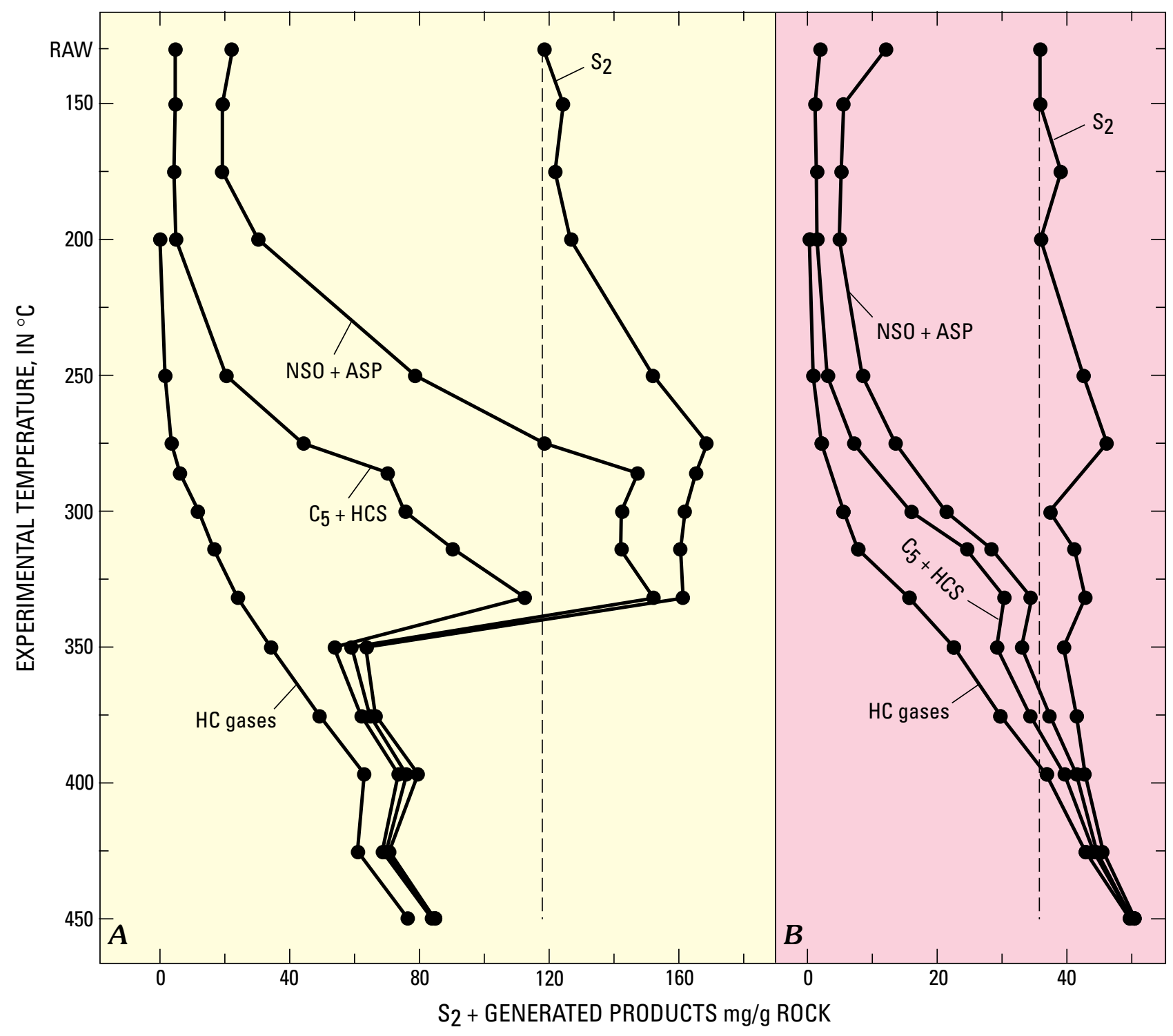

Figure 3. Plot of generated products: $\mathrm{HC}$ gases, $\mathrm{C}_{5}+$ saturated and aromatic $\mathrm{HCS}\left(\mathrm{C}_{5}+\mathrm{HCS}\right)$, and resins and asphaltenes (NSO+ASP), plus the $S_{2}$ peak $\left(S_{2}\right)$, all in milligrams per gram of rock $(\mathrm{mg} / \mathrm{g})$, for the starting rock ("RAW") and for rock samples after 30-day aqueouspyrolysis experiments on the Phosphoria Formation shale (fig. $3 A$ ) and the Rattlesnake Butte lignite (fig. $3 B$ ). The light-dashed vertical lines trace the theoretical maximum of $\mathrm{HC}$-generation capacity and generated products for both rocks. 
Figure $3 B$ is a plot of all the $\mathrm{HC}$ generation products $\left(\mathrm{C}_{1}-\right.$ $\mathrm{C}_{4} \mathrm{HC}$ gases, $\mathrm{C}_{5}+$ saturated and aromatic HCS, and resins plus asphaltenes) plus the $S_{2}$ value measured for the Soxhletextracted rock for each experimental run, all in $\mathrm{mg} / \mathrm{g}$ of rock, for the 30-day, variable-temperature, aqueous-pyrolysis experiments carried out with the Eocene Rattlesnake Butte lignite. The lignite has a starting ROCK-EVAL hydrogen index of 48.8 (Type-IV OM), with a low capacity for $\mathrm{C}_{15}+$ bitumen generation. At all experimental temperatures above $150^{\circ} \mathrm{C}$, the sum of both the products and the HC-generation potential in the lignite exceeds the sum of the original products and the original HCgeneration potential (the $S_{2}$ peak), as traced by the light-dashed vertical line, albeit only slightly for some temperatures. Thus, as with the Phosphoria shale, mass appears to be added to the OM. The same results (excess generation products given the original organic richness of the shales) were also obtained for the 30-day aqueous-pyrolysis experiments performed on the other four rocks of figures 1 and 2 .

Comparison of figure $3 A$ with $3 B$ reveals some differences. Relatively small amounts of $\mathrm{C}_{15}+\mathrm{HCS}$ are generated by the lignite compared to Phosphoria shale, and the HC gases make up a much greater normalized percentage of the total products in the lignite. Mainstage $\mathrm{HC}$ thermal destruction commences in the lignite between $333^{\circ}$ and $350^{\circ} \mathrm{C}$. However, the significant decrease in $\mathrm{C}_{5}+$ generated products, so apparent over this temperature interval in the Phosphoria shale (fig. $3 A$ ), is much less apparent in the lignite (fig. $3 B$ ). This observation is largely valid because of a much smaller amount of $\mathrm{C}_{5}+$ generated products in the lignite experiments compared to those with the Phosphoria shale.

Another difference between the lignite and Phosphoria results is that in the lignite experiments, at temperatures above $150^{\circ} \mathrm{C}$, there is an excess of generated products and HC-generation capacity over all experimental temperatures, including the highest experimental temperatures (fig. $3 B$ ). In contrast, in the Phosphoria experiments, excess products and HC-generation capacity appear to be present only between over $150^{\circ}$ and $333^{\circ} \mathrm{C}$ (fig. $3 A$ ). Both rocks have a maximum in their excess products at $275^{\circ} \mathrm{C}$ (fig. $3 A, 3 B$ ). However, the lignite has its greatest maximum in excess generated products at $450^{\circ} \mathrm{C}$ (fig. $3 B$ ), with a 40.0 percent excess, a number which is equivalent to the 42.5 percent excess of generated products and HC-generation capacity at $275^{\circ} \mathrm{C}$ in the Phosphoria experiments (fig. $3 A$ ).

The differences between the two rocks are almost certainly due in part to the vastly different OM types in the two rocks. The Phosphoria shale has hydrogen-rich Type-II-S OM, with a starting ROCK-EVAL hydrogen index of 451, a value which increases to a maximum of 507 in the $175^{\circ} \mathrm{C}$ experiment. In contrast, the lignite has hydrogen-poor Type-IV OM with a starting ROCK-EVAL hydrogen index of only 48.8, a value which increases to a maximum of 77.9 to 78.6 in the $175^{\circ}-$ $250^{\circ} \mathrm{C}$ experiments. These two different $\mathrm{OM}$ types no doubt followed different reaction paths in the aqueous-pyrolysis experiments.

Note in figure $3 B$ that, as with the Phosphoria shale, there is a steady increase in the amount of $\mathrm{HC}$ gases generated by the lignite above $350^{\circ} \mathrm{C}$. This observation has significant implications for the possible unrecognized deep-basin, high-rank gasgeneration mechanism we are concerned with.
The lignite had the most hydrogen-poor OM of the six rocks on which aqueous-pyrolysis experiments were performed (Wenger and Price, 1991). Yet the lignite generated the highest percentages of methane and $\mathrm{C}_{2}-\mathrm{C}_{4} \mathrm{HC}$ gases, as normalized to the total generated products. The $\mathrm{HC}$ gases, especially methane, are the most hydrogen-rich products generated by source rocks. That the most hydrogen-poor OM generates the highest relative amounts of hydrogen-rich product suggests that $\mathrm{C}_{5^{+}}$ side chains are minimized, and $\mathrm{C}_{1}$ to $\mathrm{C}_{4}$ side chains are maximized, on hydrogen-poor kerogens, compared to hydrogen-rich kerogens. Although the lignite generates higher percentages of $\mathrm{HC}$ gases as normalized to total products, all five of the other rocks we studied generated far higher absolute amounts of $\mathrm{HC}$ gases as normalized to the TOC content in the starting rock. Thus, hydrogen-poor OM should not necessarily be considered as a prolific gas source.

The data from figures 1-3 are best explained, in my opinion, by water in the closed water-wet aqueous-pyrolysis experiments reacting with kerogen, and producing far more $\mathrm{CO}_{2}$ before and during $\mathrm{HC}$ generation (figs. 1,2) than can be accounted for given the original oxygen content of the kerogen. Moreover, many other experimentalists have noted this same feature, including Lundegard and others (1984), Lewan (1992), and Stalker and others (1994). However, the aqueous-pyrolysis experiments of Wenger and Price (1991) also clearly demonstrate that the hydrogen from this water is being chemically incorporated into kerogen and coal, to increase their HC-generation capacity significantly beyond their starting values (fig. $3 A$, 3B). Hoering (1984) and Lewan (1991) have called upon freeradical mechanisms to account for the excess $\mathrm{CO}_{2}$ from water hydrogenating kerogen. In contrast, Siskin and Katritzky (1991), Ross (1992), Price and others (1998), and Larson (1999) have advocated ionic pathways. Price and others (1998) pointed out that the products of hydrolytic disproportionation reactions with OM were identical to those from classic organic-chemical ionic-based redox reactions, thus indicating that the reactions in Nature responsible for these products largely proceeded via ionic reaction pathways. The actual mechanism for this reaction is not important for our discussion, rather the critical observation is that the reaction clearly occurs in laboratory experiments. Moreover, this reaction is an oxidation-reduction reaction of the type envisioned by Shock (1988), Helgeson and Shock (1988), and Helgeson and others (1993) - in other words, the hydrolytic disproportionation of kerogen. Lastly, large data bases from the natural system demonstrate that the hydrogenation of kerogen by water occurs in Nature.

\section{Evidence for Kerogen Hydrogenation in Nature}

\section{Coals}

ROCK-EVAL analyses for Paleozoic to Tertiary coals from worldwide locations from Teichmüller and Durand (1983) are shown in figure 4 . Note that between $R_{0}=0.2$ and 0.7 percent, a 


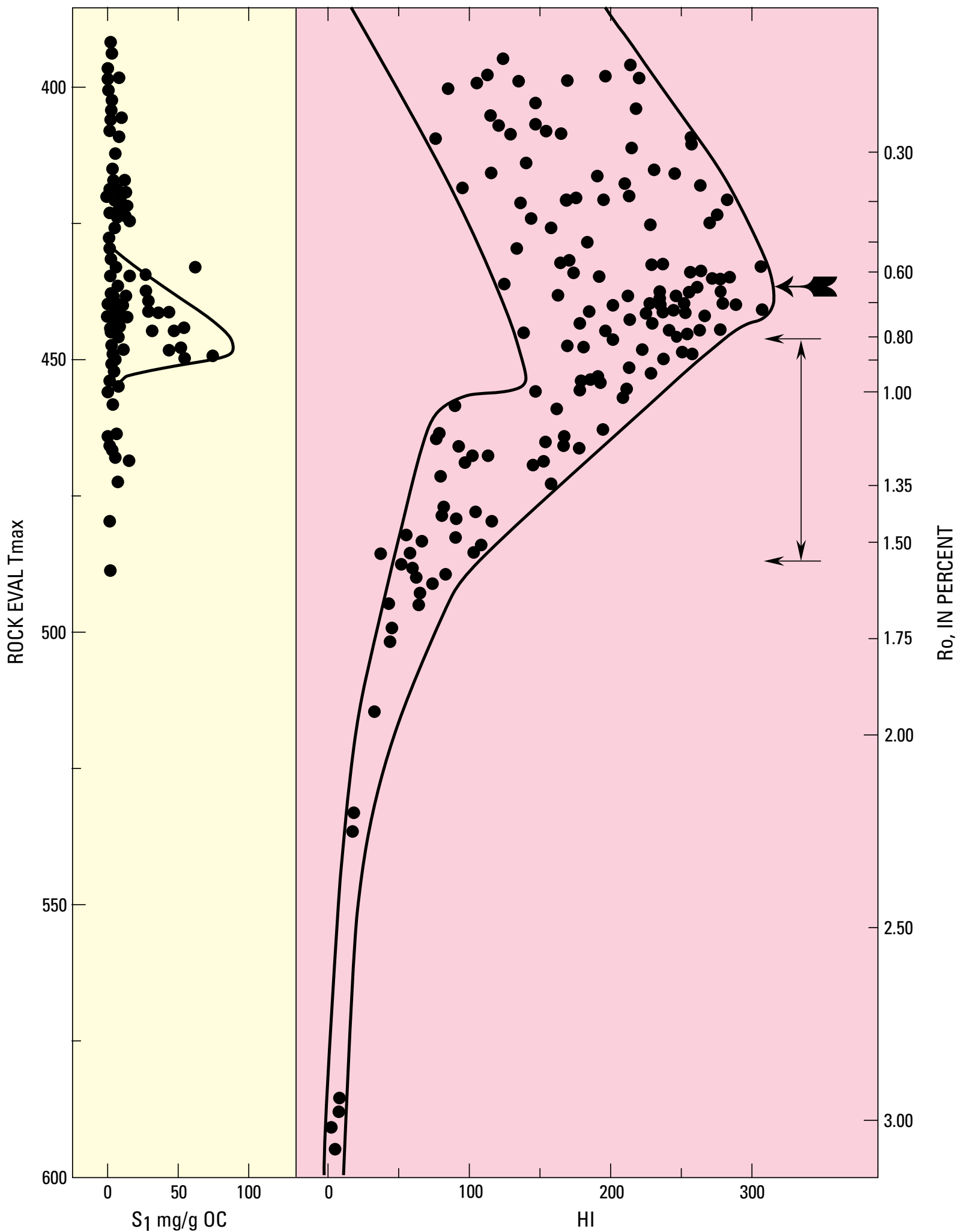

Figure 4. The ROCK-EVAL TOC-normalized $S_{1}$ and $S_{2}$ (hydrogen index) pyrolysis peaks plotted versus vitrinite reflectance $\left(R_{0}\right)$ and the ROCK-EVAL $T_{\max }$ for Paleozoic to Tertiary coals worldwide. Feathered arrow indicates the maximum in hydrogen-index data. Bracketed vertical arrows indicate maximum loss in the hydrogen index from $\mathrm{HC}$ generation. Data from Teichmüller and Durand (1983), whose original vitrinite reflectance data were given in $R_{m}$ values; $R_{m}$ was converted to $R_{0}$ by $R_{m}=1.066 R_{0}$.

dramatic increase in the hydrogen indices of the coals occurs, regarding minimum, maximum, and mean values. For example, the mean hydrogen-index value of 150 for the least mature coals increases to 220 at $R_{0}=0.7$ percent. The decrease in hydrogen indices at $R_{\mathrm{O}}$ values in excess of 0.7 percent is due to the commencement of intense $\mathrm{HC}$ generation. This is evidenced by the 
increase in the $S_{1}$ pyrolysis peak, which is equivalent to Soxhletextractable HCS (Price and others, 1984), at these same ranks.

A plot of the ROCK-EVAL hydrogen index versus mean vitrinite reflectance $\left(R_{m}\right)$ is shown in figure 5 for an entirely different set of worldwide coals from Bertrand (1984). We see the same dramatic increase in ROCK-EVAL hydrogen indices over $\mathrm{R}_{\mathrm{O}}=0.2-0.7$ percent in Bertrand's (1984) data set as occurred in figure 4. The hydrogen-index increase in figure 5 appears to be more pronounced than that of figure 4; however, this is largely due to the compressed vertical scale in figure 5 as compared to figure 4. In actuality, the two data sets are very similar; for example, in figure 5 the mean hydrogen-index values at $R_{\mathrm{O}}=0.2$ and 0.7 percent are 150 and 230 (an increase of 53 percent) versus 150 and 220 (an increase of 47 percent) in the figure 4 data.

One may attribute the increases in the hydrogen indices of the coals of figures 4 and 5 to a loss of the original oxygen in the coals via $\mathrm{CO}_{2}$ loss. Such a loss of oxygen does occur from coals and kerogens at low ranks $\left(\mathrm{R}_{\mathrm{O}}=0.2-0.8\right.$ percent $)$, and this $\mathrm{CO}_{2}$ loss would slightly increase hydrogen indices. However, given the range of original and final atomic oxygen to carbon ratios of coals, mass-balance calculations demonstrate that this oxygen loss could account for only a fraction of the increase in hydrogen indices in figures 4 and 5 . No recognized mechanism can explain the hydrogen-index increases in figures 4 and 5. Thus, I

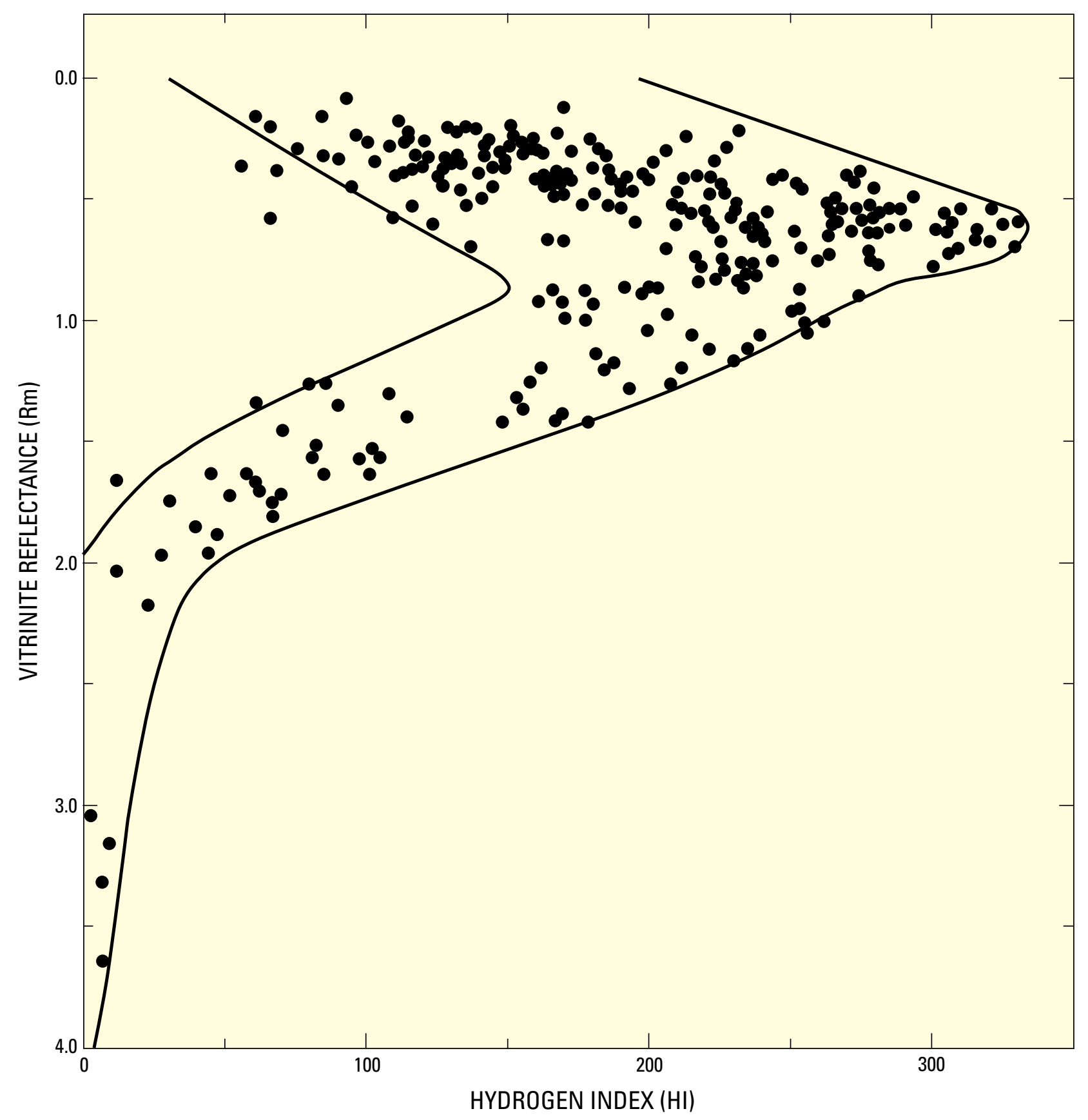

Figure 5. Mean vitrinite reflectance $\left(R_{m}\right)$ versus the ROCK-EVAL hydrogen index for coals worldwide and all geologic ages. Modified from Bertrand (1984). 
attribute these increases as evidence from the natural system that the hydrogenation of coal by water, which occurs in closed, water-wet HC-generation experiments, also occurs in Nature.

\section{Los Angeles Basin Upper Miocene Shales}

The increase in hydrogen indices at low ranks before $\mathrm{HC}$ generation occurs is not limited to coals. Figure 6 shows a large number of ROCK-EVAL analyses versus burial temperature for upper Miocene siltstones and shales with Type-III OM (ROCKEVAL hydrogen indices $<300$ ) from the Los Angeles Basin, Calif. Commencement of intense HC generation (CIHG) is evident from the increase in the TOC-normalized $S_{1}$ peak at a burial temperature of $100^{\circ} \mathrm{C}$. In figure 6 , before $\mathrm{HC}$ generation commences, as with both figures 4 and 5, minimum, maximum, and mean hydrogen-index values all dramatically increase. For example, in figure 6 at $80^{\circ} \mathrm{C}$, the mean hydrogen-index value is around 150 , and at $140^{\circ} \mathrm{C}$, where the maximum hydrogen-index values occur, the mean value is about 225 (an increase of 50 percent).

As discussed in Price and others (1999), part of the increase in hydrogen indices in figure 6 at shallow depths of burial (corresponding to burial temperatures of $40^{\circ}-80^{\circ} \mathrm{C}$ ) is from vertical facies variations in the rocks that lead to significant decreases in organic richness in the shallowest rocks. Therefore, to best gauge the extent of the contribution of kerogen hydrogenation to the increase in kerogen hydrogen indices, samples with burial temperatures less than $80^{\circ} \mathrm{C}$ in figure 6 are excluded from consideration.

The figure 6 data also demonstrate that kerogen hydrogenation is occurring in these rocks not only before, but also during, $\mathrm{HC}$ generation, as was the case in the laboratory

experiments (figs. 1-3). Thus, in figure 6, HC generation commences at $100^{\circ} \mathrm{C}$, but hydrogen indices continue to increase in spite of the loss in the hydrogen indices which must occur because of $\mathrm{HC}$ generation. Therefore from $100^{\circ}$ to $140^{\circ} \mathrm{C}$, kerogen hydrogenation is proceeding more rapidly than $\mathrm{HC}$ generation. At $140^{\circ} \mathrm{C}, \mathrm{HC}$ generation finally overtakes kerogen hydrogenation, and hydrogen indices begin to decrease. The hydrogen-index trend of figure 6 is not due to changing depositional conditions, because visual-kerogen and extractable bitumen analyses demonstrate that the $\mathrm{OM}$ of figure 6 beyond $80^{\circ} \mathrm{C}$ is uniform. I have observed the same trend of increasing hydrogen-index values over lower maturation ranks in several large data sets from different sites in the U.S. onshore Gulf Coast, and this same trend has been observed in large data sets of rocks with Type-III OM in basins worldwide (Barry Katz, Texaco, oral commun., 8/99). All of the preceding examples of kerogen or coal hydrogenation are for hydrogen-poor Type-III OM. However, hydrogenation of kerogen by water also occurs with hydrogen-rich OM in the natural system.

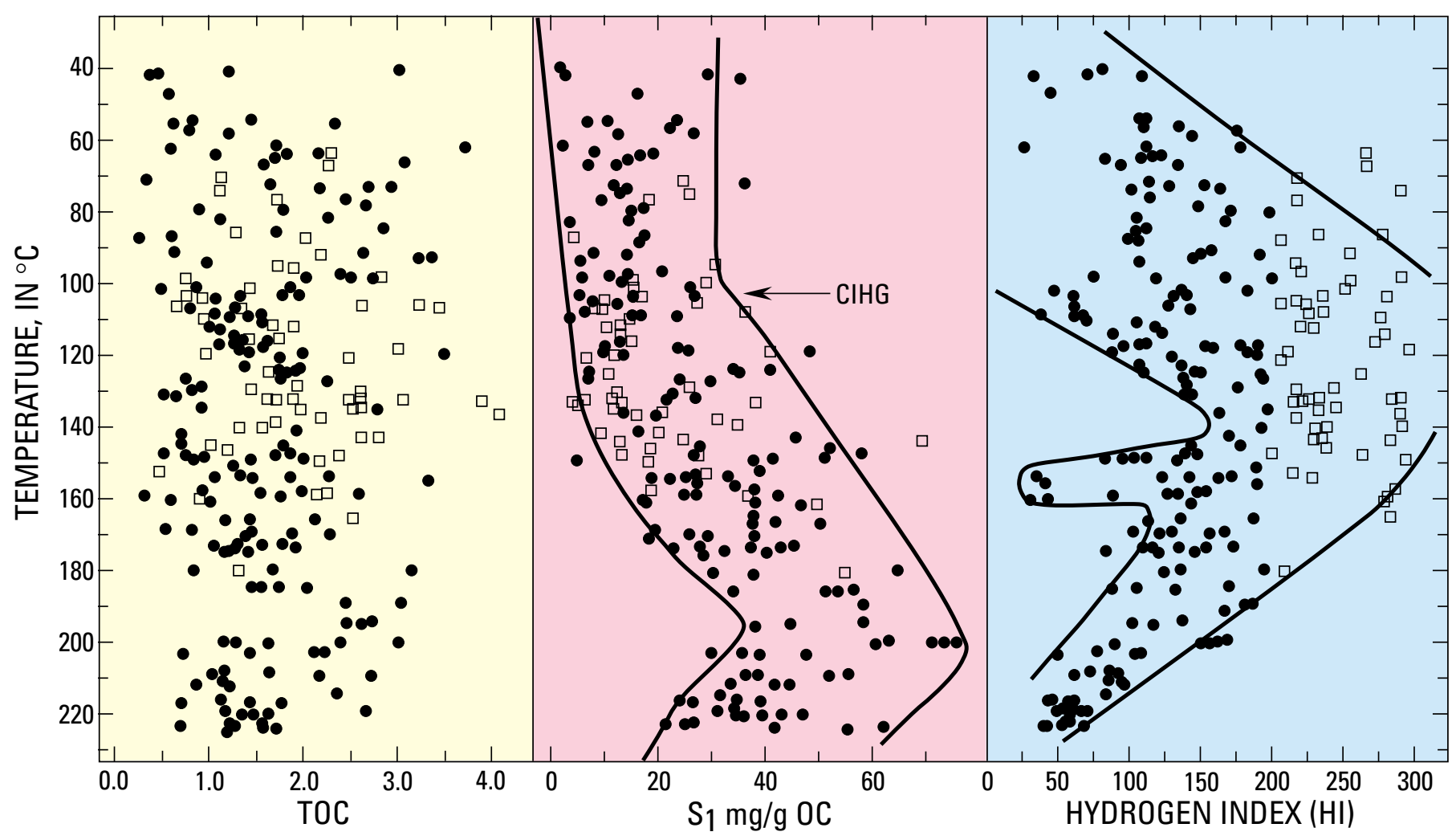

Figure 6. Plot of TOC (total organic carbon), and the TOC-normalized (milligrams per gram, $\mathrm{mg} / \mathrm{g}$ OC) ROCK-EVAL $\mathrm{S}_{1}$ and $\mathrm{S}_{2}$ (HYDROGEN INDEX) peaks, all versus burial temperature in ${ }^{\circ} \mathrm{C}$, for siltstones and shales with hydrogen-poor $0 \mathrm{M}$ (hydrogen-index values $<300$ ) from the Los Angeles Basin. Solid lines in the $S_{1}$ and hydrogen-index plots define principal trends of the data. Circles represent samples with hydrogen-index values below 200; squares represent samples with hydrogen-index values of 200 to 300 . CIHG in the TOC-normalized $\mathrm{S}_{1}$ plot is commencement of intense HC generation by that measurement. Modified from Price and others (1999). 


\section{Bakken Formation Shales}

I have collected a very large sample base of Upper Devonian-Lower Mississippian Bakken Formation shales, including all available samples on the far eastern flank of the Williston Basin, where the Bakken shales are immature (see fig. 5 of Price and others, 1984). ROCK-EVAL analyses were performed on some 1,300 of these samples by Dow Geochemical Services Inc. (DGSI), Houston, Tex. The analyses significantly enlarged a preexisting ROCK-EVAL data base of more than 400 Bakken shales, previously run at the U.S. Geological Survey laboratories. The Bakken shales are an ideal candidate to check if water also hydrogenates hydrogen-rich OM, therefore increasing its hydrogen content, and thus ROCK-EVAL hydrogen-indices. This is because a large amount of work has already been carried out, and published, on the Bakken Source System (Price and Le Fever, 1992). Moreover, no other source rock worldwide, with high TOC contents and hydrogen-rich OM, has a rock-sample base equivalent to that of the Bakken shales, regarding both geographic coverage (complete coverage of North Dakota and Montana) and range of shale maturity (extremely immature $(3,300 \mathrm{ft}(1,006 \mathrm{~m})$ of burial) to post-mature). The resulting data for both immature Bakken shales, and Bakken shales which have just commenced $\mathrm{HC}$ generation, are shown in figure 7.
Numerous investigators (including Webster, 1982, 1984; Price and others, 1984; Martiniuk, 1988; Le Fever and others, 1991; and Muscio, 1995) have documented that throughout almost all of the depositional area of the Bakken shales, both lithology and OM type of the shales are invariant. In other words, no detectable organic lateral-facies variations occur in the Bakken shales. However, concurrently, Price and others (1984) noted that as the depositional edge of the Bakken Formation is approached, facies variations do occur in the OM, presumably from variations in depositional conditions. Thus, both the initial TOC and hydrogen-index values decrease as the depositional edge of the Bakken shales is approached. Moreover, the extractable OM also changes, taking on slightly more Type-III OM characteristics. The extensive Bakken shale ROCK-EVAL data base I have compiled corroborates the previous conclusions of Price and others (1984) regarding OM variations as the Bakken Formation depositional edge is approached. To avoid these OM variations in the present considerations, only ROCKEVAL data from Bakken shales whose thickness equals or exceeds $17 \mathrm{ft}(5.2 \mathrm{~m})$ were plotted in figure 7.

Three features are immediately apparent in figure 7: (1) the steep increase in hydrogen-index values versus depth from $4,000$ to $8,300 \mathrm{ft}$ (1,219 to $2,579 \mathrm{~m})$, (2) the steep decline in hydrogen-index values deeper than about $8,300 \mathrm{ft}(2,579 \mathrm{~m})$,

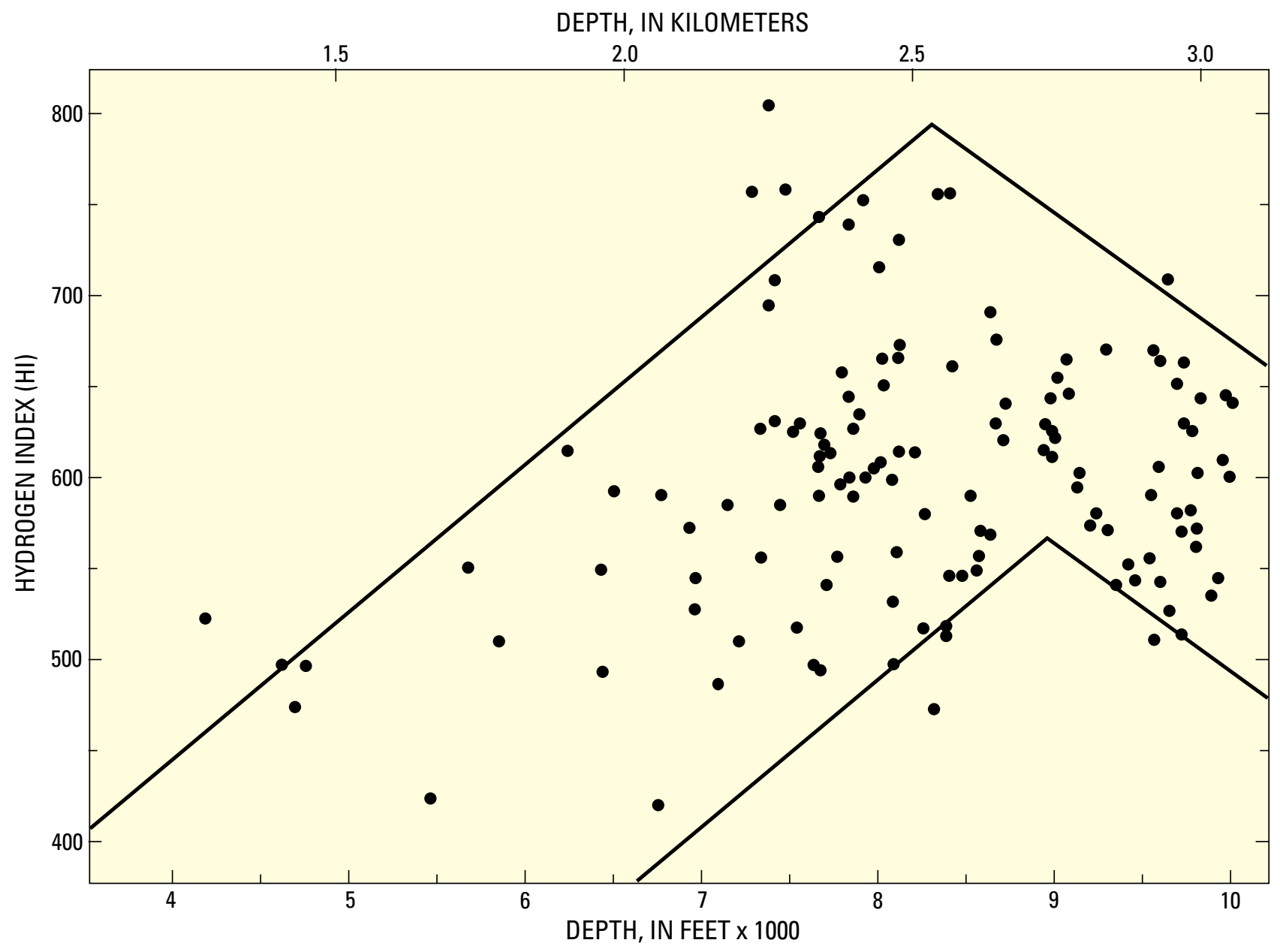

Figure 7. Plot of the ROCK-EVAL hydrogen index versus burial depth in feet and kilometers, for immature upper and lower Bakken Formation shales, Williston Basin, and for Bakken shales which have just commenced $\mathrm{HC}$ generation where total shale thickness is $17 \mathrm{ft}$ $(5.3 \mathrm{~m})$ or greater. 
and (3) the wide range in hydrogen-index values at any given depth. Concerning this last observation, although lateral-facies variations do not occur within Bakken shales removed from the depositional edge, significant random variations in TOC and hydrogen-index values do occur both vertically in the shales at any given site, and from site to site. For example, in figure 7 , from 7,500 to $8,300 \mathrm{ft}(2,286$ to $2,579 \mathrm{~m})$, hydrogen indices vary from 475 (Type-II/III OM) to 803 (Type-I OM), although most values fall between 500 and 775. TOC values (not shown in figure 7) also exhibit large variations, ranging from 15 to 40 percent. Close-spaced ( 3 to 6 in., 7.6 to $15.2 \mathrm{~cm}$ ), continuous-core samples of Bakken shale from single wells also demonstrate significant vertical variation in both TOC and hydrogen-index values. Price and others (1984) reported the same observation. Thus, the large range of hydrogen-index values in figure 7 at any given depth is due to random organic-richness variations within the Bakken shales themselves.

Because of the significant range of variation of organic richness vertically through the Bakken shales, analyses of core samples of this rock are not reliable for determining mean organic-richness values. Instead, cuttings chips of Bakken shale which have been cleaned, sieved to less than 100 mesh, and picked under a microscope to a 100 percent Bakken shale sample, are much more desirable. Such samples represent a homogenized cross section of the entire Bakken shale interval, thus best reproducing mean organic-richness values. Such cuttings chips samples made up the sample base for figure 7. Neither the trends in the figure 7 data nor the wide ranges in hydrogen-index values at any given depth can be attributed to lack of reproducibility or precision in either sampling or analysis. Seventeen random samples were inadvertently taken, cleaned, picked, and analyzed twice. The resulting ROCK-EVAL values from the paired analyses varied no more than 10 percent, and most were within 5 percent. Thus, the trends in the figure 7 data, including the large range of hydrogen-index values at any given depth, are indigenous to the shales themselves.

The strong increase in Bakken shale hydrogen-index values versus depth from 4,000 to 8,300 ft (1,219 to 2,579 m) in figure 7 is equivalent to the same trends shown in figures 4 and 5, versus $\mathrm{R}_{\mathrm{O}}$, and in figure 6 , versus burial temperature. The only obvious cause of the hydrogen-index increase in figure 7 is from water hydrogenating Bakken shale kerogen, thus increasing both its hydrogen richness and its hydrogen indices. Lateral-facies variations are not responsible for the hydrogen-index increases of figure 7 .

The significant decrease in hydrogen-index values deeper than about $8,300 \mathrm{ft}(2,579 \mathrm{~m})$ shown in figure 7 is due to the first detectable onset of intense $\mathrm{HC}$ generation, which commences at around that depth. Also note that at the onset of HC generation, the Bakken shales have mean hydrogen indices of 625, making this an extremely rich source rock. As shown in figure 7, a mean hydrogen-index value of 475 at shallow depths increases to a maximum mean value of 625 at $8,300 \mathrm{ft}(2,579 \mathrm{~m})$. This is an increase of 31.5 percent, somewhat less than the mean hydrogen-index increases in the coals of figures 4 and 5 (47 and 53 percent, respectively) and in the Los Angeles Basin shales of figure 6 (50 percent). However, all these hydrogen-index increases from the natural system ( 31.5 to 53 percent) are in the same range as was observed for the excess products generated in the 30-day, variable-temperature, aqueous-pyrolysis experiments with the Phosphoria shale and the lignite (figs. 3A, 3B; 42.0 and 40.0 percent, respectively).

Data for the Los Angeles Basin mid-Miocene shales (fig. 6) provide evidence that kerogen hydrogenation was taking place not only before, but also during, HC generation. Other evidence of kerogen hydrogenation by water during $\mathrm{HC}$ generation exists in figures 4, 5, and 7. In the coals of figure 4, HC generation commences at $\mathrm{R}_{\mathrm{O}}=0.6$ percent increase, yet minimum hydrogenindex values continue to increase, presumably from kerogen hydrogenation, until $\mathrm{R}_{\mathrm{O}}=1.0$ percent, where they begin to decrease. In figure 5, minimum hydrogen-index values for the other coal suite also continue to increase past $R_{O}=0.6$ percent, again presumably from kerogen hydrogenation, up to $R_{o}=1.0$ percent, where they again begin to decrease. In the Bakken shales of figure 7, maximum hydrogen-index values demonstrate that $\mathrm{HC}$ generation commences at 8,300 $\mathrm{ft}(2,579 \mathrm{~m})$, yet minimal hydrogen indices continue increasing in value to at least $8,900 \mathrm{ft}(2,765.7 \mathrm{~m})$.

\section{Conclusions and Implications from the Natural Data}

An abundance of data from the natural system regarding kerogen hydrogenation by water confirms that our aqueouspyrolysis experiments are replicating Nature. Moreover, the natural data also demonstrate that, as in the laboratory experiments, this kerogen hydrogenation occurs both before and during $\mathrm{HC}$ generation, and also occurs with all OM types. Because: $(1)$ the lower temperature $\left(150^{\circ}-333^{\circ} \mathrm{C}\right)$ aqueouspyrolysis experiments are replicating Nature in this regard, and (2) as discussed previously, these experiments have also replicated other formerly unrecognized characteristics of $\mathrm{HC}$ generation in Nature, it seems reasonable to assume that, with qualifications, possibly the higher temperature $\left(>350^{\circ} \mathrm{C}\right)$ experiments may also be replicating natural $\mathrm{HC}$ generation processes.

In my opinion, the hydrogenation of kerogen by water can only be explained by redox reactions between water and OM, or in other words, the hydrolytic disproportionation of kerogen. The occurrence of this kerogen-hydrogenation reaction has profound implications for HC exploration and for both source-yield and resource-base assessments: To estimate the amount of oil a source rock can generate, typically ROCK-EVAL derived organic-richness values are used from immature samples of that rock. However, the preceding discussions demonstrate that those richness values could increase by a minimum of 30 percent before $\mathrm{HC}$ generation even commences, and most probably continue to increase by similar amounts during $\mathrm{HC}$ generation. Of even more interest to us in this discussion, is that the very low hydrogen indices of "spent" kerogen may not preclude the possibility that deeply buried kerogen could still generate significant amounts of $\mathrm{HC}$ gas. 


\section{A Deep High-Rank Gas-Generation Machine?}

Seewald (1994, p. 287), in his definitive paper which clearly demonstrated the existence of the hydrolytic disproportionation of OM in the laboratory, made the following statements and speculations:

That water may contribute hydrogen directly to hydrocarbon formation has important implications for oil and natural-gas generation because water is abundant in most sedimentary environments. Thus the initial atomic $\mathrm{H} / \mathrm{C}$ composition of sedimentary organic matter may not limit the availability of requisite hydrogen for petroleum and naturalgas formation, especially at high temperatures in the deepest parts of sedimentary basins. Water may be particularly important during natural-gas generation owing to the substantial increase in the $\mathrm{H} / \mathrm{C}$ ratio of $\mathrm{CH}_{4}$ relative to the source organic material. Consequently, models that do not include water as a source of hydrogen during hydrocarbon formation may significantly underestimate the gas generation potential of organic matter.

Seewald's (1994) hypothesis about water possibly hydrogenating deeply buried, high-rank, spent kerogen, with low hydrogen to carbon ratios to manufacture a very late-stage $\mathrm{HC}$ gas is strongly supported by the same aqueous-pyrolysis experiments which have also indicated that hydrogenation of kerogen was occurring at lower ranks before and during mainstage $\mathrm{C}_{15}+\mathrm{HC}$ generation.

\section{Lignite High-Temperature Experiments}

Returning to figure $3 \mathrm{~B}$, at $350^{\circ} \mathrm{C}$ and higher, there is an excess of generated products (mainly $\mathrm{HC}$ gases) over what is possible, given the original organic richness (ROCK-EVAL $\mathrm{S}_{2}$ peak plus extractable bitumen) of the lignite. Moreover, above $350^{\circ} \mathrm{C}$, there is a continuous increase in these excess generated gases, versus increasing experimental temperatures. Furthermore, the most significant increases occur at the highest experimental temperatures where very little $\mathrm{C}_{5}+$ product remains in the system to thermally crack to gas, and also, very little $\mathrm{HC}$ generation potential is left in the lignite: the $425^{\circ} \mathrm{C}$ lignite sample had a hydrogen index of 0.39 , and the $450^{\circ} \mathrm{C}$ sample had a value of 0.29 . Clearly in these high-temperature lignite experiments, hydrogen from water must have been added to the lignite to manufacture the high-rank gases. However, from the $\mathrm{CO}_{2}$ plot for the lignite in figure $2 B$, the oxygen from the water apparently was not being assimilated into the lignite between $333^{\circ} \mathrm{C}$ and $425^{\circ} \mathrm{C}$, because $\mathrm{CO}_{2}$ production is largely invariant over these temperatures. This hypothesis is supported by the fact that the ROCK-EVAL oxygen indices of the lignite are low, and are either constant or decrease between $350^{\circ}$ and $450^{\circ} \mathrm{C}$. However, at $450^{\circ} \mathrm{C}$, where the largest jump in generated-HC gases occurs, a significant increase in the amount of excess generated $\mathrm{CO}_{2}$ also occurs. Thus, from $333^{\circ}$ to $425^{\circ} \mathrm{C}$, the oxygen from the water which hydrogenated the lignite had to be sequestered in the inorganic (mineral) phase in these experiments. If mineral species are reacting with the excess oxygen from the water hydrogenating the kerogen, the reaction paths would have to be ionic.

Seewald (1994) noted that a host of minerals with reduced iron, which would consume oxygen during oxidation of OM by water, exist in Nature. To reinforce the point, hydrolytic disproportion of OM as envisioned by Shock (1988), Helgeson and Shock (1988), and Helgeson and others (1993) involves a metastable equilibrium between water, $\mathrm{OM}$, and the minerals in a system - an equilibrium that is maintained via redox reactions between the different species. Such a metastable equilibrium affected the mineralogy of all six rocks used in our aqueouspyrolysis experiments, because obvious mineral deposits were present in the upper reaches on the walls of our reaction, above the rock-water mixtures, for all our higher temperature experiments. Thus, mineral species in our experiments appear to be partly responsible for sequestering the oxygen from the disproportionated water.

One last line of evidence further supports the conclusion that water was being consumed not only by the lignite to make $\mathrm{HC}$ gas in the $400^{\circ} \mathrm{C}$ and higher temperature experiments, but also by all five of the other rocks. In the $375^{\circ} \mathrm{C}$ and lower temperature experiments, excess water always was present in the reaction vessels after the experimental runs were completed. However, in the $400^{\circ} \mathrm{C}$ and higher temperature experiments, no visible excess water was present after the experimental runs were completed for all six rocks.

\section{Phosphoria Formation Shale High-Temperature Experiments}

In the case of the Phosphoria Formation shale, as previously discussed, pronounced $\mathrm{C}_{15}+\mathrm{HC}$ thermal destruction occurred between $333^{\circ}$ and $350^{\circ} \mathrm{C}$, accompanied by significant charring (fig. 3A). Thus, to ascertain whether or not the $\mathrm{HC}$ gases being generated at the experimental temperatures of $375^{\circ} \mathrm{C}$ and higher are exceeding the remnant $\mathrm{HC}$ generation capacity of the system inherited from the $350^{\circ} \mathrm{C}$ experiment, I plotted the amount of generated products, plus the ROCKEVAL $\mathrm{S}_{2}$ peak, all in $\mathrm{mg} / \mathrm{g}$ rock, for the high-temperature Phosphoria shale experiments (fig. $8 A$ ). From figure $8 A$, the total $\mathrm{HC}$-generation capacity of the system at $350.5^{\circ} \mathrm{C}$ is $66.5 \mathrm{mg} / \mathrm{g}$ rock. At all experimental temperatures above $350.5^{\circ} \mathrm{C}$, this number is exceeded, reaching a maximum of $79.2 \mathrm{mg} / \mathrm{g}$ rock in the $450^{\circ} \mathrm{C}$ experiment. Thus, even at these extreme experimental temperatures, excess $\mathrm{HC}$ generation capacity is being created by water hydrogenating the spent Phosphoria kerogen. This observation is corroborated by other data in figure 8 .

Note that the percentage that methane makes up of the total generated product increases from 38 percent at $350.5^{\circ} \mathrm{C}$ to 90 percent at $450.3^{\circ} \mathrm{C}$ (fig. $8 \mathrm{C}$, solid line). Methane $\left(\mathrm{CH}_{4}\right)$ is the most hydrogen-rich organic compound in both Nature and in these laboratory experiments. Given the ROCK-EVAL hydrogen indices (and elemental kerogen analyses) of these hightemperature rocks, mass-balance calculations demonstrate that insufficient hydrogen is present in the organic moieties (including the kerogen) of the Phosphoria shale experiments to allow 


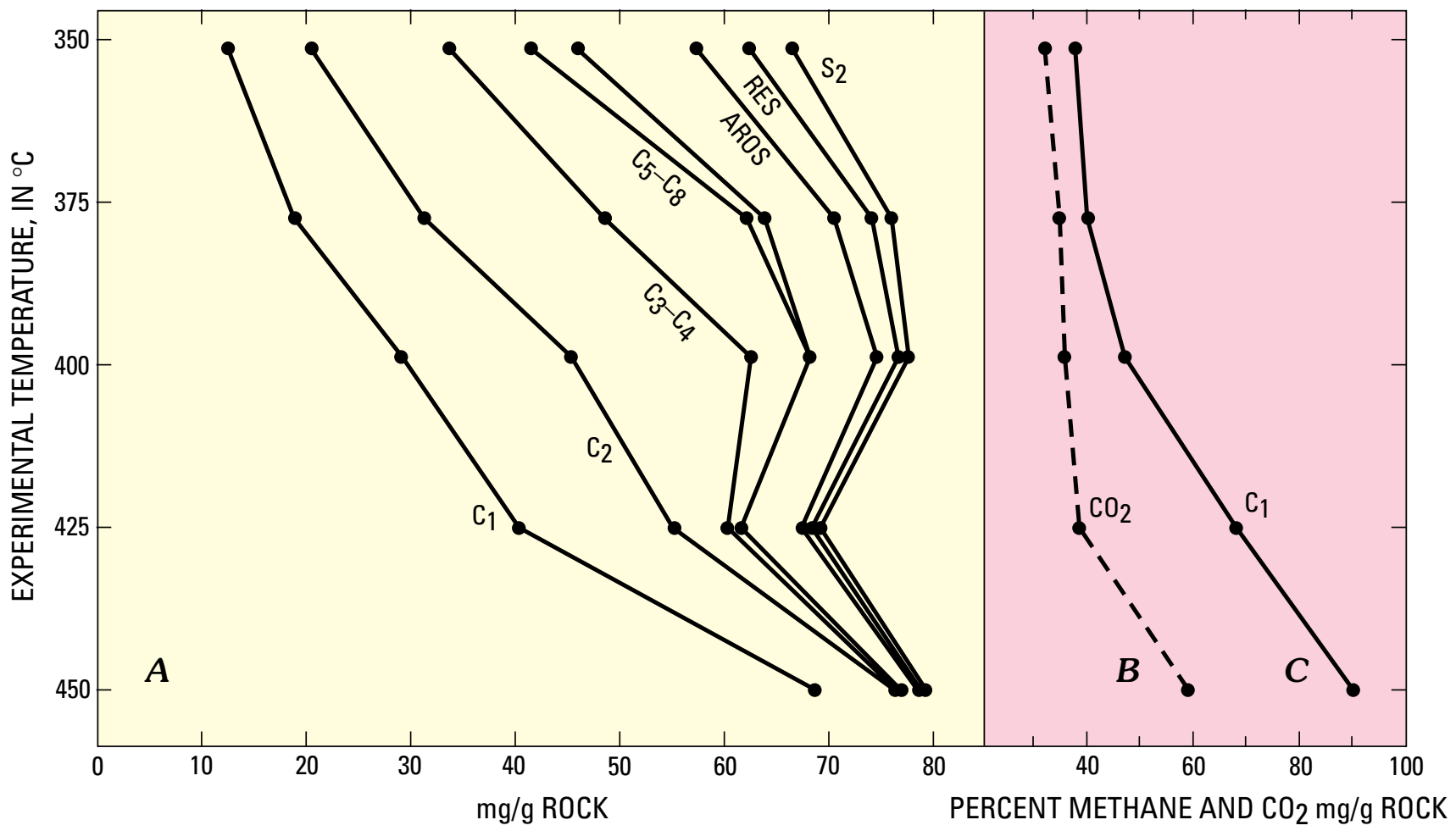

Figure 8. Plot of generated products (in milligrams/gram $(\mathrm{mg} / \mathrm{g})$ of rock) for 30 -day, variable-temperature aqueous-pyrolysis experiments at $350.5^{\circ} \mathrm{C}$ and higher for the Phosphoria Formation shale (fig. $8 A$ ). $\mathrm{C}_{1}$ is methane; $\mathrm{C}_{2}$ is ethane; $\mathrm{C}_{3}-\mathrm{C}_{4}$ are the $\mathrm{C}_{3}$ to $\mathrm{C}_{4} \mathrm{HC}$ gases; $\mathrm{C}_{5}-\mathrm{C}_{8}$ are the $\mathrm{C}_{5}$ to $\mathrm{C}_{8}$ gasoline-range HCS; AROS are the $\mathrm{C}_{8}$ aromatic HCS; the $\mathrm{C}_{8}+$ saturated HCS are unlabeled and are between " $\mathrm{C}_{5}-\mathrm{C}_{8}$ " and "AROS"; RES are resins and asphaltenes; and $\mathrm{S}_{2}$ is the ROCK-EVAL $\mathrm{S}_{2}$ pyrolysis peak. Amount of generated $\mathrm{CO}_{2}$ (in milligrams/gram of rock; $\mathrm{CO}_{2} \mathrm{mg} / \mathrm{g} \mathrm{ROCK}$ ) versus experimental temperature shown by dashed line (fig. $8 B$ ). The weight percent methane makes up of the total generated product (PERCENT METHANE) is shown by solid line (fig. 8C).

absolute concentrations of the HCS and the relative concentrations of methane both to increase with increasing experimental temperature. Clearly, as was the case with the high-temperature lignite experiments, the water-driven, high-rank deep-basin gas machine envisioned by Seewald (1994) also appears to be simulated in our high-temperature aqueous-pyrolysis experiments with the Phosphoria shale.

Note also that the amount of $\mathrm{CO}_{2}$ production in figure $8 \mathrm{~B}$ is not keeping pace with the excess HC generation. This observation dictates that, as with the lignite, the oxygen from the water hydrogenating the kerogen is also being sequestered in the inorganic phase in the Phosphoria experiments. Whatever that agent was, it appears to have been largely satiated by the $424.3^{\circ} \mathrm{C}$ experiment, given the significant jump in $\mathrm{CO}_{2}$ production from $424.3^{\circ}$ to $450.3^{\circ} \mathrm{C}$ (fig. $8 \mathrm{~B}$ ). Lastly, in figure $8 \mathrm{~A}$, note that at $424.3^{\circ} \mathrm{C}$ a second charring event occurs, besides the $350.5^{\circ} \mathrm{C}$ charring event of figure $3 A$, wherein significant amounts of the $\mathrm{C}_{5}-\mathrm{C}_{8}$ gasoline range $\mathrm{HCS}$ and the $\mathrm{C}_{3}-\mathrm{C}_{4}$ gaseous HCS are thermally destroyed.

\section{Anna Shale Member of Pawnee Limestone High-Temperature Experiments}

Figure $9 A$ is a mass-balance plot for the high-temperature experiments with the Anna Shale Member of Pawnee Limestone.
As in the case of the Phosphoria shale (fig. $3 A$ ), a massive charring event occurs between the $333^{\circ}$ and $350.5^{\circ} \mathrm{C}$ Anna shale experiments (not shown), with a huge loss of $\mathrm{C}_{8}+$ saturated and aromatic HCS and resins and asphaltenes. The Anna charring event continues in the $377.3^{\circ} \mathrm{C}$ experiment, with a continuing loss of $\mathrm{C}_{8}+$ saturated and aromatic $\mathrm{HCS}$ (fig. $9 \mathrm{~A}$ ). In the $398^{\circ} \mathrm{C}$ Anna shale experiment, the amount of generated products $(69.0$ $\mathrm{mg} / \mathrm{g}$ rock) exceeds the possible generation capacity of the system at $350.0^{\circ} \mathrm{C}(65.5 \mathrm{mg} / \mathrm{g}$ rock $)$. As in the Phosphoria shale experiments, a second charring event also occurs in the Anna shale experiments at $425^{\circ} \mathrm{C}$, wherein the $\mathrm{C}_{3}-\mathrm{C}_{8} \mathrm{HCS}$ are significantly reduced in concentration. With increasing experimental temperature to $500.5^{\circ} \mathrm{C}$, the amount of generated products continuously exceeds the possible generation capacity of the system at $350.3^{\circ} \mathrm{C}(65.5 \mathrm{mg} / \mathrm{g}$ rock $)$, reaching a maximum of $79.7 \mathrm{mg} / \mathrm{g}$ rock at $500.3^{\circ} \mathrm{C}$.

Unlike the case with the Phosphoria shale high-temperature experiments (fig. $8 \mathrm{~B}$ ), $\mathrm{CO}_{2}$ generation continuously increases in the equivalent Anna shale experiments (fig. 9B), even over temperature intervals where charring is occurring. This observation has several implications. First, the oxygensequestering moiety present in the Phosphoria shale experiments was not present at equivalent concentrations, or if present, was not active, in the Anna shale experiments. Because the experimental vessels were equivalent in both cases, the difference must be due to different mineralogies between the 


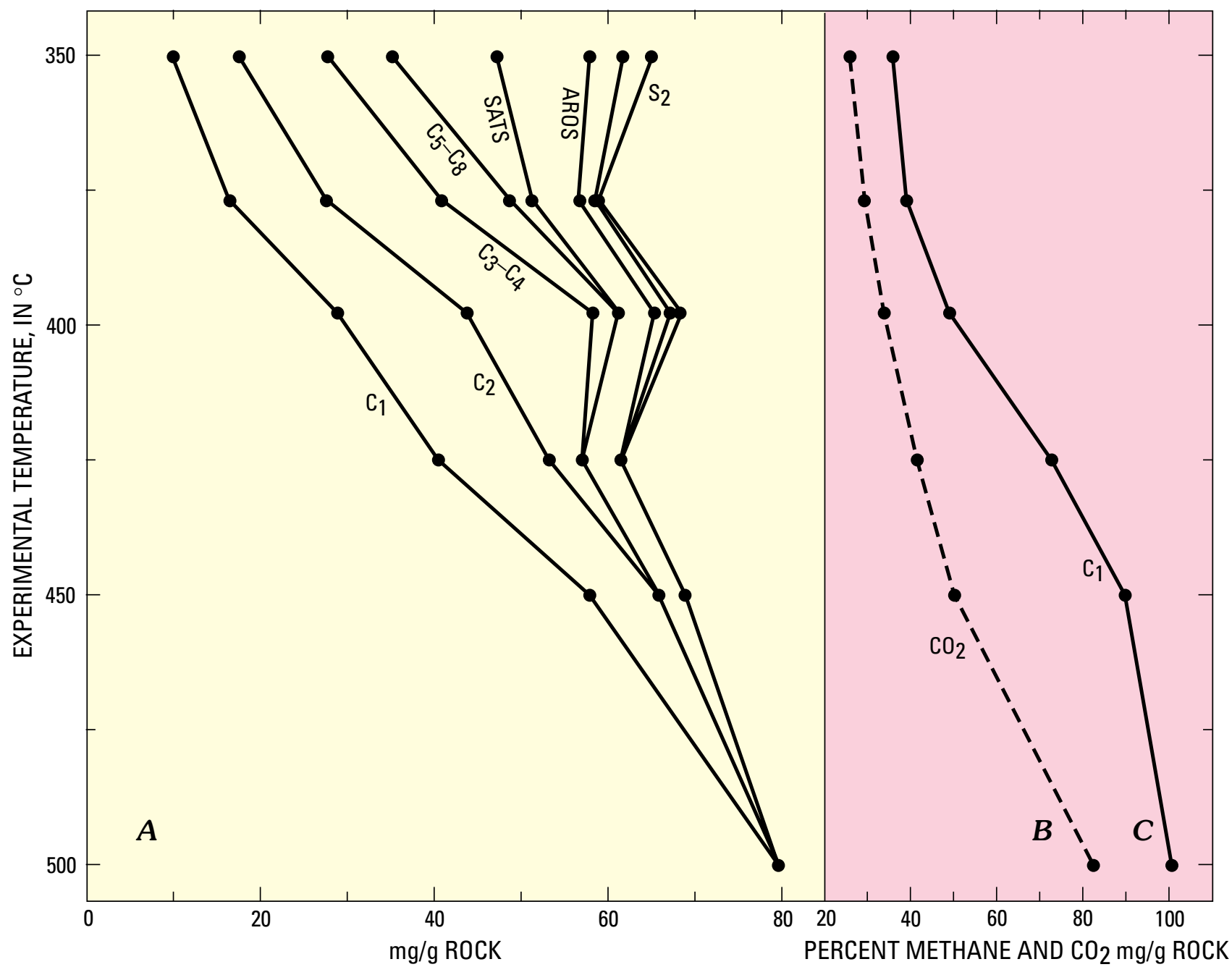

Figure 9. Plot of generated products (in milligrams per gram $(\mathrm{mg} / \mathrm{g}$ ) of rock) for 30-day, variable-temperature aqueous-pyrolysis experiments at $350.5^{\circ} \mathrm{C}$ and higher for the Anna shale (fig. $9 A$ ). $C_{1}$ is methane; $C_{2}$ is ethane; $C_{3}-C_{4}$ are the $C_{3}$ to $C_{4} H C$ gases; $C_{5}-C_{8}$ are the $C_{5}$ to $\mathrm{C}_{8}$ gasoline range HCS; SATS and AROS are the $\mathrm{C}_{8}$ + saturated and aromatic HCS, respectively; and $\mathrm{S}_{2}$ is the ROCK-EVAL $\mathrm{S}_{2}$ pyrolysis peak. The resins plus asphaltenes are not labeled and are between "AROS" and " $\mathrm{S}_{2}$ ". Amount of generated $\mathrm{CO}_{2}$ (in milligrams per gram of rock; $\mathrm{CO}_{2} \mathrm{mg} / \mathrm{g} \mathrm{ROCK}$ ) versus experimental temperature is shown by dashed line (fig. $9 B$ ). The weight percent methane makes up of the total generated product (PERCENT METHANE) is shown by solid line (fig. $9 \mathrm{C}$ ).

Phosphoria and Anna shales. Second, in the $425^{\circ} \mathrm{C}$ (charring) experiment with the Anna shale, thermal conversion of higher molecular weight material (with lower $\mathrm{H} / \mathrm{C}$ ratios) to lower molecular weight materials (with higher $\mathrm{H} / \mathrm{C}$ ratios) occurred, with an overall loss of mass in the system. Because excess $\mathrm{CO}_{2}$ was produced in the $425^{\circ} \mathrm{C}$ experiment, hydrogen enrichment of the organic system took place by water hydrogenating the OM. Thus, not enough hydrogen was available from the charred OM to supply the hydrogen requirements for the lower molecular weight $\mathrm{HC}$ gases with higher $\mathrm{H} / \mathrm{C}$ ratios. This observation demonstrates that even during the $\mathrm{C}_{15}+\mathrm{HC}$ thermal destructive phase, hydrogen from water must be added to organic phases to create lower molecular weight $\mathrm{HC}$ gases. Lastly, not only do mineral phases help govern the reaction kinetics of these highrank gas machines in laboratory situations, but also the starting kerogen type plays a role. This is because the high-temperature $\left(>350^{\circ} \mathrm{C}\right.$ ) mass-balance plots (figs. $3 A, 3 B, 8 A$, and $9 A$ ) and $\mathrm{CO}_{2}$ curves (figs. 1, 2, 8B, and $9 B$ ) for all three kerogen types are distinctly different from one another.

\section{Anna Shale Member $425^{\circ} \mathrm{C}$ Variable Water}

Another set of experiments further corroborates that water hydrogenates spent kerogen to "manufacture" high-rank gases in water-wet, closed-system laboratory experiments. In figure $10 \mathrm{~A}$, the only generation products quantitatively analyzed, methane, ethane, the $\mathrm{C}_{3}-\mathrm{C}_{4} \mathrm{HC}$ gases, and the $\mathrm{C}_{13}+$ maltene fraction (aromatic HCS and resins), are plotted versus the rock/water ratios (grams to grams) for four different 30-day experiments carried out at $425^{\circ} \mathrm{C}$ with the Anna shale, versus increasing water content. On the vertical scale of figure 10, the sample at the infinity $(\infty)$ ratio was prebaked at $100^{\circ} \mathrm{C}$ for 2 days to remove loosely bound water from the sample before the $425^{\circ} \mathrm{C}$ experiment was performed. However, more tightly bound water (inner-layer clay water, water of hydration, for example) would have still remained.

As the amount of water in the experiments increases, the amounts of all the products increase, especially methane (fig. 


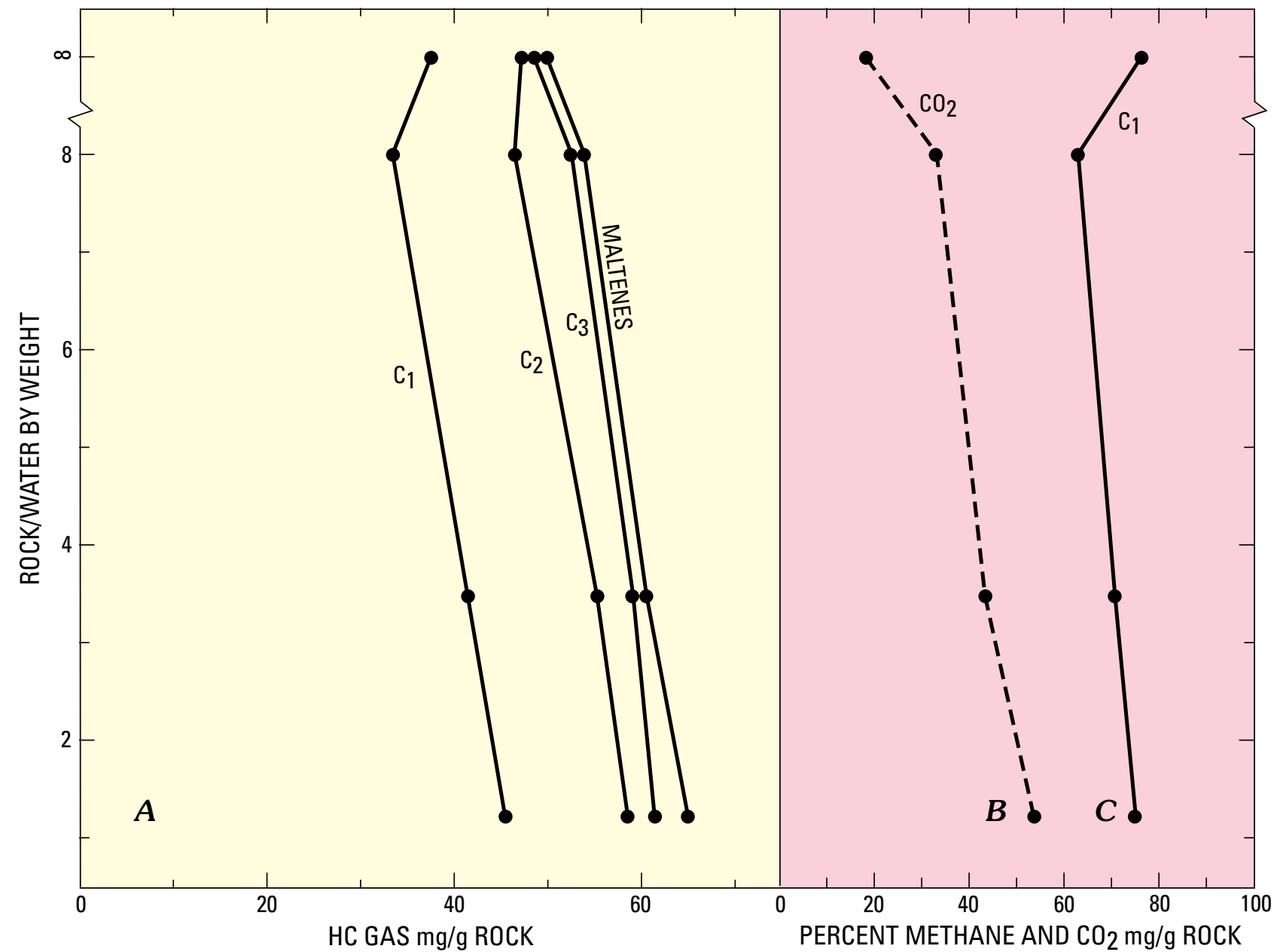

Figure 10. Plot of generated products (in milligrams per gram $(\mathrm{mg} / \mathrm{g})$ of rock) for 30 -day constant-temperature $\left(425^{\circ} \mathrm{C}\right)$ aqueouspyrolysis experiments with the Anna Shale Member of Pawnee Limestone as a function of variable rock to water ratios (fig. 10A). $C_{1}$ is methane; $C_{2}$ is ethane; $C_{3}$ is the $C_{3}$ to $C_{4} H C$ gases; and MALTENES is the sum of the $C_{13}+$ aromatic HCS, resins and asphaltenes. Amount of generated $\mathrm{CO}_{2}$ (in milligrams per gram of rock; $\mathrm{CO}_{2} \mathrm{mg} / \mathrm{g} \mathrm{ROCK}$ ) versus the rock/water ratio is shown by dashed line (fig. 10B). The weight percent methane makes up of the total product (PERCENT METHANE) is shown by solid line (fig. 10C). The sample at infinity ( $\infty$ ) on the rock/water ratio axis had no added water and was prebaked at $100^{\circ} \mathrm{C}$ for 2 days before the $425^{\circ} \mathrm{C}$ run was performed on it.

$10 \mathrm{C}$ ). Also, the amount of $\mathrm{CO}_{2}$ dramatically increases from 17.5 $\mathrm{mg} / \mathrm{g}$ rock in the dry experiment to $53 \mathrm{mg} / \mathrm{g}$ rock in the wettest experiment (rock/water equals 1.221; fig. 10B). The figure 10 data clearly demonstrate that water is hydrogenating spent kerogen to produce a methane-rich generation product, with the oxygen from the water being given off as $\mathrm{CO}_{2}$.

\section{$\mathrm{CO}_{2}$ Carbon-Isotopic Values}

Figure 11 presents $\delta^{13} \mathrm{C}$ values for the generated $\mathrm{CO}_{2}$, versus experimental temperatures, for the Anna and Phosphoria shales and the lignite. The negative $\delta^{13} \mathrm{C}$ values of figure 11 (-30.01 to -12.71) could only have been derived from substantial contributions of the biogenically derived carbon from the kerogen in these three rocks. Moreover, a cross plot of percent $\mathrm{CaCO}_{3}$ for the starting rock versus the median and range of $\delta^{13} \mathrm{C}$ values for the generated $\mathrm{CO}_{2}$ from all the experiments with a given rock demonstrates that the carbonate minerals in all six rocks used in the aqueous-pyrolysis experiments were taking part in the reaction between water and the kerogens (fig. 12).

Figure 12 shows a pronounced relationship between heavier isotopic carbon in the generated $\mathrm{CO}_{2}$ (less negative values) and increasing $\mathrm{CaCO}_{3}$ content in the rocks. The data from the Los Angeles Basin shales seem to fall off the trend, but in reality this is probably not the case, because the carbon-isotopic value of the kerogen from this composite shale is -21.97 , which is about 10 per mil heavier than that of the kerogens from the other marine shales. If this isotopic variance is taken into account by shifting the Los Angeles Basin shale data 10 per mil to the left, then the Los Angeles data lie directly on the trend.

As previously stated, quantitative carbonate-carbon analyses were run on all samples of all six rocks after each experiment, and these values for a given rock between the different experimental runs changed little, if any. Thus, any $\mathrm{CO}_{2}$ contributed from the decrepitation of carbonate minerals would have been too small to materially affect the isotopic values in figures 11 and 12 . Therefore, the pronounced trend in figure $12 \mathrm{can}$ 


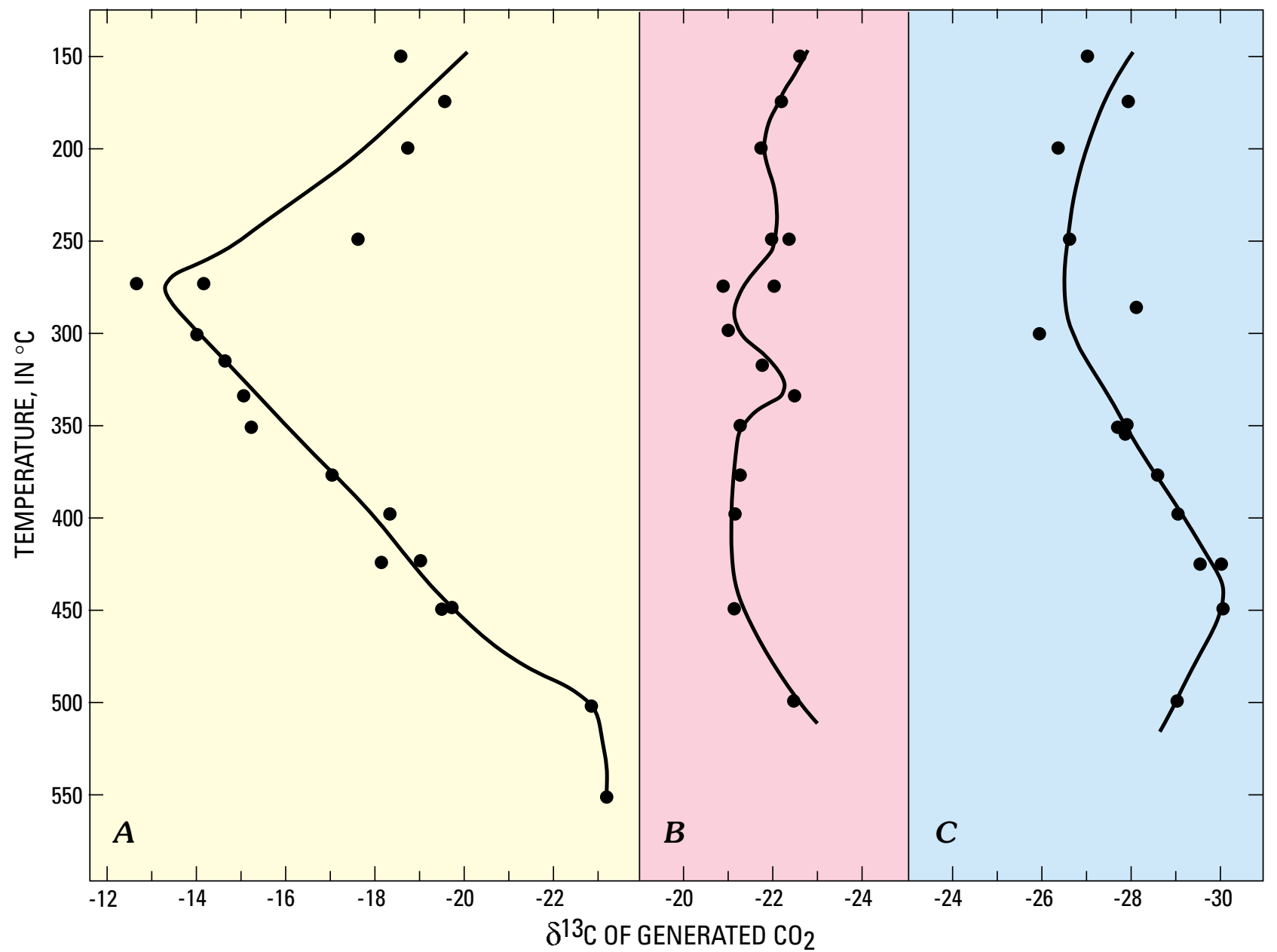

Figure 11. Plot of carbon-isotopic values of $\mathrm{CO}_{2}$ generated in 30-day variable-temperature aqueous-pyrolysis experiments, versus experimental temperature, for three different rocks: Anna Shale Member of Pawnee Limestone (fig. 11A), Rattlesnake Butte lignite (fig. $11 B$ ), and Phosphoria Formation shale (fig. 11C).

only be due to the carbon in the $\mathrm{CO}_{2}$ generated from the kerogen-water reaction isotopically equilibrating with the carbonate carbon in the minerals. In other words, the water, OM, and minerals were either in a metastable equilibrium with each other or were attempting to reach such an equilibrium.

\section{Reservations and Ramifications of a Deep-Basin Gas Machine}

The data from the various high-temperature experiments heretofore discussed conclusively demonstrate that water hydrogenates spent kerogen to produce a methane-rich isotopically light gas in laboratory situations. Can it be demonstrated that this same reaction is occurring in Nature? With the existing data from the natural system that I am familiar with, it can be neither proven, nor disproven, that this reaction occurs in Nature. However, kerogen hydrogenation by water occurs both in Nature and in our aqueous-pyrolysis experiments, both before and during mainstage $\mathrm{C}_{15}+\mathrm{HC}$ generation. From this observation, it is reasonable to assume that hydrogenation of spent kerogen by water to produce a deep-basin methane-rich gas might also occur in
Nature, because this reaction occurs in our high-temperature aqueous-pyrolysis experiments. Moreover, the widespread occurrence of late-stage isotopically light carbonate cements (demonstrating the carbon was derived from $\mathrm{OM}$ ) in deep-basin sediments (Price and others, 1998), shows that some form of OM redox reactions with water is occurring.

If it is assumed for discussion that such a reaction does occur in Nature, what would be some of the qualifications and implications of its occurrence? As proposed by Shock (1988), Helgeson and Shock (1988), Helgeson and others (1993), and Seewald (1994), water, OM, and minerals can reach a redoxbuffered metastable equilibrium. When this metastable equilibrium is reached, the hydrolytic disproportionation of OM ceases until system conditions are further changed. The possible controlling parameters that could vary during deep-basin methane generation via hydrolytic disproportionation reactions with kerogen are temperature, pressure, and fluid flow (open-fluid systems). Continuously increasing sediment burial results in continuously increasing burial temperatures and pressures (burial diagenesis). However, the pressure and temperature changes over geologic time would be slight, and theoretically, $\mathrm{OM}$, water, and mineral phases would never be far from equilibrium in closed-fluid systems. As opposed to burial diagenesis, 


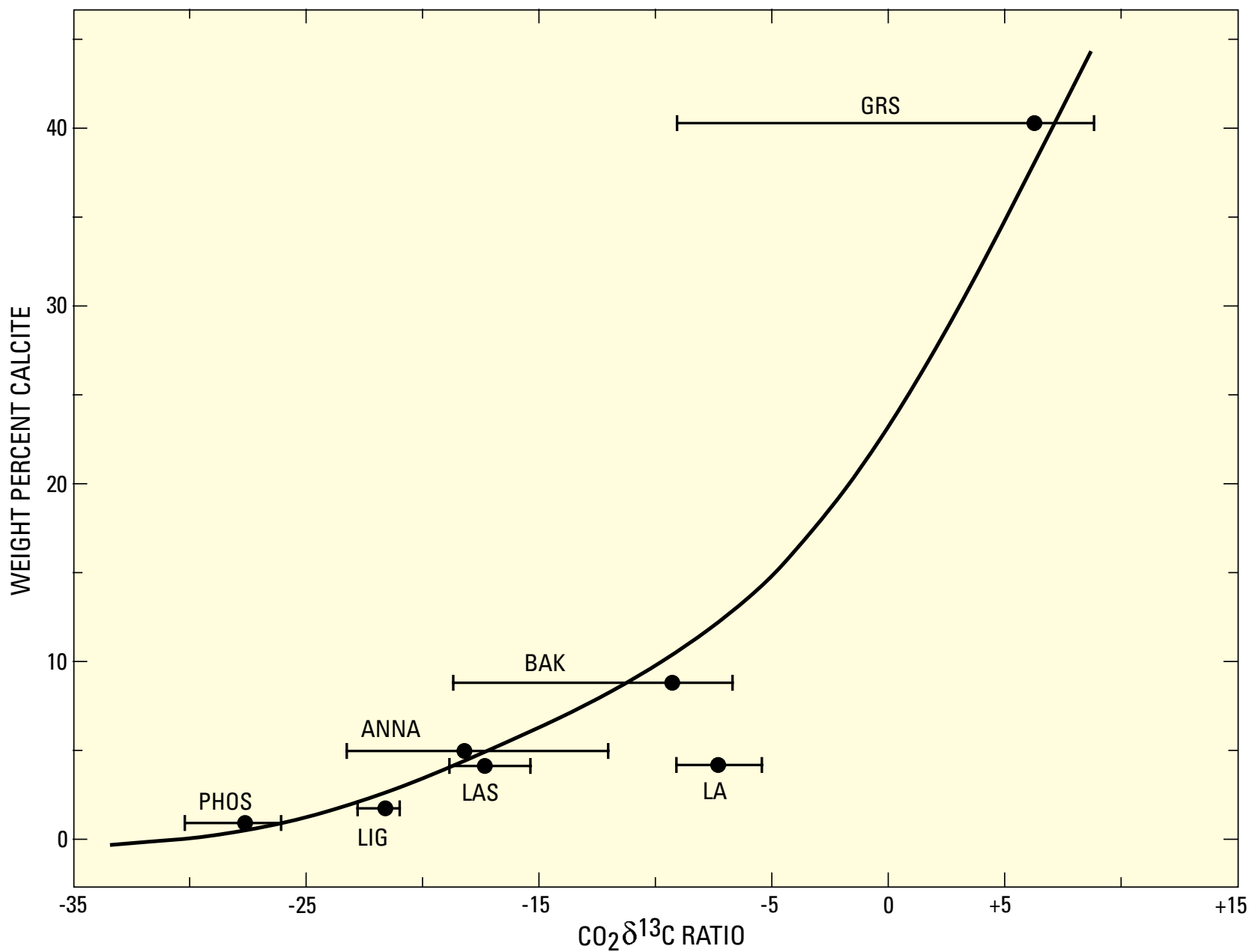

Figure 12. Plot of range (bars) and average (dots) of carbon-isotopic values for $\mathrm{CO}_{2}$ generated during 30-day variable-temperature aqueous-pyrolysis experiments carried out with six rocks versus weight percent $\mathrm{CaCO}_{3}$ in the starting rock. PHOS, Phosphoria Formation shale; LIG, Rattlesnake Butte lignite; ANNA, Anna Shale Member of Pawnee Limestone; BAK, Bakken Formation shale; GRS, Green River Formation shale; LA, composite of mid-Miocene Los Angeles Basin shales; LAS, LA sample data shifted 10 per mil to the left to take into account its isotopically heavy kerogen.

punctuated diagenesis is caused by a sudden abnormally high heat flow, which can be due to any number of geologic events (Price, 1983; Morton, 1985). As discussed in Price (1983), punctuated diagenesis is rather common in sedimentary basins. In cases of punctuated diagenesis, sudden dramatic increases in burial temperatures in the deep basin could throw the system water, OM, and minerals far out of equilibrium. This would result in kerogen, pore water, and mineral phases entering into strong redox reactions with one another, thus theoretically producing methane-rich $\mathrm{HC}$ gases, and $\mathrm{CO}_{2}$.

Price and others (1998) concluded that the principal drive for the hydrolytic disproportionation of OM was an open-fluid system (such as is found in heavy-metal ore deposition or rock metamorphism), where many volumes of pore water flow past a given site. In such cases, OM, water, and the mineral phases can never attain equilibrium with one another, and the hydrolytic disproportionation of OM achieves significant reaction extents. Thus, if the hydrogenation of spent kerogen to produce significant amounts of high-rank deep-basin methane occurs at all in Nature, it would have to take place in open or semi-open fluid systems in the deep basin.
As discussed in Price (1997b), petroleum basin depocenters traditionally have been considered to be open-fluid systems, because source-rock HC expulsion is considered to be an efficient process, which requires an open-fluid system. Thus, we may expect that deep-basin hydrogenation of spent kerogen by water could readily proceed. However, as discussed in Price and LeFever (1992), and Price (1994b, 1995, and 1997b), the position that the deep basin is an open-fluid system with efficient source-rock HC expulsion occurring from basin depocenters appears to have been significantly overstated. Additionally, the presence of abnormal fluid pressures and compartmentalization in petroleum basin depocenters worldwide (Powley, 1990; Ortoleva, 1994; Price, 1997b) clearly dictates that petroleum basin depocenters are semi-closed to closed-fluid systems. When basins are young and evolving, substantial cross-strata fluid flow does occur in basin depocenters. However, even in these cases, the depocenters may hardly be considered open-fluid systems. Otherwise, the high abnormal fluid pressures therein would not exist. Moreover, when fluid flow does occur in these young dynamic basins, it occurs in periodic bursts over geologic time, as opposed to continuous flow. 
Meaningful expulsion of oil and (or) gas from source rocks or source systems appears to depend greatly on significant physical disruption of source rocks. Such disruption occurs from intense structural activity, faulting, or salt or shale diapirism, and thus results in a much more open-fluid system. As basin evolution proceeds to the mature stage, with the inevitable cessation of structuring and decline of heat flows, basin depocenters become semi-closed to near perfectly closed fluid systems. At that time, all fluid flow in the basin depocenter ceases, basin compartmentalization occurs, and the resulting fluid compartments can remain sealed for extremely long periods of geologic time. The Anadarko Basin depocenter serves as the type example of a mature "dead" deep basin. However, rejuvenation of high heat flows, and (or) significant structuring, would accompany resurgent basin evolution.

Almost all basin evolution and fluid flow, especially in basin depocenters, occur when basins are young and dynamic. Thus, this is the time when the most significant extents of hydrolytic disproportionation reactions involved with OM would correspondingly occur. This is also the time when the most HC gas would be generated by hydration of deep high-rank kerogen by water, if the reaction occurs at all. Such reactions cannot conceivably occur in stagnant mature basins, such as the Anadarko Basin depocenter, with near perfectly closed fluid systems, wherein pore fluids long ago achieved metastable equilibrium with their surrounding OM and mineral phases.

There is an important caveat to the preceding discussion. The hydration of spent kerogen by water and resulting generation of methane-rich $\mathrm{HC}$ gas and $\mathrm{CO}_{2}$ is a volume-expansive reaction, wherein the products (gases) take up a much greater volume than the reactants. If this reaction did occur in Nature, it would be occurring in a semi-closed fluid system. Volume expansion in a constant volume system generates abnormally high fluid pressures. Thus, the kerogen hydration reaction might be self-driving, because the fracturing resulting from the reaction could expand the semi-closed fluid system, allowing an even greater localized volume of rock to take part in the reaction.

The reaction we have proposed herein for a high-rank latestage generation of an isotopically light methane-rich gas from ultra-mature kerogen is similar to the reaction scheme proposed by McNeil and BeMent (1996). In their scheme, short-chained alkyl groups on the aromatic rings of ultra-mature kerogens preferentially cleave between the first and second carbon atoms next to the aromatic ring. This results in two free radicals: (1) the cleaved alkyl group, and (2) the $\mathrm{CH}_{2}$ group remaining on the aromatic ring. McNeil and BeMent (1996) called for hydrogen to be shuttled between the kerogen and alkyl groups to satisfy the two free-radical sites, one of which is thus converted to a methyl group. The resulting methyl group still attached to the aromatic ring then preferentially cleaves off the ring if the carbon-carbon bond is a $\mathrm{C}_{12}-\mathrm{C}_{12}$ bond, rather than a $\mathrm{C}_{12}-\mathrm{C}_{13}$ bond, producing isotopically light methane. The significant difference between our reaction scheme and that of McNeil and BeMent's (1996) is that our hydrogen, which satisfies the open bonds, is derived from an external source (pore water) and not from the kerogen. Because of the limited amount of hydrogen available in high-rank kerogen, only limited amounts of methane can be generated by McNeil and BeMent's (1996) scheme.
However, if water is supplying the needed hydrogen, much greater amounts of methane could be generated. Other than the hydrogen source, the two schemes are similar, especially when compared to other mechanisms proposed to account for isotopically light high-rank methane-rich natural gas.

As previously discussed in the section, "Natural Gas Generation Mechanisms," much confusion exists concerning natural gas generation. However, let us assume that deep-basin hydrogenation of spent kerogen significantly contributes to the natural-gas volumes generated by other likely, or possible, mechanisms (cogeneration of $\mathrm{HC}$ gas with mainstage $\mathrm{C}_{15}+\mathrm{HC}$ generation with migration-fractionation, late-stage $\mathrm{HC}$ generation rich in $\mathrm{HC}$ gases, transition-metal catalysis, and demethylation reactions). In that case, what would be some of the consequences? One consequence would be that significantly more $\mathrm{HC}$ gas would be generated than expected, given the original kerogen hydrogen to carbon ratio or the original ROCK-EVAL hydrogen indices of the rock. In fact, one may expect to commonly find high-rank, basin-centered, continuous-reservoir gas deposits in the depocenters of deep petroleum basins.

To review a point hereforeto discussed in the section, "Natural Gas Generation Mechanisms," at the fluid pressures in the depocenters of deep basins, almost all $\mathrm{C}_{2}+\mathrm{HC}$ gases will condense into a liquid phase which may be under a methane-rich gas cap. According to Gussow's (1954) principle of differential entrapment, if the trap becomes filled to spill point, continued migration of methane-rich gas into the trap would cause all $\mathrm{C}_{2}+$ liquids to be displaced updip. If the trap continues filling, eventually methane would also be displaced from the spill point. At the elevated pressures and temperatures in basin depocenters, water has substantial solubilities in methane gas (Price and others, 1983). Thus, significant amounts of deep-basin pore water would go into gaseous solution in deep-basin methanerich gas deposits. Therefore, with continued migration of methane into deep traps, and displacement of water-bearing methane out of the trap at the spill point, the deep basin could become partially, or even largely, dewatered. Moreover, of all the possible methane-generating mechanisms discussed herein, both hydration of deep-basin spent kerogen and hydration of kerogen during late-stage $\mathrm{HC}$ generation would consume significant amounts of pore water. In fact, it is possible that around very rich source rocks and (or) coals, all the pore water from the adjacent rocks could be consumed by the organic-rich rocks as they generate HCS, as was the case in our high-temperature aqueouspyrolysis experiments.

Several important implications follow if parts, or even the entire depocenters, of deep petroleum basins are water-free. For example, a gas-only phase would exist in deep-basin gasbearing reservoirs. All drilling fluids, even oil-based drilling fluids, contain water. Thus, drilling through gas-only reservoirs with water-based, or mixed water- and oil-based, drilling fluids would most likely create severe permeability blocks around the wellbore. These permeability blocks could significantly damage, or totally destroy, the productive capacity of the formation around the wellbore. Such permeability blocks would arise from the presence of two or more fluid phases around the wellbore (gas, oil, and water) and the Jamin effect. (See Price, 1995, p. 345-346, and 1997b, p. 193-194, for 
further discussion.) If such permeability blocks were established around the wellbore during drilling, then drilling or completion techniques would have to be designed which would effectively eliminate the formation damage. Moreover, propped fracture treatments would not be the cure, they would only add to the problem.

The last consequence of deep-basin water-free gas reservoirs would be the possible absence of the permeability-blocking authigenic mineral phases which plague tight-gas sands. Tight-gas sands either are water- and gas-bearing now, or if only gas-bearing now, they contained water and gas when they were at maximal burial temperatures. Basins cool as they mature during progressive basin evolution. As a result of such cooling, a host of authigenic minerals precipitate from solution in the pore waters of coarse-grained rocks, slightly decreasing porosity, but dramatically decreasing permeability. If deep-basin reservoirs are now water-free, and were water-free when maximal burial temperatures existed, such late-stage deposition of authigenic minerals could not occur. Thus, water-free deep-basin gas reservoirs may not have the very low permeabilities which afflict tight-gas sands.

Even if hydrogenation of deep-basin spent kerogen by water does not occur in Nature, as discussed in Price (1995, 1997b), very deep, water-free, basin-centered, continuous-reservoir methane-rich gas accumulations of monstrous size could still exist in deep-basin depocenters. In my opinion, it is of utmost importance to determine the gas/water ratios for the few producing gas wells that have tapped these ultra-deep $(>18,000$ $\mathrm{ft}, 5,486 \mathrm{~m}$ ) gas deposits. Accurate knowledge of such gas/water ratios may allow us to: (1) better assess the origin of the gas in these deposits, (2) design appropriate drilling and completion practices for such gas-resource bases, and (3) possibly better assess the size of the in-place reserves of such gas-resource bases.

Lastly, given the possibility that very large gas deposits exist in deep-basin, basin-centered continuous-reservoirs, as has been previously advocated (Price, 1995, 1997b), it is paramount to avoid the conclusion that the resource base does not exist, or cannot be commercially produced, because of disappointing results obtained from drilling and completion techniques which are inappropriate for the unique characteristics of the resource base. All unconventional resource bases, including energyresource bases, before they become commercial, go through a time period when they are either not recognized, or if recognized, cannot be commercially produced because inappropriate production methods are being applied to them. Moreover, unconventional resource bases, when they become commercial, always do so because of a change in, or innovation of, technology. Historical retrospection of the development of any given unconventional resource base reveals that a new technological approach always addressed a then-unrecognized problem which was prohibiting efficient production of the resource base. If very large in-place deep-basin gas-resource bases do exist in most petroleum basins, which, based on firm scientific analysis, I have concluded is most likely the case (Price, 1995, 1997b), then the characteristics of these resource bases must be delineated. In this manner, appropriate drilling and completion techniques may be designed for these resource bases.

\section{Further Research}

Certain laboratory and field research could add significant insight into whether or not water is hydrogenating deep-basin, high-rank, spent kerogen to generate methane-rich $\mathrm{HC}$ gas in the natural system:

1. Further high-temperature $\left(>350^{\circ} \mathrm{C}\right)$ aqueous-pyrolysis experiments should be performed using variable-water contents with larger rock sample sizes (15-20 grams), compared to previous experiments with 4-5 gram sample sizes. In this way, changes in mineralogy versus experimental temperature could be examined. Moreover, post-experimental residual water contents (if any) should be determined. Deuterated water should be used in some experiments, with deuterium analyses performed on the $\mathrm{HC}$ products. Carbon-isotopic analyses should be performed on all products, including $\mathrm{CaCO}_{3}$ in the mineral phase. Rocks with different OM types should also be used. Lastly, ultra high-temperature $\left(550^{\circ}-650^{\circ} \mathrm{C}\right)$ experiments should be carried out.

2. Some of the same experiments in (1) should be carried out using high-rank $\left(\mathrm{R}_{\mathrm{o}}>5\right.$ percent) rocks with high TOC contents $(>4$ percent TOC) and low $(<50)$ hydrogen indices.

3. Gas/water ratios should be determined for ultra-deep $(>18,000 \mathrm{ft} ; 5,486 \mathrm{~m})$ high-rank $\left(\mathrm{R}_{\mathrm{O}}=2.5\right.$ percent $)$ gas wells.

4. Carbon-isotopic analyses should be carried out on deep, late-stage, crosscutting $\mathrm{CaCO}_{3}$ veins, to ascertain the contribution of organic carbon in such calcite cements.

5. Analysis of the gases in inclusions of late-stage isotopically light carbonate cements should be undertaken.

\section{Conclusions}

1. The traditional view that organic metamorphism in Nature is well understood, with burial temperature and geologic time as the only two controlling parameters, is unrealistic. Other important controlling parameters have gone unrecognized. One such unrecognized parameter-water-plays key roles in organic metamorphic reactions, especially in $\mathrm{HC}$ generation reactions.

2. Recent research by different investigators strongly suggests that water, minerals in rocks, and all forms of OM take part in a metastable equilibrium with each other, via aqueousbased redox reactions. This process has been termed the hydrolytic-disproportionation of OM.

3. Different investigators have compiled large bodies of data both from Nature and the laboratory, data which support the conclusion that the hydrolytic disproportionation of OM takes place in many different geologic environments and appears to play key roles in many different geologic and geochemical processes.

4. Historically, $\mathrm{C}_{2}+$ rich natural gas ("wet gas") has been thought to result primarily from the thermal destruction of the $\mathrm{C}_{15}+\mathrm{HCS}$ in reservoired oil. Moreover, high-rank, deeply buried, methane-rich "dry" gas has been held to result exclusively from thermal destruction of $\mathrm{C}_{2}+\mathrm{HCS}$, and especially of reservoired oil. The thermal cracking of $\mathrm{C}_{15}+\mathrm{HCS}$ has been 
portrayed as occurring over fairly moderate burial temperatures, $150^{\circ}-200^{\circ} \mathrm{C}$, depending on the model being used and sedimentburial time.

5. Large data bases from Nature, including but not limited to isotopically light methane-rich ("dry") gases and extreme thermal stabilities of $\mathrm{C}_{15}+\mathrm{HCS}$, demonstrate that the hypothesis of a pronounced thermal instability of $\mathrm{C}_{15}+\mathrm{HCS}$ for the origin of wet and (or) methane-rich gases is unrealistic.

6. As such, different investigators have proposed other generation mechanisms for both wet and methane-rich $\mathrm{HC}$ gases: transition-metal catalysis; late-stage demethylation of post-mature kerogens in shales; cogeneration of $\mathrm{HC}$ gases with $\mathrm{C}_{15}+\mathrm{HCS}$; late-stage generation of increasingly rich $\mathrm{C}_{8}-\mathrm{HCS}$, including the $\mathrm{C}_{4}$ - $\mathrm{HC}$ gases during the evolution of mainstage $\mathrm{C}_{15}+\mathrm{HC}$ generation; $\mathrm{C}_{1}$ to $\mathrm{C}_{4} \mathrm{HC}$-gas fractionation during migration; and late-stage hydrogenation of spent kerogen by water, via the hydrolytic disproportionation of kerogen.

7. In Nature, HC generation occurs in closed, or semiclosed, water-wet, pressurized systems, where product escape is difficult and oxygen fugacities are low. Thus, dry, open-system pyrolysis techniques, such as ROCK-EVAL pyrolysis, with moderate oxygen fugacities, low pressures and where product escape is immediate, are not good replications of HC generation in Nature. This conclusion is corroborated by the fact that products from these types of pyrolysis are not found in Nature.

8. Different water-wet, closed-system, pressurized, experimental pyrolysis approaches to $\mathrm{HC}$ generation replicate Nature much better than dry open-system pyrolysis. However, even the water-wet pyrolysis approaches do not completely replicate Nature. Thus, results from water-wet closed-system pyrolysis experiments must always be compared to data from Nature to verify that the experimental result applies to the natural system.

9. Amounts of carbon dioxide far in excess of what are possible, given the original oxygen contents of kerogens or coals, are generated in water-wet closed-system HC-generation pyrolysis experiments.

10. Mass-balance calculations of 30-day, variable-temperature aqueous-pyrolysis $\mathrm{HC}$-generation experiments demonstrate that in addition to excess $\mathrm{CO}_{2}$, generation potential plus generation products significantly in excess of what is possible, given the starting organic richness of the rocks, also result in these experiments. Moreover, hydrogen indices from postexperimental rock samples, for $150^{\circ}-200^{\circ} \mathrm{C}$ pre-HC-generation aqueous-pyrolysis experiments for six different rocks, significantly increase over the starting values of the rocks. Thus, in addition to excess $\mathrm{CO}_{2}$, the coals and kerogens in these experiments are also becoming more hydrogen-rich and are acquiring excess HC-generation capacity.

11. The excess generation products observed in our aqueous-pyrolysis experiments and the increases in the hydrogen indices of our rocks are both due to water hydrogenating our coals and kerogens via aqueous-based redox reactions, that is to say the hydrolytic disproportionation of kerogen (and coal). The oxygen from the water is given off as excess $\mathrm{CO}_{2}$.

12. Carbon-isotopic values of the $\mathrm{CO}_{2}$ from these aqueouspyrolysis experiments conclusively demonstrate that the excess $\mathrm{CO}_{2}$ in these experiments is derived from the organic carbon in the coals or kerogens.
13. Large ROCK-EVAL data bases from Nature (two coal suites, and Los Angeles Basin upper Miocene and Williston Basin Bakken shales) all demonstrate strongly increasing hydrogen indices with increasing burial depth, before, and during, mainstage $\mathrm{C}_{15}+\mathrm{HC}$ generation.

14. The strong increases in hydrogen indices in these rocks with increasing burial can only be due to water hydrogenating kerogen in the natural system, thus corroborating the results of our aqueous-pyrolysis experiments.

15. Mass-balance calculations for 30-day, variable-temperature, aqueous-pyrolysis, high-temperature $\left(>350^{\circ} \mathrm{C}\right)$ experiments demonstrate that water is hydrogenating the kerogens of all six experimental rocks to make a progressively more methane-rich gas. Moreover, the amounts of generated products in all cases exceed that which is possible, given the starting organic richness of the systems at $350^{\circ} \mathrm{C}$.

16. In some experiments, spanning certain temperature ranges, the oxygen from the water hydrogenating the kerogen was sequestered by mineral phases in the rock samples, instead of being produced as $\mathrm{CO}_{2}$. Thus, in these experiments, the mineral phases, water, and OM were all reacting with one another in an attempt to reach metastable equilibrium in the system.

17. A cross plot of $\mathrm{CO}_{2}$ isotopic-carbon values versus $\mathrm{CaCO}_{3}$ content in the starting rock also demonstrates that the carbon from the $\mathrm{OM}$ in the $\mathrm{CO}_{2}$ was being isotopically exchanged with the carbon in the $\mathrm{CaCO}_{3}$ of the rocks. This observation corroborates that the $\mathrm{OM}$, water, and mineral phases in these experiments were all reacting with one another.

18. Constant-temperature $\left(425^{\circ} \mathrm{C}\right), 30$-day, aqueous-pyrolysis Anna shale experiments with varying water content also demonstrated that water hydrogenates spent kerogen to make a methane-rich HC gas.

19. Ascertaining whether or not hydrogenation of spent kerogen by water occurs in Nature is presently not possible. However, based on the concurrence of our experimental data with comparable data from Nature regarding kerogen hydrogenation at lower ranks, it is reasonable to assume that hydrogenation of high-rank kerogen by water may possibly occur in Nature. This assumption is supported by the widespread occurrence of late-stage carbonate cements with isotopically light carbon in the depocenters of deep basins.

20. If the late-stage kerogen hydrogenation reaction does occur in Nature, certain qualifications and ramifications follow:

A. Open, or semi-open, fluid systems are the key prerequisite for significant reaction extents in hydrolytic disproportionation reactions with OM, including reactions involving hydrogenation of spent kerogen by water.

B. In basins whose depocenters are closed-fluid systems and which are maturing by burial diagenesis, it is unlikely that the extent of the reaction producing high-rank methane by kerogen hydrogenation would be large.

C. The hydrogenation of deep, high-rank spent kerogen, with consequent methane production, could likely be significant in basins maturing via punctuated, rather than burial, diagenesis.

D. This reaction would primarily occur during the youthful stages of basin evolution, such as the present-day (Neogene) U.S. Gulf Coast, when maximum cross-basin fluid flow occurs. 
E. The reaction should not occur during the mature stages of basin evolution when deep-basin depocenters are closed-fluid systems, with pronounced and unchanging compartmentalization over geologic time, the Anardarko Basin being an excellent example.

F. Because the reaction kerogen + water $\rightarrow \mathrm{CH}_{4}+\mathrm{CO}_{2}$ is volume-expansive, in some situations this reaction may be selfdriving by creating high fluid pressures that cause fracturing in the containing rocks, resulting in a more localized open-fluid system.

G. If the preceding reaction does occur, then significantly more deep-basin gas may be generated in certain situations than would be the case given the original hydrogen-richness of the $\mathrm{OM}$ in deep-basin rocks.

H. Thus, the depocenters of certain deep petroleum basins may contain continuous-reservoir, basin-centered, high-rank, methane-rich gas deposits.

I. Such deep-basin gas deposits may be water-free, because of both solution of water into gas volumes migrating out of the deep basin and deep-basin spent kerogen consuming water to make a methane-rich gas.

J. If gas-only phases exist in deep-basin reservoirs, it is probable that significant formation damage would occur to these reservoirs during drilling through them. Thus, the existence of these reservoirs may not be apparent.

$\mathrm{K}$. If deep-basin gas reservoirs exist and are water-free, they could possibly contain minimal amounts of authigenic minerals. Thus, the low permeabilities typical of tight-gas sands may not be present in these reservoirs.

\section{References Cited}

Barth, T., Borgund, A.E., and Hopland, A., 1989, Generation of organic compounds by hydrous pyrolysis of Kimmeridge oil shale-Bulk results and activation energy calculations: Organic Geochemistry, v. 14, p. $69-76$.

Baskin, D.K., 1997, Atomic $\mathrm{H} / \mathrm{C}$ ratio of kerogen as an estimate of thermal maturity and organic matter conversion: American Association of Petroleum Geologists Bulletin, v. 81, p. 1437-1450.

Bell, J.L.S., Palmer, D.A., Barnes, H.L., and Drummond, S.E., 1994, Thermal decomposition of acetate-III, Catalysis by mineral surfaces: Geochimica et Cosmochimica Acta, v. 58, p. 4155-4177.

Bertrand, P., 1984, Geochemical and petrographic characterization of humic coals considered as possible source rocks: Organic Geochemistry, v. 6, p. 481-488.

Braun R.L., and Burnham, A.K.,1991, PMOD-A flexible model of oil and gas generation, cracking, and expulsion: Organic Geochemistry, v. 19 , p. 161-172.

French, B.M., 1964, Stability of siderite, $\mathrm{FeCO}_{3}$, and progressive metamorphism of iron formation: Baltimore, Md., The John Hopkins University Ph. D. dissertation, $247 \mathrm{p}$.

Gussow, W.C., 1954, Differential entrapment of oil and gas-A fundamental principle: American Association of Petroleum Geologists Bulletin, v. 38, p. 816-853.

Guthrie, J.M., Houseknecht, D., and Johns, W.D., 1986, Relationships among vitrinite reflectance, illite crystallinity, and organic geochemistry in Carboniferous strata, Ouachita Mountains, Oklahoma and
Kansas: American Association of Petroleum Geologists Bulletin, v. 70, p. 26-33.

Hao Fang, Li Sitian, Sun Yongchuan, and Zhang Qiming, 1996, Characteristics and origin of the gas and condensate in the Yinggehi Basin, offshore South China Sea-Evidence for effects of overpressure on petroleum generation and migration: Organic Geochemistry, v. 24, p. 363-375.

Hao Fang, Sun Yongchuan, Li Sitian, and Zhang Oiming, 1995, Overpressure retardation of organic-matter maturation and petroleum generation-A case study from the Yinggehai and Qiongdongnan Basins, South China Sea: American Association of Petroleum Geologists Bulletin, v. 79, p. 551-562.

Helgeson, H.C., 1991, Organic/Inorganic reactions in metamorphic processes: Canadian Mineralogy, v. 29, p. 707-739.

Helgeson, H.C., Knox, A.M., Owens, C.E., and Shock, E.L., 1993, Petroleum, oil field waters and authigenic mineral assemblages-Are they in metastable equilibrium in hydrocarbon reservoirs?: Geochimica et Cosmochimica Acta, v. 57, p. 3295-3339.

Helgeson, H.C., and Shock, E.L., 1988, Kinetic and thermodynamic constraints on phase relations among minerals, petroleum, and aqueous solutions in diagenetic processes: International Congress Geochemistry and Cosmochemistry, Paris, France; Chemical Geology, v. 70, p. 78.

Hoering, T.C., 1968, Reactions of the organic matter in a Recent marine sediment: Carnegie Institute of Washington Yearbook, v. 67, p. 199-201.

1984, Thermal reactions of kerogen with added water, heavy water and pure organic substances: Organic Geochemistry, v. 5, p. 267-278.

Horsfield, B., Disko, V., and Leistner, F., 1989, The microscale simulation of maturation-Outline of a new technique and its potential applications: Geologische Randschau, v. 78, p. 361-374.

Horsfield, B., and Douglas, A.G., 1980, The influence of minerals on the pyrolysis of kerogens: Geochimica et Cosmochimica Acta, v. 44, p. 1119-1131.

Hunt, J.M., 1996, Petroleum geochemistry and geology, Second Edition: San Francisco, Freeman, $743 \mathrm{p}$.

Kontorovich, A.E., and Trofimuk, A.A., 1976, Lithogenezi neftegazoobrazoveniye (Lithogenesis and formation of oil and gas), in Vassoyevich, N.B., and others, eds., Goryuchiye IskopayemeProblemy Geoloii I Geokhii Noftidov I Bituminoznykh Porod, Mezhdunarodnyy; Geologicheskiy Kongress XXV Sessiya Doklady Soventskikh Geologov: Moscow, Nauka Press, p. 19-36.

Larson, J.W., 1999, A physical organic chemist looks at hydrous pyrolysis: Preprints of 217th American Chemical Society Meeting, Washington, D.C., March 21-25, p. 393-396.

Larter, S.R., 1988, Some pragmatic perspectives in source rock geochemistry: Marine and Petroleum Geology, v. 5, p. 194-204.

LeFever, J.A., Martiniuk, C.D., Dancsok, E.F.R., and Mahnic, P.A., 1991, Petroleum potential of the middle member, Bakken Formation, Williston basin, in Christopher, J.E., and Haidl, F., eds., Proceedings of the Sixth International Williston Basin Symposium: Saskatchewan Geological Society Special Publication 11, p. 74-94.

Lewan, M.D., 1991, Primary oil migration and expulsion as determined by hydrous pyrolysis, in Proceedings of the Thirteenth World Petroleum Congress: New York, John Wiley, p. 215-223.

1992, Water as a source of hydrogen and oxygen in petroleum formation by hydrous pyrolysis: Preprints of 204th American Chemical Society Meeting, Washington, D.C., Aug. 23-28, p. 1643-1649. 
1997, Experiments on the role of water in petroleum formation: Geochimica et Cosmochimica Acta, v. 61, p. 3691-3723.

Lewan, M.D., Comer, J.B., Hamilton-Smith, T., Hasenmueller, N.R., Guthrie, J.M., Hatch, J.R., Gautier, D.L., and Frankie, W.T., 1995, Feasibility study of material-balance assessment of petroleum from the New Albany shale in the Illinois Basin: U.S. Geological Survey Bulletin 2137, $31 \mathrm{p}$.

Lewan, M.D., Winters, J.C., and McDonald, J.H., 1979, Generation of oil like pyrolysates from organic-rich shales: Science, v. 203, p. 897899.

Lundegard, P.D., Land, L.S., and Galloway, W.E., 1984, Problem of secondary porosity; Frio Formation (Oligocene), Texas Gulf Coast: Geology, v. 12, p. 399-402.

Lundegard, P.D., and Senftle, J.T., 1987, Hydrous pyrolysis-A tool for the study of organic acid synthesis: Applied Geochemistry, v. 2, p. 605-612.

Mango, F.D., 1990, The origin of light cycloalkanes in petroleum: Geochimica et Cosmochimica Acta, v. 54, p. 23-27.

1991, The stability of hydrocarbons under the time-temperature conditions of petroleum genesis: Nature, v. 352, p. 146-148.

1997, The light hydrocarbons in petroleum-A critical review: Organic Geochemistry, v. 26, p. 417-440.

Mango, F.D., Hightower, J.W., and James, A.T., 1994, Catalysis in the origin of natural gas: Nature, v. 368, p. 536-538.

Martiniuk, C.D., 1988, Regional geology and petroleum potential of the Bakken Formation, Southwestern Manitoba: Manitoba Energy and Mines Open-File Report POF8-88, 34 p.

McNeil, R.I., and BeMent, W.O., 1996, Thermal stability of hydrocarbons - Laboratory criteria and field examples: Energy and Fuels, v. 10, p. 60-67.

McTavish, R.A., 1998, The role of overpressure in the retardation of organic matter maturation: Journal of Petroleum Geology, v. 21, p. 153-186.

Michels, R., Landais, P., Elie, M., Gerard, L., and Mansuy, L., 1992, Evaluation of factors influencing the thermal maturation of organic matter during confined pyrolysis experiments: Preprints 204th American Chemical Society National Meeting, v. 37, number 4, p. 1588-1594.

Mimura, K., Price, L.C., and Sugisaki, R., 1999, Characteristics and implications of organic compounds in mantle-derived rocks: Geological Society of America Annual Meeting Abstracts with Programs.

Monthioux, M., Landais, P., and Monin, J.C., 1985, Comparison between natural and artificial maturation series of humic coals from Mahakam delta, Indonesia: Organic Geochemistry, v. 22, p. 617-630.

Morton, J.P., 1985, Rb-Sr evidence for punctuated illite/smectite diagenesis in the Oligocene Frio Formation, Texas Gulf Coast: Geological Society of America Bulletin, v. 96, p. 114-122.

Muscio, G.A., 1995, The fate of oil and gas in a constrained natural system-Implications from the Bakken petroleum system: Forschungszentrum Jülich GmbH (KFA), ISSN-0944-2952, 167 p.

Ortoleva, P.J., ed., 1994, Basin compartments and seals: American Association of Petroleum Geologists Memoir 61, $447 \mathrm{p}$.

Palmer, D.A., and Drummond, SE.,1986, Thermal destruction of acetatePart l, The kinetics and mechanism of reaction in aqueous solution: Geochimica et Cosmochimica Acta, v. 50, p. 813-823.

Peters, K.E., 1986, Guidelines for evaluating petroleum source rocks using programmed pyrolysis: American Association of Petroleum Geologists Bulletin, v. 70, p. 318-329.
Powley, D.E., 1990, Pressures and hydrogeology in petroleum basins: Earth Science Reviews, v. 29, p. 215-226.

Price, L.C., 1982, Organic geochemistry of $300^{\circ} \mathrm{C}, 7-\mathrm{km}$ core samples, South Texas: Chemical Geology, v. 37, p. 205-214.

1983, Geologic time as a parameter in organic metamorphism and vitrinite reflectance as an absolute paleogeothermometer: Journal of Petroleum Geology, v. 6, p. 5-38.

1989a, Primary petroleum migration from shales with oxygen-rich organic matter: Journal of Petroleum Geology, v. 12, p. 289-324.

-1989b, Hydrocarbon generation and migration from type III kerogen as related to the oil window: U.S. Geological Survey Open-File Report 89-194, $44 \mathrm{p}$.

1993, Hydrocarbon thermal stability in nature-Limits, evidence, characteristics, and possible controls: Geochimica et Cosmochimica Acta, v. 57, p. 3261-3280.

-1994a, Metamorphic free-for all: Nature, v. 370, p. 253-254.

1994b, Basin richness versus source rock disruption from faulting-A fundamental relationship?: Journal of Petroleum Geology, v. 17, p. 5-38.

1995, Origins, characteristics, controls, and economic viabilities of deep-basin gas resources: Chemical Geology, v. 126, p. 335-349.

1997a, Minimum thermal stability levels and controlling parameters of methane, as determined by $\mathrm{C}_{15}$, hydrocarbon thermal stabilities: U.S. Geological Survey Bulletin 2146-K, p. 139-176.

1997b, Origins, characteristics, evidence for, and economic viabilities of conventional and unconventional gas resource bases: U.S. Geological Survey Bulletin 2146-L, p. 179-207.

Price, L.C., Dewitt, E., and Desborough, G., 1998, Implications of hydrocarbons in carbonaceous metamorphic and hydrothermal oredeposit rocks as related to the hydrolytic disproportionation of $\mathrm{OM}$ : U.S. Geological Survey Open-File Report 98-758, 127 p.

Price, L.C., Ging, T.G., Daws, T.A., Love, A.H., Pawlewicz, M.J., and Anders, D. E., 1984, Organic metamorphism in the MississippianDevonian Bakken shale North Dakota portion of the Williston Basin, in Woodward, J., Meissner, F.F., and Clayton, J.L., eds., Hydrocarbon source rocks of the Greater Rocky Mountain Region: Rocky Mountain Association of Geologists, p. 83-113.

Price, L.C., and LeFever, J.A., 1992, Does Bakken horizontal drilling imply huge oil resource bases in fractured shales, in Schmoker, J., ed., Geological studies relevant to horizontal drilling, examples from Western North America: Rocky Mountain Association of Geologists, p. 199-214.

Price, L.C., and McNeil, R., 1997, Thoughts on the birth, evolution, and current state of petroleum geochemistry: Journal of Petroleum Geology, v. 20, p. 118-123.

Price L.C., and Mimura, K., 1999, Widespread evidence of the hydrolytic disproportionation of organic matter in geologic systems via aqueous-based redox reactions: Geologic Society of America Abstracts with Programs.

Price, L.C., Pawlewicz, M., and Daws, T.A., 1999, ROCK-EVAL and vitrinite reflectance: U.S. Geological Survey Bulletin 2174-A, 34 p.

Price, L.C., and Schoell, M., 1995, Constraints on the origins of hydrocarbon gas from compositions of gases at their site of origin: Nature, $v$. 378, p. 368-371.

Price, L.C., and Wenger, L.M., 1992, The influence of pressure of petroleum generation and maturation as suggested by aqueous pyrolysis: Organic Geochemistry, v. 19, p. 141-159. 
Price, L.C., Wenger, L.M., Ging, T.G., and Blount, C.W., 1983, Solubility of crude oil in methane as a function of pressure and temperature: Organic Geochemistry, v. 4, p. 201-221.

Ross, D., 1992, Comments on the source of petroleum hydrocarbons in hydrous pyrolysis: Organic Geochemistry, v. 18, p. 79-81.

Sagjò, Cs., 1980, Hydrocarbon generation in a super-thick Neogene sequence in south-east Hungary-A study of the extractable organic matter, in Douglas, A.G., and Maxwell, A.G., eds., Advances in organic geochemistry 1979: Pergamon, p. 103-113.

Salisbury, G.P., 1968, Natural gas in Devonian and Silurian rocks of Permian Basin, west Texas and southeast New Mexico, in Beebe, B.W., and Curtis B.F., eds., Natural gases of North America: American Association of Petroleum Geologists Memoir 9, p.1433-1445.

Schimmelmann, A., Lewan, M.D., and Wintsch, R.P., 1999, D/H isotope ratios of kerogen, bitumen, oil, and water in hydrous pyrolysis of source rocks containing kerogen types I, II, and III: Geochimica et Cosmochimica Acta, v. 63, p. 3751-3766.

Seewald, J.S., 1994, Evidence for metastable equilibrium between hydrocarbons under hydrothermal conditions: Nature, v. 370, p. 285-287.

Shock, E.L., 1988, Organic acid metastability in sedimentary basins: Geology, v. 16, p. 886-890.

1990, Do amino acids equilibrate in hydrothermal fluids?: Geochimica et Cosmochimica Acta, v. 54, p. 1185-1189.

Siskin, M., and Katritzky, A.R., 1991, Reactivity of organic compounds in hot water-Geochemical and technological implications: Science, v. 254, p. 231-237.

Stalker, L., Farrimond, P., and Larter, S.R., 1994, Water as an oxygen source for the production of oxygenated compounds (including $\mathrm{CO}_{2}$ precursors) during kerogen maturation: Organic Geochemistry, v. 22, p. 477-486.

Sugisaki, R., and Mimura, K., 1994, Mantle hydrocarbons-Abiotic or biotic?: Geochimica et Cosmochimica Acta, v. 58, p. 2527-2542.

Teichmüller, M., and Durand, B., 1983, Fluorescence microscopial rank studies on liptinites and vitrinites in peats and coals and comparison with results of the Rock-Eval pyrolysis: International Journal of Coal Geology, v. 2, p. 197-230.

Tissot, B.P., 1984, Recent advances in petroleum geochemistry as applied to hydrocarbon exploration: American Association of Petroleum Geologists Bulletin, v. 68, p. 545-563.

Tissot, B.P., and Welte, D.H., 1984, Petroleum formation and occurrence: Berlin, Springer Verlag, $699 \mathrm{p}$.

Webster, R.L., 1982, Analysis of petroleum source rocks of the Bakken formation (lowermost Mississippian) in North Dakota: Grand Forks, N. Dak., University of North Dakota M.S. thesis, 150 p.

1984, Petroleum source rocks and stratigraphy of the Bakken Formation in North Dakota, in Woodward, J., Meissner, F.F., and Clayton, J.L., eds., Hydrocarbon source rocks of the Greater Rocky Mountain Region: Rocky Mountain Association of Geologists, p. 5781.

Wenger, L.M., and Price, L.C. 1991, Differential petroleum generation and maturation paths of the different organic matter types as determined by hydrous pyrolysis over a wide range of experimental temperatures, in Manning, D.A.C., ed., Advances in organic geochemistry: Advances and Applications in Energy and the Natural Environment, Program and Abstracts, p. 335-339.

\section{Appendix. Replication of HC Generation in the Laboratory}

\section{Open versus Closed-System Methods}

HC generation in Nature occurs over abbreviated or long geologic time periods, in water-wet, pressurized, closed or semi-closed fluid systems, where product escape is difficult, or at least retarded, and oxygen fugacities are low. In the last 10 years, HC generation, and organic metamorphism in general, have been primarily mathematically modeled from the results of open-system pyrolysis, particularly ROCK-EVAL analyses. This pyrolysis approach occurs instantly in open, dry, low-pressure systems, where product escape is immediate, and oxygen fugacities are moderate. Although ROCK-EVAL is a powerful screening tool to determine source-rock organic richness and maturity, a more inappropriate instrument with which to model natural HC generation could hardly be designed (Price, 1994a). Moreover, predictions concerning organic metamorphism, made on the basis of ROCK-EVAL derived kinetics, contradict large data bases from Nature (Price, 1993; 1997a). Lastly, as noted by Price and McNeil (1997), dry open-system pyrolysis, including ROCK-EVAL pyrolysis, yields generation products not found in Nature. These observations demonstrate that dry, open-system pyrolysis is not an acceptable replication of $\mathrm{HC}$ generation in Nature.

In contrast, results from closed-system water-wet pyrolysis experiments have been demonstrated to mimic aspects of natural HC generation. For example, Lewan and others (1979) and Lewan (1997) have simulated natural source-rock expulsion in their hydrous-pyrolysis experiments. Based on aqueous-pyrolysis experiments (Wenger and Price, 1991; and Price and Wenger, 1992), Price (1989a) reported that small concentrations of $\mathrm{HC}$ gas were generated before mainstage $\mathrm{C}_{15}+\mathrm{HC}$ generation commenced in their experiments. Moreover, large quantities of $\mathrm{C}_{1}-\mathrm{C}_{4} \mathrm{HC}$ gases were cogenerated with $\mathrm{C}_{15}+\mathrm{HCS}$ during mainstage $\mathrm{C}_{15}+\mathrm{HC}$ generation in these same experiments. Price (1989a) presented evidence that these same events occurred in Nature, an observation since corroborated by numerous other investigators, including Price and Schoell (1995). Lastly, Price and Wenger (1992) demonstrated, again from aqueous-pyrolysis experiments, that fluid pressure was an unrecognized controlling parameter in organic metamorphism, with increasing fluid pressure retarding all aspects of organic metamorphism, including HC generation. Their results have been replicated in the laboratory by other studies, including Michels and others (1992), and have also been demonstrated to occur in Nature (Hao Fang and others, 1995, 1996; McTavish, 1998).

Many variants of closed-system pyrolysis experimental techniques are available with which to study $\mathrm{HC}$ generation. Such experiments may be carried out on a micro-scale in sealed 
glass tubes (Horsfield and others, 1989), or in sealed gold bags (Monthioux and others, 1985) using only milligram amounts of source rocks, or on a much larger scale by submerging several hundred grams of rock under a water phase ("hydrous pyrolysis") to simulate natural source-rock expulsion (Lewan and others, 1979; Lewan, 1997). In contrast, in aqueous-pyrolysis experiments, 4 to 25 grams (g) of source rock are reacted with added water, usually equivalent to 11 weight percent of the rock (Price, 1989a; Wenger and Price, 1991). Proponents of each of the different closed-system experimental approaches may claim that theirs is superior to others, and each has certain advantages, and deficiencies, with respect to the others. Be that as it may, all share significant common strengths over dry, open-system pyrolysis. Thus, compared to open-system pyrolysis, closedsystem experiments: (1) occur over much longer time periods, tens of hours to months, (2) are all water-wet, with either added water or water indigenous to the sample, (3) have much lower oxygen fugacities (higher-hydrogen fugacities), and (4) retain all their generation products.

However, none of these closed-system approaches replicate natural $\mathrm{HC}$ generation exactly, one on one. For example, in all water-wet, closed-system pyrolysis experiments, much higher relative concentrations of resins and asphaltenes are generated with respect to the saturated and aromatic HCS, as compared to the case with natural $\mathrm{HC}$ generation. Thus, it is paramount in assessing the possible validity of a newly recognized facet of HC generation from such closed-system experiments that one compare the experimental results to similar data from Nature. In this manner, one may gauge if the experimental result in question is actually replicating the natural system, or instead is merely an experimental artifact. Aspects of $\mathrm{HC}$ generation, or organic metamorphism in general, hypothesized on the basis of experimental results but not corroborated by supporting data from Nature, are simply unsubstantiated hypotheses.

\section{Rock-Eval Pyrolysis}

For those unfamiliar with the details of the ROCK-EVAL analysis, the $\mathrm{S}_{2}$ peak measures the milligrams (mg) of HCS, from the HC gases to heavy HCS, which can be generated from a gram (g) of shale (the analysis is normalized to $\mathrm{mg} / \mathrm{g}$ values). For example, the Phosphoria shale used in the figure $3 A$ experiments has an $\mathrm{S}_{2}$ value of $96.6 \mathrm{mg} / \mathrm{g}$ rock for starting Soxhletextracted rock. The ROCK-EVAL hydrogen index (HI) is equal to the ROCK-EVAL $S_{2}$ peak divided by total organic carbon in weight percent $\left(\mathrm{S}_{2} / \mathrm{TOC}\right)$. The starting Soxhlet-extracted Phosphoria shale of figure 3 has a hydrogen index of 451 .

As stated, the ROCK-EVAL analysis is held by many investigators, including Braun and Burnham (1991), as an acceptable replication of $\mathrm{HC}$ generation and source rock expulsion in Nature, an unrealistic viewpoint in my opinion. Concurrently, ROCK-EVAL has come under significant criticism as not even being able to fulfill the purpose for which it is best suited: providing reasonable estimates of organic richnesses of source rocks. As an aside, these two viewpoints could not be more diametrically opposed to one another. Some investigators (Baskin, 1997) advise pronounced caution in using ROCK-EVAL hydrogen indices as a measure of kerogen HC-generation potential, or at the very least a good correlation between ROCK-EVAL hydrogen indices and kerogen hydrogen to carbon ratios should be demonstrated, which is a point well taken. Because much of the data from this study is derived from ROCK-EVAL analysis, some discussion is warranted of its analytical strengths, weaknesses, and limitations.

Significant problems do exist with the ROCK-EVAL instrument regarding accuracy and reproducibility of analyses. Moreover, I have repeatedly voiced concerns on this subject (Price and others, 1984, 1999), and still consider the variance in the reproducibility of $\mathrm{T}_{\max }$ unacceptable, except in the case of coals where $\mathrm{T}_{\max }$ is more reproducible and has an excellent correlation with $\mathrm{R}_{\mathrm{o}}$ (Tissot, 1984). Poor correlations of kerogen $\mathrm{H} /$ $\mathrm{C}$ ratios with ROCK-EVAL hydrogen indices do exist, as pointed out by Baskin (1997). The reasons for this lack of correlation have been discussed by Horsfield and Douglas (1980), Peters (1986), and Larter (1988), and largely are attributed to erroneous ROCK-EVAL analyses. The lack of correlation between kerogen $\mathrm{H} / \mathrm{C}$ and hydrogen indices thus far is limited to two cases. One of these involves very immature source rocks with hydrogen-rich OM from the California petroleum basins, where ROCK-EVAL hydrogen indices vary between 200 and 700 , whereas kerogen $\mathrm{H} / \mathrm{C}$ ratios for the same samples vary between 1.00 and 1.40 in cross plots of these two parameters, which thus are little more than scatter plots. This problem was discussed by Price and others (1999), and was largely attributed to the fact that these California immature mid-Miocene shales can, but do not always, have very high bitumen coefficients (200-400), most of this bitumen being composed of resins and asphaltenes, entities which are lost during kerogen isolation procedures. However, this material is present during the ROCKEVAL analysis, which records this material as the $S_{2}$ peak-and rightfully so, because it is $\mathrm{HC}$-generation potential. Thus, the lack of correlation in this instance is due to the fact in some cases, kerogen maceration decreases the HC-generation capacity of the rock, which is what the ROCK-EVAL instrument is measuring. As such, Price and others (1999) made the point that the lack of correlation between the two parameters in this instance is actually more due to the kerogen maceration procedure than to the ROCK-EVAL instrument. Price and others (1999) presented a cross plot of kerogen H/C ratios versus ROCK-EVAL hydrogen indices for California source rocks, a plot which had an excellent correlation between the two parameters.

The other case of a lack of correlation between kerogen $\mathrm{H} /$ $\mathrm{C}$ ratios and the hydrogen index involves rich (TOC $>7.0$ percent) source rocks, with hydrogen indices $>450$, where hydrogen-index values flatten out versus $\mathrm{H} / \mathrm{C}$ ratios which thus become almost invariant versus hydrogen-index values (Baskin, 1997, his figs. 1, 2, not shown here). The lack of correlation in this case is due to faulty calibration of the ROCK-EVAL instrument with inappropriate standards. Flame-ionization detectors, 
which are the HC detectors on the Rock-Eval instument, are notoriously nonlinear for large sample sizes, which is demonstrated in plots of response (millivolts) versus sample size. ROCK-EVAL is typically calibrated using standards with $\mathrm{S}_{2}$ peak values of 5-10. However, in a large yet-unpublished costudy with Dow Geochemical Services Inc. (DGSI), we found with very rich source rocks, specifically the Upper DevonianLower Mississippian Bakken Formation shales, which have $\mathrm{S}_{2}$ values of 100-200, that standards with such low $S_{2}$ values (510) resulted in abnormally low TOC and $S_{2}$ values being reported for the sample being analyzed. We obtained appropriate values only after calibrating the instrument with a rock with similar organic richness to that of the rock being analyzed. As part of the study with DGSI, we also examined other variables affecting the ROCK-EVAL analysis, including grain size of the powdered rock and the sample size for analysis. We found that the optimum sample size varied as a function of the rock's organic richness, and that rocks had to be ground and sieved to 100 mesh or less to optimize the analysis.

I present large ROCK-EVAL data bases in this report from analyses of samples from both Nature and from laboratory experiments. The hydrogen indices from the ROCKEVAL data bases in this study all exhibited excellent correlations in cross plots with kerogen $\mathrm{H} / \mathrm{C}$ ratios. Moreover, all samples were properly calibrated, ground and sieved, with optimum sample sizes employed. Within all sample sets, the operating parameters of the ROCK-EVAL instrument, including heating rates, were held constant. Thus, the results reported here are due entirely to variances within the samples themselves, and in no manner should be considered as analytical artifacts. In my opinion, the argument that ROCK-EVAL cannot adequately measure source-rock HC generation potential is as overstated as the argument that ROCK-EVAL closely mimics HC generation in Nature.

\section{Aqueous Pyrolysis}

In aqueous-pyrolysis HC-generation experiments, between 4 and $25 \mathrm{~g}$ of finely powdered source rock are reacted with variable amounts of added water. In most experiments, the added water makes up 11 weight percent of the rock, which is estimated to be the maximum amount of water available to a source rock in Nature. The samples are reacted for variable times, 30 days for most experiments, in stainless-steel "pipe bombs," sealed by a high-pressure, high-temperature valve. With the sealing valve inside the heating furnace, the experimental vessels may be taken to maximum temperatures of $500^{\circ} \mathrm{C}$.
However, much higher temperatures are possible if the sealing valve extends out of the furnace, and is thus not heated. Maximum pressures of 60,000 psi $(4,136.8$ bars $)$ may be obtained with these vessels; however, most experiments are carried out in the range of 2,000-5,000 psi (137.8-344.7 bars). When the desired reaction time has been reached, the vessels are cooled and the sealing valve on the pressure vessel is opened allowing the generated gases to be vented into a glass round-bottom flask, of known volume. This flask is sealed by a compressed halfhole septum (Alltech Assoc.) in a Swagelok fitting which is attached to the metal tube of a glass-metal Kovar seal. Quantitative and qualitative analyses, including carbon-isotopic analyses, can be carried out on the trapped gases. The hightemperature sealing valve is then removed and quickly replaced by another high-pressure fitting terminating in another compressed half-hole septum in a Swagelok fitting, which once again seals the reaction vessel. The vessel is heated to $80^{\circ} \mathrm{C}$ in a convection oven, and a head-space sample is removed from the reaction vessel by a gas-tight syringe with a Minerett valve, via the half-hole septum, for quantitative and qualitative $\mathrm{C}_{4}-\mathrm{C}_{7} \mathrm{HC}$ analyses. After the reaction vessel is cooled from the $80^{\circ} \mathrm{C}$ heating, the vessel is opened, and its contents (reacted source rock and generated products) are quantitatively transferred to a thimble in a Soxhlet extractor for extraction using dichloromethane.

The resulting extracted bitumen is filtered and passively evaporated (to preserve $\mathrm{C}_{8}+\mathrm{HCS}$ ) to 1 milliliter (mL) and the dichloromethane is replaced by hexane to precipitate asphaltenes, which are filtered from the sample. The remaining maltene fraction of the bitumen is then separated into saturated and aromatic HCS and resins by silica-gel/alumina column chromatography. After passive evaporation of the saturated and aromatic HCS, they are transferred to $10 \mathrm{~mL}$ volumetric flasks, and splits are taken of both fractions. One split is used for gravimetric weight determination and $\mathrm{C}_{13}+$ gas chromatography, and the other split is used for $\mathrm{C}_{8}+$ gas chromatography and isotopic determinations. Electronic integration of the $\mathrm{C}_{8}+$ and $\mathrm{C}_{13}+$ saturated- and aromatic-HC gas chromatograms allow quantitative determination of $\mathrm{C}_{8}+\mathrm{HCS}$ for both fractions. Resin and asphaltene weights are determined gravimetrically. ROCKEVAL analyses and kerogen maceration are carried out on the reacted shales, with elemental analysis being carried out on the recovered kerogen. In this manner, all products and reactants from these experiments are qualitatively and quantitatively analyzed, and mass balance calculations between generated products and original and remaining source-rock generation potential may be carried out. Experimental runs may be carried out as a function of many different parameters, including reaction temperature or pressure, water content, starting source rock, reaction-headspace volumes, and so on. 


\section{Potential for Deep Basin-Centered Gas Accumulation in Hanna Basin, Wyoming}

Geologic Studies of Basin-Centered Gas Systems

U.S. Geological Survey Bulletin 2184-A

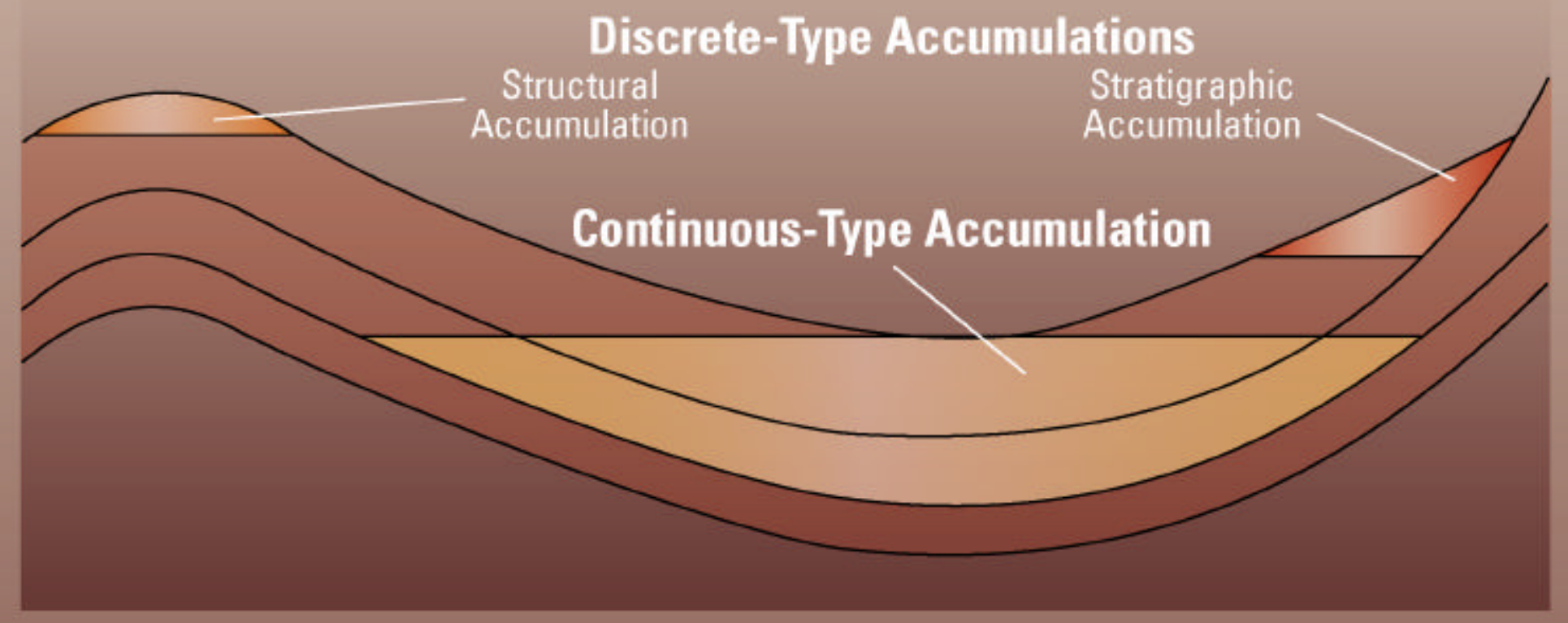




\section{Potential for Deep Basin-Centered Gas Accumulation in Hanna Basin, Wyoming}

By Michael S. Wilson, Thaddeus S. Dyman, and Vito F. Nuccio

\section{Geologic Studies of Basin-Centered Gas Systems}

Edited by Vito F. Nuccio and Thaddeus S. Dyman

U.S. Geological Survey Bulletin 2184-A

This work funded by the U.S. Department of Energy, National Energy Technology Laboratory, Morgantown, W. Va., under contracts DE-AT26-98FT40031 and DE-AT26-98FT40032, and by the U.S. Geological Survey Central Region Energy Resources Team 


\title{
U.S. Department of the Interior
}

\author{
Gale A. Norton, Secretary
}

\section{U.S. Geological Survey}

Charles G. Groat, Director

Posted online June 2001, version 1.0

This publication is only available online at:

http://geology.cr.usgs.gov/pub/bulletins/b2184-a/

Any use of trade, product, or firm names in this publication is for descriptive purposes only and does not

imply endorsement by the U.S. Government 


\section{Contents}

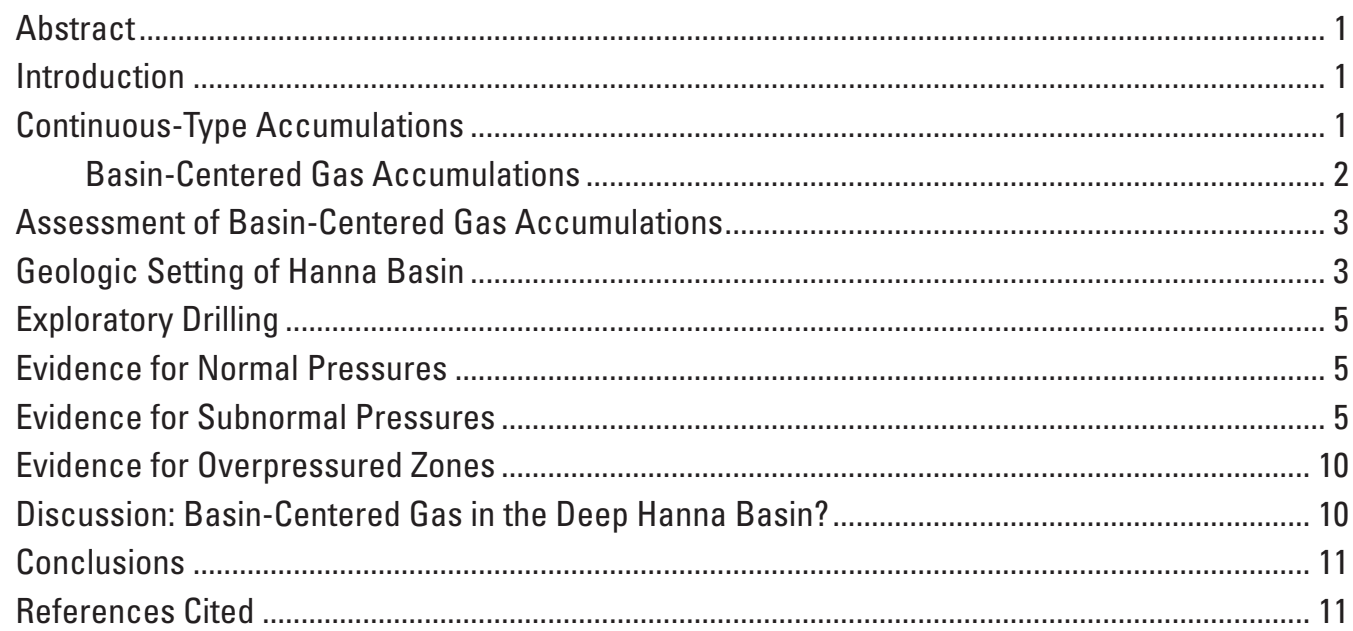

\section{Figures}

1. Map showing location of the Hanna Basin, surrounding uplifts, major faults, depth in feet to Precambrian basement in the basin center, and location of the Brinkerhoff Hanna Unit No. 1 well.

2. Stratigraphic chart showing names and average thicknesses of stratigraphic units recognized in the Hanna Basin, Wyoming.

3. Map showing structural elements, outcrop patterns, cross sections, and locations of 29 representative exploration wells in the Hanna Basin, Wyoming .

4. Cross section A-A' showing generalized structure of the Hanna Basin and approximate boundaries of the normal, subnormal, and overpressure zones based on interpretations of vitrinite reflectance measurements and well data

5. Cross section B-B' showing generalized structure of the Hanna Basin and interpreted boundaries of normal, subnormal, and overpressure zones based on interpretations of vitrinite reflectance measurements and well data 8

\section{Table}

1. Mud weights, bottom-hole temperatures and drill-stem test results for 29 representative exploration wells in the Hanna Basin, Wyoming, based on well logs and scout cards available at the Denver Earth Resources Library, Denver, Colo. 


\title{
Potential for Deep Basin-Centered Gas Accumulation in Hanna Basin, Wyoming
}

\author{
By Michael S. Wilson, ${ }^{1}$ Thaddeus S. Dyman, ${ }^{2}$ and Vito F. Nuccio ${ }^{2}$
}

\section{Abstract}

The potential for a continuous-type basin-centered gas accumulation in the Hanna Basin in Carbon County, Wyoming, is evaluated using geologic and production data including mud-weight, hydrocarbon-show, formation-test, bottomhole-temperature, and vitrinite reflectance data from 29 exploratory wells.

This limited data set supports the presence of a hypothetical basin-centered gas play in the Hanna Basin. Two generalized structural cross sections illustrate our interpretations of possible abnormally pressured compartments. Data indicate that a gas-charged, overpressured interval may occur within the Cretaceous Mowry, Frontier, and Niobrara Formations at depths below 10,000 ft along the southern and western margins of the basin. Overpressuring may also occur near the basin center within the Steele Shale and lower Mesaverde Group section at depths below 18,000 to 20,000 ft. However, the deepest wells drilled to date $(12,000$ to $15,300 \mathrm{ft})$ have not encountered overpressure in the basin center. This overpressured zone is likely to be relatively small (probably 20 to 25 miles in diameter) and is probably depleted of gas near major basement reverse faults and outcrops where gas may have escaped. Water may have invaded reservoirs through outcrops and fracture zones along the basin margins, creating an extensive normally pressured zone.

A zone of subnormal pressure also may exist below the water-saturated, normal-pressure zone and above the central zone of overpressure. Subnormal pressures have been interpreted in the center of the Hanna Basin at depths ranging from 10,000 to $25,000 \mathrm{ft}$ based on indirect evidence including lost-circulation zones. Three wells on the south side of the basin, where the top of the subnormally pressured zone is interpreted to cut across stratigraphic boundaries, tested the Niobrara Formation and recovered gas and oil shows with very low shut-in pressures.

\section{Introduction}

The primary purpose of this report is to describe the potential for a continuous-type basin-centered gas accumulation in the Hanna Basin of south-central Wyoming (fig. 1) using the published literature and computerized well and reservoir data files. The U.S. Geological Survey (USGS) is currently reevaluating the potential for basin-centered gas accumulations in high-priority basins in the United States in order to accommodate changing geologic perceptions and new data since the completion of the U.S. Geological Survey 1995 National Petroleum Assessment. This effort, which is being conducted with funding from the U.S. Department of Energy, may result in the identification of new continuous-type assessment units and petroleum systems. These potential basincentered gas accumulations vary qualitatively from low to high risk and may or may not survive rigorous geologic scrutiny leading toward a full geologic assessment based on assessment units and petroleum systems.

This report on the Hanna Basin is one of several reports that will be published as U.S. Geological Survey Bulletins. Data relating to the existence of basin-centered gas accumulations is summarized in each of these reports. No attempt is made, however, to identify potential assessment units and petroleum systems or to actually assess gas resources for potential assessment units. These reports are specifically meant to describe the geologic and production characteristics of potential assessment units.

This work is funded by the U.S. Department of Energy, National Energy Technology Laboratory, Morgantown, W. Va. (contract nos. DE-AT26-98FT40031 and DE-AT2698FT40032), and by the U.S. Geological Survey Central Region Energy Resources Team. We wish to acknowledge the helpful reviews of Mark Kirschbaum, Ronald Johnson, Thomas Judkins, and Katharine Varnes of the U.S. Geological Survey.

\section{Continuous-Type Accumulations}

\footnotetext{
${ }^{1}$ Geologic consultant, Denver, Colo.

2 U.S. Geological Survey, Denver, Colo.
}

Continuous-type accumulations are large single fields having spatial dimensions equal to or exceeding those of con- 


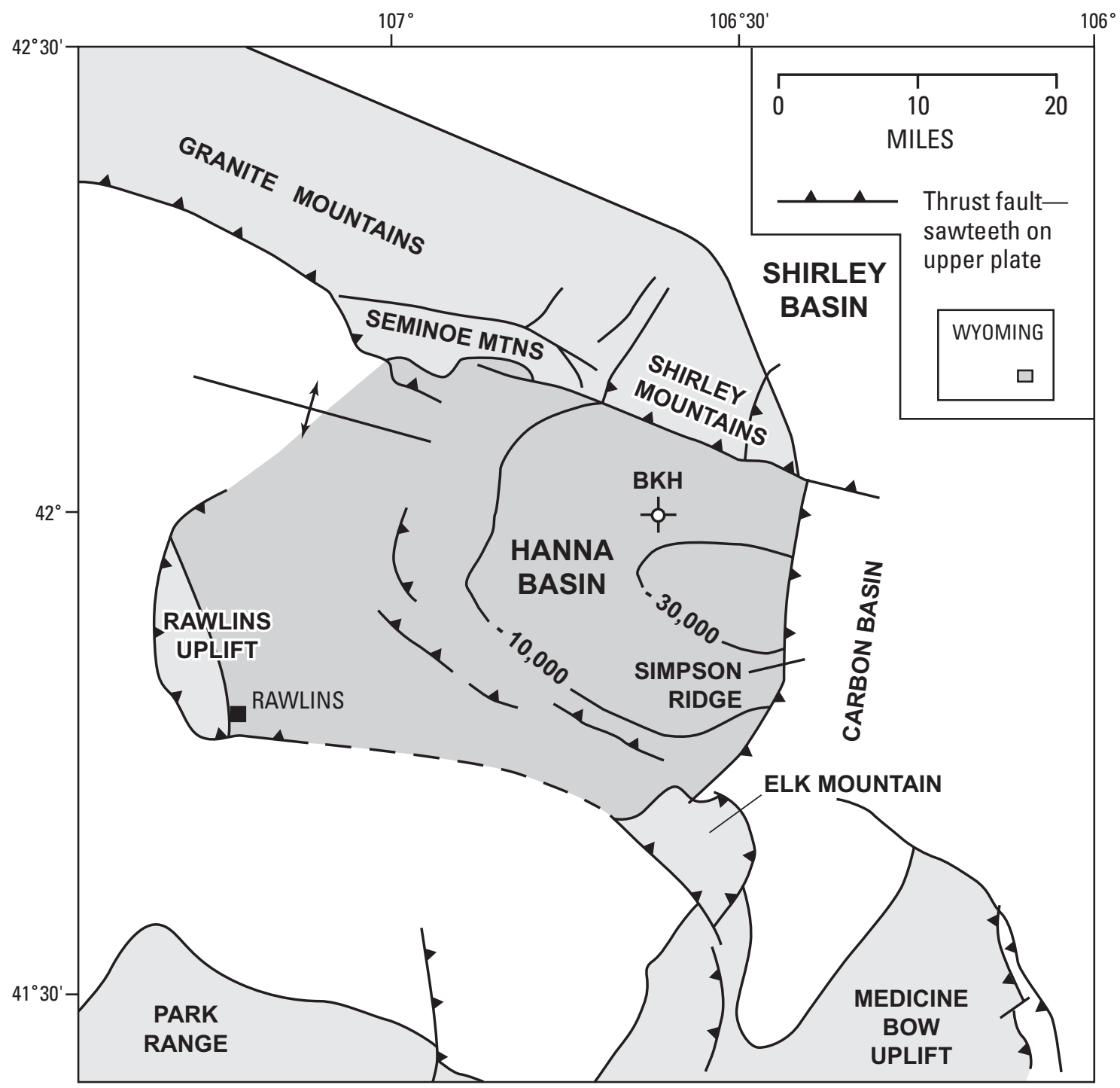

Figure 1. Map showing the location of the Hanna Basin (dark shading), surrounding uplifts (light shading), major faults, depth in feet to Precambrian basement in the basin center, and location of the Brinkerhoff Hanna Unit No. 1 well (BKH). Modified from Perry and Flores (1997, p. 52).

ventional fields. They cannot be represented in terms of discrete, countable units delineated by downdip hydrocarbonwater contacts (as are conventional fields). The definition of continuous-type accumulations used here is based on geology rather than on government regulations defining low-permeability (tight) gas. Common geologic and production characteristics of continuous-type accumulations include their occurrence downdip from water-saturated rocks, lack of obvious traps or seals, relatively low matrix permeability, abnormal pressures, large in-place hydrocarbon volumes, and low recovery factors (Schmoker, 1996).

Continuous-type plays were treated as a separate category in the U.S. Geological Survey 1995 National Petroleum Assessment and were assessed using a specialized methodology (Schmoker, 1996). These continuous-type plays are geologically diverse and fall into several categories including coalbed gas, biogenic gas, fractured-shale gas, and basin-centered gas accumulations. This report focuses on basin-centered gas.

\section{Basin-Centered Gas Accumulations}

Basin-centered gas accumulations form a special group of continuous-type gas accumulations and differ significantly 
in their geologic and production characteristics from conventional accumulations. They have the following characteristics:

1. They are geographically large and cover from tens to hundreds of square miles in areal extent, typically occupying the central, deeper parts of sedimentary basins.

2. They lack downdip water contacts, and thus hydrocarbons are not held in place by the buoyancy of water.

3. Reservoirs are abnormally pressured.

4. Gas is the pressuring phase of the reservoir.

5. Water production is usually low or absent, or water production is not associated with a distinct gas-water contact.

6. Reservoir permeability is low—generally less than 0.1 millidarcy $(\mathrm{mD})$.

7. Reservoirs are overlain by normally pressured rocks containing both gas and water.

8. Reservoirs contain primarily thermogenic gas.

9. Migration distances are not thought to be great.

10. Structural and stratigraphic traps are of minor importance.

11. Reservoirs are commonly compartmentalized.

12. Multiple fluid phases contribute to seal development in reservoirs.

13. The tops of basin-centered accumulations occur within a narrow range of thermal maturities, usually between vitrinite reflectance values of 0.75 and 0.9 percent.

Many gas accumulations may have only some of the above characteristics, and classification as a basin-centered accumulation may become highly subjective.

\section{Assessment of Basin-Centered Gas Accumulations}

Assessment of basin-centered gas (and other continuoustype) accumulations is based on the concept that a continuous accumulation can be regarded as a collection of hydrocarbon-bearing cells. In the assessment unit, cells represent spatial subdivisions defined by the drainage area of wells. Cells may be productive, nonproductive, or untested. Geologic risk, expressed as assessment-unit probability, is assigned to each play. The number of untested cells in an assessment unit and the fraction of untested cells expected to become productive (success ratio) are estimated, and a probability distribution is defined for estimated ultimate recoveries (EUR's) for those cells expected to become productive. The combination of geologic probability, success ratio, number of untested cells, and EUR probability distribution yields potential undiscovered resources for each assessment unit. Refer to Schmoker (1996) for a detailed discussion of continuous-type accumulations and their assessment.

In 1995, the U.S. Geological Survey defined 100 continuous-type oil and gas plays in sandstones, shales, chalks, and coals for all depth intervals. Of the 100 identified plays, 73 were gas plays. Eighty-six of the 100 identified plays were quantitatively assessed. Estimates of undiscovered technically recoverable gas resources from all continuous-type playsexcluding coal-bed gas plays - range from 219 trillion $\mathrm{ft}^{3}$ (TCF) (95th fractile) to 417 TCF (5th fractile), with a mean estimate of 308 TCF. Much of this resource is attributed to basin-centered gas plays.

Four categories of continuous-type basin-centered gas plays can be identified with respect to new data and perceptions since the U.S. Geological Survey 1995 National Petroleum Assessment: (1) plays that were assessed in 1995, but need to be updated because of new data; (2) plays that were identified incorrectly as conventional or continuous in 1995; (3) plays that were identified as continuous in 1995 but not assessed because of a lack of data; and (4) new continuoustype accumulations that were not identified in 1995. Basincentered gas plays were not assessed or identified in 1995 in many basins including the Wind River, Raton, Albuquerque, Bighorn, Crazy Mountains, and Hanna Basins of the Rocky Mountain region; the Anadarko and Arkoma Basins of the southern Midcontinent region; and the Colville Basin of northern Alaska.

\section{Geologic Setting of Hanna Basin}

The Hanna (fig. 1) is a deep Laramide basin located northeast of the city of Rawlins in south-central Wyoming (Perry and Flores, 1997). The basin is flanked by Precambriancored uplifts including the Shirley and Seminoe Mountains to the north, Simpson Ridge to the east, the Medicine Bow and Park Range uplifts to the south, and the Rawlins uplift to the west. Precambrian basement is about 30,000 to 40,000 $\mathrm{ft}$ deep in the eastern part of the basin (Hansen, 1986). The Hanna Basin is considered a pull-apart basin; its tectonic history has been summarized by LeFebre (1988) and Perry and Flores (1997). Strike-slip and reverse faulting along the Shirley Mountain thrust occurred during Late Cretaceous and early Paleocene time (early Laramide), whereas uplift of the Medicine Bow Mountains and Rawlins uplift occurred during late Paleocene and Eocene time (late Laramide).

Stratigraphic units in the Hanna Basin are shown in figure 2. The Cambrian through Jurassic section is less than 2,500 $\mathrm{ft}$ thick and includes the Cambrian Flathead Sandstone, Mississippian Madison Limestone, Pennsylvanian Casper Formation, Triassic Jelm and Chugwater Formations, and the Jurassic Nugget Sandstone and Sundance and Morrison Formations. The Lower and lower Upper Cretaceous fluvial and marine section includes the Cloverly Formation, Thermopolis Shale, Muddy Sandstone, and Mowry Shale. Upper Cretaceous marine and deltaic units include the Frontier Formation, Niobrara Formation, Steele Shale, Mesaverde Group, Lewis Shale, Fox Hills Sandstone, and Medicine Bow Formation. Fluvial and deltaic sediments of the Tertiary Hanna and Cretaceous 


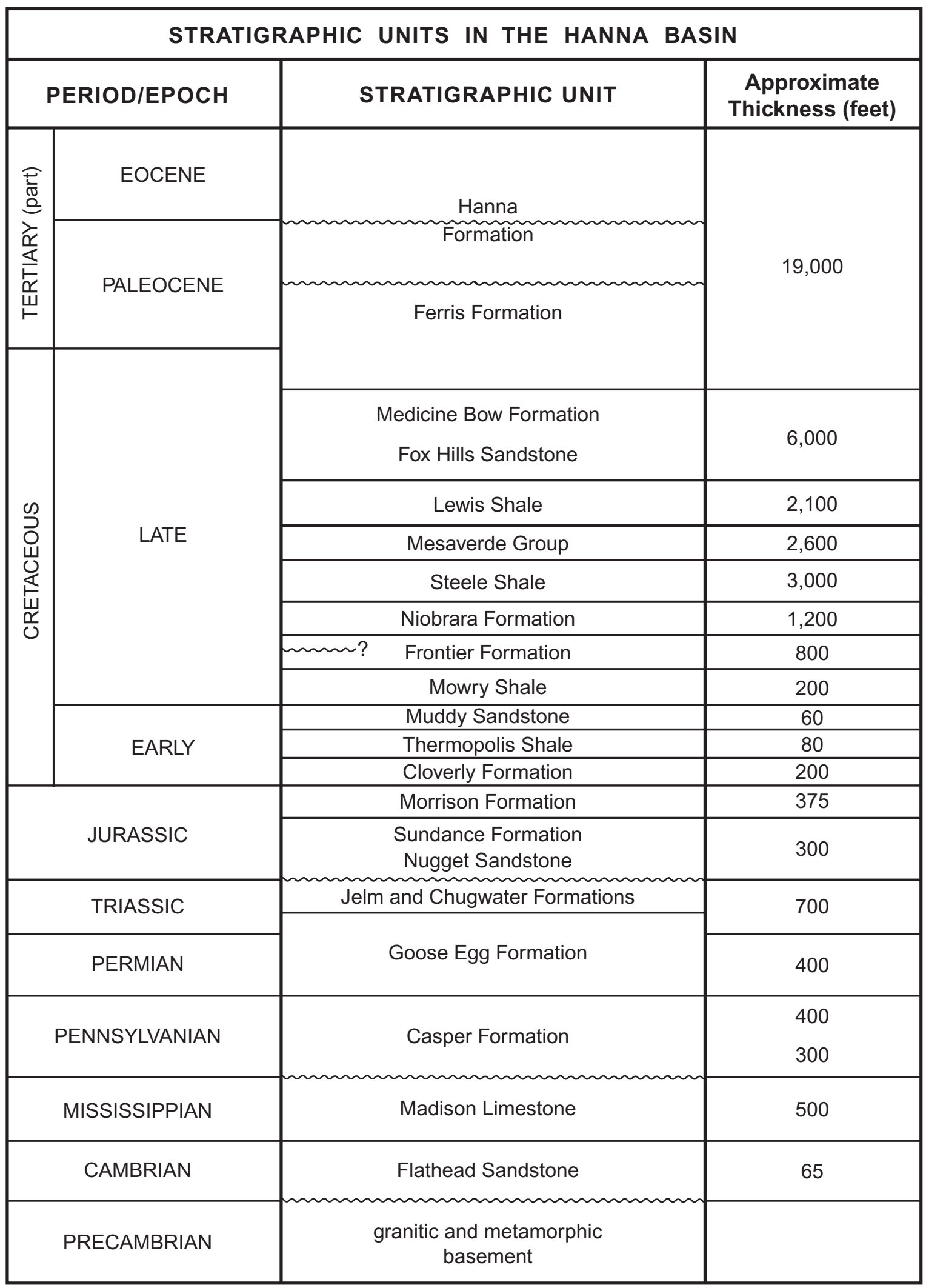

Figure 2. Stratigraphic chart showing names and average thicknesses of stratigraphic units recognized in the Hanna Basin, Wyoming. Modified from Kaplan and Skeen (1985, p. 224). 
and Tertiary Ferris Formations filled the basin as it subsided rapidly during Laramide uplift and are almost 19,000 ft thick in the basin center (Hansen, 1986). Several thousand feet of sediment have probably been removed by erosion from the basin since Miocene time, based on the presence of regional unconformities.

\section{Exploratory Drilling}

The Hanna Basin has been lightly explored for oil and gas, including coal-bed methane. The lack of exploration is due in part to the "checkerboard" lease position in which alternate sections have been held by the Union Pacific Railroad Corporation (Stone, 1966). Most of the early exploratory wells tested fault-fold structures along the flanks of the basin (Johnson and Flores, 1998), and only a few deep wells have been drilled in the basin center. A few minor oil and gas fields have been discovered, including the Rock River, Allen Lake, Big Medicine Bow, Cedar Ridge, Chapman Draw, Melton, and Simpson Ridge fields (Mapco, 1999). Figure 3 shows lines of cross section and well locations for 29 representative exploration wells. The Denver Earth Resources Library, Denver, Colo., provided much of the data used here, including geologic maps, well logs, and scout cards.

\section{Evidence for Normal Pressures}

Drilling-mud-weight, drill-stem-test, bottom-holetemperature (table 1), and vitrinite reflectance data were examined for evidence of abnormal pressures that might indicate the presence of a basin-centered gas accumulation. Figures 4 and 5 illustrate our interpretations of the approximate boundaries of normal and abnormal pressure zones in the Hanna Basin based on the limited well data available.

The Cambrian through Jurassic stratigraphic section is interpreted to be regionally water saturated and normally pressured largely due to the absence of significant hydrocarbongenerating source rocks. Several exploratory wells recovered water with near-normal pressure gradients during tests of the Jurassic Morrison and Pennsylvanian Tensleep Formations (fig. 3, symbol CKS). Some oil shows were encountered in the Triassic Chugwater Formation and Jurassic Nugget Sandstone. These shows are probably due to early (pre-Laramide) migration of oil generated from the Permian Phosphoria Formation in western Wyoming. Laramide tectonic movements disrupted and breached many of the pre-Cretaceous oil traps, and noncommercial oil shows are common in the Paleozoic section.

Water-producing Paleozoic through Tertiary reservoirs with near-normal pressure gradients $(0.40$ to $0.47 \mathrm{psi} / \mathrm{ft})$ have been encountered at depths of less than 8,000 ft along the western, southern, and southeastern margins of the basin, and at depths of less than 12,500 ft in the basin center (table 1).
The Frontier-Cloverly section was tested in three wells on the west flank of the basin (table 1, symbols MHS, CKS, and SFM), and shut-in pressures from drill-stem tests indicate near-normal pressure gradients ranging from 0.35 to 0.47 $\mathrm{psi} / \mathrm{ft}$ in this part of the basin. Several tests of the Mesaverde Group and Ferris Formation (table 1) also recovered water with near-normal pressure gradients. One of the deepest wells in the basin, the Forgotson-Nortex HBJVU No. 1-25 well (fig. 3, FGN) reached a total depth of $15,322 \mathrm{ft}$ in the lower Mesaverde Group using only 8.9 pounds per gallon (ppg) mud. Overpressures were not reported in this well. Drill-stem tests at 12,500 and 10,200 ft recovered water, and shut-in pressures indicate normal pressure gradients of $0.41 \mathrm{psi} / \mathrm{ft}$.

These results indicate extensive water-saturation at depths less than $12,500 \mathrm{ft}$ in the basin. The normally pressured zone (figs. 4 and 5) is interpreted to be an envelope extending from outcrops on the basin margins through the basin center at shallow depths, and from outcrops through the basin bottom within the Cambrian- through Jurassic-age section. Major fault zones and outcrops surrounding the basin may have allowed extensive water invasion and (or) gas leakage.

\section{Evidence for Subnormal Pressures}

Zones of subnormal pressure $( \pm 0.3 \mathrm{psi} / \mathrm{ft})$ have been found below water-saturated, normal-pressure zones and above central overpressure zones in several other basin-centered gas accumulations in the Rocky Mountain region (Meissner, 2000; Wilson and others, 1998). The subnormally pressured zones are generally interpreted to have been previously overpressured during peak gas expulsion, but loss of gas due to cooling, erosional unloading, and escape along fractures and fault zones has allowed pressures to decline to subnormal levels. Identification of subnormally pressured zones in exploration wells is often difficult because water-based drilling mud often overbalances the low-pressure gas reservoirs. Gas shows may be suppressed (Wilson and others, 1998) and formation damage may have occurred due to mud invasion. Drill-stem tests may be ineffective or inconclusive in the damaged intervals. Low or flat mud-log gas readings, problems with lost circulation, and drill-stem tests that recovered gassy mud with low shut-in pressures are often subtle clues indicating subnormally pressured zones.

Subnormal pressures have been interpreted in the central part of the Hanna Basin (figs. 4 and 5) at depths ranging from 10,000 to $25,000 \mathrm{ft}$ based on indirect evidence including lost circulation reported at $11,800 \mathrm{ft}$ in the Amoco Seminoe Reservoir No. 1 well, where 8.8 ppg mud was used. This mud may have overbalanced a low-pressure zone (fig. 3, ASR).

Temperatures high enough for gas generation have been 


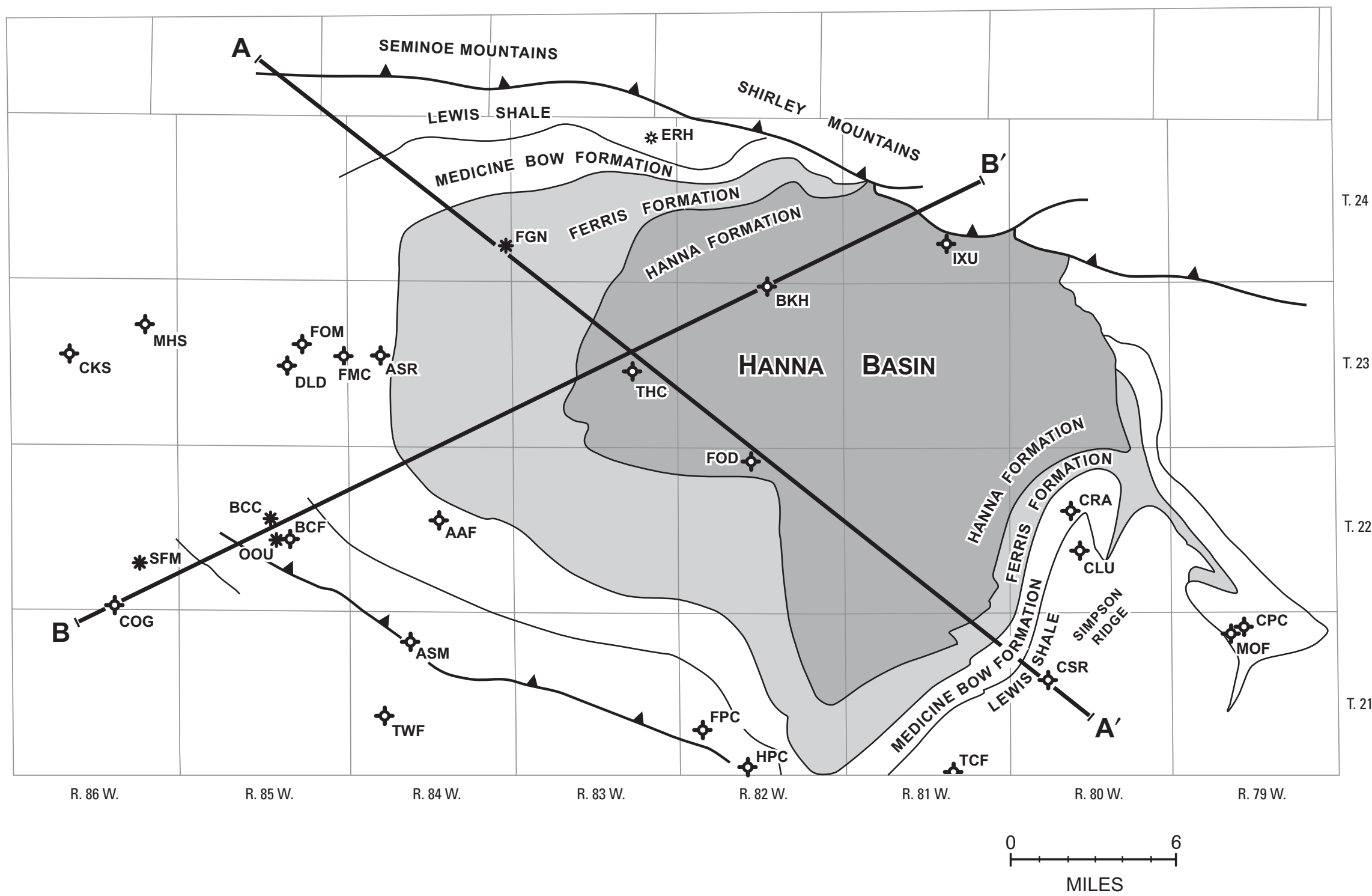

Figure 3. Map showing structural elements, outcrop patterns, locations of cross sections (figs. 4 and 5), and locations of 29 representative exploration wells in the Hanna Basin, Wyoming. Modified from Hansen (1986, p. 485) and MAPCO (1999, maps WA5 and WA6). Three-letter code identifies well name as shown in table 1. 
A

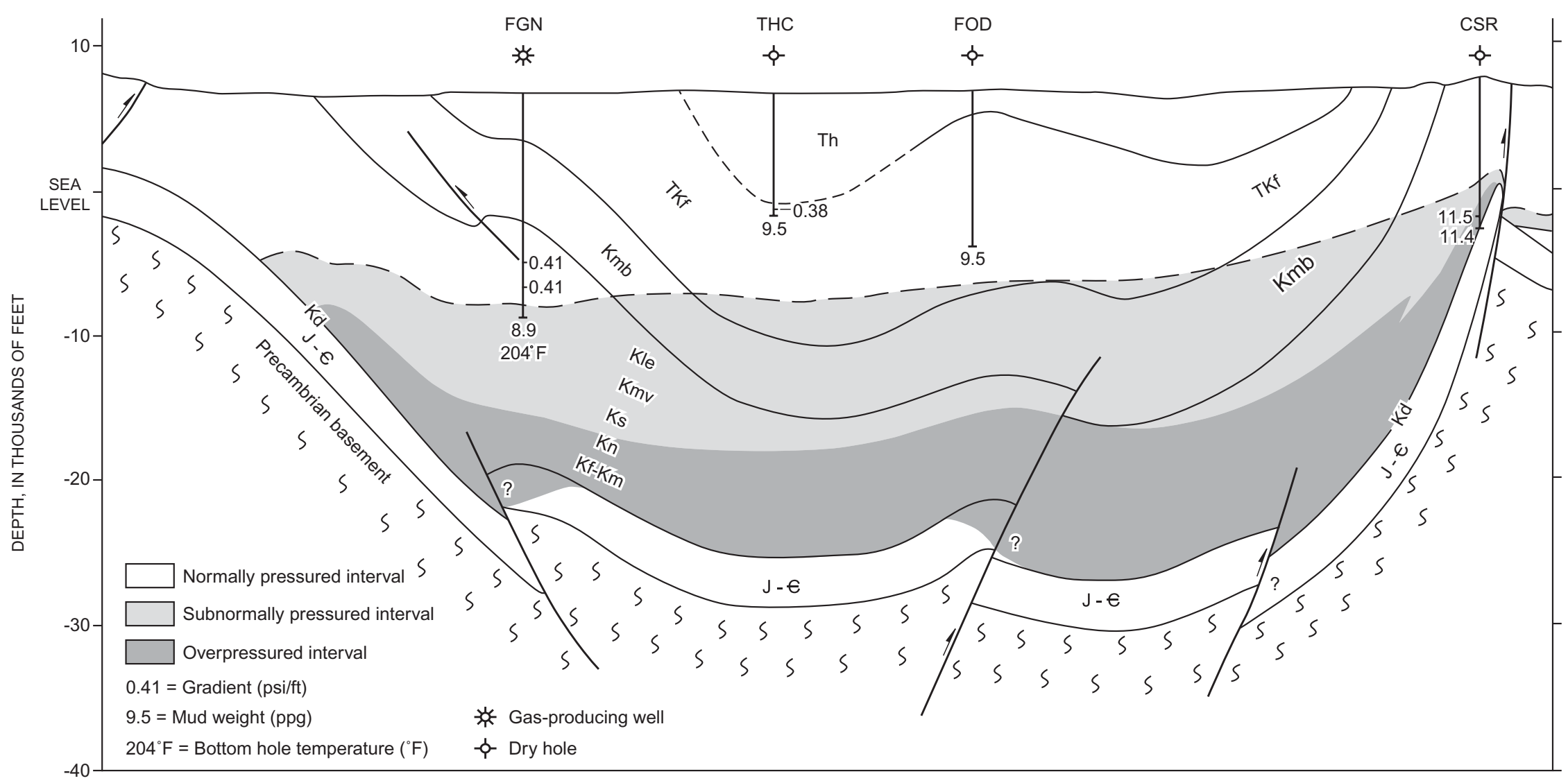

Figure 4. Cross section A-A' showing generalized structure of the Hanna Basin and approximate boundaries of the normal, subnormal, and overpressure zones based on interpretations of vitrinite reflectance measurements and well data. See figure 3 for location of cross section. See table 1 for explanation of codes used to identify wells. Th, Tertiary Hanna Formation; TKf, Tertiary-Cretaceous Ferris Formation; Kmb, Cretaceous Medicine Bow Formation; Kle, Cretaceous Lewis Shale; Kmv, Cretaceous Mesaverde Group; Ks, Cretaceous Steele Shale; Kn, Cretaceous Niobrara Formation; Kf, Cretaceous Frontier Formation; Km, Mowry Shale; J- $€$, Jurassic through Cambrian rocks. 
B

Figure 5. Cross section B-B' showing generalized structure of the Hanna Basin and interpreted boundaries of normal, subnormal, and overpressure zones, based on interpretations of vitrinite reflectance measurements and well data. See figure 3 for location of cross section. See table 1 for explanation of codes used to identify wells. Th, Tertiary Hanna Formation; TKf, Tertiary-Cretaceous Ferris Formation; Kmb, Cretaceous Medicine Bow Formation; Kle, Cretaceous Lewis Shale; Kmv, Cretaceous Mesaverde Group; Ks, Cretaceous Steele Shale; Kn, Cretaceous Niobrara Formation; Kf, Cretaceous Frontier Formation; Km, Mowry Shale; J- $€$, Jurassic through Cambrian rocks. 
Table 1. Mud weights, bottom-hole temperatures and drill-stem test results for 29 representative exploration wells in the Hanna Basin, Wyoming, based on well logs and scout cards available at the Denver Earth Resources Library, Denver, Colo.

[Fm., formation; ppg, pounds per gallon; NDXO, neutron-density crossover; Dpor, density porosity; pr., pressure; TD, total depth of well; MCFD, thousand $\mathrm{ft}^{3}$ of gas per day; BHT, bottom hole temperature; psi/ft, pounds per square inch per foot; Ro, vitrinite reflectance in percent; DST SIP, standard drill-stem test shut-in pressure; sgcm, slight gas cut mud; Ss, sandstone; Mm, Mississippian Madison Formation; PPt, Pennsylvanian Tensleep Formation; PPa, Pennsylvanian Amsden Formation; Jm, Jurassic Morrison Formation; Jn, Jurassic Nugget Sandstone; Kn, Cretaceous Niobrara Formation; Ks, Cretaceous Steele Shale; Kmv, Cretaceous Mesaverde Group; TKf, Tertiary-Cretaceous Ferris Formation

\begin{tabular}{|c|c|c|c|c|c|c|c|c|c|c|c|c|c|c|}
\hline Well Name & Symbol & Sec. & T. & R. & Year & $\begin{array}{l}T D \\
\text { feet }\end{array}$ & Fm at TD & $\begin{array}{c}\text { Mud } \\
\text { ppg } \\
\end{array}$ & $\begin{array}{c}\text { Depth } \\
\text { feet }\end{array}$ & $\begin{array}{l}\mathrm{BHT} \\
\operatorname{deg} \mathrm{F}\end{array}$ & $\underset{\mathrm{psi}}{\mathrm{DST} \text { SIP }}$ & $\begin{array}{l}\text { Depth } \\
\text { feet }\end{array}$ & $\begin{array}{c}\text { Gradient } \\
\text { psift }\end{array}$ & Comments \\
\hline Amoco Alkali Flat Unit No. 1 & AAF & 15 & $22 \mathrm{~N}$. & $84 \mathrm{~W}$. & 1978 & 9,870 & Ks & 9.6 & 9,805 & 165 & & & & No tests. Some NDXO effects. Normal pressure ?? \\
\hline Amoco Seminoe Reservoir 1 & ASR & 17 & $23 \mathrm{~N}$. & $84 \mathrm{~W}$. & 1977 & 12,100 & Kmv & $\begin{array}{l}9.1 \\
8.8\end{array}$ & $\begin{aligned} 9,791 \\
12,097\end{aligned}$ & $\begin{array}{l}160 \\
178\end{array}$ & 2,273 & 8,850 & 0.26 & $\begin{array}{l}\text { DST recovered } 1,900 \text { feet of sgcm water. Normal pressure? } \\
\text { Cored 11,720-780 feet, lost circulation. Subnormal pressure? }\end{array}$ \\
\hline Amoco St Mary's Unit No. 1 & ASM & 9 & $21 \mathrm{~N}$. & $84 \mathrm{~W}$. & 1974 & 15,553 & $\mathrm{Mm}$ & $\begin{array}{r}9.0 \\
10.0 \\
10.9\end{array}$ & $\begin{array}{r}5,968 \\
11,266 \\
14,850\end{array}$ & $\begin{array}{l}102 \\
181 \\
217\end{array}$ & & & & $\begin{array}{l}\text { Perforated Niobrara at } 10,470-10,560 \text { feet. Abandoned. } \\
\text { Probably overpressured in Niobrara \& Frontier. }\end{array}$ \\
\hline Apache U.S.Golden No. 1 & ACG & 22 & $22 \mathrm{~N}$. & $79 \mathrm{~W}$. & 1969 & 9,238 & $\mathrm{Jm}$ & 9.2 & 9,199 & 158 & & & & No tests reported. Niobrara may be subnormally pressured? \\
\hline Brinkerhoff Hanna Unit No. 1 & BKH & 3 & $23 \mathrm{~N}$. & $82 \mathrm{~W}$. & 1972 & 12,500 & TKf & 9.2 & $\begin{array}{l}10,700 \\
12,498\end{array}$ & & $\begin{array}{l}2,695 \\
241 \\
1,588\end{array}$ & $\begin{array}{r}6,350 \\
9,080 \\
10,350\end{array}$ & $\begin{array}{l}0.42 \\
\text { very low } \\
\text { very low }\end{array}$ & $\begin{array}{l}\text { Normal pressure gradient at } 6.350 \text { feet? Few shows. } \\
\text { Ro }<0.7 \% \text { above } 10,000 \text { feet.. } \\
\text { Dpor }=5-13 \% . \text { Ro }=1.2 \% \text { near TD. Subnormal pressure? }\end{array}$ \\
\hline Byron Oil Cedar Ridge No. 1 & $\mathrm{BCC}$ & 15 & $22 \mathrm{~N}$. & $85 \mathrm{~W}$. & 1982 & 10,672 & $\mathrm{Kn}$ & 12.9 & 10,648 & 160 & & & & 12.9 ppg mud, overpressure? Perforated Shannon Ss. (Steele Sh.). \\
\hline Byron Oil Cedar Ridge No. 1 & BCF & 22 & $22 \mathrm{~N}$. & $85 \mathrm{~W}$. & 1980 & 10,302 & $\mathrm{Kn}$ & $\begin{array}{r}8.9 \\
10.9\end{array}$ & $\begin{array}{r}6,185 \\
10,288\end{array}$ & $\begin{array}{l}109 \\
136\end{array}$ & & & & 10.9 ppg mud. Perforated Niobrara and Shannon Ss. (Steele Sh.). \\
\hline Chambers Klaenhammer No. 1 & CKS & 16 & $23 \mathrm{~N}$. & $86 \mathrm{~W}$. & 1976 & 9,240 & $\mathrm{Pt}$ & 10.5 & 9,240 & 140 & $\begin{array}{l}2,685 \\
2,538 \\
3,809\end{array}$ & $\begin{array}{l}6,220 \\
7,150 \\
9,180\end{array}$ & $\begin{array}{l}0.43 \\
0.37 \\
0.41\end{array}$ & 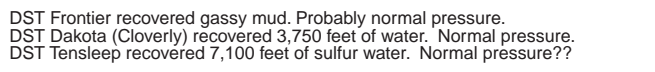 \\
\hline Champlin UPRR 44-5 No. 1 & $\mathrm{CPC}$ & 5 & $21 \mathrm{~N}$. & $79 \mathrm{~W}$. & 1982 & 11,351 & $\mathrm{Jm}$ & 9.2 & 11,338 & 185 & & & & Flowed gas and water from Morrison. Normal pressure. \\
\hline Coastal COGC-UPRR No. 1 & CLU & 21 & $22 \mathrm{~N}$. & $80 \mathrm{~W}$. & 1990 & 10,050 & $\mathrm{kf}$ & $\begin{array}{r}9.9 \\
12.0 \\
10.0\end{array}$ & $\begin{array}{r}6,300 \\
7,200 \\
10,050\end{array}$ & 164 & & & & $\begin{array}{l}\text { Gas kicks, } 12 \text { ppg mud. Overpressured Niobrara Formation } \\
\text { Steep dips, stuck pipe, two sidetracks. Abandoned. }\end{array}$ \\
\hline Colorado Oil No. 1 Gov't & COG & 34 & $22 \mathrm{~N}$. & $86 \mathrm{~W}$. & 1958 & 4,842 & $\mathrm{Pt}$ & & & & 1,523 & 4,825 & 0.31 & DST Tensleep rec. 100 feet of water. Normal pressure? \\
\hline Continental Simpson No. 1 & $\operatorname{CSR}$ & 17 & $21 \mathrm{~N}$. & $80 \mathrm{~W}$. & 1957 & 10,514 & $\mathrm{Kf}$ & $\begin{array}{l}11.5 \\
11.4\end{array}$ & $\begin{array}{r}9,870 \\
10,513\end{array}$ & $\begin{array}{l}110 \\
157\end{array}$ & & & & $\begin{array}{l}\text { Gas shows, mud weight }=11.4 \mathrm{ppg} \text { in Niobrara. Fault zone. } \\
\text { Niobrara section is probably overpressured. Abandoned. }\end{array}$ \\
\hline CRA CRA-UPRR No. 16-1 & CRA & 16 & $22 \mathrm{~N}$. & $80 \mathrm{~W}$. & 1968 & 5,013 & $\mathrm{Kmv}$ & 9.2 & 4,890 & 94 & 2,082 & 4,990 & 0.42 & DST Kmv recovered 316 feet of water. Normal pressure. \\
\hline Dillard Unit No. 41-22 & DLD & 22 & $23 \mathrm{~N}$. & $85 \mathrm{~W}$. & 1963 & 4,924 & Kmv & & & & $\begin{array}{l}1,817 \\
1,968\end{array}$ & $\begin{array}{l}4,450 \\
4,740\end{array}$ & $\begin{array}{l}0.41 \\
0.42\end{array}$ & $\begin{array}{l}\text { DST Kmv recovered } 2,694 \text { feet of water. Normal pressure. } \\
\text { DST Kmv recovered } 4,355 \text { feet of water. Normal pressure. Abandoned. }\end{array}$ \\
\hline ERG HSR No. 34 RD-1 & ERH & 2 & $24 \mathrm{~N}$. & $83 \mathrm{~W}$. & 1978 & 5,126 & Kmv & $\begin{array}{l}9.2 \\
9.3\end{array}$ & $\begin{array}{l}4,548 \\
5,126\end{array}$ & 100 & & & & Low BHT. Probably normal pressure. \\
\hline Ferguson PCR 63X-30 No. 1 & FPC & 30 & $21 \mathrm{~N}$. & $82 \mathrm{~W}$. & 1966 & 7,277 & & $\begin{array}{r}9.6 \\
10.0\end{array}$ & $\begin{array}{l}3,665 \\
7,277\end{array}$ & $\begin{array}{l}114 \\
111\end{array}$ & & & & No tests. No formation tops listed on card. \\
\hline FMC Sandstone Unit No. 1-13 & FMC & 13 & $23 \mathrm{~N}$. & $85 \mathrm{~W}$. & 1980 & 7,078 & $\mathrm{Kmv}$ & 9.6 & 7,078 & 127 & 2,953 & 7,000 & 0.42 & DST Kmv rec. 6,173 feet of water. Normal pressure. \\
\hline Forest Oil Dana Unit No. 1 & FOD & 4 & $22 \mathrm{~N}$. & $82 \mathrm{~W}$. & 1955 & 10,706 & TKf & 9.5 & 10,706 & 154 & & & & Ferris is probably normally pressured. \\
\hline Forest Oil Miller No. 14-1 & FOM & 14 & $23 \mathrm{~N}$. & $85 \mathrm{~W}$. & 1956 & 7,910 & Kmv & $\begin{array}{l}9.5 \\
9.8\end{array}$ & $\begin{array}{l}6,399 \\
7,306\end{array}$ & 127 & 450 & 7,060 & very low & DST Kmv recovered 60 feet gas-cut mud. Subnormal pressure? \\
\hline Forgotson-Nortex HBS No. 1 & FGN & 25 & $24 \mathrm{~N}$. & $84 \mathrm{~W}$. & 1982 & 15,322 & Ks & $\begin{array}{l}8.7 \\
9.0 \\
8.9\end{array}$ & $\begin{array}{l}10,023 \\
12,686 \\
15,190\end{array}$ & $\begin{array}{l}176 \\
204\end{array}$ & $\begin{array}{l}4,232 \\
5,164\end{array}$ & $\begin{array}{l}10,300 \\
12,500\end{array}$ & $\begin{array}{l}0.41 \\
0.41\end{array}$ & 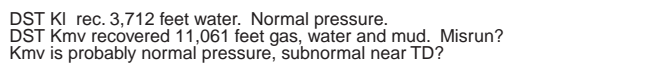 \\
\hline Humble Pass Creek No. 1 & HPC & 33 & $21 \mathrm{~N}$. & $82 \mathrm{~W}$. & 1969 & 16,850 & $\mathrm{~Pa}$ & $\begin{array}{l}9.8 \\
9.0\end{array}$ & $\begin{array}{r}6,908 \\
16,850\end{array}$ & $\begin{array}{l}110 \\
240\end{array}$ & 4,931 & 13,200 & 0.37 & $\begin{array}{l}\text { DST Ksh flowed gas } 44 \text { MCFD rec. } 1,675 \text { feet of oil } \\
\text { Kmv is probably normal pr. Niobrara may be subnormal. }\end{array}$ \\
\hline INTEX UPRR No. 10-27 & $\mathrm{IXU}$ & 27 & $24 \mathrm{~N}$. & $81 \mathrm{w}$. & 1960 & 9,587 & Kmb & 9.2 & $\begin{array}{l}6,095 \\
9,497\end{array}$ & $\begin{array}{l}115 \\
143\end{array}$ & & & & $\begin{array}{l}\text { Gas show noted at } 9,220 \text { feet. } \\
\text { No cores or tests, TD in Medicine Bow. Abandoned. }\end{array}$ \\
\hline Mobil F-14-4-G & MOF & 4 & $21 \mathrm{~N}$. & $79 \mathrm{~W}$. & 1958 & 12,623 & $\mathrm{Pt}$ & $\begin{array}{l}10.1 \\
10.0\end{array}$ & $\begin{array}{l}10,321 \\
11,246\end{array}$ & $\begin{array}{l}148 \\
172\end{array}$ & 4,962 & 11,070 & 0.45 & $\begin{array}{l}10.1 \text { ppg mud through Niobrara-Frontier. Several cores. Overpressures? } \\
\text { DST Jn tlowed gas, subnormal \& normal pressures (?) }\end{array}$ \\
\hline Murphy Haystack No. 1 & MHS & 14 & $23 \mathrm{~N}$. & $86 \mathrm{~W}$. & 1951 & 7,472 & $\mathrm{Jm}$ & 9.7 & $\begin{array}{l}6,841 \\
7,466\end{array}$ & 147 & $\begin{array}{l}2,000 \\
1,160\end{array}$ & $\begin{array}{l}6,400 \\
7,330\end{array}$ & $\begin{array}{l}0.31 \\
\text { very low }\end{array}$ & $\begin{array}{l}\text { DST Frontier recovered } 50 \text { feet gassy mud. Subnormal pressure? } \\
\text { DST Dakota (Cloverly) recovered } 1,440 \text { feet of water, trace oil. Normal pressure. }\end{array}$ \\
\hline Ohio Oil Unit No. 1 & OOU & 22 & $22 \mathrm{~N}$. & $85 \mathrm{~W}$. & 1954 & 13,177 & $\mathrm{Jm}$ & $\begin{array}{r}9.7 \\
10.9 \\
12.1 \\
11.9\end{array}$ & $\begin{aligned} 6,755 \\
10,126 \\
11,796 \\
12,213\end{aligned}$ & $\begin{array}{l}160 \\
184\end{array}$ & & & & $\begin{array}{l}\text { Gas kick, DST flowed gas from Niobrara. Abandoned. } \\
\text { Niobrara-Frontier Shale is probably overpressured. }\end{array}$ \\
\hline Sinclair Federal Melton No. 1 & SFM & 26 & $22 \mathrm{~N}$. & $86 \mathrm{~W}$. & 1961 & 3,215 & $\mathrm{Jm}$ & & & & $\begin{array}{r}962 \\
1,485\end{array}$ & $\begin{array}{l}2,245 \\
3,150\end{array}$ & $\begin{array}{l}0.43 \\
0.47\end{array}$ & $\begin{array}{l}\text { DST Frontier recovered 1,316 feet of water. Normal pressure. } \\
\text { DST in Dakotata recovered gas and mud. Normal pressure. }\end{array}$ \\
\hline True Oil Curry Federal No. 44 & TCF & 34 & $21 \mathrm{~N}$. & $81 \mathrm{w}$. & 1970 & 6,950 & $\mathrm{Jm}$ & $\begin{array}{l}10.6 \\
11.0\end{array}$ & $\begin{array}{l}6,124 \\
6,950\end{array}$ & 125 & & & & $\begin{array}{l}\text { No tests. Niobrara-Frontier may be overpressured. } \\
\text { High mud weight. }\end{array}$ \\
\hline True Oil Hanna Unit C No. 2 & THC & 23 & $23 \mathrm{~N}$. & $83 \mathrm{~W}$. & 1973 & 8,623 & TKf & 9.5 & 8,623 & & 3,146 & 8,390 & 0.38 & DST recovered 560 feet muddy water. Probably normal pressure. \\
\hline Total Walcott Fed No. 1-20 & TWF & 20 & $21 \mathrm{~N}$. & $84 \mathrm{~W}$. & 1985 & 5,172 & $\mathrm{Kn}$ & 9.2 & 5,176 & 152 & 509 & 4,400 & very low & Niobrara is probably subnormally pressured. \\
\hline
\end{tabular}


reported from deep wells in the Hanna Basin. A temperature of $204^{\circ} \mathrm{F}$ was reported from a drill-stem test at 11,871 to 15,322 ft in the Forgotson Seminoe Unit No. 1-25 (fig. 3, FGN), indicating that temperatures are high enough for a basin-centered gas accumulation to exist. However, the drilling mud used in this well was only 8.9 to 9.0 ppg and overpressures were not encountered. These rocks might have been overpressured previously, but pressures may have declined to subnormal levels due to cooling and leakage of gas through fractures and outcrops updip to the northwest. Subnormal pressure is interpreted below $15,000 \mathrm{ft}$ in this well (fig. 4).

Measured vitrinite reflectance values in the Brinkerhoff Hanna Basin Unit No. 1 well (fig. 3, BKH) vary from less than 0.7 percent above $10,000 \mathrm{ft}$ to 1.23 percent at $12,845 \mathrm{ft}$ (Law, 1984; Perry and Flores, 1997). Source rocks are thermally mature below 10,000 ft; however, normal mud weights were used in this well $(9.2 \mathrm{ppg}$ at $10,700 \mathrm{ft}$ and $9.3 \mathrm{ppg}$ at 12,498 $\mathrm{ft}$ ) indicating that overpressuring probably does not exist. A drill-stem test at 10,302 to $10,380 \mathrm{ft}$ recovered gassy mud with a very low shut-in pressure (1,588 psi), indicating a tight, damaged, or low-pressure zone. Subnormal pressures are highly likely in this depth range.

Three wells on the south and west margins of the basin (fig. 3, MHS, TWF, and HPC) tested the Niobrara and Frontier Formations and recovered gas and (or) oil shows with very low shut-in pressures. The top of the subnormally pressured zone (figs. 4 and 5) is interpreted to cut across stratigraphic boundaries near the basin margins, and these wells may have penetrated the subnormally pressured zone where it cuts across the Niobrara-Frontier-Mowry section.

\section{Evidence for Overpressured Zones}

Drilling-mud-weight data (table 1) indicate that the Niobrara-Frontier-Mowry section may be moderately overpressured at depths below $10,000 \mathrm{ft}$ along the western and southern margins of the basin. Gas shows and mud weights as high as 12.9 ppg were reported at the Byron Cedar Ridge No. 1 well (fig. 3, BCC)—reported mud weight was as high as $12.1 \mathrm{ppg}$ at the Ohio Oil Unit No. 1 (fig. 3, OOU) while drilling through the Niobrara section. Several other wells along this trend also encountered gas shows and gas kicks and used 10- to 12-ppg drilling mud through the Niobrara-Frontier interval (fig. 3, BCF, ASM, TCF, CSR, MOF, and CLU). Mud-log descriptions indicate that this interval consists of calcareous shale beds and thin, low-permeability sandstones with poor reservoir quality. Gas kicks may have occurred in locally fractured zones with unusually high permeability. Several completion attempts using perforations and artificial fracture stimulation in cased holes were unsuccessful at establishing commercial production from the Niobrara Formation in the area. This gas-saturated, fractured shale reservoir may require special completion methods.

Overpressuring was not encountered in any of the deep exploratory wells drilled near the center of the basin. The Forgotson-Nortex No. 1-25 well (FGN) reached a total depth of $15,322 \mathrm{ft}$ in the lower Mesaverde Group using $8.9 \mathrm{ppg}$ mud. This well may have penetrated subnormally pressured rocks near total depth. The limited well data available show no evidence of gas-charged overpressures within the Upper Cretaceous Mesaverde Group, Lewis Shale, Medicine Bow Formation, or in the Cretaceous and Tertiary Ferris or Tertiary Hanna Formations in the basin center. Based on these results, the top of the overpressure zone is interpreted to extend downdip from the Byron, Ohio, and Continental wells (fig. 3, BCC, OOU, CSR) and across the center of the basin at depths of 18,000 to 25,000 ft (figs. 4 and 5). This deep overpressured zone appears to have a diameter of approximately 20 to 25 miles.

Basin modeling indicates that source rocks in the Niobrara-Frontier-Mowry interval are thermally mature in the deep basin and have generated large volumes of oil and gas (Beirei and Surdam, 1986; Beirei, 1987). However, transformation models suggest that hydrocarbon generation may have peaked during Paleocene and Eocene time due to the rapid deposition of many thousands of feet of the Ferris and Hanna Formations within a 15 million year time span. Gas generation may have slowed or ceased during post-Eocene time as a result of uplift and erosion, and the overpressure zone may have receded from its maximum extent.

\section{Discussion: Basin-Centered Gas in the Deep Hanna Basin?}

The unusually high mud weights used in wells penetrating the Niobrara-Frontier-Mowry section along the southern and western margins of the basin indicate some potential for a basin-centered gas accumulation. Similar overpressures in the Niobrara-Frontier-Mowry section have been described in the Piceance Basin in western Colorado by Wilson and others (1998), in the Washakie Basin of south-central Wyoming by Kristinik and Lorenz (2000), and in the Wind River Basin by Johnson and others (1996). The interpreted boundaries of the normally pressured and subnormally pressured zones in the Hanna Basin fit the patterns of typical basin-centered gas accumulations. Basin modeling by Beirei (1987) suggests that the Niobrara-Frontier-Mowry section has probably reached (or even exceeded) the gas-generation window in the deep basin. This part of the section may have been extensively dewatered and charged with gas.

The Hanna Basin is relatively small compared to other basins in the Greater Green River Basin of southwestern Wyoming. It is surrounded by basement uplifts along fault zones that have thousands of feet of displacement. Gas may have escaped via several major fault and fracture zones or through outcrops along the margins of the basin. Extensive water invasion may be occurring along the major fault zones, and formerly abnormal pressures may be reverting to normal pres- 
sures. The interpreted pressure boundaries (figs. 4 and 5) suggest extensive normal and subnormal pressures and a relatively small (and very deep) overpressured zone.

No wells have been drilled deep enough to validate the concept of a central overpressured zone. Core analyses and measured permeability data were not found in the well data collection. Well-log analyses by Schlumberger (noted on the Brinkerhoff No. 1 density $\log$ ) indicate that sandstone porosities range from 5 to 13 percent at depths of 10,600 to 12,400 $\mathrm{ft}$. These values are typical for Cretaceous and Tertiary tight gas sands in Wyoming. Porosity and permeability ranges for thin sandstones in the Frontier Formation are unknown but probably resemble those reported by Kristinik and Lorenz (2000) for Frontier sandstones at the Sidewinder 4-H well in the Washakie Basin (9 to 12 percent, 0.04 to $0.001 \mathrm{mD}$ ). The fractured Niobrara, Frontier, and Mowry reservoirs are technically challenging reservoirs that have not yet been commercially productive in other known basin-centered gas accumulations. New technologies may be needed to produce gas from these deep, thermally mature, Cretaceous, shale-rich reservoirs in the Hanna and other Rocky Mountain basins.

\section{Conclusions}

Data for deep wells in the Hanna Basin show evidence for a shallow, normally pressured section, subnormal pressures at intermediate depths, and a gas-charged overpressured zone within the Niobrara-Frontier-Mowry section along the southern and western margins of the basin. This overpressured zone may be part of a larger, continuous gas accumulation that extends through the basin center at depths below 18,000 to $25,000 \mathrm{ft}$. No evidence was found for overpressuring in wells penetrating the Upper Cretaceous Mesaverde Group and Lewis and Medicine Bow Formations, and Cretaceous and Tertiary Ferris and Tertiary Hanna Formations, at depths of less than $15,000 \mathrm{ft}$.

Basin modeling by Beirei (1987) indicates that Cretaceous-age source rocks in the deep basin reached thermal maturity relatively quickly due to rapid burial below $18,000 \mathrm{ft}$ of the Paleocene Hanna and Upper Cretaceous and Paleocene Ferris Formations. Gas generation probably peaked in Paleocene and Eocene time and may have slowed or ceased during late Tertiary time.

Only a few deep wells have been drilled in the center of the Hanna Basin, and the deepest well drilled to date (Forgotson-Nortex No. 1, 15,322 ft total depth) did not encounter overpressured zones. An overpressured zone may have receded from its maximum extent due to erosional unroofing, cooling, and gas leakage via faults, fractures, and outcrops. The present diameter of a deep overpressured compartment may be only 20 to 25 miles. A relatively thick zone of subnormal pressure has been interpreted where previously overpressured strata have lost gas pressure.

The interpretations proposed in this report remain specu- lative due to the limited data available for the Hanna Basin. However, available data suggest a pattern favoring the presence of a basin-centered gas accumulation similar to accumulations in other basins of the Rocky Mountain region (Wilson and others, 1998).

\section{References Cited}

Beirei, M.A., 1987, Hydrocarbon maturation, source rock potential, and thermal evolution of Late Cretaceous and early Tertiary rocks of Hanna Basin, southeastern Wyoming: Laramie, Wyo., University of Wyoming M.S. thesis, $130 \mathrm{p}$.

Beirei, M.A., and Surdam, R.C., 1986, Hydrocarbon maturation, source rock potential, and thermal evolution of Late Cretaceous and early Tertiary rocks of the Hanna Basin [abs.], southeastern Wyoming: American Association of Petroleum Geologists Bulletin, v. 70, no. 8, p. 1031.

Gautier, D.L., Dolton, G.L., Takahashi, K.I., and Varnes, K.L., eds., 1996, 1995 National assessment of United States oil and gas resourcesResults, methodology, and supporting data: U.S. Geological Survey Digital Data Series 30, release 2.

Hansen, D.E., 1986, Laramide tectonics and deposition of the Ferris and Hanna Formations, south-central Wyoming: American Association of Petroleum Geologists Memoir 41, p. 481-495.

Johnson, R.C., Finn, T.M., Keefer, W.R., and Szmajter, R.J., 1996, Geology of Upper Cretaceous and Paleocene gas-bearing rocks: Wind River Basin, Wyoming: U.S. Geological Survey Open-File Report 96-090, $120 \mathrm{p}$.

Johnson, R.C., and Flores, R.M., 1998, Developmental geology of coalbed methane from shallow to deep in Rocky Mountain basins and in Cook Inlet-Matanuska Basin, Alaska, U.S.A and Canada: International Journal of Coal Geology, no. 35, p. 241-282.

Kaplan, S.S., and Skeen, R. C., 1985, North-south regional seismic profile of the Hanna Basin, Wyoming, in Gries, R.R., and Dyer, R.C., eds., Seismic Exploration of the Rocky Mountain Region: Rocky Mountain Association of Geologists and Denver Geophysical Society, p. 219-224.

Krystinik, L.F., and Lorenz, J.C., 2000, Do you want to hear the good news or the bad news? New perspectives on basin-centered gas from horizontal drilling, Frontier Formation, SW Wyoming, in Rocky Mountain Association of Geologists 2000 Basin Center Gas Symposium Abstracts, October 6, 2000: Rocky Mountain Association of Geologists.

Law, B.E., 1984, Relationships of source rock, thermal maturity and overpressuring to gas generation and occurrence of low-permeability Upper Cretaceous and lower Tertiary rocks, Greater Green River Basin, Wyoming, Colorado, and Utah, in Woodward, J., Meissner, F.F. and Clayton, J.L, eds., Hydrocarbon Source Rocks of the Greater Rocky Mountain Region: Rocky Mountain Association of Geologists Guidebook, p. 401-433.

LeFebre, G.B., 1988, Tectonic evolution of Hanna Basin, WyomingLaramide block rotation in the Rocky Mountain foreland: Laramie, Wyo., University of Wyoming Ph.D. dissertation, 240 p. 


\section{Geologic Studies of Basin-Centered Gas Systems}

MAPCO, Inc., Tulsa, Okla. 74119, 1999, Maps WA-5 and WA-6.

Meissner, F.F., 2000, Causes of anomalous deep basin fluid pressures in Rocky Mountain basins and their relation to regional gas accumulation, in Rocky Mountain Association of Geologists 2000 Basin Center Gas Symposium Abstracts, October 6, 2000: Rocky Mountain Association of Geologists.

Perry, W.J., and Flores, R.W., 1997, Sequential Laramide deformation and Paleocene depositional patterns in deep gas-prone basins of the Rocky Mountain region, in Dyman, T.S., Rice, D.D., and Westcott, P.A., eds., Geologic Controls of Deep Natural Resources in the United States: U.S. Geological Survey Bulletin 2146, p. 49-59.

Schmoker, J.W., 1996, Method for assessing continuous-type (unconventional) hydrocarbon accumulations, in Gautier, D.L., Dolton, G.L., Takahashi, K.I., and Varnes, K.L., eds., 1995 National assessment of United States oil and gas resources-Results, methodology, and supporting data: U.S. Geological Survey Digital Data Series 30, release 2 .

Stone, D.S., 1966, Evaluation of the Hanna Basin: The Mountain Geologist, v. 3, no. 2, p. 55-73.

U.S. Geological Survey National Oil and Gas Resource Assessment Team, 1995, 1995 national assessment of United States oil and gas resources: U.S. Geological Survey Circular 1118, 20 p.

Wilson, M.S., Gunneson, B.G., Peterson, K., Honore, R. and Laughland, M.M., 1998, Abnormal pressures encountered in a deep wildcat well, southern Piceance Basin, Colorado, in Law, B.E., Ulmishek, G.E., and Slavin, V.I., eds., Abnormal Pressures in Hydrocarbon Environments: American Association of Petroleum Geologists Memoir 70, p. 195-214.

Manuscript approved for publication June 14, 2001

Published in the Central Region, Denver, Colorado

Editing, layout, photocomposition-Richard W. Scott, Jr.

Cover design-Carol A. Quesenberry

Graphics by the authors 


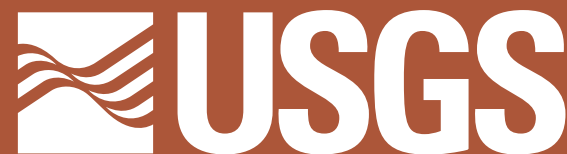

science for a changing world

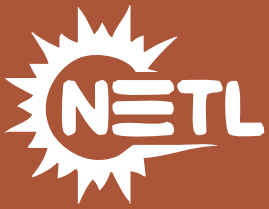

Is There a Basin-Centered Gas Accumulation in Cotton Valley Group Sandstones, Gulf Coast Basin, U.S.A?

Geologic Studies of Basin-Centered Gas Systems

U.S. Geological Survey Bulletin 2184-D

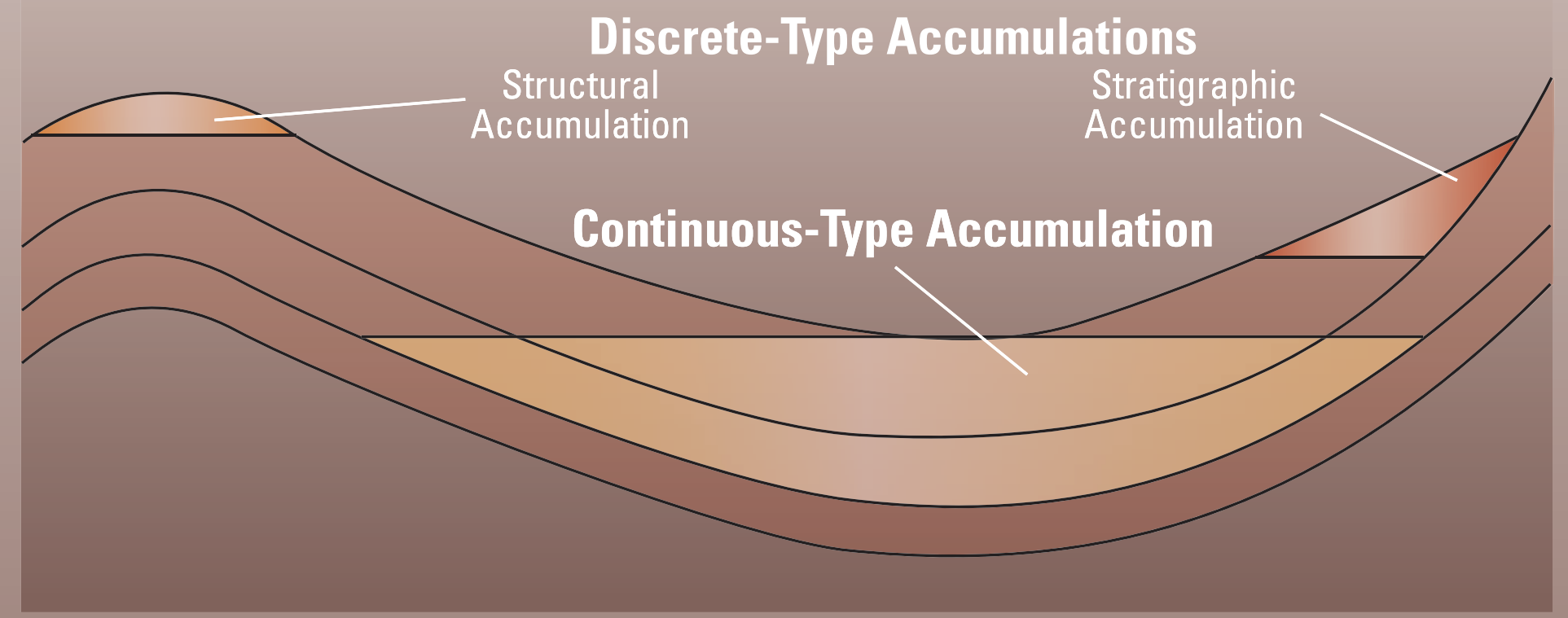

U.S. Department of the Interior

U.S. Geological Survey 


\section{Is There a Basin-Centered Gas Accumulation in Cotton Valley Group Sandstones, Gulf Coast Basin, U.S.A.?}

By Charles E. Bartberger, Thaddeus S. Dyman, and Steven M. Condon

\section{Geologic Studies of Basin-Centered Gas Systems}

Edited by Vito F. Nuccio and Thaddeus S. Dyman

U.S. Geological Survey Bulletin 2184-D

This work funded by the U.S. Department of Energy, National Energy Technology Laboratory, Morgantown, W. Va., under contracts DE-AT26-98FT40031 and DE-AT26-98FT40032, and by the U.S. Geological Survey Central Region Energy Resources Team 


\title{
U.S. Department of the Interior
}

\author{
Gale A. Norton, Secretary
}

\section{U.S. Geological Survey}

Charles G. Groat, Director

Posted online February 2002, version 1.0

This publication is only available online at:

http://geology.cr.usgs.gov/pub/bulletins/b2184-d/

Any use of trade, product, or firm names in this publication is for descriptive purposes only and does not

imply endorsement by the U.S. Government 


\section{Contents}

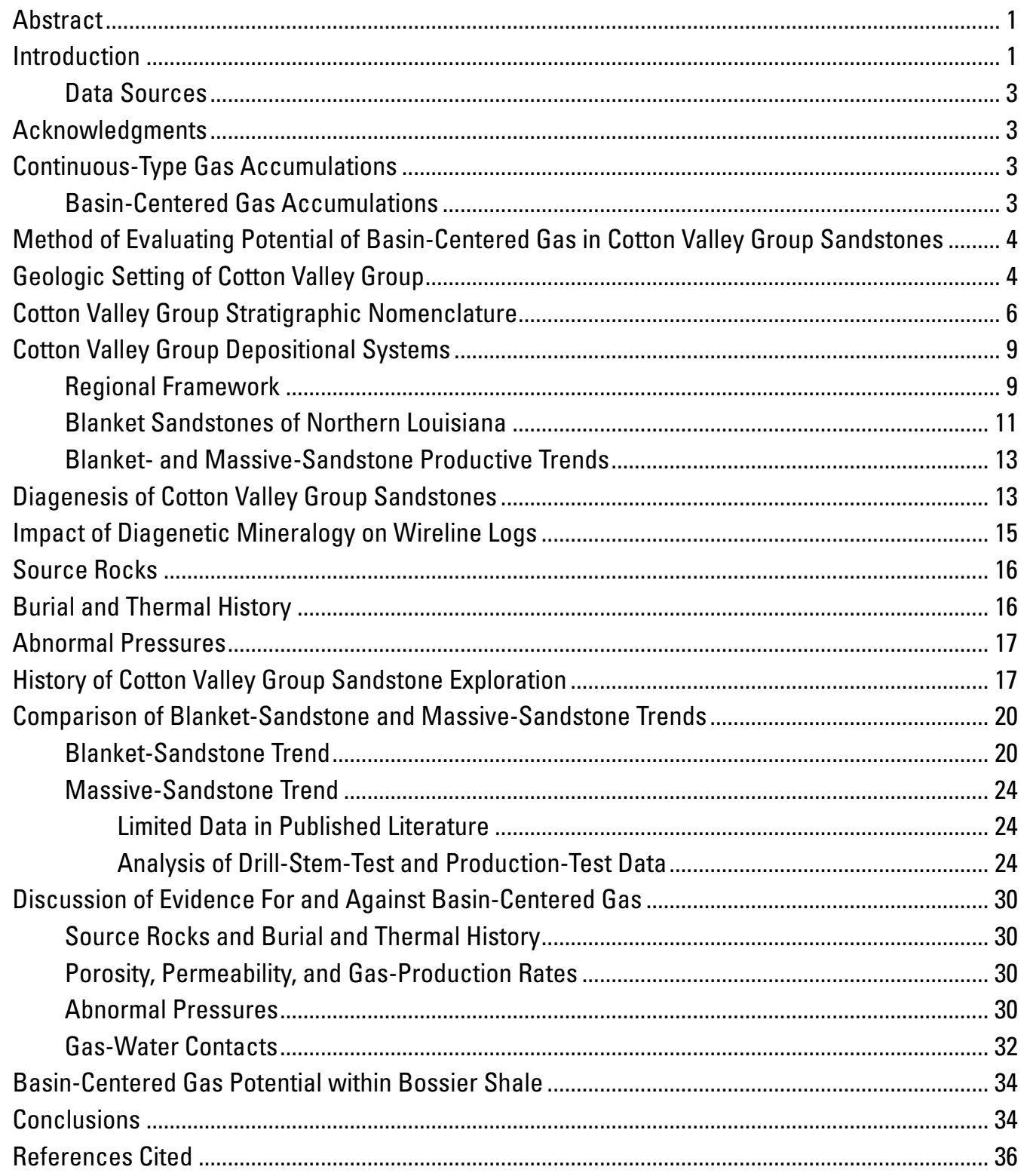

\section{Figures}

1. Map of north-central Gulf Coast Basin showing outlines of three Cotton Valley Group plays identified by the U.S. Geological Survey in the 1995 National Assessment of United States oil and gas resources. 
2. Index map of north-central Gulf Coast Basin showing major tectonic features ............... 5

3. Chronostratigraphic section of northern Louisiana ...................................................... 7

4. Generalized structure contours on top of Cotton Valley Group sandstone across northeastern Texas and northern Louisiana ........................................................... 8

5. Generalized stratigraphic nomenclature of Cotton Valley Group in northern Louisiana.

6. North-south stratigraphic cross section of Cotton Valley Group across northern Louisiana based on data from 15 wells

7. Regional paleogeographic map showing sedimentary environments of Cotton Valley Group during deposition of uppermost Cotton Valley sandstones

8-13. Map of northeastern Texas and northwestern Louisiana showing:

8. Major fields that have produced hydrocarbons from Cotton Valley Group sandstones.

9. Fluid-pressure gradients calculated from shut-in pressures in Cotton Valley Group sandstone reservoirs.

10. Geographic distribution of abnormally high pressures in Cotton Valley Group sandstone reservoirs

11. Measured values of porosity and permeability in Cotton Valley Group blanket sandstones

12. Initial rates of gas production from Cotton Valley Group blanket sandstones

13. Fields productive from Cotton Valley Group sandstones in which gaswater contacts have been identified and reported in published literature

14-15. Map of Caspiana field in northwestern Louisiana in the tight, Cotton Valley Group massive-sandstone trend showing:

14. Initial rate of gas production from Cotton Valley sandstone reservoirs

15. Ratio of initial production rate of water to initial production rate of gas

from Cotton Valley Group sandstones.

16. Schematic diagram of gas-water transition zones in high- and low-permeability reservoirs

\section{Tables}

1. Comparison of two productive trends of Cotton Valley Group sandstones in eastern Texas and northern Louisiana

2. Data on Cotton Valley Group sandstone fields in northern Louisiana 


\title{
Is There a Basin-Centered Gas Accumulation in Cotton Valley Group Sandstones, Gulf Coast Basin, U.S.A.?
}

\author{
By Charles E. Bartberger, ${ }^{1}$ Thaddeus S. Dyman, ${ }^{2}$ and Steven M. Condon ${ }^{2}$
}

\section{Abstract}

The U.S. Geological Survey (USGS), in cooperation with the U.S. Department of Energy, is reevaluating the resource potential of selected domestic basin-centered gas accumulations. Basin-centered gas accumulations are characterized by presence of gas in extensive low-permeability (tight) reservoirs in which conventional seals and trapping mechanisms are absent, abnormally high or low reservoir pressures exist, and gas-water contacts are absent.

In 1995, the USGS assessed one basin-centered gas play and two conventional plays within the trend of Jurassic and Cretaceous Cotton Valley Group fluvial-deltaic and barrierisland/strandplain sandstones across the onshore northern Gulf of Mexico Basin. Detailed evaluation of geologic and production data provides new insights into these Cotton Valley plays.

Two Cotton Valley sandstone trends are identified based on reservoir properties and gas-production characteristics. Transgressive blanket sandstones across northern Louisiana have relatively high porosity and permeability and do not require fracture stimulation to produce gas at commercial rates. South of this trend, and extending westward into eastern Texas, massive sandstones of the Cotton Valley trend exhibit low porosity and permeability and require fracture stimulation. The high permeability of Cotton Valley blanket sandstones is not conducive to the presence of basin-centered gas, but lowpermeability massive sandstones provide the type of reservoir in which basin-centered gas accumulations commonly occur.

Data on source rocks, including burial and thermal history, are consistent with the interpretation of potential basincentered gas within Cotton Valley sandstones. However, pressure gradients throughout most of the blanket- and massivesandstone trends are normal or nearly normal, which is not characteristic of basin-centered gas accumulations.

The presence of gas-water contacts in at least seven fields across the blanket-sandstone trend together with relatively high permeabilities and high gas-production rates without frac-

\footnotetext{
${ }^{1}$ Geologic consultant, Denver, Colo.

2 U.S. Geological Survey, Denver, Colo.
}

ture stimulation indicate that fields in this trend are conventional. Within the tight massive-sandstone trend, permeability is sufficiently low that gas-water transition zones are vertically extensive and gas-water contacts either have not been encountered or are poorly defined. With increasing depth through these transition zones, gas saturation decreases and water saturation increases until eventually gas saturations become sufficiently low that, in terms of ultimate cumulative production, wells are noncommercial. Such progressive increase in water saturation with depth suggests that poorly defined gas-water contacts probably are present below the depth at which wells become noncommercial. The interpreted presence of gas-water contacts within the tight, Cotton Valley massive-sandstone trend suggests that gas accumulations in this trend, too, are conventional, and that a basin-centered gas accumulation does not exist within Cotton Valley sandstones in the northern Gulf Basin.

\section{Introduction}

The U.S. Geological Survey is reevaluating the potential for occurrence of continuous-type basin-centered gas accumulations in selected basins in the United States since completion of the USGS 1995 National Petroleum Assessment. This effort, which is partly funded by the U.S. Department of Energy, might result in identification of new continuous-type gas plays and petroleum systems or reevaluation of existing plays.

As part of the 1995 National Assessment of United States Oil and Gas Resources by the USGS, Schenk and Viger (1996) identified one continuous-type basin-centered gas play and two conventional gas plays (fig. 1) within the Cotton Valley Group sandstone trend in eastern Texas and northern Louisiana. The purpose of this report is to reevaluate the 1995 USGS play definitions and parameters for establishing those plays through more extensive evaluation of data on reservoir properties, reservoir pressures, gas and water recoveries, gas-production rates, and gas-water contacts in Cotton Valley sandstones. Data favorable and unfavorable for the presence of continuous-type basincentered gas accumulations are summarized. No attempt is 


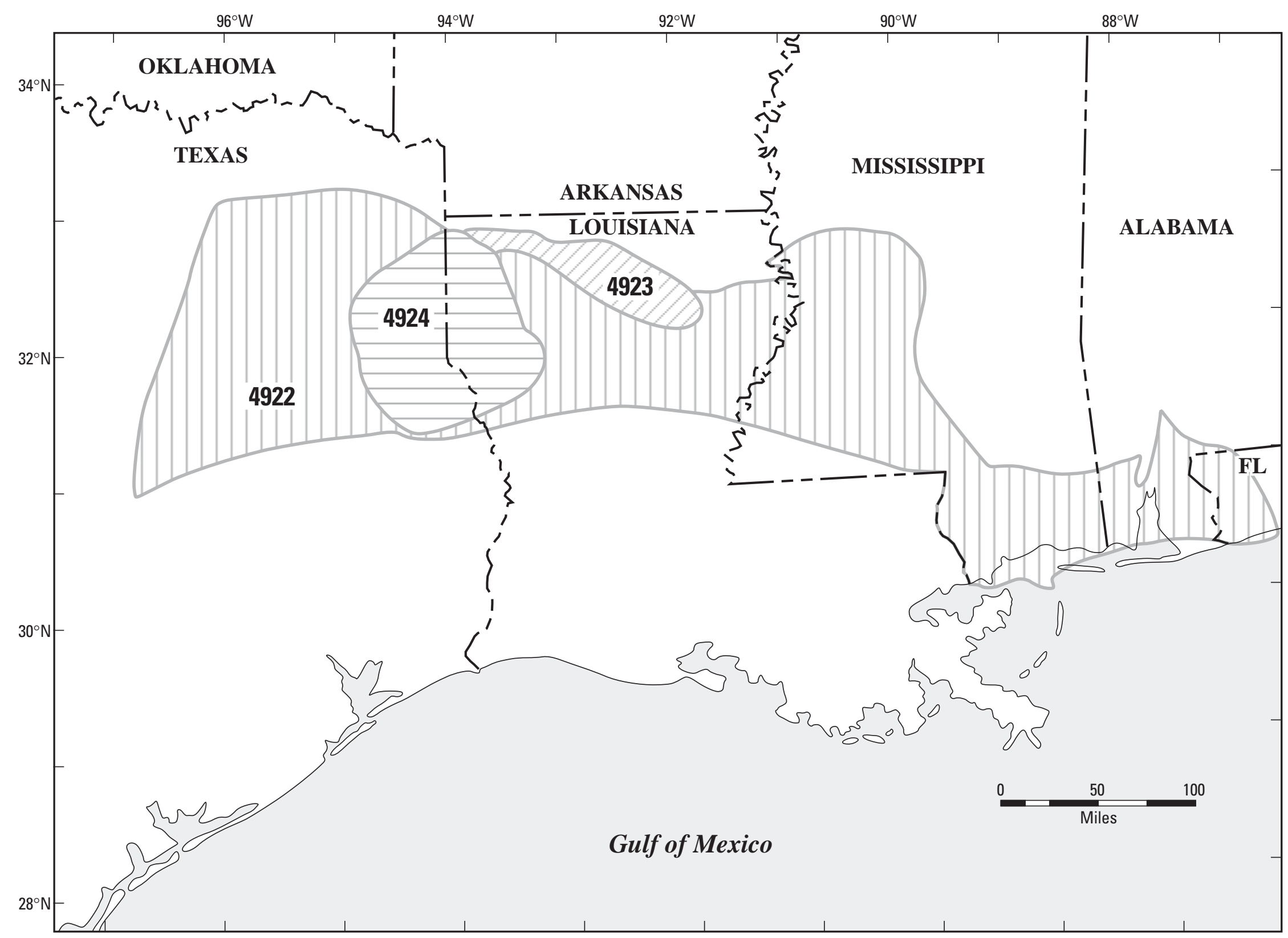

Figure 1. Map of north-central Gulf Coast Basin from Schenk and Viger (1996) showing outlines of three Cotton Valley Group plays identified by U.S. Geological Survey in the 1995 National Assessment of United States oil and gas resources. Shown are the Cotton Valley Blanket Sandstones gas play (4923) identified as a continuous gas play, and the Cotton Valley Salt Basins gas play (4922) and Cotton Valley Sabine Uplift gas play (4924) identified as conventional gas plays. 
made, however, to identify new plays and petroleum systems or to assess gas resources for potential plays.

From a regional perspective, two productive trends of Cotton Valley sandstones are recognized based on sandstonereservoir properties, gas-production rates, and necessity of hydraulic-fracturing treatments to achieve commercial production. Across northernmost Louisiana, so-called Cotton Valley blanket sandstones have sufficiently high porosity and permeability that commercial rates of gas production can be obtained without artificial well stimulation. South of this area, in northern Louisiana, and extending westward across the Sabine uplift into northeastern Texas, sandstones in the Cotton Valley massive-sandstone trend have poorer reservoir properties and require hydraulic-fracture treatments to achieve commercial rates of gas production. Because basin-centered, continuous gas accumulations characteristically occur within low-permeability reservoirs, the tight, Cotton Valley massivesandstone trend across northern Louisiana and northeastern Texas is an ideal setting in which to look for potential basincentered gas accumulations.

\section{Data Sources}

Interpretations and conclusions presented in this report are based on data from published literature and limited conversations with industry personnel, together with geologic and engineering data accessible in a publicly available CD-ROM database from IHS Energy Group (PI/Dwights Plus, a trademark of Petroleum Information/Dwights, d.b.a. IHS Energy Group). PI/Dwights Plus data evaluated for this report are current through February 2000. Primary data from PI/Dwights Plus pertinent to this study are results of drill-stem and production tests in Cotton Valley sandstones reported for individual wells. Because well-completion records depend on information provided by operators, well data in PI/Dwights Plus might be incomplete.

\section{Acknowledgments}

This work is funded by the U.S. Department of Energy, National Energy Technology Laboratory, Morgantown, W. Va. (contract nos. DE-AT26-98FT40031 and DEAT26-98FT40032), and by the U.S. Geological Survey Central Energy Team. Laura Biewick of the USGS provided instruction and assistance in using ArcView software to evaluate Cotton Valley well and test data. Gregory Zerrahn and Joseph Lott, geologists with Palmer Petroleum, Shreveport, La., assisted in obtaining reports, maps, and literature. We thank Al Brake, BP Amoco, and Al Taylor, Nomad Geosciences, for providing invaluable information on characteristics of Cotton Valley tight-gas accumulations. We acknowledge helpful reviews of this manuscript by Chuck Spencer, Curt Huffman, and Katharine Varnes of the USGS.

\section{Continuous-Type Gas Accumulations}

It is important to identify continuous-type gas accumulations because resource assessment for such gas accumulations is conducted using different methodology than that used for conventional fields. Continuous-type gas accumulations generally occur within an extensive volume of reservoir rock with spatial dimensions equal to or exceeding those of conventional hydrocarbon plays. The definition of continuous gas accumulations used here is based on geology rather than on government regulations defining low-permeability (tight) gas accumulations. Common geologic and production characteristics of continuous gas accumulations include their occurrence downdip from water-saturated rocks, lack of conventional traps or seals, reservoir rocks with low matrix permeability, presence of abnormal pressures, large in-place volumes of gas, and low recovery factors (Schmoker, 1996).

Continuous gas plays were treated as a separate category in the U.S. Geological Survey 1995 National Petroleum Assessment and were assessed using a specialized methodology (Schmoker, 1996). These continuous plays are diverse geologically and fall into several categories including coal-bed gas, biogenic gas, fractured-shale gas, and basin-centered gas accumulations. This report focuses on the potential for basincentered gas within Cotton Valley sandstones.

\section{Basin-Centered Gas Accumulations}

From studies of hydrocarbon-productive basins in the Rocky Mountain region, Law and Dickinson (1985) and Spencer (1987) identified characteristics of basin-centered gas accumulations that distinguish them from conventional ones. Basin-centered gas accumulations:

1. Are geographically large, spanning tens to hundreds of square miles in aerial extent, typically occupying the central, deeper parts of sedimentary basins.

2. Occur in reservoirs with low permeability - generally less than 0.1 millidarcy $(\mathrm{mD})$ — such that gas cannot migrate by buoyancy.

3. Lack downdip gas-water contacts because gas is not held in place by buoyancy of water. Consequently, water production is low or absent. If water is produced, it is not associated with a distinct gas-water contact.

4. Commonly occur in abnormally pressured reservoirs (generally overpressured, but occasionally underpressured).

5. Contain primarily thermogenic gas, and where overpressure is encountered, the overpressuring mechanism is thermal generation of gas.

6. Occur structurally downdip from water-bearing reservoirs that are normally pressured or occasionally underpressured.

7. Lack traditional seals and trapping mechanisms.

8. Have gas-prone source rocks proximal to the low- 
permeability reservoirs such that migration distances are short.

9. Occur in settings such that the tops of such gas accumulations occur within a narrow range of thermal maturity, usually between a vitrinite reflectance $\left(R_{o}\right)$ of 0.75 and 0.9 percent.

What causes a basin-centered, continuous gas accumulation to form? The most common scenario involves lowpermeability reservoirs in which overpressure develops in response to thermal generation of gas. Gas-prone source rocks generally must be associated with, or proximal to, lowpermeability reservoirs, and this sequence of source and reservoir rock must be buried to a depth sufficient for the source rocks to generate gas. Overpressure develops because thermal generation of gas occurs at a rate that exceeds the rate at which gas is lost updip by migration through the low-permeability reservoir. As overpressure develops, any free water in pores of the tight reservoir is forced out updip into higher permeability, normally pressured, water-bearing strata. Only bound, irreducible water remains in the tight-gas reservoir. Permeability is sufficiently low within the tight reservoir that gas does not migrate through it by buoyancy as it does through conventional reservoirs with higher permeabilities (Gies, 1984; Spencer, 1987; Law and Spencer, 1993). Instead, gas migrates slowly through the tight-gas reservoir with movement caused by the pressure differential between the region of high-pressure gas generation and the normally pressured, higher permeability, water-bearing rocks updip where gas does migrate upward rapidly by buoyancy. Thus, because of its inherent low permeability, a basin-centered gas reservoir itself retards the upward migration of gas, in effect forming its own leaky seal, and maintaining overpressured conditions.

This scenario probably describes an ideal, end-member situation. In some cases, for example, basin-centered gas accumulations have subnormal reservoir pressures resulting from significant tectonic uplift of strata in the basin. For a basin that is tectonically active and in an intermediate stage of uplift, it might be possible to find a basin-centered gas accumulation that is normally pressured. It is also possible that particular gas accumulations might have only some of the characteristics for basin-centered gas described above and that differentiating between basin-centered and conventional accumulations could be difficult and subjective. It is with this understanding that the potential for basin-centered gas in Cotton Valley sandstones is evaluated.

\section{Method for Evaluating Potential of Basin-Centered Gas in Cotton Valley Group Sandstones}

One of the main requirements for occurrence of a basincentered, continuous gas accumulation is the presence of a regional seal to trap gas in a large volume of rock across a wide geographic area. Within that large volume of rock, discrete gas accumulations having conventional seals and gaswater contacts are absent, and occurrence of gas often cuts across stratigraphic units. In classic basin-centered gas accumulations (Law and Dickinson, 1985; Spencer, 1987; Law and Spencer, 1993), the regional seal is provided by the low permeability of the reservoir itself. To evaluate the potential for the presence of a continuous gas accumulation within Cotton Valley Group sandstones, therefore, it is necessary to examine reservoir properties of Cotton Valley sandstones across the northern Gulf Coast Basin. Because reservoir properties of Cotton Valley sandstones are governed by diagenetic characteristics, which are controlled primarily by depositional environment, it is helpful to understand Cotton Valley depositional systems and related diagenetic patterns.

Although gas production from Cotton Valley sandstones seems to occur from discrete fields, it is necessary to determine if those fields are separate, conventional accumulations or socalled "sweet spots" within a regional, continuous gas accumulation. Thus, it is essential to understand what characterizes the apparent productive limits of existing Cotton Valley gas fields, including the presence or absence of gas-water contacts. For some fields in which gas-water contacts are not reported, an attempt was made to determine the presence or absence of gaswater contacts by examining fluid recoveries from drill-stem or production tests in wells on the flanks of those fields. The goal was to determine if certain Cotton Valley fields that produce from tight-gas sandstones are flanked by dry holes that tested water only, without gas, suggesting presence of a gas-water contact. To analyze test data spatially, data from PI/Dwights Plus were imported into ArcView 3.2, running on a desktop computer. While viewing the map display, test results from any particular well could be examined.

Finally, because continuous gas accumulations often are characterized by overpressure associated with thermal generation of gas from source rocks in proximity to low-permeability reservoirs, it is important to evaluate the presence and quality of potential source rocks, burial and thermal history of those source rocks, and reservoir-pressure data.

\section{Geologic Setting of Cotton Valley Group}

The Cotton Valley Group is an Upper Jurassic to Lower Cretaceous sequence of sandstone, shale, and limestone that underlies much of the northern Gulf of Mexico coastal plain from eastern Texas to Alabama (figs. 2 and 3). Cotton Valley strata occur only in the subsurface and form a sedimentary wedge that thickens southward into the Gulf Basin from a zero edge in southern Arkansas and eastern Texas (fig. 2). The downdip limit of the Cotton Valley Group has not been delineated yet by drilling. The depth to top of the Cotton Valley ranges from about 4,000 ft below sea level near the 


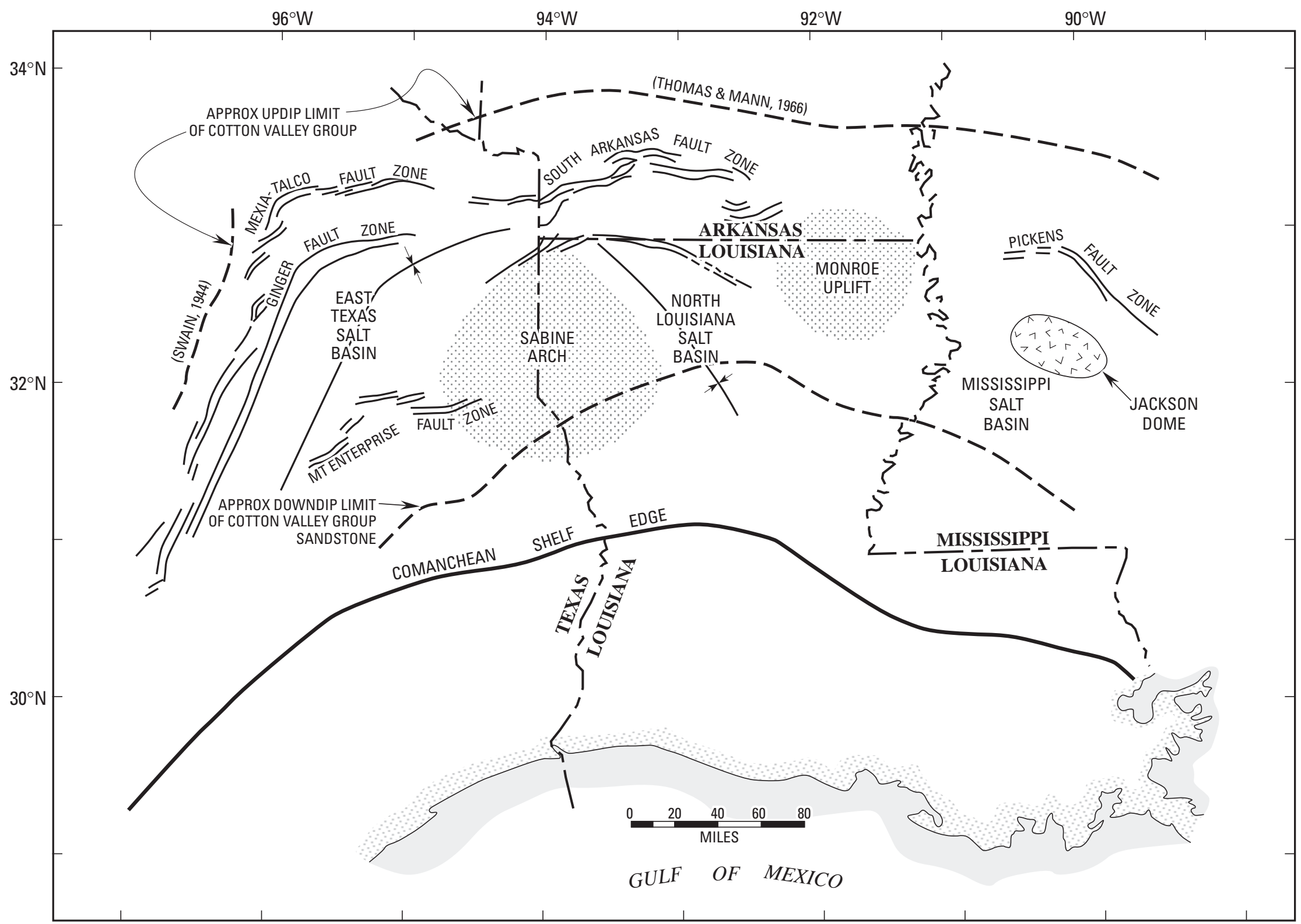

Figure 2. Index map of north-central Gulf Coast Basin, modified from Dutton and others (1993), showing major tectonic features. Sabine and Monroe uplifts were not positive features during deposition of Cotton Valley Group sediments. Cotton Valley depocenters were located across the entire northern Gulf Basin from eastern Texas to Alabama. Salt movement in East Texas and North Louisiana Salt Basins was contemporaneous with deposition of Cotton Valley Group clastic sediments. The Cotton Valley Group is an entirely subsurface sequence of strata with approximate updip limits shown here. 
updip zero edge to more than $13,000 \mathrm{ft}$ below sea level along the southern margins of the East Texas and Louisiana Salt Basins (figs. 2 and 4). In southeastern Mississippi, the top of the Cotton Valley occurs at nearly 20,000 ft below sea level. The greatest thickness of Cotton Valley rocks penetrated exceeds 5,000 ft in southeastern Mississippi (Moore, 1983).

The Cotton Valley Group and overlying Travis Peak (Hosston) Formation represent the first major influx of terrigenous clastic sediments into the Gulf of Mexico Basin following its initial formation during continental rifting in Late Triassic time (Salvador, 1987; Worrall and Snelson, 1989). Earliest sedimentary deposits in East Texas and North Louisiana subbasins (figs. 2 and 3) include upper Triassic nonmarine red beds of the Eagle Mills Formation, the thick Middle and Upper Jurassic evaporite sequence known as Werner Formation (anhydrite) and Louann Salt, and the nonmarine Norphlet Formation. Following a major regional marine transgression across the Norphlet, Upper Jurassic Smackover Formation regressive carbonates were deposited, capped by red beds and evaporites of the Buckner Formation (fig. 3). A subsequent minor marine transgression is recorded by the Gilmer Limestone or Cotton Valley Formation in eastern Texas, although equivalent facies in northern Louisiana and Mississippi are terrigenous clastics known as the Haynesville Formation. The marine Bossier Shale, lowermost formation of the Cotton Valley Group (figs. 3 and 5) was deposited conformably on Gilmer-Haynesville strata.

Louann Salt became mobile as a result of sediment loading and associated basinward tilting. Salt movement was initiated during Smackover carbonate deposition and became more extensive with influx of Cotton Valley clastics (McGowen and Harris, 1984). Many Cotton Valley and Travis Peak fields in eastern Texas, Louisiana, and Mississippi are structural or combination traps associated with Louann Salt structures. Salt structures range from small, low-relief salt pillows to large, piercement domes (McGowen and Harris, 1984; Kosters and others, 1989).

The Sabine uplift is a broad, low-relief, basement-cored arch separating the East Texas and North Louisiana Salt Basins (figs. 2 and 4). With vertical relief of 2,000 ft, the Sabine uplift has a closed area exceeding 2,500 $\mathrm{mi}^{2}$ (Kosters and others, 1989). Isopach data across the uplift indicate that it was a positive feature during deposition of Louann Salt in the Jurassic but that primary uplift occurred in late, mid-Cretaceous (101 to $98 \mathrm{Ma}$ ) and early Tertiary time (58 to $46 \mathrm{Ma}$ ) (Laubach and Jackson, 1990; Jackson and Laubach, 1991). As a high area for the past 60 m.y., the Sabine uplift has been a focal area for hydrocarbon migration in the northern Gulf Basin during that time. Numerous smaller structural highs on the uplift in the form of domes, anticlines, and structural noses provide traps for hydrocarbon accumulations, including many gas fields in Cotton Valley sandstones. Origins of these smaller structures have been attributed to salt deformation and small igneous intrusions, as summarized by Kosters and others (1989). Because the Louann Salt is thin across the Sabine uplift, Kosters and others (1989) suggest that most of the smaller structures across the Sabine uplift developed in association with igneous activity.

\section{Cotton Valley Group Stratigraphic Nomenclature}

Since the first penetration of Cotton Valley strata in northern Louisiana in 1927, complex informal stratigraphic nomenclature developed as numerous Cotton Valley oil and gas fields were discovered across the region through the 1940's. Nomenclature became complex because of local stratigraphic complexities within Cotton Valley strata in northern Louisiana and also because of regional variations in Cotton Valley depositional systems across the northern Gulf Basin. Terminology established by Swain (1944) was used until the complete revision of Cotton Valley stratigraphy by Thomas and Mann (1963) and Mann and Thomas (1964). Most subsequent reports, including the classic work of Collins (1980), have used Mann-Thomas terminology. Refinements to that terminology have been contributed by Coleman and Coleman (1981) and Eversull (1985).

Cotton Valley lithofacies and associated stratigraphic nomenclature in northern Louisiana are shown in figures 5 and 6. The basal formation of the Cotton Valley Group is the Bossier Shale, a dark, calcareous, fossiliferous, marine shale. In eastern Texas, isolated turbidite sandstones occur within the Bossier Shale (Collins, 1980). Overpressured gas currently is being produced from these sandstones in a rapidly developing new play (PI Dwights Drilling Wire, Jan. 3, 2000; Exploration Business Journal, 2nd quarter, 2000). Completely encased in marine shale, these gas-charged sandstones might represent a continuous gas accumulation.

The Bossier Shale grades upward into Cotton Valley sandstones with interbedded shales. These sandstones consist of stacked barrier-island, offshore-bar, strandplain, and fluvialdeltaic sandstones and are referred to as the Terryville massive-sandstone complex in northern Louisiana by Coleman and Coleman (1981). In eastern Texas, the stratigraphically equivalent unit is called Cotton Valley Sandstone, and it consists of braided-stream, fan-delta, and wave-dominated-delta sandstones (Wescott, 1983; Coleman, 1985; Dutton and others, 1993). Across the Cotton Valley hydrocarbon-productive trend in eastern Texas and northern Louisiana, the Terryville or Cotton Valley Sandstone averages about 1,000 to 1,400 ft in thickness (Finley, 1984; Presley and Reed, 1984). Sand deposition was interrupted in Early Cretaceous time by a regional transgressive event marked by deposition of the Knowles Limestone (figs. 5 and 6). In updip areas of eastern Texas and southern Arkansas, the Knowles Limestone pinches out, and clastic rocks of the Travis Peak, or equivalent Hosston, Formation directly overly Cotton Valley sandstones (figs. 3, 5, and 6). Saucier (1985) interprets the Knowles Limestone as the uppermost formation of the Cotton Valley Group, but Coleman 


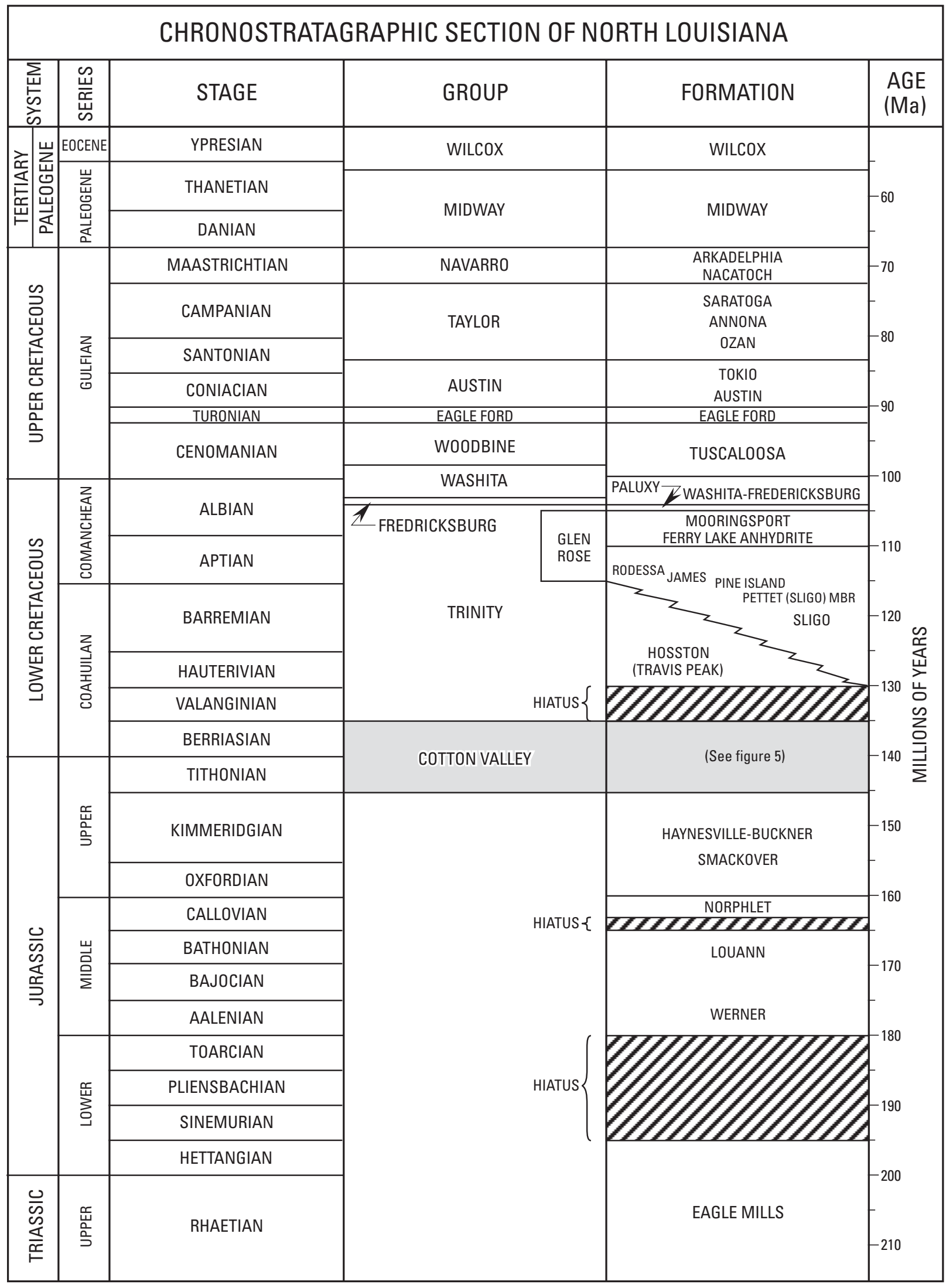

Figure 3. Chronostratigraphic section of northern Louisiana modified from Shreveport Geological Society (1987). Subdivisions of Cotton Valley Group shown in figure 5. 


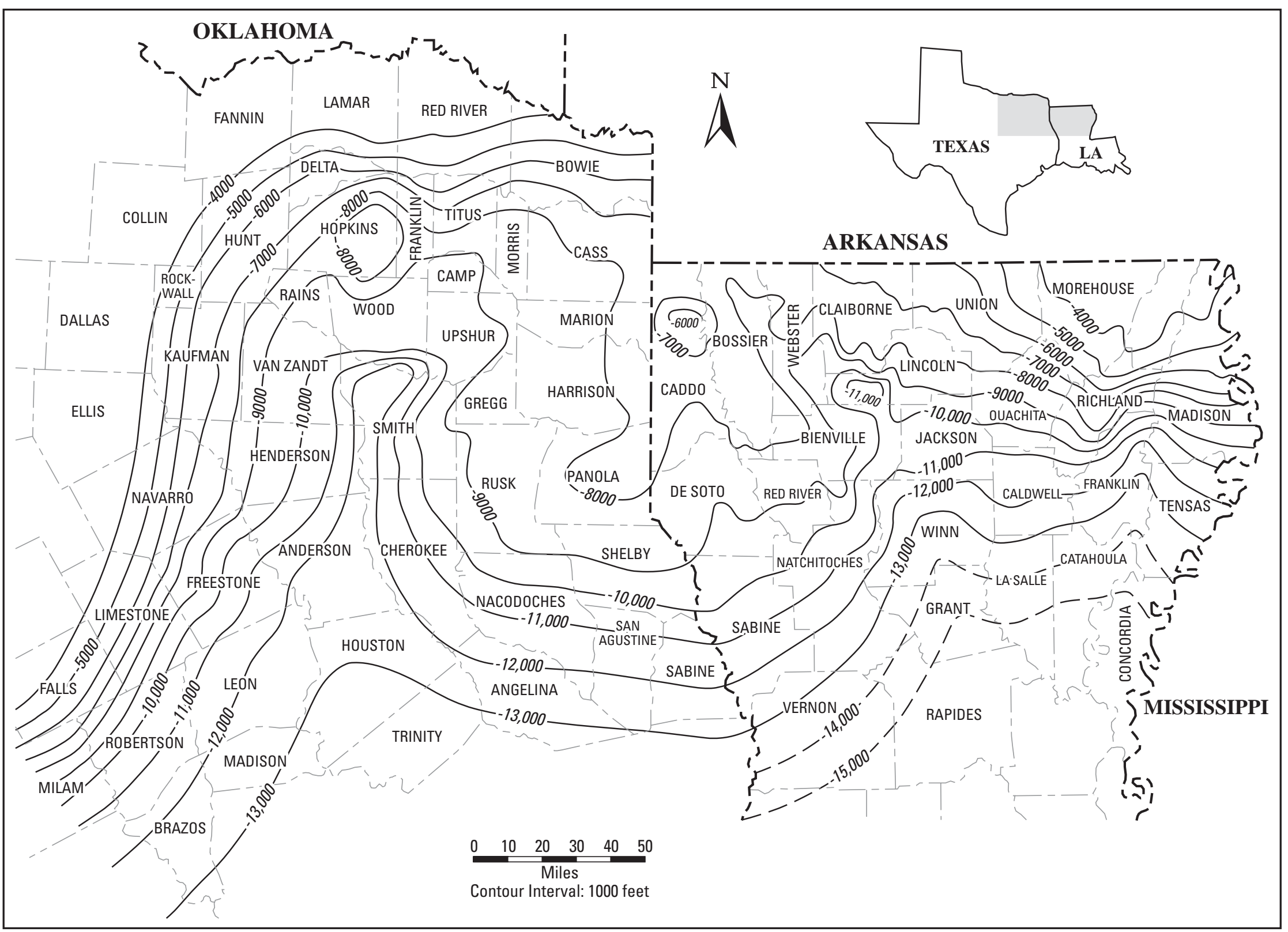

Figure 4. Generalized structure contours on top of Cotton Valley Group sandstone across northeastern Texas and northern Louisiana, modified from Finley (1984). Cotton Valley sandstone has been designated as "tight-gas sandstone" in all counties shown on this map with exception of 15 gas fields in northern Louisiana (fig. 8). 


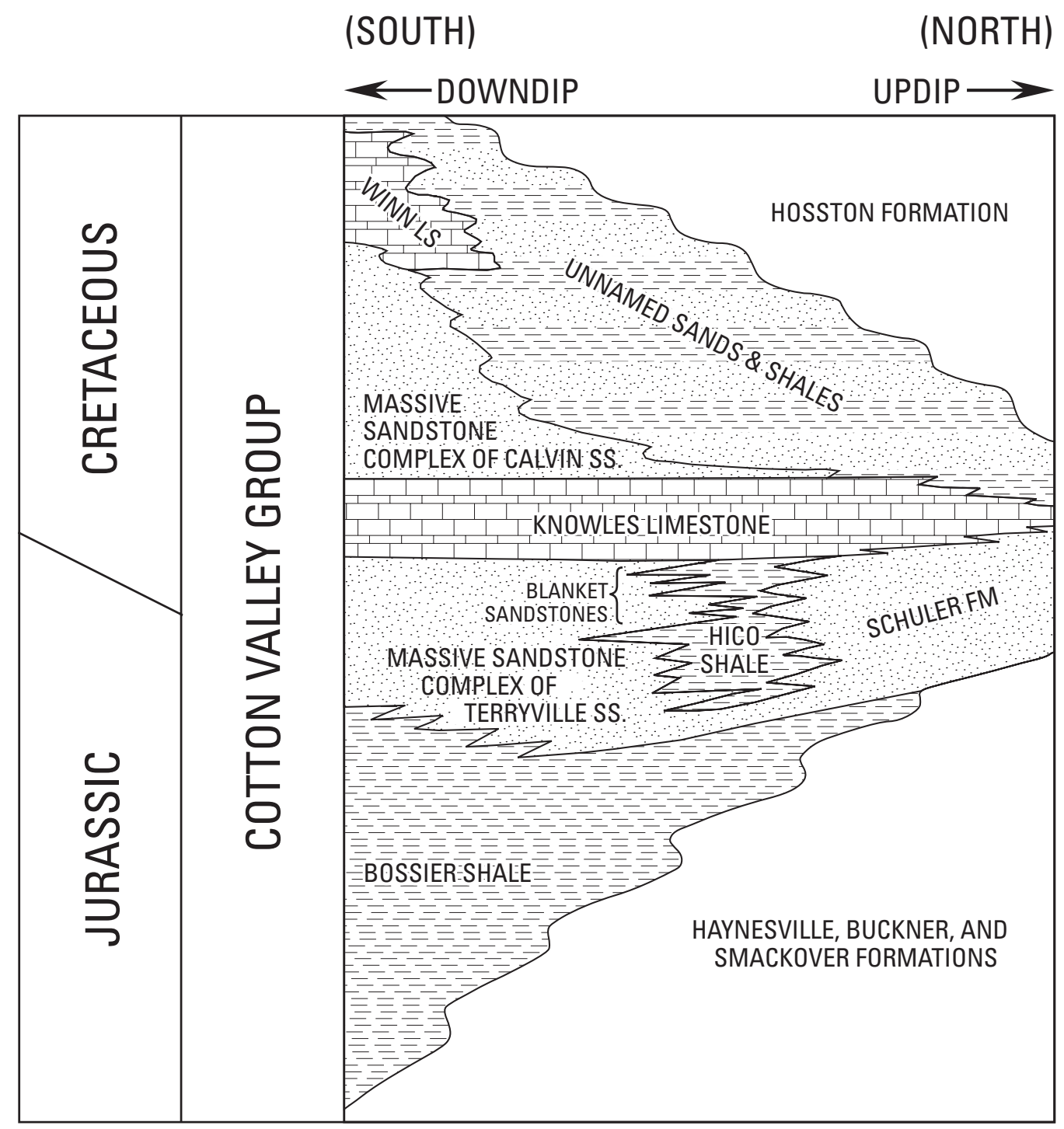

Figure 5. Generalized stratigraphic nomenclature of Cotton Valley Group (patterned units) in northern Louisiana, modified from Coleman and Coleman (1981). Schuler Formation and equivalents were assigned to Lower Cretaceous in mid 1980's (Herrmann and others, 1991). Prior to that time, entire Cotton Valley Group was considered to be Late Jurassic in age.

and Coleman (1981) include the stratigraphically higher Calvin Sandstone, Winn Limestone, and unnamed sands and shales within the Cotton Valley Group (figs. 5 and 6).

\section{Cotton Valley Group Depositional Systems}

\section{Regional Framework}

From eastern Texas to Mississippi, stacked barrier-island, strandplain, and fluvial-deltaic sandstones, known as Cotton
Valley or Terryville Sandstone, reflect influx of sands from a number of depocenters. Evolution of Cotton Valley depocenters and associated paleogeography across northern Louisiana are described and illustrated by Coleman and Coleman (1981), who subdivided the Terryville Sandstone into four depositional "events" (fig. 6) based on widespread shale breaks. Across south-central Mississippi, Moore (1983) shows three sequential paleogeographic reconstructions of Cotton Valley Group sandstone deposition. Although the setting was similar, concise paleogeographic reconstructions have not been published for the East Texas Basin; however, McGowen and Harris (1984) and Wescott (1985) provide data from which basic paleogeographic maps can be constructed. Figure 7 is a regional paleo- 
SOUTH

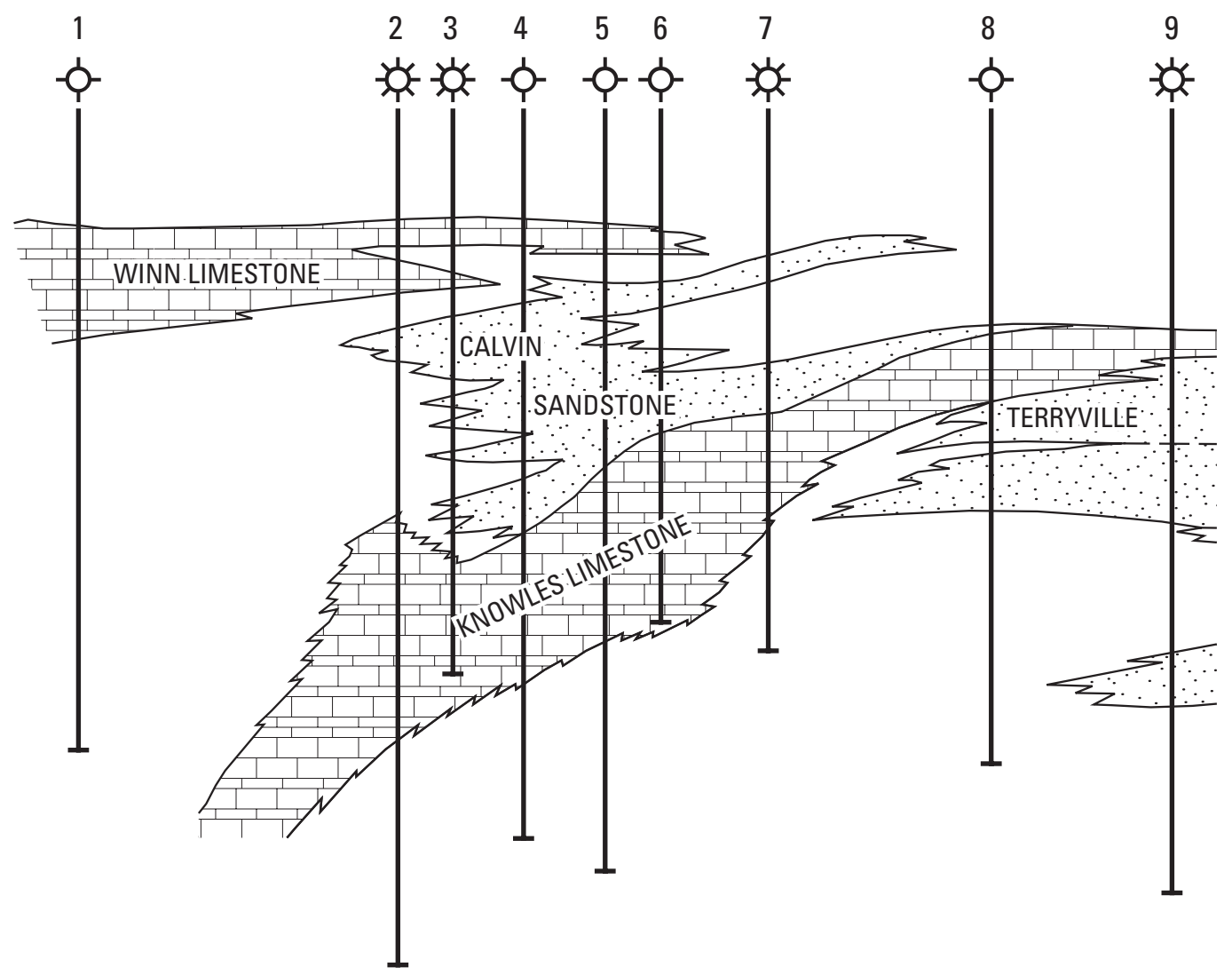

Figure 6 (above and facing page). North-south stratigraphic cross section of Cotton Valley Group across northern Louisiana based on data from 15 wells. Section is modified from Coleman and Coleman (1981) to show details of Cotton Valley blanket sandstones as identified and described by Eversull (1985) and Thomas and Mann (1963). Arrows indicate stratigraphic range of blanket sandstones. Line of cross section shown in figures 7 and 8 .

geographic map of upper Cotton Valley depositional systems (equivalent to Terryville IV of Coleman and Coleman, 1981) across the northern Gulf Basin from eastern Texas to Mississippi based on data integrated from these various workers.

As shown in figure 7, Cotton Valley fluvial-deltaic depocenters were located in present-day northeastern Texas, south-central Mississippi, and along the Louisiana-Mississippi border. The system along the Louisiana-Mississippi border represents the ancestral Mississippi River and was a locus of major clastic influx. Large quantities of sand delivered to the marine environment by this system were transported westward by longshore currents producing an extensive eastwest barrier-island or strandplain complex (Thomas and Mann, 1966). Vertical stacking of barrier-island/strandplain sands through time resulted in accumulation of the Terryville massive-sandstone complex (figs. 6 and 7). The east-west barrier-island complex across northern Louisiana sheltered a lagoon to the north from open-marine waters to the south
(Thomas and Mann, 1966). The Hico Shale accumulated in the lagoon while fluvial and coastal-plain sandstones and shales of the Schuler Formation were deposited in continental environments north of the lagoon (figs. 6 and 7). Development of a similar, but smaller, lagoon associated with barrier islandsformed from longshore-transported sands in south-central Mississippi—was documented by Moore (1983) (fig. 7). In eastern Texas, during the earliest phase of Cotton Valley Sandstone deposition, small fan deltas developed along the updip margin of the East Texas Basin (McGowen and Harris, 1984; Wescott, 1985; Black and Berg, 1987). The drainage system was immature with small fan deltas formed by numerous small streams. According to McGowen and Harris (1984), fan-delta deposition persisted through Cotton Valley time along the western margin of the East Texas Basin where fan-delta deposits characterize most of the Cotton Valley Sandstone interval. Along the northern flank of the East Texas Basin, in the region of the present-day Sabine uplift, a mature drainage system 


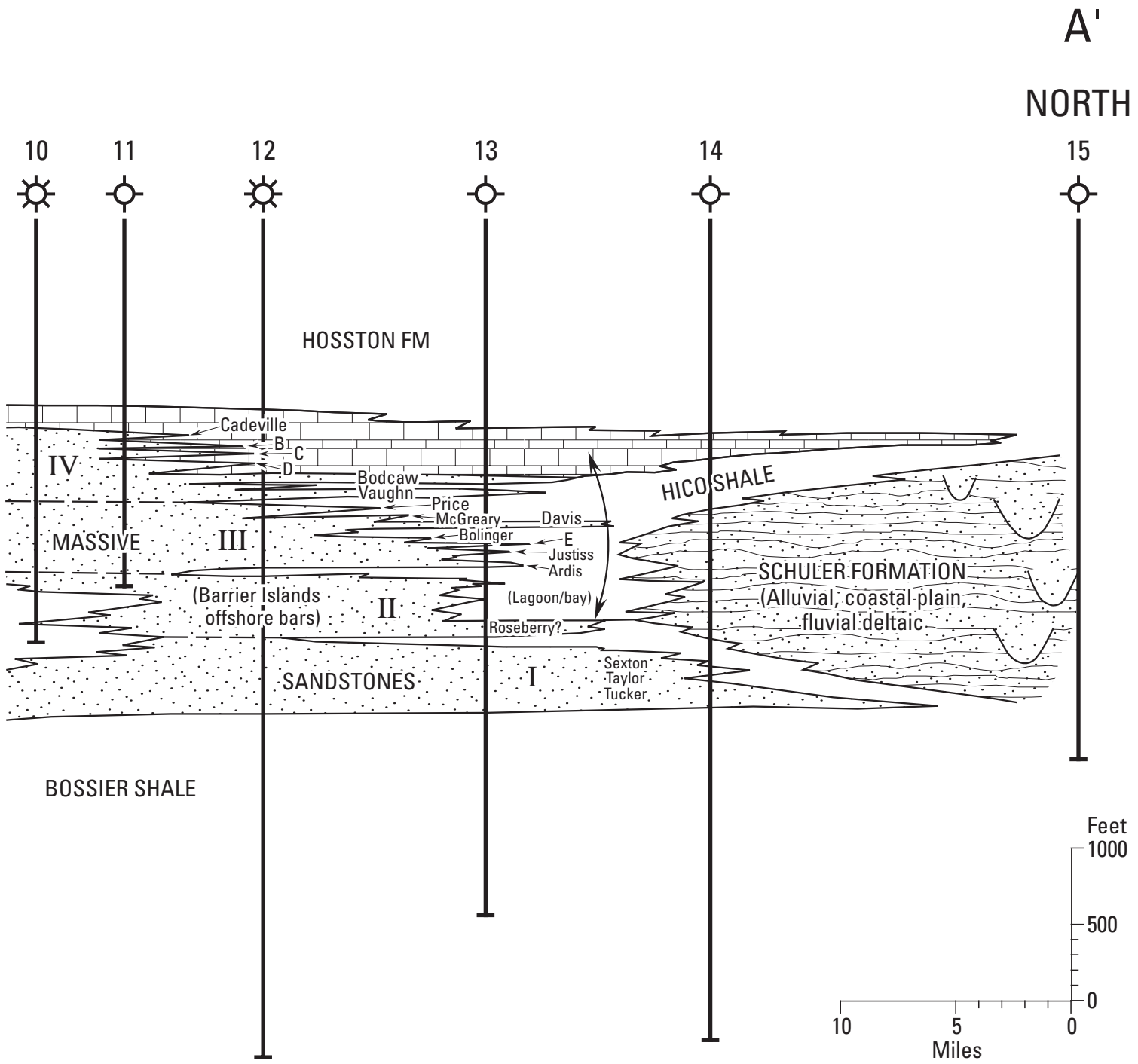

developed as fan deltas prograded basinward and evolved into a wave-dominated delta system. Sandstones of the lower part of the Cotton Valley comprising this delta system are referred to informally as the Taylor sandstone, according to Wescott (1985). After Taylor sand deposition was terminated by a subregional transgressive event, delta progradation resumed with development of a more elongate, fluvial-dominated system in the upper part of the Cotton Valley (fig. 7), referred to as the Lone Oak delta by Kast (1983).

\section{Blanket Sandstones of Northern Louisiana}

In northern Louisiana, at least 20 distinct tongues of sandstone extend landward from barrier-island deposits of the Terryville massive-sandstone complex and become thinner northward before pinching out into shales of the Hico lagoon, as shown in figure 6 . Some of these sandstones have limited geographic extent covering only part of the lagoon, whereas others extend across most or all of the lagoon and interfinger with continental deposits of the Schuler Formation on the landward side of the lagoon (Coleman and Coleman, 1981; Eversull, 1985). These sandstones have been interpreted as transgressive deposits with sand being derived from Terryville barrier islands and transported landward into the Hico lagoon during periods of relative sea-level rise and (or) diminished sediment supply (Coleman and Coleman, 1981; Eversull, 1985). These transgressive sandstones have significantly better porosity and permeability than Terryville massive sandstones from which they were derived and have been prolific producers of oil and gas from structural, stratigraphic, and combination traps discovered in the 1940's, 1950's, and 1960's across northern Louisiana (Collins, 1980; Bebout and others, 1992). Referred to informally as "blanket" sandstones (Eversull, 1985), they can be correlated readily across northern Louisiana, and, as shown in figure 6 , they were given informal names by operators during drilling in the 1940's and 1950's (Sloane, 1958; Thomas and Mann, 1963; and Eversull, 1985). 


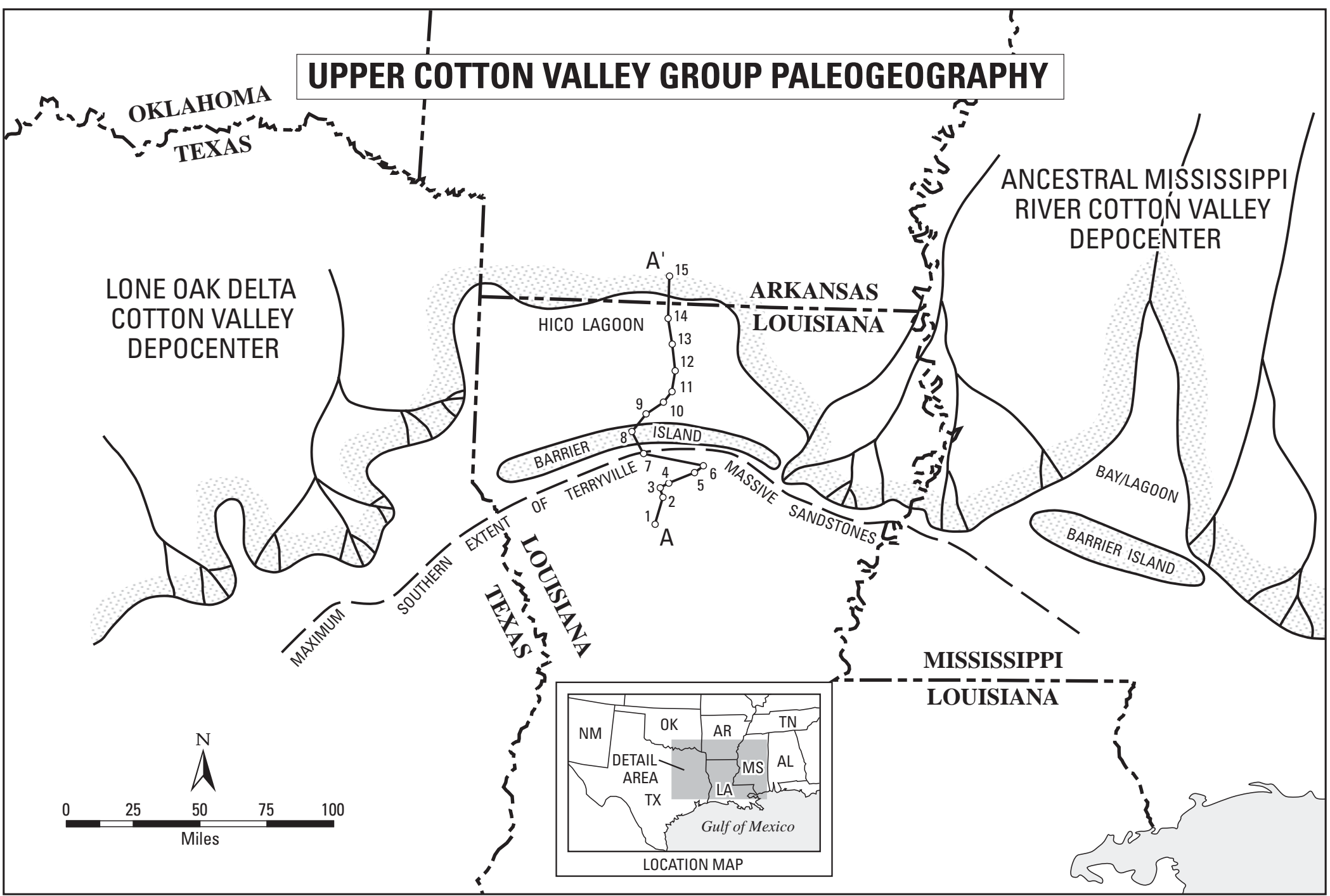

Figure 7. Regional paleogeographic map showing sedimentary environments of Cotton Valley Group during deposition of uppermost Cotton Valley sandstones (Terryville IV sandstone of Coleman and Coleman, 1981). Map synthesized from data of Thomas and Mann (1966), Coleman and Coleman (1981), Moore (1983), McGowen and Harris (1984), Wescott (1985), and Eversull (1985). Location of north-south stratigraphic cross section of Cotton Valley Group across northern Louisiana in figure 6 is illustrated by 15 numbered wells. 
Based on isopach map trends, Eversull (1985) identified two groups of blanket sandstones. Geographically more extensive sandstones of the first group span most of the Hico lagoon and often interfinger with continental deposits of the Schuler Formation. These sandstones generally are 30 to $70 \mathrm{ft}$ thick and can reach a thickness of $140 \mathrm{ft}$ toward the south where they merge with barrier-island sandstones of the Terryville massive-sandstone complex. Blanket sandstones of the second group generally are less than $30 \mathrm{ft}$ thick, have limited geographic extent, and most commonly occur in the eastern part of the Hico lagoon proximal to the fluvial-deltaic source. These sandstones pinch out northward into shales of the Hico lagoon. Transgressive, blanket sandstones of both groups collectively have significantly higher porosity and permeability than barrier-island sandstones of the Terryville massivesandstone complex to the south (Collins, 1980; Bebout and others, 1992).

\section{Blanket- and Massive-Sandstone Productive Trends}

Significant differences in reservoir properties between transgressive, blanket sandstones to the north and massive, barrier-island sandstones to the south define two different hydrocarbon-productive trends of Cotton Valley sandstones (fig. 8). Blanket sandstones have higher porosity and permeability than Terryville massive sandstones to the south. Eversull (1985) reported that blanket sandstones are cleaner and better sorted. She attributed their superior reservoir properties to high-energy reworking during transgressive events. Coleman (1985), however, reported that blanket sandstones exhibit an increase in calcite cement and clay content northward toward their pinch-out edges, and that superior reservoir properties occur because (1) clays inhibited precipitation of quartz overgrowths and (2) secondary porosity was generated through widespread dissolution of calcite cement. Absence of detrital clay coatings on sand grains in high-energy barrierisland sandstones of the Terryville massive-sandstone complex to the south, however, permitted widespread precipitation of quartz cement as syntaxial overgrowths, resulting in nearly complete occlusion of porosity (Sloane, 1958; Coleman and Coleman, 1981). Whatever the cause of porosity differences, blanket sandstones generally have sufficient porosity and permeability to flow gas or liquids on open-hole drillstem tests (DST's) and to produce gas without fracture-stimulation treatment (Collins, 1980; Bebout and others, 1992). Terryville massive sandstones to the south and west, however, have such poor reservoir properties that they generally do not flow gas or liquids during DST's, and they require hydraulic-fracture treatments before commercial production can be achieved.

\section{Diagenesis of Cotton Valley Group Sandstones}

Because understanding reservoir mineralogy is critical to successful wireline-log analysis and design of fracturestimulation treatments in Cotton Valley Group sandstones, considerable attention has been devoted to understanding diagenetic patterns of Cotton Valley sandstones, especially in the low-permeability, Cotton Valley massive-sandstone trend. Focusing on those sandstones in eastern Texas, Wescott (1983) reported that Cotton Valley sandstones are very fine grained, well-sorted quartz arenites and subarkoses with monocrystalline quartz and feldspar being the primary framework components. Principal cements include quartz, calcite, clays, and iron oxides. In unraveling the complex diagenetic history of these sandstones, Wescott (1983) interpreted two major diagenetic sequences. The most common sequence is (1) formation of clay coatings-primarily chlorite-on framework grains, usually covering grains partially, not completely, (2) precipitation of syntaxial quartz overgrowths on quartz grains, (3) dissolution of unstable grains, most commonly feldspars, (4) precipitation of clays, primarily illite and chlorite with minor kaolinite, (5) precipitation of calcite cement in both relict primary pores and secondary pores, and (6) large-scale replacement of grains and cements by calcite, resulting in poikilotopic texture in which a few relict quartz grains are "floating" in calcite. In the other, less-common diagenetic sequence, which occurs primarily in cleaner, coarser grained sandstones, calcite cementation commenced early and progressed to yield a fabric with widespread replacement of grains by calcite.

Wescott (1983) classified Cotton Valley sandstones into three general groups on the basis of primary depositional texture and resulting diagenetic characteristics. In general, Wescott (1983) found that clean, well-sorted sands deposited in high-energy environments (type I) generally are nearly completely cemented by quartz and (or) calcite, have little or no porosity and permeability, and provide little reservoir potential. In some cases, these sandstones exhibit preservation of minor amounts of primary intergranular porosity from presence of authigenic chlorite coats (Hall and others, 1984). In sands deposited in lower energy environments where abundant detrital clays remained (type II), nucleation of quartz overgrowths generally was inhibited by clays. Most clay-bearing sandstones, however, contain significantly large amounts of clay, and although abundant microporosity is associated with these clays, permeability generally is low. Highest porosities, according to Wescott (1983), occur in type-III sandstones, which developed abundant secondary porosity from dissolution of unstable grains and calcite cement. Hall and others (1984), however, reported that dissolution of unstable grains often is incomplete, secondary pores generally are poorly interconnected, and these sandstones, too, have poor 


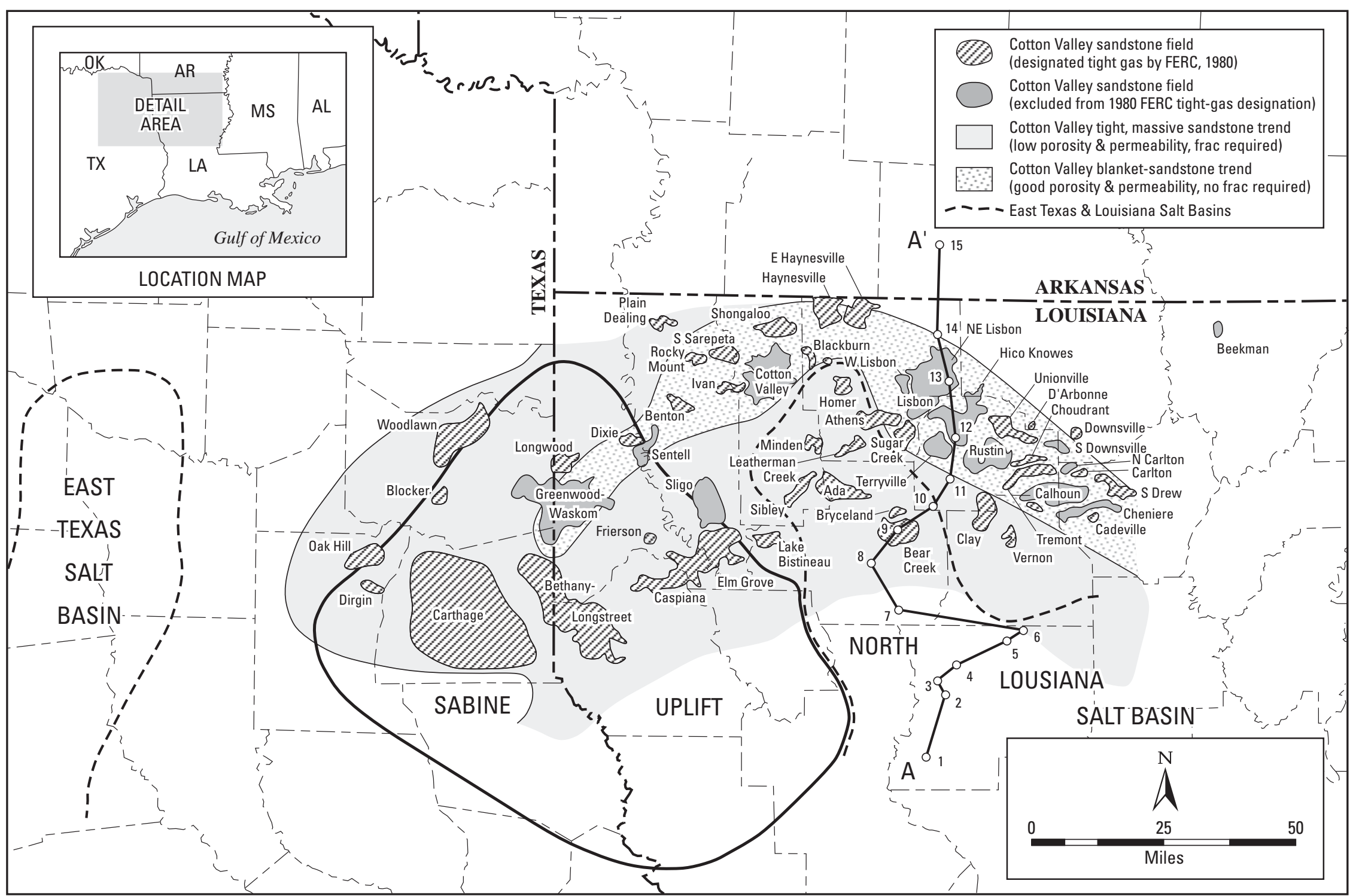

Figure 8. Map of northeastern Texas and northwestern Louisiana showing major fields that have produced hydrocarbons from Cotton Valley Group sandstones. Two different productive trends are recognized based on reservoir properties and resulting producing capabilities of Cotton Valley sandstone reservoirs. Fifteen fields excluded from "tight-gas" designation by FERC in 1980 are shown in solid dark-gray shading. Map modified from Collins (1980) and White and others (1992). Location of north-south stratigraphic cross section of Cotton Valley Group across northern Louisiana in figure 6 is illustrated by 15 numbered wells. 
permeability and require fracture stimulation to produce gas commercially.

In northern Louisiana, as interpreted by Russell and others (1984), the upper Cotton Valley Bodcaw Tongue of the Terryville Sandstone at Longwood field on the eastern flank of the Sabine uplift experienced a virtually identical diagenetic history to that described for Cotton Valley sandstones in eastern Texas by Wescott (1983). Like Wescott (1983), Russell and others (1984) reported that nucleation of quartz overgrowths was inhibited by presence of clays, but the quantity of porefilling clays generally is so large that permeability is low despite presence of high microporosity. Also, as in eastern Texas, the best reservoir sandstones are those that have low clay content and developed abundant secondary porosity through dissolution of unstable grains and cement. Similar diagenetic patterns in northern Louisiana also were reported for Cotton Valley sandstones at Frierson field by Sonnenberg (1976) and for the lowermost part of the Terryville Sandstone (the informal Taylor sandstone) at Terryville field by Trojan (1985). In addition to authigenic constituents reported in eastern Texas and northern Louisiana, Trojan (1985) also found small amounts of authigenic pyrite in Taylor sandstones at Terryville field. Pyrite occurs as small silt-size clusters (framboids). It is volumetrically the least abundant authigenic mineral reported by Trojan (1985), but its presence is significant because of its effect on wireline-log measurements of formation resistivity.

\section{Impact of Diagenetic Mineralogy on Wireline Logs}

The complex diagenetic mineralogy of tight Cotton Valley sandstones prohibits use of standard calculation procedures in reservoir evaluation with wireline logs. The main difficulty is that properties of certain diagenetic constituents result in abnormally low resistivity measurements, which lead to such high calculated water saturations that productive zones appear to be wet. Major factors contributing to abnormally low resistivities in tight Cotton Valley sandstones include bound water associated with pore-filling clays or clay coatings and conductive authigenic minerals such as pyrite and ankerite (Janks and others 1985; Turner, 1997).

Pore-lining and pore-filling clays have exceptionally high ratios of surface area to volume. Large surface area and high cation-exchange capacity of clays result in formation of a double ionic layer on clay surfaces (Almon, 1979; Snedden, 1984). This bound double layer can be significantly more conductive than pore waters, resulting in abnormally low measured resistivities, especially with induction logs (Almon, 1979; Wescott, 1983). Highly conductive authigenic minerals, such as ankerite and pyrite, in Cotton Valley sandstones also cause abnormally low resistivities. Trojan (1985) found that pyrite concentrations as low as 1 percent in Cotton Valley sandstones had a dramatic effect on resistivity measurements and hence on calculated water saturations. Standard calculation methods showed that pyrite-bearing sandstones at Terryville field in northern Louisiana had water saturations in excess of 100 percent. Trojan (1985) showed that if these sandstones were pyrite-free, calculated water saturations would be closer to 50 percent. Although water saturations in productive Cotton Valley sandstones commonly are 25 to 30 percent, water-free gas production has been achieved from zones with calculated water saturations as high as 60 percent (Nangle and others, 1982; Wilson and Hensel, 1984; Dutton and others, 1993).

Porosity measurements from wireline logs also can be affected adversely from diagenetic mineral constituents in Cotton Valley sandstones. In a study of Taylor sandstones (fig. 6) at Terryville field in northern Louisiana, Ganer (1985) demonstrated the negative impact of authigenic carbonates on porosity measurements from wireline logs. Located within the porous, permeable blanket sandstone trend, Terryville field was discovered in 1954 with production from the Cotton Valley "D" sandstone (fig. 6), one of the blanket sandstones. The Taylor sandstone occurs in the lower part of the Cotton Valley Sandstone interval, and its productive potential at Terryville field was not discovered until 1978. Unlike the stratigraphically higher blanket sandstones, the Taylor sandstone has relatively poor reservoir properties similar to those of tight Cotton Valley massive sandstones to the south. Like Wescott (1983), Ganer (1985) found that, although the Taylor sandstone is predominantly a quartz sandstone, it contains authigenic carbonate cement and locally can be composed of more than 50 percent carbonate resulting in a poikilotopic texture. With abundant secondary porosity from carbonate dissolution, these carbonate-rich sandstones are the best gas producers within the Taylor sandstone interval at Terryville field. Ganer (1985) identified several different carbonate minerals in Taylor sandstones, including calcite, ankerite, and siderite. Grain densities of these minerals are 2.71, 3.00, and 3.96 $\mathrm{g} / \mathrm{cm}^{3}$, respectively. If porosity $\operatorname{logs}$ based on a sandstone matrix (grain density of $2.65 \mathrm{~g} / \mathrm{cm}^{3}$ ) are run across an interval, such as the Taylor sandstone, containing abundant carbonate constituents with higher densities, measured porosity values will be pessimistic. Working with $420 \mathrm{ft}$ of conventional core from four wells at Terryville field, Ganer (1985) reported sandstone intervals with abundant carbonate constituents where log-measured porosities were close to zero, but core-measured porosities exceeded 6 percent. With complex effects of diagenetic minerals on both porosity and resistivity measurements from wireline logs, Ganer (1985) showed that a single porosity/water saturation limit is not suitable for evaluating productive potential of Cotton Valley sandstones at Terryville field. Ganer's conclusions probably are applicable to most, or all, of the tight, Cotton Valley massive-sandstone trend across northeastern Texas and northern Louisiana.

In comparing core-derived reservoir properties with wireline-log measurements for Cotton Valley sandstones from Carthage field in eastern Texas, Wilson and Hensel (1984) 
reported that no apparent relationship exists between porosity and permeability. From core analyses, they noted that it is not uncommon to find a sandstone interval with 10 percent porosity and 1 to $3 \mathrm{mD}$ permeability adjacent to a zone with similar porosity but with permeability less than $0.05 \mathrm{mD}$. Similarly, Ganer (1985) reported that Taylor sandstones with 8 percent porosity at Terryville field in northern Louisiana have permeabilities ranging from 0.01 to $13 \mathrm{mD}$. For Carthage field, Wilson and Hensel (1984) also noted that empirically derived values of cementation factor $(m)$ and saturation exponent $(n)$, used in calculation of water saturation, vary significantly from zone to zone. Wilson and Hensel (1984) derived general empirical values of $m$ and $n$ for Carthage field area to achieve more accurate log-derived estimates of water saturation. Because of such difficulties in determining water saturations from wireline logs, Presley and Reed (1984) stress that gas-pay cutoff values should be based on experience by operators in a given area.

A consequence of difficulties in accurate reservoir evaluation from conventional log analysis, of course, is that intervals capable of producing gas might be bypassed because of high calculated water saturations. For this study, the significance of these difficulties with wireline logs in tight Cotton Valley sandstones is that logs are of limited value in differentiating between gas-productive and wet intervals and therefore in identifying gas-water contacts on the flanks of Cotton Valley fields.

\section{Source Rocks}

Little information has been published on source rocks for hydrocarbons produced from Cotton Valley reservoirs in northern Louisiana and eastern Texas. In studying the overlying Travis Peak Formation in eastern Texas, Dutton (1987) showed that shales interbedded with Travis Peak sandstone reservoirs were deposited in fluvial-deltaic settings where organic matter commonly is oxidized and not preserved. With measured values of total organic carbon (TOC) in Travis Peak shales generally less than 0.5 percent, these shales are not considered as potential hydrocarbon source rocks (Tissot and Welte, 1978). Dutton (1987) suggested that the most likely sources for hydrocarbons in Travis Peak reservoirs in eastern Texas are laminated, lime mudstones of the lower member of the Jurassic Smackover Formation and prodelta and marine shales of the Bossier Shale, basal formation of the Cotton Valley Group (fig. 3). Sassen and Moore (1988) demonstrated that Smackover carbonate mudstones are a significant hydrocarbon source rock, charging various reservoirs in Mississippi and Alabama, and Wescott and Hood (1991) documented the Bossier Shale as a significant source rock in eastern Texas. Presley and Reed (1984) suggested that gray to black shales interbedded with Cotton Valley sandstones, as well as the underlying Bossier Shale, probably are the source for gas in Cotton Valley Sandstone reservoirs. Coleman and Coleman (1981) agreed with this interpretation for Cotton Valley sandstone reservoirs in northern Louisiana, stating that "hydrocarbons were generated from neighboring source beds."

In summary, despite limited source-rock data, it seems likely that adequate hydrocarbon source rocks occur in the Bossier Shale immediately beneath Cotton Valley sandstones and also in stratigraphically lower Smackover carbonate mudstones (fig. 3).

\section{Burial and Thermal History}

In a study of diagenesis and burial history of the Travis Peak Formation in eastern Texas, Dutton (1987) reported that measured vitrinite reflectance $\left(R_{o}\right)$ values for Travis Peak shales generally range from 1.0 to 1.2 percent. This indicates that these rocks have passed through the oil window $\left(\mathrm{R}_{\mathrm{o}}=0.6\right.$ to 1.0 percent) and are approaching the level of onset of drygas generation $\left(R_{O}=1.2\right.$ percent) (Dow, 1978). A maximum $\mathrm{R}_{\mathrm{O}}$ of 1.8 percent was measured in the deepest sample from a downdip well in Nacogdoches County, Texas. Despite thermal maturity levels reached by Travis Peak shales, the small amount, and gas-prone nature, of organic matter in these shales precludes generation of oil, although minor amounts of gas might have been generated (Dutton, 1987).

In the absence of actual measurements of $R_{0}$, values of $R_{o}$ can be estimated by plotting burial depth of a given source-rock interval versus time in conjunction with an estimated paleogeothermal gradient (Lopatin, 1971; Waples, 1980). Dutton (1987) presented burial-history curves for tops of the Travis Peak Formation, Cotton Valley Group, Bossier Shale, and Smackover Formation for seven wells on the crest and western flank of the Sabine uplift. The burial-history curves show total overburden thickness through time and use present-day compacted thicknesses of stratigraphic units. Sediment compaction through time was considered insignificant because of absence of thick shale units in the stratigraphic section. Loss of sedimentary section associated with late, midCretaceous and mid-Eocene erosional events was accounted for in the burial-history curves.

Dutton (1987) provided justification for using the average present-day geothermal gradient of $2.1^{\circ} \mathrm{F} / 100 \mathrm{ft}$ for the paleogeothermal gradient for the five northernmost wells. Paleogeothermal gradients in the two southern wells probably were elevated temporarily because of proximity to the area of initial continental rifting. Based on the crustal extension model of Royden and others (1980), Dutton (1987) estimated values for elevated paleogeothermal gradients for these two wells for 80 m.y. following the onset of rifting before reverting to the present-day gradient for the past 100 m.y.

Using estimated paleogeothermal gradients in conjunction with burial-history curves, Dutton (1987) found that calculated values of $R_{0}$ for Travis Peak shales agree well with measured values. Because of this agreement, Dutton (1987) used the same method to calculate $R_{o}$ values for tops of the Cotton Valley Group, Bossier Shale, and Smackover Forma- 
tion in eastern Texas. Estimated $\mathrm{R}_{\mathrm{O}}$ values for the Bossier Shale and Smackover in seven wells range from 1.8 to 3.1 percent and 2.2 to 4.0 percent, respectively, suggesting that these rocks have reached a stage of thermal maturity in which dry gas was generated. Assuming that high-quality, gas-prone source rocks occur within these two formations, it is likely that one or both of these units generated gas found in overlying Cotton Valley and Travis Peak reservoirs.

No such regional source-rock and thermal-maturity analysis is known for Travis Peak and Cotton Valley intervals in northern Louisiana. Scardina (1981) presented burial-history data for the Cotton Valley Group, but included no information on geothermal gradients and thermal history of rock units. Present-day reservoir temperatures in tight Cotton Valley sandstones of eastern Texas and the tight, massive Terryville Sandstone in northern Louisiana both are in the $250^{\circ} \mathrm{F}$ to $270^{\circ} \mathrm{F}$ range (Finley, 1986; White and Garrett, 1992). It is likely that Bossier and Smackover source rocks in northern Louisiana experienced relatively similar thermal history to their stratigraphic counterparts in eastern Texas and, therefore, are sources for Cotton Valley gas in northern Louisiana. Herrmann and others (1991) presented a burial-history plot for Ruston field in the Cotton Valley blanket-sandstone trend in northern Louisiana. They suggested that Smackover gas was derived locally from Smackover lime mudstones and Cotton Valley gas from Cotton Valley and Bossier shales. Their burial-history plot shows the onset of generation of gas from Smackover and Bossier source rocks at Ruston field occurred about 80 $\mathrm{Ma}$ and $45 \mathrm{Ma}$, respectively. As noted above in this report, the Sabine uplift has been a positive feature for the past 60 m.y. (Kosters and others, 1989; Jackson and Laubach, 1991). Therefore, it would have been a focal area for gas migrating from Smackover, Bossier, and upper Cotton Valley source rocks in eastern Texas and northern Louisiana.

\section{Abnormal Pressures}

Pore pressure or reservoir pressure commonly is reported as a fluid-pressure gradient (FPG) in pounds per square inch/ foot (psi/ft). Normal FPG is $0.43 \mathrm{psi} / \mathrm{ft}$ in freshwater reservoirs and $0.50 \mathrm{psi} / \mathrm{ft}$ in reservoirs with very saline waters (Spencer, 1987). Abnormally high pore pressures as high as $0.86 \mathrm{psi} / \mathrm{ft}$ have been encountered in Cotton Valley reservoirs in northeastern Louisiana (fig. 9). Multiple FPG values for a particular gas field in figure 9 refer to gradients calculated for different, stacked blanket-sandstone reservoirs penetrated in that field. Across northern Louisiana, as shown in figure 9, the highest FPG's of 0.84 and $0.86 \mathrm{psi} / \mathrm{ft}$ occur in the southeast, and gradients generally decrease to nearly normal values of 0.43 to $0.50 \mathrm{psi} / \mathrm{ft}$ in the northwest. This pattern exhibits general agreement with reservoir-pressure data for northern Louisiana summarized by Coleman and Coleman (1981) (fig. 10). The dashed line in figure 10 shows a modification of Coleman and Coleman's (1981) pressure boundary to include the 0.63 psi/ft gradient in Hico-Knowles field and $0.67 \mathrm{psi} / \mathrm{ft}$ gradient in Tremont field (fig. 9). Most significant for this study, the boundary between overpressured and normally pressured Cotton Valley sandstones (fig. 10) shows no relationship to the two different productive Cotton Valley sandstone trends defined by differences in reservoir properties (fig. 8). Additionally, most Cotton Valley sandstone reservoirs, especially in the tight, massive-sandstone trend across northwestern Louisiana and eastern Texas are normally pressured, as shown in figure 9.

\section{History of Cotton Valley Group Sandstone Exploration}

Beginning in 1937 and continuing through the early 1960's, commercial gas production was established from porous and permeable Cotton Valley Group blanket-sandstone reservoirs across northern Louisiana. Blanket sandstones flowed gas at commercial rates without artificial stimulation. Initial discoveries were in anticlinal traps associated with salt structures. Subsequent discoveries came from more complex and subtle traps, including (1) combination traps with blanket sandstones pinching out across anticlines or structural noses, and (2) stratigraphic traps with blanket sandstones pinching out on regional dip (Pate, 1963; Coleman and Coleman, 1981). By the early 1960's, the high-porosity blanket-sandstone play matured, and exploratory drilling waned. Low-porosity, lowpermeability, Cotton Valley massive sandstones to the south in Louisiana and to the west on the Sabine uplift in northwestern Louisiana and eastern Texas flowed gas at rates less than 1,000 MCFD (thousand cubic feet of gas per day) and were not commercial with gas selling at $\$ 0.18 / \mathrm{MCF}$ in the 1960's (Collins, 1980).

In the 1970's, gas production from low-permeability, Cotton Valley massive sandstones became commercial as a result of technical advances in hydraulic-fracturing techniques together with significantly higher gas prices. At Bethany field on the Sabine uplift in eastern Texas in 1972, Texaco successfully increased the rate of production from tight Cotton Valley sandstones from 500 MCFD to a sustained rate of 2,500 MCFD and 30 BCPD (barrels of condensate per day) through hydraulic fracturing (Jennings and Sprawls, 1977). In conjunction with development of improved stimulation technology, price deregulation through the Natural Gas Policy Act (NGPA) of 1978 spawned a dramatic increase in drilling for gas in low-permeability Cotton Valley sandstones (Bruce and others, 1992). In 1980, the Federal Energy Regulatory Commission (FERC) officially classified low-permeability Cotton Valley sandstones as "tight gas sands," qualifying them for additional price incentives. Production from tight Cotton Valley sandstones surged. At Carthage field in eastern Texas, for example, production from Cotton Valley sandstones increased from 2.2 BCFG (billion cubic feet of gas) in 1976 to 70.9 BCFG in 1980 (Meehan and Pennington, 1982). The large area 


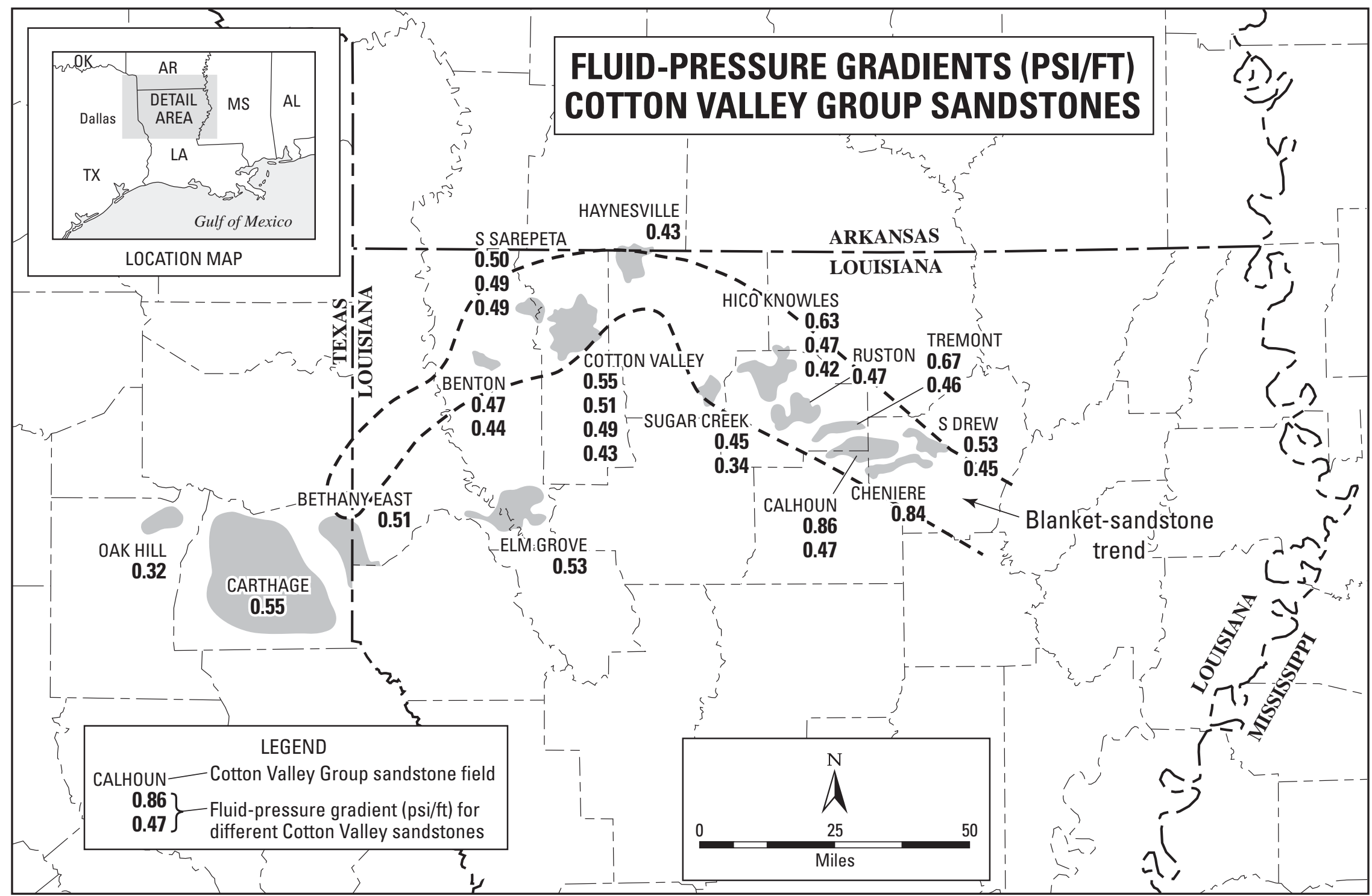

Figure 9. Map of northeastern Texas and northwestern Louisiana showing fluid-pressure gradients calculated from shut-in pressures in Cotton Valley Group sandstone reservoirs. Multiple pressure-gradient values for a particular gas field refer to gradients calculated for different, stacked blanket-sandstone reservoirs penetrated in that field. Shut-in-pressure data for Louisiana fields shown in table 2. 


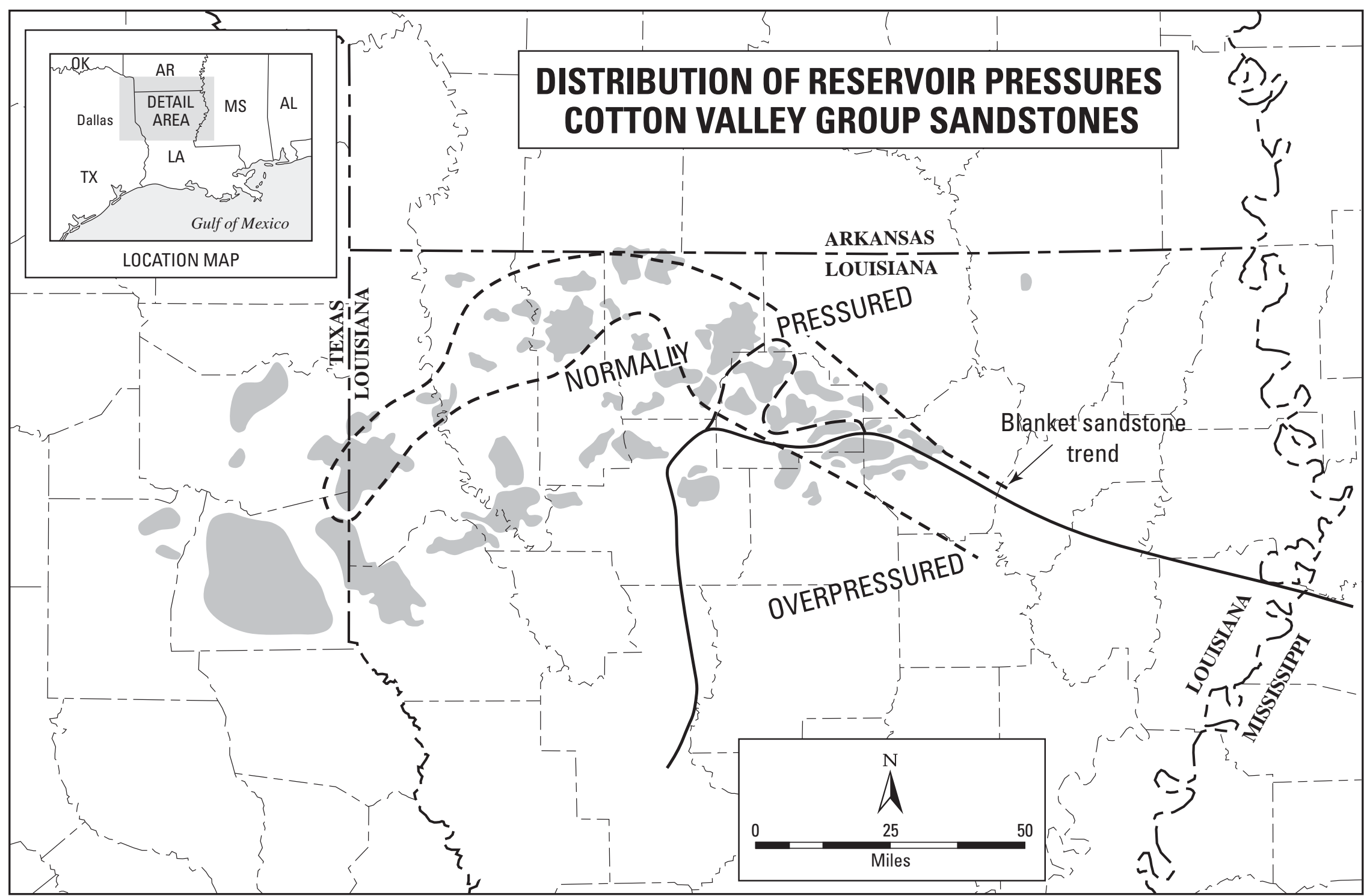

Figure 10. Map of northeastern Texas and northwestern Louisiana modified from Coleman and Coleman (1981) showing geographic distribution of abnormally high pressures in Cotton Valley Group sandstone reservoirs. Dashed line shows modific ation of Coleman and Coleman's (1981) pressure boundary to include the 0.63 psi/ft fluid-pressure gradient in Hico-Knowles field and $0.67 \mathrm{psi} / \mathrm{ft}$ gradient in Tremont field as shown in figure 9 and documented in table 2. Comparison of this map with map in figure 8 shows boundary between overpressure and normal pressure cuts across two productive trends of Cotton Valley sandstones. 
across northern Louisiana and northeastern Texas within which Cotton Valley sandstones have been designated tight-gas sandstones by FERC includes all the counties identified by name on figure 4 (Dutton and others, 1993).

\section{Comparison of Blanket-Sandstone and Massive-Sandstone Trends}

Two productive Cotton Valley sandstone trends are identified based on reservoir properties (fig. 8). As described above, Cotton Valley sandstone reservoir properties are a function of diagenetic characteristics, which are controlled primarily by variations in depositional environment. Reservoir properties, in turn, govern gas-production characteristics, including both initial rate of gas production and necessity of hydraulicfracture treatments to achieve commercial production rates. Table 1 summarizes these and other key parameters distinguishing blanket- and massive-sandstone Cotton Valley reservoir trends. Data presented in table 1 were derived from a variety of sources as indicated in the table headnote, with much of the information coming from a series of reports by the Shreveport Geological Society on oil and gas fields in northern Louisiana (Shreveport Geological Society Reference Reports, 1946, 1947, 1951, 1953, 1958, 1963, 1980, 1987). Detailed information obtained from those reports on more than 20 Cotton Valley oil and gas fields in northern Louisiana, including data on porosity, permeability, initial production rates, gas-water contacts, and FPG's, is presented in table 2.

Most of the significant fields across northern Louisiana and northeastern Texas from which Cotton Valley sandstones produce gas are shown in figure 8 . The area shown in figure 8 is part of the larger region shown in figure 4 within which
Cotton Valley sandstones were designated as tight-gas sandstones by FERC in 1980. As shown in figure 8, however, 15 Cotton Valley fields were excluded from FERC's tight-gas sandstone designation. All but one of these fields are located within the porous and permeable Cotton Valley blanketsandstone trend.

\section{Blanket-Sandstone Trend}

Transgressive, Cotton Valley blanket sandstones have porosities ranging from 10 to 19 percent and permeabilities from 1 to $280 \mathrm{mD}$ (tables 1 and 2). Porosity and permeability data are not readily available for all productive blanket sandstones in Cotton Valley fields. However, sufficient data are available from several blanket-sandstone reservoirs within a dozen fields across northern Louisiana to observe the widespread distribution of relatively high quality reservoir sandstones across the Cotton Valley blanket-sandstone trend (fig. 11). Data shown in figure 11 are derived primarily from field reports by the Shreveport Geological Society and from White and others (1992). Multiple values of porosity and permeability for a given field in figure 11 represent measured values for separate, stacked blanket-sandstone reservoirs within that field. Average porosity and permeability for Cotton Valley blanket sandstones, calculated from data in figure 11, are 15 percent and $110 \mathrm{mD}$, respectively.

The relatively high porosity and permeability of blanket sandstones is reflected in (1) the ability of these sandstones to flow gas and (or) liquids on open-hole DST's, and (2) high initial flow rates of gas from these sandstones in production tests without hydraulic-fracture stimulation treatments, as shown in figure 12. Multiple values of initial flow rates for a given field shown in figure 12 indicate rates from different stacked blanket sandstones that produce in that field. Across

Table 1. Comparison of two productive trends of Cotton Valley Group sandstones in eastern Texas and northern Louisiana.

[Data from Shreveport Geological Society (1946, 1947, 1951, 1953, 1958, 1963, 1980, 1987); Collins (1980); Nangle and others (1982); Finley (1984, 1986); Bebout and others (1992); and Dutton and others (1993). TSTM, too small to measure]

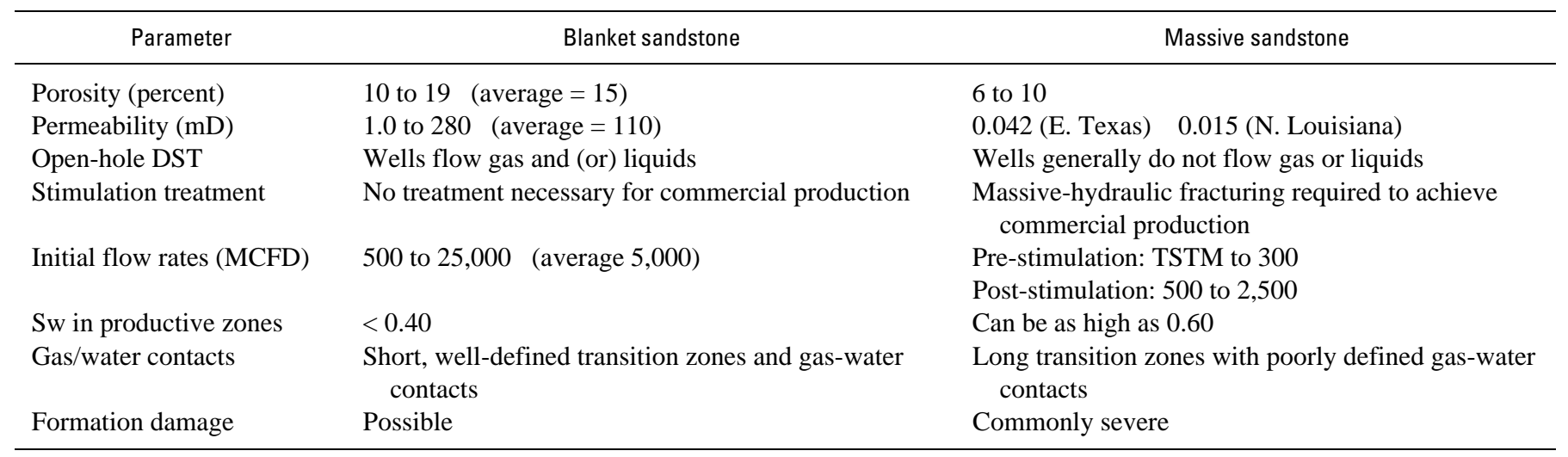




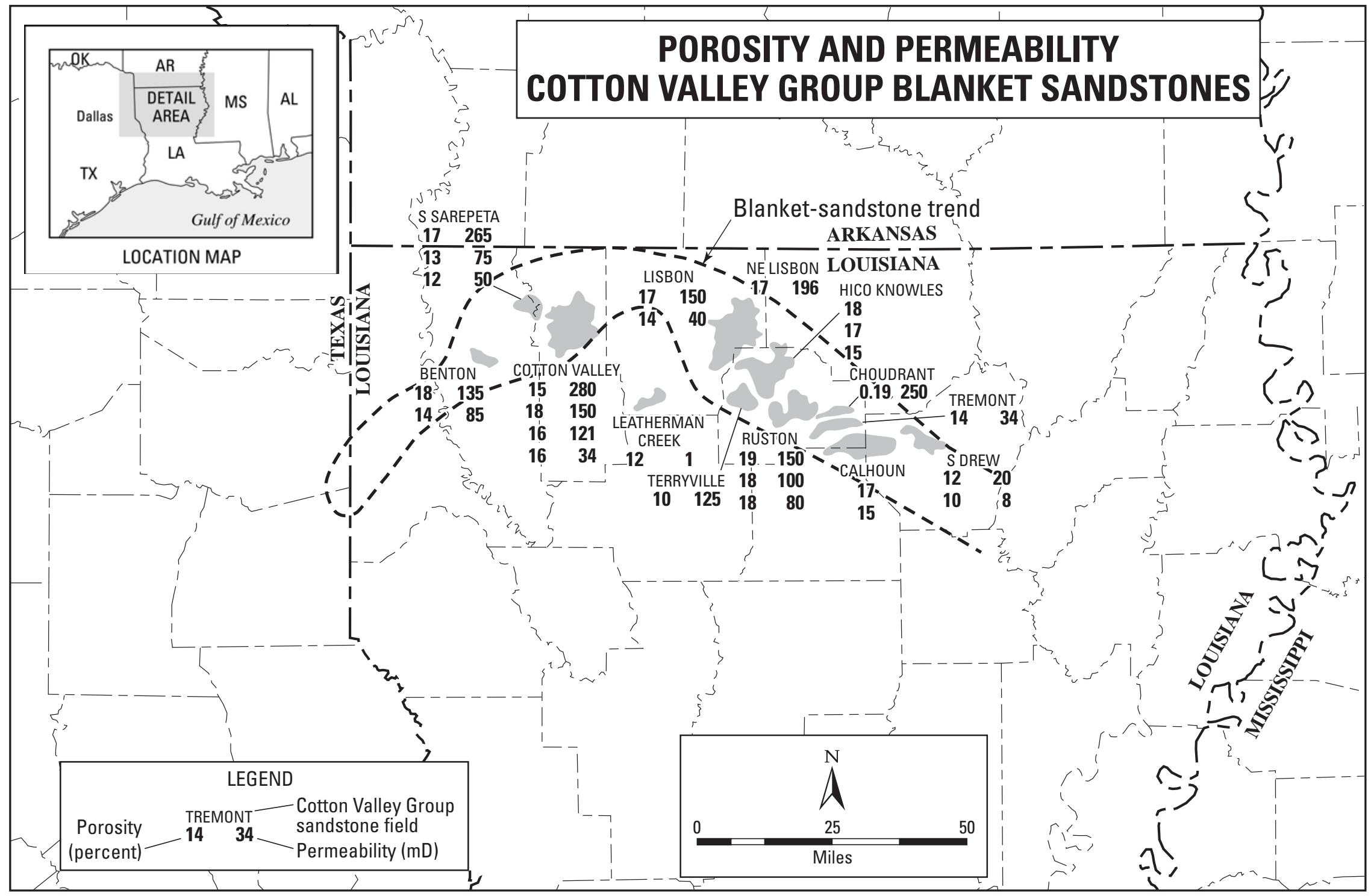

Figure 11. Map of northeastern Texas and northwestern Louisiana showing measured values of porosity and permeability in Cotton Valley Group blanket sandstones. Porosity and permeability data documented in table 2. Multiple values of porosity and permeability for a given field represent measured values for separate, stacked blanket-sandstone reservoirs in that field. 
Table 2. Data on Cotton Valley Group sandstone fields in northern Louisiana.

[See end of table for explanation of abbreviations]

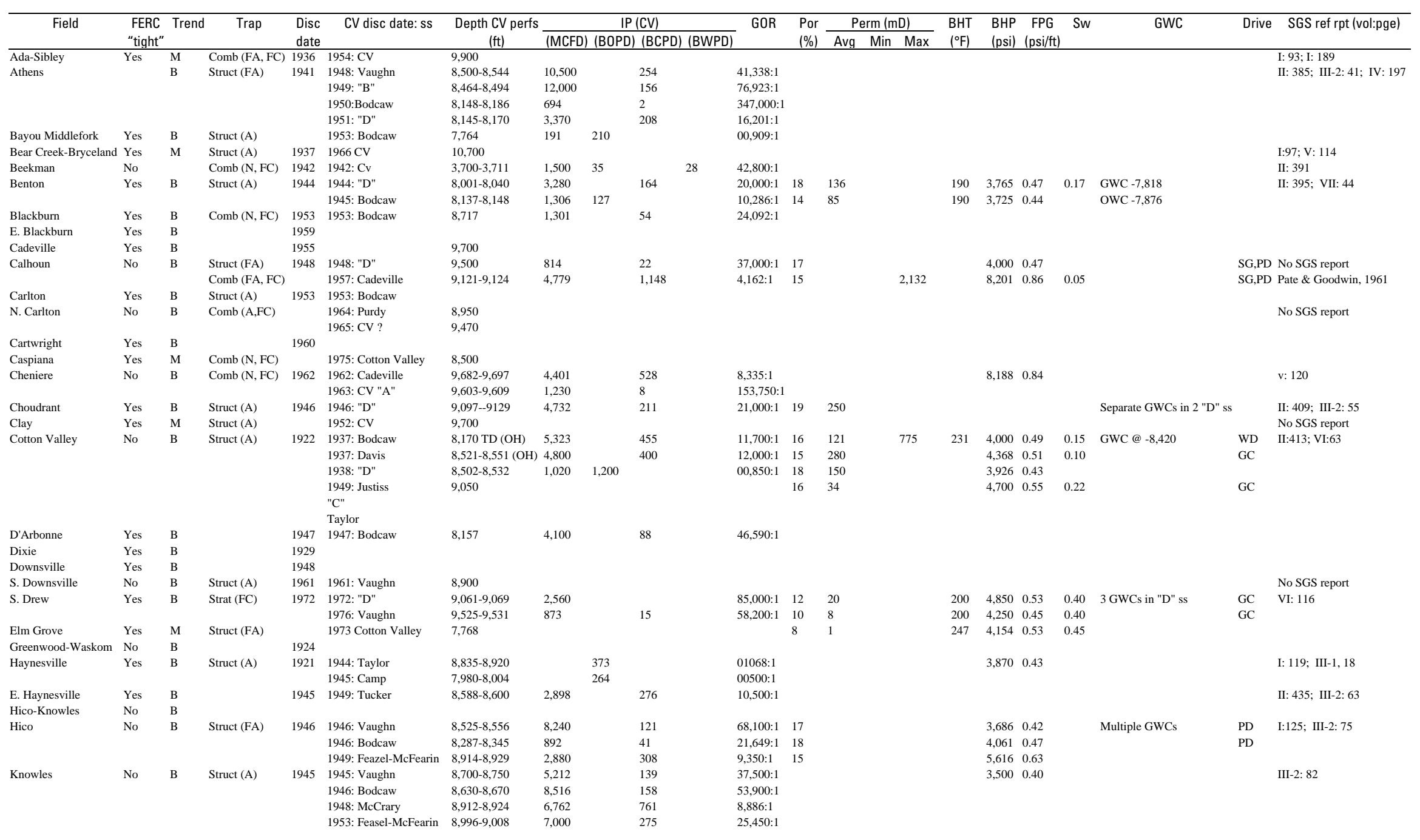


Table 2. Data on Cotton Valley Group sandstone fields in northern Louisiana—Continued.

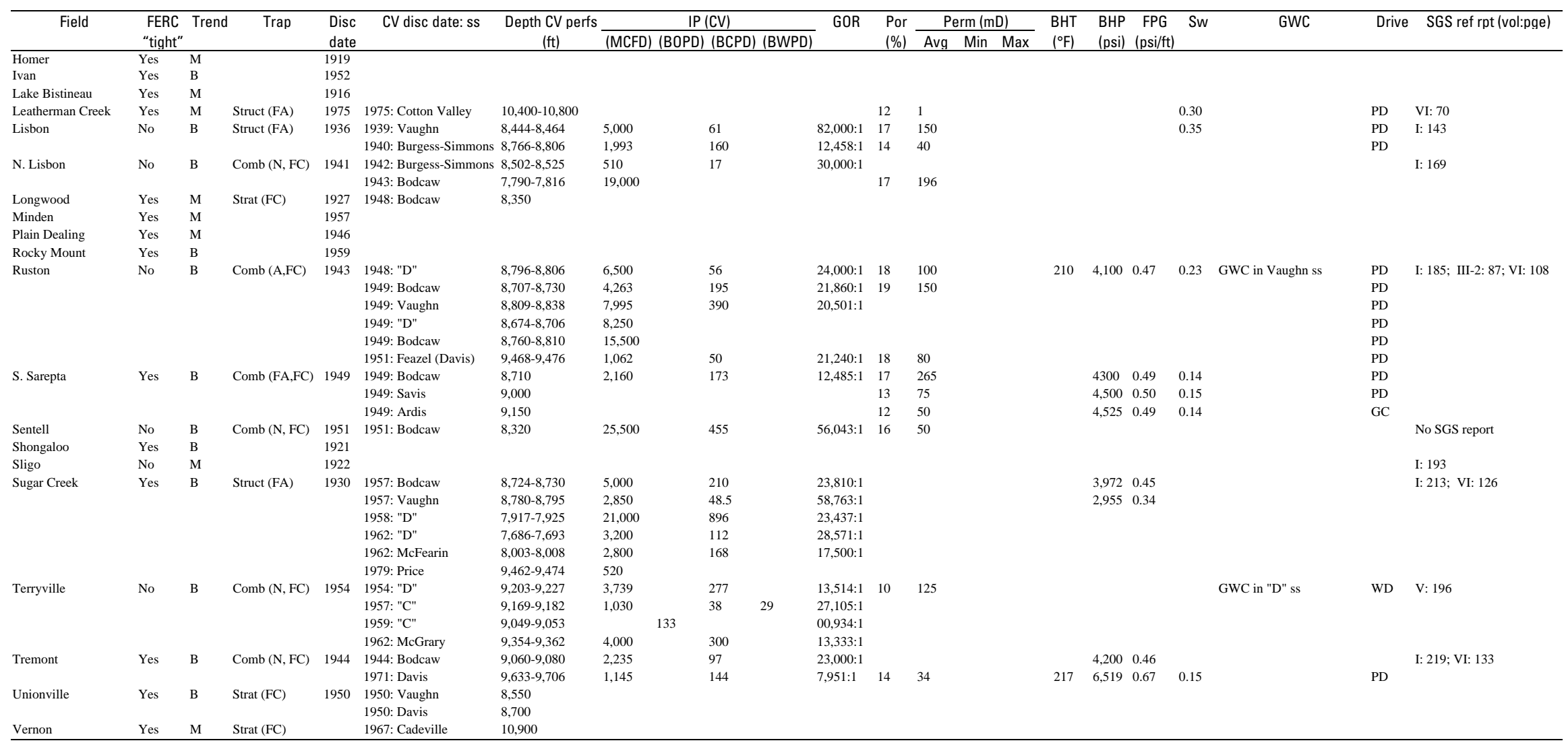

Field ... Name of field producing from Cotton Valley Group (CV) sandstone

FERC "tight" Did FERC designate the field "tight-gas sand" for Cotton Valley Group?

Trend

B, Blanket-sandstone trend

$\begin{array}{ll}\text { Trap } & \text { M, Massive-sandstone trend } \\ \text { Trapping mechanism for field }\end{array}$

Struct, structural trap

Strat, stratigraphic trap

Comb, combination structural \& stratigraphic trap

$\mathrm{A}$, anticline

FA, faulted anticline

FC, facies change (sandstone pinchout)

$\mathrm{N}$, structural nose

Disc date

Discovery date of field

CV disc date: ss Date of CV sandstone discovery and specific CV ss that was productive

Depth CV perfs

Depth in feet of CV perforations in discovery well for specific ss

$\begin{array}{ll}\text { IP }(\mathrm{CV}) & \text { IP for specific CV ss } \\ \text { GOR } & \text { Gas:oil ratio } \\ \text { Por } & \text { Porosity (decimal) } \\ \text { Perm } & \text { Permeability }(\mathrm{mD}) \text { [nonstressed] } \\ \text { BHT } & \text { Bottom hole temp }\left({ }^{\circ} \mathrm{F}\right) \\ \text { BHP } & \text { Bottom hole pressure }(\mathrm{psi}) \\ \text { FPG } & \text { Fluid-pressure gradient }(\mathrm{psi} / \mathrm{ft}) \\ \text { Sw } & \text { Water saturation }(\text { decimal) } \\ \text { GWC } & \text { Information about gas-water contact } \\ \text { Drive } & \text { Drive mechanism } \\ & \text { SG, solution gas } \\ & \text { PD, pressure depletion } \\ & \text { GC, Gas-cap expansion } \\ & \text { WD, water drive } \\ \text { SGS ref report } & \text { Shreveport Geological Society Reference Report (vol: page) }\end{array}$


the blanket-sandstone trend, as shown in figure 12, initial production rates range from $500 \mathrm{MCFD}$ to 25,000 MCFD and average 5,000 MCFD.

Gas-water contacts have been reported from seven fields across the blanket-sandstone trend as shown in figure 13. In Hico-Knowles, South Drew, and Choudrant fields, separate gas-water contacts for individual blanket-sandstone reservoirs have been identified (table 2). No gas-water contacts were encountered in Cheniere field as of 1963 or in Tremont field as of 1980 (table 2). In all other Cotton Valley fields described in Reference Reports by the Shreveport Geological Society (1946, 1947, 1951, 1953, 1956, 1963, 1987), no mention of fluid contacts was made.

\section{Massive-Sandstone Trend}

Cotton Valley sandstones in the massive-sandstone trend (fig. 8 and table 1) have significantly poorer reservoir properties than those in the blanket-sandstone trend. Massive Cotton Valley sandstones have sufficiently low permeability that they generally do not flow gas or liquids during open-hole DST's, and they require fracture-stimulation treatment to obtain commercial rates of gas production (Collins, 1980). Commercial gas production from these sandstones was not achieved until technological advances in hydraulic fracturing occurred together with higher gas prices from deregulation in the 1970's. Consequently, development of Cotton Valley fields in the tight, Cotton Valley massive-sandstone trend did not occur until the late 1970's and 1980's. Cotton Valley development drilling in Elm Grove and Caspiana fields in northern Louisiana continues at the time this report is being written (Al Taylor, Nomad Geosciences, oral commun., April 2000). A consequence of such recent development of fields in the tight, Cotton Valley massive-sandstone trend is less published information on characteristics of these fields than on older fields in the blanket-sandstone trend.

\section{Limited Data in Published Literature}

Summary information presented by Dutton and others (1993) for the tight, Cotton Valley massive-sandstone trend across northeastern Texas and northern Louisiana indicates porosities in the 6- to 10-percent range. Based on measurements from cores in 11 wells in Carthage field, one of the largest Cotton Valley fields in northeastern Texas, Wilson and Hensel (1984) reported porosities ranging from 5.8 to 8.1 percent, with an average of 6.6 percent. Associated permeabilities range from 0.02 to $0.33 \mathrm{mD}$, with an average of $0.067 \mathrm{mD}$. From core data for 126 wells in Harrison and Rusk counties in northeastern Texas, Finley (1984) reported an average permeability of $0.042 \mathrm{mD}$ for Cotton Valley sandstones. In northern Louisiana, average permeability was reported as $0.015 \mathrm{mD}$ based on data from Cotton Valley cores in 302 wells. However, there are stratigraphic intervals within the tight, Cotton Valley massive-sandstone trend with significantly higher permeabilities. Locally, permeabilities approaching 100 $\mathrm{mD}$ have been reported (Wilson and Hensel, 1984).

Significantly lower porosity and permeability of tight, Cotton Valley massive sandstones relative to blanket sandstones is reflected in poorer production characteristics. The average flow rate prior to fracture-stimulation treatment is 50 MCFD (Dutton and others, 1993). Post-stimulation rates generally are in the 500 to 2,500 MCFD range, although rates as high as 10,000 MCFD and 11,700 MCFD have been reported from Bethany field (Jennings and Sprawls, 1977) and Carthage field (Meehan and Pennington, 1982), respectively.

There are few published data on presence of gas-water contacts or production of water without gas on the flanks of Cotton Valley fields in the tight, massive-sandstone trend. Summary data presented by Nangle and others (1982) described gas-water contacts as poorly defined with long transition zones in contrast to short, well-defined transition zones with sharp gas-water contacts in the blanket-sandstone trend. Dutton and others (1993) also suggested the presence of gaswater contacts with long transition zones by indicating that calculated water saturations should be less than 40 percent to achieve successful gas completions from Cotton Valley sandstone intervals $200 \mathrm{ft}$ above the free-water level.

In northeastern Texas, where most of the drilling for tight Cotton Valley sandstones has occurred, the best reservoir potential is reported to be in wave-dominated deltaic sandstones of the Taylor sandstone in the lower part of the Cotton Valley interval (Wescott, 1983, 1985). In Oak Hill field, production logs show that Taylor sandstones contribute more than 80 percent of the gas production and that sandstones in the middle and upper Cotton Valley section contribute most of the water production, although they produce significant gas as well (Tindall and others, 1981). Presley and Reed (1984) and Dutton and others (1993) both report the presence of water-bearing sandstones in the upper Cotton Valley interval. To avoid production of water from these sandstones, fracturestimulation treatments in stratigraphically adjacent gas-bearing sandstones in the upper Cotton Valley must be significantly smaller than those in the Taylor sandstone. At Bethany field, several wells reportedly were plugged because of production of salt water from Cotton Valley sandstones (Jennings and Sprawls, 1997).

\section{Analysis of Drill-Stem-Test and Production-Test Data}

As mentioned above, general statements in published reports suggest the presence of gas-water contacts in fields that produce gas from tight Cotton Valley sandstones across northeastern Texas and northern Louisiana. Unlike data for the Cotton Valley blanket-sandstone trend, however, no documentation was found identifying specific gas-water contacts in Cotton Valley sandstones in any of the tight-gas-sandstone fields in Texas or Louisiana. In the absence of such published data, and 


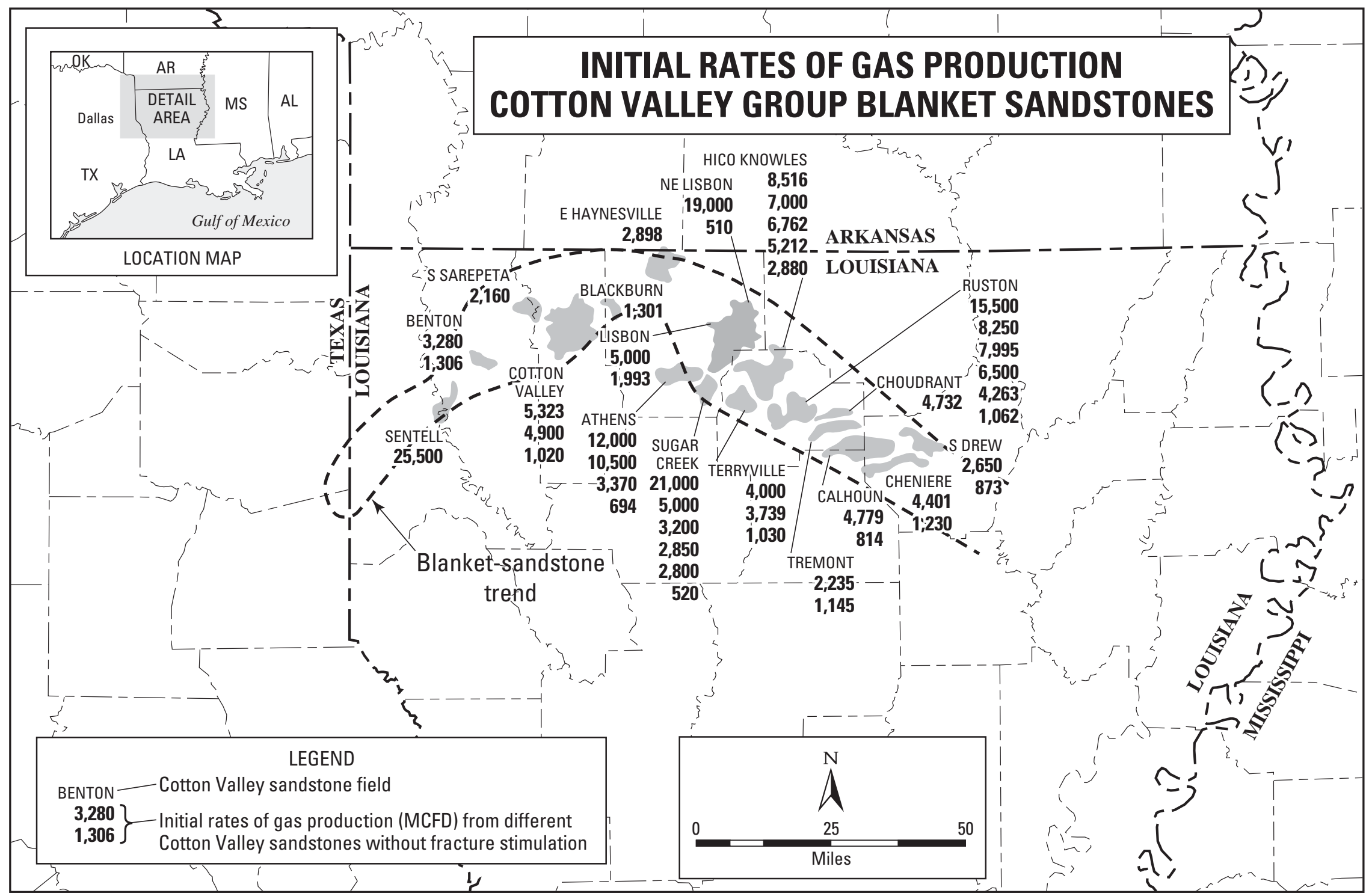

Figure 12. Map of northeastern Texas and northwestern Louisiana showing initial rates of gas production from Cotton Valley Group blanket sandstones. Multiple values of initial flow rates for a given field represent rates from different stacked blanket-sandstone reservoirs that produce in that field. All rates are from blanket sandstones, which do not require fracture-stimulation treatment for commercial production. 


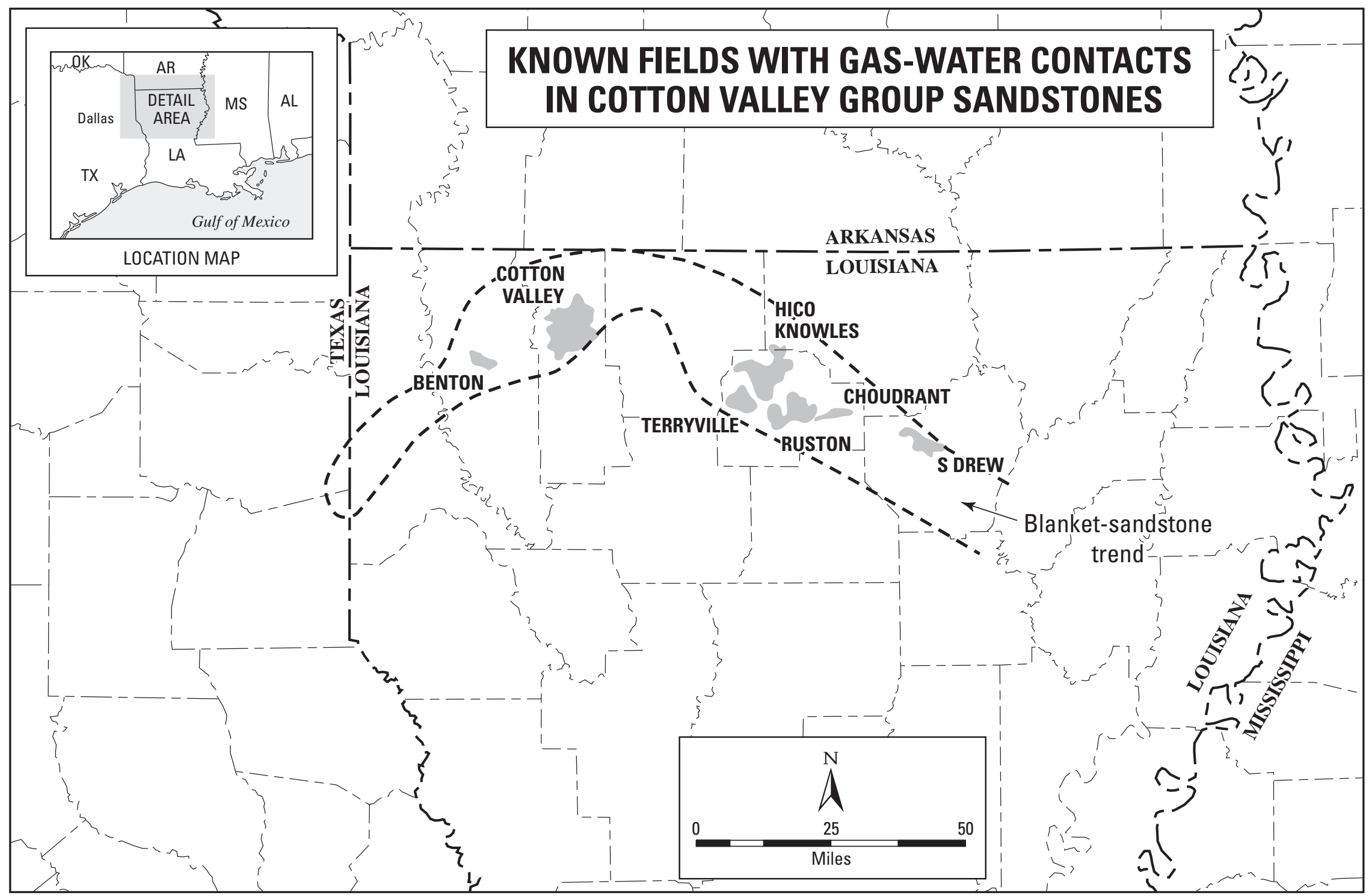

Figure 13. Map of northeastern Texas and northwestern Louisiana showing fields productive from Cotton Valley Group sandstones in which gas-water contacts have been identified and reported in published literature. Presence of gas-water contacts in these fields suggests that they are conventional gas accumulations. Details on gas-water contacts, including sources of information, are shown in table 2. 
considering the difficulties of using wireline logs to evaluate water saturations in tight Cotton Valley sandstones, an attempt was made to document the presence or absence of gas-water contacts through analysis of data from DST's and production tests. The goal was to determine if Cotton Valley fields that produce from tight-gas sandstones are flanked by dry holes that tested water without gas, suggesting presence of a gas-water contact. A data set of wells penetrating the Cotton Valley Group across most of northeastern Texas and northern Louisiana was extracted from a database (PI/Dwights Plus, a trademark of Petroleum Information/Dwights, d.b.a. IHS Energy Group) for analysis of DST and production-test data using ArcView software. Because tight Cotton Valley sandstones generally do not flow fluids on open-hole DST's, it was anticipated that the most useful data would be derived from production tests made through perforations in casing following fracture-stimulation treatments. Well data were sorted and displayed in map view using ArcView software such that wells that produce from Cotton Valley sandstones could be distinguished from dry holes with tests. While viewing the map display, test results from any particular well could be examined.

Reconnaissance analysis of data from Carthage, Bethany, Oak Hill, Waskom, and Woodlawn fields in northeastern Texas and from Bear Creek-Bryceland, Elm Grove, and Caspiana fields in northern Louisiana revealed few dry holes penetrating Cotton Valley strata on the flanks of these Cotton Valley fields. No flanking dry holes were found that tested only water. The few Cotton Valley dry holes present generally did not report tests, suggesting that no tests were performed in those wells and that, most likely, the wells were plugged based on evaluation of wireline logs.

Test results from Cotton Valley sandstones in Oak Hill field in Texas and Elm Grove-Caspiana fields in Louisiana were evaluated more rigorously, revealing several general patterns. Initial rates of gas production generally are higher in crestal wells than in flank wells in these fields, as shown for Caspiana field in figure 14. At both Oak Hill and Elm Grove-Caspiana fields, initial rates of gas production from Cotton Valley sandstones range from 1,000 to more than 4,000 MCFD in central parts of the fields and generally are less than 1,000 MCFD in structurally lower wells on edges of the fields. Many flank wells exhibit initial rates of less than 500 MCFD, as shown in figure 14. This trend exhibits more variability at Oak Hill field, where a larger number of low-rate wells occur in the center of the field. Such low-rate wells in the central part of the field could be attributed to a number of factors, including reservoir variability, formation damage during drilling, and poor fracture-stimulation treatments. All these wells must be fracture stimulated, and significant variation in success of such stimulation treatments is not uncommon. Also, initial rates on the western flank of Oak Hill field are high and show an abrupt change to dry holes rather than a gradual decline toward the flank of the field. One well there flowed gas with an initial rate exceeding 4,000 MCFD and is flanked to the west by four Cotton Valley dry holes. In three of these dry holes, Cotton Valley sandstones apparently were not tested, and a test in the fourth well must have resulted in noncommercial production with only "one unit of gas" reported.

Initial rates of water production in BWPD (barrels of water per day) also were mapped at Oak Hill and Elm GroveCaspiana fields and show no obvious patterns across these fields. No attempt was made to contour water production data for several reasons. Not only is variability in initial rate of water production high and seemingly random, but also, data are incomplete. Whereas the IHS Energy database reports initial rate of gas production for most all wells in these fields, initial rate of water production is not reported for a significant percentage of wells. In wells at Oak Hill or Elm GroveCaspiana fields, for which a value is entered in the appropriate position of the database for water production, a null value is never reported. Some volume of water production seems to occur along with gas in all these wells. Hence, it does not seem appropriate to interpret absence of water-production data for a given well as meaning zero production of water. Absence of data on initial water production is more prevalent for Oak Hill field, and that factor alone makes it difficult to analyze water production from that field. Data on initial water production at Elm Grove-Caspiana fields are more complete. Although initial rates of water production were considerably higher at Caspiana field, data were more complete for that field, and patterns of initial water production at Caspiana field were evaluated by plotting barrels of water produced per MMCFG (bbl water/MMCFG). As shown in figure 15, wells in the central part of Caspiana field commonly exhibit production of 100 or fewer bbl water/MMCFG. Progressing outward toward flanks of the field, rates of initial water production increase to 300 bbl water/MMCFG and eventually to more than $600 \mathrm{bbl}$ water/ MMCFG. The highest initial rate of water production occurs in a well on the western flank of the field where production of $1,477 \mathrm{bbl}$ water/MMCFG is reported (fig. 15). That same well had an initial rate of gas production of only 325 MMCFD, as shown in figure 14. Nevertheless, no wells that tested water only without gas from Cotton Valley sandstones were identified on the flanks of Caspiana field to suggest the presence of a gas-water contact for the field. Twenty-one Cotton Valley dry holes were identified surrounding Elm Grove-Caspiana fields. Of these, 19 wells reported no tests in the Cotton Valley sandstone interval, presumably indicating that no Cotton Valley tests were run and that Cotton Valley completions were made on the basis of wireline-log evaluation. Production tests after fracture-stimulation were run in two other wells. One reported "one unit of gas and one unit of oil," presumably indicating noncommercial rates. The other well reported only "one unit of water," suggesting that the Cotton Valley sandstone might be below a gas-water contact at that location. On the southern and western flanks of Oak Hill field, six Cotton Valley dry holes without tests were identified, again suggesting abandonment of Cotton Valley potential based on wireline-log evaluation. Production tests were run in Cotton Valley sandstones in two wells on the western flank of Oak Hill field. One reported "one unit of gas," the other "one unit of gas and one unit of water." 


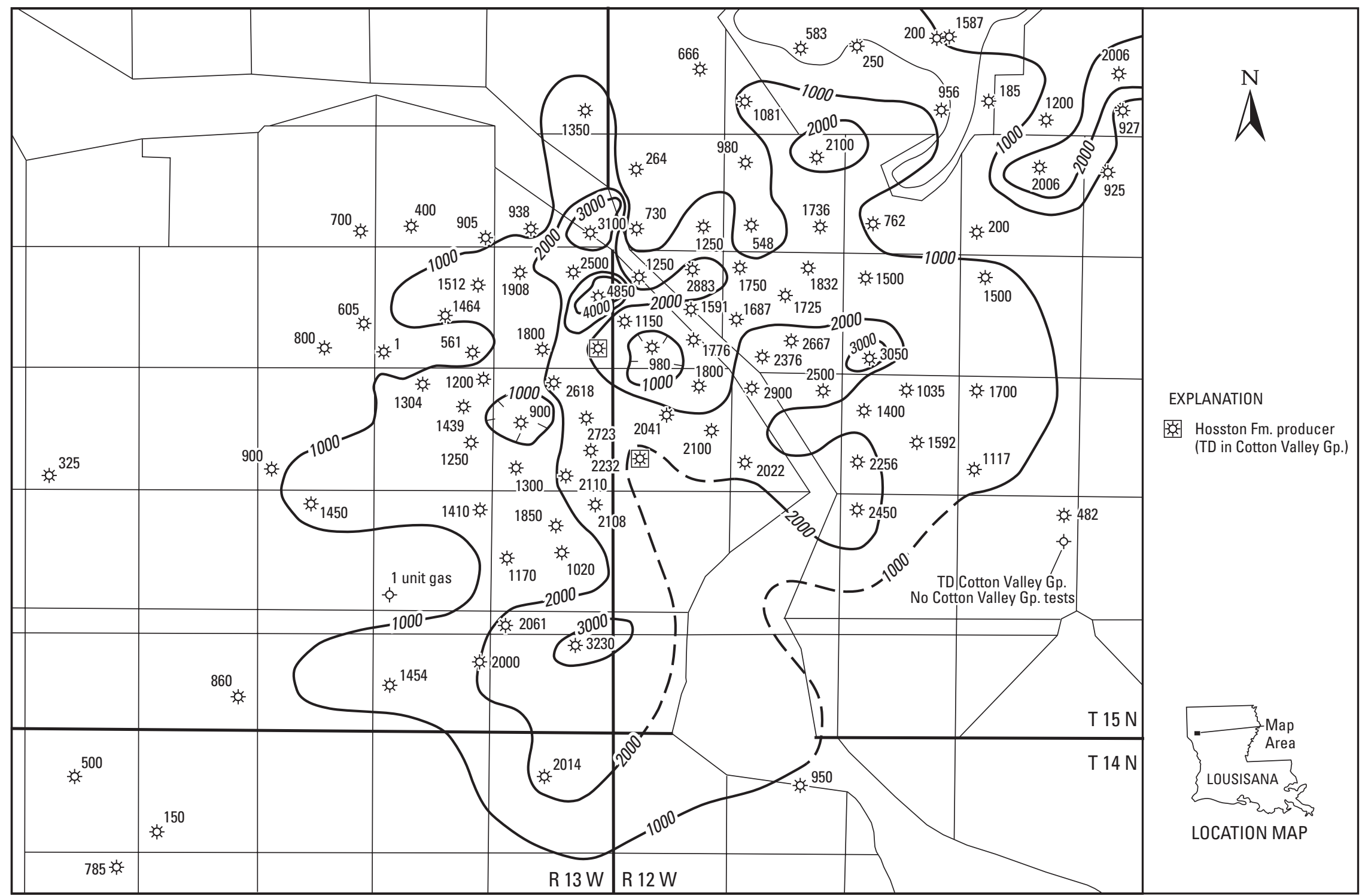

Figure 14. Map of Caspiana field in northwestern Louisiana in the tight, Cotton Valley Group massive-sandstone trend showing initial rate of gas production (MCFD) from Cotton Valley sandstone reservoirs. Data from PI/Dwights Plus, a trademark of Petroleum Information/Dwights, d.b.a. IHS Energy Group. Contour interval is 1,000 MCFD. Map shows general decrease in initial rates of gas production from center to flanks of field. 


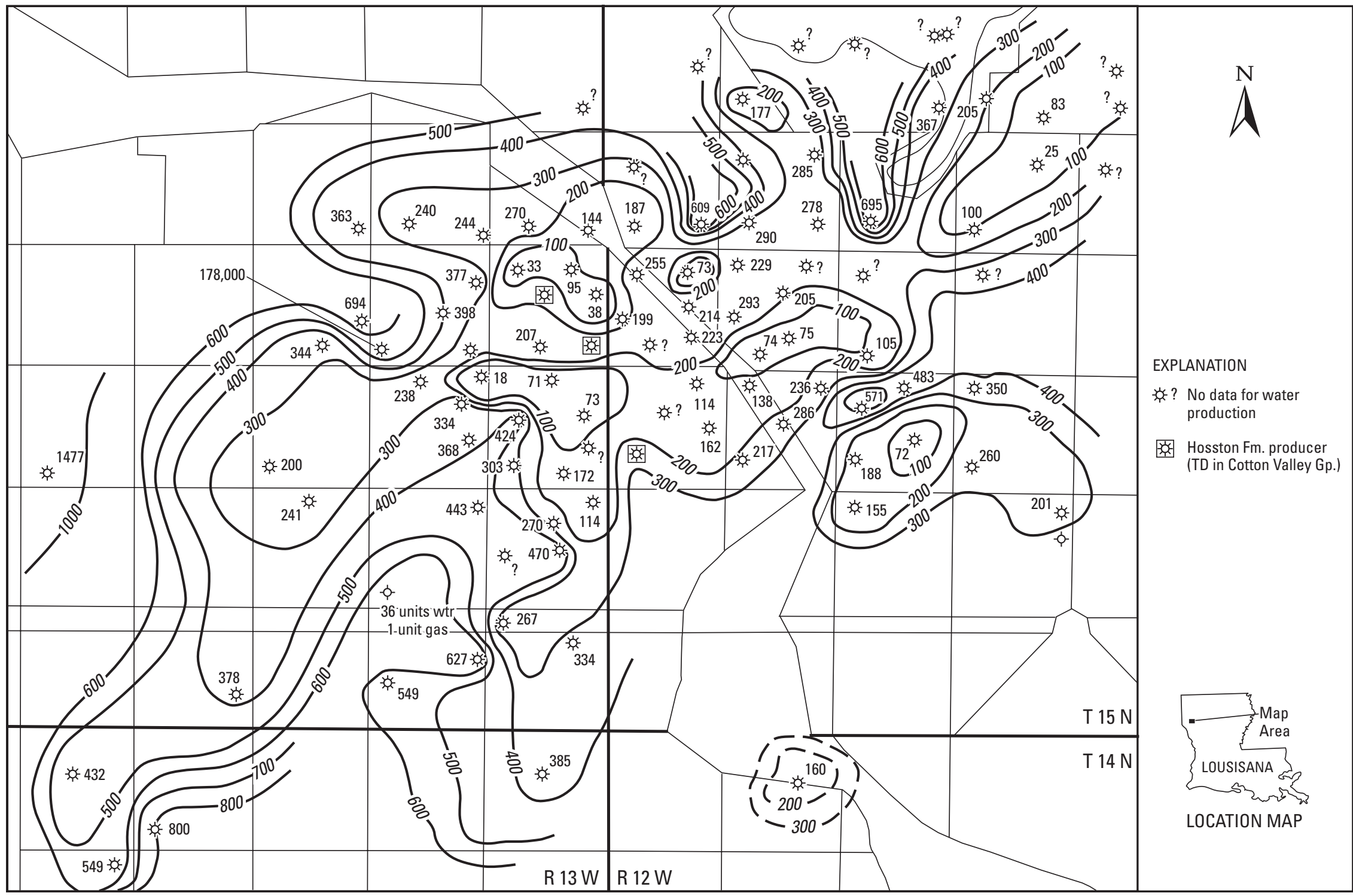

Figure 15. Map of Caspiana field in northwestern Louisiana in the tight, Cotton Valley Group massive-sandstone trend showing ratio of initial production rate of water (BWPD) to initial production rate of gas (MMCFGD) from Cotton Valley Group sandstones. Data from PI/Dwights Plus, a trademark of Petroleum Information/Dwights, d.b.a. IHS Energy Group. Contour interval is $100 \mathrm{BWPD/MMCFGD.} \mathrm{Mapped} \mathrm{data} \mathrm{show} \mathrm{progressive} \mathrm{increase} \mathrm{in} \mathrm{ratio} \mathrm{of} \mathrm{initial} \mathrm{production} \mathrm{rates} \mathrm{of} \mathrm{water} \mathrm{to} \mathrm{gas} \mathrm{from} \mathrm{crest} \mathrm{to} \mathrm{flanks} \mathrm{of} \mathrm{field.} \mathrm{This} \mathrm{suggests} \mathrm{that,} \mathrm{within} \mathrm{reservoir}$ sandstones, gas saturation is decreasing and water saturation is increasing from crest to flanks of field and indicates presence of vertically extensive gas-water transition zone. 
On the southern flank of the field, production tests were run in Cotton Valley sandstones in two Cotton Valley dry holes, but no results were reported. Evaluation of test data from Oak Hill and Elm Grove-Caspiana fields, therefore, provides no definitive information regarding presence or absence of gaswater contacts in these Cotton Valley fields.

\section{Discussion of Evidence For and Against Basin-Centered Gas}

\section{Source Rocks and Burial and Thermal History}

Source rocks responsible for generating gas in basincentered gas accumulations commonly are in stratigraphic proximity to low-permeability reservoirs that they are charging with gas. As described above, there are few published data on source rocks responsible for generating gas found in Cotton Valley sandstone reservoirs in both the blanket- and massivesandstone trends. However, the marine Bossier Shale, stratigraphically directly beneath Cotton Valley sandstones, and Smackover laminated lime mudstones, lying below the Bossier Shale, are considered to be source rocks capable of generating gas for Cotton Valley sandstone reservoirs. Gray to black marine shales interbedded with Cotton Valley sandstones also are considered to be potential source rocks. Also, as summarized above, burial- and thermal-history data for the northern Gulf Coast Basin suggest that burial depths of Bossier and Smackover source rocks, in conjunction with the regional geothermal gradient, have been sufficient to generate dry gas. Time of generation of much of the gas postdates development of both the Sabine uplift and structures in the East Texas and Louisiana Salt Basins. Hence, available data on presence of source rocks, burial and thermal history of source rocks, and timing of gas generation for Cotton Valley reservoirs would be consistent with interpretation of a potential continuous gas accumulation in massive sandstones of the Cotton Valley Group.

\section{Porosity, Permeability, and Gas-Production Rates}

Basin-centered gas accumulations commonly involve large volumes of gas-saturated rock in which gas cuts across stratigraphic units. Such gas accumulations require a regional seal to trap gas, and that seal characteristically is provided by inherent low permeability of reservoir rocks themselves. Thus, continuous gas reservoirs characteristically have low permeability, and when reservoirs are sandstones, they commonly are referred to as tight-gas sandstones.

As described above, Cotton Valley sandstone reservoirs across the northern Gulf of Mexico Basin can be divided into two groups based on reservoir properties and associated rates of gas production. Sandstones in the Cotton Valley blanketsandstone trend across northernmost Louisiana have porosities in the 10 to 19 percent range and permeabilities from 1 to 280 $\mathrm{mD}$ (table 1). These sandstones generally flow gas and (or) liquids during open-hole DST's. Gas-productive sandstones flow at initial rates ranging from 500 to 25,000 MCFD without fracture-stimulation treatment. Consequently, these sandstones are not tight-gas reservoirs, and many fields producing from Cotton Valley sandstones in the blanket-sandstone trend were excluded from tight-gas status by FERC in 1980 (fig. 8). Therefore, in the absence of some other regional top seal that could allow development of basin-wide overpressure, sandstones in this trend would not be expected to host a basincentered gas accumulation.

South of the blanket-sandstone trend in northern Louisiana lies the Cotton Valley massive-sandstone trend that extends westward across the Sabine uplift into northeastern Texas, as shown in figure 8. Cotton Valley massive sandstones generally have porosities in the 6 to 10 percent range with permeabilities commonly less than $0.1 \mathrm{mD}$. Most of these sandstones, therefore, would be defined as tight-gas sandstones, and most fields producing gas from these sandstones were designated as tightgas-sandstone fields by FERC in 1980. Tight, Cotton Valley massive sandstones generally do not flow gas and (or) liquids on open-hole DST's, and they require hydraulic-fracture treatment to produce gas at commercial rates. As shown in table 1 , prestimulation initial-production rates generally range from too small to measure (TSTM) to 300 MCFD. Post-stimulation rates commonly are 500 to 2,500 MCFD. Although higher permeability intervals occur locally within the massive-sandstone trend, as noted by Wilson and Hensel (1984), the characteristic low permeability of sandstones throughout this trend suggests that they might have potential to provide their own seal for gas in a continuous gas accumulation.

\section{Abnormal Pressures}

In a study of abnormally high pressures in basin-centered gas accumulations in Rocky Mountain basins, Spencer (1987) considered reservoirs to be significantly overpressured if FPG's exceed $0.50 \mathrm{psi} / \mathrm{ft}$ where waters are fresh to moderately saline, and $0.55 \mathrm{psi} / \mathrm{ft}$ where waters are very saline. With formation-water salinity of Cotton Valley sandstone reservoirs on the order of 170,000 ppm TDS (Dutton and others, 1993), salinity is considered high, and reservoirs should be considered to be overpressured if their FPG's exceed $0.55 \mathrm{psi} / \mathrm{ft}$.

Based on Spencer's (1987) cutoff value of $0.55 \mathrm{psi} / \mathrm{ft}$, abnormally high reservoir pressures have been encountered in Cotton Valley sandstones in an area of northeastern Louisiana, shown in figure 10, where calculated pressure gradients of 0.63 to $0.86 \mathrm{psi} / \mathrm{ft}$ occur. The boundary between areas of overpressure and normal pressure cuts across the permeable, blanketand tight, massive-sandstone trends such that overpressures occur within both reservoir trends. (figs. 8 and 10). Although overpressures associated with generation of gas might be antic- 
ipated in tight Cotton Valley sandstones, such overpressures would not be expected to develop in high-permeability blanket sandstones without a subregional top seal stratigraphically above the sandstones. As shown in figure 9 and table 2, some of the separate, stacked blanket sandstones within Hico, Tremont, and Calhoun fields are overpressured, whereas others are normally pressured. Examination of discovery dates of gas in individual sandstones shows that, in all cases for these three fields, normally pressured sandstone reservoirs were discovered prior to overpressured ones. Thus, pressure differences among individual blanket-sandstone reservoirs indicate presence of separate, compartmentalized reservoirs rather than pressure depletion from production of gas from different sandstones that are in pressure communication. Additionally, normally pressured Cotton Valley sandstones were encountered at South Drew field, whereas, at Cheniere field immediately to the west, Cotton Valley sandstones were significantly overpressured with an FPG of $0.86 \mathrm{psi} / \mathrm{ft}$. Thus, for gas fields in the blanket-sandstone trend where data are abundant, reservoir pressures exhibit significant variation from normal to abnormally high among separate sandstone reservoirs within individual gas fields and also between adjacent fields. Such compartmentalization of overpressured reservoirs in proximity to normally pressured ones, rather than development of overpressure on a regional scale, is more indicative of conventional gas fields than basin-centered gas accumulations.

Within the western half of the blanket-sandstone trend and spanning the vast majority of the tight, massive-sandstone trend across northwestern Louisiana and northeastern Texas, FPG's range from 0.32 to $0.55 \mathrm{psi} / \mathrm{ft}$ and, therefore, would be considered normal, according to the methodology of Spencer (1987). However, two episodes of erosion have occurred in northeastern Texas, one in late mid-Cretaceous time and the second in early mid-Tertiary time (Dutton, 1987; Laubach and Jackson, 1990; Jackson and Laubach, 1991). During late midCretaceous time, maximum erosion occurred on the crest of the Sabine uplift where approximately $1,800 \mathrm{ft}$ of sedimentary section were removed. Tertiary erosion resulted in removal of about 1,500 ft of section across much of northeastern Texas. Burial-history data for the Ruston field area in northern Louisiana on the boundary between overpressured and normally pressured regions, show about 1,500 and $500 \mathrm{ft}$ of uplift and loss of section, respectively, in two erosional periods (Herrmann and others, 1991). It is possible, therefore, that, with deeper burial, reservoir pressures in much or all of the massive-sandstone trend could have been higher and that pressure reduction has occurred as a result of uplift and erosion. However, some of the gas found in Cotton Valley sandstone reservoirs could have been derived from Bossier Shale source rocks. Migration of most of that gas into Cotton Valley sandstones probably commenced between 57 and $45 \mathrm{Ma}$ (Dutton, 1987; Hermann and others, 1991). Therefore, if basin-wide overpressure in Cotton Valley sandstones were to have developed in response to thermal generation of gas from Bossier Shale source rocks, its development would have postdated both the Cretaceous and Tertiary erosional events.
The sharp boundary between overpressured and normally pressured areas of Cotton Valley sandstones (fig. 10) and presence of overpressure in both permeable, blanket-sandstone and tight, massive-sandstone trends, suggest that abnormally high pressures encountered in Cotton Valley sandstones in northeastern Louisiana are not caused by thermal generation and migration of gas. Coleman and Coleman (1981) attributed development of overpressures in Cotton Valley sandstones across the region shown in figure 10 to a late stage of diagenesis in which extreme pressure, presumably overburden pressure, and temperature caused dissolution of silica at contact points of quartz-sand grains and precipitation of silica in adjacent pores. With pore waters apparently unable to escape, porosity reduction associated with this late-stage chemical compaction reportedly resulted in development of overpressure in Cotton Valley sandstones across the area shown in figure 10. According to Coleman and Coleman (1981), a significant factor in preventing fluid loss from Cotton Valley sandstones during this late diagenetic episode was presence of a tight top seal provided by the Knowles Limestone and upper Cotton Valley-lower Hosston shales.

If late-stage chemical compaction and cementation in conjunction with a top seal of tight limestone and shale are responsible for development of overpressure, it is not clear why the geographic distribution of overpressure exhibits the pattern shown in figure 10. Perhaps an alternative mechanism for generating the distribution of overpressures within Cotton Valley sandstones shown in figure 10 could be one reported by Parker (1972) as the cause for overpressures in Jurassic Smackover sandstone and carbonate reservoirs to the east in Mississippi. Parker (1972) noted that much of the Smackover gas is sour and has a relatively high content of $\mathrm{CO}_{2}$ and (or) $\mathrm{N}_{2}$. He suggested that migration of gases derived from Late Cretaceous emplacement of the Jackson (igneous) dome (fig. 2) might be responsible for "inflation" of pressures in well-sealed Smackover reservoirs. Specifically, Jones (1977) suggested that $\mathrm{H}_{2} \mathrm{~S}$ and $\mathrm{CO}_{2}$ present in Smackover gas in Mississippi were derived from Smackover anhydrite and limestone/dolomite, respectively, which had been subjected to magmatic intrusion. The mapped pattern of overpressured Cotton Valley sandstones (fig. 10) extends east-southeastward into Mississippi directly toward the location of Jackson dome (fig. 2) (Studlick and others, 1990). Evidence supporting such a mechanism of overpressure development in Cotton Valley sandstones of northeastern Louisiana would be documentation of elevated levels of $\mathrm{CO}_{2}$ and (or) $\mathrm{N}_{2}$ in overpressured Cotton Valley sandstone reservoirs.

In summary, within most of the tight, Cotton Valley massive-sandstone trend across northwestern Louisiana and northeastern Texas, Cotton Valley reservoirs are slightly, but not significantly, overpressured. Based on the methodology and terminology of Spencer (1987), these reservoirs would be characterized as normally pressured. Basin-centered, continuous gas accumulations commonly are significantly overpressured. Although pressure data for the tight, Cotton Valley massivesandstone trend are not definitive, they tend to suggest that a 


\section{Geologic Studies of Basin-Centered Gas Systems}

basin-centered gas accumulation characterized by abnormally high pressures from geologically recent to present-day thermal generation of gas does not occur within Cotton Valley sandstone reservoirs.

\section{Gas-Water Contacts}

Perhaps the most definitive criterion for establishing the presence of a continuous gas accumulation is absence of gaswater contacts. Gas-water contacts are distinctive features of conventional gas accumulations. Presence of a gas-water contact indicates a change from gas-saturated to water-saturated porosity within a particular reservoir unit. This implies that a well drilled into that reservoir structurally below the gas-water contact should encounter only water, thereby demonstrating the absence of a continuous gas accumulation in that immediate area.

Within the blanket-sandstone trend across northernmost Louisiana, gas-water contacts have been reported in seven fields, as shown in figure 13. Because of relatively high porosity and permeability in blanket sandstones, gas-water contacts are sharp and often are reported as depth below sea level to the nearest foot. Separate gas-water contacts for individual, stacked blanket sandstones have been identified in Hico-Knowles, South Drew, and Choudrant fields (table 2 ). The seven fields in which gas-water contacts have been described are distributed across the blanket-sandstone trend (figure 13). Because of the relatively uniform distribution of high-permeability Cotton Valley sandstone reservoirs with conventional shale seals in fields across the blanket-sandstone trend, it is likely that all Cotton Valley fields in this trend have well-defined gas-water contacts similar to those documented in the seven fields shown in figure 13. The Cotton Valley blanketsandstone trend was defined as a continuous gas accumulation in the 1995 National Assessment of United States Oil and Gas Resources by the USGS (Schenk and Viger, 1996). However, the presence of abundant gas-water contacts across this area suggests that the blanket-sandstone trend should be redefined as a conventional gas play.

Evaluating the presence or absence of gas-water contacts in the tight, Cotton Valley massive-sandstone trend is more difficult. No reference to specific gas-water contacts for Cotton Valley massive sandstones in any Cotton Valley gas field has been found in the published literature. Nangle and others (1982) and Dutton and others (1993), however, make general statements indicating that gas-water contacts are present in Cotton Valley fields across the tight, Cotton Valley massivesandstone trend.

Although Taylor sandstones in the lower part of the Cotton Valley section produce gas in all significant Cotton Valley fields in the tight, massive-sandstone trend, waterbearing sandstones have been reported along with gas-charged sandstones in the middle and upper Cotton Valley interval in some fields. The seal for gas in wave-dominated deltaic Taylor sandstones at Waskom field reportedly is provided by marsh and lagoonal shales (CER Corporation and S.A. Holditch \& Associates, 1991). This seal would be considered conventional rather than one provided by the low permeability of the reservoir sandstones. Along with Taylor sandstones, most of the upper Cotton Valley sandstone interval produces gas at some fields, such as Carthage field, according to Al Brake (BP, oral commun., 2000). At other fields, such as Woodlawn and Blocker, however, gas is produced only from lower Cotton Valley Taylor sandstones and from a few sandstones in the uppermost Cotton Valley section. Intervening middle and upper Cotton Valley sandstones are reportedly water-bearing. The presence of individual gas-bearing and water-bearing sandstone intervals, separated by conventional shale seals, suggests the presence of gas-water contacts and is more indicative of conventional gas accumulations than of continuous gas accumulations.

The complex diagenetic mineralogy of tight Cotton Valley sandstones probably precludes use of wireline logs to identify gas-water contacts. As reported above, complex diagenetic mineralogy of tight Cotton Valley sandstones dramatically affects values of resistivity and porosity measured by wireline $\operatorname{logs}$ and, hence, the determination of water saturation by standard calculation techniques. Because of vertical and lateral diagenetic variations, accurate determination of water saturation is difficult without accompanying lithologic data from cores or cuttings to calibrate wireline logs. Examination of production-test data from wells flanking many Cotton Valley gas fields in the tight-gas-sandstone trend reveals no dry holes that tested water without gas. Therefore, even if wireline logs provided accurate estimates of water saturations in tight Cotton Valley sandstones, few wells apparently exist in which logs could be used to identify gas-water contacts.

Reconnaissance evaluation of DST and production-test data from Cotton Valley sandstones in a number of fields in the tight-gas-sandstone trend revealed few dry holes penetrating Cotton Valley sandstones on flanks of those fields. No dry holes were found that tested water without gas, thereby implying existence of a gas-water contact for a particular field. Likewise, detailed examination of test data from all wells within and flanking Oak Hill and Elm Grove-Caspiana fields in the tight-gas-sandstone trend revealed no flank dry holes that tested water without gas.

Initial rates of gas production from wells on the flanks of Cotton Valley fields in the tight-gas, massive-sandstone trend, however, generally are lower than from crestal wells, as illustrated for Caspiana field in figure 14. Also, as shown for Caspiana field in figure 15, the ratio of initial rate of water production to initial rate of gas production in terms of bbl water/ MMCFG is significantly higher in flank wells. Initial rates of gas production from crestal wells commonly range from 1,000 to more than 4,000 MCFD and the ratio of initial rate of water to gas generally is less than $200 \mathrm{bbl}$ water/MMCFG and often below $100 \mathrm{bbl}$ water/MMCFG (figs. 14 and 15). Initial rates of gas production from flank wells generally are less than 1,000 MCFD, and water production initially is significantly higher, usually in the 300 to $600 \mathrm{bbl}$ water/MMCFG range, 


\section{SCHEMATIC DIAGRAM OF TRANSITION ZONES IN HIGH-AND LOW-PERMEABILITY SANSTONE RESERVOIRS}

\section{CROSS SECTION OF STRUCTURE}

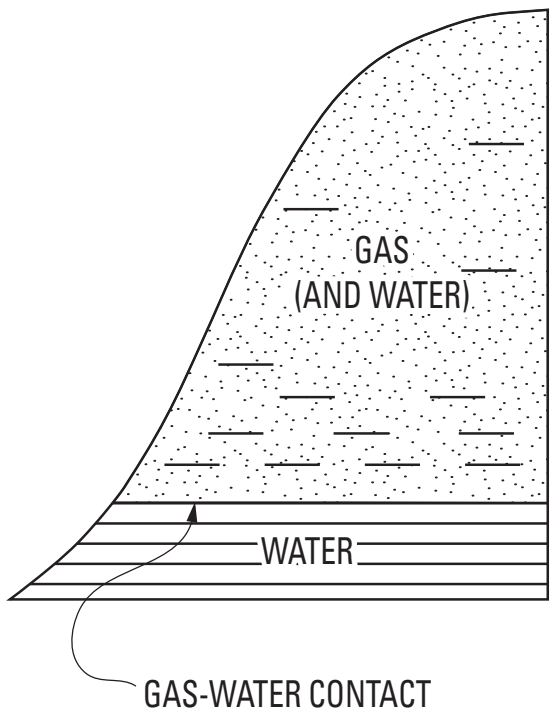

FLUID SATURATION

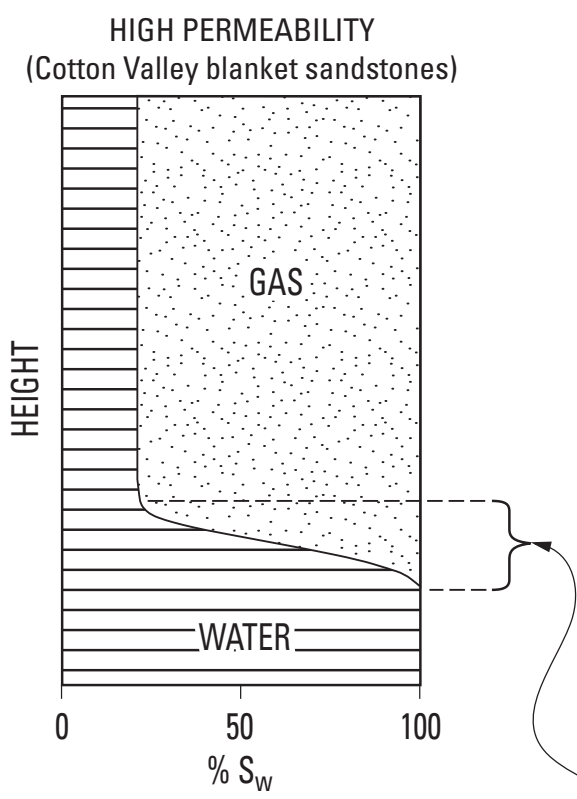

LOW PERMEABILITY
(Cotton Valley massive sandstones)

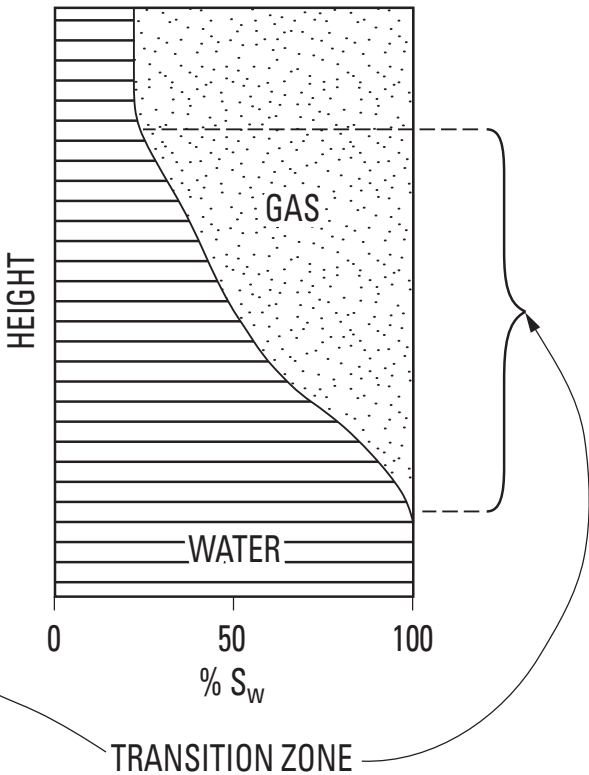

Figure 16. Schematic diagram of gas-water transition zones in high- and low-permeability reservoirs. Modified from Levorsen (1967).

but sometimes exceeding 1,000 bbl water/MMCFG (figs. 14 and 15). These data suggest a decrease in gas saturation and an accompanying increase in water saturation in Cotton Valley sandstones from crestal wells to flank wells and that a commercial limit to gas production has been reached, although gas-water contacts have not been encountered.

Corroborating these suggestions from figures 14 and 15 and data reported by Nangle and others (1982) is the experience of Al Taylor (Nomad Geosciences, oral commun., 2000) who reports the presence of vertically extensive gas-water transition zones in Cotton Valley sandstone fields in the massive-sandstone trend. In moving structurally lower from the crest of one of these tight-gas Cotton Valley fields through the long gas-water transition zone toward the presumed gas-water contact, gas saturation of sandstone reservoirs continually decreases while water saturation simultaneously increases (fig. 16). Wells that are low in the transition zone on the edges of Cotton Valley fields in the tight-gas-sandstone trend exhibit low initial rates of gas production and high initial rates of water production, as shown by some flank wells at Caspiana field in figures 14 and 15. Hyperbolic decline rates of gas production in conjunction with lower gas saturations of reservoir sandstones in these transition-zone wells result in such low cumulative production of gas that these wells are marginally commercial to noncommercial and, in effect, are dry holes (Al Taylor, Nomad Geosciences, oral commun., 2000).
Hence, commercial limits of gas production are reached before gas-water contacts can be encountered by development drilling. This probably could be documented by mapping cumulative gas production or estimated ultimate gas recovery from wells in these Cotton Valley fields.

Knowing gas saturations of Cotton Valley reservoir sandstones from log calculations and capillary properties of those sandstones from core analyses at Caspiana field in northwestern Louisiana, Al Taylor (Nomad Geosciences, oral commun., 2000) estimated gas-column heights required to produce those gas saturations. From column-height data, he determined the position of gas-water contacts below sea level. Estimates made in this fashion for the structural level of the gas-water contact at Caspiana field using data from a number of wells cluster within a zone about $75 \mathrm{ft}$ thick, suggesting the presence of a single gas-water contact for the field. A Cotton Valley well situated structurally below this estimated gas-water contact reportedly tested water without gas from Cotton Valley sandstones. Because of the vertically extensive gas-water transition zones present in fields producing gas from tight Cotton Valley sandstones in the massive-sandstone trend, Al Taylor (Nomad Geosciences, oral commun., 2000) suggests that structural or stratigraphic traps with less than $150 \mathrm{ft}$ of vertical closure will not have sufficient gas saturation to produce gas at commercial rates. 
In summary, Cotton Valley blanket sandstones across northernmost Louisiana have sufficiently high porosity and permeability that gas accumulations exhibit short transition zones and have sharp gas-water contacts. Gas fields in this trend have clearly defined productive limits, beyond which wells produce water only. However, low-permeability Cotton Valley sandstones in the tight-gas massive-sandstone trend across northern Louisiana, the Sabine uplift, and East Texas Basin display long gas-water transition zones with poorly defined gas-water contacts. Productive limits of fields in this trend are difficult to define based on data from production tests or wireline logs. In conjunction with long gas-water transition zones, structural dips are gentle on the flanks of these gas accumulations. As development drilling progresses down the flank of one of these fields through the long gas-water transition zone, gas saturations in the sandstone reservoir decrease and water saturations increase. Eventually gas saturations become sufficiently low that, in terms of ultimate cumulative gas production, wells become marginally commercial to noncommercial at a structural position still within the transition zone above the gas-water contact. Consequently, development wells on the flanks of these gas accumulations generally have not encountered gas-water contacts. If drilling and completion costs hypothetically were reduced to zero, causing even the smallest amount of gas recovery to be commercial, development drilling could progress down the full length of transition zones, and gas-water contacts probably would be encountered. The progressive increase in water saturation with depth within these tight-gas Cotton Valley fields, therefore, suggests that poorly defined gas-water contacts are present below the depth at which wells become noncommercial. The presence of gaswater contacts in both Cotton Valley blanket- and massivesandstone trends suggests that gas accumulations in these trends are conventional and that a basin-centered gas accumulation does not exist within Cotton Valley sandstones in the northern Gulf of Mexico Basin.

\section{Basin-Centered Gas Potential within Bossier Shale}

A basin-centered, continuous-gas accumulation might have been discovered recently in sandstones within the Bossier Shale, the lower formation of the Cotton Valley Group. In a currently developing play on the western flank of the East Texas Basin, gas is being produced from turbidite sandstones within the Bossier Shale. These turbidite sandstones probably are downdip time-equivalent deposits of deltaic sandstones in the lower portion of the Cotton Valley and reportedly were deposited seaward of the underlying Haynesville Formation carbonate platform edge in a slope or lowstand-fan setting. Accommodation space was provided by salt withdrawal such that updip and lateral traps currently are formed by pinch out of sandstone into shale. Two stacked, stratigraphically separate
Bossier turbidite-fan systems reportedly occur at depths of 13,000 to 14,000 ft. Two fields, Dew and Mimms Creek, with combined estimated recoverable reserves of more than one TCFG, currently are being developed by Anadarko Petroleum, one of the main operators. As of January 2000 (PI-Dwights Drilling Wire, Jan 3, 2000; Jan 12, 2000), Anadarko had drilled more than 100 wells with only one dry hole in this Bossier sandstone play. Gas-charged sandstones reportedly are overpressured, and no water has been encountered in the system (Exploration Business Journal, 2nd quarter, 2000). Within the upper turbidite-fan interval, porosity ranges from 6 to 15 percent and permeability from 0.01 to $1.0 \mathrm{mD}$. Initial production rates from wells average 3 to 4 MMCFGD after fracture stimulation and decline exponentially with estimated per-well recoveries of 1 to $5 \mathrm{BCFG}$. In the lower sandstone interval, porosity ranges from 9 to 20 percent, permeability from 1 to $10 \mathrm{mD}$, pressures are higher, and initial production rates of as much as $30 \mathrm{MMCFGD}$ have been obtained. This play does not seem to involve the classic type of basin-centered gas accumulation with the trap produced by inherent low permeability of reservoir sandstones. Instead, the trap seems to be provided by marine shales that completely encase these turbidite sandstones, but the sandstone reservoirs are overpressured, seem to lack water and gas-water contacts, and are gas-charged over an extensive area, as demonstrated by only one dry hole in more than 100 wells drilled.

\section{Conclusions}

1. The Cotton Valley Group represents the first major influx of clastic sediment into the Gulf of Mexico Basin. Major depocenters were located in south-central Mississippi, along the Louisiana-Mississippi border, and in northeastern Texas. Sands supplied by the ancestral Mississippi River drainage along the LouisianaMississippi border were swept westward by longshore currents, creating an east-west barrier-island or strandplain system across northern Louisiana that isolated a lagoon to the north. More than 1,000 ft of stacked barrier-island sands accumulated as the Terryville massive-sandstone complex. Periodic transgressive events reworked barrier-island sands, transporting them northward into the lagoon. These transgressive sandstones pinch out into lagoonal shales, can be correlated across northern Louisiana, and are referred to informally as blanket sandstones.

2. Two major Cotton Valley sandstone-reservoir trends are identified based on reservoir properties and associated characteristics of gas production. Transgressive, blanket sandstones across northernmost Louisiana have porosities ranging from 10 to 19 percent and permeabilities from 1 to $280 \mathrm{mD}$. These sandstones flow gas and (or) liquids during open-hole DST's and do not require fracture-stimulation treatment to produce gas at commercial rates. Fields producing from these 
sandstone reservoirs were developed during the 1940's through 1960's. Cotton Valley massive sandstones to the south, and extending westward across the Sabine uplift into eastern Texas, exhibit porosities from 6 to 10 percent and permeabilities generally less than $0.1 \mathrm{mD}$. Designated as tight-gas sandstones by FERC, these reservoirs commonly do not flow gas or liquids during DST's, and they require fracture-stimulation treatments to achieve commercial rates of production. Gas production from these sandstones in eastern Texas and northern Louisiana was not established until the mid 1970's when advances in hydraulic-fracture techniques occurred in conjunction with a significant increase in gas prices as a result of price deregulation.

3. Porosity and permeability of Cotton Valley sandstones are controlled by diagenetic properties, which in turn are governed by depositional environment. Although diagenetic patterns and mineralogy are complex, highenergy, clean sandstones generally are cemented by authigenic quartz and (or) calcite and have poor reservoir properties. In lower energy sandstones, clay coatings on quartz grains inhibited development of quartz overgrowths, resulting in preservation of primary porosity. High clay content, however, generally imparts poor permeability to these sandstones. The best reservoir sandstones are those which have experienced development of significant secondary porosity from dissolution of calcite cement and unstable framework grains.

4. The complex diagenetic mineralogy of tight Cotton Valley sandstones precludes use of standard calculation methods in reservoir evaluation with wireline logs. Bound water associated with pore-filling clays or clay coatings and conductive minerals such as pyrite result in abnormally low resistivity measurements leading to such high calculated water saturations that productive zones often appear wet. Also resulting in erroneous reservoir evaluations are pessimistic measurements of porosity with wireline logs caused by the presence of high-density carbonate minerals such as ankerite and siderite. Therefore, without lithologic data from cores or drill cuttings to calibrate wireline logs, such logs are of limited value in differentiating between gas-productive and wet intervals and therefore are of limited value in identifying gas-water contacts on the flanks of Cotton Valley fields.

5. Abnormally high reservoir pressures with fluidpressure gradients exceeding $0.55 \mathrm{psi} / \mathrm{ft}$ occur in Cotton Valley sandstones in northeastern Louisiana. The boundary between the overpressured area on the east and normally pressured region to the west cuts across the permeable, blanket- and tight, massive-sandstone trends such that overpressures occur within both reservoir trends. Within the blanket-sandstone trend, where pressure data are more abundant, some Cotton Valley fields are overpressured whereas adjacent fields are normally pressured. Also, within certain fields, some of the stacked blanket sandstones are overpressured whereas others are normally pressured. Such compartmentalization of overpressured reservoirs in proximity to normally pressured ones, rather than development of overpressure on a regional scale, suggests that these blanket-sandstone fields are conventional gas accumulations and not part of a basin-centered gas accumulation. Also, the occurrence of normally pressured reservoirs across the majority of the tight, Cotton Valley massive-sandstone trend is not indicative of presence of a basin-centered, continuous gas accumulation. Geographic distribution of overpressures in Cotton Valley sandstones suggests that overpressuring was caused by "inflation" of existing pressures in tightly sealed reservoirs by gases derived from emplacement of the nearby Jackson (igneous) dome.

6. Gas found in Cotton Valley sandstone reservoirs is believed to be derived from (1) interbedded Cotton Valley marine shales, (2) underlying marine shales of the Bossier Shale, and (or) (3) stratigraphically lower, Jurassic Smackover laminated, lime mudstones. These source rocks are believed to have been buried to sufficient depths relative to the regional geothermal gradient to have generated dry gas during the past 60 m.y. Timing of gas generation and migration is favorable because it postdates development of the Sabine uplift, smaller structures on and flanking the uplift, and salt structures in the East Texas and Northern Louisiana Salt Basins. Stratigraphic proximity of source rocks to Cotton Valley sandstone reservoirs and appropriate thermal maturity and time of generation and migration would be consistent with interpretation of a potential basin-centered gas accumulation.

7. Presence of a gas-water contact is perhaps the most definitive criterion suggesting that a gas accumulation is conventional rather than a "sweetspot" within a basin-centered, continuous gas accumulation. Within the Cotton Valley blanket-sandstone trend across northernmost Louisiana, short gas-water transition zones and well-defined gas-water contacts have been reported in seven gas fields. Relatively high porosity and permeability of blanket sandstones and associated high gasproduction rates achieved without fracture stimulation throughout the trend suggest that all gas fields within the blanket-sandstone trend probably have well-defined gas-water contacts; therefore, these gas accumulations are conventional.

8. Within the tight, massive-sandstone trend, porosity and permeability are sufficiently low that gas-water transition zones are long and gas-water contacts poorly defined. Productive limits of these tight-gas-sandstone Cotton Valley fields are not defined by wells that encounter a gas-water contact or test water without gas from a zone below a gas-water contact, as in the blanket-sandstone trend. With increasing depth through 
vertically extensive gas-water transition zones, gas saturation in reservoir sandstones decreases and water saturation increases. Eventually gas saturations become sufficiently low that, in terms of cumulative gas production, wells become marginally commercial to noncommercial at a structural position still within the transition zone above the gas-water contact. Therefore, development wells on the flanks of gas accumulations in the tight, Cotton Valley massive-sandstone trend rarely encounter gas-water contacts. If even the smallest amount of gas recovery were commercial, development drilling probably would progress down the full length of transition zones, and gas-water contacts would be encountered in these gas accumulations. The presence of gas-water contacts in gas accumulations within the tight, Cotton Valley massive-sandstone trend suggests that accumulations in this trend, too, are conventional and that a basin-centered gas accumulation does not exist within Cotton Valley sandstones in the northern Gulf of Mexico Basin.

9. A basin-centered, continuous gas accumulation might occur in turbidite sandstones within the Bossier Shale, the lower formation of the Cotton Valley Group. In a currently developing play on the western flank of East Texas Basin, gas production with estimated recoverable reserves exceeding one TCFG is being obtained from sandstone reservoirs, interpreted as slope or lowstandfan deposits, that are completely encased in marine shales. Reservoirs are significantly overpressured and no water has been encountered in the system. More than 100 successful wells and only one dry hole have been drilled.

\section{References Cited}

Almon, W.R., 1979, A geologic appreciation of shaly sands: Society of Professional Well Log Analysts, Twentieth Annual Logging Symposium, p. WW 1-WW14.

Bebout, D.G., White, W.A., Garrett, C.M., Jr., and Henz, T.F., 1992, Atlas of major central and eastern Gulf Coast gas reservoirs: University of Texas at Austin, Bureau of Economic Geology, 88 p.

Black, C.E., and Berg, R.R., 1987, Fan-delta reservoirs in the lower Cotton Valley Group (Jurassic), Kildare field, northeast Texas: Gulf Coast Association of Geological Societies Transactions, v. 37, p. 35-42.

Bruce, P.L., Hunter, J.L., Kuhlman, R.D., and Weinheimer, D.D., 1992, New fracturing techniques reduce tight gas sand completion problems: Oil and Gas Journal, v. 90, no. 41, p. 72-76.

CER Corporation, and S.A. Holditch \& Associates, eds., 1991, Staged field experiment no. 3: Application of advanced technologies in tight-gas sandstones-Travis Peak and Cotton Valley Formations, Waskom field, Harrison County, Texas: Gas Research Institute Report 91/0048, $253 \mathrm{p}$.
Coleman, J.L., Jr., and Coleman, C.J., 1981, Stratigraphic, sedimentologic and diagenetic framework for the Jurassic Cotton Valley Terryville massive sandstone complex, northern Louisiana: Gulf Coast Association of Geological Societies Transactions, v. 31, p. 71-79.

Coleman, J.L., Jr., 1985, Diagenesis of Cotton Valley Sandstone (Upper Jurassic), east Texas: Implications for tight-gas formation pay recognition: Discussion: American Association of Petroleum Geologists Bulletin, v. 69, no. 5, p. 813-815.

Collins, S.E., 1980, Jurassic Cotton Valley and Smackover reservoir trends, east Texas, north Louisiana, and south Arkansas: American Association of Petroleum Geologists Bulletin, v. 64, no. 7, p. 1004-1013.

Dow, W.G., 1978, Petroleum source beds on continental slopes and rises: American Association of Petroleum Geologists Bulletin, v. 62, no. 9, p. 1584-1606.

Dutton, S.P., 1987, Diagenesis and burial history of the Lower Cretaceous Travis Peak Formation, east Texas: University of Texas, Bureau of Economic Geology, Report of Investigations No. 164, 58 p.

Dutton, S.P., Clift, S.J., Hamilton, D.S., Hamlin, H.S., Hentz, T.F., Howard, W.E., Akhter, M.S., and Laubach, S.E, 1993, Major lowpermeability sandstone gas reservoirs in the continental United States: University of Texas, Bureau of Economic Geology, Report of Investigations No. 211, 221 p.

Eversull, L.G., 1985, Depositional systems and distribution of Cotton Valley blanket sandstones in northern Louisiana: Gulf Coast Association of Geological Societies Transactions, v. 35, p. 49-57.

Finley, R.J., 1984, Geology and engineering characteristics of selected low-permeability gas sandstones: A national survey: University of Texas, Bureau of Economic Geology, Report of Investigations No. $138,220 p$.

Finley, R.J., 1986, An overview of selected blanket-geometry, lowpermeability gas sandstones in Texas, in Spencer, C.W., and Mast, R.F., eds., Geology of Tight-Gas Reservoirs: American Association of Petroleum Geologists Studies in Geology No. 24, p. 69-85.

Ganer, B.L., 1985, Case history of Cotton Valley sand log interpretation for a north Louisiana field: Journal of Petroleum Technology, v. 37, no. 11, p. $1995-2005$.

Gies, R.M., 1984, Case history for a major Alberta deep-basin gas trap: The Cadomin Formation, in Masters, J.A., ed., ElmworthCase Study of a Deep-Basin Gas Field: American Association of Petroleum Geologists Memoir 39, p. 115-140.

Hall, C.D., Janks, J.S., and Ladle, G.H., 1984, Sedimentology and diagenesis of the Cotton Valley Sandstone in the Amoco No. 1 Cullers well, Rusk County, Texas, in Presley, M.W., ed., The Jurassic of East Texas: Tyler, Texas, East Texas Geological Society, p. 127-140.

Herrmann, L.A., Lott, J.A., and Davenport, R.E., 1991, Ruston fieldU.S.A., Gulf Coast Basin, Louisiana, in Beaumont, E.A., and Foster, N.H., eds., American Association of Petroleum Geologists Treatise of Petroleum Geology, Structural Traps V, p. 151-186.

Jackson, M.L.W., and Laubach, S.E., 1991, Structural history and origin of the Sabine arch, east Texas and northwest Louisiana: University of Texas at Austin, Bureau of Economic Geology, Geological 
Circular 91-3, $47 \mathrm{p}$.

Janks, J.S., Sanness, T., and Rasmussen, B.A., 1985, Diagenesis of the Cotton Valley sandstones, Catahoula Creek field, southern Mississippi: Gulf Coast Association of Geological Societies Transactions, v. 35, p. 415-423.

Jennings, A.R., and Sprawls, B.T., 1977, Successful stimulation in the Cotton Valley Sandstone-A low-permeability reservoir: Journal of Petroleum Technology, v. 29, no. 10, p. 1267-1276.

Jones, P.H., 1977, Geopressuring mechanism of Smackover gas reservoirs, Jackson dome area, Mississippi: Discussion: Journal of Petroleum Technology, v. 29, no. 5, p.584-585.

Kast, J.A., 1983, Depositional environments of Schuler Formation (Cotton Valley sands), Upshur County, Texas [abs.]: American Association of Petroleum Geologists Bulletin, v. 67, no. 3, p. 493.

Kosters, E.C., Bebout, D.G., Seni, S.J., Garrett, C.M., Jr., Brown, L.F., Jr., Hamlin, H.S., Dutton, S.P., Ruppel, S.C., Finley, R.J., and Tyler, Noel, 1989, Atlas of major Texas gas reservoirs: University of Texas at Austin, Bureau of Economic Geology, 161 p.

Laubach, S.E., and M.L.W. Jackson, 1990, Origin of arches in the northwestern Gulf of Mexico Basin: Geology, v. 18, p. 595-598.

Law, B.E., and Dickinson, W.W., 1985, Conceptual model for origin of abnormally pressured gas accumulations in low-permeability reservoirs: American Association of Petroleum Geologists Bulletin, v. 69 , no. 8 , p. $1295-1304$.

Law, B.E., and Spencer, C.W., 1993, Gas in tight reservoirs-An emerging major source of energy, in Howell, D.G., ed., The Future of Energy Gases: U.S. Geological Survey Professional Paper 1570, p. 233-252.

Levorsen, A.I., 1967, Geology of petroleum: San Francisco, W.H. Freeman and Co., $724 \mathrm{p}$.

Lopatin, N.V., 1971, Temperature and geologic time as factors of carbonification [in Russian]: Izvestiya Akademii Nauk SSSR, Seriya Geologischeskaya, no 3., p. 95-106.

Mann, C.J., and Thomas, W.A., 1964, Cotton Valley Group (Jurassic) nomenclature, Louisiana and Arkansas: Gulf Coast Association of Geological Societies Transactions, v. 14, p. 143-152.

McGowen, M.K., and Harris, D.W., 1984, Cotton Valley (Upper Jurassic) and Hosston (Lower Cretaceous) depositional systems and their influence on salt tectonics in the East Texas Basin: University of Texas, Bureau of Economic Geology, Geological Circular 84-5, 41p.

Meehan, D.N., and Pennington, B.F., 1982, Numerical simulation results in the Carthage Cotton Valley field: Journal of Petroleum Technology, v. 34, no. 1, p. 189-198.

Moore, T., 1983, Cotton Valley depositional systems of Mississippi: Gulf Coast Association of Geological Societies Transactions, v. 33, p. 163-167.

Nangle, P., Fertl, W.H., and Frost, E., Jr., 1982, What to expect when logging the Cotton Valley trend: World Oil, v. 195, no. 5, p. 175-195.

Parker, C.A., 1972, Geopressures in the Smackover on Mississippi, in Abnormal Subsurface Pressure Symposium, Baton Rouge: Society of Petroleum Engineers SPE 3885, p.109-114.
Pate, B.F., 1963, Significant north Louisiana Cotton Valley stratigraphic traps: Gulf Coast Association of Geological Societies Transactions, v. 13, p. $177-183$.

Pate, B.P., and Goodwin, R.N., 1961, Calhoun field, Jackson, Lincoln, Ouachita Parishes, Louisiana: Gulf Coast Association of Geological Societies Transactions, v. 11, p. 197-201.

Presley, M.W., and Reed, C.H., 1984, Jurassic exploration trends of east Texas, in Presley, M.W., ed., The Jurassic of East Texas: Tyler, Texas, East Texas Geological Society, p. 11-22.

Royden, L., Sclater, J.G., and Von Herzen, R.P., 1980, Continental margin subsidence and heat flow: Important parameters in formation of petroleum hydrocarbons: American Association of Petroleum Geologists Bulletin, v. 64, no. 2, p. 173-187.

Russell, B.J., Jr., Sartin, A.A., and Ledger, E.B., 1984, Depositional and diagenetic history of the Bodcaw Sand, Cotton Valley Group (Upper Jurassic), Longwood field, Caddo Parish, Louisiana: Gulf Coast Association of Geological Societies Transactions, v. 34, p. 217-228.

Salvador, A., 1987, Late Triassic-Jurassic paleogeography and origin of Gulf of Mexico Basin: American Association of Petroleum Geologists Bulletin, v. 71, no. 4, p. 419-451.

Sassen, R., and Moore, C.H., 1988, Framework of hydrocarbon generation and destruction in eastern Smackover trend: American Association of Petroleum Geologists Bulletin, v. 72, no. 6, p. 649-663.

Saucier, A.E., 1985, Geologic framework of the Travis Peak (Hosston) Formation of east Texas and north Louisiana, in Finley, R.J., Dutton, S.P., Lin, Z.S., and Saucier, A.E., The Travis Peak (Hosston) Formation: Geologic Framework, Core Studies, and Engineering Field Analysis: University of Texas, Bureau of Economic Geology, [contract report prepared for the Gas Research Institute under contract no. 5082-211-0708], $233 \mathrm{p}$.

Scardina, A.D., 1981, Tectonic subsidence history of the North Louisiana Salt Basin: Louisiana State University, M.S. thesis, 103 p.

Schenk, C.J., and Viger, R.J., 1996, East Texas Basin and MississippiLouisiana Salt Basins provinces, Region 6-Gulf Coast, geologic framework, in Gautier, D.L., Dolton, G.L., Takahashi, K.I., and Varnes, K.L., eds., 1995 National Assessment of United States Oil and Gas Resources-Results, Methodology, and Supporting Data: U.S. Geological Survey Digital Data Series DDS-30, release 2.

Schmoker, J.W., 1996, Method for assessing continuous-type (unconventional) hydrocarbon accumulations, in Gautier, D.L., Dolton, G.L., Takahashi, K.I., and Varnes, K.L., eds., 1995 National Assessment of United States Oil and Gas Resources-Results, Methodology, and Supporting Data: U.S. Geological Survey Digital Data Series 30, release 2.

Shreveport Geological Society, 1946, Reference report on certain oil and gas fields of north Louisiana, south Arkansas, Mississippi, and Alabama: Shreveport Geological Society Reference Volume I, 333 p.

Shreveport Geological Society, 1947, Reference report on certain oil and gas fields of north Louisiana, south Arkansas, Mississippi, and Alabama: Shreveport Geological Society Reference Volume II, $503 p$.

Shreveport Geological Society, 1951, Reference report on certain oil and gas fields of north Louisiana, south Arkansas, Mississippi, and 


\section{$38 \quad$ Geologic Studies of Basin-Centered Gas Systems}

Alabama: Shreveport Geological Society Reference Volume III, no. $1,42 \mathrm{p}$.

Shreveport Geological Society, 1953, Reference report on certain oil and gas fields of north Louisiana, south Arkansas, Mississippi, and Alabama: Shreveport Geological Society Reference Volume III, no. 2, $109 \mathrm{p}$.

Shreveport Geological Society, 1958, Reference report on certain oil and gas fields of north Louisiana, south Arkansas, Mississippi, and Alabama: Shreveport Geological Society Reference Volume IV, $204 \mathrm{p}$.

Shreveport Geological Society, 1963, Report on selected north Louisiana and south Arkansas oil and gas fields and regional geology: Shreveport Geological Society Reference Volume V, 202 p.

Shreveport Geological Society, 1980, Report on selected oil and gas fields, north Louisiana and south Arkansas: Shreveport Geological Society Reference Volume VI, $160 \mathrm{p}$.

Shreveport Geological Society, 1987, Report on selected oil and gas fields, Ark-La-Tex and Mississippi: Shreveport Geological Society Reference Volume VII, 153 p.

Sloane, B.J., Jr., 1958, The subsurface Jurassic Bodcaw sand in Louisiana: Louisiana Geological Survey, Geological Bulletin No. 33, $33 \mathrm{p}$.

Snedden, J.W., 1984, Validity of the use of the spontaneous potential curve shape in the interpretation of sandstone depositional environments: Gulf Coast Association of Geological Societies Transactions, v. 34, p. 255-263.

Sonnenberg, S.A., 1976, Interpretation of Cotton Valley depositional environment from core study, Frierson field, Louisiana: Gulf Coast Association of Geological Societies Transactions, v. 26, p. 320-325.

Spencer, C.W., 1987, Hydrocarbon generation as a mechanism for overpressuring in Rocky Mountain region: American Association of Petroleum Geologists Bulletin, v. 71, no. 4. p. 368-388.

Studlick, J.R.J., Shew, R.D., Basye, G.L., and Ray, J.R., 1990, A giant carbon dioxide accumulation in the Norphlet Formation, Pisgah anticline, Mississippi, in Barwis, J.H., McPherson, J.C., and Studlick, J.R.J., eds., Sandstone Petroleum Reservoirs: New York, Springer-Verlag, p. 181-203

Swain, F.M., 1944, Stratigraphy of Cotton Valley beds of northern Gulf Coastal Plain: Amerdican Association of Petroleum Geologists Bulletin, v. 28, no. 5. p. 577-614.

Thomas, W.A., and Mann, C.J., 1963, Correlation chart of the upper Cotton Valley sands, in Herrmann, L.A., ed., Shreveport Geological Society Reference Report, v. V, p. 9-17.

Thomas, W.A., and Mann, C.J., 1966, Late Jurassic depositional environments, Louisiana and Arkansas: American Association of Petroleum Geologists Bulletin, v. 50, no. 1. p. 178-182.

Tindall, W.A., Neal, J.K., and Hunter, J.C., 1981, Evolution of fracturing the Cotton Valley sands in Oak Hill field: Journal of Petroleum Technology, v. 33, no. 5, p.799-807.

Tissot, B.P., and Welte, D.H., 1978, Petroleum formation and occurrence: New York, Springer-Verlag, 538 p.
Trojan, M., 1985, Effects of diagenesis on reservoir properties and log response, Upper Jurassic Taylor sandstone, Cotton Valley Group, Lincoln Parish, Louisiana: Gulf Coast Association of Geological Societies Transactions, v. 35, p. 515-523.

Turner, J.R. 1997, Recognition of low resistivity, high permeability reservoir beds in the Travis Peak and Cotton Valley of east Texas: Gulf Coast Association of Geological Societies Transactions, v. 47, p. 585-593.

Wapples, D.W., 1980, Time and temperature in petroleum formation: Application of Lopatin's method to petroleum exploration: American Association of Petroleum Geologists Bulletin, v. 64, no. 6, p. 916-926.

Wescott, W.A., 1983, Diagenesis of Cotton Valley Sandstone (Upper Jurassic), east Texas: Implications for tight gas formation pay recognition: American Association of Petroleum Geologists Bulletin, v. 67, no. 6, p. 1002-1013.

Wescott, W.A., 1985, Diagenesis of Cotton Valley Sandstone (Upper Jurassic), east Texas: Implications for tight gas formation pay recognition: Reply: American Association of Petroleum Geologists Bulletin, v. 69, no. 5, p. 816-818.

Wescott, W.A., and Hood, W.C., 1991, Hydrocarbon generation and migration routes in the East Texas Basin: Gulf Coast Association of Geological Societies Transactions, v. 41, p. 675.

White, W.A., and Garrett, C.M., Jr., 1992, KJ-1. Hosston Formation and Cotton Valley Group sandstones-Sabine uplift, in Bebout, D.G., White, W.A., Garrett, C.M., Jr., and Hentz, T.F., eds., Atlas of Major Central and Eastern Gulf Coast Gas Reservoirs: University of Texas, Bureau of Economic Geology, p. 63-64.

White, W.A., Garrett, C.M., Jr., and Woodward, M., 1992, JS-1. Cotton Valley shallow-marine sandstone-ARKLA region, in Bebout, D.G., White, W.A., Garrett, C.M., Jr., and Hentz, T.F., eds., Atlas of Major Central and Eastern Gulf Coast Gas Reservoirs: University of Texas, Bureau of Economic Geology, p. 72-74.

Wilson, D.A., and Hensel, W.M., 1984, The Cotton Valley Sandstone of east Texas: A log-core study, in Presley, M.W., ed., The Jurassic of East Texas: Tyler, Texas, East Texas Geological Society, p. 141-152.

Worrall, D.M., and Snelson, S., 1989, Evolution of the northern Gulf of Mexico, with emphasis on Cenozoic growth faulting and the role of salt, in Bally, A.W., and Palmer, A.R., eds., The Geology of North America; An Overview: Geological Society of America, The Geology of North America Series, v. A, p. 97-138.

Manuscript approved for publication October 26, 2001

Published in the Central Region, Denver, Colorado

Editing, layout, photocomposition-Richard W. Scott, Jr. Cover design, graphics consultation-Carol A. Quesenberry Graphics by the authors 


\section{DEEP NATURAL GAS RESOURCES}

\section{T.S. Dyman, R.E. Wyman, V.A. Kuuskraa, M.D. Lewan, and T.A. Cook INTRODUCTION}

The United States is rapidly depleting its oil reserves and exploration companies are increasingly looking overseas for new prospects. However, estimates of domestic natural gas resources remain high. According to the National Petroleum Council (1992), the United States contains nearly 1,300 trillion cubic feet (TCF) of recoverable natural gas resources. In 1995, the U.S. Geological Survey (USGS) estimated that 939 TCF of technically recoverable natural gas remained to be discovered or was part of reserve appreciation from known fields in the onshore areas and State waters of the United States (U.S. Geological Survey Oil and Gas Resource Assessment Team, 1995). Of this USGS resource, 113.7 trillion cubic feet (Tcf) of technically-recoverable gas remains to be discovered from the deeper portions of deep sedimentary basins. Worldwide estimates of deep gas are also high. The U.S. Geological Survey World Petroleum Assessment 2000 Project recently assessed undiscovered conventional gas and oil resources in eight regions of the world outside the U.S. (U.S. Geological Survey World Energy Assessment Team, 2000) and estimated a mean undiscovered conventional gas resource of 844 Tcf below $4.5 \mathrm{~km}$ (Table 3). Exploration for deep natural gas resources deserves special attention because these resources are widespread and occur in diverse geologic environments.

Efficiently finding and developing deep undiscovered natural gas resources depend on improving our knowledge of the geology and reservoir characteristics of deep sedimentary basins, continued advances in exploration, drilling, and completion technologies, and improved economics. During the 1990's, deep natural gas exploration and development were strongly influenced both by advances in technology and by lower unit costs. This progress in technology and costs helped spur the development of frontier plays such as the deep Norphlet Play in the eastern Gulf Coast basin, the low-permeability deep Cretaceous plays of the Green River basin, and the deep Madison Play on Madden anticline in the Wind River basin.

Our purpose in preparing this report is to summarize the current state of deep gas exploration and production for three primary reasons. (1) Natural gas may form in the deep central portions of basins and migrate into shallower regions where it is trapped. An understanding of deep basin processes will aid in understanding the occurrence of natural gas in shallow basin environments as well as deep ones. (2) The deeper parts of many sedimentary basins have not been adequately drilled, and opportunities for undiscovered accumulations remain good. (3) Economic conditions strongly affect the development of deep reservoirs. Economic and (or) technologic improvements could produce conditions appropriate for increased exploration. Therefore, it is very important to maintain a database of information on deep natural gas resources and reservoirs.

This report includes a discussion of the geologic and tectonic framework of deep sedimentary basins, an historical perspective of deep drilling and production in the U.S., the origins of deep gas, recent estimates of undiscovered gas in the U.S. and the world, exploration strategies for deep gas, economic and technologic problems associated with deep gas exploration and development, and the outlook for future development.

\section{DEFINITIONS}

\section{Deep Sedimentary Basins and Gas Systems}

From a geological perspective, deep natural gas resources are generally defined as those resources occurring in reservoirs at or below 15,000 feet. From an operational point of view, 
"deep" is often thought of in a relative sense based on the geologic and engineering knowledge of gas (and oil) resources in a particular area. For example, in the Anadarko and Gulf Coast basins, many wells have been drilled to depths exceeding 15,000 feet, and deep production is well established. Conversely, in the San Juan basin, relatively few wells have exceeded 10,000 feet, and the basin itself barely exceeds 15,000 feet. We know less about potential petroleum resources in the San Juan basin in the 10,000 to 15,000-ft interval than we know about resources in the Gulf Coast and Anadarko basins below 15,000 feet. Also, problems associated with drilling and completing wells vary significantly for different depth intervals in different basins. Wells may encounter overpressured intervals, sour gas, or special drilling problems at any depth. In the longer term, it may be useful to view deep resources in a relative sense by understanding the geologic changes that occur with increasing depth regardless of the absolute depth of those resources. For the purpose of this report, however, deep basins and resources are defined as those at or below 15,000 feet.

Ultra-deep gas is defined as gas occurring below 25,000 feet. Few penetrations, and even fewer successful completions, have exceeded 25,000 feet. Except for a few ultra-deep wells in the Anadarko, Gulf Coast, Rocky Mountain, and Permian basins, little is known about ultra-deep gas resources. Assuming deep sediments exist, significant natural gas production could be achieved in the future from such great depths, assuming technological difficulties and high costs can be countered with highly productive wells.

Deep gas can be found in either conventionally-trapped or unconventional (continuous-type) basin-center accumulations. The term "continuous-type" accumulation is used by the U.S. Geological Survey to describe and assess large single fields having spatial dimensions equal to or exceeding those of conventional fields. Continuous gas accumulations were described as "pervasive" by Davis (1984) for deep gas accumulations in the Western Canada basin (see also Masters, 1984). Continuous accumulations are geologically diverse and fall into several categories including coal-bed gas, shallow biogenic gas, fractured shale gas, and basin-center gas. Only basin-center gas comprises a significant portion of deep continuous gas resources. Common geologic and production characteristics of basin-center accumulations include their occurrence down dip from water-saturated rocks, lack of obvious traps or seals, proximity of source and reservoir rocks, relatively low matrix permeability, abnormal pressures, large in-place hydrocarbon volumes, and low recovery factors (Schmoker, 1996). Some deep gas accumulations, however, may have geologic and production characteristics typical of both conventional and unconventional gas, and a genetic classification is difficult to establish for them.

The nature of deep gas petroleum systems is tied in part to whether gas accumulations are conventional or continuous. For continuous accumulations, source and reservoir rocks are closely related, and migration distances are short. For conventional accumulations long distance migration is possible. Under favorable geologic conditions, deep basin-center gas systems may source shallow basin-margin conventional accumulations.

Active petroleum systems include source rocks that vary significantly in depth and thermal maturity. Identifying these systems is tied more to whether the accumulation is conventional or unconventional rather than on depth.

1. They are geographically large and cover from 10's to 100's of square miles in areal extent, typically occupying the central, deeper parts of sedimentary basins.

2. They lack downdip water contacts, and thus hydrocarbons are not held in place by the buoyancy of water.

3. Reservoirs are abnormally pressured.

4. Gas is the pressuring phase of the reservoir.

5. Water production is usually low or absent, or water production is not associated with a distinct gas-water contact.

6. Reservoir permeability is low - generally less than 0.1 millidarcy (md).

7. Reservoirs are overlain by normally-pressured rocks containing both gas and water.

8. Reservoirs contain primarily thermogenic gas.

9. Migration distances are not thought to be great. 
10. Structural and stratigraphic traps are of minor importance.

11. Reservoirs are commonly compartmentalized.

12. Multiple fluid phases contribute to seal development in reservoirs.

13. The tops of basin-center accumulations occur within a narrow range of thermal maturities, usually between a vitrinite reflectance of 0.75 and $0.9 \%$.

\section{GENERAL GEOLOGIC FRAMEWORK}

Both conventional and unconventional natural gas accumulations are widely distributed in deep sedimentary basins of the U.S. (Fig. 1) and are associated with a variety of geologic environments. From a plate-tectonic perspective, deep sedimentary basins occur in two primary structural settings: passive margins not associated with plate boundaries and basins associated with active or once-active plate margins (Perry, 1997). Passive margin basins such as the Western Gulf Coast basin are relatively simple and are associated with crustal cooling. Plate-margin basins are more geologically complex and include both forearc basins and foreland basins. Major foreland basins include the Appalachian, Arkoma, and Rocky Mountain basins. Complex plate-convergence basins include the Anadarko, Hanna, Wind River, and Paradox basins. Intracratonic basins such as the Michigan, Illinois, and Williston basins encounter basement rocks at or near 15,000 feet (Fig. 1) and are not considered to be important for deep gas development.

Both carbonate and clastic reservoirs are productive in the deepest wells penetrated, depending on the basin in question. In the onshore and offshore parts of the Gulf Coast basin, deep clastic reservoirs include the Jurassic Cotton Valley, Cretaceous Tuscaloosa, and a host of Tertiary reservoirs. Carbonate reservoirs of the Jurassic Smackover Formation also produce gas at depths exceeding 15,000 feet. In the Permian basin, the deepest gas wells produce from carbonates of the Ordovician Ellenberger Formation and carbonates of Permian age. In the Anadarko basin, deep gas wells commonly produce from both clastic (e.g. Pennsylvanian Morrow and Atoka reservoirs) and carbonate (Cambrian-Ordovician Arbuckle and Silurian Hunton reservoirs) reservoirs (Dyman and Cook, in press).

\section{HISTORICAL PERSPECTIVE}

According to the December 1998 version of IHS Energy Group's Well History Control System (WHCS), 20,715 wells have been drilled deeper than 15,000 feet in the United States (IHS Energy Group, 1998; Dyman and Cook, in press). These deep wells are distributed widely and are drilled into rocks of various ages and lithologies, but they represent less than one percent of the more than three million oil and gas wells drilled in the U.S.

The Anadarko basin of Oklahoma, where record-breaking deep wells were drilled in the 1970's and early 1980's, has been traditionally viewed as the center of deep drilling in the U.S. The first deep gas discovery was in 1956 in the Carter-Knox field in the southern part of the Anadarko basin. This well produced an open-flow potential of 31 million cubic feet of gas per day (MMcfd) from the Ordovician Simpson Group at a depth of 15,300 feet. Other deep discoveries followed in southern Oklahoma and in the Texas Panhandle and led to a series of deep recordbreaking wells drilled to test the limits of deep gas. The gas supply surplus and resulting price drop in the mid-1980's, however, brought a subsequent halt to deep drilling (Reeves and others, 1998).

Table 1 contains identification and location information from the IHS Energy Group WHCS files for the 12 deepest wells drilled in the U.S. regardless of completion classification (IHS Energy Group, 1998). All of these wells were drilled in Oklahoma and Texas in the Anadarko and Permian basins. The deepest well drilled in the U.S., the Lone Star Bertha Rogers No. 1, was completed in 1974 as a dry hole in the Anadarko basin in Oklahoma. The well was drilled as a wildcat to a depth of 31,441 feet and penetrated the Upper Cambrian and Lower Ordovician Arbuckle Group at 31,236 feet after almost a year and a half of drilling.

The second deepest well, the Lone Star Earnest Baden No. 1, although drilled to more than 30,000 feet, was completed as a gas well in the Middle Pennsylvanian Atoka Formation at a depth of approximately 16,500 feet. The third deepest well, the Hunt Energy 1-9 Cerf Ranch unit, was 
drilled as a wildcat and, although abandoned, it reported gas in the Lower Ordovician Ellenberger Group at 22,535 feet. Of the remainder, wells 4 and 6 through 9 were drilled and abandoned and wells 5, 11 and 12 were completed as gas wells.

\section{ORIGINS OF DEEP GAS}

Less is known about the origins of deep gas than about the origins of gas at shallower depths because fewer wells have been drilled into the deeper portions of many basins. Much of the shallow gas may have its origins in the deeper parts of basins and has migrated to shallower depths during basin evolution (Price, 1997). Some of the many variables contributing to the origin of deep gas include the thermal stability of methane, the role of water and non-hydrocarbon gases in natural gas generation, porosity loss with increasing thermal maturity, the kinetics of deep gas generation, thermal cracking of oil to gass, and source rock potential based on thermal maturity and kerogen type. Articles by Pepper and Dodd (1995), Pepper and Corvi (1995), Dyman and others, eds. (1997), Gas Research Institute (1998), and Dyman and Kuuskraa eds. (in press) include detailed discussions of the variables contributing to the origins of deep gas.

\section{Experimental Simulations - Laboratory Pyrolysis Methods}

Recent experimental simulations using laboratory pyrolysis methods have provided much information on the origins of deep gas. Volumetric results from these experiments can be compared to reservoir gas volumes from known accumulations. In a significant review of published laboratory-pyrolysis data, Henry and Lewan (in press) compared different gas-generation kinetic models with respect to timing and generation of gas from the published literature. These models are based primarily on different types of laboratory pyrolysis methods, which include open-system anhydrous pyrolysis such as Rock-Eval (Behar and others, 1997); closed-system anhydrous pyrolysis such as microscale sealed (MSSV) pyrolysis (Horsfield and others, 1992); and closedsystem hydrous pyrolysis such as flexible gold-bag autoclaves (Knauss and others, 1997). These kinetic models were examined in two hypothetical basin scenarios that represent end-member heating rates of $1^{\circ}$ and $10^{\circ} \mathrm{C} / \mathrm{m} . \mathrm{y}$. Results of these laboratory studies suggest that:

(1) Basins with slow heating rates, where source rocks subside slowly through low thermal gradients, are more likely to yield deep gas from kerogen than basins with fast heating rates and rapid subsidence rates.

(2) According to the open- and composite-pyrolysis models, Type-III kerogen will yield the most deep gas of the three kerogen types irrespective of heating rate, implying that basins with deeply buried coals are most likely to contain deep gas.

(3) According to the open- and composite-pyrolysis models, Type-I kerogen has the lowest potential for deep-gas generation, implying that basins with deeply buried hydrogen-rich source rocks are not likely to contain deep gas.

(4) Thermal cracking of oil, which is predicted by the anhydrous- and hydrous-pyrolysis models, will generate the most deep gas irrespective of heating rate. Therefore, the main requirement for deep gas accumulation in this geologic setting is that the original oil trap remains competent throughout the burial history. The Gulf Coast offshore and the Anadarko basin may serve as examples of this geologic setting.

(5) No significant differences occur between the different pyrolysis kinetic models in the predicted amount of deep gas generated from kerogen. However, the hydrous-pyrolysis model considers only Type-II kerogen, and more hydrous-pyrolysis experiments with kinetic models for gas generation from Type-I, Type-IIS, and Type-III kerogens are needed to test this preliminary conclusion.

(6) A significant difference occurs between the predicted amounts of deep gas generated from the cracking of reservoir oil by the anhydrous- and hydrous-pyrolysis kinetic models. The kinetic model derived from hydrous pyrolysis indicates that reservoir oil is more thermally stable and that oil cracking to gas requires higher thermal stress levels than those predicted by the anhydrous-pyrolysis model.

Henry and Lewan (in press) recommended that future experimental studies to test their conclusions include an inventory of heating rates and gas recoveries for different 
basins, particularly those with deeply buried coal and lacustrine source rocks. In this way, basins with the greatest potential for deep gas can be targeted. More experimental work is recommended on the cracking of oil in the presence of water. In addition, these future experiments need to consider the catalytic effects of commonly occurring reservoir minerals and their surfaces. Experiments published to date on the cracking of reservoir oil have neglected the potential effects of minerals on gas generation.

\section{GAS RESOURCE ESTIMATES}

U.S. Geological Survey 1995 National Petroleum Assessment

Deep undiscovered conventional and unconventional (continuous-type) basin-centered natural gas resources were assessed as part of the U.S. Geological Survey 1995 National Petroleum Assessment using a geologically-based play analysis method (Gautier and others, 1996). Mean estimates of undiscovered gas resources were subdivided into depth slices by applying an average of two density functions to play depth ranges (Dyman and others, 1996). The U.S. Geological Survey estimated that a mean resource of 113.7 trillion cubic feet (Tcf) of technically-recoverable gas remains to be discovered from the deeper portions of deep sedimentary basins in the onshore U.S. and State waters (Table 2). Of this mean resource, 55.3 Tcf of technically-recoverable nonassociated gas and associated gas from oil fields was estimated for 101 deep conventional plays in the lower-48 states and Alaska. About one-half of this mean estimated resource (27.4 Tcf) is located in the Gulf Coast region in the western Gulf basin and Louisiana--Mississippi Salt Basins petroleum provinces. This estimate does not include deep resources attributed to small fields (ultimate recoverable production $<6$ billion cubic feet of gas), reserve growth from known fields, or deep gas from Federal offshore waters.

The number of deep conventional plays decreases with increasing depth. Of the 101 deep conventional plays, 73 plays have maximum depths ranging from 15,000 to 20,000 feet, whereas 20 have maximum depths ranging from 20,000 to 25,000 feet, and only five have maximum depths ranging from 25,000 to 30,000 + feet. Three plays exceed 30,000 feet in depth (Dyman and others, 1996).

An additional 58.4 Tcf of deep, technically-recoverable gas was estimated for portions of six basin-centered gas plays in the Pacific, Colorado Plateau and Basin and Range, and Rocky Mountain and Northern Great Plains regions (Table 2). Four of the six deep basin-center gas plays are in Cretaceous and Tertiary low-permeability sandstone reservoirs in the Greater Green River basin of Wyoming and are estimated to contain about 50 percent ( $55.2 \mathrm{Tcf}$ ) of the entire undiscovered deep gas resource of the U.S. (Dyman and others, 1996). The disparity in numbers of plays and resources of conventional (101 plays--55.3 Tcf) and unconventional plays (6 plays-58.4 Tcf) may be due in part to a lack of data dealing with the distribution of poorly-understood, continuous-type basin-centered gas plays. A number of deep continuous gas plays were identified but not assessed by the U.S. Geological Survey in 1995.

Other organizations also assess deep gas resources in the U.S. The Gas Research Institute (GRI) (Gas Research Institute, 2000), the Potential Gas Committee (PGC) (Potential Gas Committee, 1999), and the National Petroleum Council (NPC) (National Petroleum Council, 1992; 1999) have published their own estimates of deep gas using different assessment methods and procedures. Dyman and others (1996) present a comparison of these deep gas assessments by region in the U.S. For a detailed discussion of the many ways in which these national petroleum assessments differ from each other refer to Dyman and Schmoker (1996).

\section{U.S. Geological Survey World Petroleum Assessment 2000}

The U.S. Geological Survey World Petroleum Assessment 2000 Project recently assessed undiscovered conventional gas and oil resources in eight regions of the world outside the U.S. (U.S. Geological Survey World Energy Assessment Team, 2000). The resources assessed were those having the potential to be added to reserves within the next thirty years. This study is a worldwide analysis of the estimated volumes and distribution of deep ( $>4.5 \mathrm{~km}$ or about 15,000 feet), undiscovered conventional natural gas resources based on that work. A total of 246 assessment units in 128 priority geologic provinces, 96 countries, and two jointly held areas were 
assessed using a probabilistic petroleum system approach. Priority geologic provinces were chosen using a ranking of 937 provinces worldwide. Lower priority provinces were not assessed for the World Petroleum 2000 Project; however, "boutique" provinces were assessed if they were politically, technologically, or geographically important.

The U.S. Geological Survey World Petroleum Assessment Team did not assess undiscovered petroleum resources in the U.S. For this project, volumes of deep conventional undiscovered gas resources in the U.S. were taken from estimates of 101 deep plays (out of a total of 550 conventional plays in the U.S.) from the U.S. Geological Survey 1995 National Assessment of Oil and Gas Resources (see previous section).

A probabilistic method was designed to subdivide gas resources into depth slices using a median-based triangular probability distribution as a probability model for drilling depth to estimate the percentages of estimated gas resources below various depths. For both the World Petroleum Assessment 2000 and the 1995 National Assessment of Oil and Gas Resources, minimum, median, and maximum depths were assigned to each assessment unit and play; these depths were used in our analysis.

A total of 274 deep assessment units and plays in 123 petroleum provinces were identified. These deep assessment units and plays contain a mean undiscovered conventional gas resource of $844 \mathrm{Tcf}$ below $4.5 \mathrm{~km}$ (Table 3). Of this resource, about $23 \mathrm{Tcf}$ of gas occurs below $7.5 \mathrm{~km}$ (about 25,000 feet). The deep undiscovered conventional gas resource ( $844 \mathrm{Tcf}$ ) is about 17 percent of the total world gas resource $(4,928 \mathrm{Tcf})$ based on the priority and boutique provinces assessed and including 259 Tcf of U.S. gas from the U.S. 1995 National Assessment. The average maximum depth for all assessment units and plays is $5.9 \mathrm{~km}$. Of the eight regions, the Former Soviet Union (Region 1) contains the largest estimated volume of undiscovered deep gas with a mean resource of $343 \mathrm{Tcf}$. The second largest estimated deep gas volume (142 Tcf) occurs in Europe (Region 4), and the third largest estimated deep gas volume occurs in the Middle East and North Africa (Region 2).

\section{DEEP PRODUCTION}

As of December 1998, 20,572 wells had been drilled deeper than 15,000 feet in the U.S., of which 11,522 were classified as producing gas and/or oil (IHS Energy Group, 1998; Table 4). Of those 11,522 producing wells, 5,119 were completed from the formation encountered at total depth. Wells may have included more than one producing formation, but only the first and deepest producing formation below 15,000 feet listed in the file was recognized for this study. These 5,119 wells, form a subset of wells actually producing gas or oil below 15,000 feet. This summary is based solely on observations from the IHS WHCS data and does not take into account oil and gas wells that are not in these files. The inclusion of non-WHCS wells could affect the results reached here.

Table 5 summarizes the final well classification by depth interval for the 5,119 wells in the WHCS file that produce oil or gas from the formation encountered at total depth. Gas wells outnumber oil wells for every depth interval. The percent of gas wells to total producing wells ranges from 71 percent in the 15,000 to 16,000 foot interval to 100 percent in the 25,000 ft and greater interval. For all depths greater than 15,000 feet, gas wells make up nearly 76 percent of the deep wells producing from formations encountered at total depth.

Table 6 contains geologic and completion information for 52 ultradeep ( $>25,000$ feet) wells drilled in the U.S as of December 1998 (IHS Energy Group, 1998). For the entire U.S., 27 of these 52 ultradeep wells were completed as gas or oil wells (producing at any depth). Of the 27 producing wells, ten wells were reported as producing from Permian reservoirs in the Permian basin, six wells were reported as producing from the Ordovician Ellenberger Formation in the Permian basin, and five wells were reported as producing from Hunton Group reservoirs in the Anadarko basin. 
Based on the set of 48 ultra-deep wells (after subtracting four abandoned, suspended, or injection wells from the original 52 ultra-deep wells), a historic success ratio of more than 50 percent has been achieved. Exxon holds the record as operator for the largest number of ultradeep wells in the U.S. with 12; ten of these wells were drilled in the Permian basin.

\section{STRATEGY FOR EXPLORATION AND DRILLING}

Exploration and drilling strategies may need to be modified from conventional thinking as deeper prospects are considered. Abnormal pressures are often associated with a pervasively gas-charged (continuous-type) reservoir. Exploration strategies for these tight gas plays requires the identification of relatively high porosity and/or permeability zones. Even lowmatrix reservoir porosity can be enhanced by natural fractures associated with anticlinal flexure or faulting. For Cretaceous reservoirs at fields like Madden in the Wind River basin, which is considered by us a "sweetspot" in a larger basin-center accumulation, fracture permeability is best developed along the crest but decreases significantly off structure. For other fields, such as Elmworth field in the Western Canada basin in Alberta, the distribution of high permeability conglomerate zones plays an important role in reservoir quality. Horizontal drilling is especially effective in accessing fractured reservoirs, particularly when vertical fractures are abundant.

Because deeper formations are generally tighter, special care should be given to minimizing formation damage while drilling. Careful selection of drilling fluids should be a priority; in particular, aqueous fluids can be very damaging due to infusion of water into the formation. A drilling strategy using underbalanced drilling procedures could lead to significant improvement in the success rate. Not only would this procedure reduce reservoir impairment, it would allow for a continuous evaluation of the formations being penetrated. Drilling rates could be increased, and a greater penetration between round trips would help to reduce costs and insure that all productive zones would be recognized (McLennan and others, 1997).

\section{ECONOMIC AND TECHNOLOGIC PROBLEMS OF DEEP DRILLING}

A recent Gas Research Institute study analyzed finding costs and gas recoveries for 5000-ft depth intervals in the U.S. lower-48 states onshore regions (Reeves and others, 1998). Results showed that even though onshore deep gas wells $(>15,000$ feet $)$ produce an average $6.58 \mathrm{Bcf} /$ well, compared to $0.81 \mathrm{Bcf} /$ well for shallow wells $(5,000-10,000 \mathrm{ft}$ interval), deep wells cost nearly 10 times more to drill than do shallow wells (Table 7). However, well costs and gas recoveries vary widely among different gas plays in different basins allowing for some economically viable deep gas plays with higher reserves and lower completion costs.

For ultradeep plays in the Rocky Mountain region such as the deep Madden gas play in the Wind River basin, per well costs can easily exceed $\$ 10$ million, and very high recoveries are required to justify the costs. A well drilled to 40,000 feet could cost from $\$ 25$ to $\$ 50$ million assuming that drilling costs increase proportional to the square of the depth drilled below 25,000 feet (Wyman, 1993). Such extreme depths would initially require significant technological development, and additional costs. To justify such high expenditures it would be necessary to find sizeable accumulations even with current high gas prices.

Wyman (1993) also estimated needed per well reserves and gas-in-place based on net gas price to the producer and net thickness of producing interval (Table 8 ) in order to determine the size of a geologic target to justify the costs of ultra-deep drilling. Assumptions included average well density of one well per section, an undiscounted return on investment of 5 to 1 (due to high risk or dry hole premiums), cost to drill and complete a 40,000-ft well of $\$ 50$ million, initial flow rates of at least 20 million cubic feet of gas per day, 7 percent porosity, 30 percent water saturation, and average gas recovery of 65 percent of the original gas in place. For example, if the net price to the producer is $\$ 3.00 / \mathrm{Mcf}$, one would need to successfully complete 207 feet of producing interval given the above assumptions (Wyman, 1993). The data in Table 8 suggest that a substantial reduction in drilling costs or a reduction in the dry hole rate or risk premium through improved technology could have a major impact on the economic viability of deep gas prospects as shown in Table 8. Higher gas prices would also provide incentives to explore for and develop deep gas. 
Recently, many companies have completed deep wells in the U.S. at far lower costs. Union Pacific Resources has successfully completed deep horizontal Frontier Formation wells $(>15,000$ feet deep) for $\$ 3$ to $\$ 5$ million each in the Greater Green River basin of southwest Wyoming. The company has also completed Austin Chalk wells at Giddings field in south Texas in the 13,000 to 15,000 foot range for an average cost of $\$ 5$ million per well and a 50\% chance of economic success. Barrett Resources has successfully completed wells in deep Frontier Formation reservoirs in the Wind River basin at depths of 20,000 feet for costs ranging from $\$ 8$ to $\$ 10$ million. These wells have encountered high temperatures and pressures, thereby requiring costly reservoir stimulation (Gas Research Institute, 1998).

Economic and technologic problems represent the biggest challenges to deep drilling. Problems associated with hostile drilling environments (e.g. high temperatures and pressures, and acid gases such as $\mathrm{CO}_{2}$ and $\mathrm{H}_{2} \mathrm{~S}$ ), well completions, and high costs present the greatest obstacles to drilling, evaluating, and completing deep gas wells (Wyman, 1993; Reeves and others, 1998).

Andersen and others (1989) determined that rig time (day drilling rate times days of drilling) was the largest single cost item for deep gas wells. Several factors that can reduce well costs include improving penetration rates by improved bit design, development of high temperature downhole motors, and/or underbalanced drilling.

Even though the overall success ratio for deep wells is over 50 percent (see Table 3), a lack information on geology, geophysics and reservoir quality continues to be a major barrier to deep gas exploration (Wyman, 1993). As discussed earlier, traditional exploration methods may need to be modified to better understand the following: (1) the nature of deep continuous-type basin-centered gas accumulations, (2) the relationship between early hydrocarbon emplacement and preservation of reservoir porosity and permeability, and (3) the distribution of natural fracture systems. A great deal of information about deeper faults and possible traps may be interpreted from shallower wells (Ehrlich 2001). Wyman (1993) identified an exploration strategy for ultradeep wells (>25,000 feet) emphasizing the spatial distribution of sedimentary facies, geohistorical analysis, and integrated geological/geophysical models. Such models should include an assessment of source rocks, and a characterization of potential reservoirs. Understanding the interrelationships of porosity (including porosity preservation), permeability (matrix and natural fractures), fluid types and pressures, diagenesis, burial history, and subsequent tectonic activity is essential.

\{NOTE for TED: Add to references - Ehrlich, Robert; Broussard, Neal J.; Gay, S. Parker. A Strategy for the Next Cycle of North American Exploration, To be published 2001.\}

Improving well completion and stimulation methods for deep gas wells remains a major challenge due to the high temperatures, pressures and corrosive gases encountered at great depths. Well completion improvements should include better control of acid-reaction times during matrix stimulation, maintaining hydraulic fracture fluid stability of hydraulic fracture fluid while avoiding formation damage. Data suggest that for deep wells, hydraulically fractured wells are not necessarily more productive than less expensive acidized wells (Spencer and Wandrey, 1997). Additional research is needed to better understand proppant and rock failure during and after hydraulic fracturing, lithologic response to acidizing, and the stability of deep reservoir rocks during production. A better understanding of appropriate treatment selection and design for deep reservoirs could reduce stimulation costs.

Non-hydrocarbon gases can severely limit the economic success of deep gas wells. Managing $\mathrm{H}_{2} \mathrm{~S}$ and $\mathrm{CO}_{2}$ can be especially expensive and difficult, requiring special safety precautions. The production of hot, sour gas requires special tubulars and complex gas-processing techniques. Developing lower cost, acid-resistant coatings for tubulars and advanced membranes for gas separation could help to lower development costs (Reeves and others, 1998). Special attention should be given to develop packers and sealing elements that can withstand high temperatures and corrosive fluids. Since conventional well-logging tools are generally not suitable for detailed evaluation of deep formations (Reeves and others, 1998), advanced logging tools and sophisticated analytical techniques are important for deep formation evaluation. Critical petrophysical analyses can incorporate information from logs, well cuttings, drilling shows, penetration rates, and other drilling results to better characterize deep reservoirs. Technologies such as petrographic image 
analysis and auto-fluorescent illumination can be helpful in evaluating microfractures that may be the key to profitable production in deep tight formations.

\section{OUTLOOK}

Because of the highly mature state of drilling and production in many U.S. basins, exploration companies are looking for new opportunities and prospects. Natural gas accumulations in deep sedimentary basins provide frontier opportunities for exploration.

Despite the many challenges associated with deep drilling, exploration for deep gas continues in the U.S. in the Gulf Coast, Rocky Mountains, Permian and Anadarko basins. Future estimates of gas resources based on the GRI Hydrocarbon Supply Model (Cochener and Brandenburg, 1998), which is driven by exploration and production economics, projects the greatest growth in annual deep gas production in five onshore regions between 1995 and 2015: South Louisiana (788 Bcf/year), Texas Gulf (574 Bcf/year), Permian basin (484 Bcf/year), Eastern Gulf (208 Bcf), and Midcontinent (128 Bcf/year). Cochener and Brandenburg further suggest that the trend toward increased deep drilling in the Gulf Coast region is due at least in part to a recent decline in drilling and production costs. The notable absence of Rocky Mountain basins on their list of deep gas development may be due to their economic model that favors shallow targets in the region. Based on the U.S. Geological Survey's 1995 natural gas assessment (Dyman and others, 1996), more than 57 Tcf of deep undiscovered technically-recoverable gas resides in Rocky Mountain basins, particularly in the Greater Green River basin of Wyoming. A significant portion of the deep gas resource of the Rocky Mountain region is being and will be economically developed (V.A. Kuuskraa, unpublished data).

New information resulting from deep drilling will add to our geologic database of deep reservoirs and increase the quality of resource assessments and improve drilling and completion practices. However, research and development programs focusing on technologic improvements and cost-cutting measures will be needed (Reeves and others, 1998). Cooperative programs could result from regional industry workshops such as those recently held by GRI that highlighted advances in deep drilling and needs for improved technology growth (Oil and Gas Journal, 1998).

Based on an analysis of natural gas resource assessments, many areas hold significant promise for future exploration. One such area involves re-evaluating and assessing existing conventional and unconventional gas plays that were poorly understood and not assessed by the U.S. Geological Survey in 1995. For that assessment, many deep continuous-type plays were identified but not assessed because of a lack of basic geologic and petroleum-related information (Dyman and others, 1996). These basin-centered gas plays could contain significant undiscovered technically-recoverable gas resources. In addition to these plays, others may exist that were not previously identified. Rocky Mountain basins such as the Albuquerque, Wind River, Big Horn, Hanna, and Crazy Mountains basins, the Permian basin, California and Alaska basins, and the Midcontinent rift are potential areas to investigate.

\section{REFERENCES CITED}

Andersen, E.E., Maurer, W.C., and Pittard, G.T., 1989, Deep drilling cost sensitivity analysis: Gas Research Institute Topical Report 89-18.

Behar, F., Vandenbroucke, M., Tang, Y., Marquis, F., and Espitalie, J., 1997, Thermal cracking of kerogen in open and closed systems: determination of kinetic parameters and stoichiometric coefficients for oil and gas generation: Organic Geochemistry, v. 26, p. 321-339.

Cochener, J., and Brandenburg, C., 1998, Expanding the role of onshore deep gas: GasTIPS (Gas Research Institute), v. 4, no. 3, p. 4-8.

Davis, T.B., 1984, Subsurface pressure profiles in gas-saturated basins, in Masters, J.A., ed., Elmworth-case study of a deep basin gas field: American Association of Petroleum Geologists Memoir 38, p. 189-203. 
Dyman, T.S., Schmoker, J.W., and Root, D.H., 1996, Assessment of deep conventional and continuous-type (unconventional) natural gas plays in the U.S.: U.S. Geological Survey Open-File report 96-529, $22 \mathrm{p}$.

Dyman, T.S., and Schmoker, J.W., 1996, Comparison of national oil and gas assessments: U.S. Geological Survey Open-File Report 97-445, 30 p.

Dyman, T.S., Rice, D.D., and Westcott, P.A., eds., 1997, Geologic controls of deep natural gas resources in the United States: U.S. Geological Survey Bulletin 2146, 239 p.

Dyman, T.S., and Kuuskraa, V.A., eds., in press, Studies of deep natural gas: U.S. Geological Survey Bulletin 2173.

Dyman, T.S., and Cook, T.A., in press, Summary of deep oil and gas wells in the U.S. through 1998, in Dyman, T.S., and Kuuskraa, V.A., eds., Studies of deep natural gas: U.S. Geological Survey Bulletin 2173.

Ehrlich, Robert; Broussard, Neal J.; Gay, S. Parker, 2001, A Strategy for the Next Cycle of North American Exploration

Gas Research Institute, 1998, GRI Deep Gas Forum Meeting Notes, in Hill, D.G., Kuuskraa, V.A., and Dyman, T.S., eds., Building a technical foundation for deep gas development-Deep Gas Forum Series 2: Gas Research Institute, Denver, CO., October 15-16, 1998, unpaginated.

Gas Research Institute, 2000, GRI baseline projection of U.S. energy supply and demand 2000 edition: Gas Research Institute.

Gautier, D.L., Dolton, G.L., Takahashi, K.I., and Varnes, K.L., eds., 1996, 1995 National Assessment of United States Oil and Gas Resources - results, methodology, and supporting data: U.S. Geological Survey Digital Data Series DDS-30, Release 2, one CD-ROM.

Henry, A.A., and Lewan, M.D., in press, Comparison of kinetic-model predictions of deep gas generation, in Dyman, T.S., and Kuuskraa, V.A., eds., Studies of deep natural gas: U.S. Geological Survey Bulletin 2173.

Horsfield, B., Schenk, H.J., Mills, N., and Welte, D.H., 1992, An investigation of the in-reservoir conversion of oil to gas--Compositional and kinetic findings from closed- system programmed-temperature pyrolysis: Advances in Organic Geochemistry, v. 19, p. 191-204.

IHS Energy Group, 1998, PI-Dwights WHCS (through October 1998): Available from IHS Energy Group, Denver, CO 80112.

Knauss, K.G., Copenhaver, S.A., Braun, R.L., and Burnham, A.K., 1997, Hydrous pyrolysis of New Albany and Phosphoria Shales--Production kinetics of carboxylic acids and light hydrocarbons and interactions between the inorganic and organic chemical systems: Organic Geochemistry, v. 27, p. 477-496.

Masters, J.A., ed., Elmworth-case study of a deep basin gas field: American Association of Petroleum Geologists Memoir 38, p. 189-203. 
McLennan, J., Carden, R.S., Curry, D., Stone, R.C., and Wyman, R.E., 1997, Underbalanced Drilling Manual: Gas Research Institute Report (GRI) 97/0236, unpaginated.

National Petroleum Council, 1992, The potential for natural gas in the United States, volumes I and II: National Petroleum Council, 520 p. (combined).

National Petroleum Council, 1999, Meeting the challenges of the Nations growing natural gas demand-Volume 1 summary report: National Petroleum Council, 53 p. with appendices.

Oil and Gas Journal, 1998, Advances, needs highlighted for deep U.S. gas drilling: Oil and Gas Journal, Nov. 3, 1998, p. 82-84.

Perry, W.J., Jr., 1997, Structural settings of deep natural gas accumulations in the conterminous United States, in Dyman, T.S., Rice, D.D., and Westcott, P.A., eds., Geologic controls of deep natural gas resources in the United States: U.S. Geological Survey Bulletin 2146, p. 41-46.

Pepper, A.S., and Corvi, P.J., 1995, Simple kinetic models of petroleum formation-Part I, Oil and gas generation from kerogen: Mar. Petroleum Geology, v. 12, p. 291-319.

Pepper, A.S., and Dodd, T.A., 1995, Simple kinetic models of petroleum formation-Part II, Oil-gas cracking: Mar. Petroleum Geology, v. 12, p. 321-340.

Price, L.C., 1997, Origins, characteristics, evidence for and economic viabilities of conventional and unconventional gas resource bases, in Dyman, T.S., Rice, D.D., and Westcott, P.A., eds., Geologic controls of deep natural gas resources in the United States: U.S. Geological Survey Bulletin 2146, p. 181-207.

Potential Gas Committee, 1999, Potential supply of natural gas in the United States--Report of the Potential Gas Committee (December 31, 1998): Potential Gas Agency, Colorado School of Mines, Golden, CO., 130 p.

Reeves, S.R., Kuuskraa, J.A., and Kuuskraa, V.A., 1998, Deep gas poses opportunities, challenges to U.S. operators: Oil and Gas Journal, May 4, 1998, p. 133-140.

Spencer, C.W., and Wandrey, C.J., 1997, Initial potential test data from deep wells in the United States, in Dyman, T.S., Rice, D.D., and Westcott, W.A., eds., Geologic controls of deep natural gas resources in the United States; U.S. Geological Survey Bulletin 2146, p. 63-69.

Wyman, R.E., 1993, Challenges of ultradeep drilling, in Howell, D.G., ed., The Future of Energy Gases: U.S. Geological Survey Professional paper 1570, p. 205-216.

\section{Figure caption:}

Figure 1. Generalized map of conterminous United States and Alaska showing basins containing rocks greater than 15,000 feet (about 4,600 m) deep. Shaded areas represent entire basins. WY-UT-ID $=$ Wyoming- Utah-Idaho. Federal offshore areas identified but not discussed in report.

\section{Table captions:}

Table 1. The 12 deepest exploration and production wells in the U.S. in decreasing order of total depth. 
Table 2. Estimates of undiscovered natural gas by region for depths of 15,000 feet or greater from the 1995 U.S. Geological Survey (USGS) National Petroleum Assessment. Data are mean estimates. Gas in billions of cubic feet (Bcf) and rounded to nearest Bcf. Data include associated gas from oil accumulations and non-associated gas. Onshore regions and state waters only. Unconventional gas primarily includes gas in lowpermeability (tight) sandstones. Resource estimates based on current technology case only. Estimates do not include undiscovered gas from small fields (less than $6 \mathrm{Bcfg}$ ). Refer to Gautier and others (1996) for detailed explanation of assessment.

Table 3. Summary data by region for deep undiscovered conventional gas resources in the world using World Petroleum Assessment 2000 and 1995 National Assessment for U.S. assessment results (U.S. Geological Survey World Energy Assessment Team, 2000).

Table 4. Total deep wells by depth interval for U.S. based on final well completion classification.

Table 5. Numbers of deep producing wells by depth interval in U.S. by region.

Table 6. Summary data for wells drilled deeper than 25,000 feet by province/basin in the U.S.

Table 7. Estimated average reserves for onshore gas wells in the lower-48 U.S. by depth interval. Data from Reeves and others (1998).

Table 8. Required reserves, gas in place, and net thickness of producing interval per well for economic deep gas. Data from Wyman (1993). Bcf, Billions of cubic feet of gas; \$/Mcf, cost in dollars per million cubic feet of gas. Assumptions include average well density equals 1 well per section, an undiscounted return on investment of 5 to 1 , cost to drill and complete a 40,000-ft well equals $\$ 50$ million, initial flow rates of at least 20 million cubic feet of gas per day, 7 percent porosity, 30 percent water saturation, and average gas recovery of 65 percent of original gas in place. 


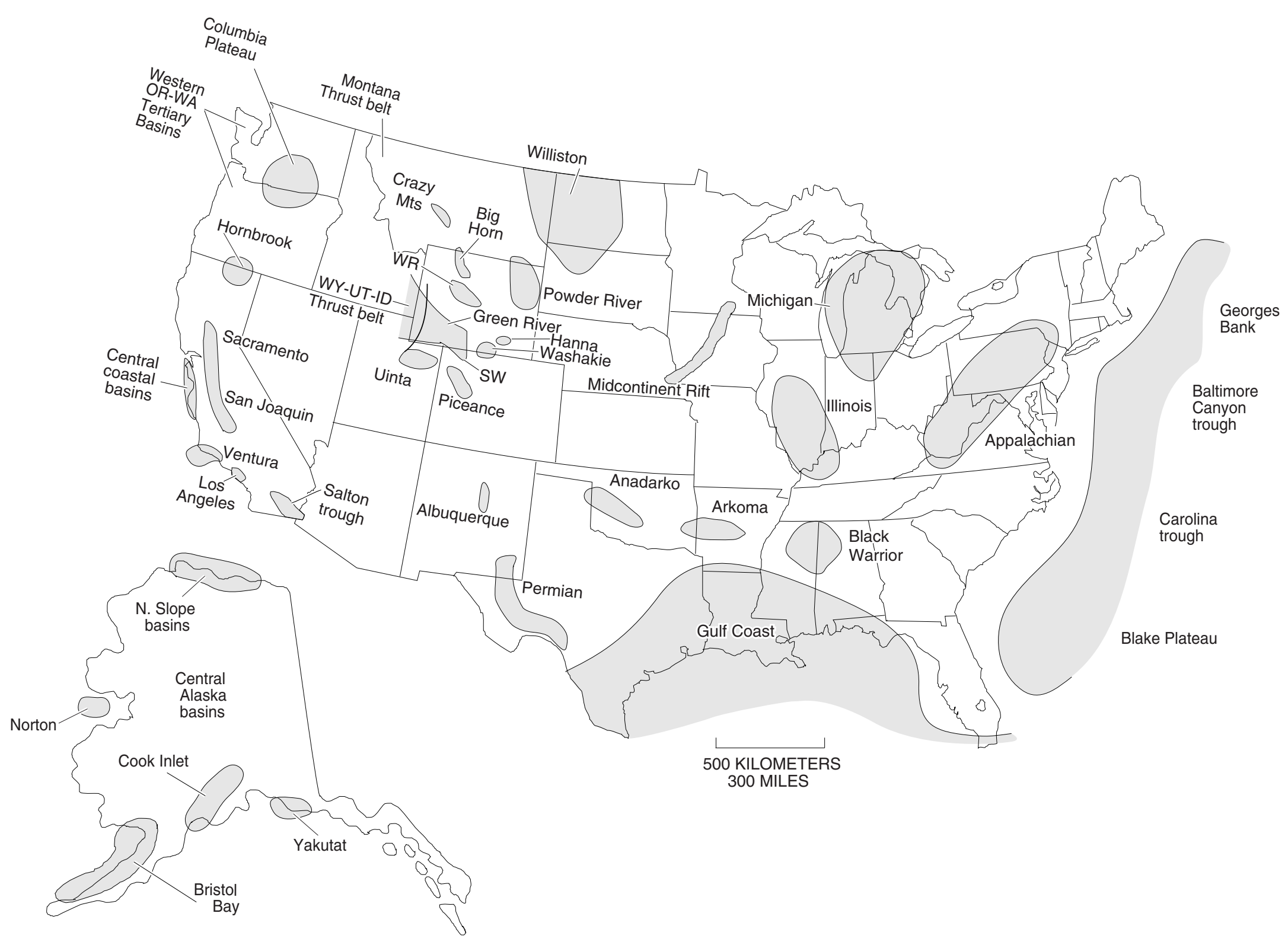


Table 1. The 12 deepest exploration and production wells in the U.S. in decreasing order of total deptha

\begin{tabular}{lllll}
\hline Operator & Well Name & $\begin{array}{l}\text { Date } \\
\text { Completed }\end{array}$ & $\begin{array}{l}\text { Total } \\
\text { Depth (feet) }\end{array}$ & $\begin{array}{l}\text { Basin- } \\
\text { State }\end{array}$ \\
\hline 1. Lone Star Prod. & \#1 Bertha Rogers & 1974 & 31,441 & A-OK \\
2. Lone Star Prod. & \#1 Earnest R. Baden & 1972 & 30,050 & A-OK \\
3. Hunt Energy Corp. & 1-9 Cerf Ranch & 1983 & 29,670 & P-TX \\
4. Riata Energy & Cerf Ranch & 1994 & 29,670 & P-TX \\
5. Gulf Oil Corp. & 2 Emma Lou Unit \#1 & 1980 & 29,622 & P-TX \\
6. GHK Corp. & \#1-34 Duncan & 1983 & 29,312 & A-OK \\
7. GHK Corp. & \#1-1 Robinson & 1984 & 29,241 & A-OK \\
8. Chevron USA & \#1 University 23-3 & 1981 & 28,747 & P-TX \\
9. Ralph Lowe Estate & \#1-17 University & 1972 & 28,500 & P-TX \\
10. Kimball Production & University \#17 & 1982 & 28,500 & P-TX \\
11. McCulloch Oil & \#1 Easley & 1973 & 27,050 & A-OK \\
12. Napeco Inc. & \#1 Centurion & 1981 & 27,019 & P-TX \\
\hline
\end{tabular}

aData taken from IHS Energy Group WHCS file updated through December, 1998. Wells listed regardless of completion class.

$\mathrm{b}_{\mathrm{A}}=$ Anadarko basin; $\mathrm{P}=$ Permian basin; $\mathrm{OK}=$ Oklahoma; $\mathrm{TX}=$ Texas. 
Table 2. Estimates of undiscovered natural gas by region for depths of 15,000 feet or greater from the 1995 U.S. Geological Survey (USGS) National Petroleum Assessment. Data are mean estimates. Gas in billions of cubic feet (Bcf) and rounded to nearest Bcf. Data include associated gas from oil accumulations and non-associated gas. Onshore regions and state waters only. Unconventional gas primarily includes gas in low-permeability (tight) sandstones. Resource estimates based on current technology case only. Estimates do not include undiscovered gas from small fields (less than $6 \mathrm{Bcf}$ ). Refer to Gautier and others (1996) for detailed explanation of assessment.

U.S. Geological Survey (USGS) 1995 National

Petroleum Assessment

\begin{tabular}{lrrr}
\hline Region & $\begin{array}{c}\text { Conventional } \\
\text { gas resources } \\
(\mathrm{Bcf})\end{array}$ & $\begin{array}{r}\text { Unconventional } \\
\text { gas resources } \\
(\mathrm{Bcf})\end{array}$ & $\begin{array}{c}\text { Total } \\
\text { gas resources } \\
(\mathrm{Bcf})\end{array}$ \\
\hline Alaska & 17,936 & 0 & 17,936 \\
Pacific & 550 & 2,636 & 3,186 \\
Rocky Mountains & 1,946 & 55,212 & 57,158 \\
Colorado Plateau & 130 & 570 & 700 \\
West Texas- & & & 4,705 \\
Eastern New Mexico & 4,705 & 0 & 27,439 \\
Gulf Coast & 27,439 & 0 & 2,264 \\
Midcontinent & 2,264 & 0 & 294 \\
Eastern & 294 & 0 & 113,682 \\
& & &
\end{tabular}


Table 3. Summary data by region for deep undiscovered conventional gas resources in the world using World Petroleum Assessment 2000 and 1995 National Assessment for U.S. assessment results (U.S. Geological Survey World Energy Assessment Team, 2000). [AU, assessment unit; undisc. conv., undiscovered conventional gas; Tcf, trillions of cubic feet; Bcf, billions of cubic feet]

\begin{tabular}{|c|c|c|c|c|c|c|c|}
\hline Region & $\begin{array}{l}\text { Deep AU's/ } \\
\text { provinces }\end{array}$ & $\begin{array}{l}\text { Total gas }(\text { Tcf }) \\
(>4.5 \mathrm{~km} />7.5 \mathrm{~km})\end{array}$ & $\begin{array}{l}\text { Total gas (Tcf) } \\
\text { (all depths) }\end{array}$ & $\begin{array}{l}\text { Average } \\
\text { percent } \\
\text { deep gas }\end{array}$ & $\begin{array}{l}\text { Average max- } \\
\text { imum depth }\end{array}$ & $\begin{array}{l}\text { Dominant } \\
\text { province(s) }\end{array}$ & $\begin{array}{l}\text { Significant regional example: } \\
\text { AU, province, mean undisc. conv. } \\
\text { resource, primary reservoir(s) }\end{array}$ \\
\hline $\begin{array}{l}\text { Former Soviet } \\
\text { Union-Region } 1\end{array}$ & $37 / 12$ & $343 / 0.5$ & 1,611 & 21 & 5,857 & $\begin{array}{l}\text { Caspian } \\
\text { provinces }\end{array}$ & $\begin{array}{l}\text { Central Offshore, S. Caspian, } 71 \text { Tcf, } \\
\text { Tertiary shelf turbidites }\end{array}$ \\
\hline $\begin{array}{l}\text { Mideast- } \\
\text { North Africa- } \\
\text { Region } 2\end{array}$ & $24 / 11$ & $131 / 0$ & 1,370 & 10 & 5,391 & $\begin{array}{l}\text { Red Sea basin, } \\
\text { Zagros Fold } \\
\text { Belt, Sirte Basin } \\
\text { Rub Al Khali Basin }\end{array}$ & $\begin{array}{l}\text { Paleozoic reservoirs, Rub Al Khali } \\
\text { Basin, } 46 \text { Tcf, Permian sandstones }\end{array}$ \\
\hline $\begin{array}{l}\text { Asia Pacific- } \\
\text { Region } 3\end{array}$ & $20 / 12$ & $38 /<0.1$ & 379 & 10 & 5,915 & $\begin{array}{l}\text { Kutei Basin } \\
\text { Sichuan Basin }\end{array}$ & $\begin{array}{l}\text { Tarim Basin Excluding Marginal } \\
\text { Foldbelts, Tarim basin, } 23 \mathrm{Tcf} \\
\text { Ordovician carbonates }\end{array}$ \\
\hline $\begin{array}{l}\text { Europe- } \\
\text { Region } 4\end{array}$ & $18 / 8$ & $142 / 0.7$ & 312 & 46 & 6,500 & $\begin{array}{l}\text { N. Sea Graben, } \\
\text { Pannonian Basin, } \\
\text { Carpathian- } \\
\text { Balkhanian Basin }\end{array}$ & $\begin{array}{l}\text { Mid-Norway Continental Margin, } \\
\text { Vestford-Helgeland, } 70 \mathrm{Tcf} \text {, mixed } \\
\text { clastics-carbonates }\end{array}$ \\
\hline $\begin{array}{l}\text { N. America- } \\
\text { Region } 5 \\
\text { (excluding U.S) }\end{array}$ & $12 / 4$ & $22 / 0$ & 155 & 14 & 5,667 & $\begin{array}{l}\text { Villahermosa Uplift } \\
\text { Alberta Basin }\end{array}$ & $\begin{array}{l}\text { Tamabra-like Debris-flow Breccia } \\
\text { Limestone Overlying Evaporites, } \\
\text { Villahermosa Uplift, 20.4 Tcf, Tertiary carb. } \\
\text { res }\end{array}$ \\
\hline $\begin{array}{l}\text { U.S. portion- } \\
\text { Region } 5\end{array}$ & $101 / 43$ & $55 /$ not calculated & 259 & 21 & 5,898 & $\begin{array}{l}\text { Gulf Coast, } \\
\text { Rocky Mts., } \\
\text { N. Alaska }\end{array}$ & $\begin{array}{l}\text { Eastern Thrust Belt, Northern AK, } 9 \text { Tcf } \\
\text { Carbonate and clastic reservoirs }\end{array}$ \\
\hline $\begin{array}{l}\text { Central and } \\
\text { S. America- } \\
\text { Region } 6\end{array}$ & $42 / 22$ & $88 / 11$ & 487 & 18 & 6,425 & $\begin{array}{l}\text { Eastern Venezuela } \\
\text { Basin, Campos } \\
\text { Basin, Middle Mag- } \\
\text { dalena, Santa Cruz- } \\
\text { Tarija Basin } \\
\end{array}$ & $\begin{array}{l}\text { Sub-Andean Fold-Thrust Belt, Santa Cruz- } \\
\text { Tarija Basin, } 10 \text { Tcf, Silurian through } \\
\text { Tertiary clastic reservoirs }\end{array}$ \\
\hline $\begin{array}{l}\text { Sub-Saharan } \\
\text { Africa-Region } 7\end{array}$ & $10 / 5$ & $14 / 0$ & 235 & 6 & 5,200 & $\begin{array}{l}\text { W. Central Coastal } \\
\text { Niger Delta }\end{array}$ & $\begin{array}{l}\text { Akata Reservoirs, Niger Delta, } 8.6 \mathrm{BCF} \text {, } \\
\text { Tertiary turbidite reservoirs }\end{array}$ \\
\hline $\begin{array}{l}\text { South Asia- } \\
\text { Region } 8\end{array}$ & $10 / 7$ & $11 / 0.1$ & 120 & 9 & 6,100 & $\begin{array}{l}\text { Ganges-Brah- } \\
\text { maputra Delta, } \\
\text { Indus, Bombay }\end{array}$ & $\begin{array}{l}\text { Central Basin, Ganges-Brahmaputra } \\
\text { Delta, 5.3 Bcf, Tertiary turbidite sandstone } \\
\text { reservoirs }\end{array}$ \\
\hline
\end{tabular}


Table 4. Total deep wells by depth interval for U.S. based on final well completion classification ${ }^{\mathrm{a}}$

\section{Final well classification}

\begin{tabular}{|c|c|c|c|c|c|c|c|c|c|c|c|c|}
\hline \multicolumn{2}{|c|}{ gas wells / } & \multirow[b]{2}{*}{ Dry $^{d}$} & \multicolumn{3}{|c|}{ 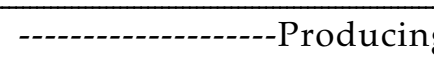 } & \multicolumn{3}{|c|}{ wells------------------- } & \multirow[b]{2}{*}{$\begin{array}{l}\text { Prod. } \\
\text { totalj }\end{array}$} & \multirow[b]{2}{*}{$\begin{array}{l}\text { Prod. } \\
\text { gask }^{-}\end{array}$} & \multicolumn{2}{|c|}{ Total prod wells / } \\
\hline Depth ${ }^{b}$ & $\operatorname{Misc}^{\mathrm{C}}$ & & $\mathrm{Oil}^{\mathrm{e}}$ & $\operatorname{Gas}^{\mathrm{f}}$ & $\begin{array}{l}\text { Oil } \\
\text { mulg }\end{array}$ & $\begin{array}{l}\text { Gas } \\
\mathrm{mul}^{\mathrm{h}}\end{array}$ & $\begin{array}{l}\text { Oil- } \\
\text { Gas }^{\mathrm{i}}\end{array}$ & $\begin{array}{l}\text { Total } \\
\text { wells }\end{array}$ & & & total wells $(\%)$ & $\begin{array}{l}\text { total prod. well } \\
(\%)\end{array}$ \\
\hline $15-16$ & 270 & 3,072 & 1,249 & 2,905 & 140 & 171 & 49 & 7,856 & 4,514 & 3,076 & 57 & 68 \\
\hline $16-17$ & 203 & 2,199 & 621 & 1,952 & 69 & 119 & 21 & 5,184 & 2,782 & 2,071 & 54 & 74 \\
\hline $17-18$ & 125 & 1,279 & 354 & 1,302 & 26 & 61 & 5 & 3,152 & 1,748 & 1,363 & 55 & 78 \\
\hline $18-19$ & 72 & 832 & 176 & 768 & 5 & 21 & 4 & 1,878 & 974 & 789 & 52 & 81 \\
\hline $19-20$ & 43 & 396 & 72 & 426 & 2 & 29 & 1 & 969 & 530 & 455 & 55 & 86 \\
\hline $20-21$ & 24 & 268 & 63 & 279 & 2 & 17 & 2 & 655 & 363 & 296 & 55 & 82 \\
\hline $21-22$ & 22 & 159 & 29 & 229 & 0 & 17 & 1 & 457 & 276 & 246 & 60 & 89 \\
\hline $22-23$ & 20 & 111 & 15 & 213 & 0 & 6 & 0 & 365 & 234 & 219 & 64 & 94 \\
\hline $23-24$ & 4 & 39 & 2 & 46 & 0 & 0 & 0 & 91 & 52 & 46 & 57 & 88 \\
\hline $24-25$ & 1 & 36 & 0 & 17 & 0 & 0 & 0 & 54 & 18 & 17 & 33 & 94 \\
\hline $25-26$ & 1 & 15 & 1 & 14 & 0 & 0 & 0 & 31 & 16 & 14 & 52 & 88 \\
\hline $26-27$ & 1 & 3 & 2 & 3 & 0 & 0 & 0 & 9 & 5 & 3 & 56 & 50 \\
\hline $27-28$ & 0 & 0 & 0 & 2 & 0 & 0 & 0 & 2 & 2 & 2 & 100 & 100 \\
\hline $28-29$ & 1 & 2 & 1 & 0 & 0 & 0 & 0 & 4 & 1 & 0 & 25 & 0 \\
\hline $29-30$ & 0 & 3 & 0 & 2 & 0 & 0 & 0 & 5 & 2 & 2 & 40 & 100 \\
\hline $30-31$ & 1 & 0 & 0 & 1 & 0 & 0 & 0 & 2 & 1 & 1 & 50 & 50 \\
\hline $31-32$ & $\underline{0}$ & 0 & 0 & 1 & 0 & 0 & 0 & 1 & 1 & 1 & 100 & 100 \\
\hline Totals & 788 & 8,414 & 2,585 & 8,160 & 244 & 441 & 83 & 20,715 & 11,519 & 8,601 & 56 & 75 \\
\hline
\end{tabular}

a Data taken from IHS Energy Group Well History Control System (WHCS) file updated through December 1998 (IHS Energy Group, 1998).

$\mathrm{b}$ Depth interval in thousands of feet.

${ }^{\mathrm{C}}$ Miscellaneous wells include those with unknown final completion classification, sulfur wells,

suspended wells, dry development wells, injection wells, and drilled and abandoned wells.

$\mathrm{d}$ Producing wells may be producing at any depth.

e Oil producing wells.

Gas producing wells.

g Oil wells producing from multiple horizons.

${ }_{\mathrm{h}}^{\mathrm{h}}$ Gas wells producing from multiple horizons.

i Oil and gas producing wells.

j Total producing wells from any depth.

${ }^{\mathrm{k}}$ Wells from gas and multiple gas columns together. 
Table 5. Numbers of deep producing wells by depth interval in U.S. by region ${ }^{\mathrm{a}}$.

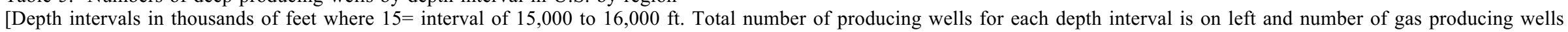
is on right]

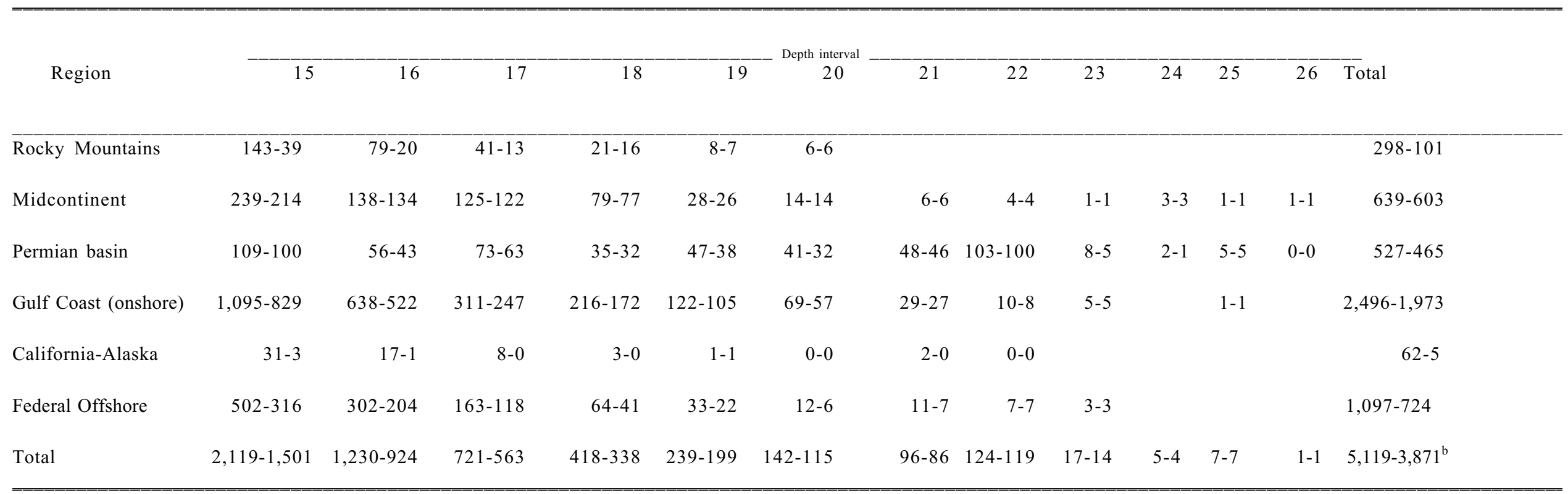

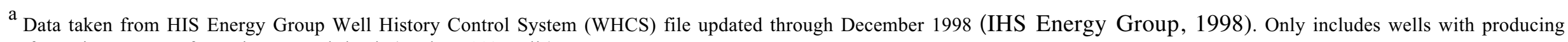
formation same as formation at total depth (total= 5,119 wells).

b Total number of gas producing wells does not include 120 wells from multiple producing formations. 
Table 6. Summary data for wells drilled deeper than 25,000 feet by province/basin in the U.S .

[Con., Concepts; compl., completion; OK, Oklahoma; Rep., representative; no., number; Inj., injection; prod., producing; Off., Offshore; TD, total depth of well; dashed lines indicate no data; GHK and LLE are company names]

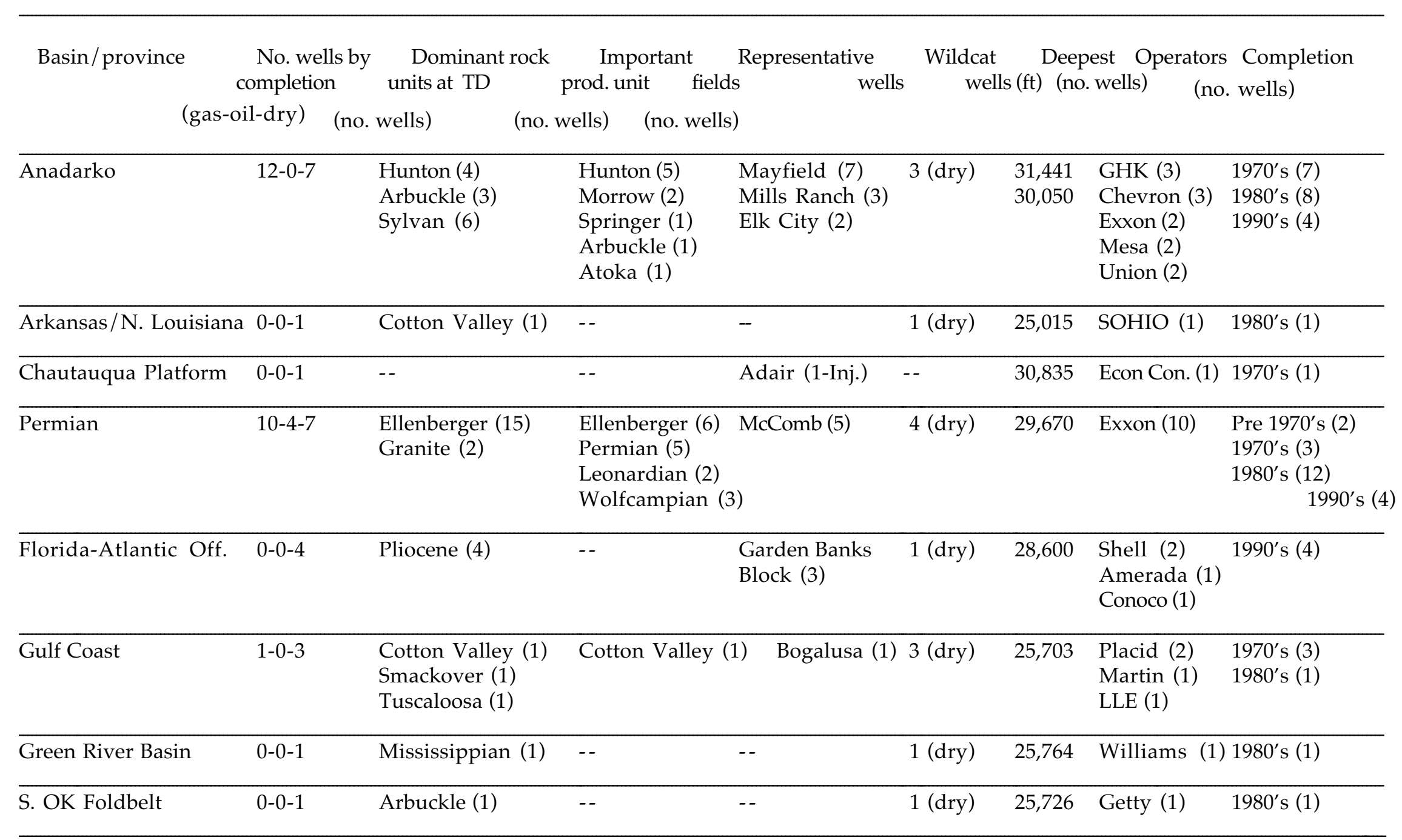

a Data taken from IHS Energy Group WHCS file updated through December, 1998 (IHS Energy Group, 1998). 
Table 7. Estimated average reserves for onshore gas wells in the lower-48 States by depth interval. Data from Reeves and others (1998). [Bcf, Billions of cubic feet of gas; \$/Mcf, cost in dollars per million cubic feet of gas. Cost includes allocated dry-hole costs.]

\begin{tabular}{llrr}
$\begin{array}{l}\text { Depth range } \\
\text { in feet }\end{array}$ & $\begin{array}{l}\text { Gas recovery } \\
(\mathrm{Bcf})\end{array}$ & Cost $(\$)$ & \multicolumn{1}{c}{$\begin{array}{c}\text { Finding cost } \\
(\$ / \mathrm{Mcf})\end{array}$} \\
\hline & & & 0.20 \\
$0-5,000$ & 0.81 & 160,000 & 0.43 \\
$5,000-10,000$ & 1.33 & 579,000 & 0.50 \\
$10,000-15,000$ & 3.20 & $1,584,000$ & 0.82 \\
$>15,000$ & 6.58 & $5,373,000$ &
\end{tabular}


Table 8. Required reserves, gas in place, and net thickness of producing interval per well for economic deep gas. Data from Wyman (1993). Bcf, Billions of cubic feet of gas; \$ Mcf, cost in dollars per million cubic feet of gas. Assumptions include average well density equals 1 well per section, an undiscounted return on investment of 5 to 1 , cost to drill and complete a 40,000-ft well equals $\$ 50$ million, initial flow rates of at least 20 million cubic feet of gas per day, 7 percent porosity, 30 percent water saturation, and average gas recovery of 65 percent of original gas in place.

\begin{tabular}{llll}
$\begin{array}{l}\text { Net gas price } \\
\text { To producer } \\
\text { (\$ per Mcf) }\end{array}$ & $\begin{array}{l}\text { Needed reserves } \\
\text { per well } \\
\text { (Bcf) }\end{array}$ & $\begin{array}{l}\text { Gas in place } \\
\text { (Bcf per section) }\end{array}$ & $\begin{array}{l}\text { Net thickness } \\
\text { of producing interval } \\
\text { (feet) }\end{array}$ \\
\hline & & & \\
2.00 & 125 & 192 & 312 \\
3.00 & 83 & 127 & 207 \\
5.00 & 50 & 77 & 125 \\
7.00 & 35 & 54 & 88 \\
9.00 & 28 & 43 & 70
\end{tabular}


Table 9. Required reserves per well for economic deep gas resources. Data from Advanced Resources International, Arlington, VA. Assumptions same as Table 8 except that return on investment is reduced to 3 to 1 and well costs reduced to $\$ 30$ million.

\begin{tabular}{ll} 
Net gas price & Needed reserves \\
To producer & per well \\
$(\$$ per $M c f)$ & $(B c f)$ \\
\hline
\end{tabular}

$3.00 \quad 30$

$\begin{array}{ll}5.00 & 18\end{array}$ 